\title{
Sistemas de Assentamento e Estilo Tecnológico: Uma Proposta Interpretativa para a Ocupação Pré-colonial do Alto Vale do Rio dos Sinos, Rio Grande do Sul
}

\author{
Adriana Schmidt Dias \\ Professor Orientador: Paulo Antônio Dantas De Blasis \\ Tese apresentada ao Programa Interdepartamental de Pós- \\ graduação em Arqueologia, Faculdade de Filosofia, Letras e \\ Ciências Humanas da Universidade de São Paulo para \\ obtenção do título de Doutor.
}

São Paulo

2003 


\section{Agradecimentos}

Esta tese de doutorado é fruto de dez anos de trabalhos como pesquisadora associada ao Projeto Arqueológico de Santo Antônio da Patrulha (PASAP), desenvolvidos junto ao Museu Arqueológico do Rio Grande do Sul (MARSUL). Um agradecimento inicial é dirigido ao seu coordenador, André Luiz Jacobus, que acompanhou este projeto desde seus primeiros passos, compartilhando minhas dúvidas e estimulando minhas reflexões. Agradeço também ao MARSUL pelo apoio institucional para as pesquisas de campo e laboratório e pela possibilidade de consulta às coleções e ao acervo documental sob sua guarda. À diretora Zilá Kolling e aos funcionários Alberto Tavares de Oliveira, Ana Maria Assunção, Senilda Ignácio, Elvira Zachert, Jurandir Braz e Gilmar de Souza, agradeço pelo carinho com que me receberam.

Ao meu orientador, Paulo Antônio Dantas De Blasis, agradeço pela confiança na possibilidade de viabilização deste projeto e pela disposição para pensar em conjunto os caminhos de construção desta tese. Agradeço também à FAPESP pelo auxílio financeiro para realização dos trabalhos de campo através do projeto de Auxílio Pesquisa Os Sistemas de Assentamento Pré-coloniais de Caçadores Coletores no Alto Vale do Rio dos Sinos, Município de Santo Antônio da Patrulha, RS (Processo FAPESP 2000\07609-0), coordenado por Paulo A Dantas De Blasis.

Aos colegas do Departamento de História da Universidade Federal do Rio Grande do Sul (UFRGS), especialmente à Profa. Silvia M. Copé, agradeço pelo apoio e incentivo através da concessão de licença integral das atividades docentes nos últimos quatro anos. À CAPES agradeço pela bolsa de doutorado, através do Programa de PICDT/CAPES, que possibilitou o apoio financeiro necessário para a realização desta tese.

A realização das pesquisas de laboratório no curto espaço de tempo disponível só foi possível em função da dedicação e empenho de Daniel Vieira (in memorian) e Cassiano Ignácio, responsáveis pela curadoria das coleções dos sítios escavados, e de Tânia Maria Schmidt Dias e Sirlei Hoeltz que me auxiliaram no inventário e análise destas coleções. Rafael Scavoni foi responsável pela composição gráfica e editoração do trabalho e Fabíola Silva, Lucas Bueno, Sirlei Hoeltz e Valéria Assis, dispuseram-se a ler o texto original, sendo seus comentários fundamentais para estruturar a forma final desta tese. A todos eles, minha total gratidão. 
Gostaria de agradecer também aos moradores das localidades do Monjolo, Evaristo, Furna, Pinheiros, Bom Retiro, Passo da Forquilha, Campestre e Canto dos Guilhermes, pela disposição em nos auxiliar em nosso trabalho de campo, possibilitando acesso a suas propriedades e oferecendo informações sobre a existência de sítios e sobre as pesquisas arqueológicas realizadas na região há 30 anos atrás. Em especial agradeço à Dona Maria Genari, nosso Anjo da Guarda, e aos seus filhos Camila, Graziela e Fernando, por nos acolherem em sua casa ao longo dos dois anos de trabalhos na região, fazendo com que nos sentíssemos como parte da família.

Por fim, agradeço a Cláudio Carle e a André Jacobus que compartilharam comigo a responsabilidade da coordenação das escavações e aos amigos que colaboraram com seu tempo e suor para que as atividades previstas por este projeto se concretizassem. Participaram dos trabalhos de campo arqueólogos, professores, alunos de graduação e pósgraduação das seguintes Instituições: Faculdades Porto Alegrenses (FAPA), Museu Arqueológico do Rio Grande do Sul (MARSUL), Pontifícia Universidade Católica do Rio Grande do Sul (PUCRS), Tromso Universitet (TU), Universidad de Buenos Aires (UBA), Universidade Estadual do Mato Grosso do Sul (UEMS), Universidade do Extremo Sul Catarinense (UNESC), Universidade Federal de Pelotas (UFPel), Universidade Federal do Rio Grande do Sul (UFRGS), Universidad de La Plata (ULP), Universidade Luterana do Brasil (ULBRA), Universidad Nacional del Centro de la Província de Buenos Aires (UCPBA), Universidade de Santa Cruz do Sul (UNISC), Universidade de São Paulo (USP) e Universidad de la Republica de Uruguay (URU).

Agradeço a cada um por terem me acompanhado no caminho e transformado esta tese em uma criação coletiva, tão prazerosa: Adriana Silva (UFRGS), Airton Cardoso (PUCRS), Alberto Oliveira (PUCRS), Alejandra Matarrese (ULP), Alejandro Ferrari (URU), Alexandre Freiberger, Daniel Vieira, Ana Cristina Carle (PUCRS), Ana Paula Porterie (ULP), André Loureiro (UFPel), André Penin Lima (USP), André Proença (UFRGS), Angelica Uvietta (ULP), Anibal Gustavo Casanova (URU), Anselmo DiMarco (UCPBA), Augustina Massigoge (ULP), Beatriz Landa (UEMS), Bianca Demore (PUCRS), Camila Souza (USP), Carolina K. B. Dias (USP), Carolina Rosa (UFRGS), Chimene Nobre (UFPel), Clarisse Jacques (UFRGS), Cláudia Plens (USP), Cláudio Rickens (UNESC), Daniela Pereira (ULBRA), Daniella Amaral (USP), Danilo Assunção (USP), Deise Maricato (FAPA), Desirée da Cunha (PUCRS), Diogo Costa (FAPA), Édison Cruxen (PUCRS), Eduardo Girotto (USP), Elisângela Oliveira (USP), Estela Mariani (ULP), Etienne Rousselet (PUCRS), Fábio V. Cerqueira (UFPel), Fabíola Silva (USP), 
Frank Roberg (TU), Gilberto da Silva (USP), Gustavo Wagner (PUCRS), Gilmar Pinheiro (USP), Gislene Monticelli (PUCRS), Guillermo Lamenza (ULP), Jaisson Lino (UNESC), João Darcy Saldanha (UFRGS), João Luis Passos (USP), Juan Martin Dabezies (URU), Julia Berra (USP), Julia Simioli (ULP), Juliano Campos (UNESC), Juliano Silva (UFRGS), Julio Spota (UBA), Junior Domicks (PUCRS), Klaus Hilbert (PUCRS), Lázaro D’Angerot (UCPBA), Leonardo Castelhano (PUCRS), Levy Figuti (USP), Lígia Giardini (USP), Lílian Carlos (UFRGS), Lucas Bueno (USP), Lucía Constantin (ULP), Luciana Schleder (UFRGS), Luciane Monteiro (USP), Manoel Carrera (UCPBA), Marcela Amoedo (UBA), Marcio Letona (UFRGS), Marcos Plischuk (ULP), Margarida Lavado (USP), Maria Florencia Ávila (UBA), Maria Florência Fajardo (ULP), Maria Gabriela Gregorini (ULP), Maria Jose Cigorrage (ULP), Maria Julia Arregui (ULP), Maria Martha Sarmiento (ULP), Mariana Cabral (UFRGS), Mariana Neumann (UFRGS), Mirian Carle (PUCRS), Newton Miranda (UES), Nicanor Marsans (ULP), Nicolás Rivas (URU), Pablo Messineo (UCPBA), Paula Baladão (UFRGS), Paulo De Blasis (USP), Paulo Santos (PUCRS), Rafael Bartolomucci (USP), Rafael Lopes (ULBRA), Rafael Milheira (UFPel), Ramiro Barberena (UBA), Renata Rauber (PUCRS), Ricardo Monma (USP), Robson Rodrigues (USP), Rodrigo Angrizani (UFRGS), Sandra Nami Amenomori (USP), Sergio Iriarte (UCPBA), Sirlei Hoeltz (PUCRS), Vanderlise Barão (UFRGS), Vanesa Bagaloni (ULP), Vera Thaddeu (UNISC), Veronica Puente (UBA) e Yamandu Hilbert (PUCRS). 


\section{Sumário}

Introdução. .8

\section{Capítulo 1 - Os Conceitos de Sistema de Assentamento e Estilo Tecnológico e suas} Implicações para o Estudo das Indústrias Líticas do Sul do Brasil.

1.1. A Relação entre Homem e Espaço na Arqueologia: Os Conceitos de Padrão e Sistema de Assentamento.

1.2. Estudos Etnoarqueológicos de Sistemas de Assentamento Caçador Coletor e suas Contribuições para a Construção de Modelos Arqueológicos.

1.3. O Conceito de Estilo Tecnológico como Instrumento para a Interpretação da Variabilidade de Conjuntos Líticos.

1.4. Possibilidades dos Estudos de Sistema de Assentamento e Estilo Tecnológico para a Construção de Modelos Interpretativos para os Caçadores Coletores do Sul do Brasil: As Tradições Umbu e Humaitá..... .46

Capítulo 2 - Estratégias de Estudo Regional dos Sistemas de Assentamento Précoloniais do Alto Vale do Rio dos Sinos, Rio Grande do Sul...

2.1. Características Ambientais da Região do Alto Vale do Rio dos Sinos. .53

2.2. Propostas Metodológicas para o Estudo de Sistemas de Assentamento Pré-coloniais no Vale do Alto Rio dos Sinos. .58

2.3. Características das Unidades Amostrais de Prospecção nos Diferentes Setores da Área Piloto. .65

2.4. Os Sítios Arqueológicos Identificados na Área Piloto: Características Gerais. 73

Capítulo 3 - Sistema de Assentamento de Caçadores Coletores no Alto Vale do Rio dos Sinos: A Tradição Umbu. . .81

3.1. Modelos Etnoarqueológicos de Mobilidade e Sistema de Assentamento Caçador Coletor em Floresta Tropical.

3.2. Os Sítios da Tradição Umbu no Alto Vale do Rio dos Sinos: Características de Implantação. .87 
3.3. Contribuições da Etnoarqueologia para a Construção de um Modelo de Sistema de Assentamento para os Caçadores Coletores da Tradição Umbu no Alto Vale do Rio dos Sinos 103

\section{Capítulo 4 - Variabilidade Intra-sítio e Inter-sítios em um Sistema de Assentamento} Caçador Coletor: Propostas Interpretativas para o Alto Vale do Rio dos Sinos.......122

4.1. Estudos de Variabilidade Intra-sítio e suas Contribuições para a Interpretação de Áreas de Atividade em Sítios de Caçadores Coletores

4.2. Escavando Abrigos sob Rocha: Problemas Geoarqueológicos e Propostas Metodológicas

4.3. Três Versões sobre o Mesmo Tema: Aspectos da Variabilidade Intra-sítio para os

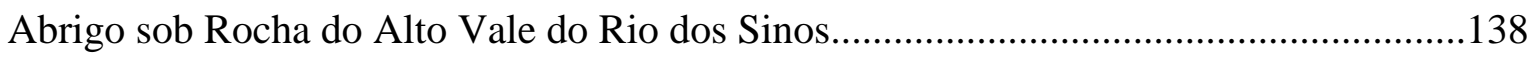

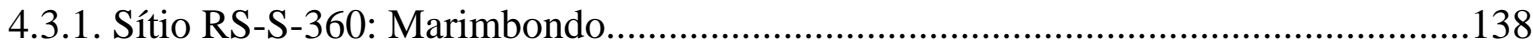

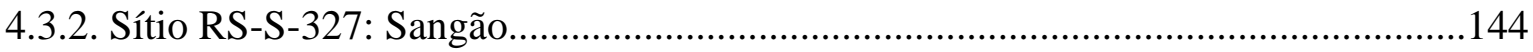

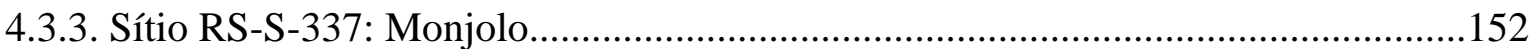

4.4. Os Abrigos sob Rocha como Área de Atividade Doméstica: Aspectos da Variabilidade Inter-sítios de Caçadores Coletores no Alto Vale do Rio dos Sinos 160

\section{Capítulo 5 - Sistemas de Assentamento de Horticultores no Alto Vale do Rio dos}

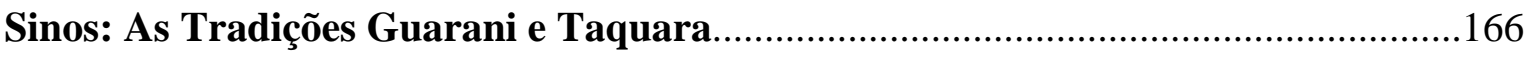

5.1. Os Horticultores da Tradição Guarani no Alto Vale do Rio dos Sinos. 166

5.1.1. Por um Modelo Etnoarqueológico do Sistema de Assentamento Guarani Pré-colonial no Sul do Brasil. 166

5.1.2. Os Sítios da Tradição Guarani do Alto Vale do Rio dos Sinos: Características de Implantação.

5.1.3. O Tekohá do Alto Vale do Rio dos Sinos: Um Modelo Interpretativo para o Sistema de Assentamento da Tradição Guarani. 187

5.2. Os Horticultores da Tradição Taquara no Alto Vale do Rio dos Sinos. 196

5.2.1. Modelo de Mobilidade e Sistema de Assentamento Jê Pré-colonial no Sul do Brasil: Um Objeto em Construção. 196

5.2.2. Os Sítios da Tradição Taquara do Alto Vale do Rio dos Sinos: Características de Implantação. .204

5.2.3. Uma Primeira Aproximação sobre o Sistema de Assentamento Jê no Alto Vale do Rio dos Sinos. 208 
5.3. Uma Estrada para a Conquista do Sul: O Início do Povoamento Luso-africano no Alto Vale do Rio dos Sinos

\section{Capítulo 6 - Estilo Tecnológico e as Indústrias Líticas do Alto Vale do Rio dos Sinos:}

6.1. Artefatos Líticos como Índices de Comportamento: Propostas Metodológicas para a Implementação de Estudos de Estilo Tecnológico.... 220

6.2. Indústrias Líticas de Caçadores Coletores do Alto Vale do Rio dos Sinos: a Tradição Umbu.

6.2.1. Estratégias de Seleção de Matérias Primas. .229

6.2.2. Estratégias de Redução e Composição dos Conjuntos Líticos. .232

6.2.3. Relação entre Estratégias de Redução e Produção de Artefatos. 243

6.3. Indústrias Líticas de Horticultores do Alto Vale do Rio dos Sinos: as Tradições Guarani e Taquara. .253

6.3.1. Estratégias de Seleção de Matérias Primas. 253

6.3.2. Estratégias de Redução e Composição dos Conjuntos Líticos. .254

6.3.3. Relação entre Estratégias de Redução e Produção de Artefatos. 262

6.4. A Relação entre Estilo Tecnológico e Variabilidade Artefatual no Estudo das Indústrias Líticas do Alto Vale do Rio dos Sinos.

Conclusões. 277

Referências Bibliográficas. 297

Anexo 1 - Mapa Geral da Região Nordeste do Rio Grande do Sul (1:250.000)................327

Anexo 2 - Mapa da Área Piloto do Alto Vale do Rio dos Sinos (1:50.000)..... 329

Anexo 3 - Mapa de Distribuição dos Sítios Arqueológicos na Área Piloto (1:50.000).....331

Anexo 4 - Croquis dos Sítios Arqueológicos. 333

Anexo 5 - Perfis das Escavações. 349

Anexo 6 - Planos de Plotagens das Escavações..... 356

Anexo 7 - Mapas de Densidade de Material Lítico. 399 


\section{Introdução}

De meados do século XIX até 1950, as pesquisas arqueológicas desenvolvidas no Brasil centraram-se em questões pontuais, relacionadas à cronologia do povoamento inicial de nosso território e à origem natural ou artificial dos sambaquis costeiros (Barreto, 1999/2000; Funari, 1994; Prous, 1992). De acordo com Barreto, foi somente na década de 1960 que a arqueologia passou a ser uma prioridade acadêmica no país:

Diferentemente das outras ciências sociais no Brasil, a arqueologia surgiu dentro das Universidades, não através de projetos intelectuais específicos, mas a partir de campanhas preservacionistas, promovidas por alguns poucos intelectuais indignados com a destruição acelerada dos sítios arqueológicos e a falta de profissionais especializados para resgatá-los (Barreto, 1999/2000: 40).

A promulgação, em 1961, da lei federal 3924, referente à proteção das jazidas arqueológicas brasileiras, é derivada deste processo, criando a necessidade de formação de quadros profissionais no campo da arqueologia para proteção de um patrimônio até então praticamente desconhecido e em acelerado processo de destruição. A demanda por cursos de formação profissional e pelo desenvolvimento de projetos de larga escala que permitissem conhecer a realidade arqueológica do país viabilizou o desenvolvimento de programas coordenados por equipes estrangeiras ${ }^{1}$, marcados por duas tradições de pesquisa distintas, a norte americana e a francesa.

Foi através de um curso de análise cerâmica, promovido em 1962 pela Universidade Federal do Paraná, que Betty Meggers e Clifford Evans marcaram os primeiros passos da influência teórico-metodológica da escola histórico-cultural norte americana na arqueologia brasileira. Oriundos deste curso foram os profissionais, vinculados a diversas instituições, que atuaram nos programas de pesquisa de caráter

\footnotetext{
${ }^{1}$ Entre 1949 e 1950, Meggers e Evans desenvolveram seus primeiros trabalhos no Brasil com o objetivo de testar as hipóteses de Steward quanto à origem andina da cultura Marajoara. Também Joseph e Annette Emperaire, entre 1955 e 1958, realizaram escavações em sítios costeiros no Paraná e em São Paulo, com o objetivo de testar as hipóteses de Paul Rivet sobre o povoamento da América, obtendo as primeiras datações radiocarbônicas para o país. Também realizaram escavações em sítios lito-cerâmicos do vale do rio Ivaí, no Paraná. Nesta mesma época, escavações foram promovidas por Wesley Hurt na região de Lagoa Santa, Minas Gerais, e por Hurt e Alan Bryan em sambaquis costeiros do Paraná e de Santa Catarina (Dias, 2001a; Prous, 1999).
} 
nacional coordenados por Meggers e Evans nas décadas de 1960 e 1970, como o Programa Nacional de Pesquisas Arqueológicas (PRONAPA), entre 1965 e 1970, o Programa de Pesquisas Paleo-indígenas (PROPA), entre 1972 e 1978, e o Programa Nacional de Pesquisas Arqueológicas da Bacia do Amazonas (PRONAPABA), entre 1977 e 1983. Em comum, todos estes projetos de larga escala justificavam-se na medida em que o Brasil consistia "99\% terra incógnita” em termos arqueológicos e esta falta de informação correspondia em um obstáculo para a reconstituição do desenvolvimento cultural na América do Sul (Dias, 1994, 1995a).

Em sua atuação no Brasil a escola americana se caracterizou por trabalhos prospectivos padronizados, concentrados ao longo de cursos de rios e voltados ao estabelecimento de cronologias relativas ou absolutas. As intervenções nos sítios, geralmente, restringiram-se a coletas de superfície assistemáticas de amostras mínimas para elaboração de seriações, de acordo com as orientações do método Ford, acompanhadas de sondagens de pequena extensão, realizadas em níveis artificiais de 10 cm, sendo os resultados obtidos sistematizados através dos conceitos de fase e tradição, adaptados das propostas de Willey e Phillips (Ford 1962; Chmyz 1966; Evans e Meggers 1965; Meggers e Evans 1970; Willey \& Phillips, 1958). Os dados gerados por estes Programas e por outros pesquisadores que seguiram as mesmas diretrizes de pesquisa, contabilizam hoje milhares de sítios em todo território nacional, associados a centenas de datações radiocarbônicas, distribuídos em três Tradições Pré-cerâmicas, correlacionadas a ocupações caçadoras coletoras, e nove Tradições Ceramistas, associadas a grupos horticultores (Prous 1992).

Em contrapartida, as diretrizes teórico-metodológicas dos Programas assumiram conotações paradigmáticas, passando a definição de fases e tradições a constituir o objetivo último do trabalho arqueológico para uma série significativa de pesquisadores ao longo das décadas de 1970 e 1980. A importância relegada aos métodos acabou por mascarar o corpo teórico que guiava os objetivos da pesquisa e conduziu a equívocos interpretativos quanto à capacidade explicativa dos conceitos utilizados. Por sua vez, o estudo arqueológico de caçadores coletores desempenhou um papel secundário nos programas de pesquisa relacionados à escola americana, cuja orientação privilegiava as sociedades ceramistas ${ }^{2}$. O

\footnotetext{
${ }^{2}$ De acordo com Evans e Meggers (1965: 3-4), “por centenas de milhares de anos, representando milhares de gerações, o inventário cultural cresceu muito pouco. (...) Os limites de seu próprio poder (...) estabeleceram uma barreira na evolução da cultura e somente através da domesticação de animais e plantas é que a evolução cultural se deu de maneira mais acelerada”.
} 
corolário dessa experiência é um quadro difuso de fases e tradições pré-cerâmicas que se distribuem por todo o país, sendo as coleções líticas descritas de forma esquemática, a partir de alguns artefatos considerados enquanto fósseis guia. A fragmentação da pesquisa, restrita à abrangência dos conceitos empregados, e a ausência de dados contextuais contribuíram para que as tentativas posteriores de sistematização dos dados relativos à ocupação caçadora coletora para as áreas pesquisadas se mostrassem frágeis (Dias, 1994: 42-44; ver também Dias 1995a, 1999a, 2001a).

Quanto à atuação da escola francesa no país, sua origem remonta à ação de Paul Rivet, que desde a década de 1950 integrava “o grupo já considerável de historiadores, sociólogos e etnólogos franceses que viriam a fundar e desenvolver as ciências sociais na Universidade de São Paulo”, possibilitando a captação de recursos financeiros para fundação de Instituto de Pré-história da USP (Barreto, 1999/2000:20). Foi por intermédio de Rivet que os Emperaire iniciaram suas pesquisas no Brasil formando, nas décadas de 1960 e 1970, um grupo de arqueólogos alinhados com os métodos de pesquisa idealizados por Leroi-Gourhan para o estudo do Paleolítico francês. Os Emperaire trabalharam no Brasil principalmente sítios de caçadores coletores, realizando escavações em superfícies amplas, voltadas à reconstrução de solos de ocupação. O primeiro curso de tecnologia lítica ministrada no país foi oferecido por Annette Laming Emperaire, em 1962, também na Universidade Federal do Paraná, seguindo as propostas tipológicas vigentes na França nas décadas de 1950 e 1960 (Barreto, 1999: 209; ver também Laming-Emperaire, 1967)

Em 1971, Laming-Emperaire chefiaria a primeira Missão Franco-brasileira na região de Lagoa Santa, em Minas Gerais, cuja proposta original tinha por objetivo estudar as transformações climáticas da transição Pleistoceno-Holoceno no Brasil Central e suas influências sobre as formas de adaptação humana. O projeto encerrou-se em 1977, com o falecimento de sua coordenadora, mas seus colaboradores franceses e brasileiros continuaram desenvolvendo pesquisas em Minas Gerais, Piauí e Mato Grosso (Prous 1996, 1999). As principais contribuições das Missões Franco-brasileiras relacionam-se ao desenvolvimento de estudos de tecnologia lítica e arte rupestre, bem como a implementação de projetos de campo de longa duração voltados a investigar aspectos do povoamento inicial do território brasileiro. Os estudos de tecnologia lítica avançaram significativamente, adaptando as orientações tipológicas francesas à realidade local, incluindo o desenvolvimento de projetos de arqueologia experimental, estudos tecno-tipológicos e de funcionalidade lítica a partir de análises de marcas de uso. Os estudos de arte rupestre, inicialmente influenciados pela ótica estruturalista, também foram redimensionados, tendo 
em vista as particularidades dos contextos locais, e voltaram-se ao registro e definição de unidades estilísticas e ao estabelecimento de seqüências cronológicas.

Prous nos oferece um quadro sintético dos desdobramentos das relações entre ambas escolas no país:

Durante a década de 1970 e parte da década de 1980, a maioria dos arqueólogos nacionais foi se enquadrando em um dos dois clãs principais, chamados no Brasil de escola francesa e escola americana, com objetivos, métodos e habilidades diversos. Poucos pesquisadores, percebendo que ambas escolas eram em parte complementares, tentaram escapar a esta dicotomia; polarizou-se, então de maneira negativa, o panorama arqueológico no país, o que dificultou a reflexão crítica e atrasou a penetração de outras tendências inovadoras, como a da chamada arqueologia processual, triunfante no mundo anglo-saxônica na década de 1970 (Prous, 1999: 30).

Barreto complementa esta análise ao destacar que a arqueologia praticada no Brasil, entre as décadas de 1960 e 1980, estava marcada pela preocupação em resgatar e preservar, sem necessariamente interpretar, o contexto arqueológico, sendo maior a atenção devotada às áreas técnicas, sobretudo relacionadas aos métodos de escavação, classificação, datação e documentação. Igualmente, esta tendência foi reforçada pela influência da tradição européia na academia brasileira que, na virada do século, associou a arqueologia à história natural, passando esta mais tarde a se desenvolver como uma sub-disciplina da história (como pré-história), jamais se constituindo enquanto parte da antropologia ou como uma ciência social autônoma ${ }^{3}$ (Barreto, 1999: 207).

Estes fatores retardaram a absorção pela comunidade acadêmica brasileira das tendências teóricas da arqueologia internacional, fenômeno que também pode ser observado naquele momento para os demais países latino-americanos (Politis, 2003). Este quadro se reverteu somente em meados da década de 1980, quando uma segunda geração de arqueólogos brasileiros passa a desenvolver pesquisas alinhadas às orientações teóricometodológicas processualistas. Em relação à arqueologia de caçadores coletores, este

\footnotetext{
3 “Assim, enquanto o campo da Antropologia e o estudo das sociedades indígenas vivas florescem no Brasil a partir dos anos 40 (...) a arqueologia (...) desenvolve-se sem incorporar as teorias estruturalistas ou funcionalestruturalistas [vigentes nestas áreas] (...). Por outro lado, apesar de próxima à História, a arqueologia no Brasil também não absorveu nada da forte influência dos historiadores marxistas (...) e tampouco da influência francesa (...) da École des Annales, também bastante fortes nos Departamentos de História no Brasil” (Barreto, 1999: 208).
} 
grupo voltou suas pesquisas a questão dos sambaquis, objeto que havia sido tratado de forma periférica por ambas escolas nas décadas anteriores, centrando sua atenção em estudos de abastecimento, antropologia biológica e processos de formação de sítios. A arqueologia de caçadores coletores continentais, no entanto, manteve-se alheia a este processo até recentemente, sendo raros os trabalhos que acompanhassem o debate teórico internacional sobre o tema que se desenvolvia tanto na antropologia, quanto na arqueologia neste mesmo período.

Os caçadores coletores fazem parte do pensamento ocidental desde o século XVII. Filósofos como Hobbes e Rousseau utilizaram sua imagem como ponto de partida para especulações sobre a vida no estado de natureza, tornando-se estas construções cada vez mais elaboradas a partir do acúmulo de relatos de viajantes, resultando nos primeiros esboços da evolução social presente nos trabalhos do iluminismo francês (em Diderot, Voltaire e Montesquieu) e escocês (em Adam Smith). Contudo, a imagem do modo de vida caçador coletor caracterizada por Thomas Hobbes, no Leviatã, em 1651, como “solitária, pobre, repulsiva, brutal e curta” é a que irá se cristalizar no pensamento ocidental, de forma direta ou indireta, até o século XX (Barnard, 1999: 376-378; Lee \& Daly, 1999: 7).

A construção dos caçadores coletores como objeto de estudo formal estrutura-se no século XIX, com o evolucionismo social, mantendo uma estreita relação com as préconcepções esboçadas anteriormente ${ }^{4}$. Estudos voltados à classificação das distintas formas de organização das sociedades surgiram na década de 1870, a partir de releituras das obras de Darwin, destacando-se os trabalhos Herbert Spencer (1876) e de Lewis Morgan (1877). Estes por sua vez, influenciaram fortemente a nascente sociologia, marcando a compreensão de Marx e Engels quanto às formas de organização político-econômicas précapitalistas $^{5}$ (Barnard, 1999: 379-380; Renfrew \& Bahn, 1995: 24-27). O modelo do Darwinismo Social ou Evolucionismo Unilinear reflete preocupações historicamente determinadas, defendendo a noção de progresso contínuo e inexorável das sociedades para formas sociais cada vez mais complexas, a caminho da perfeição representada pela

\footnotetext{
${ }^{4}$ De acordo com Gamble (1990:13), o “século da Europa” (1815-1914) presenciou a culminação de três processos de longa duração: o completo desenvolvimento de uma economia internacional, a criação do aparato do Estado Moderno e o nascimento da ciência. As vantagens práticas e potenciais deste avanço dependiam de uma mudança radical na forma de conceber, investigar e utilizar a natureza. $O$ desenvolvimento das ciências humanas está vinculado a este movimento, que também sentou as bases dos estudos geológicos e evolutivos, de forma inextrincável.

${ }^{5}$ Analisando a estruturação do campo das ciências humanas para o período, Lee e Daly (1999: 7) apontam que "enquanto os sociólogos adotaram como sua tarefa, compreender as sociedades urbanas das metrópoles
} 
sociedade ocidental. Desta forma, o modelo proposto relaciona natureza e evolução por oposição, ou seja, a evolução social progressiva age contra as forças materiais do ambiente. Portanto, ao serem dominadas pelas necessidades da subsistência, as sociedades caçadoras coletoras corresponderiam a fósseis vivos do estágio mais primitivo da evolução social (Bettinger, 1991: 4; Kelly, 1995: 6-8). A nascente arqueologia do século XIX incorpora o discurso evolucionista social para organizar os registros arqueológicos de caçadores coletores com grande profundidade temporal que passam a ser encontrados na Europa, oferecendo suporte empírico para esta visão da realidade ao revelar o progressivo controle das sociedades humanas sobre a natureza, inter-relacionando evolução biológica e tecnológica (Champion et al, 1996; Gamble, 1990; Trigger, 1992).

Na primeira metade do século XX, o repúdio aos esquemas evolucionistas clássicos marca o nascimento da antropologia moderna, assumindo os estudos de caçadores coletores um status fundamental na construção de distintas correntes teóricas ${ }^{6}$. Entre as décadas de 1930 e 1960, os estudos antropológicos de caçadores coletores se polarizam entre duas linhas de pensamento distintas, relacionadas às formas de organização destas sociedades. A primeira enfatiza os fatores estruturais do parentesco, relacionados ao conceito de horda ${ }^{7}$, de Radcliff-Brown, definido em Organização Social das Tribos Australianas, de 1931, modelo retomado e ampliado por Levi-Strauss, na década de 1940. A segunda, destaca a relação entre exploração de recursos e dinâmica da organização social, sendo apresentada por Julian Steward, em seu artigo The economic and social basis of primitive bands, de 1936, no qual o autor redefine a noção de horda através do conceito de bando patrilinear ${ }^{8}$ (Lee \& Daly, 1999: 8). As propostas de Steward foram questionadas por Service, em Primitive Social Organization, de 1962, através do conceito de bando

ocidentais, os antropólogos ocuparam-se do resto do mundo: classificando a diversidade humana e teorizando sobre as condições do presente”.

${ }^{6}$ Lee e Daly (1999: 8) destacam a importância da etnografia de caçadores coletores na obra dos fundadores da antropologia moderna, como os estudos de Boas, no noroeste da Columbia Britânica, e de Kroeber, na Califórnia, para a tradição histórico cultural; os trabalhos de Radcliffe-Brown, entre os Adaman, e de Malinovski, entre os aborígines australianos, para a tradição estrutural-funcionalista; e as obras de Durkheim e Mauss, baseadas na literatura etnográfica sobre os aborígines australianos e esquimós.

${ }^{7}$ As hordas organizam-se a partir de grupos masculinos patrilinearmente relacionados que vivem e trabalham em um estado totêmico e trocam mulheres com outros grupos masculinos. São caracterizadas pela patrilinearidade, patrilocalidade, territorialidade e exôgamia (Lee \& DeVore, 1968: 7).

${ }^{8}$ Os bandos patrilineares seriam um dos três tipos de estrutura de organização social possível para os caçadores coletores, seguidos pelas formas matrilineares e compostas. Os bandos patrilineares são definidos por possuírem autonomia política, posse coletiva da terra transmitida por vínculo patrilinear, exogamia e patrilocalidade, sendo o território do bando ocupado por várias unidades domésticas ou famílias elementares bilaterais (Barnard, 1983: 195). 
patrilocal $^{9}$, gerando entre os antropólogos dos anos 1960 e 1970 um entusiasmo sem precedente pela antropologia ecológica, em geral, e pelos estudos de caçadores coletores, em particular (Barnard, 1983: 195-196; Kelly, 1995: 11-12; Lee \& DeVore, 1968: 7-8).

Contudo, o desenvolvimento dos estudos etnográficos sobre o tema acabou por comprometer o modelo de Service ${ }^{10}$. De acordo com Barnard, “durante este período, as novas gerações acadêmicas deram o coup de grace no modelo patrilocal. Em todo o mundo, sociedades compostas por comunidades de pequena escala demonstraram não ser, essencialmente, nem virilocais, nem patrilineares em qualquer sentido. Fluxo, flexibilidade e fluidez tornaram-se as novas palavras de ordem para descrever a sua organização social” (Barnard, 1983: 196). Avaliando as repercussões atuais quanto ao debate relativo as formas de organização social caçadora coletora, Lee e Daly concluem:

É digno de nota que as teorias sobre a organização dos bandos continuam a ser dominadas por estes dois paradigmas alternativos: um enfoque ecológico $e$ adaptacionista que enfatiza os fatores materiais para a vida social forrageira e um enfoque estrutural que vê o parentesco, sistemas de casamento e outros fatores sociais como determinantes primários. Os dois enfoques não são de forma alguma incompatíveis e, embora as duas tendências sejam ainda discerníveis no estudo de caçadores coletores, muitos pesquisadores têm [hoje] destacado a dialética entre forças ecológicas e sociais da vida forrageira (Lee \& Daly, 1999: 8).

As críticas ao modelo de Steward e Service, no final dos anos 1960, substitui a ênfase em estudos de organização social por modelos centrados nas relações econômicosociais dos sistemas de subsistência caçador coletor (Barnard, 1983: 197). O ponto de partida para esta nova definição da visão dos caçadores coletores como objeto de interesse das ciências humanas está representado pelo Congresso Man the Hunter, realizado em Chicago, em 1966, sob a organização de Richard Lee e Irving DeVore. Segundo Kelly (1995: 14), este representou o divisor de águas para os estudos de caçadores coletores do século XX, reunindo casos etnográficos e arqueológicos da África, Austrália, América do Sul e do Norte, Sub-ártico e Ártico, para discutir aspectos de demografia, organização

\footnotetext{
${ }^{9}$ Service sugere que os bandos patrilocais corresponderiam à base da organização social de todos os grupos caçadores coletores do passado, sendo as formas compostas uma aculturação recente (Barnard, 1983: 195).

10 As estruturas de organização de bando patrilocais de Service não foram confirmadas pelos estudos etnográficos realizados na África por Turbull, entre os Mbuit-Pygmeus, e por Lee e Marshall, entre os !Kung
} 
social e política, territorialidade e evolução, com grande ênfase em questões ambientais e de subsistência.

Um novo paradigma de pesquisa surge para as sociedades caçadoras coletoras, equacionando aspectos de sua economia com as teorias sobre organização social de bando, representado pelo conceito de estilo nomádico, de Lee e DeVore (1968: 11-12), e sumarizado por Kelly (1995: 14-15) através do modelo forrageiro generalizado. Segundo este, as sociedades caçadoras coletoras caracterizam-se pelos seguintes parâmetros gerais:

a) igualitarismo relacionado à mobilidade, pois esta restringe a quantidade de posses individuais e mantém a igualdade material;

b) baixa densidade populacional, mantida abaixo da capacidade de suporte do meio, através de controle intencional da natalidade, organizando-se a sociedade em pequenos grupos que se agregam sazonalmente para fins sociais;

c) ausência de territorialidade, pois a adaptação de longa duração à variabilidade dos recursos requer que os caçadores coletores sejam capazes de circular entre distintas áreas, tornado a defesa de territórios um obstáculo adaptativo;

d) estocagem mínima de alimentos, tendo em vista a relação entre mobilidade, densidade populacional e abundância de recursos; e

e) fluidez na composição do bando, sendo mantidos os laços sociais através de visitas periódicas inter-grupais e mitigadas as tensões internas através da possibilidade de fissão do grupo.

As reflexões apresentadas na conferencia Man the Hunter encontraram sua melhor tradução no conceito de sociedade afluente original de Marshal Sahlins (1968, [1972] 1977), que pode ser considerado um marco na representação das sociedades caçadoras coletoras na antropologia contemporânea. Por sua vez, a exploração teórica do modelo de Sahlins, bem como a revisão crítica de suas bases empíricas caracteriza, em termos gerais, as tendências dos estudos na área ao longo das últimas três décadas (Barnard, 1983; Bender \& Morris, 1988; Bettinger, 1991; Lee e Daly, 1999; Myers, 1988).

Segundo Kelly, o conceito de sociedade afluente original pode ser compreendido a partir do contexto no qual foi elaborado.

As noções de progresso do século XIX entravam em colapso, e no lugar de uma inexorável escalada, a evolução parecia 
agora uma descida em espiral de um estado de graça inicial, uma queda do Éden. Crescentemente insatisfeitos, os ocidentais buscavam um modo de vida alternativo, no qual as posses materiais significavam pouco, onde as pessoas viviam em harmonia, onde não havia fronteiras nacionais a defender (Kelly, 1995: 15).

A utilização da imagem dos caçadores coletores para a construção de um discurso engajado em uma crítica à sociedade contemporânea está presente na base do modelo de Sahlins, que se contrapõe à noção de que a riqueza é um produto da evolução cultural.

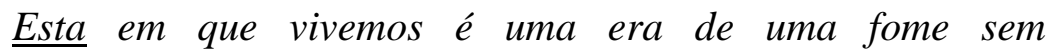
precedentes. Agora na época do maior poder tecnológico, a fome é uma instituição (...) [e] aumenta relativa $e$ absolutamente com a evolução da cultura. Este paradoxo responde, por completo, o meu ponto de vista. (...) A evolução da economia conheceu, então dois movimentos contraditórios: o enriquecimento, porém simultaneamente o empobrecimento, a apropriação com relação à natureza, porém a expropriação com relação ao homem. (...) A pobreza é um estado social. E como tal é uma invenção da civilização (...) [e] foi só quando a cultura se aproximou do ápice de suas conquistas materiais que se construiu o altar do Inalcançável: as necessidades infinitas (Sahlins, [1972] 1977: 51-53).

Para Sahlins, uma sociedade afluente é aquela na qual todas as necessidades materiais das pessoas são facilmente satisfeitas. Considerar as sociedades caçadoras coletoras como afluentes é negar que a condição humana é "uma tragédia decretada onde o homem é prisioneiro do trabalho árduo que significa a perpétua disparidade entre suas carências ilimitadas e a insuficiência de seus meios” (Sahlins, [1972] 1977: 13). Os caminhos possíveis para a afluência podem se dar tanto produzindo muito (modo de Galbraith) ou desejando pouco (caminho Zen). No primeiro caso, adota-se a postura da economia de mercado, segundo a qual as necessidades humanas são infinitas, enquanto os meios para satisfazê-las são limitados. No segundo caso, as sociedades caçadoras coletoras partem de uma premissa distinta da sociedade contemporânea, na qual as necessidades humanas são finitas e adequadas aos meios técnicos disponíveis para satisfazê-las (Sahlins, [1972] 1977: 13-14). Para o autor,

A sombria visão tradicional da situação dos caçadores coletores é pré-antropológica e extra-antropológica; é, por sua vez, histórica e refere-se ao contexto econômico mais amplo no qual a antropologia opera. Remonta a época em 
que escreveu e teorizou Adam Smith e provavelmente a uma época em que ainda não se escrevia. É possível que seja um dos preconceitos mais claros do Neolítico, uma apreciação ideológica relativa a capacidade do caçador para explorar os recursos da terra a qual está de acordo com o empenho histórico de privá-lo da mesma (Sahlins, [1972] 1977: 15).

No caminho Zen para a afluência adotado pelos caçadores coletores, na esfera da não-subsistência as necessidades são facilmente satisfeitas de forma igualitária, tendo em vista a simplicidade tecnológica, a noção de partilha dos recursos (sharing) que norteia a vida social e a divisão sexual do trabalho. A chave para compreender o modo Zen caçador coletor encontra-se no seguinte princípio organizador: "não desejar é não carecer” (Sahlins, [1972] 1977: 24). Portanto, o baixo padrão de acumulação não é restrito pelas demandas da subsistência, mas em função de suas estratégias de organização, centrada na mobilidade, para a qual "a fortuna é uma carga agoniante” quando é necessário transportá-la, uma vez que "mobilidade e propriedade são incompatíveis" (Sahlins, [1972] 1977: 24). Esta perspectiva lança as bases para um entendimento da economia caçadora coletora por princípios norteadores distintos dos pressupostos da teoria econômica ortodoxa ${ }^{11}$. Nas palavras de Sahlins:

Pode-se sentir a tentação de dizer que o caçador é um "Homem Anti-econômico". Pelo menos no que diz respeito aos artigos não essenciais para a subsistência, ele é o oposto da caricatura clássica imortalizada na primeira página de qualquer tratado sobre "Princípios Gerais da Economia". (...) Desde a perspectiva interna da economia é errôneo afirmar que as necessidades estão "restringidas", os desejos "reprimidos" e inclusive que a noção de fortuna é "limitada". Ditas afirmações implicam de antemão na noção de Homem Econômico e na luta do caçador coletor com sua própria natureza inferior dominada, finalmente, por um voto cultural de pobreza. Essas palavras implicam na renúncia a uma possibilidade de aquisição que, em realidade, nunca chegou a desenvolver-se, na supressão de um desejo que nunca se pensou. O Homem Econômico é uma invenção

\footnotetext{
11 "Quanto mais aprendemos sobre os caçadores coletores, mais percebemos que as crenças culturais envolvendo o capitalismo moderno de mercado não refletem uma 'natureza humana' universal. Concepções (...) de que os humanos são naturalmente competitivos e aquisitivos e de que a estratificação social é natural, não se aplica a muitos dos povos caçadores coletores. A escola dominante de teoria econômica no mundo industrializado, a economia neoclássica, considera estes atributos como essenciais para o avanço econômico e a afluência (...). Porém, a existência de sociedades vivendo adequadamente, e mesmo alegremente, sem indústria, agricultura e poucas posses materiais oferecem um desafio ao conceito de natureza humana adotado pela maioria dos economistas” (Gowdy, 1999: 391). Para outras críticas relativas a teoria econômica neoclássica, tendo por base a concepção de sociedade afluente original ver Gowdy $(1998,1999)$.
} 
burguesa, (...) [e] não se trata que os caçadores coletores hajam dominado seus "impulsos" materialistas, senão que simplesmente nunca fizeram deles uma instituição (Sahlins, [1972] 1977: 26).

Para analisar os aspectos relacionados à subsistência caçadora coletora, Sahlins faz uso dos dados relativos à produção alimentícia de dois estudos de caso etnográficos ${ }^{12}$. Com base nas conclusões de ambas pesquisas, o autor propõe uma estrutura geral para a subsistência caçadora coletora baseada nos seguintes princípios: os caçadores coletores trabalham pouco e a obtenção do alimento não se dá através de um investimento contínuo, mas organiza-se de forma intermitente, deixando muito tempo livre para o ócio, o qual redunda em uma "proporção de sono durante o dia per capta maior que em qualquer condição social” (Sahlins, [1972] 1977: 27). Outro aspecto que caracteriza esta estratégia de subsistência está relacionado a "estudada despreocupação” com a falta de previsão, estando esta orientada para o presente e expressa por duas inclinações econômicas complementares: prodigalidade e ausência de estocagem de excedentes alimentares. Estes aspectos relacionam-se a relação contraditória entre acúmulo de riqueza e mobilidade e orientam-se pela manutenção dos recursos naturais (Sahlins, [1972] 1977: 44-45). A economia caçadora coletora é seriamente afetada pela eminência de diminuição dos recursos, “daí a primeira e fundamental contingência da caça e da coleta: exigem movimento para manter uma produção vantajosa”, o mesmo aplicando-se quanto ao constrangimento demográfico (Sahlins, [1972] 1977: 47).

A caça e a coleta têm toda a força que lhe proporciona suas debilidades. O deslocamento periódico e as restrições quanto à fartura e à população são, ao mesmo tempo, imperativos da prática econômica e adaptações criativas. (...) É precisamente neste marco que se faz possível a afluência. A mobilidade e a moderação põem os fins dos caçadores ao alcance dos seus recursos técnicos. É assim que uma modalidade de produção não evoluída pode-se mostrar tão eficaz (Sahlins, [1972] 1977: 49).

As críticas quanto à abrangência do conceito de sociedade afluente original assumem um papel central na antropologia de caçadores coletores nas décadas de 1980 e 1990, estimulando o debate e o desenvolvimento das pesquisas em torno de quatro 
tendências gerais. A primeira estaria caracterizada por um enfoque relacionado à tradição materialista histórica e neo-marxista, que busca ampliar a carga interpretativa do modelo de afluência original através de uma vinculação mais explícita à sociologia comparativa. Uma segunda linha de pesquisa pode ser designada como adaptacionista, sócio-ecológica ou ecológico comportamental e está centrada na análise de aspectos adaptativos relativos à subsistência caçadora coletora. A preocupação central desta linha de pesquisa está voltada a exploração dos suportes empíricos do modelo de afluência através de referências teóricometodológicos Neo-Darwinistas, a fim de compreender os mecanismos adaptativos gerais que regem o comportamento forrageiro. Por fim, as críticas ao modelo de afluência original a partir de uma tendência teórica pós-estruturalista, vinculam-se aos enfoques revisionistas ou historicistas, cuja ênfase situa-se na necessidade de contextualização histórica da pesquisa etnográfica, e aos enfoques indigenistas ou humanistas, voltados à discussão de políticas sociais relacionadas às sociedades caçadoras coletoras remanescentes (Barnard, 1983; Bender \& Morris, 1988; Bettinger, 1991; Burch, 1996; Kelly, 1995; Lee [1992] 1998; Lee \& Daly, 1999; Myers, 1988).

Nas décadas de 1970 e 1980 o modelo de sociedade afluente original estimulou o aprofundamento das discussões teóricas quanto às características da economia política caçadora coletora, através de uma incorporação mais explícita de referenciais marxistas, divididos em duas vertentes. A primeira está centrada em um enfoque materialista histórico, com influência inicial de Meillassoux, estando as análises teóricas voltadas a compreender as relações de produção próprias às sociedades caçadoras coletoras. Derivam destas reflexões os conceitos de modo de produção forrageiro ${ }^{13}$, de Leacock e Lee (1982; ver também Lee, 1981, 1988) e de modo de produção doméstico ${ }^{14}$, de Sahlins ([1972]

12 O primeiro corresponde aos dados arrolados por McCarthy, McCarthy e McArthur junto à Expedição Científica Americana-australiana realizada a Arnhem Land em 1948 e o segundo diz respeito aos dados arrolados por Lee (1968) entre os !Kung San do Kalahari.

${ }^{13}$ Em termos gerais, o modo de produção forrageiro é caracterizado pela posse coletiva dos meios de produção (terra e seus recursos), pelo direito ao acesso recíproco dos recursos de outros através de alianças sociais ou de casamento, pela pouca ênfase na acumulação, pelas relações de divisão e reciprocidade que norteiam a distribuição dos recursos obtidos e pelo acesso igualitário aos instrumentos necessários à aquisição de recursos (Kelly, 1995: 31). Para a crítica neo-marxista ao conceito de modo de produção forrageiro ver Ingold (1988, 1999).

${ }^{14} \mathrm{O}$ conceito de modo de produção doméstico de Sahlins centra-se nas relações de reciprocidade que ordenam a interação social pré-capitalista, estando mais diretamente relacionado às formas de organização sociais segmentárias de agricultores e pastores. Segundo este, as unidades elementares da sociedade, são as unidades domésticas autônomas de produção e consumo que possuem acesso imediato aos seus próprios meios de subsistência, sendo a reciprocidade um mediador de relações de distribuição da produção entre unidades domésticas (Ingold, 1999: 400-401). 
1977), bem como as propostas tipológicas de Woodburn ${ }^{15}$ ([1982] 1998), quanto aos sistemas de produção caçador coletor.

Uma segunda vertente de análise, influenciada por Godelier, parte das críticas do estrutural marxismo ou neo-marxismo à ortodoxia materialista, segundo as quais a compreensão das diferenças significativas, em termos sociológico, das sociedades caçadoras coletoras deve abranger as relações internas ou processos constitutivos da vida social, não se restringindo apenas a aspectos da subsistência. Diferente do materialismo dialético, a ênfase da análise recai sobre as relações sociais de produção, segundo as quais os caçadores coletores são também movidos por relações inerentes de exploração e contradições entre relações sociais e ideológicas. Destaca-se nesta linha de pesquisa os trabalhos de Tim Ingold que enfatizam as relações sociais que embasam a apropriação coletiva dos recursos e a noção de territorialidade entre os caçadores coletores, buscando compreender reciprocidade e redistribuição não como categorias adaptativas, mas como aspectos constitutivos do modo de vida caçador coletor (Ingold, 1986, 1988, 1999, 2000). Os aspectos políticos relacionados ao conceito de bando também são questionados pela ótica neo-marxista, enfatizando as relações dialéticas e conflitantes também presentes nas sociedades não estratificadas, como o demonstrado pelos estudos de gênero (Leacock, [1992] 1998; ver também Endicott, 1999).

A principal contribuição da linha de pesquisa marxista, em suas distintas vertentes, reside no fato de transformar o sujeito social em um componente crítico para a compreensão antropológica das sociedades caçadoras coletoras. Contudo, o debate estimulado por esta corrente, por se centrar em discussões de ordem conceitual voltadas à construção de modelos gerais sobre o comportamento caçador coletor, carece, muitas vezes, de bases empíricas (Barnard, 1983: 201-208; Bender e Morris, 1988: 5-7; Kelly, 1995: 29-32; Myers, 1988: 267-273).

Fazendo frente à imprecisão da base empírica dos modelos materialistas de subsistência caçadora coletora, uma linha de oposição delineia-se a partir da adoção dos modelos ecológicos de forragem optima, elaborados por Charcov, e de referenciais

\footnotetext{
15 De acordo com o modelo do autor a organização das estratégias de subsistência entre as sociedades caçadoras coletoras pode se dar de duas formas básicas em função do tipo de retorno de investimento no trabalho. Nas sociedades igualitárias a subsistência organiza-se prevendo o retorno imediato, sem criação de excedentes, sendo os recursos consumidos diariamente. Uma forma alternativa de organização da subsistência prevê o retorno retardado dos benefícios do trabalho, havendo estocagem de alimento para consumo posterior ou investimento em benefícios sociais relacionados à reciprocidade, podendo estes grupos ser ou não igualitários (Kelly, 1995: 31).
} 
interpretativos do comportamento humano derivados da sócio-biologia e do neodarwinismo. Com fortes raízes na tradição ecológico cultural e neo-evolucionista da antropologia norte americana, os defensores desta vertente advogam em favor de um paradigma estritamente científico no estudo dos grupos caçadores coletores através do uso de estratégias nomotéticas de pesquisa e de metodologias quantitativas de análise (Lee \& Daly, 1999: 9-11; Lee [1992] 1998: 167-169).

A escolha deste enfoque teórico para o estudo da subsistência caçadora coletora centra-se no fato de que, em termos comportamentais, estes grupos são definidos por sua economia considerada ecológica por natureza, ao lidar com recursos não domesticados ou manejados ativamente (Winterhalder, 2001: 12). Por outro lado, parte-se do princípio de que os humanos estão suscetíveis aos mesmos processos evolutivos que os animais, sendo sua adaptação também resultante de processos de seleção natural e reprodução diferencial. Desta forma, a ecologia comportamental busca saber como os processos evolutivos e, em particular, a seleção natural, modelam as sociedades humanas (Kelly, 1995: 49-50). Em termos gerais, a ecologia comportamental preocupa-se com a persistência diferencial da variabilidade do comportamento de forragem entre caçadores coletores através do tempo. A relação com o referencial neo-darwinista associa-se à busca dos mecanismos adaptativos que regem as tomadas de decisões e como um dado comportamento é transmitido, modificado e/ou descartado ${ }^{16}$. Sua atenção está voltada à interação entre comportamento humano e meio ambiente, examinando, em especial, aspectos da seleção alimentar e como as escolhas de forragem afetam a interação social e são afetadas por esta, através do investimento parental, das relações de gênero e da reciprocidade e distribuição alimentar, entre outros.

As estratégias de análise se dão através da aplicação de modelos matemáticos, derivados da micro-economia, desenvolvidos por ecologistas interessados em compreender quais fatores afetam o comportamento forrageiro não-humano. Estes modelos foram

\footnotetext{
${ }^{16}$ Kelly (2000: 64-65) ressalta que a ecologia comportamental difere-se de outros enfoques evolutivos como o selecionista ou a arqueologia evolutiva que tratam o conceito de seleção como um traço que aumenta a adequação reprodutiva de seus portadores, tornando-se mais comum ao longo do tempo. A ênfase na ecologia comportamental situa-se no sucesso replicativo de um traço e não no sucesso reprodutivo de seus portadores. Para uma melhor compreensão das diferenças centrais na antropologia de vertente neo-darwinista norte americana ver a defesa da ecologia comportamental em Bettinger (1987, 1991), Kelly $(1995,2000)$ e Whinterhalder (1981, 2001); e a defesa do selecionismo ou arqueologia evolutiva em O'Brien e Lyman (2000) e na coletânea de artigos centrais a esta vertente teórica editada por O’Brien (1996).
} 
adaptados ao estudo de populações modernas de caçadores coletores ${ }^{17}$, baseado no pressuposto de que o objetivo da forragem é sempre maximizar a taxa de retorno energético por unidade de tempo de forragem, sendo também comumente utilizados em análises arqueológicas. A partir da aplicação destes modelos de forragem optima busca-se predizer quão diversificada uma dieta pode ser (diet breath model), em quais locais podese buscar alimentos (patch choise model) ou por quanto tempo deve-se buscar alimento em um dado local (marginal value theorem) ${ }^{18}$ (Bettinger, 1991: 83-84; Kelly, 2000: 64-67). Por sua vez, os modelos permitem realizar predições, baseados em um número limitado de parâmetros, que identificam as qualidades básicas de soluções adaptativas recorrentes em determinados tipos de ambientes (Kelly, 1995: 109; Winterhalder, 1981: 13).

Analisando os desdobramentos atuais desta linha de pesquisa, Lee e Daly (1999: 11) destacam o fato de que enquanto alguns defensores desta corrente enfocam questões de demografia e subsistência de uma posição historicamente contextualizada, reconhecendo o impacto das forças externas na organização socio-econômica das populações estudadas, um número significativo continua "a marchar sob a bandeira da sociobiologia neodarwiniana”, estreitando seu foco de análise em modelos quantitativos dos comportamentos forrageiros como se estes existissem em isolamento, falhando em reconhecer os caçadores como atores conscientes, "vivendo e enfrentando, através do tempo, os mesmos desafios que o resto dos habitantes do planeta que os cercam”. Ingold ressalta que o uso de teorias gerais biológicas como a neo-Darwiniana tem pouco a contribuir para a compreensão da ação, intenção ou preferências subjetivas humanas, uma vez que foram originalmente desenvolvidas para compreender como animais não-humanos, desprovidos de razão, foram capazes de desenvolver estratégias de comportamento altamente racionais. A aplicação e teste de modelos preditivos para as populações

\footnotetext{
${ }^{17}$ Os principais estudos etnográficos para teste dos modelos da ecologia comportamental correspondem aos trabalhos de Hawkes, Hill, Kaplan e Hurtado entre os Aché do Paraguai, aos estudos comparativos de Hawkes e O’Connel entre os Alyawara da Austrália, os Hazda e os !Kung San da África Ocidental e do Sul e os estudos de Winterhalder e Smith para as populações caçadoras coletoras do ártico e sub-ártico (Bettinger, 1991: 98-99; para referências bibliográficas específicas sobre estes trabalhos ver Kelly, 1995; Lee \& Daly, 1999).

18 Os modelos de forragem optima mais usualmente utilizados pela ecologia comportamental são os seguintes: modelo de amplitude de dieta (diet breath model) (Winterhalder, 1981: 23-26; Bettinger, 1991: 8487; Kelly, 1995: 78-90), modelo de escolha de área de forragem (patch choise model) (Winterhalder, 1981: 26-30; Bettinger, 1991: 87-90; Kelly, 1995: 90-98); teorema do valor marginal (marginal value theorem) (Bettinger, 1991: 90-93), modelo do lugar central de forragem (central place foraging) (Bettinger, 1991: 9397), modelo de programação linear (linear programming) (Bettinger, 1991: 116-118; Kelly, 1995: 74-77), modelo de Z-score (Bettinger, 1991: 119-124) e modelo de capacidade de suporte (carrying capacity)
} 
caçadoras coletoras, na visão de Ingold, não revelam os processos de seleção natural do mundo real, mas são apenas reflexos da razão científica no espelho da natureza, que incorporam modelos de comportamento como se correspondessem a explicações para o comportamento (Ingold, 1992: 799-800; 2000: 38). Igualmente, deve-se considerar que a seleção de recursos voltados para alimentação corresponde a um aspecto culturalmente definido e os modelos de forragem optima não dão conta dos recursos que são explorados ou excluídos por razões não energéticas ou por seu valor não-alimentar, bem como das motivações sócio-ideológicas relacionadas, por exemplo, à seletividade (tabus alimentares) e ao empenho diferencial no grupo quanto à produtividade (prestígio masculino) (Kelly, 1995: 109).

Uma outra vertente crítica ao modelo de afluência original, de orientação pósestruturalista, está relacionada ao chamado enfoque revisionista ou historicista que parte do princípio que a categoria caçador coletor foi definida como um tipo evolutivo, fortemente baseada em um referencial ecológico, reduzindo o estudo destas populações ao privilegiar um presente etnográfico atemporal. As principais críticas partem do princípio de que a compreensão das estruturas organizativas das sociedades caçadoras coletoras depende da contextualização histórica destes grupos, marcada pelo contato com a sociedade envolvente, seja no passado pré-colonial, seja no presente etnográfico. Defendendo a idéia de que não se pode tratar as sociedades não-ocidentais como a-históricas, esta linha de pesquisa busca situar os caçadores coletores em suas histórias específicas e desconstruir a bagagem conceitual e as preconcepções impostas a esta categoria de estudo.

A maior parte das críticas do enfoque revisionista centra-se no paradigma ecológico adotado ma maioria das análises, na falta de sentido analítico da categoria caçador coletor e na impossibilidade de utilizar fontes etnográficas como meios de interpretação do passado pré-histórico, principalmente em termos econômicos. O chamado “debate do Kalahari” representa uma parte significativa da discussão revisionista, cujas críticas principais estão presentes em Schrire (1984). A ênfase do debate relaciona-se ao fato de que a história dos !Kung San faz parte de um sistema social de trocas, interação e intercâmbio com outras sociedades, principalmente os pastoralistas de língua Bantu, ao longo de séculos (Myers, 1988: 262-263; ver também Burch, 1996). Esta perspectiva pósestruturalista produziu uma forte reação nos estudos tradicionais da área, trazendo como 
aspecto positivo um redirecionamento das pesquisas comparativas que passaram a enfatizar aspectos da variabilidade do comportamento e destacar como os históricos de contato intergrupais afetam as estruturas sociais e econômicas remanescentes dos caçadores coletores e desencadeiam estratégias de resistência (Kent, 1996; Lee 1991, [1992] 1998; Lee \& DeVore, 1998; Yellen, 1990, [1990] 1998; ver também Bird-David, 1988, 1996, [1992] 1998; Woodburn, 1988).

Central a este modelo está o questionamento de em que medida os aspectos sócioculturais observados entre os caçadores coletores lhes são intrínsecos ou produto da interação com sociedades não caçadoras coletoras. Contudo, este tipo de reflexão, designado por Kelly como “modelo interdependente” ou “modelo primitivo profissional”, aos desconsiderar em suas análises aspectos de ordem evolutiva ou ecológica, recai em um estereótipo que reduz todas as características comuns aos caçadores coletores a um produto da interação com outras sociedades. Em última instância, este novo estereótipo, centrado em questões de poder e controle, trata os caçadores coletores como um proletariado rural despossuído, negando seu valor enquanto objeto de estudo antropológico e/ou arqueológico (Kelly, 1995: 23-27).

Um exemplo da aplicação do modelo interdependente para o estudo dos caçadores coletores de florestas tropicais pode ser encontrado no debate desencadeado pelos trabalhos de Bailey, Headland e colaboradores (Bailey et al, 1989; Bailey \& Headland, 1991; Headland, 1987; Headland \& Reid, 1989). Inspirados nos modelos ecológicos ortodoxos, definidos por Steward e seguidos por Meggers e Lathrap, os autores advogam pela impossibilidade de subsistência caçadora coletora em ambiente tropical sem acesso direto ou indireto a produtos cultivados, tendo em vista a baixa disponibilidade natural de lipídios e carboidrato nestes ambientes (Myers, 1982; Rival, 1999). No início da década de 1990, este modelo sofreu severas críticas, centradas na metodologia empregada pelos autores que se baseou na utilização inadequada de princípios de analogia geral e na análise superficial dos sistemas de subsistência estudados ${ }^{19}$. Em resposta às críticas, Headland e Bailey (1991), reorientaram suas propostas originais, refutando a idéia de homogeneidade dos ambientes tropicais e admitindo que a ligação entre caçadores coletores e vizinhos

\footnotetext{
${ }^{19}$ Ver Bahuchet, McKey e Garine (1991) para a economia do inhame selvagem entre os Pigmeus do Congo; Dwyer e Minnegal (1991) para a economia de caça entre os Kubo da Papua Nova Guiné; Brosius (1991) para a importância da coleta de sagu entre os Penan de Borneo; Stearman (1991) para a subsistência caçadora coletora entre os Yuqui na Amazônia Boliviana; Endicott e Bellwood (1991) para análise da economia caçadora coletora dos Batek na Península Malaia; e Politis (1996a) para os Nukak da amazônia colombiana.
} 
agricultores foi superestimada nas propostas originais, podendo as relações de troca ser efetivamente orientadas por princípios econômicos alheios à subsistência.

Por último, os enfoques indigenistas ou humanistas, correspondem a uma segunda vertente de análise da perspectiva pós-estruturalista, voltada a compreender, sem propósitos comparativos, a realidade política da vida caçadora coletora associada ao engajamento nas lutas por autonomia e questões agrárias, destacando, igualmente, o universo simbólico destes grupos. De acordo com esta ótica, os caçadores coletores contemporâneos vivem em um mundo no qual a relação de diálogo entre culturas não pode ser desconsiderada, uma vez que define muito do significado corrente das estruturas estudadas, devendo a pesquisa antropológica assumir um engajamento cientificamente responsável (Kelly, 1995: 27; Lee \& Daly, 1999: 11; Myers, 1988: 274-276; ver também Bodley, 1999; Endicott, 1997; Gibson, 1997; Hitchcock, 1999; Kaare, 1996; Layton, 2001; Merculieff, 1996; Scott, 1997; Tonkinson, 1997; Trigger, 1999).

O modelo de afluência da década de 1970 apresenta reflexos na arqueologia de caçadores coletores, principalmente nos países de língua inglesa, dominada até então por um paradigma de pesquisa histórico-cultural. Segundo Bettinger (1991: 58-59), os modelos para caçadores coletores derivados da Nova Arqueologia das décadas de 1960 e 1970, ao centraram-se nos referenciais teóricos da ecologia cultural e do neo-funcionalismo, não obtiveram sucesso na construção de modelos sobre a adaptação humana relacionados aos aspectos que causam mudança nos sistemas culturais. A influência dos estudos antropológicos sobre o tema, por sua vez, fez com que em finais da década de 1970 e início dos anos 1980 as pesquisas arqueológicas de caçadores coletores tenham desenvolvido reflexões mais sofisticadas quanto à relação entre modelos explicativos e dados empíricos que se desenvolveram em torno de três linhas de pesquisa básicas.

Uma primeira tendência está relacionada ao desenvolvimento de modelos actualísticos voltados à interpretação do registro arqueológico de caçadores coletores através de teorias de médio alcance, relacionadas aos estudos etnoarqueológicos de Lewis Binford e a arqueologia comportamental de Michael Schiffer. Destacam-se os estudos dos processos de formação de sítio, bem como a elaboração de modelos interpretativos sobre mobilidade, sistema de assentamento, variabilidade intra-sítio e organização tecnológica para o estudo arqueológico de sociedades caçadoras coletoras.

Uma segunda linha de pesquisa está associada à aplicação e teste de modelos heurísticos derivados da ecologia comportamental aos contextos arqueológicos de caçadores coletores. A ênfase destes estudos tem se centrado nos aspectos adaptativos dos 
sistemas de subsistência e nos mecanismos que levam a mudança e transformação nos padrões observados, sendo também utilizada como referencial de análise sobre padrões organizativos da tecnologia lítica (Kelly, 2000).

Por fim, o desenvolvimento das pesquisas arqueológicas de caçadores coletores revelou um registro marcado pela variabilidade adaptativa e por um padrão de complexidade raramente encontrado no registro etnográfico, estimulando a incorporação deste objeto pela arqueologia social. Estes estudos têm centrado suas reflexões na compreensão e caracterização dos processos de transformação econômica e política que conduzem à emergência de complexidade social, polarizando a variabilidade das formas de organização das sociedades caçadoras coletoras entre categorias opostas: sociedades simples versus complexas, igualitárias versus não igualitárias, de retorno imediato versus retorno retardado (Arnold, 1996; Cohen, 1995; Gamble, 2000; Gould, 1995; Hayden et al, 1995; Hayden, 1996; Kelly, 1995; Price \& Brown, 1995; Rowley-Conwy, 2001).

As tendências teóricas da pesquisa contemporânea de caçadores coletores só recentemente têm sido incorporadas à arqueologia brasileira. O teste de modelos de sistema de assentamento e mobilidade para ocupações caçadoras coletoras associadas à Tradição Umbu foi realizado por De Blasis $(1988,1996)$, para o vale do rio Ribeira do Iguape (São Paulo), seguindo a mesma tendência as pesquisa de De Masi (2001) para as ocupações litorâneas da Lagoa da Conceição, em Florianópolis (SC). Também um primeiro passo para o teste de modelos heurísticos relacionados à ecologia comportamental foi realizado por Kipnis (2002), no estudo dos contextos arqueológicos de caçadores coletores da transição Pleistoceno-Holoceno, associados à região de Santana do Riacho e Peruaçu, em Minas Gerais.

A proposta desta tese volta-se para contribuir na ampliação das reflexões teóricas relativas à arqueologia de caçadores coletores no sul do Brasil, através do teste de modelos actualísticos sobre mobilidade, sistema de assentamento, variabilidade intra-sítio e organização tecnológica. Nos últimos 30 anos, as pesquisas arqueológicas sobre o tema na região organizaram-se em torno de três linhas de pesquisa. Em um primeiro momento, entre as décadas de 1960 e 1970, a ênfase centrou-se no levantamento de dados de campo e no estabelecimento de datações a fim de definir conjuntos culturais diferenciados espaçotemporalmente através dos conceitos de fase e Tradição arqueológica. A década de 1980, marca uma segunda etapa, voltada à elaboração de sínteses dos trabalhos anteriores, procurando dar uma coerência interpretativa aos dados e criar um primeiro modelo quanto aos modos de vida representados pelos conjuntos líticos até então identificados. Estas 
sínteses estimularam, na década de 1990, o desenvolvimento de estudos tecno-tipológicos sistemáticos para as coleções do Rio Grande do Sul, com o objetivo de compreender o universo subjacente ao conceito de Tradição e preencher as lacunas interpretativas deixadas pelos trabalhos iniciais (Dias, 1999a: 52).

No entanto, para compreender quais aspectos comportamentais influenciam a variabilidade lítica representada pelo conceito de Tradição, torna-se necessário adotar uma orientação teórico-metodológica que considere a inter-relação dos sítios arqueológicos como unidades que compõe um sistema de assentamento. Por outro lado, o desenvolvimento de projetos de caráter regional de tal tipo deve orientar-se por modelos que iluminem as formas de estruturação dos sistemas de mobilidade e assentamento próprios às sociedades caçadoras coletoras e como estas se refletem na organização da tecnologia, gerando variabilidade entre os conjuntos líticos. As contribuições do conceito de sistema de assentamento e dos estudos etnoarqueológicos de caçadores coletores para a construção de modelos arqueológicos sobre o tema são avaliados no primeiro capítulo desta tese. A interpretação da variabilidade dos conjuntos artefatuais de caçadores coletores a partir do conceito de estilo tecnológico, em sua inter-relação com a estruturação de um sistema de assentamento, também são tratadas neste capítulo, sendo estes os instrumentais teóricos utilizados na elaboração de modelos interpretativos desenvolvidos ao longo deste trabalho.

Em um primeiro momento, nosso estudo estava direcionado para a análise de contextos arqueológicos relacionados exclusivamente aos caçadores coletores da Tradição Umbu. Tendo em vista esta orientação inicial, optou-se por trabalhar com a região do Alto Rio dos Sinos, no Estado do Rio Grande do Sul, cujos resultados de pesquisas anteriores apontavam para um grande potencial para este tipo de estudo. Contudo, tendo em vista a orientação teórico-metodológica deste trabalho, o desenvolvimento das pesquisas de campo acabaram também por revelar conjuntos líticos identificados em vários sítios da área, associados a sistemas de assentamento de grupos horticultores Guarani e Jê, cujas características correspondiam aos fósseis guia clássicos da Tradição Humaitá (choppers, chopping tools, talhadores e bifaces de grande porte). Desta forma, ampliamos nossa análise a fim de incorporar a proposta original problemáticas também relacionadas à Tradição Humaitá, cujos conjuntos líticos, pelo menos na região estudada, apresentam uma correlação contextual clara com sistemas de assentamento de grupos horticultores. As características ambientais da região estudada, as propostas metodológicas empregadas nas 
prospecções e os resultados obtidos encontram-se no capítulo dois, tratando os capítulos seguintes das especificidades de cada um dos sistemas de assentamento estudados.

Para a interpretação dos aspectos que caracterizam o sistema de assentamento associado à Tradição Umbu, optamos por trabalhar com um referencial analítico derivado de pesquisas etnoarqueológicas sobre sociedades caçadoras coletoras adaptadas a áreas florestais, cujo ambiente apresenta correlação com o encontrado na área de estudo. Raros são os trabalhos etnoarqueológicos para caçadores coletores de áreas tropicais ${ }^{20}$ voltados a testar a validade do modelo de sistema de assentamento forrageiro proposto por Binford (1980). Uma exceção a este quadro corresponde aos estudos realizados por Politis entre os Nukak, da Colômbia (1996a, 1996b, 1996c, 1998, 2001; Politis et al, 1997; Politis \& Sauders, 2001) e por Borrero e Yacobbacio (1989) e Jones (1993) para os Aché, do Paraguai. Seguindo estes autores, no capítulo três abordamos como os dados etnoarqueológicos sobre mobilidade caçadora coletora em área de floresta tropical podem contribuir para gerar um modelo interpretativo sobre o sistema de assentamento representado pelo conjunto de sítios arqueológicos relacionados à Tradição Umbu, identificados em nossa área de estudo.

Com o objetivo de testar os modelos propostos, realizamos escavações em três sítios de caçadores coletores associados a abrigos sob rocha. Estas escavações foram orientadas para a realização de estudos comparativos quanto à variabilidade intra-sítio e inter-sítios relacionados a um sistema de assentamento caçador coletor. Os resultados destas escavações que complementam as conclusões do capítulo anterior, bem como a interpretação dos dados obtidos a luz dos modelos etnoarqueológicos de formação do registro arqueológico de grupos forrageiros de floresta tropical são apresentados no capítulo quatro.

O mesmo tipo de estratégia interpretativa empregado no estudo do sistema de assentamento caçador coletor foi utilizado para a análise dos sistemas de assentamento de horticultores da região estudada, relacionados às Tradições Guarani e Taquara, analisados no capítulo cinco. Os modelos etnoarqueológicos para os sistemas de assentamento Guarani pré-colonial do sul do Brasil, desenvolvidos por vários autores ao longo da década

\footnotetext{
${ }^{20}$ Esta escassez, em parte, é motivada por uma pré-concepção sobre a natureza dos caçadores coletores de floresta tropical, derivados dos modelos ortodoxos, das décadas de 1950 e 1960, e reforçados pelos modelos interdependentes, no início dos anos 1990. A ausência de dados arqueológicos que questionassem estes pressupostos, garantiu sua permanência até recentemente, sendo as críticas ao modelo derivadas de variados trabalhos de ecologia humana que permitiram revisar as hipóteses de limitação protéica e de carboidratos para a manutenção de caçadores coletores na floresta tropical.
} 
de 1990, foram utilizados para a interpretação dos sítios localizados nas prospecções realizadas. A construção de modelos de mobilidade e sistema de assentamento para as populações Jê pré-coloniais relacionadas à Tradição Taquara, encontra-se, por sua vez, em seus primeiros passos, sendo os resultados destas pesquisas incorporados à análise apresentada neste mesmo capítulo. A relação entre ocupações pré-coloniais e as frentes de colonização portuguesa que se estabelecem na região no início do século XVIII, concluem nosso estudo sobre os sistemas de assentamento pré-colonais no Alto Vale do Rio dos Sinos.

Tomando por base os dados contextuais, derivados de nossas pesquisas de campo, realizamos no último capítulo o estudo comparativo da organização tecnológica dos conjuntos líticos associados aos três distintos grupos culturais identificados na região estudada. Organizamos nossa análise de acordo com a premissa teórica de que estilo tecnológico é o resultado de escolhas culturalmente determinadas, que se refletem na seleção das matérias primas, nas técnicas e seqüências de produção e nos resultados materiais destas escolhas. A comparação entre estilos tecnológicos de distintas indústrias líticas de uma mesma região permite, portanto, antever a possibilidade de distinção entre identidades sociais ou culturais no registro arqueológico. Através desta estratégia buscamos interpretar a variabilidade artefatual das indústrias líticas do sul do Brasil, analisando de forma comparativa os conjuntos líticos identificados na região do Alto Vale do Rio dos Sinos, destacando as distintas estratégias empregadas relacionadas à organização da tecnologia lítica pelos grupos caçadores coletores, associados à Tradição Umbu, e pelos grupos horticultores, relacionados às Tradições Guarani e Taquara, cujas características seriam tradicionalmente relacionadas à Tradição Humaitá.

Buscamos a partir dos resultados das pesquisas no Alto Vale do Rio dos Sinos apontar uma via alternativa de interpretação para as indústrias líticas do sul do Brasil, baseada em uma perspectiva teórico-metodológica que procura compreender os aspectos contextuais que geram variabilidade entre os conjuntos líticos relacionados a distintas formas de apropriação do espaço regional. Procuramos, desta forma, oferecer subsídios, além do artefato guia, que permitam compreender quais aspectos justificam interpretar a variabilidade de conjuntos líticos em um contexto regional em termos de Tradições Arqueológicas. 


\section{Capítulo 1}

\section{Os Conceitos de Sistema de Assentamento e Estilo Tecnológico e suas Implicações para o Estudo das Indústrias Líticas do Sul do Brasil}

\subsection{A Relação entre Homem e Espaço na Arqueologia: Os Conceitos de Padrão e Sistema de Assentamento}

A preocupação em compreender a relação entre organização social e padrão residencial é uma constante na arqueologia desde meados do século XIX. Porém, na arqueologia americana a estruturação de programas de pesquisa delineados para lidar com esta problemática só ocorreu na década 1940, através da influência de Julian Steward nas as pesquisas de Gordon Willey, no vale Viru (Peru). Seu trabalho vai, pela primeira vez, inferir, de forma explícita, a relação entre processos culturais e os padrões regionais de assentamento. Os estudos dos padrões de assentamento compreendem que a relação entre homem e paisagem não é aleatória, mas mediada pela natureza do ambiente e pelos níveis de organização tecnológica e de interação social (Parsons, 1972).

Rompendo com a tradição histórico-cultural, Willey enfatizava que a compreensão das mudanças no registro arqueológico deve contemplar suas transformações internas e não ser, simplesmente, atribuída às noções de difusão ou migração. No contexto de uma arqueologia de assentamento, os sítios individuais passam a ser vistos como formadores de uma cadeia de inter-relações na qual cada sítio desempenha um papel diferente e complementar. Desta forma, os estudos de padrão de assentamento passaram a ser vistos como um recurso importante de informação sobre aspectos demográficos, sociais, políticos e religiosos das sociedades pretéritas. Igualmente, estas pesquisas passaram a integrar diferentes níveis de análise espacial na arqueologia, tanto em termos micro-estruturais, relacionados ao assentamento em si, quanto macro-estruturais, através do estudo comparativo entre assentamentos distribuídos na paisagem (Chang, 1968).

Os trabalhos de Willey influenciaram o desenvolvimento de estudos de padrões de assentamento nas décadas de 1950 e 1960, envolvendo extensos projetos arqueológicos regionais nos EUA, na Mesoamérica, no Oriente Próximo e no Extremo Oriente (Trigger, 1992). De acordo com Trigger (1968: 54), dois tipos de enfoque dominaram os estudos de 
padrão de assentamento naquele período. O primeiro seria marcado pelo determinismo ecológico de Leslie-White, que compreende o padrão de assentamento como resultante da interação entre ambiente e desenvolvimento tecnológico, enfatizando os estudos inter-sítios ou macro-estruturais. Uma das principais defensoras desta perspectiva foi Betty Meggers, cujos trabalhos na década de 1950 na foz do Amazonas, marcaram o início de uma forte influência desta vertente na arqueologia brasileira que ainda se faz presente (Neves, 1999). Um segundo enfoque das pesquisas de padrão de assentamento centra-se em aspectos sociais, políticos e ideológicos refletidos nas formas de ocupação do espaço, enfatizando as análises intra-sítio, como pode ser exemplificado pelos trabalhos de Sears (1968), para a origem dos Estados Antigos no Novo Mundo, e Vogt (1968), no estudo da estrutura dos Centros Cerimoniais Maia.

As pesquisas quanto à relação homem-espaço nas décadas de 1960 e 1970 são marcadas por uma revisão crítica na arqueologia americana dos limites do conceito de padrão de assentamento, sendo este substituído pela noção de sistema de assentamento. De acordo com esta, os estudos de padrões de assentamento observariam, basicamente, a relação geográfica e fisiográfica de um grupo contemporâneo de sítios de uma única cultura. Por sua vez, o conceito de sistema de assentamento permitiria compreender a relação funcional entre um grupo contemporâneo de sítios, associados ao padrão de assentamento de uma mesma cultura (Parsons, 1972: 132).

Esta estratégia de pesquisa, adotada pela Nova Arqueologia ou Arqueologia Processual, estrutura-se a partir de uma noção sistêmica de cultura, segundo a qual pessoas, coisas e lugares são os componentes de um campo que consiste dos subsistemas ambiental e socio-cultural. Assim, uma das características básicas de um sistema cultural seria a integração de indivíduos e unidades sociais, desempenhando distintas tarefas em diferentes locais (Binford, 1965). Partindo de uma perspectiva regional, “cada sítio representa uma visão parcial e limitada do comportamento regional (...). Em cada sítio, o uso do espaço e a tecnologia desenvolvida (...) são uma resposta específica a circunstâncias concretas. Em outras palavras, vislumbram um sistema cultural no qual tiveram lugar diferentes atividades, em espaços distintos” (Binford, [1983] 1994: 117). A noção de sistema de assentamento, pressupõe que os sítios distribuem-se intencionalmente no espaço, em função tanto do contexto social, quanto do contexto ambiental, não podendo ser explicados como entidades isoladas. A compreensão de que os ambientes social e natural influenciaram a distribuição dos sítios no espaço são noções críticas para a explicação da 
variabilidade de sua distribuição e de seu papel no sistema de implantação (Plog \& Hill, 1971: 8-9).

Os conceitos de "sítios de atividade limitada" (Plog \& Hill, 1971) e de "complexo situacional de sítios” (Binford, [1983] 1994) são frutos de pesquisas voltadas à compreensão da relação diferencial do uso do espaço em contextos intra/inter sítios. Sítios de atividade limitada corresponderiam a locais onde uma ou algumas atividades foram realizadas por populações, cujo domicílio situa-se em outro local, sendo sua distribuição determinada pela localização do sítio-base ou de conjuntos de recursos a serem explorados (Plog \& Hill, 1971: 13). Por sua vez, o conceito de “complexo situacional de sítios” traduz a idéia de conjuntos de sítios contemporâneos, onde ocorrem diferentes etapas de um processo produtivo que são seqüenciais, destacando a percepção de que existem sítios especializados em diferentes atividades (Binford, [1983] 1994: 125-126). Deve-se ressaltar que "a unidade básica da arqueologia é o sítio, mas sua finalidade é utilizar esta unidade para estudar o comportamento humano do passado” (Binford, [1983] 1994: 141). Portanto, estudos da relação espacial intra/inter-sítios tornam-se fundamentais para a efetiva compreensão da relação entre os sítios que fazem parte de um mesmo sistema de assentamento pré-histórico.

A arqueologia européia, por sua vez, também se preocupou com a relação espacial entre os sítios arqueológicos desde o século XIX. Sofrendo uma forte influência da escola antropo-geográfica alemã, as pesquisas iniciais centraram-se na elaboração de mapas de distribuição de sítios e artefatos de forma a distinguir e explicar complexos culturais préhistóricos, bem como relacionar padrões de assentamento com a geografia e a paisagem (Clarke, 1977: 2). Na Inglaterra, esta tradição floresceu no início do século XX, sendo substituída entre as décadas de 1930 e 1950, por um enfoque paleo-econômico, capitaneado por Graham Clark, com enfatize nos estudos de padrão de subsistência préhistóricos. Este enfoque influenciou o desenvolvimento, na década de 1960, das pesquisas de Higgs e Vita-Finzi quanto às áreas de captação de recursos dos sítios (site catchment analysis), explorando a relação entre recursos ambientais disponíveis na vizinhança de um assentamento e seus possíveis padrões de exploração sazonal (Trigger, 1992). Outra linha de pesquisa arqueológica, voltada ao estudo das configurações espaciais intra-sítio, foi implementada na França por Leroi-Gouhran, nas décadas de 1950 e 1960, através do 
desenvolvimento de técnicas de escavação em superfícies amplas, contribuindo significativamente para o registro de solos de ocupação ${ }^{1}$.

Observa-se que nas décadas de 1960 e 1970, a teoria sistêmica também influenciou o surgimento na Inglaterra de linhas de pesquisa voltadas ao estudo da relação entre homem e espaço, através da chamada arqueologia espacial. De acordo com Clarke (1977: 5-9), esta se preocuparia com as conseqüências espaciais das atividades humanas em sua articulação com sítios, sistemas de sítios e ambiente, estudando o fluxo destas atividades em diferentes escalas de agregação, sejam estas em nível micro (nas estruturas), semimicro (nos sítios) e macro (entre sítios de uma área). Esta postura corresponderia a uma crítica aos estudos de sistema de assentamento desenvolvidos pela Nova Arqueologia norte americana, uma vez que esta não usaria modelos teóricos apropriados para compreender a relação espacial entre conjuntos arqueológicos nos sítios e/ou nos componentes de um sistema regional de sítios. Buscando sanar estas lacunas, a arqueologia espacial adotou teorias e sub-teorias derivadas da economia, da geografia e da ecologia para buscar compreender a configuração espacial entre assentamentos, como por exemplo a Teoria Locacional, de Van Thünen, e a Teoria do Lugar Central, de Christaller (Clarke, 1977). Esta linha de pesquisa gerou uma grande quantidade de trabalhos voltados à aplicação de técnicas estatísticas e quantitativas no estudo de padrões de distribuição arqueológica intra e inter-sítios, voltados à elaboração de modelos matemáticos relativos a explicação do comportamento espacial humano. Este tipo de enfoque teve ampla repercussão no estudo de sistemas de troca a longa distância e da origem de sociedades complexas na pré-história européia e exemplos de sua aplicação podem ser encontrados nos trabalhos de Hodder (1977) e Hodder e Orton ([1976] 1990).

O estudo da relação entre homem e espaço encontrou novos direcionamentos nas décadas de 1980 e 1990 através da arqueologia da paisagem e da etnoarqueologia. Derivando seus conceitos da ecologia da paisagem e da biogeografia evolutiva, a arqueologia da paisagem pressupõe que o registro arqueológico encontra-se disperso, conformando estruturas que são o produto da ação combinada de processos naturais e culturais, cujas mudanças dizem respeito a alterações de longa duração, associadas à

\footnotetext{
1 Avaliando esta linha de pesquisa, Gallay (1986) percebe que a aplicação das técnicas de escavação horizontais ou por decapagem, apresentaram bons resultados no estudo de sítios simples a céu aberto, com baixos índices de perturbação, porém possuem pouco valor para a compreensão de sítios de estratigrafia mais complexa.
} 
evolução da paisagem. Arqueologicamente, uma perspectiva funcional da paisagem considera como as populações humanas reagiram à heterogeneidade da distribuição espaço-temporal dos recursos. Assim, a paisagem arqueológica deve ser entendida como uma entidade dinâmica, cujas características podem determinar a variabilidade e a heterogeneidade de respostas em termos de estratégias adaptativas por diversas populações humanas ao longo do tempo (Lanata, 1997). Em última instância, este enfoque, ao integrar os Sistemas de Informação Geográfica (GIS) à pesquisa arqueológica, permite compreender diferentes estratégias de apropriação da paisagem por populações humanas, na medida em que os padrões de distribuição de sítios resultam de opções culturais ajustadas e transformadas pela realidade topográfica. Os sistemas de assentamento passam a ser entendidos como resultados de numerosos aspectos, inter-relacionando ideais culturais, experiência econômica e realidade topográfica (Zubrow, 1996; ver também Morais, 1999, 2000; Rossignol, 1992; Wandsnider, 1992).

Por seu turno, as pesquisas etnoarqueológicas voltadas ao estudo da estrutura dos assentamentos humanos permitiram aprimorar e testar as proposições do modelo sistêmico quanto aos processos dinâmicos de uso do espaço e suas conseqüências na formação do registro arqueológico. De acordo com David \& Kramer (2001: 227) os sistemas de assentamento observados pela arqueologia são inferenciais, derivados de inúmeras associações e distribuições de resíduos que sobreviveram a uma variedade de ações que se desenvolveram ao longo do tempo em diferentes locais da paisagem. A pesquisa etnoarqueológica pode, por outro lado, observar uma amostra de tais atividades diretamente e, mais facialmente, inferir, a partir desta, a natureza dos sistemas de assentamento e subsistência. As pesquisas etnoarqueológicas dos sistemas de assentamento partem da premissa de que nenhuma comunidade, independente do sistema de subsistência, está limitada espacial e funcionalmente a um único sítio. Assim os estudos etnoarqueológicos podem ilustrar o grau de variação do uso do espaço, permitindo aos arqueólogos modificar e refinar suas orientações de pesquisa a fim de incorporar expectativas específicas quanto ao tipo de organização espacial e correlatos materiais associados a uma dada estratégia adaptativa em particular.

As pesquisas etnoarqueológicas sobre sistemas de assentamento se dividem entre aquelas centradas no estudo de padrões intra-sítio, voltadas à análise de áreas de atividade (Hudson, 1993, Kent, 1984, 1987, 1993a; Kroll e Price, 1991; entre outros) e aquelas voltadas a compreender os processos de utilização e/ou abandono do espaço regional 
(Binford, 1978, [1983] 1994; Cameron \& Tomka, 1996; Gould, 1978, 1980; Yellen, 1977a; entre outros).

\subsection{Estudos Etnoarqueológicos de Sistemas de Assentamento Caçador Coletor} e suas Contribuições para a Construção de Modelos Arqueológicos:

Segundo Silva (2000), a arqueologia sempre fez uso do dado etnográfico para embasar suas interpretações sobre os vestígios do passado. O uso de analogias etnográficas gerais para a interpretação do registro arqueológico tornou-se sistemático a partir do século XIX, com evolucionismo clássico, sendo esta estratégia alvo de críticas a partir do desenvolvimento do difusionismo, do relativismo cultural e do particularismo histórico, na primeira metade do século XX. A partir deste momento, são consideradas pertinentes somente as comparações entre populações historicamente relacionadas, diminuindo o interesse pelo dado etnográfico e pelo uso das analogias como recurso interpretativo na arqueologia. Este cenário só irá modificar-se na década de 1960, a partir da influência do estrutural-funcionalismo na arqueologia, marcando uma retomada dos paralelos etnográficos, acompanhada de uma reflexão crítica quanto ao modo como se deveria conduzir o raciocínio analógico.

Embora não houvesse consenso metodológico quanto à função das analogias na interpretação do registro arqueológico naquele momento, ao longo das décadas de 1960 e 1970 vários trabalhos foram produzidos com vistas a coletar dados etnográficos que pudessem contribuir para a interpretação arqueológica ${ }^{2}$. É neste momento que o termo etnoarquelogia começa a ser empregado sistematicamente para definir este tipo de procedimento de pesquisa, enfatizando-se os estudos dos padrões de subsistência e assentamento, produção e utilização da cultura material e formação do registro arqueológico.

\footnotetext{
${ }^{2}$ Dentre estes, Silva destaca as pesquisas etnoarqueológicas realizadas entre populações caçadoras coletoras como as de Gould que investigou aspectos da adaptabilidade dos aborígenes australianos no Deserto Ocidental, identificando diferentes variáveis que poderiam condicionar as estratégias de exploração dos recursos ambientais, a seletividade de matérias-primas para a confecção do instrumental lítico, o uso do espaço e o padrão de descarte dos materiais. Destacam-se também as pesquisas realizadas por Yellen quanto ao padrão de residência dos !Kung, na África, a fim de entender os processos de formação dos sítios de atividades específicas e das áreas de atividades, discutindo o aspecto da visibilidade dos contextos arqueológicos. Igualmente importantes neste momento são os trabalhos de Binford quanto às estratégias de
} 
Para Binford os princípios interpretativos sobre a dinâmica do passado não podem ser testados no registro arqueológico, pois suas características são estáticas e contemporâneas e o passado é dinâmico e conhecido inferencialmente. Inferências sobre o passado só podem ser testadas em termos actualísticos ${ }^{3}$, ou seja, em situações onde a dinâmica do processo de formação arqueológico pode ser examinada de forma experiencial e direta. Tal concepção demanda uma postura uniformitarista, segundo a qual as causas dos fenômenos dinâmicos do presente, que contribuem para formação de um registro arqueológico estático, são as mesmo que agiram no passado. Através das pesquisas etnoarqueologicas podemos observar a coincidência entre dinâmica do comportamento e seus derivados materiais estáticos comuns ao passado e ao presente. A analogia permite formular proposições sobre o passado a serem testadas no registro arqueológico, pois oferece à arqueologia a possibilidade de construção de modelos elaborados sobre o conhecimento corrente disponível e sobre o grau de variabilidade na forma, estrutura e funcionamento dos sistemas culturais. A pesquisa etnoarqueologica constitui-se, para Binford, em um recurso para formular e testar hipóteses que buscam a relação entre fenômenos culturais e materiais, possibilitando a criação de modelos sobre as sociedades do passado, com base em estudos contextuais do registro arqueológico (Binford, [1968] 1972a, 1983a,).

Segundo Silva (2000), no final da década de 1970, Binford coloca um fim ao debate em torno do papel da analogia nas pesquisas de vertente processualista ao relacionar a etnoarqueologia às teorias de médio alcance. Esta postura encontra sua síntese em Kent (1987), que subdivide as abordagens que utilizam um raciocínio analógico para a interpretação arqueológica em duas categorias distintas. A primeira corresponde a “arqueologia antropológica”, cujo objetivo é reconstruir uma história cultural utilizando-se para isso da analogia histórica direta e da analogia geral. Um segundo enfoque seria a da “etnografia arqueológica” que procura no registro etnográfico, dados que auxiliam na interpretação de aspectos específicos do registro arqueológico. Ambas abordagens têm objetivos distintos da etnoarqueologia, uma vez que esta não visa reconstruir uma história cultural e nem prover analogias. Para Kent, a etnoarqueologia é uma estratégia de pesquisa que visa identificar princípios gerais do comportamento humano com relação ao mundo

caça e descarne dos Nunamiut, no Alaska, com o objetivo de contribuir para o entendimento das freqüências dos resíduos faunísticos encontrados em diferentes contextos arqueológicos (Silva, 2000).

${ }^{3}$ Optamos por utilizar este neologismo do termo inglês actualistc cuja versão para o português perderia o sentido original. 
material e, neste sentido, contribuir para a construção de teorias arqueológicas de médio alcance que procuram identificar os princípios que regem os processos de formação do registro arqueológico.

De acordo com Silva (2000), a partir da crítica pós-processualista, os aspectos simbólicos da relação do homem com o mundo material passam também a ser incorporados à pesquisa etnoarqueológica. Desta forma, enquanto a etnoarqueologia processual procura identificar regularidades interculturais associadas às teorias de médio alcance, a etnoarqueologia pós-processual procura entender os princípios estruturais subjacentes à relação homem versus mundo material, específicos em cada contexto. A autora ressalta, no entanto, que estas distintas abordagens etnoarqueológicas não são de todo irreconciliáveis na medida compartilham o objetivo comum de construir, a partir da experiência etnográfica orientada por um “olhar arqueológico”, modelos interpretativos quanto à relação dialética entre prática e simbolismo na ação dos homens com o mundo material.

As pesquisas de Yellen (1977a) entre os !Kung San do Kalahari, desenvolvidas entre 1968 e 1975, correspondem a um dos primeiros estudos etnoarqueológicos voltados a compreender as implicações espaciais, em termos arqueológicos, dos sistemas de assentamento e mobilidade de grupos caçadores coletores. Contudo, são os trabalhos etnoarqueológicos de Binford entre os Nunamiut, desenvolvidos entre 1969 e 1973, e entre os Alyawara, em 1974, que aprofundam as reflexões relativas à amplitude das teorias de médio alcance para a interpretação dos registros arqueológicos associados aos sistemas de assentamento de caçadores coletores. De forma geral, os trabalhos etnoarqueológicos de Binford sobre os sistemas de assentamento caçadores coletores organizam-se em torno de três problemas centrais: variabilidade intra-sítio, variabilidade inter-sítios pertencentes a um mesmo sistema de assentamento e variabilidade entre sistemas de assentamento, em função de diferentes estratégias adaptativas (Dias, 2000a).

Seus estudos da variabilidade artefactual intra-sítio centram-se nas relações dinâmicas associadas à organização tecnológica e suas conseqüências em termos de freqüência numérica, relação espacial e diversidade formal dos artefatos nos sítios arqueológicos. As implicações para a interpretação da funcionalidade do registro arqueológico estariam associadas à relação entre equipamentos, áreas de atividade e padrões de descarte, na medida em que os artefatos produzidos por um único grupo podem ser diferentemente manufaturados, usados e descartados, dependendo de seu papel na 
organização tecnológica e da sua relação com as atividades realizadas nos diferentes sítios ocupados por um mesmo sistema cultural (Binford, [1977] 1983b; 1979).

Os estudos etnoarqueológicos de Binford sobre a variabilidade inter-sítios pertencentes a um mesmo sistema de assentamento buscam compreender as propriedades funcionais dos locais de atividade de um sistema, estudando a relação entre dinâmica de uso do espaço e vestígios estáticos produzidos por estas atividades. Os sítios arqueológicos em suas associações repetitivas de artefatos e estruturas representam a variabilidade do posicionamento espacial do sistema em função de estratégias de adaptação à dinâmica ambiental, seja esta sazonal ou de longa duração. Portanto, os padrões de variabilidade entre conjuntos de artefatos associados a sítios cronologicamente correlatos de uma mesma região podem simplesmente representar mudança nos potenciais econômicos dos locais de implantação dos sítios, derivados da diferenciação interna de um sistema em ação (Binford, [1978] 1983c, [1978] 1983d, [1982] 1983e, [1981] 1983f, [1987] 1989a, 1991a).

Por fim, Binford procura explicar a variabilidade entre sistemas de assentamento e subsistência caçadora coletora em função de diferentes estratégias adaptativas desenvolvidas pelos grupos. Com base em estudos interculturais, o autor discute as implicações arqueológicas das adaptações caçadoras coletoras, em diferentes contextos ambientais, tendo por base dados etnográficos, etnohistóricos e etnoarqueológicos, com o objetivo de entender quais fatores condicionam ou causam padrões diferentes na variabilidade inter-sítios no registro arqueológicos de um mesmo grupo. Assim, as variações nos sistemas de subsistência e mobilidade são interpretadas como uma função do tipo de ambiente, estando a mobilidade residencial associada à produtividade ambiental e esta, por sua vez, condiciona as estratégias de subsistência predominantes (Binford, 1980, 1990, 2001).

De acordo com Binford (1980), os sistemas de assentamento caçadores coletores organizam-se de acordo com dois modelos opostos. O primeiro, denominado forrageiro, caracteriza adaptações ecológicas a áreas tropicais, sub-tropicais e áridas, tomando por base os estudos etnoarqueológicos entre os !Kung San (Botswana) e os Alyawara (Austrália). O modelo forrageiro caracteriza-se por uma alta mobilidade residencial, de caráter sazonal, entre uma série de recursos conectados (matérias primas, fontes de água, fauna e flora) em um território amplo, não apresentando estratégias de estocagem de alimento. As estratégias de subsistência se dão através de saídas diárias em torno da base residencial, sempre situada próxima a recursos críticos, sendo a permanência nos sítios breve. O tamanho do grupo e a quantidade de movimentos residenciais podem variar ao 
longo do ciclo anual, dependendo da dispersão dos recursos. O sistema de assentamento forrageiro apresenta maiores possibilidades de um estudo funcional de sítios arqueológicos na medida em que é composto por apenas dois contextos espaciais de descarte:

a) a base residencial, na qual ocorrem atividades de manufatura, processamento, consumo e manutenção. Esta possui maior visibilidade arqueológica, pois pode sofrer reocupações ao longo do ciclo sazonal; e

b) as locações que seriam locais nos quais ocorrem atividades extrativas, sendo ocupadas por um período breve que redunda em uma baixa visibilidade arqueológica.

O segundo modelo descrito por Binford com base em seus estudos etnoarqueológicos entre os Nunamiut (Alaska), corresponde ao sistema de assentamento coletor. Este é caracterizado pelo semi-sedentarismo, ecologicamente adaptado a áreas temperadas e boreais, apresentando alto grau de variabilidade inter-sítio em função da baixa mobilidade. Os recursos disponíveis são mapeados pelo grupo através de movimentos residenciais, sendo a caça e a coleta organizada de forma logística, através da ação de grupos de tarefa especializados. A mobilidade é condicionada pela distribuição dos recursos e realizada por grupos especializados que deixam a base residencial e estabelecem-se em acampamentos associados à procura e processamento de alimento que será estocado para consumo ao longo do ano. O sistema de assentamento relacionado a estas estratégias logísticas gera uma grande variedade de sítios de difícil identificação arqueológica, dentre os quais destacam-se:

a) as bases residenciais;

b) os acampamentos, que correspondem a centros de operação temporárias onde se organizam estratégias extrativas específicas;

c) as locações, que são os locais onde se procura ou processa matérias primas;

d) as estações que são locais específicos na paisagem onde se planeja estratégias de caça, como os postos de observação de manadas; e

e) os esconderijos (caches) nos quais se estoca a caça processada.

As propostas de Binford foram testadas por Kelly (1995: 120) através da contrastação entre dados etnográficos de caçadores coletores e condições ecológicas, concluindo o autor que o modelo proposto deve ser considerado como um contínuo de formas e possibilidades de sistemas de assentamentos entre caçadores coletores. Desta forma, em áreas onde se observa uma distribuição homogênea de recursos ao longo do ciclo anual, a organização dos sistemas de assentamento tende ao modelo forrageiro. Por 
outro lado, o modelo coletor apresenta maior correlação com áreas que apresentam um padrão sazonal mais marcado de distribuição de recursos. Kelly, porém, ressalta que o modelo de Binford deveria agregar outras dimensões da mobilidade de caçadores coletores que influenciam a estrutura dos sistemas de assentamento. Em um primeiro momento, a disponibilidade de biomassa primária é um fator determinante do número de movimentos residenciais e distância entre estas ao longo do ciclo anual. Porém, a proximidade de fontes de água, combustível e matéria prima, bem como aspectos de habitabilidade dos sítios por questões sanitárias também determinam a localização e tempo de permanência nas bases residenciais. Por fim, “a localização de outros grupos de caçadores coletores (ou não caçadores coletores) podem também condicionar o movimento, tanto atraindo, como repelindo forrageiros, dependendo da relação” (Kelly, 1995: 126). Igualmente, o modelo de Binford desconsidera que a mobilidade também é uma necessidade social entre caçadores coletores, ao reduzir os riscos adaptativos pelo estreitamento das relações de cooperação entre distintos bandos que ocupam um dado território, mediado através de sistemas de ritual, alianças, reciprocidade e troca de informações, sendo uma estratégia de manutenção da autonomia cultural dos grupos (David \& Kramer, 2001; Kelly, 1995; Politis, 1996a, 1996b; Wiessner 1982).

Por outro lado, a principal contribuição do modelo de mobilidade e assentamento de Binford reside na idéia de que os sítios arqueológicos associados a sistemas caçadores coletores não podem ser entendidos como entidades estáticas e isoladas, sendo a sua variabilidade relacionada ao papel que representaram em um sistema de uso do espaço regional mais amplo ${ }^{4}$. "O número e a diversidade de assentamentos de um sistema indicam a necessidade de pensar os sítios como entidades variáveis, usadas para diferentes propósitos pelo mesmo grupo social” (David \& Kramer, 2001: 237).

\footnotetext{
${ }^{4}$ Dentre as pesquisas etnoarqueológicas voltadas a interpretação funcional dos contextos deposicionais em sítios caçadores coletores destacamos os modelos de Yellen (1977a, Binford ([1978] 1983c, [1978] 1983d, [1982] 1983e, [1981] 1983f, 1991a) e O’Connel (1987). Especificamente para floresta tropical temos os modelos de Politis (1996a, 1996b, 1996c) e Borrero e Yaccobbacio (1987). Estes modelos serão discutidos nos capítulos 3 e 4, enquanto referenciais interpretativos para os contextos arqueológicos de caçadores coletores estudados.
} 


\subsection{O Conceito de Estilo Tecnológico como Instrumento para a Interpretação} da Variabilidade de Conjuntos Líticos:

Segundo Dias e Silva (2001: 95-97), o uso do conceito de sistema tecnológico implica na compreensão de que as técnicas desenvolvidas por uma dada sociedade estão sistemicamente constituídas. Nas últimas décadas os estudos antropológicos sobre o tema têm se desenvolvido, principalmente, a partir de dois enfoques distintos. O primeiro, de vertente materialista, entende que os sistemas tecnológicos são o resultado de estratégias adaptativas, inter-relacionadas com as limitações e possibilidades do meio natural e as demandas da organização sócio-econômica das populações. Desta forma, os sistemas tecnológicos são analisados como um modo a partir do qual os homens viabilizam sua existência frente ao meio natural. A investigação centra-se sobre o entendimento das interrelações entre os sistemas tecnológicos e aspectos como disponibilidade de matérias primas, características físicas dos materiais, atribuições funcionais a que se destinam os artefatos e sua eficiência na exploração do meio natural.

O segundo enfoque de análise está associado a uma ótica estruturalista que concebe os sistemas tecnológicos como uma construção social resultante de escolhas culturalmente determinadas. Os sistemas tecnológicos são vistos como um recurso e um produto de criação e manutenção de um ambiente natural e social, simbolicamente constituído, sendo a investigação voltada para o entendimento de sua relação com os demais sistemas de representação social. Neste sentido, a tecnologia pode ser definida como o corpus de artefatos, comportamentos e conhecimentos transmitidos de geração a geração e utilizados nos processos de transformação e utilização do mundo material.

Os estudos de estilo tecnológico vinculam-se a esta segunda vertente teórica, pois compreendem o fenômeno estilístico como algo inerente e subjacente aos processos de produção dos quais resultam os aspectos visuais relacionados à morfologia e à decoração dos artefatos. Destaca-se que o estilo não é um fenômeno unidimensional, integrando várias concepções e, ao mesmo tempo, apresentando uma multi-funcionalidade em diferentes contextos sócio-culturais ${ }^{5}$ (Dias e Silva, 2001: 96). No entanto, segundo

\footnotetext{
${ }^{5}$ As pesquisas sobre o conceito de estilo na antropologia têm se desenvolvido sobre uma ampla gama de aspectos abrangendo temas como processos de difusão relacionados a sua dimensão histórica e regional; a sua relação com questões associadas à organização social, como construção de identidades, contextos de ensino-aprendizagem, cosmologia, estruturas cognitivas, estratégias de poder e processos de produção da cultura material (Dias e Silva, 2001: 96-97).
} 
Hegmon (1992), as diferentes perspectivas analíticas e explicativas sobre a categoria estilo compartilham alguns princípios básicos: 1) que o estilo refere-se a um determinado modo de fazer algo ou alguma coisa; 2) que este modo de fazer implica em escolhas dentre possibilidades alternativas; e 3) que é próprio de um determinado tempo e lugar.

Dias e Silva (2001: 97-100) destacam que o debate em torno da aplicabilidade do conceito de estilo para o estudo de indústrias líticas é de longa data na arqueologia, não encontrando consenso até o presente. As divergências derivam de orientações teóricas diferenciadas e centram-se, principalmente, em como a variabilidade dos conjuntos líticos relaciona-se com questões de ordem estilística, funcional ou étnica. Para a arqueologia histórico-cultural o estilo é sempre um código diagnóstico de etnicidade. A interpretação das semelhanças e diferenças nos padrões morfológicos dos artefatos costuma ser feita em termos de unidades histórico-culturais, com conotações étnicas, e as mudanças ao longo do tempo nestes padrões são explicadas, principalmente, em termos de processos de difusão e migração. De acordo com esta perspectiva teórica, o estilo pode ser lido na forma dos artefatos, sendo as variações morfológicas interpretadas como resultantes da ação de grupos étnicos diferentes. Portanto, a ordenação de artefatos em tradições ou fases centrase na noção de que a semelhança estilística denota proximidade cultural. Por outro lado, estilo e função são considerados como esferas dicotômicas, sendo o primeiro explicado de acordo com o contexto histórico-cultural e o segundo, em termos de ação física.

A discussão sobre a relação entre estilo e função, adquiriu novas conotações a partir do enfoque processualista, sendo ilustrada pelo debate entre Sackett e Binford quanto à relação entre o conceito de estilo e a variabilidade de indústrias líticas. Ambos autores estruturam seus argumentos a partir da crítica à interpretação tradicional quanto à variabilidade dos conjuntos líticos do Paleolítico Médio e Superior. Para Binford (1962), a variabilidade dos conjuntos de artefatos deve ser compreendida tendo em vista sua função contextual primária no sistema cultural, podendo ser classificados em três grupos distintos. O primeiro corresponde aos artefatos tecno-econômicos, cuja função primária está relacionada à exploração do meio físico, sendo sua variabilidade explicável em termos adaptativos. Uma segunda categoria de artefatos seria a do tipo socio-técnica, cujo contexto funcional primário está associado ao sistema social, funcionando como um meio extra-somático de articulação dos indivíduos entre si em grupos coesos capazes de, eficientemente, manterem-se e manipularem a tecnologia. Por fim, os artefatos ideotécnicos têm como contexto funcional primário os componentes ideológicos do sistema social, correspondendo aos itens que promovem um meio simbólico no qual os indivíduos 
são enculturados. Presentes em todas estas classes gerais de artefatos, estão as características formais que podem ser chamadas de estilísticas que não são diretamente explicáveis em termos da natureza da matéria prima, da tecnologia de produção ou da variabilidade da estrutura tecnológica e social do sistema cultural. O estilo é concebido enquanto uma forma acessória (adjunct form), cujas qualidades formais tem por função promover uma base simbólica de identidade ao grupo, estando associada a itens não utilitários da cultura.

Sackett (1982: 82-93) considera que o enfoque processual sobre estilo peca por uma visão funcional extrema, ao entendê-lo como um elemento não utilitário da variação formal, funcionando simbolicamente como um tipo de iconologia social para identificação de grupos humanos. Para Sackett, o estilo não se restringe a uma única categoria tipológica, como a morfologia. Segundo o autor:

O estilo pode ser encontrado na escolha da matéria prima, nas técnicas de lascamento para redução de núcleos e na produção de artefatos, nos tipos alternativos de retoques marginais, nos vários ângulos de uso de borda, na forma de uso e rejuvenescimento do artefato. (...) [Estes fatores] podem oferecer um ar de familiaridade aos conjuntos de artefatos que sugerem um estilo etnicamente significativo (Sackett, 1982: 106).

Para Sackett (1986: 630) a noção de estilo não é um domínio diferente da forma, mas uma qualidade latente e inerente a qualquer variação artefatual, na medida em que a forma é constituída de escolhas feitas pelo artesão, conscientemente ou não, de um amplo espectro a sua disposição. Estas escolhas tecnológicas determinam a variação isocréstica ${ }^{6}$ e são ditadas pela tradição na qual o artesão foi enculturado como membro de um grupo social. Por ser limitada socialmente, a variação isocréstica traduz-se em noções de design peculiares a certos lugares e tempos, sendo diagnóstica de etnicidade. Estilo e função são noções complementares e as variações isocrésticas podem ser vistas em sentido amplo, abrangendo desde a cadeia operatória que dá origem ao artefato até suas formas de uso e descarte. Portanto, estilo e função são aspectos complementares que determinam a morfologia dos artefatos e as características das cadeias operatórias que lhes dão origem. O aspecto funcional de um artefato reside na maneira como a sua forma serve a um

\footnotetext{
${ }^{6}$ Sackett elabora este conceito a partir de um neologismo do grego Isos - igual e chrestikós - bom para o uso, útil, usual, que sabe se servir de, habilitado para se servir de (Bailly, 1990).
} 
determinado fim e o aspecto estilístico reside na variante étnica ou escolha isocréstica em que esta forma surge, ou seja, nas escolhas tecnológicas (Sackett, 1977: 75).

As críticas de Binford ao conceito de estilo tecnológico defendido por Sackett centram-se na relação entre variabilidade dos conjuntos de artefatos e estrutura de um sistema de assentamento caçador coletor. Baseado em seus estudos etnoarqueológicos, Binford critica a associação entre variabilidade artefatual e o conceito de estilo enquanto correlato de etnicidade, pois condições situacionais diferenciadas podem levar a produção de restos arqueológicos altamente variáveis por um mesmo grupo nos diferentes sítios que fazem parte de seu sistema de assentamento. Se por um lado, as escolhas isocrésticas promovem flexibilidade adaptativa ao grupo para lidar com a dinâmica ambiental (social e natural) na qual vive, por outro, a variabilidade funcional implica em seleções, cujo contexto pode variar de forma independente em relação às identidades sociais, sendo difícil reconhecer a diferença entre conjuntos produzidos por membros de um mesmo grupo étnico e conjuntos análogos produzidos por membros de diferentes grupos (Binford, 1989b: 55-65; [1986] 1989d: 558-559).

Refletindo sobre as críticas de Binford, Sackett $(1986,1993)$ aponta que a possibilidade de diferenciação de conjuntos líticos produzidos por distintos grupos culturais seria ditada também pelo contexto de deposição dos artefatos. Portanto, os padrões de variabilidade tecnológica derivados de variações étnicas, também se refletiriam em diferenças quanto as formas de exploração dos recursos, as características estruturais dos sistemas de assentamento e a maneira como os artefatos são descartados nos sítios ${ }^{7}$.

A reflexão sobre a relação entre estilo tecnológico, função e etnicidade foi aprofundada a partir dos estudos de Wiessner $(1983,1989)$ sobre a variabilidade das pontas de projétil dos !Kung San do Kalahari. Neste estudo etnoarqueológico, a autora buscou demonstrar que a variação estilística presente nos artefatos de um mesmo grupo também é utilizada como um instrumento para transmitir mensagens a respeito de identidades sociais coletivas e individuais. Para a autora, o estilo é um elemento ativo na transmissão de mensagens e, no caso dos San, é empregado conscientemente nos processos de identificação social e individual. Segundo Wiessner, quanto maior o nível de interação

\footnotetext{
${ }^{7}$ Na década de 1970 Jelinek já advertia que o potencial de uma coleção lítica para estudos estilísticos pode variar em função das técnicas de escavação e amostragem empregadas no trabalho de campo, dos contextos de deposição natural, do sistema de assentamento do grupo estudado e da natureza dos recursos a sua disposição (Jelinek, 1976: 21-22).
} 
social, mais sutil é a diferença entre as pontas de projétil, porém num contexto mais amplo, elas servem como demarcadoras dos grupos de linguagem San. Desta forma, as pontas de projétil transformam-se em instrumentos constantemente distribuídos nas redes de reciprocidade, implicando no acesso dos indivíduos pertencentes aos diferentes grupos de linguagem aos recursos existentes nos vários territórios ocupados pelos San.

Para Sackett (1985) a variação isocréstica que ocorre nos conjuntos de pontas de projétil dos San é, em última instância, inconsciente, surgindo em função das diferentes tradições artesanais em que os indivíduos de variados grupos de linguagem inserem-se. Segundo Sackett, o estilo seria subjacente às características dos artefatos em si, residindo nas escolhas isocrésticas feitas dentre alternativas variadas durante o processo produtivo. Wiessner $(1985,1993)$ complementa esta visão de Sackett ao destacar que existe uma diferença entre os comportamentos que geram escolhas isocrésticas, produto da repetição e da imitação associadas ao processo de ensino-aprendizagem, e os que se associam a escolhas estilísticas intencionais, relacionadas ao processo dinâmico de comparação dos indivíduos entre si. Neste caso, a variação nas pontas San não se explica apenas por variações isocrésticas relacionadas à cadeia operatória, mas derivam de um comportamento intencional relacionado à demarcação de fronteiras culturais, podendo alguns atributos dos artefatos ser utilizados, mais do que outros, como instrumentos ativos de comunicação de etnicidade e identidade social e individual.

Partindo da reflexão teórica sobre o conceito de estilo tecnológico, Dias e Silva (2001: 101) sugerem que a variabilidade entre conjuntos líticos associados a distintos contextos de uma dada área resulta de escolhas tecnológicas que são culturalmente determinadas. Os estilos tecnológicos estão representados nestas escolhas, que se refletem na seleção das materiais primas, nas técnicas e seqüências de produção escolhidas e nos resultados materiais destas escolhas, representadas pelas categorias de artefatos produzidas. Portanto, o estilo tecnológico é produto de uma tradição cultural e seu estudo, relacionado a outros aspectos de ordem contextual, pode servir como indicador de identidades sociais ou culturais presentes no registro arqueológico.

É da comparação entre estilos tecnológicos de indústrias líticas de distintas categorias de sítios de uma mesma região que podemos antever a possibilidade de distinção entre identidades sociais ou culturais no registro arqueológico de caçadores coletores. Contudo, esta percepção demanda um suporte contextual de análise, na medida em que um estilo tecnológico só adquire sentido quando compreendido como parte de um sistema tecnológico e este, por sua vez, de um sistema cultural mais amplo. Assim, as 
cadeias operatórias de uma determinada indústria lítica devem ser compreendidas em conjunto e associadas ao contexto situacional da região estudada, através de estudos comparativos, para possibilitar a interpretação da variabilidade artefatual. No caso do estudo das indústrias líticas do sul do Brasil, estas discussões sobre a natureza dos sistemas tecnológicos e a dimensão estilística das tecnologias são fundamentais, pois obrigam a complexificar os parâmetros vigentes em sua análise.

\subsection{Possibilidades dos Estudos de Sistema de Assentamento e Estilo} Tecnológico para a Construção de Modelos Interpretativos sobre os Caçadores Coletores do Sul do Brasil: As Tradições Umbu e Humaitá

As Tradições Umbu e Humaitá foram definidas a partir das atividades no sul do Brasil do Programa Nacional de Pesquisas Arqueológicas (PRONAPA), sendo os sítios líticos identificados ao longo das décadas de 1960 e 1970 distribuídos em 42 fases arqueológicas. A definição destas fases foi pautada pelas distinções morfológicas dos tipos de artefatos e pela distribuição geográfica e cronológica dos conjuntos líticos que, em muitos casos, ocupavam a mesma região contemporaneamente. Em finais da década de 1970 estas Tradições pré-cerâmicas foram formalmente definidas e ao longo da década seguinte várias sínteses foram elaboradas no sentido de sistematizar os dados das pesquisas (Kern 1981, 1983, 1991a; Meggers \& Evans, 1977; Prous 1992; Ribeiro 1979, 1990; Schmitz, 1981, 1984, 1985a,1987; Schmitz e Brochado, 1981a, 1981b). Enquanto as pontas de projétil representavam o fóssil guia da Tradição Umbu, a Tradição Humaitá foi definida em função da presença de peças bifaciais de grande porte e morfologia variada, destacando-se as de forma bumerangóide, além de choppers, chopping tools, raspadores plano-convexos e lascas retocadas.

Com o desenvolvimento dos estudos arqueológicos no Rio Grande do Sul ao longo das décadas de 1980 e 1990, tornou-se cada vez mais difícil entender a relação entre estas duas supostas ocupações caçadoras coletoras utilizando-se como referência apenas a presença de fósseis guia. Vários pesquisadores dedicaram-se neste período ao estudo tecno-tipológico de coleções de ambas Tradições a fim de avaliar as permanências e descontinuidades sofridas por estas indústrias líticas ao longo do tempo, embora tenham sido raras as propostas interpretativas quanto à variabilidade observada (Dias, 1994, 1995b, 1996, 1999b, 2000b, 2000c; Goldmeier \& Schmitz, 1989; Hilbert, 1994; Hoeltz, 1995, 
1997a, 1997b; Milder, 1994, 1995; Rütshilling, 1985, 1987, 1989; Rütshilling \& Schmitz, 1989).

O questionamento quanto à validade da utilização do conceito de Tradição para compreender estas manifestações, levaram Hilbert (1994) a sugerir que as Tradições Umbu e Humaitá fariam parte de uma mesma indústria lítica, estando a variabilidade dos conjuntos de artefatos relacionada a distinções funcionais dos conjuntos de sítios associados a um mesmo sistema de assentamento. A fim de investigar as possibilidades desta hipótese, Hoeltz (1995, 1997a, 1997b) e Dias (1994, 1995b, 1996, 1999b) desenvolveram estudos tecno-tipológicos de coleções líticas derivadas das pesquisas arqueológicas das décadas anteriores, associadas a diferentes áreas do Estado, com o objetivo de compreender as distinções em termos de organização tecnológica entre ambas Tradições. Refletindo sobre os resultados destas pesquisas, Dias e Silva (2001), destacam que se por um lado as indústrias líticas da Tradição Umbu apresentam uma extrema homogeneidade, a diversidade dos conjuntos relacionados à Tradição Humaitá pode ser melhor entendida se observada em relação aos contextos regionais de distribuição dos sítios. Estes, em geral, estão associados a áreas tradicionalmente ocupadas por horticultores, associados à Tradição Taquara e a Tradição Guarani, podendo estes sítios líticos fazer parte dos sistemas de assentamento destes grupos ceramistas.

Tal hipótese torna-se consistente se considerarmos que a definição destas Tradições Pré-cerâmicas está associada a duas pré-concepções derivadas do enfoque históricocultural: a) que todos os conjuntos líticos de um mesmo grupo devem ser homogêneos, e que portanto, distinções entre conjuntos líticos pressupõem grupos culturalmente distintos; e b) que todo sítio lítico é necessariamente relacionado a um grupo caçador coletor. A ausência de estudos regionais e escavações contextualizadas, acompanhadas de estudos tecno-tipológicos centrados na interpretação da variabilidade lítica, contribuíram, ao longo dos anos, para firmar estas pré-concepções e transformar a Tradição Humaitá em um depositário de conjuntos líticos, muitas vezes dispares entre si, que não se encaixavam em conjuntos formais tecnologicamente mais claros, como os da Tradição Umbu. Embora o conceito de Tradição arqueológica corresponda a um expediente de classificação que diagnostica variabilidade entre conjuntos artefatuais, não explica como dois grupos caçadores coletores possam ter compartilhado o mesmo espaço por milhares de anos, inviabilizando qualquer tipo de estratégia interpretativa sobre territorialidade e mobilidade para estas populações. 
Avaliando esta questão, observa-se na literatura que várias fases da Tradição Humaitá englobaram, em muitos casos, conjuntos líticos associados a sítios cerâmicos de superfície, interpretados como representando sobreposição de ocupações. Uma exceção a este quadro, infelizmente subutilizada em pesquisas posteriores, foi oferecida por De Masi e Schmitz (1987), ao apresentarem pela primeira vez critérios de análise definidos e resultados sistematizados para o estudo de artefatos líticos da Tradição Guarani no Rio Grande do Sul, abrangendo diversos sítios dos vales dos rios Jacuí, Toropí, Vacacaí, Ijuí, Pardinho, Caí, dos Sinos, Camaquã e margens das lagoas litorâneas. Os conjuntos em geral caracterizam-se pela presença de lascas e núcleos unipolares e bipolares, cuja matéria prima preferencial é de origem local, além dos artefatos polidos próprios da Tradição Guarani. Destacam-se as coleções dos rios Jacuí e Caí, cujo conjunto artefatual apresenta talhadores elaborados sobre seixos, considerados tradicionalmente fósseis guia da Tradição Humaitá.

Situação semelhante observa-se em estudos recentemente realizados no vale do Alto Rio Uruguai por Hilbert e colaboradores, na área de implantação da Usina Hidrelétrica de Machadinho (Hilbert, Hoeltz e Costa, 1999, 2000; ver também Costa, 2000). Foram localizados nas prospecções 58 sítios arqueológicos, dos quais 15 apresentaram somente material lítico, estando o restante das coleções marcadas pela associação entre material cerâmico da Tradição Guarani e artefatos líticos. As coleções líticas de 42 destes sítios foram analisadas e seus resultados apontam para um predomínio de lascas e núcleos unipolares e bipolares de matérias primas de origem local, sendo os artefatos bifaciais identificados representados por talhadores unifaciais e bifaciais, elaborados sobre seixo de basalto, cuja morfologia os agregaria à Tradição Humaitá, em claro contexto de associação com os sítios arqueológicos da Tradição Guarani. Estudos etno-históricos sobre a indústria lítica Guarani, também apontam para uma possibilidade de variabilidade artefatual que as classificações formais derivadas do PRONAPA não dão conta, abrindo margem para a presença de artefatos lascados de grande porte voltados a atividades de sulcar, cortar, aplainar e fender, associados ao trabalho em madeira (Noelli 1993; Noelli e Dias 1995).

Por sua vez, os raros estudos de coleções líticas associadas à Tradição Taquara/Itararé apontam na mesma direção que o observado para as indústrias líticas da Tradição Guarani. Dados recentes derivados do resgate arqueológico das áreas afetadas pelas Usinas Hidrelétricas de Quebra-Queixo e Barra Grande, em Santa Catarina e no norte do Rio Grande do Sul, revelaram conjuntos líticos diversificados e abundantes em 
associação com sítios da Tradição Itararé. O estudo tecno-tipológico de ambas coleções demonstrou que os conjuntos líticos típicos da Tradição Humaitá, correspondem à categoria artefatual predominante, estando também presentes lascas e núcleos unipolares com distribuição variada de plataformas (Cope et al, 2002; Henriques, 2002; Henriques \& Passos, 2001; Hoeltz \& Brüggemann, 2003).

Partindo destas considerações iniciais, torna-se claro que um primeiro passo necessário para o avanço do conhecimento sobre os modos de vida das sociedades caçadoras coletoras do sul do Brasil, está relacionado à revisão crítica dos modelos vigentes até o presente e da validade dos conceitos utilizados em sua construção. Para tanto, faz-se necessário uma reorientação das estratégias de análise das coleções líticas, de categorias funcionais para aquelas definidas a partir da organização tecnológica. É somente através deste tipo de estratégia metodológica que se poderá construir um referencial empírico que permita interpretações sobre a variabilidade de conjuntos líticos de uma mesma área ou de regiões distintas. Contudo, estes dados devem, necessariamente, ser acompanhados de estudos contextuais de caráter regional, baseados no conceito de sistema de assentamento, para que se possa entender a relação dos sítios de uma região como entidades dinâmicas, fruto de estratégias de mobilidade e uso do espaço por distintas sociedades pretéritas. É este problema que deve orientar as futuras pesquisas sobre caçadores coletores no sul do Brasil e acreditamos que uma utilização acrítica do conceito de Tradição tecnológica pouco tem a contribuir neste sentido.

Um exemplo da abrangência deste tipo de enfoque para o estudo de grupos caçadores coletores é oferecido por De Blasis nas pesquisas desenvolvidas no médio vale do rio Ribeira do Iguape, ao sul do Estado de São Paulo (De Blasis 1988, 1989, 1990, 1996, 1999). Suas pesquisas objetivaram estudar as ocupações pré-coloniais a partir de um enfoque regional, com ênfase no levantamento dos padrões de assentamento, partindo do pressuposto de que a maneira com que os sítios arqueológicos se dispõem e organizam em uma dada área, refletem os padrões de interação destes assentamentos humanos com o meio ambiente (De Blasis, 1988, 1990). Os trabalhos de campo permitiram a identificação de 72 sítios líticos a céu aberto (com área inferior a $1.800 \mathrm{~m}^{2}$ ) e 3 abrigos sob rocha associados à Tradição Umbu. Em sua maioria, os sítios encontram-se agrupados nos fundos de vales inter-montanos, implantados nos terraços fluviais aplainados, ao abrigo das cheias, ou nos patamares mais baixos das vertentes. Os sítios distribuem-se de forma regular e pouco espaçada, representando, possivelmente, ocupações continuadas da área, o que reforça a idéia de um sistema de assentamento formado por unidades sociológicas 
concomitantes e integradas. A análise da variabilidade das indústrias líticas associada a estes sítios permitiu definir uma tipologia básica para a ocupação da área. Os sítios maiores e mais densos, de indústria variada, corresponderiam a sítios de atividade diversificada, estando circundados por sítios mais discretos, ligados à manutenção e reciclagem de artefatos, associados a atividades específicas. Os abrigos sob rocha ocupariam um papel periférico neste sistema de assentamento.

Dando continuidade as pesquisas, o autor buscou, em um segundo momento, compreender as características internas destes assentamentos e entender a sua concomitância e articulação, a partir de estudos comparativos intra e inter-sítios (De Blasis, 1996). Para tanto, centrou sua análise na ocupação em um trecho do vale do rio Betari, localmente conhecido como Bairro da Serra. Os estudos de campo permitiram a localização de 20 sítios líticos a céu aberto, cuja configuração espacial era semelhante à identificada nas pesquisas anteriores. A tipologia dos sítios reforça a idéia de que os sítios de atividade diversificada constituem-se em espaços residenciais/domésticos, caracterizados por áreas de atividade multifuncionais, atestadas pela variabilidade das indústrias líticas ${ }^{8}$.

Como se pode observar a partir dos resultados das pesquisas de De Blasis, a compreensão da variabilidade lítica representada pelas Tradições Umbu e Humaitá, em termos espaciais e temporais, demanda o desenvolvimento de estudos centrados na observação e avaliação da relação funcional entre grupos de sítios pertencentes a um mesmo sistema de assentamento, através do estabelecimento de análises comparativas intra e inter-sítios. Ao entendermos a mobilidade como um aspecto estruturante das sociedades caçadoras coletoras, passamos a perceber os sítios como entidades funcionais relacionadas sistemicamente a um modo específico de ocupação do espaço regional. Este é o instrumental teórico básico para que possamos compreender o registro estático como produto de comportamento humano e perceber a variabilidade artefatual como resultado de um sistema de relações.

Por sua vez, o modelo forrageiro, proposto por Binford (1980) e testado por Politis (1996a) para caçadores coletores de floresta tropical, mostra-se um instrumento fecundo para a elaboração de hipóteses interpretativas quanto às características dos sistemas de

\footnotetext{
${ }^{8}$ A única datação obtida para a área, 1250 anos AP, leva a conclusão de que esta corresponderia à manifestação mais setentrional da Tradição Umbu, alcançando a região montanhosa do médio Ribeira em uma época que o planalto estava ocupado por sociedades horticultoras (De Blasis, 1996: 104).
} 
assentamento caçador coletor do sul do Brasil a serem testadas através de projetos de campo centrados em comparações intra e inter-sítios. Por outro lado, o teste destes modelos associados a um referencial analítico orientado pela noção de estilo tecnológico pode nos oferecer bases teóricas mais seguras para discutir as possíveis distinções observadas nas indústrias líticas das Tradições Umbu e Humaitá. Para que possamos estabelecer uma segunda etapa dos estudos de caçadores coletores no sul do Brasil, tornase necessário, portanto, investir no desenvolvimento teórico-metodológico de linhas de pesquisa especificamente voltadas para este objeto. O binômio Tradição Umbu-Humaitá caracteriza conjuntos líticos distintos, mas o sentido sócio-cultural destas diferenças não é claro, necessitando investigações sistemáticas e intensivas, baseadas na revisão crítica dos dados disponíveis.

Com base nas referências teóricas e nos problemas de pesquisa acima expostos, buscamos analisar a problemática da variabilidade das indústrias líticas do sul do Brasil a partir das seguintes hipóteses de trabalho:

1. As cadeias operatórias relacionadas à produção de diferentes categorias de artefatos associadas a sítios arqueológicos correlacionados em uma determinada área manifestam um estilo tecnológico que possui significado cultural em termos de identidade social e/ou cultural.

2. A partir da identificação de padrões tecno-estilísticos pela comparação da organização tecnológica das indústrias de diferentes sítios líticos de uma mesma região, pode-se avaliar se a variabilidade nos conjuntos representa variações regionais e/ou temporais de uma ampla tradição tecnológica ou correspondem a categorias funcionais vinculadas ao uso diferenciado do espaço, em função do padrão de assentamento representado pelos sítios arqueológicos.

A partir destas hipóteses, os objetivos que nortearam nossa análise são os seguintes:

1. Partindo do conceito de estilo tecnológico, compreender a variabilidade das indústrias líticas para um determinado sistema de assentamento, a partir do estudo de diferentes sítios de uma dada região.

2. Definir o perfil tecnológico das ocupações relacionadas aos sítios arqueológicos localizados nesta região, abrindo a possibilidade de comparação destes contextos com outros, regional e temporalmente diferenciados.

3. Compreender em que medida um possível padrão estilístico-tecnológico relaciona-se a identidades sociais/regionais. 
4. Identificar a relação entre estabilidade e variação nestas indústrias, buscando interpretar em que medida o estilo tecnológico relaciona-se com aspectos funcionais, adaptativos e simbolicamente determinados.

5. Compreender o uso do espaço por sociedades caçadoras coletoras na região estudada através de pesquisas de campo de caráter prospectivo e escavações centradas na análise da variabilidade intra e inter-sítios.

Em um primeiro momento, nosso estudo estava direcionado para a análise de contextos arqueológicos relacionados exclusivamente à Tradição Umbu. Tendo em vista esta orientação inicial, optou-se por estudar a região do Alto Vale do Rio dos Sinos, no Estado do Rio Grande do Sul, cujos resultados de pesquisas anteriores apontavam para um grande potencial para a exploração desta temática. Contudo, tendo em vista a orientação regional deste estudo, o desenvolvimento das pesquisas de campo acabaram também por revelar conjuntos líticos identificados em vários sítios da área, associados a sistemas de assentamento de grupos horticultores Guarani e Jê, que correspondiam aos fósseis guia clássicos da Tradição Humaitá (choppers, chopping tools, talhadores e bifaces de grande porte).

Desta forma, ampliamos nossa análise a fim de incorporar à proposta original problemáticas também relacionadas à Tradição Humaitá, cujos conjuntos líticos, pelo menos na região estudada, apresentam uma forte correlação contextual com os sistemas de assentamento de grupos horticultores. Frente a esta problemática, a análise lítica orientada pela noção de estilo tecnológico e baseada em dados contextuais gerados a partir de estudos regionais orientados por uma concepção sistêmica de uso do espaço, torna-se uma ferramenta fundamental para o estudo de identidades sociais e culturais presentes na variabilidade de conjuntos líticos relacionados ao conceito de Tradição. 


\section{Capítulo 2}

\section{Estratégias de Estudo Regional dos Sistemas de Assentamento Pré- coloniais do Alto Vale do Rio dos Sinos, Rio Grande do Sul}

\subsection{Características Ambientais da Região do Alto Vale do Rio dos Sinos}

O vale do rio dos Sinos está associado à Região Hidrográfica da Bacia do Lago Guaíba, pertencente à Bacia do Atlântico Sudeste. Está situado na região nordeste do Rio Grande do Sul que corresponde à encosta inferior do extremo sudeste da Serra Geral, delimitada ao sul pela várzea do rio Gravataí e a leste pela baixada litorânea. Nossa área de estudo situa-se no extremo oriental da Depressão Central do Rio Grande do Sul, em uma região próxima da Planície Costeira Interna e do Planalto de Araucárias. A pluviosidade anual da região encontra-se entre 1500 e 1750 mm, situando-se a temperatura média entre $18^{\circ}$ e $20^{\circ}$ C. Devido a estas condições, seu clima é classificado como mesotérmico brando ou tropical temperado brando, com condições super-úmidas, sem seca. A média de temperaturas em janeiro encontra-se na casa dos $22^{\circ}$ aos $24^{\circ} \mathrm{C}$, situando-se em julho entre $13^{\circ}$ e $15^{\circ} \mathrm{C}$ (Jacobus et al, 1995: 428).

As nascentes do rio dos Sinos estão relacionadas à Área Serrana da Unidade Geomorfológica Serra Geral, correspondendo a uma continuação da Área dos Aparados da Serra. Abrange as rochas vulcânicas da Formação Serra Geral, onde o entalhamento da drenagem foi capaz de seccionar as várias seqüências de derrames, expondo as rochas basais areníticas da Formação Botucatu, sendo a erosão fluvial responsável pela intensa dissecação do relevo. Para leste, registram-se as maiores cotas altimétricas e vales fluviais com aprofundamentos superiores a $352 \mathrm{~m}$, relacionados à rede de drenagem do rio dos Sinos. A Área Serrana entra em contato ao sul com a Região Geomorfológica Depressão Central Gaúcha através de relevos abruptos que variam de escarpas e ressaltos topográficos a bordas de patamares estruturais, estando originalmente coberta por florestas estacionais deciduais e semideciduais (IBGE, 1986: 334-336).

O alto curso do rio dos Sinos relaciona-se a Unidade Geomorfológica Patamares da Serra Geral, que corresponde a uma continuidade da Unidade Geomorfológica anterior, avançado sobre as Unidades Geomorfológicas Planície Costeira Interna e Externa, a leste, e a Unidade Geomorfológica Depressão do Rio Jacuí, ao sul. Representa testemunhos de 
recuo da linha de escarpa a qual desenvolveu-se nas seqüências vulcânicas e sedimentares de cobertura da Província Paraná. Estende-se sobre as rochas efusivas básicas da Formação Serra Geral, observando-se nas áreas de maior entalhamento da drenagem o afloramento de arenitos da Formação Botucatu.

Na sua parte leste as formas de relevo apresentam um controle estrutural marcado, evidenciado por sulcos estruturais e vales fluviais a eles adaptados, cujos aprofundamentos variam entre 192 e 260 m. O relevo está representado por formas alongadas e subparalelas, por vezes, com ocorrência de cristas simétricas como as associadas à drenagem do rio dos Sinos. O direcionamento geral do seu curso é no sentido leste-oeste, seccionando a Unidade Patamares da Serra Geral, deixando para o sul de seu canal principal um grande bloco isolado e alongado, denominado regionalmente de Serra do Paredão. Nas bordas do rio dos Sinos, onde a dissecação é mais intensa, predomina o afloramento de rochas areníticas da Formação Botucatu.

Para oeste, a Unidade Patamares da Serra Geral apresenta-se na forma de colinas e vales fluviais com aprofundamentos entre 57 e 75 m, associados à ocorrência de morros testemunhos dispersos e à presença localizada de cristas simétricas. Estas formas de relevo apresentam-se interpenetradas por amplas áreas planas resultantes de acumulação fluvial ou da acumulação de depósitos de enxurradas que se associam aos cursos fluviais de maior competência erosiva da área. A passagem de formas de relevo dissecadas para os modelados de acumulação faz-se através de rupturas de declive, nos quais geralmente afloram rochas areníticas da Formação Botucatu, sendo a cobertura vegetal original representada pela floresta estacional decidual (IBGE, 1986: 336-338).

A região nordeste do Rio Grande do Sul é caracterizada por duas Unidades Geológicas distintas, a Formação Serra Geral e a Formação Botucatu (Dias, 1994: 93-95). A Formação Serra Geral constitui-se de uma sucessão de corridas de lavas, em geral de composição básica, apresentando uma seqüência superior de rochas efusivas ácidas. É considerado como um agrupamento de seqüências espessas de vulcanitos fissurais, predominantemente basálticos, que tem como contrapartes inúmeros diques, sills e corpos irregulares de diabásio. Sua distribuição basal é representada ao leste e ao sul por escarpas que configuram os limites do Planalto das Araucárias. Estas se amenizam ao se prolongarem para o extremo oeste do Rio Grande do Sul, constituindo aí o Planalto da Campanha (IBGE, 1986: 221-222). As rochas basálticas da Formação Serra Geral formaram-se a partir do rápido resfriamento das corridas de magma efusivo. As rochas basálticas, quando frescas, apresentam uma variedade de cores que grada do cinza-escuro 
ao negro, com tonalidades esverdeadas. Quando alteradas, apresentam em geral colorações em tom verde, castanho avermelhado e castanho claro. As colorações escuras devem-se principalmente a granulação fina e a presença de ferromagnesianos. Estas rochas podem ainda apresentar agregados intersticiais constituídos por quartzo, calcedônia, plagioclásio mais sódico e feldspato potássico. A coloração das rochas basálticas pode variar em função do seu estado de conservação. As rochas mais escuras, variando do cinza ao negro, apresentam-se melhor conservadas do intemperismo, enquanto as variantes avermelhadas apresentam-se mais decompostas. Estas últimas, por serem menos resistentes, liberam uma série de minerais secundários, como o quartzo e a hematita (IBGE, 1986: 228; Rambo, [1956] 1994: 236).

Os basaltos da Formação Serra Geral apresentam uma baixa cristalização, possuindo zonas de fratura ou diaclasiamento descontínuo, em função da velocidade em que ocorreu seu resfriamento. Estas fraturas podem dar-se de forma horizontal, nos limites inferior e superior do derrame, onde o resfriamento foi mais rápido, ou de forma vertical, provocada por um resfriamento mais lento no centro do derrame. Evidenciam-se nestes derrames basálticos zonas vesiculares ou vacuolares formadas pela retenção de gases, na forma de bolhas, durante a consolidação do magma. Possuindo forma esférica ou semi-esférica, estas vesículas ou drusas podem ser preenchidas, total ou parcialmente, por cristais de quartzo, calcedônia, calcita ou zeolita.

O quartzo constitui-se na principal formação secundária do basalto, gerando-se a partir da infiltração e deposição de água saturada de sílica $\left(\mathrm{SiO}_{2}\right)$ nas áreas vesiculares localizadas, principalmente, nas áreas de diaclasiamento horizontal, onde há uma maior propensão à retenção de água. O quartzo no interior das drusas pode individualizar-se de forma micro-cristalina, nas calcedônias e ágatas, ou macro-critalina, na forma de cristais de quartzo hialino. Tanto o quartzo como a calcedônia possui dureza 7 na escala de Mohs, fratura concóide e brilho vítreo As calcedônias são formadas por finas fibras de quartzo, podendo apresentar coloração variada, causada pela inclusão de outros minerais, em função da sua alta porosidade. Sua ocorrência pode dar-se em chapas de estratificação horizontal nas rochas superficiais do planalto, em camadas concêntricas que envolvem os agrupamentos de quartzo macro-cristalino no interior das drusas ou em "pérolas" nos leitos dos rios e arroios. As formas macro-cristalinas do quartzo hialino possuem o formato de um prisma hexagonal piramidado, com faces estriadas horizontalmente, e tamanho médio em torno de $10 \mathrm{~cm}$ de comprimento e $5 \mathrm{~cm}$ de largura. Em ambos os casos, as drusas, a partir das quais se formam, ficam livres pela desestruturação da rocha de encaixe, através 
da erosão. A ação do sol pode fazer com que as drusas desagreguem-se, espalhando os cristais de quartzo ao solo, podendo estes, bem como as drusas intactas, sofrer arraste pela ação fluvial ou pluvial (Dana \& Hurlbut, 1976: 526; Grehs, 1976: 131; Leinz \& Amaral, 1989: 41; Rambo, [1956] 1994: 244-246; Schumann, 1985: 24-50).

A Formação Botucatu é constituída por arenitos eólicos, de granulação média à fina e estratificação cruzada, situados sob os derrames basálticos da Formação Serra Geral. Os sedimentos da Formação Botucatu desenvolvem-se na Bacia do Paraná, desde o Rio Grande do Sul, abrangendo o território uruguaio, o nordeste da Argentina, o leste do Paraguai até os Estados de Mato Grosso e Rondônia. No Rio Grande do Sul, a formação estende-se desde a fronteira com o Uruguai, na região de Santa do Livramento, prolongando-se para o norte, em grande parte recoberta pelos derrames basálticos da Formação Serra Geral. É constituída por arenitos com estrutura típica de deposição eólica, apresentando coloração vermelha, rosa e esbranquiçada, sendo finos a médios, geralmente quartzosos e friáveis devido à matriz reduzida, apresentando grãos foscos e geralmente arredondados. A principal característica destes arenitos é a ausência de variação litológica, constituindo-se de um empilhamento de cunhas arenosas que apresentam um prolongamento maior na direção do vento, com as mesmas propriedades texturais, estruturais e mineralógicas (IBGE, 1986: 217-220).

Estas rochas sedimentares são constituídas essencialmente por grãos de quartzo interligados por um cimento predominantemente limonítico, formado pela mistura de óxido e hidróxido de ferro, o que lhe dá uma boa consistência e uma coloração avermelhada. Em alguns casos, o arenito da Formação Botucatu fundiu-se quando entrou em contato com as lavas efusivas da Formação Serra Geral, dando origem ao arenito silicificado. O arenito silicificado apresenta coloração avermelhada, brilho graxo, extrema dureza e fratura concoidal. Esta variante do arenito geralmente ocorre em nichos, faixas ou diques encaixados no basalto, jamais se formando na linha de contato entre as Formações Botucatu e Serra Geral. Na linha de contato direto, o cozimento do arenito foi menos intenso, por ser a areia dificilmente fusível e má condutora de temperatura. Contudo, nas porções encravadas ou injetadas, o calor mais violento do interior da torrente, agiu de todos os lados, conseguindo fundir o quartzo (Grehs, 1976: 128; Rambo, [1956] 1994: 236-238).

Na borda nordeste do Planalto, as Formações Serra Geral e Botucatu estão sujeitas à erosão devido à alta pluviosidade da região, facilitando arraste de suas rochas por ação fluvial. A ação da chuva torna estas rochas mais friáveis, permitindo o desbastamento de suas camadas externas que são arrastadas, na forma de blocos para o leito dos rios que 
contribuem para uma desestruturação mais violenta. Segundo Rambo ([1956] 1994: 254255), "o planalto rio-grandense é uma grande plataforma eruptiva, tendo as bordas franjadas, recortadas e parcialmente destruídas pelos rios, alojados nas fendas primitivas de esfriamento".

Quanto à cobertura vegetal original da área do Alto Rio dos Sinos, suas nascentes estão associadas à floresta estacional semidecidual, que apresenta uma composição de $20 \%$ a 50\% de árvores caducidófilas no período desfavorável (inverno). Em geral, o Alto Rio dos Sinos apresenta três variantes da floreta estacional semi-decidual de acordo com a altitude em relação ao nível do mar: floresta das terras baixas (até $30 \mathrm{~m}$ ), floresta submontana (30 até $400 \mathrm{~m}$ ) e floresta montana (de 400 até $1000 \mathrm{~m}$ ). A floresta das terras baixas está restrita às planícies originalmente inundáveis do rio dos Sinos, em altitudes de até $30 \mathrm{~m}$, constituídas de depósitos aluvionares do Quaternário, onde predominam as seguintes espécies: angico (Parapiptadenia rígida), ipê-amarelo (Tabebuia umbellata), figueira do mato (Fícus organensis), tarumã (Vitex megapotamica), canjerana (Cabralea canjerana), tucaneira (Cytharexylum myrianthum), entre outras. A floresta submontana, em altitudes superiores a $30 \mathrm{~m}$, está representada na bacia do Rio dos Sinos, no estrato superior, por mata-olho (Pachystroma longofolium), tanheiro (Alchornea triplinervea), maria-mole (Guapira opposita), camboatá (Cupania vernalis), entre outras. No estrato médio estão presentes laranjeira-do-mato (Actinostemon concolor), catiguá (Trichilia clausseni) e cincho (Sorocea bonplandii), entre outras. Ao norte do vale do rio dos Sinos, no sentido da Serra Geral, a floresta apresenta composição pouco diferente, predominando sobre os patamares mata-olho (Pachystroma longifolium) e batinga (Eugenia rostrifolia), como representantes dos dois estratos. A floresta montana se limita ao norte, com cotas de altitude de $800 \mathrm{~m}$, com a floresta ombrófila mista, podendo-se encontrar espécies como a guajuvira (Patagonula), o angico vermelho (Parapiptadenia rígida), o louro pardo (Cordia trichotoma), a canjerana (Cabralea canjerana) e o tanheiro (Alchornea triplinervea). Em geral, as palmáceas são representadas pelo jerivá (Arecastrum romanzoffianum), presente em todas as formações florestais do sul do Brasil (IBGE, 1986: 574-576). 
2.2. Propostas Metodológicas para o Estudo de Sistemas de Assentamento Précolonias no Alto Vale do Rio dos Sinos

Para a implementação de nossa proposta de trabalho optou-se por estudar a região do Alto Vale do Rio dos Sinos, que abrange os municípios de Santo Antônio da Patrulha, Caraá e Rolante, no Estado do Rio Grande do Sul (Anexo 1). Esta escolha deu-se em função dos antecedentes de pesquisas arqueológicas para a região nordeste do Rio Grande do Sul, em especial no município de Santo Antônio da Patrulha, que apontavam para uma ocupação caçadora coletora consistente na área.

Durante as atividades do PRONAPA e o PROPA, Eurico T. Miller registrou 111 sítios arqueológicos associados à Tradição Umbu (fases Umbu e Itapuí) na região nordeste do Estado, sendo apenas 5 destes a céu aberto (fase Camuri), cuja cronologia de ocupação se estenderia entre 6.000 e 1740 anos AP. As pesquisas arqueológicas no município de Santo Antônio da Patrulha ${ }^{1}$ desenvolveram-se entre 1965 e 1975, resultando na localização de 17 sítios cerâmicos a céu aberto da Tradição Guarani, 15 sítios pré-cerâmicos em abrigos sob rocha da Tradição Umbu e 4 sítios líticos a céu aberto afiliados à Tradição Humaitá, totalizando 36 sítios arqueológicos. Foram realizadas na época duas datações radiocarbônicas que apontaram contemporaneidade na ocupação de dois dos sítios em abrigo sob rocha da área, apresentando o sítio RS-S-359: Aterrado uma datação de 1740+65 AP (SI 2344) e o sítio RS-S-328: Caipora uma datação de 1655+65 AP (SI 2345). Os vestígios arqueológicos provenientes destas pesquisas foram analisados por Miller com o objetivo de estabelecer seqüências seriadas para a obtenção de cronologias relativas, que resultaram na definição de duas fases cerâmicas para a Tradição Guarani (Maquiné, Paranhana), uma fase cerâmica para a Tradição Neo-brasileira (Monjolo), duas fases précerâmicas para a Tradição Umbu (Umbu e Itapuí) e uma fase pré-cerâmica da Tradição Humaitá (Camboatá) (Miller, 1967, 1974).

As coleções e a documentação resultante destas pesquisas encontra-se atualmente sob a guarda do Museu Arqueológico do Rio Grande do Sul (MARSUL). Sua avaliação, porém, demonstra que estas se apresentam incompletas, sendo poucos os sítios que possuem ficha de registro de pesquisa arqueológica, documentação gráfica ou informações

\footnotetext{
1 Naquele momento os limites municipais de Santo Antônio da Patrulha abrangiam áreas atualmente pertencentes aos municípios de Caraá e Rolante. As localidades pesquisadas por Miller foram as seguintes: Arroio Carvalho, Arroio da Furna, Barrocadas, Campestre, Castelhana, Catanduva, Fraga, Guarda Velha, Lombas, Monjolo, Mont Serrat, Passo da Forquilha e Pinheirinho (Jacobus, 1994a).
} 
quanto as suas coordenadas geográficas. Várias coleções arqueológicas da área também não possuem a totalidade ou parte dos vestígios devidamente identificados entre o acervo do MARSUL.

Em função destas deficiências, André Luiz Jacobus implementou em 1994, com o apoio institucional do MARSUL, o Projeto Arqueológico de Santo Antônio da Patrulha (PASAP), com o objetivo de retomar as pesquisas neste município sob perspectivas teórico-metodológicas que permitissem preencher as lacunas deixadas pelos trabalhos anteriores (Jacobus, 1994a; Jacobus et al, 1995). Entre 1994 e 1997, o PASAP desenvolveu pesquisas arqueológicas prospectivas e de escavação, vinculadas ao subprojeto Formação da Sociedade Nacional, em sítios históricos dos séculos XVIII e XIX situados nas localidades de Guardas Velhas e Aldeias Velhas (Barros, 1996; Jacobus, 1994b, 1996a, 1996b, 1998). Atividades de pesquisa relacionadas à ocupação caçadora coletora no município de Santo Antônio da Patrulha também foram desenvolvidas pelo PASAP entre 1994 e 1999, tendo sido analisadas as coleções líticas de sítios da Tradição Umbu pesquisados pelo PRONAPA em Santo Antônio da Patrulha (Dias, 1999b, 2000b, 2000c), e realizados levantamentos de sítios em abrigos sob rocha nas localidades de Guarda Velha, Monjolo e Campestre Novo. Estas permitiram a localização de oito sítios arqueológicos $^{2}$ registrados durante o PRONAPA, cuja documentação de campo arquivada junto ao MARSUL não apresentava dados relativos a sua posição geográfica, sendo também registrados outros três sítios em abrigo sob rocha ${ }^{3}$ inéditos na área, dois dos quais apresentando materiais arqueológicos associados à Tradição Umbu (Jacobus, 1994b).

Os nove sítios arqueológicos em abrigo sob rocha associados à Tradição Umbu vistoriados até aquele momento apresentavam condições razoáveis de preservação, permitindo novas intervenções para estudos de organização intra-sítio, bem como para obtenção de amostras de material orgânico para datações radiocarbônicas. Este aspecto, bem como as características das indústrias líticas das coleções do PRONAPA já analisadas, influenciaram nossa escolha da região do Alto Vale do Rio dos Sinos para a

\footnotetext{
${ }^{2}$ Os sítios em abrigo sob rocha, pesquisados pelo PRONAPA, que foram localizados entre 1994 e 1995 são os seguintes: RS-S-262: Guarda Velha-1, RS-S-264: Toca do Sino, RS-S-265: Campestre, RS-S-327: Sangão, RS-S-337: Monjolo, RS-S-358: Toca Grande-2, RS-S-360: Marimbondo e RS-S-361: Mato da Toca. Nas prospecções realizadas entre 2000 e 2001 foram localizados os seguintes sítios registrados durante o PRONAPA: RS-S-326: Toca dos Carrapatos, RS-S-328: Caipora e RS-S-359: Aterrado. Na documentação das pesquisas do PRONAPA, disponíveis para consulta no MARSUL, nenhum destes sítios possuía informações quanto as suas coordenadas geográficas.

${ }^{3}$ São estes os sítios RS-S-388: Guarda Velha-6, RS-S-390: Jovelino e RS-S-391: Dodô. Nenhum destes foi sondado quando de sua localização pelo PASAP.
} 
implementação de um projeto relativo ao sistema de assentamento caçador coletor. $\mathrm{O}$ projeto recebeu o apoio institucional do MARSUL, responsável pela salvaguarda dos acervos e documentação de pesquisa resultante ${ }^{4}$, e recebeu financiamento de pesquisa da Fundação de Amparo a Pesquisa do Estado de São Paulo (FAPESP) ${ }^{5}$.

A definição do tamanho da área a ser prospectada, por sua vez, deu-se em função de um padrão mínimo derivado do modelo etnoarqueológico de mobilidade caçadora coletora em área de floresta tropical, derivado dos trabalhos de Politis entre os Nukak da Colômbia $^{6}$ (1996a, 1996b). Tendo por base estes critérios, foram selecionados como limites naturais para a área piloto a ser prospectada os principais cursos de água associados à drenagem do Alto Rio dos Sinos. Sua área total foi definida em $216 \mathrm{Km}^{2}$, com $18 \mathrm{Km}$ de extensão no sentido leste-oeste e $12 \mathrm{Km}$ no sentido norte-sul, sendo seus limites naturais os seguintes:

A) Limite Norte (UTM 22J 6716000$)^{7}$ : Sua parte leste é limitada pelo alto vale do arroio Grande (afluente da margem direita do rio dos Sinos) e pelos vales alto e médio do arroio do Monge (afluente da margem direita do arroio Rolantinho). A oeste está o médio vale do arroio Rolantinho (afluente da margem esquerda do rio Rolante) e o baixo vale do arroio do Monge.

B) Limite Sul (UTM 22J 6704 000) $)^{8}$ : Sua parte leste é limitada pelos vales baixo e médio do arroio Caraá (afluente da margem esquerda do rio dos Sinos) e sua parte oeste corresponde à várzea esquerda do rio dos Sinos.

C) Limite Leste (UTM 22J 558 000): Sua porção norte é limitada pelo vale do arroio Sertão (afluente da margem direita do rio dos Sinos), estando ao sul o alto vale do arroio Caraá.

D) Limite Oeste (UTM 22J 540 000): O norte está delimitado pelo vale do rio dos Sinos e as nascentes dos arroios Campestre Velho (afluente da margem direita do rio dos Sinos) e Rolantinho da Figueira (afluente da margem esquerda do arroio

\footnotetext{
${ }^{4}$ Todos os sítios registrados durante as prospecções realizadas por este projeto de tese foram identificados de acordo com o sistema do PRONAPA, recebendo as siglas RS-S (Rio Grande do Sul, vale do rio dos Sinos), RS-LC e RS-LN (Rio Grande do Sul, litoral central e norte), um número seqüencial e um nome, geralmente da localidade em que se encontram ou do proprietário da área onde se situa o sítio.

${ }^{5}$ Processo de Auxílio Pesquisa FAPESP 2000\07609-0, sob coordenação do Prof. Dr. Paulo A. Dantas De Blasis.

${ }^{6} \mathrm{O}$ detalhamento deste modelo etnoarqueológico encontra-se no capítulo 3.

${ }^{7}$ Limite municipal entre Santo Antônio da Patrulha e Rolante.

${ }^{8}$ Limite municipal entre Santo Antônio da Patrulha e Caraá.
} 
Rolantinho), situando-se na porção sul o vale do arroio Madeira (afluente da margem esquerda do rio dos Sinos).

A porção leste da área piloto compreende o município de Caraá, situando-se nesta sua sede municipal e as localidades de Vila Nova, Quebrada do Rio dos Sinos e Sertão Rio dos Sinos. Ao norte situa-se o município de Rolante, compreendendo as localidades de Alto Rolantinho, Rolantinho da Figueira e Alto Caconde. O município de Santo Antônio da Patrulha abriga o restante da área pesquisada, abrangendo as localidades de Guarda Velha, Rincão do Herval, Monjolo, Bom Retiro, Pinheiros, Campestre Novo, Campestre Velho, Canto dos Guilhermes, Passo da Forquilha, Evaristo e Furna.

O plano de estudo da área piloto estruturou-se a partir de estratégias de campo organizadas em múltiplos estágios (Binford, 1964; Plog, Plog \& Wait, 1978; Redman, 1973; Schiffer [1987] 1996; Schiffer et al, 1980). De acordo com esta concepção, o trabalho de campo foi idealizado da seguinte forma:

1) reconhecimento geral das potencialidades da área para pesquisa arqueológica;

2) prospecção probabilística de amostragens do terreno total da área piloto;

3) sondagem das características de subsolo de sítios selecionados com base em seu potencial arqueológico;

4) escavações de sítios escolhidos a partir dos resultados da etapa anterior.

Os trabalhos de campo realizaram-se entre fevereiro de 2000 e janeiro de 2002, totalizando 158 dias de atividades, dos quais 70 dias relacionam-se ao desenvolvimento das três primeiras etapas de campo acima mencionadas, estando o restante do tempo associado às escavações de três sítios em abrigos sob rocha, cujos resultados serão apresentados no capítulo quatro.

Para o reconhecimento geral das potencialidades de pesquisa arqueológica da região foram levantados seus dados geomorfológicos e ambientais através da análise dos mapas de Levantamento de Recursos Naturais do IBGE (Folha SH.22 Porto Alegre e parte das folhas SH.21 Uruguaiana e SI.22 Lagoa Mirim), escala 1:1.00.000, e dos mapas do Ministério do Exército que abrangem a área piloto (folhas SH.22-X-C-V-1 Barra do Ouro, SH.22-X-C-IV-2 Rolante, SH.22-X-C-V-3 Osório e folha SH.22-X-C-IV-4 Santo Antônio da Patrulha), com escala de 1:50.000. A partir da análise preliminar destes dados, em fevereiro de 2000 foi implementada uma vistoria extensiva prévia nos vales do rio dos 
Sinos e dos arroios Grande, Pinheiro, Sertão, Caraá, Pedra Branca ${ }^{9}$ e Restinga, abrangendo dois compartimentos topográficos distintos: várzea e meia encosta/encosta. O objetivo desta atividade foi registrar nas áreas a serem prospectadas as atuais condições de acesso, visibilidade de solo e intensidade da ocupação humana contemporânea (tipo de atividade agrícola e extensão da malha viária e urbana), bem como manter contatos prévios com os moradores da região e inspecionar locais aptos à ocupação humana a fim de definir as estratégias de prospecção a serem adotadas.

Levando-se em consideração o tipo de contexto arqueológico conhecido, o tamanho da área piloto e os resultados da vistoria extensiva, organizamos nosso plano de prospecção combinando estratégias de levantamento por amostragem probabilística estratificada com estratégias de levantamento abrangente extensivo (Araújo, 2001). Nos levantamentos por amostragem probabilística o universo da pesquisa pode ser subdividido em unidades distintas, chamadas unidades amostrais, cujos limites podem ser naturais ou arbitrários (Binford, 1964: 141). A escolha da distribuição espacial, da fração e do tamanho destas unidades amostrais são determinadas pela probabilidade de descoberta de sítios que pode variar em função das propriedades do registro arqueológico (tamanho dos sítios e densidade de artefatos em superfície) e das características de sua área de implantação (acessibilidade e visibilidade do terreno) (Schiffer et al, 1980: 8-9).

De forma geral, o plano de amostragem pode se dar de maneira aleatória, sistemática ou estratificada, podendo-se, de acordo com o contexto, combinar estas estratégias. De acordo com um plano aleatório, as unidades amostrais são eleitas por qualquer instrumento que garanta que a probabilidade de uma unidade ser selecionada é equivalente a qualquer outra. Um plano sistemático de amostragem, por sua vez, envolve a distribuição eqüidistante das unidades amostrais na área de pesquisa. Por fim, um plano estratificado pressupõe uma distribuição equivalente das unidades amostrais de prospecção, orientadas pelas características ambientais da área a ser pesquisada (Binford, 1964; Plog, 1976; Plog, Plog \& Wait, 1978; Schiffer et al, 1980).

Optou-se por estabelecer unidades amostrais de prospecção com limites arbitrários, na forma de quadrados de $1 \mathrm{Km}^{2}$, subdivididos em 4 quadrantes de 500 metros de lado. Em função das características do relevo, da cobertura vegetal e do sistema hidrográfico,

\footnotetext{
${ }^{9}$ Esta área foi avaliada quanto ao seu potencial arqueológico e acessibilidade e posteriormente excluída da área piloto deste projeto. Assim, os dois sítios da Tradição Guarani ali localizados durante as vistorias extensivas (RS-S-400 e RS-S-401) que constam da relação total dos sítios estudados não se situam dentro dos limites definidos para a área piloto.
} 
decidiu-se distribuir as unidades amostrais entre os dois estratos geomorfológicos distintos que caracterizam a área piloto, compreendendo as planícies de inundação ao sul e as meias encostas e encostas que marcam sua paisagem ao norte. Para estabelecer a quantidade de unidades amostrais a serem prospectadas e garantir uma padronização na sua distribuição entre os estratos ambientais selecionados, elegeu-se as áreas de confluência de corpos de água como locais preferenciais para a sua localização. Esta escolha baseou-se em pesquisas sobre os contextos de implantação de sítios da Tradição Umbu em outras regiões (De Blasis, 1988, 1996), bem como nos dados arqueológicos disponíveis para área. Também, em termos gerais, as pesquisas arqueológicas sobre grupos horticultores da Tradição Guarani, no Estado do Rio Grande do Sul, também apontam para este mesmo modelo de implantação (Noelli, 1993; Schmitz, 1991). Portanto, o padrão de distribuição das unidades amostrais de prospecção proposto apresentaria uma alta probabilidade de localização de sítios a céu aberto que complementariam os dados disponíveis para ocupação de sítios em abrigo sob rocha.

No mapa da área piloto, elaborado com base nas cartas do Ministério do Exército ${ }^{10}$ (escala 1:50.000), estabeleceu-se uma malha de quadriculamento de $1 \mathrm{Km}^{2}$ sobreposta aos cursos de água, selecionando-se as unidades amostrais associadas às áreas de confluência. Partindo deste procedimento padrão, foram selecionadas 56 unidades amostrais a serem prospectadas que correspondem a uma fração de $25 \%$ da área piloto. Os limites das unidades amostrais foram registrados por coordenadas UTM, permitindo sua localização em campo com o auxílio de GPS.

Por sua vez, o mapa geral da área piloto foi dividido em quatro setores para facilitar a avaliação comparativa dos dados obtidos nas prospecções. Em cada um dos setores as unidades amostrais de prospecção foram registradas por uma numeração seqüencial, no sentido leste-oeste, sendo os quadrantes que as subdividem designado por letras, no sentido horário. Das 56 unidades amostrais selecionadas para prospecção na área piloto, 13 situamse no setor nordeste $\mathrm{e}^{11}, 15$ no setor sudeste $\mathrm{e}^{12}, 12$ no setor noroeste ${ }^{13}$ e 16 no setor sudoeste $\mathrm{e}^{14}$ (Anexo 2).

\footnotetext{
${ }^{10} \mathrm{O}$ mapa da área piloto distribui-se entre as seguintes cartas do Ministério do Exército - Diretoria de Serviço Geográfico/ Região Sul do Brasil, com escala de 1:50.000: Barra do Ouro (folha SH.22-X-C-V-1), Rolante (folha SH.22-X-C-IV-2), Osório (folha SH.22-X-C-V-3) e Santo Antonio da Patrulha (folha SH.22-X-C-IV4).

${ }^{11}$ Abrange as localidades de Alto Caconde, Canta Galo, Cerro, Furna, Evaristo, Pinheiros (pertencentes ao município de Santo Antônio da Patrulha), Sertão Rio dos Sinos e Vila Nova (situadas no município de Caráa).
} 
Para cada quadrante das unidades amostrais de prospecção foi preenchida uma ficha padrão, registrando as seguintes informações: 1) equipe responsável pela atividade; 2) data da prospecção; 3) nome e endereço dos proprietários da área; 4) coordenadas limites do quadrante; 5) descrição geral das condições do terreno; 6) pontos de referência na paisagem para localização dos limites do quadrante; 7) tipo de atividade realizada na área (características das linhas de caminhamento); 8) acessibilidade; 9) presença ou proximidade de corpos d’água; 10) topografia; 11) visibilidade de solo; 12) alterações do terreno por ação humana; 13) tipos de cultivo ou cobertura vegetal; 14) extensão de áreas cultivadas ou de cobertura vegetal; 15) outros tipos de alteração humana ou natural; 16) presença de sítios arqueológicos em superfície; 17) coordenadas dos sítios arqueológicos; 18) outras observações sobre o quadrante prospectado. Este procedimento garantiu o registro padronizado de informações para posteriores descrições e comparações das áreas prospectadas, auxiliando na avaliação do tipo de informação resgatada.

O registro dos sítios arqueológicos localizados, por sua vez, foi realizado de acordo com a ficha padrão do Instituto do Patrimônio Histórico Nacional (IPHAN). Por sítio arqueológico definiu-se qualquer local discreto e potencialmente interpretável que apresente agrupamentos de materiais culturais (artefatos, ecofatos e estruturas), sendo limitado espacialmente pela mudança na densidade destes itens (Plog, Plog \& Wait, 1978: 389). Também foram considerados como sítios arqueológicos evidências arqueológicas isoladas ou em agrupamentos dispersos (non-sites), na medida em que podem representar áreas em um sistema de assentamento onde ocorreram atividades específicas que não produziram uma quantidade de resíduos significativa ou nas quais a ação antrópica e/ou natural condicionou uma baixa densidade de materiais em superfície (Thomas, 1975; Dunnel \& Dancey, 1983).

A vistoria geral do terreno nas unidades amostrais de prospecção se deu através de levantamentos abrangentes extensivos, utilizando como táticas básicas a vistoria dos locais onde ocorre exposição natural ou artificial do solo (linhas de erosão ou boçorocas, trilhas de gado, barrancas de estrada ou de rio) e a prospecção sistemática intensiva em terrenos

\footnotetext{
12 Abrange as localidades de Evaristo, Quebrada Rio dos Sinos, Passo da Forquilha (pertencentes ao município de Santo Antônio da Patrulha), Rio dos Sinos e o centro municipal de Caraá.

13 Abrange as localidades de Rolantinho da Figueira, Morro da Figueira, Alto Rolantinho (pertencentes ao município de Rolante), Alto Caconde, Canto dos Guilhermes, Campestre Velho, Campestre Novo e Campestre (situadas no município de Santo Antônio da Patrulha).

${ }^{14}$ Abrange as localidades de Campestre Novo, Monjolo, Bom Retiro, Guarda Velha e Rincão do Herval (município de Santo Antônio da Patrulha).
} 
arados, localizados durante os caminhamentos. Nos locais que apresentaram maior visibilidade de solo, como áreas agrícolas e de vegetação mais esparsa, foi realizada linhas de caminhamento paralelas, distanciadas entre 2 e $5 \mathrm{~m}$. Zonas que apresentavam cobertura vegetal por pasto sofreram vistoria extensiva, devido à impossibilidade de visualização de solo, com exceção das linhas de erosão (boçorocas), freqüentes neste tipo de contexto (Schiffer et al, 1980: 7). Para testar a eficiência do sistema de prospecção por unidades amostrais, foram também realizados levantamentos extensivos nas áreas de meia encosta e encosta, situadas no entorno dos limites das unidades amostrais de prospecção devido à probabilidade de apresentarem abrigos sob rocha e outros tipos de sítios arqueológicos. Nestas realizou-se também prospecção sistemática intensiva das áreas aradas ou com visibilidade de solo. Entrevistas com os moradores locais complementaram esta atividade, oferecendo informações sobre a existência de abrigos sob rocha em áreas fora dos quadrantes de prospecção, geralmente encobertos por mato secundário, e de sítios cerâmicos em locais já cultivados, mas atualmente sem visibilidade de solo devido à cobertura vegetal por pasto.

\subsection{Características das Unidades Amostrais de Prospeç̧ão nos Diferentes} Setores da Área Piloto

A rede viária local é bastante extensa, permitindo o acesso facilitado às unidades amostrais selecionadas. Por outro lado, as áreas selecionadas para a prospecção encontramse atualmente ocupadas por pequenas propriedades rurais, cuja economia é voltada para atividades agropecuárias de subsistência. Portanto, a visibilidade do terreno é marcada pelos ciclos agrícolas, sendo o cronograma das prospecções orientado de acordo com o calendário dos cultivos.

As prospecções ocorreram entre outubro de 2000 e dezembro de 2001, totalizando 50 dias de atividades. A vistoria de uma unidade amostral de prospecção foi realizada em média por uma equipe de cinco a três pessoas, a cada dia de trabalho. Das 56 unidades de prospecção vistoriadas, $15,6 \%$ não foram prospectadas de forma intensiva em função das condições do terreno ou impossibilidade de acesso. As áreas não prospectadas situam-se, em geral, nas zonas de interflúvios da várzea, sendo cobertas por pastos alagadiços utilizados para criação de gado e búfalos ou para cultivo de arroz, com ampla alteração de terreno pela ação de arado mecânico e construção de canais de escoamento. Tendo em 
vista a alta pluviosidade da região, estas áreas encontram-se alagadas ao longo de todo o ano, sendo baixa a probabilidade de localização de evidências arqueológicas em superfície, o que justificou sua não inspeção. Nos demais casos a presença de capões de mato secundário, encobrindo encostas e meias encostas, impediu o acesso às unidades amostrais de prospecção.

Quanto às características ambientais gerais das unidades amostrais de prospecção, sua distribuição entre os estratos topográficos da área piloto deu-se da seguinte forma: 38,8\% encontram-se na meia encosta, 35,7\% corresponde à várzea, 11,1\% situam-se na zona de intersecção entre várzea e meia encosta, 9,3\% associam-se à área de encosta, estando os 4,9\% restantes relacionados a morros testemunho. As altitudes em relação ao nível do mar predominantes nas unidades amostrais de prospecção situam-se entre 0 e 20 m (22,3\%), 20 e $40 \mathrm{~m}(14,7 \%), 40$ e $60 \mathrm{~m}(11,6 \%)$ e 80 e $100 \mathrm{~m}(10,7 \%)$, estando as unidades restantes distribuídas de forma eqüitativa em altitudes ascendentes que atingem até $400 \mathrm{~m}$.

O setor nordeste da área piloto corresponde a uma área de encosta com declividade acentuada, cortada por vales encaixados associados às nascentes dos arroios Sertão, Grande e Pinheiros, afluentes da margem direita do rio dos Sinos, e do arroio Rolantinho. As altitudes deste setor são as mais elevadas da área piloto, estando entre 100 e 850 m. Das unidades amostrais de prospecção associadas a este setor, 78,8\% estão relacionadas a meias encostas e $21,1 \%$ às encostas. Tendo em vista estas características, as altitudes em relação ao nível do mar predominantes nas unidades amostra estão entre 80 e $100 \mathrm{~m}$ (19,2\%), 200 e 220 m (30,7\%), 280 e 300 m (15,3\%) e 380 a 400 m (17,3\%).

O setor sudeste da área piloto caracteriza-se pela intersecção entre várzeas e meia encosta, relacionada às nascentes do rio dos Sinos. Na sua porção oeste, as várzeas do rio dos Sinos e de seus afluentes, arroios Caraá (margem esquerda) e Sertão (margem direita), seguem um curso encaixado em uma encosta montanhosa, correspondendo a uma várzea mais elevada, com altitudes médias entre 30 e $50 \mathrm{~m}$. A meia encosta que acompanha os principais cursos de água possui altitudes entre 80 e 120 m, formando platôs elevados com declividade suave sobre a área de inundação. A porção leste deste setor é marcada por uma várzea extensa, com altitudes entre 19 e 38 m, que caracteriza o interflúvio entre o rio dos Sinos e o arroio Grande (seu afluente da margem direita) e a confluência do arroio Pinheiros com o arroio Grande. A várzea corresponde à característica topográfica da maioria das unidades amostrais de prospecção deste setor (51,6\%), estando o restante representado pela intersecção da várzea com a meia encosta $(21,6 \%)$ e pela meia encosta 
(26,6\%) que se estende em direção ao norte. Nestas, predominam altitudes entre 0 e $20 \mathrm{~m}$ (15\%), 40 e 60 m (15\%) e 80 e 100 m (13,3\%).

O setor noroeste da área piloto corresponde a uma área de encosta com declividade acentuada, cortada por vales encaixados de pequenos arroios, tributários da margem direita do rio dos Sinos e da margem esquerda do Arroio Rolantinho. A porção norte deste setor corresponde ao vale encaixado do arroio Rolantinho, com altitudes médias da meia encosta entre 100 e $160 \mathrm{~m}$, estando os pontos mais elevados da encosta associados a cotas entre 250 e 400 m de altitude. Sua porção sul é caracterizada pela várzea do arroio Campestre, afluente da margem direita do rio dos Sinos, com altitude média de $48 \mathrm{~m}$. A meia encosta onde se situam suas nascentes tem altitudes médias entre 100 e 160 m, estando os topos de morros da área entre 200 e 230 m. As características topográficas deste setor acompanham a tendência do setor sudoeste da área piloto, sendo grande a quantidade de abrigos sob rocha associados às áreas de semi-encosta. Quanto à topografia das unidades amostrais de prospecção neste setor, 50\% destas está relacionada à meia encosta, distribuindo-se as restantes entre a várzea (20,8\%), a intersecção entre meia encosta e várzea (8,3\%) e encosta (20,8\%). As altitudes para as unidades amostrais do setor são elevadas em geral, situando-se entre 100 e 120 m (20,8\%), 140 e 160 m (12,5\%) e 180 e 200 m (22,9\%).

As altitudes mais baixas da área piloto situam-se no setor sudoeste. As várzeas baixas do rio dos Sinos e dos arroios Grande e da Restinga (seus afluentes da margem direita) caracterizam esta área que possui altitudes entre 10 e 20 m. Morros testemunho areníticos associados à formação de abrigos sob rocha se destacam nesta paisagem de várzea, com altitudes médias entre 50 e $70 \mathrm{~m}$. A meia encosta que circunda o eixo principal do rio dos Sinos também apresenta baixas altitudes, situando-se entre 60 e $160 \mathrm{~m}$, apresentando também a formação de abrigos sob rocha. O pacote sedimentar é pouco espesso, deixando exposto em vários pontos a base arenítica na forma de lajedos. Quanto à topografia das unidades amostrais de prospecção, predomina neste setor aquelas associadas à várzea (60,9\%), estando o restante relacionado à intersecção entre meia encosta e várzea (12,5\%), à meia encosta $(9,3 \%)$ e aos morros testemunhos $(17,1 \%)$. As altitudes nestas unidades amostrais situam-se entre 0 e 20 m (57,8\%), 20 e 40 m (10,9\%) e 40 e 60 m $(17,1 \%)$. 
Tabela 1. Topografia nas Unidades Amostrais de Prospecção

\begin{tabular}{|c|c|c|c|c|c|c|c|c|c|c|}
\hline Topografia & $\begin{array}{c}\text { Setor } \\
\text { Nordeste } \\
\text { (área em } \\
\mathbf{K m}^{2} \text { ) }\end{array}$ & $\%$ & $\begin{array}{c}\text { Setor } \\
\text { Sudeste } \\
\text { (área em } \\
\mathbf{K m}^{2} \text { ) }\end{array}$ & $\%$ & $\begin{array}{c}\text { Setor } \\
\text { Noroeste } \\
\text { (área em } \\
\mathbf{K m}^{2} \text { ) }\end{array}$ & $\%$ & $\begin{array}{c}\text { Setor } \\
\text { Sudoeste } \\
\text { (área em } \\
\mathbf{K m}^{2} \text { ) }\end{array}$ & $\%$ & Total & $\%$ \\
\hline Encosta & 2,75 & 21,2 & 0 & 0 & 2,5 & 20,8 & 0 & 0 & 5,25 & 9,3 \\
\hline Meia encosta & 10,25 & 78,8 & 4 & 26,6 & 6 & 50 & 1,5 & 9,3 & 21,75 & 38,8 \\
\hline $\begin{array}{l}\text { Intersecção } \\
\text { meia encosta } \\
\text { e várzea }\end{array}$ & 0 & 0 & 3,25 & 21,6 & 1 & 8,3 & 2 & 12,5 & 6,25 & 11,1 \\
\hline Várzea & 0 & 0 & 7,75 & 51,6 & 2,5 & 20,8 & 9,75 & 60,9 & 20 & 35,7 \\
\hline $\begin{array}{c}\text { Morro } \\
\text { testemunho }\end{array}$ & 0 & 0 & 0 & 0 & 0 & 0 & 1,5 & 9,3 & 1,5 & 2,6 \\
\hline $\begin{array}{l}\text { Intersecção } \\
\text { morro } \\
\text { testemunho e } \\
\text { várzea }\end{array}$ & 0 & 0 & 0 & 0 & 0 & 0 & 1,25 & 7,8 & 1,25 & 2,2 \\
\hline Total & 13 & 100 & 15 & 100 & 12 & 100 & 16 & 100 & 56 & 100 \\
\hline
\end{tabular}

Tabela 2. Altitudes nas Unidades Amostrais de Prospecção

\begin{tabular}{|c|c|c|c|c|c|c|c|c|c|c|}
\hline $\begin{array}{l}\text { Altitude } \\
\text { (metros) }\end{array}$ & $\begin{array}{c}\text { Setor } \\
\text { Nordeste } \\
\text { (área em } \\
\mathbf{K m}^{2} \text { ) }\end{array}$ & $\%$ & $\begin{array}{c}\text { Setor } \\
\text { Sudeste } \\
\text { (área em } \\
\mathbf{K m}^{2} \text { ) }\end{array}$ & $\%$ & $\begin{array}{c}\text { Setor } \\
\text { Noroeste } \\
\text { (área em } \\
\mathbf{K m}^{2} \text { ) }\end{array}$ & $\%$ & $\begin{array}{c}\text { Setor } \\
\text { Sudoeste } \\
\text { (área em } \\
\mathbf{K m}^{2} \text { ) }\end{array}$ & $\%$ & Total & $\%$ \\
\hline $0-20$ & 0 & 0 & 2,25 & 15 & 1 & 8,3 & 9,25 & 57,8 & 12,5 & 22,3 \\
\hline $20-40$ & 0,5 & 3,8 & 6 & 4 & 0 & 0 & 1,75 & 10,9 & 8,25 & 14,7 \\
\hline $40-60$ & 0 & 0 & 2,25 & 15 & 1,5 & 12,5 & 2,75 & 17,1 & 6,5 & 11,6 \\
\hline $60-80$ & 0 & 0 & 0,75 & 5 & 1,25 & 10,4 & 1 & 6,2 & 3 & 5,3 \\
\hline $80-100$ & 2,5 & 19,2 & 2 & 13,3 & 1,25 & 10,4 & 0,25 & 1,5 & 6 & 10,7 \\
\hline $100-120$ & 0 & 0 & 1,5 & 10 & 2,5 & 20,8 & 0,25 & 1,5 & 4,25 & 7,5 \\
\hline $120-140$ & 0 & 0 & 0 & 0 & 0 & 0 & 0 & 0 & 0 & 0 \\
\hline $140-160$ & 0,75 & 5,7 & 0 & 0 & 1,5 & 12,5 & 0,75 & 4,6 & 3 & 5,3 \\
\hline $160-180$ & 0,5 & 3,8 & 0,25 & 1,6 & 0 & 0 & 0 & 0 & 0,75 & 1,3 \\
\hline $180-200$ & 0 & 0 & 0 & 0 & 2,75 & 22,9 & 0 & 0 & 2,75 & 4,9 \\
\hline $200-220$ & 4 & 30,7 & 0 & 0 & 0 & 0 & 0 & 0 & 4 & 7,1 \\
\hline $220-240$ & 0 & 0 & 0 & 0 & 0,25 & 2 & 0 & 0 & 0,25 & 0,4 \\
\hline $240-260$ & 0,5 & 3,8 & 0 & 0 & 0 & 0 & 0 & 0 & 0,5 & 0,8 \\
\hline $260-280$ & 0 & 0 & 0 & 0 & 0 & 0 & 0 & 0 & 0 & 0 \\
\hline $280-300$ & 2 & 15,3 & 0 & 0 & 0 & 0 & 0 & 0 & 2 & 3,5 \\
\hline $300-320$ & 0 & 0 & 0 & 0 & 0 & 0 & 0 & 0 & 0 & 0 \\
\hline $320-340$ & 0 & 0 & 0 & 0 & 0 & 0 & 0 & 0 & 0 & 0 \\
\hline $340-360$ & 0 & 0 & 0 & 0 & 0 & 0 & 0 & 0 & 0 & 0 \\
\hline $360-380$ & 0 & 0 & 0 & 0 & 0 & 0 & 0 & 0 & 0 & 0 \\
\hline $380-400$ & 2,25 & 17,3 & 0 & 0 & 0 & 0 & 0 & 0 & 2,25 & 4 \\
\hline Total & 13 & 100 & 15 & 100 & 12 & 100 & 16 & 100 & 56 & $100 \%$ \\
\hline
\end{tabular}



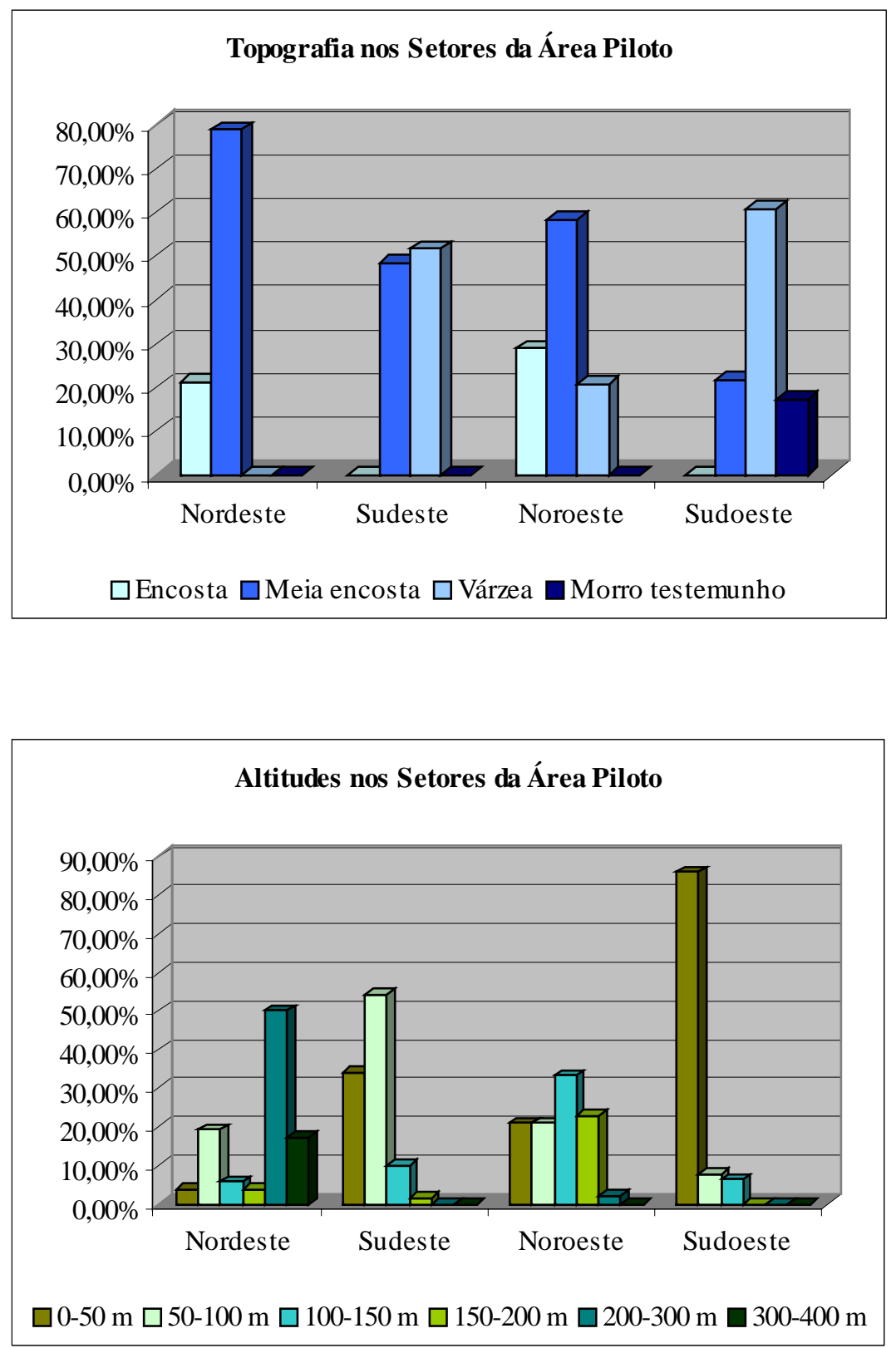

Em 84,37\% das unidades amostrais de prospecção observamos uma visibilidade de solo baixa devido ao tipo de cobertura vegetal predominante. Os índices mais baixos de visibilidade de solo encontram-se no setor nordeste da área piloto, com 96,1\% da área coberta por unidades amostrais sem visibilidade de solo, e no setor sudoeste, com 90,6\%. Por seu turno, os melhores índices de visibilidade de solo encontram-se nos setores onde as atividades agrícolas são mais intensas. No setor sudeste, 30\% da área coberta por unidades amostrais de prospecção apresentava condições razoáveis de visibilidade de solo e no setor noroeste $18,6 \%$ encontravam-se também nestas condições. A malha urbana cobre 7,3\% da área total abrangida pelas unidades amostrais de prospecção, apresentando baixa 
visibilidade de solo em geral, com exceção dos locais que apresentavam pequenas hortas cultivadas próximas às casas.

Tabela 3. Visibilidade do Solo nas Unidades Amostrais de Prospecção

\begin{tabular}{|c|c|c|c|c|c|c|c|c|c|c|}
\hline $\begin{array}{l}\text { Visibilidade } \\
\text { de solo }\end{array}$ & $\begin{array}{c}\text { Setor } \\
\text { Nordeste } \\
\text { (área em } \\
\mathbf{K m}^{2} \text { ) }\end{array}$ & $\%$ & $\begin{array}{c}\text { Setor } \\
\text { Sudeste } \\
\text { (área em } \\
\mathbf{K m}^{2} \text { ) }\end{array}$ & $\%$ & $\begin{array}{c}\text { Setor } \\
\text { Noroeste } \\
\text { (área em } \\
\mathbf{K m}^{2} \text { ) }\end{array}$ & $\%$ & $\begin{array}{c}\text { Setor } \\
\text { Sudoeste } \\
\text { (área em } \\
\mathbf{K m}^{2} \text { ) }\end{array}$ & $\%$ & Total & $\%$ \\
\hline Alta & 0 & 0 & 0 & 0 & 0,5 & 4,3 & 0 & 0 & 0,5 & 0,8 \\
\hline Média & 0,5 & 3,8 & 4,5 & 30 & 1,75 & 14,5 & 1,5 & 9,4 & 8,25 & 14,7 \\
\hline Baixa & 12,5 & 96,2 & 10,5 & 70 & 9,75 & 81,2 & 14,5 & 90,6 & 47,25 & 84,3 \\
\hline Total & 13 & 100 & 15 & 100 & 12 & 100 & 16 & 100 & 56 & 100 \\
\hline
\end{tabular}

A maior parte da área prospectada encontra-se coberta por pastagens utilizadas para criação de gado (42,8\%), nas zonas de várzea, ou pastagens associadas a mato secundário (21,2\%), nas áreas de meia encosta. A presença de cobertura vegetal total por mato secundário (17\%) e plantações de banana associadas a mato secundário (3,5\%) também são expressivas, relacionadas às zonas de meia encosta e encosta, com baixa visibilidade de solo. Em ambos os casos, estas áreas já foram ocupadas por atividades agrícolas intensas no passado, tendo sido abandonadas ao longo dos últimos 30 anos em função do êxodo rural decorrente da crise do setor agro-pecuário no Estado.

Portanto, apenas 7,9\% da área coberta por unidades amostrais de prospecção apresentou relativa visibilidade de solo associada às áreas aradas. Destas, 5,6\% relacionam-se ao cultivo misto de pequena extensão, voltado à produção de milho, mandioca, cana, capim elefante e aveia, utilizados como forragem de inverno para o gado, além de roças de subsistência de feijão, batata, abóbora e hortaliças. O restante das áreas cultivadas está associada à agricultura extensiva de arroz e milho (2,2\%).

O setor sudeste da área piloto apresentou a maior extensão de áreas cultivadas, representando 16,2\% da área das unidades amostrais prospectadas. Estes índices são mais baixos nos demais setores, atingindo 6,6\% no setor noroeste, 4,8\% no setor sudoeste e 3,1\% no setor nordeste. Foram registrados os tipos de alterações de terreno nas áreas cultivadas inspecionadas nas unidades amostrais, predominando a utilização de arado de boi em 79,4\% dos casos, estando a utilização de arado mecânico relacionada ao cultivo extensivo de arroz e milho. 
Tabela 4. Cobertura Vegetal nas Unidades Amostrais de Prospecção

\begin{tabular}{|c|c|c|c|c|c|c|c|c|c|c|}
\hline $\begin{array}{c}\text { Tipo de } \\
\text { cobertura vegetal }\end{array}$ & $\begin{array}{c}\text { Setor } \\
\text { Nordeste } \\
\text { (área em } \\
\mathbf{K m}^{2} \text { ) }\end{array}$ & $\%$ & $\begin{array}{c}\text { Setor } \\
\text { Sudeste } \\
\text { (área } \\
\text { em } \\
\mathbf{K m}^{2} \text { ) }\end{array}$ & $\%$ & $\begin{array}{c}\text { Setor } \\
\text { Noroeste } \\
\text { (área em } \\
\mathbf{K m}^{2} \text { ) }\end{array}$ & $\%$ & $\begin{array}{c}\text { Setor } \\
\text { Sudoeste } \\
\text { (área em } \\
\mathbf{K m}^{2} \text { ) }\end{array}$ & $\%$ & $\begin{array}{c}\text { Total } \\
\text { (área } \\
\text { em } \\
\mathbf{K m}^{2} \text { ) }\end{array}$ & $\%$ \\
\hline $\begin{array}{l}\text { Cobertura vegetal } \\
\text { relacionada a } \\
\text { centros urbanos }\end{array}$ & 1,455 & 11,1 & 0,992 & 6,6 & 1,155 & 9,6 & 0,5 & 3,1 & 4,102 & 7,3 \\
\hline Pasto & 0,410 & 3,1 & 7,715 & 51,4 & 4,410 & 36,7 & 11,485 & 71,7 & 24,020 & 42,8 \\
\hline $\begin{array}{l}\text { Pasto e mato } \\
\text { secundário }\end{array}$ & 2,567 & 19,7 & 2,947 & 19,6 & 3,631 & 30,2 & 2,735 & 17 & 11,881 & 21,2 \\
\hline Mato secundário & 6,157 & 47,3 & 0,910 & 6 & 2 & 16,6 & 0,500 & 3,1 & 9,567 & 17 \\
\hline $\begin{array}{c}\text { Plantações de } \\
\text { banana e mato } \\
\text { secundário }\end{array}$ & 1,997 & 15,3 & 0 & 0 & 0 & 0 & 0 & 0 & 1,997 & 3,5 \\
\hline Plantações mistas & 0,412 & 3,1 & 0,932 & 6,2 & 0,787 & 6,5 & 0,500 & 3,1 & 2,632 & 4,7 \\
\hline $\begin{array}{l}\text { Plantações de } \\
\text { milho e cana }\end{array}$ & 0 & 0 & 0,482 & 3,2 & 0,015 & 0,1 & 0,030 & 0,1 & 0,528 & 0,9 \\
\hline $\begin{array}{l}\text { Plantações de } \\
\text { milho e arroz }\end{array}$ & 0 & 0 & 1,019 & 6,7 & 0 & 0 & 0,250 & 1,5 & 10269 & 2,2 \\
\hline Total & 13 & 100 & 15 & 100 & 12 & 100 & 16 & 100 & 56 & 100 \\
\hline
\end{tabular}

Tabela 5. Alteração de Terreno nas Áreas Cultivadas Inspecionadas

\begin{tabular}{|c|c|c|c|c|c|c|c|c|c|c|}
\hline $\begin{array}{c}\text { Tipo de } \\
\text { alteração }\end{array}$ & $\begin{array}{c}\text { Setor } \\
\text { Nordeste } \\
\left(n^{0} \text { roças) }\right.\end{array}$ & $\%$ & $\begin{array}{c}\text { Setor } \\
\text { Sudeste } \\
\left(n^{0} \text { roças }\right)\end{array}$ & $\%$ & $\begin{array}{c}\text { Setor } \\
\text { Noroeste } \\
\left(\mathrm{n}^{0} \text { roças }\right)\end{array}$ & $\%$ & $\begin{array}{c}\text { Setor } \\
\text { Sudoeste } \\
\left(\mathrm{n}^{0} \text { roças }\right)\end{array}$ & $\%$ & Tota & $\%$ \\
\hline $\begin{array}{l}\text { Arado de } \\
\text { boi }\end{array}$ & 16 & 100 & 21 & 58,3 & 14 & 100 & 11 & 91,6 & 62 & 79,5 \\
\hline $\begin{array}{c}\text { Arado } \\
\text { mecânico }\end{array}$ & 0 & 0 & 15 & 41,6 & 0 & 0 & 1 & 8,3 & 16 & 20,5 \\
\hline Total & 16 & 00 & 36 & 100 & 14 & 100 & 12 & 100 & $7 \varepsilon$ & 100 \\
\hline
\end{tabular}

Cobertura Vegetal nas Unidades Amostrais de Prospecção

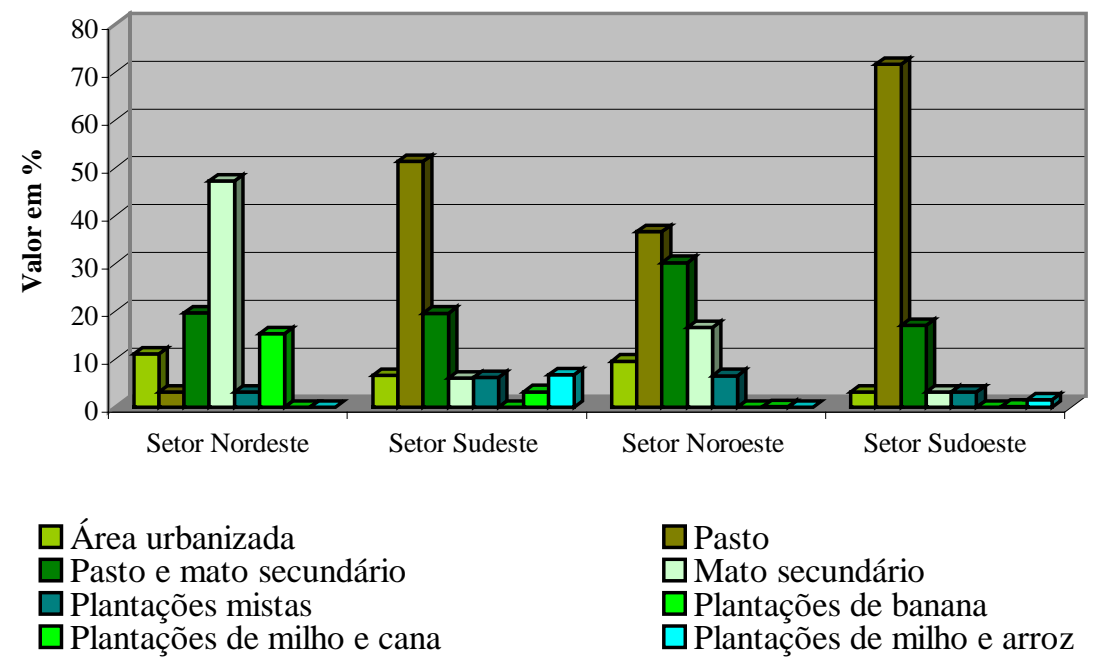


A cobertura vegetal por pasto associado ou não a mato secundário predomina na porção sul da área piloto, associada à planície de inundação do rio dos Sinos, sendo característica de $71 \%$ da paisagem das unidades amostrais do setor sudeste e $88,7 \%$ do setor sudoeste. Originalmente coberta por mata primária, a porção sul da área piloto foi desmatada de forma sistemática ao longo dos últimos 50 anos, com maior intensidade na década de 1970 em função da implantação de cultivos extensivos de cana de açúcar, cuja cultura entrou em decadência em meados da década de 1980. Conforme informações dos proprietários locais, o cultivo de cana de açúcar foi substituído pelo cultivo extensivo de arroz. Porém, no setor sudoeste da área piloto este não apresentou resultados satisfatórios devido às condições sedimentares do terreno, cuja base arenítica impede o escoamento da água das cheias. Atualmente a economia da área está voltada à criação de gado vacum, ovelhas e búfalos, sendo os cultivos voltados à produção de forragem de inverno (milho, mandioca, cana de açúcar e capim elefante), cobrindo apenas 3,3\% da área das unidades amostrais prospectadas. As planícies de inundação mais elevadas que caracterizam o setor sudeste da área piloto apresentaram maior adequação ao cultivo extensivo de arroz, por vezes associado ao milho, que caracterizam $6,7 \%$ de sua cobertura vegetal. A prática de agricultura de subsistência também é mais intensa neste setor, representando 9,4\% da sua paisagem.

Observa-se que no setor nordeste da área piloto as áreas anteriormente desmatadas para cultivo, estão sendo retomadas pelo mato secundário (47,3\%), por vezes associado ao cultivo de banana nas encostas (15,3\%), sendo baixo os índices de áreas cultivadas, que correspondem a 3,1\% da área coberta por unidades amostrais de prospecção. O setor noroeste da área piloto apresenta uma cobertura vegetal mais heterogênea, em comparação aos demais setores, também marcada pelo desmatamento e abandono de áreas anteriormente cultivadas que estão sendo retomadas pelo mato secundário nas encostas $(16,6 \%)$ ou aproveitadas como pastagens para o gado (36,7\%), por vezes associadas a mato secundário (30,2\%), nas meias encostas e nas planícies de inundação. 


\subsection{Os Sítios Arqueológicos Identificados na Área Piloto: Características}

\section{Gerais}

A implementação dos métodos de prospecção propostos resultou na localização de 61 sítios arqueológicos, concentrados principalmente na porção sul da área piloto, junto à várzea do rio dos Sinos (Anexo 3). Ao todo foram localizados na área piloto 50 abrigos sob rocha, em sua maioria na porção oeste da área piloto, sendo 18 destes confirmados como sítios arqueológicos. Do total de sítios arqueológicos em abrigos sob rocha, 70\% está afiliado culturalmente à Tradição Umbu e 6\% apresentam ocupações da Tradição Umbu associadas à ocupações históricas. Do restante, $18 \%$ possuem afiliação cultural indeterminada ou apenas ocupação histórica.

Dentre os 43 sítios arqueológicos a céu aberto localizados, 69\% estão associados culturalmente à Tradição Guarani e 11\% estão vinculados à Tradição Taquara. Sítios a céu aberto da Tradição Umbu são representados por apenas 2\% da amostra total da área piloto, sendo históricos os demais sítios arqueológicos localizados (18\%). A maioria destes foi identificada através do levantamento intensivo de áreas aradas, com exceção de dois, localizados através da vistoria de boçorocas.

Através de entrevistas com os proprietários das áreas vistoriadas foram registradas, principalmente no setor sudeste, 14 informações referentes à presença de sítios cerâmicos da Tradição Guarani em áreas já cultivadas, mas atualmente cobertas por pastagens para a criação de gado, necessitando estes dados confirmação através de sondagens de subsuperfície. Por fim, as prospecções também permitiram a localização de 19 afloramentos rochosos associados à área de implantação dos sítios pesquisados, sendo 7 destes de arenito silicificado, 10 de basalto e 2 afloramentos mistos de arenito silicificado e basalto. As matérias-primas mostraram-se de boa qualidade para lascamento, apresentando correlação com os conjuntos líticos identificados nos sítios arqueológicos pesquisados. 
Tabela 6. Tipos de Informações Obtidas através das Prospecções na Área Piloto

\begin{tabular}{|c|c|c|c|c|c|}
\hline Ocorrências & $\begin{array}{c}\text { Setor } \\
\text { Nordeste }\end{array}$ & $\begin{array}{c}\text { Setor } \\
\text { Sudeste }\end{array}$ & $\begin{array}{c}\text { Setor } \\
\text { Noroeste }\end{array}$ & $\begin{array}{c}\text { Setor } \\
\text { Sudoeste }\end{array}$ & Total \\
\hline $\begin{array}{c}\text { Sítios arqueológicos } \\
\text { Informações de sítios cerâmicos da }\end{array}$ & 8 & 24 & 11 & 18 & 61 \\
\hline $\begin{array}{c}\text { Tradição Guarani em áreas cobertas por } \\
\text { pastagens }\end{array}$ & 0 & 10 & 4 & 0 & 14 \\
\hline $\begin{array}{c}\text { Abrigos sob rocha sem evidências de } \\
\text { ocupação humana }\end{array}$ & 2 & 4 & 19 & 7 & 32 \\
\hline $\begin{array}{c}\text { Afloramentos de arenito } \\
\text { Afloramentos de basalto }\end{array}$ & 0 & 4 & 3 & 0 & 7 \\
\hline Afloramentos mistos de arenito e basalto & 4 & 4 & 2 & 0 & 10 \\
\hline
\end{tabular}

Os levantamentos abrangentes extensivos nas unidades amostrais de prospecção permitiram a localização de 52,4\% do total de sítios identificados. Os levantamento extensivo em sua periferia permitiram ampliar a amostragem de sítios para a área piloto ao privilegiar os locais com maior probabilidade de apresentar vestígios arqueológicos, em função dos resultados obtidos nos levantamentos extensivos nas unidades amostrais de prospecção. Privilegiou-se no emprego desta última metodologia as áreas de meia encosta, encobertas por mato secundário, associadas à presença de abrigos sob rocha, e as áreas aradas, em geral, por apresentarem maior visibilidade de solo.

Comparando os resultados das metodologias empregadas, observa-se que ambas são complementares, na medida em que há uma equivalência nos tipos e quantidade de sítios localizados em geral e por setor da área piloto. Observa-se um predomínio dos sítios a céu aberto na porção leste da área piloto, independentemente da metodologia empregada. No caso dos sítios em abrigos sob rocha, estes se concentram na porção oeste da área piloto, embora apresentem uma relação numérica eqüitativa com os sítios a céu aberto nas unidades amostrais de prospecção. Esta situação não ocorre nos levantamentos extensivos na periferia das unidades amostrais, áreas geralmente relacionadas às meias encostas encobertas por mato secundário, nas quais predominam os sítios em abrigo sob rocha. A baixa visibilidade de solo nestes locais pode haver condicionado o padrão observado, podendo esta hipótese ser testada através de prospecções intensivas de sub-solo. 
Tabela 7.1. Sítios Localizados através de Levantamento Abrangente Extensivo nas Unidades Amostrais de Prospeç̧ão

\begin{tabular}{|c|c|c|c|c|c|c|c|c|c|c|}
\hline Tipos de sítios & $\begin{array}{c}\text { Setor } \\
\text { Nordeste }\end{array}$ & $\mathbf{\%}$ & $\begin{array}{c}\text { Setor } \\
\text { Sudeste }\end{array}$ & $\mathbf{\%}$ & $\begin{array}{c}\text { Setor } \\
\text { Noroeste }\end{array}$ & \% & $\begin{array}{c}\text { Setor } \\
\text { Sudoeste }\end{array}$ & \%otal & \% \\
\hline $\begin{array}{c}\text { Sítio a céu aberto em } \\
\text { área arada }\end{array}$ & 6 & 100 & 10 & 91 & 2 & 33,3 & 4 & 44,5 & 22 & 68,7 \\
\hline $\begin{array}{c}\text { Edificação Histórica } \\
\text { Sítio a céu aberto em }\end{array}$ & 0 & 0 & 1 & 9 & 0 & 0 & 0 & 0 & 1 & 3,1 \\
\hline $\begin{array}{c}\text { boçoroca de pasto } \\
\text { Abrigo sob rocha }\end{array}$ & 0 & 0 & 0 & 0 & 1 & 16,7 & 0 & 0 & 1 & 3,1 \\
\hline \begin{tabular}{c} 
Total \\
\hline
\end{tabular} & 6 & 100 & 11 & 100 & 6 & 100 & 9 & 100 & 32 & 100 \\
\hline
\end{tabular}

Tabela 7.2. Sítios Localizados através de Levantamento Extensivo na Periferia das Unidades Amostrais de Prospecção

\begin{tabular}{|c|c|c|c|c|c|c|c|c|c|c|}
\hline Tipos de Sítios & $\begin{array}{c}\text { Setor } \\
\text { Nordeste }\end{array}$ & $\%$ & $\begin{array}{c}\text { Setor } \\
\text { Sudeste }\end{array}$ & $\%$ & $\begin{array}{c}\text { Setor } \\
\text { Noroeste }\end{array}$ & $\%$ & $\begin{array}{c}\text { Setor } \\
\text { Sudoeste }\end{array}$ & $\%$ & Total & $\%$ \\
\hline $\begin{array}{l}\text { Sítio a céu aberto em } \\
\text { área arada }\end{array}$ & 1 & 50 & 11 & 91,6 & 1 & 25 & 5 & 50 & 18 & 62 \\
\hline Edificação Histórica & 0 & 0 & 0 & 0 & 0 & 0 & 1 & 10 & 1 & 3,4 \\
\hline $\begin{array}{l}\text { Sítio a céu aberto em } \\
\text { boçoroca de pasto }\end{array}$ & 0 & 0 & 0 & 0 & 0 & 0 & 0 & 0 & 1 & 3,4 \\
\hline Abrigo sob rocha & 1 & 50 & 1 & 8,3 & 3 & 75 & 4 & 40 & 9 & 31 \\
\hline Total & 2 & 100 & 12 & 100 & 4 & 100 & 10 & 100 & 29 & 100 \\
\hline
\end{tabular}

Tipos de Sítios Arqueológicos na Área Piloto

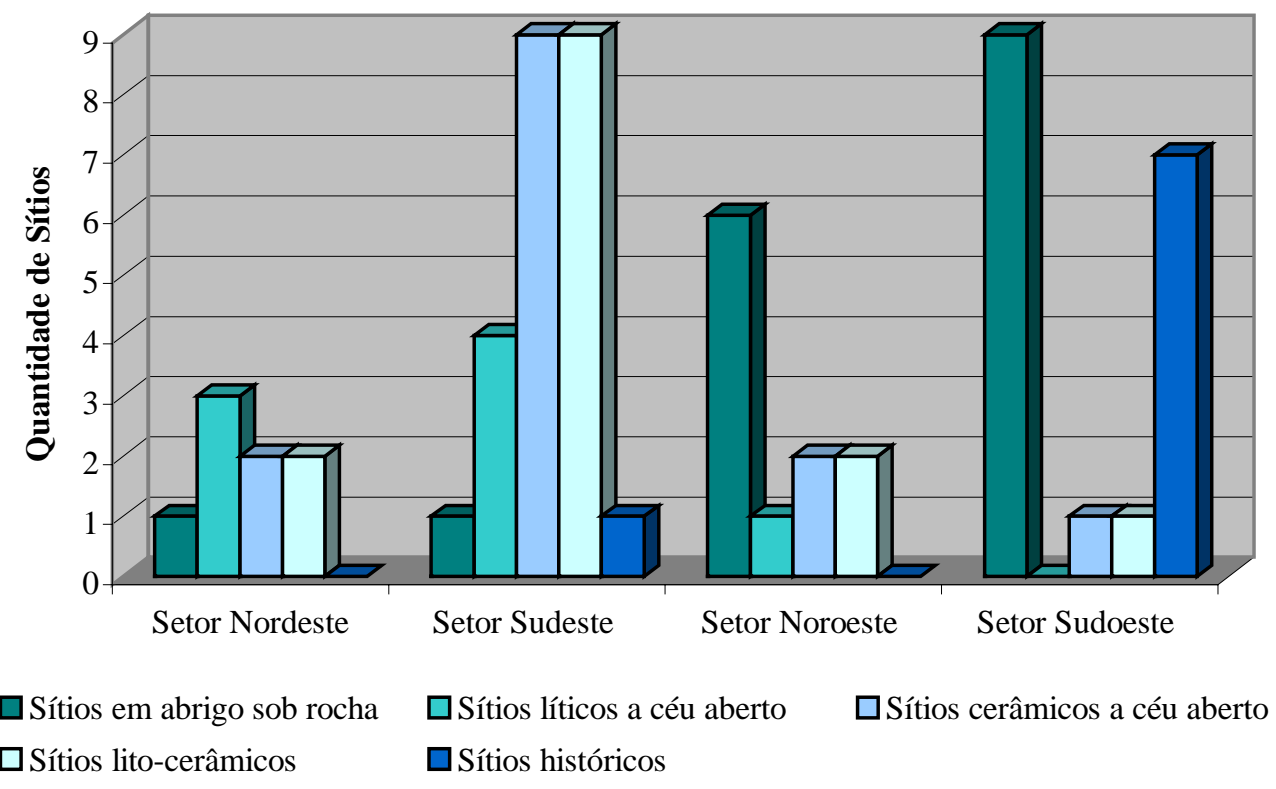


Em função do tamanho e das características de cobertura vegetal da área piloto, dos objetivos que nortearam as pesquisas de campo, dos resultados obtidos pelas prospecções, das características dos sítios identificados, bem como da disponibilidade de tempo e recursos, optou-se por não intensificar os sistemas de levantamento amostral empregados através de metodologias de prospecção mais intensivas, associadas a sondagens de sub-superfície (Fish \& Kowalewski, 1990; Kintigh, 1988; Krakker et al, 1983; Lightfoot, 1986, 1989; Nance, 1979; Nance \& Ball, 1986; 1989; Shott, 1989a). Porém, os dados apurados até o momento sobre a densidade de sítios por unidade amostral de prospecção permitem o planejamento de futuras intervenções de sub-superfície que podem trazer subsídios para melhor avaliar a real densidade de sítios arqueológicos na área piloto, a exemplo de outros trabalhos (De Blasis, 1996; Araújo, 2001).

Em termos gerais, a divisão da área piloto em setores apresentou resultados distintos quanto aos tipos de sítios arqueológicos identificados, representando padrões pretéritos culturalmente distintos quanto à ocupação do espaço. As distinções quanto à densidade de sítios em cada setor podem estar relacionadas ao tipo de cobertura vegetal predominante, bem como as características dos sistemas de assentamento observados.

Nas prospecções do setor nordeste da área piloto foram localizados 8 sítios arqueológicos que correspondem a 13,1\% do total de sítios identificados. Dentre estes, destaca-se um abrigo sob rocha com associação de restos esqueletais humanos, pesquisado durante o PRONAPA, indicando seu padrão de implantação e tipo de sepultamentos associação provável com a Tradição Taquara. Foram localizados ainda outros 2 abrigos sob rocha na área, porém sem evidências de ocupação humana. Os demais sítios são a céu aberto, estando 5 vinculados também a Tradição Taquara e 2 a Tradição Guarani. Os sítios da Tradição Taquara estão associados às nascentes e curso médio do arroio Grande, próximos ao limite norte da área piloto. Destes apenas um apresentou evidências cerâmicas, um é lito-cerâmico e os demais são sítios líticos que vinculamos à Tradição Taquara em função de seu padrão de implantação e das características tecnológicas dos artefatos líticos, estando 4 destes associados a afloramentos de basalto de boa qualidade para lascamento. Quanto aos sítios da Tradição Guarani, um possuía apenas fragmentos cerâmicos e o outro apresentou associação entre artefatos líticos e cerâmicos. Estes sítios Guarani encontram-se próximos aos limites entre os setores nordeste e sudeste da área piloto, acompanhando o padrão de sítios localizados neste último.

No setor sudeste da área piloto foram registrados 24 sítios arqueológicos que representam 39,3\% do total de sítios localizados na área piloto. Destes, um corresponde a 
um sítio histórico do final do século XIX, com edificações remanescentes, um é um abrigo sob rocha associado à Tradição Umbu e os demais 22 são sítios a céu aberto associados à Tradição Guarani. Os sítios da Tradição Guarani situam-se preferencialmente ao longo das meias encostas que limitam as várzeas do rio dos Sinos e dos arroios Caraá e Grande, dos quais 8 apresentaram apenas evidências cerâmicas, 9 eram lito-cerâmicos e 5 apresentaram apenas artefatos líticos bifaciais. A afiliação cultural destes sítios líticos deu-se através de comparação com as indústrias dos sítios lito-cerâmicos da Tradição Guarani identificados na área. Através de pesquisas no acervo documental do MARSUL e de entrevistas com moradores locais foi possível identificar entre os sítios da Tradição Guarani, pelo menos três pesquisados durante o PRONAPA por Eurico Miller, em 1966, cuja localização até o presente era desconhecida. Igualmente, as entrevistas com os moradores permitiram o mapeamento de 10 possíveis ocorrências de sítios da Tradição Guarani em áreas anteriormente cultivadas e hoje cobertas por pasto. As prospecções nas meias encostas deste setor possibilitaram ainda a localização de 4 abrigos sob rocha, os quais não apresentaram evidencias de ocupação humana pretérita. Também foram identificados 9 afloramentos rochosos, em sua maioria associados aos sítios da Tradição Guarani, sendo 4 de arenito silicificado, 4 de basalto e um afloramento misto de basalto e arenito silicificado, todos oferecendo matéria-prima de boa qualidade para lascamento.

No setor noroeste da área piloto foram registrados 11 sítios arqueológicos, que correspondem a 18,03\% dos sítios localizados na área piloto. Destes 6 são em abrigos sob rocha, um corresponde a um sítio lítico a céu aberto e 4 são sítios cerâmicos a céu-aberto da Tradição Guarani. Os sítios em abrigos sob rocha registrados neste setor estão associados à Tradição Umbu, com exceção de um cuja afiliação cultural não pode ser determinada. Três foram pesquisados durante o PRONAPA, sendo o restante localizado durante nossas pesquisas na área. As prospecções nas encostas deste setor da área piloto permitiram ainda a localização de outros 19 abrigos sob rocha, os quais não apresentaram evidências de ocupação humana pretérita. Os sítios em abrigo sob rocha estão situados nas meias encostas que limitam o vale do arroio Campestre, representando uma continuidade da paisagem de inserção dos sítios em abrigo sob rocha do setor sudoeste. O único sítio lítico a céu aberto associado à Tradição Umbu foi localizado neste setor, nas proximidades de um conjunto de sítios em abrigo sob rocha, através da vistoria de uma linha de erosão em área coberta por pasto (boçoroca). Quanto aos sítios a céu aberto associados à Tradição Guarani, dois são lito-cerâmicos e dois apresentaram apenas fragmentos cerâmicos, apresentando um padrão de implantação semelhante ao observado no setor sudeste. 
Entrevistas com os moradores da área permitiram também o registro de 4 locais atualmente cobertos por pasto que apresentavam cerâmica da Tradição Guarani quando cultivados. Também foram identificados 6 afloramentos rochosos, em sua maioria associados aos sítios Guarani, sendo 3 de arenito silicificado, 2 de basalto e um afloramento misto de arenito silicificado e basalto, todos oferecendo matéria-prima de boa qualidade para lascamento.

No setor sudoeste da área piloto foram localizados 18 sítios arqueológicos, representando 29,5\% dos sítios registrados na área piloto, dos quais 10 são em abrigo sob rocha e 8 são sítios a céu aberto. Os sítios em abrigo sob rocha situam-se, em sua maioria, em morros testemunhos associados às várzeas do rio dos Sinos e arroio Restinga. Oito estão associados à Tradição Umbu, sendo que um destes também apresenta vestígios de uma ocupação do século XVIII. Quanto aos demais, um apresentou apenas vestígios esqueletais, cuja afiliação cultural até o presente é indeterminada, e o outro foi ocupado como residência por pelo menos 30 anos por um trabalhador rural, falecido há 10 anos, sendo considerado um sítio histórico do século XX. Também foram registrados outros sete abrigos sob rocha que não apresentaram evidências de ocupação humana. Dos 8 sítios a céu aberto localizados, 2 estão associados à Tradição Guarani, sendo um cerâmico e o outro lito-cerâmico. Os demais são históricos, sendo um da primeira metade do século XVIII e o restante da segunda metade do século XIX ${ }^{15}$.

Do conjunto total de sítios arqueológicos identificados na área piloto 49,1\% estão associados à Tradição Guarani, 24,5\% à Tradição Umbu, 8,1\% à Tradição Taquara, 13,1\% são sítios históricos e 4,9\% apresentam afiliação cultural indeterminada. A distribuição destes sítios arqueológicos no espaço regional e as cronologias até o presente obtidas apontam para a existência, portanto, de três sistemas de assentamento pré-coloniais distintos na área piloto.

\footnotetext{
${ }^{15}$ Este setor já havia sido pesquisado durante o PRONAPA que identificou 7 dos sítios em abrigos sob rocha e um sítio histórico a céu aberto. As prospecções realizadas pelo PASAP nas localidades de Guarda Velha e Campestre, entre 1994 e 1995, permitiram a localização de mais 3 sítios em abrigo sob rocha e 4 sítios históricos a céu aberto, sendo o restante dos sítios identificados durante as prospecções deste projeto.
} 


\section{Tabela 8. Tipos de Sítios Arqueológicos por Afiliação Cultural na Área Piloto}

\begin{tabular}{|c|c|c|c|c|c|c|c|c|c|c|}
\hline Tipos de sítios & $\begin{array}{c}\text { Setor } \\
\text { Nordeste }\end{array}$ & $\%$ & $\begin{array}{l}\text { Setor } \\
\text { Sudeste }\end{array}$ & $\%$ & $\begin{array}{c}\text { Setor } \\
\text { Noroeste }\end{array}$ & $\%$ & $\begin{array}{c}\text { Setor } \\
\text { Sudoeste }\end{array}$ & $\%$ & Total & $\%$ \\
\hline $\begin{array}{l}\text { Sítios em abrigos sob } \\
\text { rocha com afiliação } \\
\text { cultural indeterminada }\end{array}$ & 0 & 0 & 0 & 0 & 1 & 9 & 1 & 5,5 & 2 & 3,2 \\
\hline $\begin{array}{c}\text { Sítios em abrigos sob } \\
\text { rocha da Tradição } \\
\text { Taquara }\end{array}$ & 1 & 12,5 & 0 & 0 & 0 & 0 & 0 & 0 & 1 & 1,6 \\
\hline $\begin{array}{l}\text { Sítios em abrigos sob } \\
\text { rocha da Tradição Umbu }\end{array}$ & 0 & 0 & 1 & 4,1 & 5 & 45,4 & 7 & 38,8 & 13 & 21,3 \\
\hline $\begin{array}{c}\text { Sítios em abrigos sob } \\
\text { rocha com ocupação } \\
\text { histórica e da Tradição } \\
\text { Umbu }\end{array}$ & 0 & 0 & 0 & 0 & 0 & 0 & 1 & 5,5 & 1 & 1,6 \\
\hline $\begin{array}{c}\text { Sítios em abrigos sob } \\
\text { rocha com ocupação } \\
\text { histórica }\end{array}$ & 0 & 0 & 0 & 0 & 0 & 0 & 1 & 5,5 & 1 & 1,6 \\
\hline $\begin{array}{c}\text { Sítios líticos a céu aberto } \\
\text { da Tradição Umbu }\end{array}$ & 0 & 0 & 0 & 0 & 1 & 9 & 0 & 0 & 1 & 1,6 \\
\hline $\begin{array}{c}\text { Sítios cerâmicos a céu } \\
\text { aberto da Tradição } \\
\text { Guarani }\end{array}$ & 1 & 12,5 & 8 & 33,3 & 2 & 18,1 & 1 & 5,5 & 12 & 19,6 \\
\hline $\begin{array}{c}\text { Sítios lito-cerâmicos a } \\
\text { céu aberto da Tradição } \\
\text { Guarani }\end{array}$ & 1 & 12,5 & 9 & 37,5 & 2 & 18,1 & 1 & 5,5 & 13 & 21,3 \\
\hline $\begin{array}{l}\text { Sítios líticos a céu aberto } \\
\text { da Tradição Guarani }\end{array}$ & 0 & 0 & 5 & 20,8 & 0 & 0 & 0 & 0 & 5 & 8,1 \\
\hline $\begin{array}{c}\text { Sítios cerâmicos a céu } \\
\text { aberto da Tradição } \\
\text { Taquara }\end{array}$ & 1 & 12,5 & 0 & 0 & 0 & 0 & 0 & 0 & 1 & 1,6 \\
\hline $\begin{array}{c}\text { Sítios lito-cerâmicos a } \\
\text { céu aberto da Tradição } \\
\text { Taquara }\end{array}$ & 1 & 12,5 & 0 & 0 & 0 & 0 & 0 & 0 & 1 & 1,6 \\
\hline $\begin{array}{c}\text { Sítios líticos da Tradição } \\
\text { Taquara }\end{array}$ & 3 & 37,5 & 0 & 0 & 0 & 0 & 0 & 0 & 3 & 4,9 \\
\hline $\begin{array}{l}\text { Sítios históricos a céu } \\
\text { aberto }\end{array}$ & 0 & 0 & 0 & 0 & 0 & 0 & 5 & 27,7 & 5 & 8,1 \\
\hline $\begin{array}{c}\text { Sítios históricos com } \\
\text { edificações } \\
\text { remanescentes }\end{array}$ & 0 & 0 & 1 & 4,1 & 0 & 0 & 1 & 5,5 & 2 & 3,2 \\
\hline Total & 8 & 100 & 24 & 100 & 11 & 100 & 18 & 100 & 61 & 100 \\
\hline
\end{tabular}

Os 15 sítios de caçadores coletores localizados na área piloto estão relacionados, em sua maioria, a abrigos sob rocha e concentram-se nos setores noroeste e sudoeste da área piloto, em torno da várzea do rio dos Sinos e de seus afluentes, arroios Restinga, Campestre e Pinheiros. A única exceção corresponde a um sítio lítico a céu aberto que dista menos de 100 m de dois abrigos sob rocha associados à Tradição Umbu, indicando uma correlação em termos de sistema de assentamento. 
Por sua vez, os 30 sítios a céu aberto relacionados à Tradição Guarani, situam-se principalmente no setor sudeste da área piloto, na meia encosta que acompanha os cursos de água de maior porte da região como o rio dos Sinos e os arroios Caraá e Grande. Do total de sítios Guarani localizados, 44,8\% são lito-cerâmicos, 41,3\% apresentam somente evidencias cerâmicas e 13,7\% estão representados por material lítico.

Os 5 sítios a céu aberto da Tradição Taquara identificados nas prospecções situamse no setor nordeste da área piloto, apresentando três destes apenas evidências líticas. Estes sítios estão associados às nascentes e ao curso médio dos arroios Grande e Sertão, em área de encosta e meia encosta, com altitudes médias entre 100 e $400 \mathrm{~m}$. Um dos abrigos localizado neste setor da área piloto também foi adscrito a este sistema de assentamento, em função das características de seu acervo e de seu padrão de implantação.

As datações obtidas até o presente apontam igualmente para uma distinção cronológica entre estes distintos sistemas de assentamento. As 12 datações associadas aos contextos de caçadores coletores apontam uma cronologia de ocupação da área entre 8.800 e 440 anos AP. Os sítios da Tradição Taquara apresentam uma posição espacial associada às áreas de maior altitude que caracterizam o limite norte da área piloto, podendo representar a fronteira de um território de domínio que se estende ao norte da região estudada, abrangendo o planalto meridional. Estes sítios apresentaram-se pouco preservados não possuindo condições para obtenção de amostras passíveis de datação. Porém, se relacionarmos a este sistema de assentamento a datação de 1655+65 AP (SI 2345) para o sítio em abrigo sob rocha associado à mesma área de implantação, podemos sugerir uma correlação cronológica com os assentamentos de caçadores coletores. Quanto aos sítios da Tradição Guarani, a baixa qualidade de preservação destes contextos, tendo em vista a intensidade das atividades agrícolas na área, impediu o estabelecimento de seqüências de datações previstas originalmente. Somente foi possível datar por termoluminescencia um sítio da Tradição Guarani e as duas datações obtidas (165+20 e 205+25 anos AP) apontam para uma ocupação contemporânea ao início da presença portuguesa na região. Mesmo que estas datações representem um momento terminal da ocupação Guarani na área, pode-se sugerir que a presença de grupos horticultores no Alto Vale do Rio dos Sinos é posterior aos contextos associados a caçadores coletores, a semelhança do observado para as áreas dos rios Jacuí e Pardo, no Rio Grande do Sul. 


\title{
Capítulo 3
}

\section{Sistema de Assentamento de Caçadores Coletores no Alto Vale do Rio dos Sinos: A Tradição Umbu}

\author{
3.1. Modelos Etnoarqueológicos de Mobilidade e Sistema de Assentamento \\ Caçador Coletor em Floresta Tropical
}

Existem atualmente vários grupos na bacia Amazônica e nas terras baixas tropicais, em geral, que mantém modos de vida caçador coletor. Alguns estão associados à família lingüística Tupi-Guarani, como os Xetá, Guajá, Siriono e Aché, sugerindo que no passado correspondessem a populações horticultoras que abandonaram os cultivos em função do impacto da colonização ocidental ${ }^{1}$. Os demais caçadores coletores que habitam o noroeste da Amazônia relacionam-se à família lingüística Makú-Puinave, sendo atualmente identificados seis grupos étnico-lingüísticos distribuídos geograficamente entre o Brasil e a Colômbia, principalmente no lado leste do rio Negro, entre os rios Guaviare e CaquetáJapurá. São estes os Hupdu, os Yuhup, os Kawka ou Bará, os Nukak, os Dow e os Nadob, sendo os dois últimos pouco conhecidos etnograficamente ${ }^{2}$. Os grupos pertencentes à família lingüística Maku não formam uma unidade homogênea. Embora possuam afinidades lingüísticas e de modo de vida, sofreram o impacto de contato com a sociedade ocidental de formas e em graus variados, tendo todos adotado algum tipo de prática horticultura. Entre os Nukak, os cultígenos representam menos de 5\% da dieta anual, enquanto entre os Hupdu, Yuhup e Bará a horticultura contribui significativamente para a

\footnotetext{
${ }^{1}$ Estes grupos demonstram, segundo o autor, que a adoção de práticas horticultoras são reversíveis e que a incorporação dos cultígenos na dieta não é um processo linear. O caso destas populações falantes de línguas do tronco Tupi demonstra que sob condições específicas que dificultam a subsistência horticultora, a ênfase na caça e na coleta pode garantir a subsistência do grupo (Politis, 2001: 30).

${ }^{2}$ Segundo Cabrera-Becerra e colaboradores (2001: 30-35) desde o século XVIII, o termo Maku tem sido utilizado pela sociedade ocidental para referir-se a grupos dos quais se capturavam pessoas para escravidão ou a grupos nômades das áreas interfluviais, sem agricultura, que mantém uma relação de subordinação com grupos ribeirinhos sedentários, alguns dos quais da família lingüística Maku-Puinave. Esta denominação genérica se expandiu pelo noroeste da Amazônia entre povos de distintas famílias lingüísticas sendo empregada, com sentido pejorativo, para grupos que não falam a sua língua e que foram tomados como servos ou escravos com a chegada dos comerciantes europeus. As diversas denominações presentes na literatura etnográfica para os povos que pertencem à família lingüística Maku-Puinave encontram-se em Cabrera-Becerra e colaboradores (2001).
} 
subsistência, baseada na mandioca e em produtos industrializados, influenciando de forma significativa os padrões de assentamento e mobilidade tradicionais (Politis, 2001: 30-32).

O território Nukak ${ }^{3}$ abrange aproximadamente $10.000 \mathrm{Km}^{2}$, distribuído entre os rios Guaviare e Irinida, no setor colombiano da floresta Amazônica. Sua população foi estimada entre 400 e 500 indivíduos ${ }^{4}$, organizados em bandos exogâmicos autônomos, compostos por várias famílias (geralmente não mais que cinco), com entre 12 e 44 indivíduos por bando, possuindo a maioria dos grupos co-residentes entre 20 e 30 indivíduos. A composição dos bandos não é fixa em função dos movimentos individuais entre bandos vizinhos que fazem parte de afiliações grupais mais amplas (munu). Estes, por sua vez, compartilham territórios contíguos onde ocorrem reorganizações de grupos maiores, casamentos, visitas sociais e rituais, tendo sido identificadas até o presente pelo menos 6 destas afiliações mais amplas. A falta de hierarquização social, os fortes padrões de solidariedade e a alta mobilidade residencial correspondem às características marcantes dos Nukak (Politis, 1996b: 495; 2001: 32).

Os Nukak apresentam uma alta dependência de recursos vegetais silvestres, principalmente de frutos com alto valor calórico e protéico, cujo acesso é regular ao longo do ano, correspondendo os produtos cultivados entre 5\% e $10 \%$ da dieta. Os meses chuvosos de inverno estão associados, principalmente, a coleta de larvas e de frutos de árvores e palmeiras. O período de seca que caracteriza o verão relaciona-se ao consumo de recursos concentrados, associados à pesca e à exploração do mel e de outros produtos de abelhas nativas, como própolis, geléia real, pólen, além das larvas. O consumo de invertebrados e a caça contribuem significativamente na dieta ao longo do ciclo anual. A caça está centrada em várias espécies de macaco, sendo também capturados tartarugas, pássaros e porcos do mato. Os animais de maior porte, como antas, veados e onças, estão excluídos da dieta, sendo considerados tabus alimentares (Politis, 1996a: 167-230 e 335378; ver também Politis et al, 1997; Politis \& Saunders, 2001).

Segundo Politis (1996a: 131-165; 1996b: 496-497), os Nukak apresentam várias dimensões do território ocupado. No território do bando, cujos limites, em geral, são demarcados por rios, desenvolve-se a maioria das atividades cotidianas, associadas à

\footnotetext{
${ }^{3}$ No caso dos Nukak os primeiros contatos formais com a sociedade ocidental somente ocorreram no final da década de 1980. Os trabalhos de campo etnoarqueológicos desenvolveram-se entre 1990 e 1995, totalizando 6 meses de pesquisa com a colaboração de Gustavo Martinez e Julián Rodriguez (1996a: 37).

4 No final da década de 1980 os missionários estabelecidos em Laguna Pavón estimavam a população total Nukak entre 700 e 1000 indivíduos, dos quais 350 mantinham contato regular com a Missão, embora outros autores apontem estimativas de até 2000 indivíduos (Politis, 1996b: 495).
} 
mobilidade residencial, compreendendo uma extensão que pode ser estimada em algumas centenas de quilômetros quadrados. O território regional, por sua vez, pode ser estimado entre 1000 e $2000 \mathrm{Km}^{2}$, agregando o território de vários bandos de um mesmo grupo de afiliação, cujos membros podem mover-se sem restrição e visitar-se em função de objetivos sociais relacionados aos sistemas de parentesco ou rituais. Além dos territórios regionais e dos bandos locais, os Nukak também viajam para regiões distantes ocupadas por bandos com os quais raramente ou nunca mantém contato. Algumas destas viagens são organizadas de forma logística para extração de canas para a confecção de zarabatanas, porém, em alguns casos, tensões sociais entre bandos podem levar ao deslocamento de indivíduos ou famílias para além do território regional do grupo ${ }^{5}$. Uma quarta dimensão do território Nukak corresponde aos locais distantes habitados pelos não-Nukak, estando uma última dimensão territorial, de ordem mítica ou ideológica, associada à cosmogonia Nukak.

A alta mobilidade que caracteriza o sistema de assentamento Nukak organiza-se em torno de dois eixos principais, um residencial e outro logístico ${ }^{6}$ (Politis, 1996a: 83-130; 1996b: 497-500; 2001: 32-34). Em função deste aspecto, o sistema de assentamento Nukak se caracteriza por apenas dois tipos básicos de sítios: a) as bases residenciais, ocupadas por 2 a 5 unidades domésticas, cada qual com sua própria fogueira; e b) os acampamentos transitórios, associados a viagens de exploração de recursos específicos ou visitas. Este padrão apresenta correlação com o modelo forrageiro de Binford (1980), segundo o qual a alta mobilidade residencial produz um sistema de assentamento com baixa variabilidade de sítios. Os contextos espaciais de descarte no modelo forrageiro restringem-se às bases

\footnotetext{
${ }^{5}$ As pressões das frentes colonizadoras têm promovido uma reorganização dos territórios, o que certamente aumentou as tensões inter-bandos e impeliu alguns Nukak a deslocarem-se por grandes distancias em busca dos territórios ancestrais. As visitas à Missão de Laguna Pavón 2 por Nukak doentes ou em busca de trocas também tem se tornado freqüente (Politis, 1996b: 496).

${ }^{6}$ O padrão de mobilidade Nukak na década de 1990 se distingue de forma considerável de outros grupos Maku, cuja subsistência encontra-se centrada no cultivo da mandioca. Estudos realizados na década de 1970 para os Hupdu apontam que a mobilidade residencial era limitada e os grupos permaneciam em uma mesma aldeia entre dois a seis anos, com saídas diárias para o abastecimento atingindo distancias de até 3 horas de caminhada. Quando as áreas de caça estão a mais de meio dia de caminhada, várias famílias ou todo o grupo deslocam-se para caçar, pescar e coletar frutos. Estes deslocamentos ocorrem, em média, uma vez por mês e sua duração pode variar entre 2 a 30 dias, quando são construídos pequenos acampamentos residenciais, a semelhança do padrão Nukak, ocupados por 3 a 5 dias. Cada família, em geral, passa 70 dias por ano na floresta nestas viagens de forragem, passando os homens adultos e os adolescentes em média 100 dias por ano desempenhando estas atividades. Um padrão de mobilidade logístico similar é encontrado entre os Bará, Yuhup e Nadob que passam longos períodos de tempo nos acampamentos residenciais, somente entrando na floresta para viagens logísticas, durante as quais constroem acampamentos temporários ocupados por pouco dias (Politis, 2001: 34-35).
} 
residenciais, nas quais ocorrem atividades de manufatura, processamento, consumo e manutenção dos artefatos, e às locações que seriam locais onde ocorrem atividades específicas, com períodos breves de ocupação e baixa visibilidade arqueológica.

A mobilidade residencial está relacionada à substituição de um sítio habitacional por outro, conduzindo a construção e ocupação de um novo acampamento. A estrutura espacial e tempo de ocupação das bases residenciais, bem como o espaçamento entre estas, varia de acordo com a estação. O tempo de permanência nas bases residenciais é pequeno, variando entre 5 dias (no inverno) e 2 dias (no verão) e distando entre si, em média, entre 4 Km (no inverno) e $9 \mathrm{Km}$ (no verão) ${ }^{7}$. Também se observam nas diferentes estações do ano distinções na organização dos sítios e nos padrões de descarte decorrentes. Em média, ocorrem entre 80 e 70 mudanças residenciais ao longo do ciclo anual, sendo o raio estimado do território de um bando local de algumas centenas de quilômetros quadrados.

As saídas diárias para obtenção de recursos são geralmente feitas pelos homens adultos, e estão associadas à caça, à pesca e à coleta de mel e de outros subprodutos das abelhas, bem como de matériais primas vegetais para a manufatura de artefatos. As mulheres podem ocasionalmente tomar parte destas saídas, mas geralmente sua contribuição para a subsistência se centra na coleta de frutas e, ocasionalmente, plantas cultivadas nas vizinhanças do acampamento residencial. A média das distâncias percorridas em termos diários é de 8,41 Km (sendo mais freqüente a média de $1 \mathrm{Km}$ em torno do acampamento), independente da estação do ano, e o tempo despendido nestas viagens é variável, correspondendo a um máximo de 10 horas. Estas ocorrem sempre durante o dia e só raramente os grupos retornam ao acampamento depois do anoitecer.

A mobilidade logística é menos freqüente e implica nos deslocamentos de um ou mais indivíduos a partir do sítio residencial para o desenvolvimento de tarefas específicas relacionadas à obtenção de recursos, coleta de informações, condução de atividades rituais, entre outras. As estratégias de mobilidade logística podem ocorrer em termos diários, retornando os indivíduos à base residencial no mesmo dia ou podem ser mais complexas e prolongadas, envolvendo a construção de acampamentos transitórios para o pernoite.

De acordo com Politis, existe uma grande variabilidade nos padrões de mobilidade residencial entre os caçadores coletores, podendo esta ser estimada com base na literatura etnográfica, entre 1 a 60 translados ao ano, com médias de distâncias entre acampamentos

\footnotetext{
${ }^{7}$ De acordo com Politis (1996a: 147), durante o ciclo anual as distâncias entre os acampamentos variam entre 0,9 e 18,1 Km, com uma média de 6,5 Km, revelando uma conduta distinta de acordo com a estação.
} 
oscilando entre 2,4 e $69,5 \mathrm{Km}$. O caso Nukak apresentaria uma das taxas de mobilidade mais alta entre grupos caçadores coletores atuais, embora as médias de distâncias entre os acampamentos sejam as mais baixas dentre os casos etnográficos analisados por Kelly (1995). Contudo, Politis destaca que este comportamento coincide com as expectativas de Binford $(1980,1990)$ para os caçadores de área tropical, caracterizado por alta mobilidade residencial, com baixa permanência nos sítios. O autor ressalta, no entanto, que este padrão não pode ser explicado somente em função de aspectos de ordem tecno-econômica, pois também carrega em si aspectos históricos, sociais e ideológicos fundamentais para a estruturação da sociedade Nukak (Politis, 1996a: 154-157).

A alta mobilidade apresentada por este grupo é, concomitantemente, geradora e produto de estratégias de manipulação e manejo ambiental relacionadas ao sistema de ocupação do espaço. A manipulação de várias espécies vegetais apresenta uma relação estreita com diversas atividades associadas ao sistema de assentamento adotado. O corte de árvores e plantas para a construção dos acampamentos favorece a competição por luz e nutrientes entre as espécies comestíveis, cujas sementes são descartadas em abundância nas áreas habitacionais, gerando, em longo prazo, “hortas” silvestres às quais os Nukak retornam freqüentemente em seus ciclos de mobilidade.

As partes da paisagem que vão sendo ocupadas com maior freqüência, tendem a concentrar palmáceas e outras árvores úteis, e, por sua vez, tornam-se, então, setores preferenciais de ocupação. Como os Nukak não ocupam os acampamentos abandonados, estes setores vão crescendo a medida em que se agregam acampamentos e se transformam em uma paisagem construída. Em suma, a mobilidade residencial é também uma estratégia para aumentar a concentração de recursos vegetais, e desta forma, a produtividade das espécies alimentícias do bosque tropical (Politis, 1996a: 157).

Com base nestes dados, o autor conclui que a mobilidade residencial de caçadores coletores de floresta tropical não deve ser vista exclusivamente como o resultado de uma estratégia de adaptativa voltada unicamente à preservação dos recursos disponíveis. A mobilidade não seria, portanto, uma conseqüência da limitação dos recursos, mas uma estratégia para aumentar a sua produtividade ${ }^{8}$ (Politis, 1996a : 165). Stearman (1991)

\footnotetext{
${ }^{8}$ Contrariando as expectativas do modelo ortodoxo, o tipo de manipulação do ambiente observado entre os Nukak permite sugerir que este possa representar um padrão comportamental comum aos caçadores coletores
} 
observa o mesmo padrão entre os Yuquí da Amazônia boliviana, destacando a relação entre coleta de frutas e caça de espécies arbóreas e terrestres que delas também se alimentam na estação chuvosa. Este tipo de comportamento que gera "jardins de caça" próximos aos assentamentos residenciais é destacado por Linares (1976) como um fator importante para concentração artificial de suprimentos de carboidratos e proteínas nas florestas tropicais, possibilitando o aumento da biomassa animal e funcionando como um substituto para a domesticação.

Deve-se destacar que outros fatores de ordem social também estão relacionados às estratégias de mobilidade dos Nukak, representando um papel importante dentro do conjunto de critérios considerados quando da decisão de mudança das bases residências. Destacam-se entre estes os aspectos de ordem sócio-ideológicos que determinam as tomadas de decisões quanto à mudança residencial relacionada à morte· de um membro do grupo ou a necessidade de encontro com outros bandos para a realização de atividades rituais, casamentos, intercâmbios de informações e visitas familiares. A mobilidade também é uma estratégia utilizada para aliviar tensões entre bandos vizinhos, a fim de evitar ou mediar conflitos, e permite o intercâmbio de bens com outras populações, como no caso Nukak os medicamentos e os produtos industrializados obtidos junto às Missões religiosas e aos colonos que vivem na área ${ }^{9}$. O controle sanitário também é um fator importante relacionado ao abandono das bases residenciais. Após alguns dias de ocupação, o lixo acumulado no piso ou em alguns setores da unidade habitacional, passa a produzir mau cheiro e a atrair grande quantidade de insetos. Igualmente, a alta mobilidade pode ser uma estratégia para reduzir ou evitar a incidência de certas doenças tropicais, sendo baixos os índices de malária ou doenças parasitárias entre estas populações (Politis, 1996a: 157163).

Tendo por base os dados relativos ao sistema de mobilidade e assentamento Nukak, elaboramos nossa proposta de estudo regional para Alto Vale do Rio dos Sinos com o objetivo de compreender a forma de estruturação de um sistema de assentamento caçador coletor relacionado à Tradição Umbu. Através das prospecções realizadas foram identificados 15 sítios de caçadores coletores associados à Tradição Umbu concentrados nos setores noroeste e sudoeste da área piloto, em torno da várzea do rio dos Sinos e de

de floresta tropical ao longo de todo o Holoceno, contribuindo para aumentar a sua produtividade (Politis, 1996a: 335-354).

${ }^{9}$ A análise detalhada dos distintos aspectos sociais que influenciam o sistema de mobilidade Nukak pode ser encontrada em Cabrera-Becerra e colaboradores (2001: 100-174). 
seus afluentes, arroios Restinga, Campestre e Pinheiros. Destes, 14 estão associados a abrigos sob rocha e apenas um encontra-se a céu aberto. A partir dos resultados das prospecções e sondagens realizadas, três dos sítios que apresentaram maior potencial arqueológico foram selecionados para escavações mais amplas com o objetivo de estudar sua variabilidade contextual e estabelecer uma cronologia de suas ocupações, tratadas no próximo capítulo.

\subsection{Os Sítios da Tradição Umbu no Alto Vale do Rio dos Sinos:} Características de Implantação

Foram localizados nas prospecções da área piloto 50 abrigos sob rocha, optando-se por realizar sondagens de sub-superfície em 13 destes através de tradagens e/ou poçostestes $^{10}$. Esta atividade teve por objetivo confirmar a ocupação pré-colonial e avaliar o potencial arqueológico dos sítios para futuras escavações. As tradagens foram realizadas através de uso de cavadeira que produziu intervenções circulares de $30 \mathrm{~cm}$ de diâmetro, aprofundando-se até atingir a rocha matriz, sendo os sedimentos peneirados. Estas intervenções foram distribuídas em intervalos regulares e orientadas de forma linear ou hexagonal a partir da linha mestra estabelecida na entrada dos abrigos. A partir dos resultados obtidos ampliaram-se as sondagens através da realização de poços teses em quatro sítios, dois dos quais foram selecionados para escavações mais amplas.

A ocupação arqueológica foi confirmada em 18 abrigos sob rocha da área pesquisada, sendo 14 associados à Tradição Umbu. Quanto aos sítios em abrigo sob rocha restantes, um apresentou apenas evidências de uma ocupação histórica recente ${ }^{11}$, um está

\footnotetext{
${ }^{10}$ Os sítios sondados que apresentaram evidências arqueológicas foram os seguintes: RS-S-395: Deobaldino Marques, RS-S-337: Monjolo, RS-S-327: Sangão, RS-S-391: Dodô, RS-S-417: Jair Oliveira e RS-S-419: Dirceu Oliveira. Não apresentaram evidências arqueológicas associadas à Tradição Umbu nas sondagens os sítios RS-S-326: Toca dos Carrapatos, RS-S-390: Jovelino, RS-S-418: Abrigo do Petroglifo, Abrigo 8, Abrigo 17, Abrigo 19.

${ }^{11}$ O sítio RS-S-390: Jovelino (UTM 22J 543 848/6706 800) situa-se em meia encosta, a $70 \mathrm{~m}$ de altitude e possui 13,4 $\mathrm{m}$ de abertura, $4 \mathrm{~m}$ de profundidade e $4 \mathrm{~m}$ de altura. Este abrigo foi utilizado como moradia por mais de 30 anos por um trabalhador rural da localidade conhecido como Jovelino, que faleceu há 7 anos atrás. Em superfície ainda se encontram objetos pertencentes a Jovelino, sendo classificado este abrigo como um sítio histórico uma vez que nas sondagens realizadas não foram identificadas evidências de ocupação précolonial.
} 
associado ao sistema de assentamento da Tradição Taquara ${ }^{12}$, apresentando os demais afiliação cultural indeterminada em função do tipo de amostras obtidas ${ }^{13}$ (tabela 1).

Em relação ao conjunto de 32 abrigos sob rocha para os quais não foram identificadas evidências de ocupação pretérita, 18 (65,5\%) não apresentam condições de habitabilidade, devido à ausência de sedimentação ou em função do alto grau de umidade em seu interior, sendo afetados pelas cheias dos rios e pela presença de vertentes. Em relação aos 14 restantes, três não apresentaram evidências em sub-superfície nas sondagens, podendo os demais, apesar da ausência de material arqueológico em superfície, apresentar possibilidades de ocupação humana a serem averiguadas (tabela 2).

Os sítios arqueológicos da Tradição Umbu em abrigos sob rocha identificados estão associados a áreas de meia encosta e a morros testemunhos, com altitudes médias entre 30 e 100 m. A distância dos cursos de água está entre 10 e 300 m, em média, sendo a orientação predominante nordeste (28\%), leste (17\%) e oeste (17\%). O único sítio a céu aberto da Tradição Umbu localizado encontra-se próximo a dois sítios em abrigo sob rocha, estando associado a uma pequena colina situada na base de um morro testemunho.

\footnotetext{
${ }^{12}$ O sítio RS-S-328: Caipora está a uma altitude de $300 \mathrm{~m}$ e corresponde a uma fenda no basalto, com orientação sudeste, situado a $1,5 \mathrm{Km}$ a leste do arroio Sertão. O sítio foi registrado por Eurico Miller em 1968, quando foram realizadas coletas de superfície, apresentando uma coleção de fragmentos ósseos humanos, com datação de 1655+65 AP (SI 2345). Por apresentar associação com algumas lascas de basalto, o sítio foi classificado durante o PRONAPA como associado à Tradição Humaitá, contudo está relacionado ao sistema de assentamento da Tradição Taquara, sendo esta sua provável associação cultural.

${ }^{13}$ O sítio RS-S-262: Guarda Velha-1 (UTM 22J 543 600/6703 900) tem orientação oeste, possuindo 32 m de abertura, $9 \mathrm{~m}$ de profundidade e $5 \mathrm{~m}$ de altura estimada. Está localizado a pelo menos $30 \mathrm{~m}$ acima da nascente de um pequeno arroio, sendo a abertura voltada para uma encosta abrupta o que torna o acesso possível somente pela parte superior do abrigo, no topo do morro testemunho. Este foi escavado em 20/11/1965, tendo sido realizados três cortes estratigráficos que totalizaram uma área de $15 \mathrm{~m}^{2}$. A escavação ocorreu em níveis artificiais de $10 \mathrm{~cm}$, atingindo uma profundidade de $40 \mathrm{~cm}$, sem evidências em subsuperfície. No fundo do abrigo, foram coletados em superfície 1373 fragmentos ósseos humanos, representados apenas pelos pós-crânios, com um número mínimo de 7 indivíduos adultos (catálogo MARSUL 388 e 389). Este sítio foi associado por Eurico Miller à Tradição Umbu, porém as características da coleção fogem ao padrão conhecido para os sítios de caçadores coletores da área nordeste do Estado. Igualmente, os moradores mais antigos da localidade acreditam que estes esqueletos pertenciam a soldados assassinados durante a Revolução Federalista do final do século XIX, sendo, portanto, necessário à datação destes conjuntos ósseos. O sítio RS-S-326: Toca dos Carrapatos (UTM 22J 542 558/ 6709 397) está situado em um pequeno vale encaixado, permanentemente alagado pelo arroio Campestre, a uma altitude de $33 \mathrm{~m}$. O abrigo possui $60 \mathrm{~m}$ de abertura, $19 \mathrm{~m}$ de profundidade e altura estimada de $10 \mathrm{~m}$, sendo sua orientação sudoeste. No acervo documental do MARSUL há registro de pesquisas arqueológicas entre 15 e 16/5/1966 e 27 e 28/9/1970, porém até o presente seu acervo não foi localizado (nº de catálogo junto ao MARSUL: 7717 a 728 e 2536 a 2546). Foram realizadas 19 tradagens com cavadeira neste sítio, distribuídas de forma linear a $5 \mathrm{~m}$ da linha de goteira, indicando a presença do piso arenítico entre as profundidades de 10 e $70 \mathrm{~cm}$. Somente uma das intervenções apresentou evidências de ossos de mamífero de médio porte, entre eles uma falange de espécie não identificada, impossibilitando a afiliação cultural.
} 
Apresenta baixa visibilidade e densidade de material, podendo representar uma extensão das áreas de atividades relacionadas aos sítios em abrigo sob rocha.

A área de implantação dos caçadores coletores possui aproximadamente $40 \mathrm{Km}^{2}$, distribuindo-se os sítios entre dois conjuntos (Anexo 3). O primeiro está associado aos morros testemunhos ao longo da várzea do rio dos Sinos e de seus afluentes, arroios Restinga, Grande e Pinheiros, em uma área que abrange em torno de $16 \mathrm{Km}^{2}$. Os abrigos distanciam-se entre 4 e $1 \mathrm{Km}$, sendo a média das distâncias entre os sítios de 1,5 Km. Fazem parte deste grupo os sítios em abrigo sob rocha: RS-S-395: Deobaldino Marques, associado à confluência dos arroios Pinheiros e Grande; RS-S-337: Monjolo e RS-S-361: Mato da Toca, associados à confluência do arroio Grande e rio dos Sinos; RS-S-391: Dodô, RS-S-264: Toca do Sino, RS-S-327: Sangão, RS-S-360: Marimbondo e RS-S-265: Campestre, associados à confluência do arroio Restinga e rio dos Sinos; e RS-S-388: Guarda Velha 6, associados à confluência de arroios de pequeno porte com o curso principal do rio dos Sinos.

O segundo conjunto de sítios situa-se $2 \mathrm{Km}$ ao norte, associado às meias encostas que acompanham o vale do arroio Campestre. Distribuindo-se por uma área de $1 \mathrm{Km}^{2}$, os sítios apresentam uma média de $300 \mathrm{~m}$ de distância entre si, estando associados à confluência de dois pequenos cursos de água formadores do arroio Campestre. Fazem parte deste conjunto o sítio a céu aberto RS-S-420: Boçoroca e os sítios em abrigo sob rocha RSS-358: Toca Grande, RS-S-359: Aterrado, RS-S-417: Jair de Oliveira, 418: Petroglifo e RS-S-419: Dirceu de Oliveira.

Dos sítios do primeiro conjunto, o abrigo RS-S-395: Deobaldino Marques (UTM 22J 549 750/6707 650) representa o ponto mais distante a leste do padrão de implantação de sítios de caçadores coletores, no limite da área onde passam a predominar os sítios da Tradição Guarani. Está situado na vertente noroeste de um morro testemunho em meio à planície de inundação associada à confluência dos arroios Grande e Pinheiros, do qual dista 1,5 Km, em altitude de $50 \mathrm{~m}$. Sua orientação é noroeste, apresentando $46 \mathrm{~m}$ de abertura, 17 m de profundidade máxima e altura estimada de $8,5 \mathrm{~m}$.

Neste sítio foram escavados dois poços-testes, em níveis artificiais de $10 \mathrm{~cm}$, e realizadas 10 tradagens com cavadeira. As tradagens foram distribuídas por sistema linear, acompanhando a linha de goteira, distando $2 \mathrm{~m}$ entre si e atingindo, em média, $1 \mathrm{~m}$ de profundidade. Os trados de número 2 e 6 apresentaram fragmentos ósseos de mamíferos de maior porte e sedimentos de coloração cinza, sendo a área do trado 2 selecionada para realização de um poço-teste, de 2 x $1 \mathrm{~m}$. Este atingiu uma profundidade de $80 \mathrm{~cm}$, 
revelando um pacote sedimentar arenoso e homogêneo, de coloração marrom, com alto índice de umidade, em função das infiltrações da linha de goteira e da ação de uma vertente na extremidade oeste do abrigo. O material arqueológico distribui-se ao longo de toda a estratigrafia, com baixa densidade, predominando vestígios arqueofaunísticos de pequeno e médio porte e resíduos de lascamento em basalto, destacando-se no conjunto dois artefatos ósseos (pontas de projétil). Um segundo poço-teste, com dimensões 1 x $1 \mathrm{~m}$, foi efetuado entre dois buracos de “caçadores de tesouro", situados junto à parede leste do abrigo, atingindo uma profundidade de $70 \mathrm{~cm}$. Este produziu uma grande quantidade de ossos de pequenos roedores, fragmentos de carapaça de gastrópodes e alguns fragmentos de lascamento de basalto, apresentando características sedimentares semelhantes ao poçoteste anterior (Anexo 4 - croqui 1 ).

A $4 \mathrm{Km}$ a oeste do sitio RS-S-395: Deobaldino Marques situa-se o abrigo sob rocha RS-S-337: Monjolo (UTM 22J 546 300/6706 800). O sítio está localizado na meia encosta de um morro testemunho, com altitude de $150 \mathrm{~m}$, estando voltado para a planície de inundação da confluência do rio dos Sinos com o arroio Grande. A orientação da abertura é leste e sua extensão é de $47 \mathrm{~m}$, a profundidade máxima é de $15 \mathrm{~m}$, estando a altura estimada em 20 m. Este abrigo foi registrado por Eurico Miller em 1969, durante o PRONAPA, como um sítio histórico, em função da presença em superfície de cerâmica definida como pertencente à fase Monjolo da Tradição Neo-brasileira, datada do início do século XVIII, não sendo realizadas intervenções arqueológicas na época. O abrigo foi durante muitos anos utilizado como curral, havendo uma área de desmoronamento na sua porção sul em função da ação do pisoteio do gado. Atualmente comporta um santuário à Nossa Senhora da Saúde, onde todos os meses são celebradas missas pela comunidade do Monjolo.

As novas visitas ao sítio permitiram o registro de suas coordenadas geográficas, tendo sido identificado material arqueológico associado à Tradição Umbu em superfície e na linha de goteira. Uma primeira tentativa de sondagem de sub-superfície deu-se em fevereiro de 2000, a partir da realização de 14 tradagens efetuadas com cavadeira, cujos resultados determinaram a abertura de um poço-teste de 2 x $1 \mathrm{~m}$, escavado em níveis artificiais de $10 \mathrm{~cm}$. Foi utilizado um sistema de tradagens linear, acompanhando a linha de goteira, sendo estabelecida a primeira linha de tradagens a $4 \mathrm{~m}$ da linha mestra, distando as intervenções $2 \mathrm{~m}$ entre si. Também foram realizadas outras três intervenções complementares para o interior do abrigo. As tradagens atingiram profundidades entre 40 cm e 1,30 m, indicando um piso arenítico irregular na base do abrigo e evidenciando 
fragmentos arqueofaunísticos de animais de pequeno e médio porte e resíduos de lascamento em basalto. Os sedimentos revelaram-se arenosos e homogêneos, de coloração marrom, com pouco grau de umidade. O poço-teste foi escavado nas proximidades de um buraco de "caçador de tesouro" presente junto à parede norte do abrigo, evidenciando uma fogueira, associada a restos ósseos de gado e cerâmica do século XVIII. Os sedimentos mostraram-se arenosos, compactos e homogêneos até a profundidade de $45 \mathrm{~cm}$ quando se evidenciou um bloco de arenito na base do poço teste, sobre o qual foi realizada a fogueira.

O plano de construção de um altar para a igreja determinou a ampliação das escavações, a título de salvamento arqueológico. Em julho de 2001 foi escavada uma área de $7 \mathrm{~m}^{2}$, evidenciando estruturas históricas do século XVIII associadas à fogueira identificada no poço teste, cuja metodologia e resultados serão tratados no próximo capítulo. Igualmente, optou-se por maximizar o sistema de sondagens de sub-superfície a fim de detectar áreas que apresentassem evidências de ocupação caçadora coletora. Foram realizados poços de testes de 50 x $50 \mathrm{~cm}$, cuja distribuição obedeceu ao plano de quadriculamento do sítio, escavados em níveis artificiais de $5 \mathrm{~cm}$ e a distanciados $3,5 \mathrm{~m}$, correspondendo cada sondagem ao canto nordeste de uma quadrícula. A primeira linha de sondagens (linha B) situa-se a $2 \mathrm{~m}$ da linha mestra, comportando 6 intervenções. A segunda linha de sondagens está a 7 metros da linha mestra (linha G), possuindo 3 intervenções. As sondagens atingiram profundidades variadas até serem interrompidas pela presença de blocos de arenito, entre os 20 e 70 cm, confirmando para o restante da área do sítio a irregularidade do piso já identificada pelas sondagens anteriores. Todas as intervenções apresentaram densidade relativa de material lítico e arqueofaunístico ao longo da estratigrafia, apresentando maior concentração até os 50 cm. A sondagem B8 revelou a presença de material lítico e ósseo associado à Tradição Umbu. Porém encontrava-se perturbada pela ação de um formigueiro, responsável pela desagregação de seus sedimentos, de onde possivelmente se originaram os materiais líticos da Tradição Umbu encontrados na linha de goteira. Quanto às demais sondagens realizadas, a que apresentou maior densidade de resíduos de lascamento em basalto e fragmentos de carvão, foi a que correspondeu ao canto nordeste da quadrícula B12. A partir desta foi ampliado um poço teste de 2 x $1 \mathrm{~m}$ que apresentou evidências aos $30 \mathrm{~cm}$ de profundidade de uma estrutura de fogueira e de uma área de lascamento relacionada a uma ponta de projétil. Em função destes resultados, este sítio foi escolhido para a realização de escavações amplas voltadas ao estudo da variabilidade intra-sítio de caçadores coletores na área (Anexo 4 - croqui 2). 
A um $1 \mathrm{Km}$ a noroeste do sítio RS-S-337: Monjolo, situa-se o sítio RS-S-361: Mato da Toca (UTM 22J 545 100/670/350). O abrigo está associado a um morro testemunho, com altitude de $68 \mathrm{~m}$, localizado em meio à planície de inundação do arroio Restinga e do rio dos Sinos. A várzea alagadiça encontra-se coberta por pasto e é utilizada para criação de gado, estando a base do morro coberta por mato secundário que esconde a entrada do abrigo. Suas dimensões são $23 \mathrm{~m}$ de abertura, $6 \mathrm{~m}$ de profundidade e $5 \mathrm{~m}$ de altura, sendo sua orientação sudoeste. Entre 18 e 26/04/1970 foi escavada por Eurico Miller uma área de $36 \mathrm{~m}^{2}$ que produziu uma amostragem de 363 peças líticas da Tradição Umbu, além de fragmentos ósseos e conchíferos (números de catálogo MARSUL: 2393 a 2419). Ao todo foram escavadas 4 quadrículas de 3 x $3 \mathrm{~m}$, cujos estratos foram divididos em níveis artificiais de $10 \mathrm{~cm}$, atingindo uma espessura de $1 \mathrm{~m}$. Embora não haja datações para este sítio, o material apresenta uma distribuição contínua ao longo da estratigrafia. O abrigo foi novamente visitado, sendo registrada suas coordenadas geográficas e verificada suas condições de preservação. Observou-se que a área das escavações de 1970 ainda encontra-se aberta, sofrendo intensa erosão nos perfis das quadrículas devido à ação de infiltrações, optando-se por não realizar novas intervenções em função da intensa ação da umidade e erosão neste sítio (Anexo 4 - croqui 3).

Em meio à planície de inundação da confluência do arroio Restinga com o rio dos Sinos localiza-se o abrigo sob rocha RS-S-391: Dodô (UTM 22J 543 788/ 6706 316), na base de um morro testemunho com uma altitude de $65 \mathrm{~m}$, distante 1,5 $\mathrm{Km}$ a sudoeste do sítio RS-S-361: Mato da Toca. O sítio possui orientação nordeste, com 25 m de abertura, 4,9 m de profundidade e 2,5 m de altura e foi moradia ocasional, por pelo menos 10 anos, de um andarilho, conhecido na localidade de Campestre como Dodô, falecido há 4 anos atrás. A superfície do sítio encontra-se coberta por vestígios desta ocupação recente, tendo sido identificado na linha de goteira lascas de redução de biface. Para orientar as sondagens de sub-superfície foi estabelecida uma linha mestra de $20 \mathrm{~m}$ de extensão, com orientação de $340^{\circ}$, localizada entre a linha de goteira e a parede do fundo do abrigo, sobre a qual foram realizadas 8 tradagens com cavadeira, distantes $2 \mathrm{~m}$ entre si, que atingiram profundidades entre $98 \mathrm{~cm}$ e 1,19 m até a rocha matriz. Da superfície até os $10 \mathrm{~cm}$, em média, observa-se uma linha de cinzas e carvão associada à ocupação de Dodô, apresentando a estratigrafia, até $1 \mathrm{~m}$ de profundidade, um pacote sedimentar homogêneo constituído de sedimentos arenosos, de granulação fina e coloração marrom escuro, tornando-se amarelados e de granulação mais grossa quando da proximidade da rocha matriz. Em apenas duas das tradagens, na área central do abrigo, foram detectadas lascas 
unipolares de basalto que associamos á ocupação caçadora coletora. Em função desta baixa densidade de material optou-se por não realizar poços-teste neste sítio.

A $1 \mathrm{Km}$ a oeste do sítio RS-S-391: Dodô, no mesmo ambiente alagadiço de implantação, destaca-se outro morro testemunho com altitude de $52 \mathrm{~m}$. Este apresentou dois sítios com evidências de ocupação humana pretérita associada à Tradição Umbu. Situado na base nordeste deste morro está o sítio RS-S-264: Toca do Sino (UTM 22J 542 398/6706 319), estando encoberto pela mata ciliar que segue o curso do rio dos Sinos, distando deste menos de $50 \mathrm{~m}$. Sua orientação é nordeste, possuindo $10 \mathrm{~m}$ de abertura, 2,5 m de profundidade e uma altura de 4,5 m. O sítio foi pesquisado por Eurico Miller em 27/11/1965, tendo sido realizado um corte estratigráfico de 2 x 1 m, até a profundidade de $30 \mathrm{~cm}$, em níveis artificiais de $10 \mathrm{~cm}$. O material destas escavações recebeu numeração de catálogo junto ao MARSUL ( $n^{\circ}$ 400-402), porém não foi localizado no acervo. Novas visitas a este abrigo permitiram o registro de suas coordenadas geográficas e de suas condições de preservação, tendo sido coletados em superfície e na linha de goteira lascas e um núcleo unipolar em arenito silicificado. Optou-se por não realizar sondagens neste sítio em função das suas pequenas dimensões e das perturbações identificadas, na forma de buracos erodidos que comprometem sua parte central, possivelmente relacionados às escavações da década de 1960 (Anexo 4 - croqui 4).

O sítio RS-S-327: Sangão (UTM 22J 542 295/6706 313) situa-se na vertente leste deste morro testemunho, a uma altitude de $50 \mathrm{~m}$. Suas dimensões são $25 \mathrm{~m}$ de abertura, 10 m de profundidade e 6 metros de altura, possuindo orientação sul. Seu acesso se dá pela porção oeste, estando a abertura voltada para uma encosta abrupta, 7 metros acima do rio dos Sinos. Em função da dificuldade de acesso e das características de implantação, este sítio não possui utilização atual, garantindo melhor condições de preservação que os demais sítios da área. O sítio foi escavado por Eurico Miller em duas etapas de campo entre 22 e 23/5/1966 e 10 e 17/05/1970. Na época foram realizadas 12 quadrículas de 1,5 x $1,5 \mathrm{~m}$, em níveis artificiais de $10 \mathrm{~cm}$, totalizando uma área escavada de 29,25 $\mathrm{m}^{2}$. Estas quadrículas se distribuíram em duas trincheiras, ao longo da parede norte e cortando a área central do abrigo. A coleção do PRONAPA é composta por 791 peças líticas associadas à Tradição Umbu, além de restos arqueofaunísticos e artefatos ósseos (números de catálogo junto ao MARSUL: 729 a 733 e 2547 a 2559).

A primeira vistoria do sítio, em abril de 2000, permitiu observar que a área escavada nas décadas de 1960 e 1970 ainda encontrava-se exposta, sendo fortemente atingida pela erosão, dividindo a área preservada do sítio em dois blocos testemunhos nos 
seus lados oeste e leste. Também foi registrada a presença de um testemunho preservado das escavações anteriores junto à parede norte que corresponderia às quadrículas 12A e 12B do plano de quadriculamento original. Optou-se, inicialmente, por realizar uma limpeza dos perfis das escavações anteriores, o que evidenciou um pacote estratigráfico marcado, do topo à base, pela presença de fogueiras, com grande concentração de cinza concrecionada pela umidade, carvão e restos arqueofaunísticos, distribuídas tanto ao longo da trincheira norte, quanto da trincheira central. Selecionamos este sítio para a realização de escavações mais amplas tendo em vista suas condições excepcionais de preservação e alto potencial para o estudo de áreas de atividade em sítios caçador coletor. Para estabelecer quais áreas a serem escavadas e determinar os métodos a serem empregados, foram realizados dois poços-teste de 2 × $1 \mathrm{~m}$, em ambos os lados da trincheira central.

A fim de orientar estas sondagens, uma linha mestra foi fixada junto à linha de goteira do abrigo e a partir desta estabelecemos um novo sistema de quadriculamento. $\mathrm{O}$ primeiro poço-teste situa-se na porção leste do sítio e foi escavado em abril de 2000, a partir de níveis artificiais de $10 \mathrm{~cm}$. Está situado a $5 \mathrm{~m}$ da linha mestra, correspondendo às quadrículas E8 e F8. Até os $20 \mathrm{~cm}$ de profundidade, observou-se uma grande densidade de material lítico e arqueofaunístico associada a áreas de fogueiras sobrepostas e extensas. Este aspecto determinou que optássemos por dar continuidade às escavações apenas na quadrícula E8, reservando-se a quadricula F8 para uma escavação contextual mais detalhada no futuro.

Ao longo da escavação, pode se observar um pacote sedimentar homogêneo, de granulação fina e coloração marrom escura até a profundidade de $50 \mathrm{~cm}$, onde se evidenciou a presença do piso arenítico, com distribuição contínua de material arqueológico. Observou-se na quadrícula E8 a presença de uma estrutura de fogueira, marcada por vários episódios de reutilização, com aproximadamente $30 \mathrm{~cm}$ de espessura, entre a profundidade de $20 \mathrm{~cm}$ e a base da escavação. A ela estavam associados fragmentos de carapaças de bivalves de rio e de gastrópodes, bem como fragmentos ósseos de animais de porte variado. Percebeu-se que o principal fator de perturbação que afetou a área desta sondagem correspondia a duas grandes galerias de tatu que afetavam a integridade da fogueira evidenciada, comprometendo o estudo de áreas de atividade para este setor do sítio. Uma análise preliminar dos restos arqueofaunísticos resgatados apontaram, também, uma alta densidade de ossos de pequenos roedores, resultantes da ação de processos naturais. A sondagem situa-se abaixo de uma inflexão do teto do abrigo que cruza o setor leste do sítio longitudinalmente, representando este material os restos alimentares das 
corujas que ali se abrigavam, aspecto que afetaria os estudos zooarqueológicos das coleções provenientes das escavações.

Tendo em vista estes resultados, optou-se por realizar, em janeiro de 2001, uma nova sondagem de 2 x $1 \mathrm{~m}$ na porção oeste do sítio, na área que corresponde às quadrículas D14 e D13, cuja metodologia obedeceu aos mesmos critérios empregados nas escavações do sítio RS-S-360. Os resultados desta sondagem, apontaram um contexto deposicional mais estável, afetado em menor grau por galerias de tatu, bem como uma menor incidência de restos esqueletais de roedores depositados por processos naturais. Na quadrícula D13 foi identificada, aos $20 \mathrm{~cm}$ de profundidade, uma fogueira com $30 \mathrm{~cm}$ de espessura que apresentava evidencias de reutilização ao longo do tempo. Amostras de carvão de diferentes níveis desta fogueira foram datadas, indicando um intervalo de utilização desta estrutura por aproximadamente 3000 anos, entre as datações dos níveis superiores e da base. Estes resultados determinaram a escolha da área da segunda sondagem para a ampliação das escavações e também permitiram redimensionar os métodos empregados, detalhados no próximo capítulo (Anexo 4 - croqui 5).

Distante $1 \mathrm{Km}$ a nordeste do conjunto de abrigos anterior, situa-se o sítio RS-S360: Marimbondo (UTM 22J 543 074/6707 535) em uma meia encosta encoberta por mato secundário. Sua orientação é oeste e suas dimensões são $50 \mathrm{~m}$ de abertura, $14 \mathrm{~m}$ de profundidade e $10 \mathrm{~m}$ altura, sendo o sítio utilizado como curral ao longo dos últimos 30 anos. Entre 4 e 12/04/1970 foi escavada por Eurico Miller uma área de 24,5 $\mathrm{m}^{2}$ neste sítio, distribuída em 11 quadrículas de 1,5 x 1,5 m. As escavações se deram em níveis artificiais de $10 \mathrm{~cm}$, atingindo uma profundidade de $70 \mathrm{~cm}$. A coleção derivada das escavações do PRONAPA para este sítio é composta por 2108 peças líticas associadas à Tradição Umbu, além de fragmentos ósseos e conchíferos (números de catálogo junto ao MARSUL: 2332 a 2392).

Um dos proprietários do abrigo, que participou como auxiliar de campo nas primeiras escavações, informou-nos que logo após o encerramento dos trabalhos a área que sofreu intervenções foi aterrada. Contudo, a ação do pisoteio do gado ao longo dos anos provocou intensa erosão junto à linha de goteira, destruindo o local onde originalmente situava-se a maior parte das quadrículas escavadas na década de 1970 . Também se observa na área central do abrigo a presença de um extenso cupinzeiro que causou intensa erosão, praticamente dividindo o sítio em dois setores. O setor sul apresenta maior profundidade, porém é mais afetado pela ação da umidade, formando-se na sua boca, em dias de chuva intensa, uma pequena cachoeira. O setor norte, por sua vez, possui 
melhores condições de luminosidade e proteção contra a ação das chuvas. Tendo em vista a grande dimensão do abrigo e as distinções em termos de habitabilidade entre os dois setores do sítio, realizamos sondagens de sub-superfície a fim de determinar as áreas a serem escavadas.

Tendo em vista que a abertura do abrigo possui uma forma de ferradura, estabeleceu-se a partir do centro do sítio duas linhas mestras formando um ângulo de $55^{\circ}$ entre si que acompanhavam a linha de goteira do abrigo. Estas linhas mestras foram utilizadas para orientação das sondagens, tendo sido realizadas 25 tradagens com o uso de cavadeira, distribuídas a distâncias regulares. O sistema de sondagem obedeceu a um padrão de distribuição hexagonal, o que ampliaria a probabilidade de localização de evidencias em sub-solo, tendo em vista a baixa densidade de materiais arqueológicos observada nas tradagens já realizadas em outros abrigos sob rocha a partir de um traçado linear (Krakker et al, 1983). No setor sul do abrigo foram realizadas 14 tradagens, sendo as três primeiras junto à parede sul do abrigo. Estas atingiram a $1 \mathrm{~m}$ de profundidade um lençol de água, associado à ação da linha de goteira, revelando sedimentos argilosos e de coloração marrom. As demais tradagens neste setor deram-se a $6 \mathrm{~m}$ da linha mestra, divididas em três linhas, distantes $2 \mathrm{~m}$ entre si. Os pontos de tradagem distaram $4 \mathrm{~m}$ entre si nas linhas, de forma a intercalarem-se, formando hexágonos. Estas atingiram profundidades entre $80 \mathrm{~cm}$ e 1,2 m, apresentando-se os sedimentos arenosos e de coloração marrom escura até os $50 \mathrm{~cm}$, quando se tornaram argilosos e avermelhados, indicando a proximidade do lençol de água relacionado a infiltrações da linha de goteira. Somente quatro das tradagens realizadas nas proximidades da área central do abrigo evidenciaram a presença do piso arenítico, entre 35 e 70 cm de profundidade. Do conjunto de intervenções no setor sul do sítio nenhuma apresentou evidências arqueológicas e somente duas revelaram sedimentos arenosos de coloração acinzentada, associados a fragmentos de carvão, próximo ao fundo do abrigo, local onde foi delimitado uma das áreas de escavação.

No setor norte do abrigo foram realizadas 11 tradagens, distribuídas igualmente de acordo com o sistema hexagonal. As tradagens na área central permitiram observar que o cupinzeiro estendia-se até a parede do fundo do abrigo, cobrindo uma extensão de pelo menos $10 \mathrm{~m}$ e atingindo a profundidade de $90 \mathrm{~cm}$. As demais tradagens atingiram a rocha matriz entre 70 e $35 \mathrm{~cm}$ de profundidade, revelando sedimentos arenosos, de granulação grossa e coloração marrom clara. Foram localizadas lascas de basalto em três das intervenções na porção norte do abrigo a partir dos quais foi estabelecida a malha das 
escavações neste setor, cuja metodologia e resultados serão tratados no próximo capítulo (Anexo 4 - croqui 6).

O conjunto de abrigos sob rocha da margem direita do rio dos Sinos ainda é composto pelo sítio RS-S-265: Campestre-1 (UTM 22J 541 738/6707 340). Situado na porção mesial de um morro testemunho extenso, encoberto por mato secundário, com altitude máxima de 89 m, está a 1,5 Km a oeste do sítio RS-S-360: Marimbondo, marcando o limite oeste da presença de sítios em abrigo sob rocha da área pesquisada. A orientação do abrigo é oeste, possuindo $16 \mathrm{~m}$ de abertura, $6 \mathrm{~m}$ de profundidade e $4 \mathrm{~m}$ de altura. $\mathrm{O}$ sítio foi escavado por Eurico Miller em duas etapas de campo entre 27 e 29/11/1965 e 12 e 27/09/1970. Na época foram realizadas duas trincheiras paralelas, a primeira de 3 x $1 \mathrm{~m}$ e a segunda composta de 5 quadrículas de 1,5 x 1,5 m, totalizando 14,25 $\mathrm{m}^{2}$ escavados, centrados na porção sul do sítio. As escavações foram realizadas em níveis artificiais de 10 $\mathrm{cm}$, atingindo uma profundidade de $1,3 \mathrm{~m}$. O acervo é composto 782 peças líticas associadas à Tradição Umbu, além de fragmentos ósseos e conchíferos, distribuídos de forma contínua ao longo da estratigrafia ( $\mathrm{n}^{\circ}$ de catálogo junto ao MARSUL: 403 a 422 e 2505 a 2535).

As visitas realizadas ao sítio permitiram verificar suas condições de preservação, apresentando sua porção norte uma pequena área conservada. O setor sul, por sua vez, encontra-se totalmente perturbado em função do desmoronamento dos perfis e dos testemunhos das escavações anteriores que permaneceram descobertas, formando um grande buraco a partir do centro do abrigo em direção à parede norte. Embora estes sedimentos tenham praticamente atulhado a área escavada, foi possível observar parte do perfil norte de uma das antigas trincheiras que ainda se mantinha intacto. Este apresentou um pacote sedimentar arenoso, de granulação fina e coloração marrom clara, estando ausentes estruturas de fogueiras ou lentes de carvão, apresentando fragmentos de lascamento que também ainda afloram na linha de goteira. $\mathrm{O}$ alto grau de perturbação deste sítio determinou que não fossem planejadas novas intervenções (Anexo 4 - croqui 7).

Por fim, no limite sul da área piloto, na margem esquerda do rio dos Sinos, prospecções realizadas em 1993 permitiram o registro de um sítio em abrigo sob rocha situado em meia encosta, a uma altitude de 100 m. O sítio RS-S-388: Guarda Velha-6 (UTM 22J 542 450/6704 750) possui orientação noroeste e suas dimensões estão estimadas em $60 \mathrm{~m}$ de abertura, $13 \mathrm{~m}$ de profundidade e $20 \mathrm{~m}$ de altura máxima. O sítio apresentou lascas de redução de biface em arenito silicificado associadas à linha de goteira, sendo 
inicialmente associado à Tradição Umbu, embora não tenham sido realizadas sondagens neste abrigo a fim de avaliar o tipo de ocupação (Jacobus, 1994b).

O segundo conjunto de sítios da Tradição Umbu está associado a três morros testemunhos situados na confluência de dois pequenos arroios com o curso médio do arroio Campestre. O maior de todos os abrigos pesquisados na área piloto situa-se neste conjunto, correspondendo ao sítio RS-S-358: Toca Grande-2 (UTM 22J 543 881/ 6710 055). Este foi escavado por Eurico Miller em três etapas de campo, entre 1970 e 1972. Localiza-se na meia encosta de um morro testemunho, a $51 \mathrm{~m}$ de altitude, circundado pela planície de inundação do arroio Campestre, estando a $100 \mathrm{~m}$ a sudeste de um dos braços do arroio. O sítio possui $87 \mathrm{~m}$ de abertura, por $25 \mathrm{~m}$ de profundidade e $6 \mathrm{~m}$ de altura, sendo sua orientação nordeste. Entre 1970 e 1972 foi escavada uma área de 173,2 m² que produziu uma amostragem de 5199 peças líticas associadas à Tradição Umbu, além de restos arqueofaunísticos ( $\mathrm{n}^{\circ}$ de catálogo junto ao MARSUL: 1930 a 2139, 2801 a 2989, 5000 a 5154). Ao todo foram escavadas 77 quadrículas de 1,5 x 1,5 m, cujos estratos foram divididos em níveis artificiais de $10 \mathrm{~cm}$, atingindo uma espessura de 1,5 m.

Atualmente situa-se em um parque pertencente à comunidade Adventista de Santo Antônio da Patrulha, sendo utilizado como templo. O sítio foi destruído na década de 1980, sendo seus sedimentos retirados com retro-escavadeira, correspondendo à rocha matriz ao atual piso do templo. Foram também retirados grandes blocos situados junto à parede sul para dar lugar ao altar. A consulta à documentação de campo das pesquisas de Miller indica a presença de um petroglifo neste sítio que não foi localizado em novas visitas ao abrigo, pois possivelmente estava associado aos blocos que foram retirados. Infelizmente, este petroglifo não foi registrado por fotografia ou desenho na época destas pesquisas, não se dispondo de informações sobre sua posição original, forma, dimensões ou técnica de confecção (Anexo 4 - croqui 8).

Em uma meia encosta a 500 m a noroeste do sítio RS-S-358: Toca Grande, situa-se um pequeno abrigo sob rocha, com orientação nordeste, a 32 m de altitude. O sítio RS-S419: Dirceu Oliveira (UTM 22J 543 328/6710 336) está a 100 metros de um braço do arroio Campestre e apresenta $26 \mathrm{~m}$ de abertura total, por 11,5 m de profundidade máxima e $5 \mathrm{~m}$ de altura, tendo seu nicho principal $18 \mathrm{~m}$ de abertura. Foram realizadas sondagens com cavadeira neste sítio, orientadas a partir de um sistema hexagonal, distribuídas entre duas linhas paralelas, distantes $1 \mathrm{~m}$ entre si. A primeira linha de tradagens distancia-se $5 \mathrm{~m}$ da linha mestra estabelecida junto a abertura do abrigo e nela foram realizadas 5 tradagens, distando a primeira $4 \mathrm{~m}$ da parede oeste e as demais $2 \mathrm{~m}$ entre si. A profundidade dos 
trados da primeira linha encontra-se entre $30 \mathrm{~cm}$ e $1 \mathrm{~m}$ atingindo o piso arenítico. Apresentou sedimentos homogêneos e arenosos, de granulação grossa e coloração marrom escura, adquirindo uma consistência mais argilosa nas tradagens realizadas próximas a linha de goteira. Na segunda linha foram realizadas 3 tradagens, revelando um pacote sedimentar semelhante, estando o piso a profundidades entre 40 e $90 \mathrm{~cm}$. Em duas das tradagens realizadas na área central do abrigo foram identificados uma lasca unipolar, uma borda retocada de artefato bifacial, uma pré-forma de ponta de projétil e um seixo com possíveis marcas de utilização, todos em basalto, além de fragmentos de carvão. A vistoria de superfície também permitiu a localização de material arqueológico junto à linha de goteira, na forma de uma lasca de arenito silicificado, duas placas de basalto com lascamentos e um artefato bifacial.

Tendo em vista o resultado das sondagens, foram realizados três poços-teste a partir dos pontos de sondagem que apresentaram materiais arqueológicos, totalizando uma área escavada de $5 \mathrm{~m}^{2}$. O método de escavação utilizado foi semelhante ao dos demais sítios deste projeto, a ser detalhado no próximo capítulo. O primeiro poço-teste, de $2 \times 1 \mathrm{~m}$, corresponde às quadrículas D3 e E3, estando a $4 \mathrm{~m}$ da linha mestra. Este revelou um pacote sedimentar arenoso e homogêneo até uma profundidade $15 \mathrm{~cm}$ quando atinge o piso arenítico do abrigo, sendo possível identificar a presença de material arqueológico até a profundidade de $25 \mathrm{~cm}$ somente na quadrícula E3. O segundo poço-teste, de $1 \mathrm{x} 1 \mathrm{~m}$, corresponde à quadrícula $\mathrm{H} 4$, situada a $7 \mathrm{~m}$ da linha mestra, próxima à parede do fundo do abrigo. Este atingiu uma profundidade de $30 \mathrm{~cm}$, apresentando material arqueológico até os $15 \mathrm{~cm}$. O último poço-teste, de $2 \times 1 \mathrm{~m}$, corresponde às quadrículas F5 e G5, estando a 6 $\mathrm{m}$ da linha mestra e atingindo uma profundidade de $40 \mathrm{~cm}$ até o piso arenítico. O pacote sedimentar é semelhante as demais sondagens apresentando maior densidade de material arqueológico até os $25 \mathrm{~cm}$. Os vestígios arqueológicos correspondem a, aproximadamente, 250 peças líticas, representadas em sua maioria por fragmentos de lascamento e lascas unipolares de basalto e arenito silicificado, tendo também sido identificada uma ponta de projétil pedunculada e com bordas serrilhadas em calcedônia. Não foram identificados nas sondagens vestígios arqueofaunísticos ou estruturas de fogueira, encontrando-se nos primeiros níveis pequenos fragmentos de carvão esparsos, inadequados para datações radiocarbônicas o que determinou que não fossem ampliadas as áreas de escavação (Anexo 4 - croqui 9).

A 500 m a oeste do sítio RS-S-419: Dirceu Oliveira situa-se um morro testemunho, com 60 m de altitude, no qual foram identificados dois sítios arqueológicos em abrigo sob 
rocha. O primeiro corresponde ao sítio RS-S-359: Aterrado (UTM 22J 542 988/ 6710 100), situado na vertente nordeste deste morro, em uma meia encosta abrupta, $10 \mathrm{~m}$ acima do curso de um braço do arroio Campestre, do qual dista menos de $50 \mathrm{~m}$. Sua orientação é nordeste e possui $26 \mathrm{~m}$ de abertura, $11 \mathrm{~m}$ de profundidade e $8 \mathrm{~m}$ de altura. Este abrigo foi pesquisado por Eurico Miller em duas etapas de campo em 1970 e 1972, quando se escavou uma área de 132,7 $\mathrm{m}^{2}$, distribuída entre 58 quadrículas de 1,5 x 1,5 m, cujos estratos foram divididos em níveis artificiais de $10 \mathrm{~cm}$, atingindo uma profundidade de 80 cm, com distribuição contínua de material ao longo da estratigrafia. Foi realizada uma datação radiocarbônica para este sítio, obtendo-se um resultado de 1740+65 anos AP (SI 2344). Os trabalhos de campo produziram uma coleção de 4451 peças líticas, associada à Tradição Umbu, além de fragmentos ósseos e conchíferos. Também foi encontrado um sepultamento, possivelmente de um indivíduo do sexo feminino, do qual somente o crânio encontra-se localizado junto acervo do MARSUL ( $n^{\circ}$ de catálogo junto ao MARSUL: 2140 a 2338, 4410 a 4532). A vistoria deste sítio indicou que praticamente não restavam sedimentos preservados que permitissem novas intervenções (Anexo 4 - croqui 10).

O sítio RS-S-417: Jair Oliveira (UTM 22J 543 045/ 6709 994) localiza-se na vertente leste do mesmo morro testemunho, distando menos de $50 \mathrm{~m}$ do sítio anterior. O abrigo apresenta $26 \mathrm{~m}$ de abertura, $12 \mathrm{~m}$ de profundidade máxima, no nicho central, e altura aproximada de $6 \mathrm{~m}$. Sua orientação é nordeste e encontra-se a $200 \mathrm{~m}$ do córrego acima mencionado, sendo utilizado como curral e como local de pernoite ocasional por um dos empregados da propriedade. A linha de goteira encontra-se intensamente afetada por erosão, comprometendo a integridade do sítio. Segundo informações do proprietário, este processo iniciou-se há cinco anos atrás, quando o abrigo passou a ser utilizado como curral. O sítio apresentava lascas de redução de biface em arenito silicificado e uma lasca bipolar de quartzo na linha de goteira, além de fragmentos de cerâmica torneada, vidro e louça moderna decorrentes das ocupações contemporâneas.

Foi estabelecida uma linha mestra acompanhando a linha de goteira do abrigo e paralelas a esta foram demarcadas mais três linhas, distantes 2 m entre si, para orientação das tradagens. Foram realizadas 31 tradagens com cavadeira, posicionadas de forma intercalada entre as linhas, obedecendo a um traçado hexagonal.Também foram feitas 7 intervenções fora das linhas de tradagem, três das quais no interior de nichos nas paredes do abrigo e quatro em linha reta, a partir da linha mestra em direção a um platô situado na frente do abrigo. As tradagens, em geral, evidenciaram sedimentos homogêneos e arenosos, de coloração marrom escura entre os 80 e $90 \mathrm{~cm}$ de profundidade, tornando-se 
amarelado no contato com a rocha matriz. Somente as tradagens da primeira linha apresentaram uma consistência mais argilosa em função da ação da linha de goteira. As tradagens realizadas no platô em frente ao abrigo atingiram $1 \mathrm{~m}$ de profundidade, apresentando um pacote sedimentar homogêneo, argiloso e marrom escuro, sem associação com material arqueológico. Em somente uma das intervenções foi identificada uma ponta de projétil pedunculada, em basalto, não sendo localizados nenhum outro tipo de evidências arqueológicas nas demais tradagens o que determinou a não ampliação das sondagens (Anexo 4 - croqui 11).

Um terceiro morro testemunho situado a $500 \mathrm{~m}$ ao sul dos sítios acima descritos, apresenta um conjunto de 9 abrigos sob rocha, dos quais dois possuem evidências de ocupação humana pretérita. O sítio RS-S-418: Abrigo do Petroglifo (UTM 22J 542 697/ 6709 593) está a $15 \mathrm{~m}$ de altitude, na base da vertente leste deste morro, em um pequeno vale encaixado entre dois paredões, encoberto por mato secundário. Possui $13 \mathrm{~m}$ de abertura, 3 m de profundidade e, aproximadamente, $4 \mathrm{~m}$ de altura, com orientação norte. No setor oeste do sítio situa-se um bloco de arenito, com superfície parcialmente polida, no qual foi identificada a presença de um petroglifo. O bloco apresenta dimensões aproximadas de 100 x $80 \mathrm{~cm}$, possuindo fraturas recentes causadas por marreta na sua parte superior e em ambas laterais. Estas fraturas podem ter afetado a parte superior da figura e foram causadas por "caçadores de tesouros” que procuravam ouro no seu interior, segundo o proprietário do sítio. O petroglifo possui $93 \mathrm{~cm}$ de comprimento máximo por 68 cm de largura, apresentando a forma de um tridáctilo invertido que converge para uma cruz, conferindo a figura um aspecto de representação antropomorfa. A parte correspondente ao tridáctilo invertido foi realizada através de picoteamento, sendo a parte superior, em forma de cruz, bem como a as incisões da base de duas das terminações do tridáctilo, produzida por raspagem.

A fim de realizar sondagens de sub-superfície neste sítio foi estabelecida uma linha mestra, junto à linha de goteira, paralela a qual foram realizadas duas linhas de tradagem, distribuídas de forma a obedecer a um traçado hexagonal. Foram feitas 6 intervenções com cavadeira, distantes entre si $2 \mathrm{~m}$, sendo a primeira realizada ao lado do bloco do petroglifo. Nesta, observou-se entre a superfície e os $15 \mathrm{~cm}$ uma grande quantidade de fragmentos de arenito, possivelmente relacionados à quebra do bloco e à deterioração das paredes do abrigo. Entre 15 e $75 \mathrm{~cm}$ de profundidade os sedimentos apresentaram-se argilosos e de coloração marrom escura, quando atingem uma linha de água, associada à ação da linha de goteira. As tradagens realizadas na primeira linha evidenciaram sedimentos arenosos de 
coloração marrom clara até $25 \mathrm{~cm}$ de profundidade, tornando-se mais escuros até os $70 \mathrm{~cm}$ de profundidade, quando assumem uma consistência argilosa e uma coloração amarelada até atingirem a linha de água presente a $1 \mathrm{~m}$ de profundidade. As demais tradagens junto à parede do abrigo apresentaram sedimentos arenosos de coloração avermelhada entre 30 e $50 \mathrm{~cm}$, atingindo a rocha matriz entre 38 e $70 \mathrm{~cm}$ de profundidade (Anexo 4 - croqui 12 e desenho 1).

Destaca-se que este abrigo corresponde ao único sítio com arte rupestre conhecido para o vale do rio dos Sinos. Embora, nenhuma das intervenções tenha evidenciado materiais arqueológicos em sub-superfície, associamos este sítio à ocupação caçadora coletora da área em função da semelhança estilística de seu petroglifo com outros sítios rupestres associados à Tradição Umbu identificados nos vales dos rios Jacuí, Ibicuí-Mirim e Caí, na área central do Estado, e do rio Quaraí, na região da Campanha sul-rio-grandense (Schmitz e Brochado, 1982; Ribeiro, 1978; Ribeiro e Féris, 1984). Estas manifestações rupestres estão associadas ao Estilo Pisadas que possui datações de 2945+85 AP (SI 1001) e 1165_35 AP (SI 1000) para o abrigo RS-MJ-15: Canhemborá, no vale do médio rio Jacuí, e de 905+95 AP (SI 1196) para o abrigo RS-SM-7: Abrigo da Pedra Grande, no vale do alto rio Jacuí (Schmitz e Brochado, 1982). Também nesta mesma área o sítio em abrigo sob rocha RS-452-1: Ivorá apresenta painéis com petroglifos, tendo sido datado em 2190+80 AP (Beta Analytics 129549) (Castelhano, 2003).

Entre os abrigos RS-S-417: Jair Oliveira e RS-S-418: Petroglifo foi localizado o único sítio a céu aberto relacionado ao sistema de assentamento de caçadores coletores na área piloto. O sítio RS-S-420: Boçoroca (UTM 22J 543 066/ 6709 856) corresponde a um sítio lítico identificado através da vistoria de uma área de erosão (boçoroca) na base de uma pequena elevação do terreno, coberta por pasto, distando dos sítios anteriores menos de $200 \mathrm{~m}$. O sítio está a uma altitude de $26 \mathrm{~m}$, distando $200 \mathrm{~m}$ de um braço do arroio Campestre, sendo coberto pelas águas em período de cheias. O pacote sedimentar de origem aluvial é pouco espesso, possuindo menos de $50 \mathrm{~cm}$, sobrepondo-se a lajes de arenito que afloram em vários pontos. Foram identificados nesta linha de erosão um núcleo e uma lasca unipolar de basalto, além de um machado polido elaborado sobre placa de basalto. A vistoria do terreno circundante através de linhas de caminhamento não indicou a presença em superfície de outras evidências arqueológicas. Por outro lado, as condições de declividade do terreno e a pouca espessura do pacote sedimentar impediu a realização de sondagens de sub-solo. 


\subsection{Contribuições da Etnoarqueologia para a Construção de um Modelo de} Sistema de Assentamento para os Caçadores Coletores da Tradição Umbu no Alto Vale do Rio dos Sinos

O modelo forrageiro de Binford, associado aos dados etnoarqueológicos de Politis e às tendências da literatura antropológica contemporânea sobre caçadores coletores, permitem levantar a hipótese de que um sistema de assentamento associados aos grupos caçadores coletores da Tradição Umbu poderia ser caracterizado por três princípios gerais.

Em primeiro lugar, destaca-se a idéia de que a manutenção de um sistema de assentamento caçador coletor adaptado a áreas florestais é mediado pela alta mobilidade, demandando, portanto, um território amplo. Este território, por sua vez, comportaria duas dimensões distintas: uma regional, associada ao grupo de afiliação, e uma local, associada às áreas de forragem dos bandos que compõe o grupo de afiliação, cujas fronteiras são marcadas pela alta fluidez.

Uma segunda característica estaria associada às estratégias de mobilidade que correspondem ao marco estrutural deste tipo de organização social. A alta mobilidade agiria de forma a potencializar a capacidade produtiva do ambiente e manter os vínculos sociais e o fluxo de informação entre os distintos bandos locais que fazem parte de um grupo de afiliação e que compartilham o mesmo território regional.

Por fim, os sítios arqueológicos derivados de um sistema de assentamento caracterizado pela alta mobilidade seriam o produto de intervalos breves de ocupação, gerando vestígios materiais pouco densos e altamente dispersos na paisagem. Estes sítios possuiriam baixa variabilidade funcional e alta probabilidade de apresentar depósitos primários, podendo variar entre dois tipos: unidades habitacionais e locações relacionadas a atividades específicas.

Seguindo este modelo, podemos sugerir que a área piloto do Alto Vale do Rio dos Sinos, com $216 \mathrm{Km}^{2}$, representaria um território de forragem de um bando local, correspondendo a uma porção mínima de um território regional mais amplo, associado a um grupo de afiliação. Tomando o caso Nukak como referência, este hipotético território regional abrangeria uma área mínima de $1.000 \mathrm{Km}^{2}$. Contudo, a extensão do território Nukak representa uma realidade marcada pela disputa de terras com as frentes coloniais. Portanto, no período pré-contato, possivelmente, os territórios regionais para grupos forrageiros relacionados à Tradição Umbu poderiam ser mais extensos. Especificamente para nosso estudo de caso, sugerimos que a borda nordeste do planalto sul-rio-grandense, 
compreendendo os vales dos rios Taquari, Caí, Sinos e Maquiné, bem como a planície litorânea adjacente, corresponderia a um território regional de um grupo de afiliação, comportando vários territórios de forragem de bandos locais, cujos membros poderiam mover-se sem restrição em função de objetivos de ordem social e econômica. Este aspecto de fluidez da organização social e do uso do espaço, por sua vez, implicaria em uma organização tecnológica homogênea para a área deste território regional, em função do fluxo constante de informações e pessoas, características estas que podem ser percebidas através dos estudos de coleções líticas da Tradição Umbu já realizados para as áreas dos vales dos rios dos Sinos, Caí e Maquiné (Dias, 1994, 1995b, 1996, 1999b, 2000b, 2000c).

As questões de ordem ambiental associadas ao modelo etnoarqueológico de sistema de assentamento para caçadores coletores em área tropical merecem uma avaliação mais detalhada quanto a sua aplicabilidade para o sul do Brasil, tendo em vista suas peculiaridades ambientais e a amplitude temporal da ocupação humana. Segundo Araújo e colaboradores (2003: 13), os estudos palinológicos desenvolvidos nos últimos anos para as áreas costeiras dos Estados do Paraná, Santa Catarina e Rio Grande do Sul indicam uma melhora constante das condições climáticas ao longo de todo o Holoceno. Embora o Último Máximo Glacial e o Último Glacial tenham apresentado um clima extremamente seco e frio, com expansão de pradarias onde hoje ocorre uma variedade de ecossistemas florestais, durante o Holoceno houve uma tendência bastante recuada para o aumento da pluviosidade na área costeira. Isto se deu, provavelmente, em função de fatores orográficos, havendo indícios da presença na área de uma incipiente floresta chuvosa já em torno de 12.300 anos AP. Com base nestes dados, os autores sugerem que a ocupação humana do sul do Brasil parece não ter sofrido restrições em função da umidade, temperatura e sazonalidade de recursos, apresentando-se estável frente a um clima mais moderado se comparado com o Brasil Central (em relação à disponibilidade de água) e com o Pampa Argentino (em relação às baixas temperaturas e disponibilidade de água). A tendência ao longo do Holoceno para a região sul do Brasil seria de um clima mais úmido e quente associado à expansão da floresta sub-tropical desde pelo menos 12.000 anos AP, correspondendo estas condições paleoclimáticas e paleoambientais benignas um fator de atração e fixação populacional bastante antiga para a área (Araújo et al, 2003: 19).

Estudos comparativos de palinologia e sedimentologia realizados por Stevaux (2000) entre áreas do sul e centro do Brasil e do centro e nordeste da Argentina, também apontam neste sentido. Os dados apresentados pelo autor demonstram um aumento da umidade, em termos gerais para a área estudada, iniciado-se entre 10.200 e 7.300 anos 
atrás, perdurando até 3.500 e 2.500 anos AP. Um estudo palinológico realizado para a porção continental da região nordeste do Rio Grande do Sul, no município de Montenegro, indica também uma tendência ao desenvolvimento inicial da Floresta Estacional por volta de 9.800 anos AP, apresentando estes dados contemporaneidade com o início da ocupação caçadora coletora na área (Grala \& Lorscheitter, 2001; ver também Ribeiro \& Ribeiro, 1999). Por sua vez, os estudos palinológicos desenvolvidos por Behling e Negrelle (2001), em área de mata atlântica situada na fronteira entre Santa Catarina e Paraná, demonstraram que entre 12.200 e 6.700 anos atrás esta já apresentava uma cobertura vegetal com características florestais marcadas, estando o pleno desenvolvimento da floresta ombrófila densa datada nesta área entre 6.700 e 4.300 anos AP.

Com base nos dados paleoclimáticos e paleoambientais disponíveis, podemos sugerir que a borda nordeste do planalto sul-brasileiro apresentou características ambientais estáveis marcada pela presença de floresta sub-tropical desde o início de sua ocupação por populações caçadoras coletoras por volta de 9.000 anos atrás. Diferente das áreas tropicais, nas florestas sub-tropicais a produtividade da flora é constante, possuindo ciclos fenológicos distintos de acordo com as estações, sendo o regime de chuvas igualmente distribuído ao longo do ano. Portanto, os sistemas de mobilidade que caracterizaram os caçadores coletores de floresta sub-tropical associados à Tradição Umbu não estariam tão estritamente relacionados à presença concentrada de determinados recursos em função de ciclos sazonais de chuvas, como no caso das áreas tropicais ${ }^{14}$. Por sua vez, as características mais restritas das florestas sub-tropicais quanto à disponibilidade de vegetais para coleta parecem indicar que a caça, possivelmente, representou um papel mais importante para obtenção de recursos alimentares do que o previsto por um modelo derivado da etnoarqueologia Nukak. Destaca-se, também, que até o presente não há dados zooarqueológicos que indiquem que a pesca tenha sido uma fonte regular de proteína para estes grupos, reforçando o papel da caça no sistema de subsistência. Estes fatores conjugados refletiriam-se na necessidade de áreas de forragem mais amplas do que observado para os caçadores de floresta tropical a fim de preservar os recursos disponíveis,

\footnotetext{
${ }^{14}$ Atualmente, as temperaturas no verão são elevadas, podendo atingir entre 35 e $40^{\circ} \mathrm{C}$. No inverno, porém, as altitudes do relevo condicionam um aumento das chuvas, associado a diminuição das temperaturas, também afetadas pela ação de massas polares, estando as médias anuais abaixo dos $15^{\circ} \mathrm{C}$. A duração da pluviosidade também assinala as diferenças entre as zonas tropicais e sub-tropicais brasileiras. Para a zona sub-tropical as chuvas são igualmente distribuídas ao longo do ano, devido à orografia e aos conflitos entre as massas de ar tropical e polar, atingindo atualmente médias anuais em torno de 2.000 mm (Kern, 1991b: 3940).
} 
tendo em vista o padrão disperso da caça neste tipo de ambiente e o retorno a longo prazo das estratégias de manejo das espécies arbóreas exploradas.

Quanto à exploração dos recursos litorâneos pelas populações caçadoras coletoras da Tradição Umbu, ressaltamos que os dados arqueológicos disponíveis indicam que estas adaptações costeiras estão relacionadas à estabilização progressiva e recente da linha de costa do litoral sul brasileiro. No entanto, esta possibilidade não deve ser descartada para períodos mais recuados, podendo os sítios derivados destas ocupações costeiras antigas terem sido destruídos pelos vários episódios de transgressão-regressão marinha que caracterizam o Holoceno como um todo.

Os dados geológicos disponíveis para formação da planície costeira do Rio Grande do Sul apontam que pelo menos até 7.300 anos atrás o nível do mar estava $10 \mathrm{~m}$ abaixo do atual, ocorrendo neste momento uma importante transgressão marinha, cujo clímax deu-se entre 6.000 e 5.500 anos AP, atingindo o nível médio do mar cotas entre 4 e 5 m acima das atuais. Durante esta transgressão, a faixa costeira situava-se junto às margens ocidentais da Lagoa dos Quadros e a cerca de $10 \mathrm{~km}$ a leste da margem oriental da Lagoa dos Barros. Esta correspondia ao único manancial de água doce disponível para a exploração caçadora coletora da região costeira durante este período, aspecto atestado pela ocupação sobre paleo-duna do sítio RS-LC-76 (IBGE, 1986; Medeanic et al, 2001; ver também Hoeltz \& Hilbert, 2000).

Estima-se que as oscilações climáticas que caracterizam o Holoceno Final, foram marcadas por vários episódios de regressão e transgressão marinha, causando transformações ambientais significativas no litoral gaúcho. Entre estas se destaca a formação de restingas, a individualização da Lagoa dos Patos, mais ao sul, e a formação de uma seqüência de lagoas, ao norte. Embora não haja datações que permitam fixar temporalmente a estabilização da linha de costa atual do litoral norte gaúcho, estima-se que esta tenha se dado por volta de 2.000 anos AP, estando nesta faixa temporal os sítios arqueológicos mais antigos da área relacionados tanto à ocupação caçadora coletora, quanto às ocupações horticultoras (Wagner, 2001: 28-42).

Os recursos costeiros, provavelmente, também exerceram um fator de atração para as populações caçadoras coletoras da Tradição Umbu que ocuparam o Alto Vale do Rio dos Sinos. Evidências de uma exploração ocasional recuada no tempo podem ser observadas pela presença de dentes de tubarão e conchas marinhas associadas às coleções dos sítios RS-S-358: Toca Grande e RS-S-327: Sangão. Possivelmente, estas excursões à costa foram freqüentes ao longo da ocupação dos sítios estudados, apresentando-se esta 
mais aberta e próxima ao vale do Alto Rio dos Sinos até pelo menos 5.000 anos AP. Contudo, ressaltamos que a exploração sazonal dos recursos costeiros só teria se tornado mais efetiva para as populações caçadoras coletoras da região nordeste do Rio Grande do Sul a partir da estabilização da linha de costa, quando estes ambientes tornaram-se mais produtivos em função da formação dos sistema de lagoas e banhados do litoral norte que passam a concentrar recursos de caça e pesca na primavera e no verão. Para as regiões litorâneas dos Estados de São Paulo, Paraná e Santa Catarina, nas quais a linha de costa se estabilizou em um período mais recuado, a atração dos recursos costeiros sobre as populações caçadoras coletoras continentais pode representar os períodos iniciais de uma especialização adaptativa que, mais tarde, deu origem às populações sambaquianas.

Quanto aos tipos de sítios relacionados a um sistema de assentamento caçador coletor para a área nordeste do Estado, observamos a partir da literatura arqueológica a presença de 89 sítios associados à Tradição Umbu na região, cujas datações permitem sugerir uma ocupação constante deste território regional ao longo de pelo menos 9.000 anos (tabelas 3.1 e 3.2.). Do conjunto de sítios identificados, 35 ocorrem em abrigos sob rocha, associados a morros testemunho areníticos, que correspondem a formações geológicas comuns na paisagem da porção leste da Depressão Central Gaúcha. A maioria das datações disponível também foi realizada a partir de amostras obtidas nas escavações deste tipo específico de sítio que, em geral, apresenta seqüências estratigráficas de ocupação contínuas e boas condições de preservação de material orgânico. Portanto, sugerimos que os abrigos sob rocha da borda nordeste do planalto sul-rio-grandense representavam marcos na paisagem, sistematicamente re-ocupados como bases residenciais ao longo do ciclo anual de forragem por distintos grupos locais. O sistema de assentamento de caçadores coletores neste território regional também comportaria sítios a céu aberto, de igual funcionalidade, porém estes apresentariam um padrão de distribuição mais disperso na paisagem, sendo sua preservação mais rara.

Os sítios em abrigo sob rocha identificados para o Alto Vale do Rio dos Sinos estariam relacionados a este sistema regional, tendo sido ocupados de forma continuada ao longo de 8.000 anos, segundo as datações obtidas. Partindo do modelo de mobilidade assumido, estes abrigos teriam sido ocupados como bases residenciais por breves períodos de tempo pelos bandos locais ${ }^{15}$ que percorriam a área ao longo do seu ciclo anual de

\footnotetext{
15 Os dados apresentados por Politis (1996a) quanto ao tamanho dos grupos co-residentes representam um padrão confirmado por estudos comparativos baseados na etnografia contemporânea de caçadores coletores
} 
mobilidade, aspectos que serão tratados no próximo capítulo. A curta permanência nos sítio redundaria na baixa densidade de material arqueológico observada nas sondagens, porém as ocupações teriam se dado de forma recorrente ao longo do tempo. Devido a grande disponibilidade de abrigos na região estudada, os sítios teriam sido ocupados em diferentes ocasiões pelos grupos co-residentes, porém dificilmente mais de um abrigo teria sido utilizado em um mesmo momento. Por representarem marcos na paisagem, estes sítios sofreram vários episódios de re-ocupação que produziram pacotes estratigráficos contínuos e, em alguns casos, com alto grau de preservação de unidades de deposição primária em função dos intervalos de abandono entre as ocupações.

Igualmente, observa-se que houve uma preferência na escolha de determinados sítios para o estabelecimento das bases residenciais, pois dos 50 abrigos sob rocha identificados na área piloto, somente 14 foram ocupados por caçadores coletores. Destacase que destes sítios, apenas 8 apresentaram uma densidade de materiais arqueológicos mais significativa o que indicaria uma utilização mais freqüente, estando a maior concentração de sítios com estas características, mais próximos à várzea do rio dos Sinos. As características geomorfológicas particulares ao Alto Rio dos Sinos que disponibilizam uma grande quantidade de abrigos passíveis de serem ocupados pode servir de parâmetro para compreensão de conjuntos arqueológicos mais densos associados a sítios em abrigo sob rocha. Sítios deste tipo que apresentam grande densidade de material arqueológico representariam episódios de ocupação também breves, porém mais freqüentes e menos espaçados no ciclo de mobilidade. Isto permitiria explicar a densidade de materiais observada, por exemplo, para os sítios RS-LN-01: Cerrito Dalpiaz, no vale do rio Maquiné, RS-C-43: Capivara, no vale do rio Caí, e RS-TQ-58: Garivaldino, no vale do rio Taquari, situados em áreas onde a disponibilidade de abrigos é menor, encontrando-se estes mais dispersos na paisagem (Miller, 1969; Dias, 1994, 1999b; Ribeiro \& Ribeiro, 1999).

Sugerimos que o sistema de assentamento do Alto Vale do Rio dos Sinos, igualmente, comportaria uma quantidade significativa de sítios a céu aberto que corresponderiam a unidades habitacionais, porém a alta mobilidade e a curta duração das ocupações produziria um conjunto de vestígios materiais pouco densos, a exemplo das características ocupacionais identificadas nos abrigos sob rocha sondados. Portanto, os sítios a céu aberto teriam pouca visibilidade em função da baixa densidade de vestígios 
não-perecíveis e da alta dispersão na paisagem, na medida em que não sofreriam episódios de re-ocupação. As condições de detecção destes sítios a céu aberto seriam menos favoráveis na área piloto tendo em vista a intensidade da ação agrícola contemporânea e a baixa visibilidade de solo relacionada à cobertura vegetal predominante. Igualmente, a baixa densidade de materiais que caracterizam as ocupações arqueológicas em abrigo sob rocha evidenciada nas sondagens dos sítios da área piloto permite deduzir que a utilização de uma metodologia de prospecção de sub-superfície (full-coverage) dificilmente reverteria em uma maior eficiência na localização de sítios líticos a céu aberto associados a este sistema de assentamento.

A pequena quantidade de sítios líticos a céu aberto associados à Tradição Umbu na área piloto, representada por apenas um sítio, também pode ser um reflexo da re-ocupação constante dos abrigos, redundando em uma concentração ainda menor de sítios a céu aberto. As áreas da borda nordeste do planalto sul-rio-grandense nas quais os abrigos sob rocha são escassos, como os vales dos rios Jacuí e Pardo, apresentam uma maior concentração de sítios líticos a céu aberto, sendo os raros abrigos ocupados no alto rio Jacuí relacionados à presença de arte rupestre. Alguns destes sítios a céu aberto da área mais central do Estado apresentam grande densidade de material arqueológico, o que pode indicar episódios de re-ocupação, cuja motivação pode estar relacionada à disponibilidade de determinados recursos locais, como fontes de matérias primas, ou ainda responder a outros fatores de ordem social. A retomada das pesquisas arqueológicas nestas áreas, sob perspectivas teórico-metodológicas orientadas por um modelo de sistema de assentamento como o adotado para o estudo da região do Alto Rio dos Sinos podem iluminar esta questão, já que os dados produzidos pelas pesquisas anteriores são insuficientes para explicar tais fenômenos.

O modelo de sistema de assentamento adotado prevê, além das unidades habitacionais, a presença de sítios associados a atividades específicas (locations). Sugerimos que estes sítios de atividades específicas para um sistema de assentamento associado à Tradição Umbu poderiam ser de dois tipos. Um primeiro estaria relacionado a locais de extração de matéria prima, geralmente associados a afloramentos rochosos de boa qualidade ou determinados pontos da paisagem, ao longo de cursos de água de maior fluxo, que concentrariam seixos ou placas derivados de arraste fluvial. Um segundo tipo de sítio de atividade específica estaria relacionado ao sistema simbólico do grupo, estando 
caracterizado pela presença de gravações rupestre (petroglifos) em blocos isolados na paisagem ou associados a abrigos sob rocha.

As prospecções na área piloto não permitiram a identificação de sítios de extração de matéria prima relacionados ao sistema de assentamento caçador coletor. Os sítios líticos associados a afloramentos de arenito silicificado e basalto identificados apresentam-se, em geral, relacionados às ocupações horticultoras da área. Por sua vez, a análise das coleções líticas da Tradição Umbu indicou uma tendência a utilização das matérias primas disponíveis nas proximidades dos sítios, não havendo estratégias de redução inicial intensiva próxima aos locais de coleta, a semelhança do observado para o vale do rio Caí (Dias, 1994, 1995b). Contudo, isto não inviabiliza a possibilidade de que este tipo de sítio de atividade específica venha a ocorrer em sistemas de assentamento associados à Tradição Umbu em locais nos quais a disponibilidade das matérias primas apresenta-se distinta.

Dos sítios identificados na área piloto apenas um apresentou características de um sítio de atividade específica associado ao universo simbólico dos grupos de caçadores coletores que ocuparam a região, relacionado a gravuras rupestres. Manifestações semelhantes foram identificadas em associação a sítios da Tradição Umbu nos vales dos rios Caí, Taquari e Alto Jacuí, com datações entre 2945_85 AP (SI 1001) e 630+205 AP (SI 1201), apresentando contemporaneidade com a ocupação caçadora coletora da área piloto. A ausência de materiais arqueológicos nas sondagens do sítio RS-S-418: Petroglifo pode corresponder a um indicador das características funcionais peculiares deste sítio no sistema de assentamento da área ${ }^{16}$.

Por fim, o modelo de sistema de assentamento proposto para a Tradição Umbu na região nordeste do Estado coloca em questão a coerência do esquema histórico-cultural tradicionalmente aceito para a área, segundo o qual esta teria sido compartilhada por pelo menos 6.000 anos por dois diferentes grupos de caçadores coletores, portadores de indústrias líticas distintas, relacionados às Tradições Umbu e Humaitá. O modelo teórico aqui adotado para o entendimento das formas de organização de uma sociedade caçadora coletora inviabiliza a impossibilidade de dois distintos grupos de afiliação compartilharem o mesmo território regional, o que causaria um desequilíbrio no arranjo dos territórios de forragem dos diferentes grupos locais. Isto se daria em função da pressão demográfica sobre os recursos, já que a manutenção do sistema de subsistência em um modelo de 
assentamento forrageiro demanda uma densidade populacional baixa e dispersa na paisagem. Igualmente, espera-se que grupos que compartilham o mesmo território regional apresentem-se conectados por laços sociais, representados em um padrão homogêneo para a cultura material que refletiria, em última instância, o fluxo constante de informações e pessoas na área (Wiessner, 1983, 1989).

Para avaliar o embasamento empírico do modelo histórico-cultural, utilizamos os dados levantados por Jacobus relativos às pesquisas arqueológicas de caçadores coletores para a região nordeste do Rio Grande do Sul, abrangendo os vales dos rios Vacacaí, Jacuí, Pardo, Taquari, Antas, Caí, Sinos e planície litorânea norte (tabelas 3.1 e 3.2) (Jacobus, 2000: 31-42 e 108-155). Ao todo foram registrados nesta região 236 sítios líticos, sendo a afiliação cultural definida pelo fator presença/ausência de fósseis guia. Do conjunto total de sítios, 37,7\% foram associados à Tradição Umbu por apresentarem em suas coleções pontas de projétil líticas, dos quais $60 \%$ são a céu aberto e $40 \%$ em abrigo sob rocha, apresentando 11 destes sítios associação com petroglifos. Foram associados à Tradição Humaitá 23,3\% dos sítios da região nordeste do Estado, sendo 96,5\% destes a céu aberto, apresentando suas coleções bifaces de grande porte e morfologia variada ou conjuntos de resíduos de lascamento sem a presença de pontas de projétil líticas. Utilizando os fósseis guia como único critério para avaliação dos conjuntos líticos resgatados, os sítios que apresentavam associação entre bifaces e pontas de projétil (6,7\%), bem como destes artefatos com fragmentos cerâmicos das Tradições Taquara e Guarani (12\%) foram considerados como representando sobreposições de ocupações pré-coloniais. Igualmente, todos os sítios cujas sondagens ou coletas de superfície não proporcionaram fósseis guia não foram relacionados ao esquema histórico-cultural da região, sendo a afiliação cultural considerada indeterminada ou indefinida (20,3\%).

Por sua vez, estas pesquisas, permitiram a obtenção de 32 datações para a área. A maioria das datações $(87,5 \%)$ relaciona-se a sítios em abrigo sob rocha associados à Tradição Umbu ${ }^{17}$, indicando uma ocupação constante da região por grupos caçadores

\footnotetext{
${ }^{16}$ Os resultados das escavações do sítio em abrigo sob rocha RS-452-1: Ivorá, situado no Alto Rio Jacuí, que apresenta extensos painéis com petroglifos do Estilo Pisadas apontam no sentido de confirmação da hipótese funcional apresentada por nosso modelo (Castelhano, 2003).

${ }^{17}$ Os sítios em abrigo sob rocha associados à Tradição Umbu que apresentam datações são os seguintes: a) para o alto vale do rio Jacuí, associados a petroglifos, temos os sítios RS-MJ-14, com duas datações de 2945+85 AP (SI 1001) e 1165+35 AP (SI 1000), RS-MJ-53a, com uma datação de 905_95 AP (SI 1196), e RS-452-1: Ivorá, com uma datação de 2190+80 AP (BA 129549); b) para o vale do rio Taquari, o sítio RSTQ-58 apresenta 4 datações de 9430+360 AP (BA 44739), 8290+130 AP (BA 32183), 8020+150 AP (BA 33458) e 7250+350 AP (BA 44740); c) para o vale do rio Caí estão datados os sítio RS-C-14, com duas
} 
coletores por um período de pelo menos 9.000 anos. Do conjunto de sítios líticos da Tradição Humaitá apenas um, a céu aberto, apresentou uma datação contemporânea à ocupação da Tradição Umbu na área. Contudo, as características do material lítico e do seu contexto de deposição apresentam fortes evidências de corresponderem ao produto de arraste fluvial associado a lentes naturais de carvão ${ }^{18}$. Igualmente, outros sítios a céu aberto com datações mais recentes relacionadas à Tradição Humaitá também apresentam associação com cerâmica das Tradições Guarani e/ou Taquara, podendo estes conjuntos líticos estar relacionados às ocupações horticultoras da área ${ }^{19}$. Este tipo de associação também foi observado para o Alto Vale do Rio dos Sinos, permitindo sugerir que esta representa a realidade da maior parte dos sítios líticos associados à Tradição Humaitá em toda a borda nordeste do planalto sul-rio-grandense, principalmente nos vales dos rios Jacuí e Pardo que apresentam uma densa ocupação de horticultores.

A partir dos dados acima expostos e dos resultados das pesquisas de campo desenvolvidas no Alto Vale do Rio dos Sinos, sugerimos que um único grupo caçador coletor, associado à Tradição Umbu, ocupou a região nordeste do Rio Grande do Sul. Os sítios líticos identificados como pertencentes à Tradição Humaitá para esta região estariam relacionados aos sistemas de assentamento de horticultores da região ou corresponderiam a sítios de atividades específicas relacionados ao sistema de assentamento da Tradição

datações de 5655+140 AP (SI 1199) e 745+115 AP (SI 1198) e RS-C-12, com uma datação de 630+205 AP (SI 1201); d) para o vale do rio Maquiné possuímos 3 datações para o sítio RS-LN-01 de 5950+190 AP (SI 234), 5680+240 AP (SI 235) e 4280+180 AP (SI 233); e) para o vale o do rio dos Sinos dispomos de 13 datações, distribuídas entre os sítios RS-S-327, com 7 datações de 8800+40 AP (BA 160845), $7330 \pm 40$ AP (BA 165626), 4710+40 AP (BA 154352), 4610+140 AP (BA 160847), 4160+100 AP (BA 154351), $3940+40$ AP (BA 160849) e 3730+60 AP (BA 160846), RS-S-359 com uma datação de 1740+65 AP (SI 2344), RS-S360 com uma datação de 920+40 AP (BA 154354), e RS-S-337 com 4 datações de 7390+40 AP (BA 154353), 5230+40 AP (BA 165625), 520+70 AP (BA 165623) e 440+90 AP (BA 165621). A única datação para sítios a céu aberto da Tradição Umb̄u está associada ao vale dō rio dos Sinos para o sítio RS-S-308, sendo de 575+80 AP (SI 804) (Jacobus, 2000).

${ }^{18} \mathrm{O}$ sítio, RS-A-12, está associado às barrancas do rio das Antas, apresentando uma datação de 6620+175 (SI-933). Sua indústria é caracterizada por Miller como representada por "toscos artefatos líticos (...) confeccionados a partir de seixos rolados (...) lascões e lascas de basalto” (1971:40). O autor destaca que em “todas as peças observa-se o arredondamento e o polimento natural nas áreas lascadas e cristas interlascadas. Esse desbaste natural, ocasionado pelos detritos transportados pelas águas, (...) muito dificilmente são distinguíveis de seixos naturais e possivelmente chegam a se confundir. (...) Como o número de peças é mínimo e maiores conhecimentos acerca do contexto integral dos sítios implicariam em extensas escavações, consideramos estas caracterizações mais como um ensaio preliminar” (Miller, 1971: 41). Apesar das ressalvas de Miller, este material foi associado à fase Antas, considerada a mais antiga para a Tradição Humaitá no Rio Grande do Sul por diversos autores (Kern, 1981; Schmitz, 1981, 1984; Schmitz \& Brochado, 1981a; 1981b; Simões, 1972).

${ }^{19}$ São estes os sítios a céu aberto RS-RP-81, com uma datação de 380+80 AP (SI 4166) e RS-RP-86, com duas datações de 2920_120 AP (SI 4167) e 1425_115 AP (SI 4168). Ambos apresentam conjuntos líticos associados à Tradição Umbu e Humaitá, bem como cerâmica das Tradições Taquara e Guarani, podendo o carvão datado estar associado a qualquer uma das ocupações (Jacobus, 2000). 
Umbu nos quais as pontas de projétil estariam ausentes. A fim de testar esta hipótese, no entanto, deve-se retomar, com uma perspectiva crítica, as coleções líticas derivadas destes trabalhos anteriores, bem como desenvolver novos projetos de campo na região nordeste do Estado, orientados por problemáticas teóricas mais apropriadas ao estudo de grupos caçadores coletores. 
Tabela 1. Sítios Arqueológicos em Abrigos sob Rocha no Alto Vale do Rio dos Sinos

\begin{tabular}{|c|c|c|c|c|c|c|c|c|c|}
\hline Nome do sítio & $\begin{array}{l}\text { Coordenadas } \\
\text { UTM 22J }\end{array}$ & $\begin{array}{l}\text { Dimensões } \\
\text { (abertura, } \\
\text { profundidade, } \\
\text { altura) }\end{array}$ & Orientação & Intervenções & Material arqueológico & Localidade & Altitude & $\begin{array}{l}\text { Distância } \\
\text { de água }\end{array}$ & Topografia \\
\hline $\begin{array}{c}\text { RS-S-262: } \\
\text { Guarda Velha } 1\end{array}$ & $\begin{array}{l}543600- \\
6703900\end{array}$ & $32 \times 9 \times 5 \mathrm{~m}$ & Oeste & $\begin{array}{c}\text { Coleta de superfície e } 3 \\
\text { quadrículas até } 40 \mathrm{~cm} \\
\text { de profundidade }\left(15 \mathrm{~m}^{2}\right. \\
\text { escavados) }\end{array}$ & $\begin{array}{c}\text { Fragmentos ósseos } \\
\text { humanos sem datação. } \\
\text { Sem afiliação cultural } \\
\text { definida }\end{array}$ & $\begin{array}{l}\text { Guarda } \\
\text { Velha }\end{array}$ & $100 \mathrm{~m}$ & $200 \mathrm{~m}$ & Encosta \\
\hline $\begin{array}{l}\text { RS-S-264: Toca } \\
\text { do Sino }\end{array}$ & $\begin{array}{l}542398- \\
6706319\end{array}$ & $10 \times 2,5 \times 4,5 \mathrm{~m}$ & Nordeste & $\begin{array}{c}\text { Coletas de superfície e } \\
2 \text { quadrículas até } 30 \mathrm{~cm} \\
\text { de profundidade }\left(2 \mathrm{~m}^{2}\right. \\
\text { escavados) }\end{array}$ & $\begin{array}{c}\text { Lítico da Tradição } \\
\text { Umbu }\end{array}$ & $\begin{array}{l}\text { Campestre } \\
\text { Novo }\end{array}$ & $30 \mathrm{~m}$ & $50 \mathrm{~m}$ & Várzea \\
\hline $\begin{array}{l}\text { RS-S-265: } \\
\text { Campestre } 1\end{array}$ & $\begin{array}{l}541738- \\
6707340\end{array}$ & $16 \times 6 \times 4 \mathrm{~m}$ & Oeste & $\begin{array}{c}8 \text { quadrículas até } 1,3 \mathrm{~m} \\
\text { de profundidade }(14,25 \\
\left.\mathrm{m}^{2} \text { escavados }\right)\end{array}$ & $\begin{array}{c}\text { Lítico da Tradição } \\
\text { Umbu }\end{array}$ & $\begin{array}{l}\text { Campestre } \\
\text { Novo }\end{array}$ & $89 \mathrm{~m}$ & $1000 \mathrm{~m}$ & Meia- encosta \\
\hline $\begin{array}{l}\text { RS-S-326: Toca } \\
\text { dos Carrapatos }\end{array}$ & $\begin{array}{l}542558- \\
6709397\end{array}$ & $60 \times 19 \times 10 \mathrm{~m}$ & Sudoeste & $\begin{array}{l}18 \text { tradagens até } 70 \mathrm{~cm} \\
\text { de profundidade }\end{array}$ & $\begin{array}{c}\text { Fragmentos de } \\
\text { arqueofauna. } \\
\text { Sem associação cultural } \\
\text { definida. }\end{array}$ & $\begin{array}{l}\text { Campestre } \\
\text { Novo }\end{array}$ & $33 \mathrm{~m}$ & $300 \mathrm{~m}$ & Várzea \\
\hline $\begin{array}{l}\text { RS-S-327: } \\
\text { Sangão }\end{array}$ & $\begin{array}{l}542 / 295- \\
6706 / 313\end{array}$ & $25 \times 10 \times 6 \mathrm{~m}$ & Sudeste & $\begin{array}{l}\text { Coletas de superfície, } \\
24 \text { quadrículas até } 80 \\
\text { cm de profundidade } \\
\left(41,25 \text { m² }^{2} \text { escavados }\right)\end{array}$ & $\begin{array}{l}\text { Lítico da Tradição } \\
\text { Umbu com datações de } \\
8800+40 \text { AP (Beta } \\
\text { 160845), 7390+40 AP } \\
\text { (Beta 154353), } 4710+40 \\
\text { (Beta 154352), } \\
4610 \pm 140 \text { AP (Beta } \\
\text { 160847), 4160+100 AP } \\
\text { (Beta 154351). 3940+40 }\end{array}$ & $\begin{array}{l}\text { Campestre } \\
\text { Novo }\end{array}$ & $52 \mathrm{~m}$ & $7 \mathrm{~m}$ & Várzea \\
\hline
\end{tabular}




\begin{tabular}{|c|c|c|c|c|c|c|c|c|c|}
\hline & & & & & $\begin{array}{l}\text { AP (Beta 160849), } \\
3730+60 \text { AP (Beta } \\
\text { 160846). }\end{array}$ & & & & \\
\hline $\begin{array}{l}\text { RS-S-328: } \\
\text { Caipora }\end{array}$ & $\begin{array}{l}557804- \\
6709448\end{array}$ & $5,4 \times 8 \times 2,5 \mathrm{~m}$. & Leste & Coleta de superfície & $\begin{array}{c}\text { Fragmentos ósseos } \\
\text { humanos com datação } \\
\text { de 1655+65 AP (SI } \\
\text { 2345). Possível afiliação } \\
\text { cultural à Tradição } \\
\text { Taquara }\end{array}$ & Furna & $300 \mathrm{~m}$ & $1500 \mathrm{~m}$ & Encosta \\
\hline $\begin{array}{l}\text { RS-S-337: } \\
\text { Monjolo }\end{array}$ & $\begin{array}{l}546300- \\
6706800\end{array}$ & $47 \times 14 \times 20 \mathrm{~m}$ & Leste & $\begin{array}{l}\text { Coletas de superfície, } \\
27 \text { quadrículas, } 9 \\
\text { sondagens e } 16 \\
\text { tradagens até } 1,30 \text { m de } \\
\text { profundidade ( } 29 \mathrm{~m}^{2} \\
\text { escavados) }\end{array}$ & 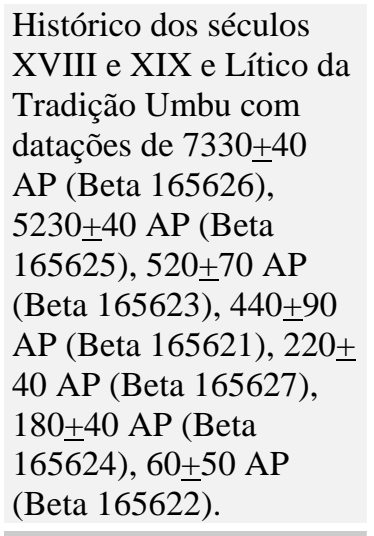 & Monjolo & $150 \mathrm{~m}$ & $600 \mathrm{~m}$ & Meia- encosta \\
\hline $\begin{array}{l}\text { RS-S-358: Toca } \\
\text { Grande } 2\end{array}$ & $\begin{array}{l}543881- \\
6710055\end{array}$ & $87 \times 25 \times 6 \mathrm{~m}$ & Nordeste & $\begin{array}{l}77 \text { quadrículas até } 1,5 \\
\text { m de profundidade } \\
\left(173,2 \mathrm{~m}^{2} \text { escavados }\right)\end{array}$ & $\begin{array}{c}\text { Lítico da Tradição } \\
\text { Umbu }\end{array}$ & $\begin{array}{l}\text { Campestre } \\
\text { Novo }\end{array}$ & $51 \mathrm{~m}$ & $100 \mathrm{~m}$ & Meia-encosta \\
\hline $\begin{array}{l}\text { RS-S-359: } \\
\text { Aterrado }\end{array}$ & $\begin{array}{l}542988- \\
6710100\end{array}$ & $26 \times 11 \times 8 \mathrm{~m}$ & Nordeste & $\begin{array}{l}58 \text { quadrículas até } 80 \\
\text { cm de profundidade } \\
\left(132,7 \mathrm{~m}^{2} \text { escavados }\right)\end{array}$ & $\begin{array}{l}\text { Lítico da Tradição } \\
\text { Umbu com datação de } \\
\text { 1740_65 AP (SI 2344) }\end{array}$ & $\begin{array}{l}\text { Campestre } \\
\text { Novo }\end{array}$ & $60 \mathrm{~m}$ & $50 \mathrm{~m}$ & Meia-encosta \\
\hline $\begin{array}{l}\text { RS-S-360: } \\
\text { Marimbondo }\end{array}$ & $\begin{array}{l}543074- \\
6707535\end{array}$ & $50 \times 14 \times 10 \mathrm{~m}$ & Oeste & $\begin{array}{l}40 \text { quadrículas e } 23 \\
\text { tradagens até } 1,10 \mathrm{~m} \text { de } \\
\text { profundidade ( } 55 \mathrm{~m}^{2} \\
\text { escavados) }\end{array}$ & $\begin{array}{l}\text { Lítico da Tradição } \\
\text { Umbu com datação de } \\
\text { 920+40 AP (Beta } \\
\text { 154354) }\end{array}$ & $\begin{array}{l}\text { Campestre } \\
\text { Novo }\end{array}$ & $110 \mathrm{~m}$ & $300 \mathrm{~m}$ & Meia-encosta \\
\hline $\begin{array}{c}\text { RS-S-361: Mato } \\
\text { da Тоса }\end{array}$ & $\begin{array}{l}545100- \\
6707350\end{array}$ & $23 \times 6 \times 5 \mathrm{~m}$ & Sudoeste & $\begin{array}{l}4 \text { quadrículas até } 1 \mathrm{~m} \text { de } \\
\text { profundidade ( } 36 \mathrm{~m}^{2} \\
\text { escavados) }\end{array}$ & $\begin{array}{c}\text { Lítico da Tradição } \\
\text { Umbu }\end{array}$ & Monjolo & $58 \mathrm{~m}$ & $600 \mathrm{~m}$ & Várzea \\
\hline $\begin{array}{c}\text { RS-S-388: } \\
\text { Guarda Velha } 6\end{array}$ & $\begin{array}{l}542 / 450- \\
6704 / 750\end{array}$ & $60 \times 13 \times 20 \mathrm{~m}$ & Noroeste & Coleta de superfície & $\begin{array}{c}\text { Lítico da Tradição } \\
\text { Umbu }\end{array}$ & $\begin{array}{l}\text { Guarda } \\
\text { Velha }\end{array}$ & $50 \mathrm{~m}$ & $700 \mathrm{~m}$ & Meia-encosta \\
\hline
\end{tabular}




\begin{tabular}{|c|c|c|c|c|c|c|c|c|c|}
\hline $\begin{array}{l}\text { RS-S-390: } \\
\text { Jovelino }\end{array}$ & $\begin{array}{l}543848- \\
6706800\end{array}$ & $13,4 \times 4 \times 4 \mathrm{~m}$ & Sul & 6 tradagens até $1,10 \mathrm{~m}$ & $\begin{array}{l}\text { Histórico do Século XX. } \\
\text { Sem evidências } \\
\text { arqueológicas pré- } \\
\text { históricas }\end{array}$ & $\begin{array}{l}\text { Campestre } \\
\text { Novo }\end{array}$ & $70 \mathrm{~m}$ & $200 \mathrm{~m}$ & Meia-encosta \\
\hline RS-S-391: Dodô & $\begin{array}{l}543788- \\
6706316\end{array}$ & $25 \times 4,9 \times 2,5 \mathrm{~m}$ & Leste & $\begin{array}{l}\text { Coletas de superfície e } \\
8 \text { tradagens até } 1,19 \text { m } \\
\text { de profundidade }\end{array}$ & $\begin{array}{c}\text { Lítico da Tradição } \\
\text { Umbu }\end{array}$ & $\begin{array}{l}\text { Campestre } \\
\text { Novo }\end{array}$ & $30 \mathrm{~m}$ & $50 \mathrm{~m}$ & Várzea \\
\hline $\begin{array}{l}\text { RS-S-395: } \\
\text { Deobaldino } \\
\text { Marques }\end{array}$ & $\begin{array}{l}549750- \\
6707650\end{array}$ & $46 \times 17 \times 8,5 \mathrm{~m}$ & Norte & $\begin{array}{c}3 \text { quadrículas e } 9 \\
\text { tradagens até } 1,10 \mathrm{~m} \text { de } \\
\text { profundidade ( } 3 \mathrm{~m}^{2} \\
\text { escavados) }\end{array}$ & $\begin{array}{c}\text { Lítico da Tradição } \\
\text { Umbu }\end{array}$ & Bom Retiro & $50 \mathrm{~m}$ & $1000 \mathrm{~m}$ & Meia-encosta \\
\hline $\begin{array}{l}\text { RS-S-417: Jair de } \\
\text { Oliveira }\end{array}$ & $\begin{array}{l}543045- \\
6709994\end{array}$ & $26 \times 12 \times 6 \mathrm{~m}$ & Nordeste & $\begin{array}{c}30 \text { tradagens até } 1 \mathrm{~m} \text { de } \\
\text { profundidade }\end{array}$ & $\begin{array}{c}\text { Lítico da Tradição } \\
\text { Umbu }\end{array}$ & $\begin{array}{l}\text { Campestre } \\
\text { Novo }\end{array}$ & $54 \mathrm{~m}$ & $200 \mathrm{~m}$ & Várzea \\
\hline $\begin{array}{l}\text { RS-S-418: } \\
\text { Petroglifo }\end{array}$ & $\begin{array}{l}542697- \\
6709593\end{array}$ & $13 \times 3 \times 4 \mathrm{~m}$ & Norte & $\begin{array}{l}6 \text { tradagens até } 85 \mathrm{~cm} \\
\text { de profundidade }\end{array}$ & $\begin{array}{c}\text { Petroglifo }(93 \text { x } 68 \mathrm{~cm}) \\
\text { em bloco possivelmente } \\
\text { relacionado à Tradição } \\
\text { Umbu. }\end{array}$ & $\begin{array}{l}\text { Campestre } \\
\text { Novo }\end{array}$ & $15 \mathrm{~m}$ & $1000 \mathrm{~m}$ & Várzea \\
\hline $\begin{array}{l}\text { RS-S-419: Dirceu } \\
\text { de Oliveira }\end{array}$ & $\begin{array}{l}543328- \\
6710336\end{array}$ & $26 \times 11,5 \times 5 \mathrm{~m}$ & Nordeste & $\begin{array}{l}8 \text { tradagens até } 90 \mathrm{~cm} \\
\text { de profundidade e } 5 \\
\text { quadrículas até } 40 \mathrm{~cm} \\
\text { de profundidade ( } 5 \mathrm{~m}^{2} \\
\text { escavados). }\end{array}$ & $\begin{array}{c}\text { Lítico da Tradição } \\
\text { Umbu }\end{array}$ & $\begin{array}{l}\text { Campestre } \\
\text { Novo }\end{array}$ & $32 \mathrm{~m}$ & $100 \mathrm{~m}$ & Meia-encosta \\
\hline
\end{tabular}


Tabela 2. Abrigos sob Rocha sem Evidências de Ocupação Humana no Alto Vale do Rio dos Sinos

\begin{tabular}{|c|c|c|c|c|c|c|c|}
\hline $\begin{array}{l}\text { Número da } \\
\text { ocorrência }\end{array}$ & $\begin{array}{l}\text { Coordenadas } \\
\text { UTM 22J }\end{array}$ & $\begin{array}{l}\text { Dimensões } \\
\text { (abertura, } \\
\text { profundidade, } \\
\text { altura) }\end{array}$ & Orientação & $\begin{array}{l}\text { Intervenções e } \\
\text { Observações }\end{array}$ & Localidade & Altitude & Topografia \\
\hline Abrigo 1 & $\begin{array}{l}545501- \\
6710288\end{array}$ & $15 \times 2 \times 1,5 \mathrm{~m}$ & Sudoeste & Sem sedimentação & Canto dos Guilhermes & $101 \mathrm{~m}$ & Encosta \\
\hline Abrigo 2 & $\begin{array}{l}545556- \\
6710197\end{array}$ & Não determinada & Sudoeste & $\begin{array}{l}\text { Bloco inclinado de } \\
\text { grandes dimensões, } \\
\text { com baixa } \\
\text { sedimentação }\end{array}$ & Canto dos Guilhermes & $102 \mathrm{~m}$ & Encosta \\
\hline Abrigo 3 & $\begin{array}{l}544123- \\
6710276\end{array}$ & $20 \times 6 \mathrm{~m} \times 3 \mathrm{~m}$ & Sudoeste & & Canto dos Guilhermes & $84 \mathrm{~m}$ & Meia-encosta \\
\hline Abrigo 4 & $\begin{array}{l}544124- \\
6710389\end{array}$ & $15 \times 1 \times 1,8 \mathrm{~m}$ & Noroeste & & Canto dos Guilhermes & $99 \mathrm{~m}$ & Meia-encosta \\
\hline Abrigo 5 & $\begin{array}{l}544155- \\
6710181\end{array}$ & $20 \times 2 \times 3 \mathrm{~m}$ & Sudoeste & & Canto dos Guilhermes & $81 \mathrm{~m}$ & Meia-encosta \\
\hline Abrigo 6 & $\begin{array}{l}544327- \\
6709313\end{array}$ & $70 \times 1,5 \times 3 \mathrm{~m}$ & Leste & Sem sedimentação & Campestre Novo & $93 \mathrm{~m}$ & Meia-encosta \\
\hline Abrigo 7 & $\begin{array}{l}544266- \\
6709312\end{array}$ & $20 \times 2 \times 2 m$ & Noroeste & Sem sedimentação & Campestre Novo & $96 \mathrm{~m}$ & Meia-encosta \\
\hline Abrigo 8 & $\begin{array}{l}542802- \\
6709724\end{array}$ & $28 \times 8 \times 4 m$ & Sudoeste & $\begin{array}{l}11 \text { tradagens até } 90 \mathrm{~cm} \\
\text { de profundidade (piso) }\end{array}$ & Campestre Novo & $19 \mathrm{~m}$ & Meia-encosta \\
\hline Abrigo 9 & $\begin{array}{l}542750- \\
6709676\end{array}$ & $15 \times 3 \times 3 \mathrm{~m}$ & Sudoeste & & Campestre Novo & $20 \mathrm{~m}$ & Meia-encosta \\
\hline Abrigo 10 & $\begin{array}{l}542692- \\
6709677\end{array}$ & Não determinada & Sudoeste & $\begin{array}{l}\text { Sem sedimentação e } \\
\text { sem acesso }\end{array}$ & Campestre Novo & $30 \mathrm{~m}$ & Meia-encosta \\
\hline
\end{tabular}




\begin{tabular}{|c|c|c|c|c|c|c|c|}
\hline Abrigo 11 & $\begin{array}{l}542596- \\
6709617\end{array}$ & $17 \times 8 \times 2,3 \mathrm{~m}$ & Norte & $\begin{array}{l}\text { Alta inclinação e } \\
\text { vertente no interior }\end{array}$ & Campestre Novo & $13 \mathrm{~m}$ & Meia-encosta \\
\hline Abrigo 12 & $\begin{array}{l}543350- \\
6710639\end{array}$ & Não determinada & $\begin{array}{l}\text { Oeste e } \\
\text { leste }\end{array}$ & $\begin{array}{l}\text { Meseta de arenito com } \\
\text { aba de } 2 \text { m de, } \\
\text { profundidade em } \\
\text { média, circundando } \\
\text { toda a formação }\end{array}$ & Campestre Novo & $58 \mathrm{~m}$ & Meia-encosta \\
\hline Abrigo 13 & $\begin{array}{l}543346- \\
6710635\end{array}$ & $10 \times 4 \times 5 m$ & Sudeste & $\begin{array}{l}\text { Sem acesso. Situa-se a } \\
\text { pelo menos } 5 \text { m acima } \\
\text { do nível do solo }\end{array}$ & Campestre Novo & $63 \mathrm{~m}$ & Meia-encosta \\
\hline Abrigo 14 & $\begin{array}{l}543123- \\
6710669\end{array}$ & Não determinada & Nordeste & Sem sedimentação & Campestre Novo & $58 \mathrm{~m}$ & Meia-encosta \\
\hline Abrigo 15 & $\begin{array}{l}542630- \\
6709273\end{array}$ & Não determinada & Sudoeste & Sem sedimentação & Campestre Novo & $34 \mathrm{~m}$ & Meia-encosta \\
\hline Abrigo 16 & $\begin{array}{l}542639- \\
6709276\end{array}$ & Não determinada & Sul & Baixa sedimentação & Campestre Novo & $42 \mathrm{~m}$ & Meia-encosta \\
\hline Abrigo 17 & $\begin{array}{l}542727- \\
6709353\end{array}$ & $32 \times 4 \times 2,5 \mathrm{~m}$ & Sudeste & $\begin{array}{l}7 \text { tradagens até } 70 \mathrm{~cm} \\
\text { de profundidade (piso) }\end{array}$ & Campestre Novo & $42 \mathrm{~m}$ & Meia-encosta \\
\hline Abrigo 18 & $\begin{array}{l}541300- \\
6709300\end{array}$ & Não determinada & Sudeste & $\begin{array}{c}\text { Em seu interior há } \\
\text { colméia de abelhas } \\
\text { nativas com } 2 \text { m de } \\
\text { altura impedindo o } \\
\text { acesso. Pode } \\
\text { corresponder ao sítio } \\
\text { RS-S-336: Campestre } \\
2\end{array}$ & Campestre Novo & $40 \mathrm{~m}$ & Meia-encosta \\
\hline Abrigo 19 & $\begin{array}{l}546234- \\
6707086\end{array}$ & $28 \times 9 \times 5 \mathrm{~m}$ & Sudeste & $\begin{array}{l}1 \text { tradagem até } 20 \mathrm{~cm} \\
\text { de profundidade (piso) }\end{array}$ & Monjolo & $150 \mathrm{~m}$ & Meia-encosta \\
\hline Abrigo 20 & $\begin{array}{c}5461506706 \\
700\end{array}$ & $10 \times 2,5 \times 1,5 \mathrm{~m}$ & Nordeste & Sem sedimentação & Monjolo & $250 \mathrm{~m}$ & Meia-encosta \\
\hline Abrigo 21 & $\begin{array}{l}545174- \\
6706262\end{array}$ & $12 \times 6 \times 4$ & Oeste & & Monjolo & $40 \mathrm{~m}$ & Várzea \\
\hline Abrigo 22 & $\begin{array}{c}5436506708 \\
400\end{array}$ & $10 \times 2,5 \times 2 \mathrm{~m}$ & Oeste & $\begin{array}{l}\text { Sem sedimentação, } \\
\text { apresentando vertente } \\
\text { em seu interior }\end{array}$ & Campestre Novo & $50 \mathrm{~m}$ & Meia-encosta \\
\hline Abrigo 23 & $\begin{array}{l}545100- \\
6704250\end{array}$ & $15 \times 3 \times 2 \mathrm{~m}$ & Norte & Sem sedimentação & Guarda Velha & $50 \mathrm{~m}$ & Meia-encosta \\
\hline
\end{tabular}




\begin{tabular}{|c|c|c|c|c|c|c|c|}
\hline Abrigo 24 & $\begin{array}{l}542945- \\
6707000\end{array}$ & $15 \times 5 \times 5 \mathrm{~m}$ & Leste & $\begin{array}{l}\text { Baixa sedimentação, } \\
\text { apresentando vertente } \\
\text { em seu interior }\end{array}$ & Campestre & $50 \mathrm{~m}$ & Meia-encosta \\
\hline Abrigo 25 & $\begin{array}{l}541738- \\
6707500\end{array}$ & $45 \times 6,5 \times 8 \mathrm{~m}$ & Oeste & $\begin{array}{l}\text { Sem sedimentação. } \\
\text { Situa-se no mesmo } \\
\text { morros testemunho do } \\
\text { sítio RS-S-265: } \\
\text { Campestre 1, em } \\
\text { posição mais elevada } \\
\text { na encosta. }\end{array}$ & Campestre & $90 \mathrm{~m}$ & Meia-encosta \\
\hline Abrigo 26 & $\begin{array}{l}542295- \\
6706313\end{array}$ & $24 \times 7 \times 5,4 \mathrm{~m}$ & Sudeste & $\begin{array}{l}\text { Situa-se no mesmo } \\
\text { morro testemunho do } \\
\text { sítio RS-S-327: } \\
\text { Sangão, em posição } \\
\text { mais baixa na encosta, } \\
\text { sendo afetado pelas } \\
\text { cheias do rio. }\end{array}$ & Campestre & $45 \mathrm{~m}$ & Várzea \\
\hline Abrigo 27 & $\begin{array}{l}552449- \\
6706249\end{array}$ & $4 \times 2 \times 1,5 \mathrm{~m}$ & Sul & Sem sedimentação & Passo da Forquilha & $71 \mathrm{~m}$ & Meia-encosta \\
\hline Abrigo 28 & $\begin{array}{l}552683- \\
6707519\end{array}$ & $10 \times 2 \times 1,5 \mathrm{~m}$ & Nordeste & & Evaristo & $100 \mathrm{~m}$ & Meia-encosta \\
\hline Abrigo 29 & $\begin{array}{l}552663- \\
6707166\end{array}$ & $15 \times 2 \times 2 \mathrm{~m}$ & Nordeste & $\begin{array}{l}\text { Sem sedimentação. } \\
\text { Situado no topo de } \\
\text { uma encosta íngreme, } \\
\text { a } 147 \text { m de altitude. }\end{array}$ & Evaristo & $147 \mathrm{~m}$ & Meia-encosta \\
\hline Abrigo 30 & $\begin{array}{l}551383- \\
6704300\end{array}$ & $20 \times 3 \times 2 \mathrm{~m}$ & Norte & & Passo da Forquilha & $100 \mathrm{~m}$ & Meia-encosta \\
\hline Abrigo 31 & $\begin{array}{l}551088- \\
6709253\end{array}$ & $15 \times 6 \times 2,5 \mathrm{~m}$ & Sudoeste & & Pinheiros & $100 \mathrm{~m}$ & Meia-encosta \\
\hline Abrigo 32 & $\begin{array}{l}549343- \\
6708941\end{array}$ & $9 \times 1,5 \times 2 \mathrm{~m}$ & Sudeste & $\begin{array}{c}\text { Apresenta vertente em } \\
\text { seu interior }\end{array}$ & Bom Retiro & $50 \mathrm{~m}$ & Meia-encosta \\
\hline
\end{tabular}


Tabela 3.1. Afiliação Cultural e Cronologia de Sítios Líticos a Céu Aberto na Região Nordeste do Estado

\begin{tabular}{|c|c|c|c|c|c|c|c|c|}
\hline Bacia Hidrográfica & Umbu & Humaitá & Indefinida & $\begin{array}{c}\text { Umbu } \\
\text { com petroglifos }\end{array}$ & $\begin{array}{l}\text { Petroglifos } \\
\text { indefinida }\end{array}$ & $\begin{array}{l}\text { Umbu e } \\
\text { Humaitá }\end{array}$ & $\begin{array}{c}\text { Com cerâmica Guarani } \\
\text { e/ou Taquara }\end{array}$ & $\begin{array}{l}\text { Datações } \\
\text { (AP) }\end{array}$ \\
\hline Vacacaí & 2 & 0 & 1 & 0 & 0 & 0 & 0 & - \\
\hline Alto Jacuí & 9 & 23 & 3 & 1 & 3 & 2 & 6 & - \\
\hline Taquari e Antas & 9 & 3 & 3 & 1 & 0 & 0 & 0 & $6620+175$ (SI 933) \\
\hline Caí & 4 & 0 & 4 & 0 & 1 & 0 & 1 & - \\
\hline Sinos & 9 & 10 & 8 & 0 & 1 & 0 & 0 & $\begin{array}{c}575+80 \\
\text { (SI 804) }\end{array}$ \\
\hline Lagoas Litorâneas & 2 & 3 & 3 & 0 & 0 & 0 & 1 & - \\
\hline Total & 52 & 53 & 27 & 2 & 6 & 16 & 23 & \\
\hline
\end{tabular}


Tabela 3.2. Afiliação Cultural e Cronologia de Sítios Líticos em Abrigos sob Rocha na Região Nordeste do Estado

\begin{tabular}{|c|c|c|c|c|c|c|c|}
\hline Bacia Hidrográfica & Umbu & Humaitá & Indefinida & $\begin{array}{c}\text { Umbu } \\
\text { com petroglifos }\end{array}$ & $\begin{array}{l}\text { Petroglifos } \\
\text { indefinida }\end{array}$ & $\begin{array}{c}\text { Com cerâmica } \\
\text { Guarani e/ou } \\
\text { Taquara }\end{array}$ & $\begin{array}{l}\text { Datações } \\
\text { (AP) }\end{array}$ \\
\hline Alto Jacuí & 0 & 0 & 0 & 3 & 0 & 0 & $\begin{array}{c}2945+85 \text { (SI 1001) } \\
2190+80 \text { (BA 129549) } \\
1165+35 \text { (SI 1000) } \\
905+95 \text { (SI 1196) }\end{array}$ \\
\hline Baixo Jacuí e Pardo & 0 & 0 & 5 & 0 & 0 & 1 & - \\
\hline Taquari e Antas & 4 & 0 & 2 & 1 & 3 & 2 & $\begin{array}{l}9430+360 \text { (BA 44739) } \\
8290+130 \text { (BA 32183) } \\
8020+150 \text { (BA 33458) } \\
7250+350 \text { (BA 44740) }\end{array}$ \\
\hline Caí & 6 & 2 & 0 & 4 & 0 & 2 & $\begin{array}{c}5655+140 \text { (SI 1199) } \\
745+115 \text { (SI 1198) } \\
630+205 \text { (SI 1201) }\end{array}$ \\
\hline Sinos & 15 & 0 & 5 & 1 & 0 & 0 & $\begin{array}{c}8800 \pm 40 \text { (BA 160845) } \\
7390 \pm 40 \text { (BA 154353) } \\
7330 \pm 40 \text { (BA 165626) } \\
5230 \pm 40 \text { (BA 165625) } \\
4710 \pm 40 \text { (BA 154352) } \\
4610 \pm 140 \text { (BA 160847) } \\
4160 \pm 100 \text { (BA 154351) } \\
3940 \pm 40 \text { (BA 160849) } \\
3730 \pm 60 \text { (BA 160846) } \\
1740+65 \text { (SI 2344) } \\
920 \pm 40 \text { (BA 154354) } \\
520 \pm 70 \text { (BA 165623) } \\
440 \pm 90 \text { (BA 165621) }\end{array}$ \\
\hline Lagoas Litorâneas & 1 & 0 & 0 & 0 & 0 & 0 & $\begin{array}{l}5950+190(\text { SI 234) } \\
5680+240 \text { (SI 235) } \\
4280+180(\text { SI 233) }\end{array}$ \\
\hline Total & 26 & 2 & 12 & 9 & 3 & 5 & - \\
\hline
\end{tabular}




\section{Capítulo 4}

\section{Variabilidade Intra-sítio e Inter-sítios em um Sistema de Assentamento Caçador Coletor: Propostas Interpretativas para o Alto Vale do Rio dos Sinos}

\subsection{Estudos de Variabilidade Intra-sítio e suas Contribuições para a Interpretação de Áreas de Atividade em Sítios de Caçadores Coletores}

Analisando o desenvolvimento das pesquisas sobre variabilidade intra-sítio, Kroll e Price (1991:1-3) destacam que, embora esta seja uma preocupação presente na arqueologia desde finais do século XIX, foi somente a partir da década de 1960 que esforços significativos passaram a ser realizados para a interpretação deste tipo de dado, podendo-se dividir o desenvolvimento das pesquisas em três distintos estágios. Um primeiro momento é marcado pela realização de mapas de sítio utilizados para identificar a ausência de distúrbios naturais e a presença de conjuntos de estruturas e de padrões de distribuição de artefatos, sendo as concentrações horizontais de evidências identificadas como solos habitacionais (living floors). Exemplos de trabalhos realizados sob esta orientação seriam as monografias de Graham Clark, para o sítio Mesolítico de Star Carr, e de Mary Leakey, para os sítios do Paleolítico Inferior de Olduvai.

Um segundo estágio das pesquisas sobre variabilidade intra-sítio estende-se entre o início da década de 1960 e meados da década de 1970, divergindo em três direções. Uma primeira linha de pesquisa relaciona-se a análise visual dos sítios arqueológicos através da realização de mapas compostos por múltiplos planos de sobreposição, utilizados para análise de determinadas associações entre conjuntos de artefatos e tipos de estruturas, complementados por planos de remontagem de artefatos e fragmentos ósseos. O estudo do sítio do Paleolítico Superior de Pincevent, por LeroiGourhan e colaboradores, estabeleceu um padrão a partir do qual se baseou a maioria dos trabalhos subseqüentes que obedecem a esta orientação ${ }^{1}$.

\footnotetext{
${ }^{1}$ Uma revisão bibliográfica abrangente sobre escavações de sítios do Paleolítico Médio e Superior que seguem esta orientação de pesquisa pode ser encontrada em Dibble e colaboradores (1998).
} 
Um enfoque alternativo desenvolveu-se paralelamente, tendo como objetivo buscar meios para a interpretação da variabilidade dos conjuntos líticos Musterienses, através da utilização de técnicas quantitativas derivadas de modelos estatísticos da ecologia e da geografia. A maior parte destes trabalhos centrou-se na identificação de padrões não-aliatórios nas associações entre as categorias de artefatos e vestígios arqueofaunísticos, com o objetivo de definir áreas de atividade e kits de artefatos, sendo os trabalhos de Lewis e Sally Binford pioneiros nesta área² (Binford, 1972b, [1973] 1983g; Binford \& Binford [1966] 1983; Binford, 1968).

Os resultados parciais e as lacunas demonstradas por ambos enfoques deram origem, em meados da década de 1970, a uma terceira vertente de estudos voltada à compreensão de como os processos de formação do registro arqueológico afetam a variabilidade intra-sítio. Buscando interpretar as configurações espaciais observadas, diferentes áreas como a etnoarqueologia, a arqueologia experimental, a geoarqueologia e a tafonomia passam a atuar no sentido de definir como os agentes culturais e naturais contribuem para a formação do registro arqueológico. Exemplos desta corrente podem ser encontrados nos estudos etnoarqueológicos de Binford ${ }^{3}$ e nos trabalhos de Schiffer relacionados aos processos de formação do registro arqueológico (Schiffer, [1972] 1995a, [1975] 1995b, [1976] 1995c, [1985] 1995d, [1987] 1996). Segundo as palavras deste autor,

Uma prioridade no trabalho arqueológico é identificar a natureza dos processos de formação cultural e nãocultural que criam um dado depósito ou conjunto de depósitos. Para atingir isto, devemos considerar os artefatos como meramente partículas peculiares numa matriz sedimentar que poderiam ter sido sujeitadas por processos culturais e ambientais de formação a uma variedade de alterações mecânicas e químicas. Ao registrar e analisar estes efeitos sistemáticos (...) pode-se apreciar os agentes do passado responsáveis pelos arranjos complexos de materiais culturais e ambientais (depósitos) observados hoje. O conhecimento obtido da etnoarqueologia, da arqueologia experimental, da tafonomia e da geoarqueologia contribui de forma importante para o esforço de compreender os distintos sedimentos encontrados pelo arqueólogo (Schiffer, [1987] 1996: 302).

\footnotetext{
${ }^{2}$ Ver também para exemplos de aplicação destas metodologias Hietala (1984), Hodder e Orton ([1976] 1990), Jonhson (1984) e Munday (1984), entre outros.

${ }^{3}$ Para uma revisão bibliográfica dos trabalhos etnoarqueológicos de Binford ver Dias (2000a).
} 
Kroll e Price (1991: 3) destacam que a orientação dos estudos de variabilidade intra-sítio atualmente representa a convergência destes três distintos caminhos, derivando em uma diversidade de enfoques. Estudos experimentais e geoarqueológicos desenvolvidos nos últimos anos têm contribuído significativamente para a revisão crítica da noção de contextos deposicionais anteriormente interpretados a priori como living floors (Dibble et al 1998; Gifford-Gonzalez et al, 1985; Gregg et al, 1991; Schiffer [1985] 1995d, [1987] 1996; Villa, 1982). A associação de estudos estatísticos de conjuntos artefatuais com aspectos dos processos de formação de sítios, derivados de pesquisas etnoarqueológicas, tem apresentado resultados interessantes na interpretação de conjuntos líticos relacionados a contextos deposicionais marcados por palimpsestos arqueológicos (Carr, 1984, 1987, 1991; Hivernel \& Hooder, 1984; Spurling \& Hayden, 1984; Whallon, 1984). As pesquisas etnoarqueológicas sobre a relação entre variabilidade intra-sítio e padrões de descarte para sítios caçadores coletores tem contribuído, por sua vez, para a geração de modelos arqueológicos voltados à interpretação de aspectos da organização tecnológica refletidos nas indústrias líticas (Chatters, 1987; Keeley, 1991; Shott, 1986, 1989b; Stevenson, 1985, 1991).

Esta linha de pesquisa também influenciou o desenvolvimento de modelos interpretativos derivados de estudos tafonômicos e zooarqueológicos sobre conjuntos arqueofaunísticos para a interpretação de funcionalidade de sítio de caçadores coletores (Bartram et al, 1991; Binford, 1978, 1981; Bunn et al 1988; Hudson, 1993; Monahan 1998; O’Connel, Hawkes \& Jones, 1988, 1990, 1992; Yellen, 1977b, 1991a, 1991b). Por fim, estudos etnoarqueológicos de sociedades caçadoras coletoras voltados à compreensão dos processos culturais que atuam na formação dos registros arqueológicos têm contribuído para enriquecer os parâmetros interpretativos quanto à variabilidade artefatual intra-sítio, destacando-se estudos sobre relações de gênero (O’Connel et al, 1991), relações de parentesco e reciprocidade (Gargett \& Hayden, 1991) e relações entre sistema de mobilidade e estrutura de sítios habitacionais (Binford, 1978, [1978] 1983c, 1991a, 1991b; Binford \& O’Connel, [1984] 1989; Gamble \& Boismier, 1991; Gould, 1971, 1978, 1980; Gould \& Yellen, 1987, 1991; Kent, 1991; O’Connel, 1987; Yellen, 1977a; ver também David \& Kramer, 2001).

Embora a literatura etnoarqueológica sobre variabilidade intra-sítio para grupos caçadores coletores seja atualmente extensa, a maioria destes estudos está voltada à caracterização de contextos a céu aberto. Walthall (1998: 225) destaca que existem 
registros etnográficos sobre a utilização de abrigos sob rocha por grupos caçadores coletores no Ártico, no leste e sudoeste da África, no sudeste da Ásia, na Índia central e do sul, na Papua Nova Guiné e no oeste da Austrália. Porém, raros são os estudos etnoarqueológicos realizados até o presente que se centraram na caracterização das formas de ocupação específicas a este tipo de contexto ${ }^{4}$.

Contando com estes registros limitados, Galanidou (2000) analisou os dados etnoarqueológicos disponíveis quanto à ocupação de 35 abrigos sob rocha, por distintas culturas, com o objetivo de compreender as causas da variabilidade espacial identificada nos estudos arqueológicos deste tipo de sítio $^{5}$. Em termos gerais, a autora observou que não há um modelo intercultural uniforme na distribuição das estruturas e áreas de atividades neste tipo de sítio, pois cada grupo usa suas próprias habilidades técnicas e preferências materiais para criar condições habitacionais que lhes sejam familiares. Portanto, distintos grupos adaptam-se às restrições espaciais dos abrigos sob rocha de acordo com seus próprios modelos conceituais e simbólicos quanto à organização do espaço $^{6}$. Porém, a autora observa que os abrigos são utilizados para propósitos semelhantes por grupos que compartilham o mesmo tipo de habitat e têm modos similares de subsistência. Desta forma, as ocupações em abrigos sob rocha como áreas domésticas assemelha-se espacialmente aos acampamentos a céu aberto ${ }^{7}$ (Galanidou, 2000: 270-273).

\footnotetext{
${ }^{4}$ Alguns exemplos de estudos etnoarqueológicos de áreas de atividades em abrigos sob rocha podem ser encontrados em Binford ([1978] 1983c), Gorecki (1991), Nicholson e Cane (1991) e Parkington e Mills (1991).

${ }^{5}$ Dos sítios em abrigo sob rocha analisados pela autora, 20 estão associados a grupos de caçadores coletores da Tanzânia, Namíbia, África do Sul e Oeste da Austrália e 15 foram utilizados como acampamentos temporários por grupos horticultores que realizam expedições de caça nas florestas da Indonésia e da Papua Nova Guiné (Galanidou, 2000: 244).

${ }^{6}$ Os estudos realizados na Papua Nova Guiné por Goreki entre três distintas populações horticultoras que utilizam abrigos sobre rocha para acampamentos temporários durante expedições de caça complementam as idéias de Galanidou. Segundo o autor "a compreensão do espaço disponível e o uso potencial varia não somente de um grupo para o outro, mas também de acordo com a duração da ocupação, a presença e o gênero dos visitantes, o tamanho do grupo e, acima de tudo, com a topografia e a vegetação que circundam cada sítio. Não é, portanto, possível falar de duas histórias idênticas para o uso destes abrigos” (Gorecki, 1991: 240).

${ }^{7}$ A principal diferença observada nas ocupações em abrigos sob rocha entre grupos de caçadores coletores e horticultores centra-se no maior investimento por parte destes últimos na construção de estruturas habitacionais (Galanidou, 2000: 271).
} 
A autora destaca que o tamanho destes nichos naturais não afeta nem o tipo, nem a duração das ocupações ${ }^{8}$. Por outro lado, as fogueiras desempenham um papel central na ocupação, domesticando a cavidade natural e oferecendo um ponto focal em torno do qual as pessoas agem e interagem, sendo o elemento estrutural da organização espacial e o meio para a reprodução de formas de uso do espaço familiares aos ocupantes do abrigo. O tamanho do abrigo também não determina o número de fogueiras, estando sua freqüência relacionada à atitude específica de cada grupo em relação à reutilização de estruturas antigas, ao caráter das atividades que se desenvolvem em seu entorno e à composição social dos ocupantes do abrigo. Portanto, o tipo de fogueira escolhido, sua localização e possível reutilização são três variáveis importantes para o estudo de estruturas de sítios em caso de palimpsestos arqueológicos.

Quanto à questão da análise etnoarqueológica de áreas de atividades em abrigos sob rocha, Galanidou destaca que, na ausência de seus ocupantes, torna-se difícil perceber estruturas que foram ocupadas contemporaneamente ou observar fronteiras claras entre distintas ocupações no tempo, uma vez que os vestígios das ocupações mais recentes acabam incorporando os detritos de ocupações prévias ${ }^{9}$. Em meio a este palimpsesto percebe-se apenas redundâncias nos padrões estruturais das ocupações que podem ou não corresponder a áreas de atividade. Contudo, as evidências apontam que abrigos sob rocha utilizados intermitentemente pelos mesmos grupos tendem a conter conjuntos artefatuais e estruturais (site forniture) muito similares. Portanto, a estrutura do sítio pode, como outros aspectos da cultura material, ter uma dupla função. Durante sua ocupação o sítio expressa as idéias do grupo sobre a organização espacial, ao garantir familiaridade e conforto. Suas características, por sua vez, são também um meio de comunicação não verbal que transmite uma mensagem sobre a identidade cultural e os direitos de acesso aos abrigos, entendidos como recursos da área de

8 “O número de fogueiras utilizadas durante cada episódio de ocupação é um elemento culturalmente definido por habitação e só secundariamente é uma função do tamanho do grupo ou do tipo de atividades que ocorrem no sítio” (Galanidou, 2000: 248).

${ }^{9}$ Gorecki destaca em seus estudos etnoarqueológicos de ocupação de abrigos que os materiais deixados em superfície nunca derivam de uma única ocupação, representando a acumulação de detritos de inúmeras visitas de grupos de vários tamanhos, cuja permanência se entende por períodos variados. Alguns abrigos foram utilizados apenas uma vez, enquanto outros foram utilizados várias vezes. Por outro lado, os solos ocupacionais nunca são estáticos, adquirindo formas variadas, derivadas de distintas atividades que geram diferentes concentrações. Eventualmente estes solos ocupacionais podem ser cobertos por sedimentos de acordo com as condições geomorfológicas de cada abrigo, porém é mais comum que os pisos ocupacionais "antigos” acabem por misturarem-se com os detritos das ocupações recentes (Gorecki, 1991: 255). 
domínio, cuja exploração é negociada e mediada pelas relações sociais entre distintos grupos locais ${ }^{10}$.

A autora conclui que a estrutura espacial dos sítios em abrigos sob rocha e cavernas serviria aos mesmos propósitos que o estilo na cultura material: portar informações sobre a identidade do grupo para outros grupos. Portanto, em um estudo arqueológico deste tipo de sítio não se deve focar a análise da variabilidade intra-sítio a um momento individual na ocupação, mas buscar padrões redundantes na estrutura espacial que abranjam mais de um evento ocupacional. Uma vez que os traços gerais da estrutura espacial de um dado sítio sejam identificados, deve-se buscar estabelecer como estes padrões estão relacionados ao seu papel no sistema de assentamento do qual faz parte, através de análises comparativas com os padrões espaciais observados em outros sítios da mesma área de implantação.

Quanto às questões especificamente relacionadas aos padrões de descarte, a autora observa que há uma grande diversidade de comportamento em função dos hábitos de consumo, crenças religiosas, restrições e tabus relativos ao que deve ser descartado e onde este descarte deve ocorrer, correspondendo esta variação também a um índice de identidade cultural.

Observamos que os padrões de adaptação humana às restrições dos abrigos sob rocha não são universais, uma vez que a percepção do espaço e os sentimentos sobre conforto e impureza são culturalmente específicos. Os diferentes hábitos de consumo e a deposição de refugo de diferentes grupos culturais dão origem a sítios com conteúdos e densidade variáveis. (...) [Contudo] sítios arqueológicos utilizados pelo mesmo grupo cultural devem exibir traços idênticos, gerados por padrões de descarte específicos àquela cultura (Galanidou, 2000: 253).

Em termos arqueológicos, porém, podem ocorrer variações nos padrões de descarte apresentados por um mesmo grupo cultural em função do papel específico que

\footnotetext{
${ }^{10}$ Para exemplificar esta questão Galanidou destaca os grupos da Papua Nova Guiné, estudados por Gorecki. Os abrigos situados próximos às fronteiras tribais são freqüentemente inspecionados a fim de detectar se outro grupo fez uso deles, sendo este comportamento entendido como intrusão ou "roubo" de um recurso. Na ausência dos "donos por direito" do sítio, os artefatos e estruturas que neles permanecem claramente anunciam sua identidade e seus direitos sobre os territórios ao seu redor (Galanidou, 2000: 268).
} 
o sítio em abrigo representa no sistema de assentamento como um todo ${ }^{11}$. A autora conclui que o único modo viável de entender como os padrões de descarte afetam a variabilidade intra-sítio se dá através da adoção de um enfoque contextual, que se baseie em uma perspectiva inter-sítios para formular explicações sobre as variações espaciais intra-sítio (Galanidou, 2000: 255). Segundo Galanidou:

Devemos também começar a tratar os padrões redundantes no uso do espaço de abrigos sob rocha $e$ cavernas como um aspecto da cultura material que pode nos dizer muito sobre a identidade cultural e social [dos seus ocupantes] nunca esquecendo que a comparação inter-sítios é vital para nossa compreensão da variação espacial intra-sítio (Galanidou, 2000: 273).

Os estudos etnoarqueológicos disponíveis quanto às características estruturais e aos processos de formação de sítios relacionados a sistemas de assentamentos de caçadores coletores em floresta tropical estão relacionados a contextos a céu aberto, destacando-se os trabalhos de Politis (1996a, 1996c), para os Nukak da Colômbia, e de Borrero e Yacobaccio (1989) e Jones (1993), para os Aché do Paraguai. No entanto, sugerimos que para a construção de modelos interpretativos quanto às ocupações de abrigos sob rocha relacionados à Tradição Umbu pode-se também utilizar como subsídio os dados etnoarqueológicos apresentados por estes autores, tomando como premissa as conclusões de Galanidou (2000), segundo a qual as ocupações em abrigos sob rocha como áreas domésticas assemelha-se espacialmente aos acampamentos a céu aberto.

A base da arquitetura dos assentamentos Nukak é representada por unidades domésticas que se agregam para formar os acampamentos residenciais, sendo cada uma destas ocupadas por uma família nuclear, cujas atividades organizam-se em torno de um

\footnotetext{
${ }^{11}$ Este aspecto é exemplificado pelo trabalho de Nicholson e Cane ao compararem as ocupações em abrigo sob rocha com os sítios a céu aberto entre os Aborígenes que ocupam o deserto oeste australiano. Ao todo foram comparadas as estruturas espaciais de 15 acampamentos a céu aberto e 11 abrigos sob rocha. Dentre estes últimos, 5 foram utilizados como acampamentos temporários durante a estação seca e 6 foram utilizados para atividades cerimoniais, apresentando associação com pinturas rupestres. Em função destas diferenças funcionais no sistema de assentamento, os abrigos apresentaram distinções nos conjuntos de vestígios, padrões de descarte e presença de estruturas, apresentando os sítios habitacionais características estruturais semelhantes aos acampamentos a céu aberto, embora a maior parte das áreas de atividade domésticas tenha se concentrado junto a sua parte exterior (Nicholson \& Cane, 1991: 345).
} 
fogão central ${ }^{12}$. As unidades domésticas possuem uma dimensão espacial, correspondendo ao lugar onde se dorme, se cozinha e se realizam distintas tarefas. Porém, possui também uma dimensão familiar e social, onde se estrutura a aprendizagem e a socialização dos indivíduos (Politis, 1996a: 87). Este padrão igualmente é observado entre os Aché ${ }^{13}$ para os acampamentos transitórios de forragem em meio à floresta (Borrero \& Yacobaccio, 1989: 10-12; Jones, 1993: 102-104).

Em geral, para os Nukak observa-se entre duas a cinco unidades domésticas por acampamento residencial, sendo sua dimensão proporcional ao número de ocupantes e sua forma variável de acordo com o ciclo anual de chuvas ${ }^{14}$. No inverno a média de superfície ocupada por pessoa é de 3,89 $\mathrm{m}^{2}$ e no verão é um pouco superior, com 4,46 $\mathrm{m}^{2}$. Observa-se que quando ocorre a junção de dois grupos a média de superfície por pessoa diminui, chegando a 2,61 $\mathrm{m}^{2}$, indicando uma tendência de que em áreas de floresta tropical as unidades domésticas tendem a estar próximas, caracterizando-se por acampamentos compactos (Politis, 1996a: 124-129). As pequenas dimensões dos acampamentos de caçadores coletores em floresta tropical também são registradas para os Aché, com média de 22,6 $\mathrm{m}^{2}$ de área total, comportando entre 5 a 6 fogueiras associadas às unidades domésticas, com uma média em torno de $2 \mathrm{~m}^{2}$ por adulto (Jones, 1993: 102).

Embora os acampamentos residenciais Nukak apresentem as mesmas dimensões e estrutura arquitetônica ao longo do ciclo anual ${ }^{15}$, as diferenças relacionadas à presença

\footnotetext{
12 As unidades domésticas podem comportar ainda um ou dois fogões laterais quando da presença de esposas secundárias ou parentes não casados, como jovens solteiros e viúvas com seus filhos. O autor também se refere a outros tipos de sítios não residenciais que fazem parte do sistema de assentamento Nukak, como os acampamentos transitórios para pernoite quando de viagens rápidas com fins específicos, os refúgios periféricos aos acampamentos residenciais, ocupados para pernoite por visitantes jovens, as construções retangulares associadas às áreas de cultivo e os acampamentos das crianças que correspondem a réplicas do acampamento dos adultos, utilizados para fins lúdicos (Politis, 1996a: 118124).

${ }^{13}$ Estas expedições de forragem são realizadas regularmente na região em torno da sede da Missão Católica onde o grupo está assentado a maior parte do tempo, durando em média entre uma semana e um mês. São realizadas por grupos de 4 a 7 famílias nucleares, comportando ao todo entre 20 a 35 pessoas. Os acampamentos são ocupados, em média, por apenas um dia, sendo a permanência mais prolongada na estação de chuvas (Jones, 1993: 102).

${ }^{14}$ Entre os Nukak as bases residenciais quase nunca são re-ocupadas, uma vez que quando abandonadas se transformam em áreas de alta concentração de plantas úteis e sua limpeza para novas ocupações implicaria na destruição do potencial produtivo do local. Igualmente, se neste está sepultado algum membro do grupo, os Nukak acreditam que seu espírito permanece nas imediações, podendo trazer prejuízos durante a noite. Também há a crença de que a ocupação de acampamentos abandonados de outros grupos pode trazer enfermidades (Politis, 1996a: 117).

${ }^{15}$ A estrutura dos acampamentos se caracteriza pela utilização de árvores pré-existentes às quais são anexadas, por amarras, um sistema de postes e travessões centrais e secundários que suportam as redes
} 
de cobertura na estação chuvosa se refletem nos padrões de distribuição das unidades domésticas e também nos sistemas de descarte (Politis, 1996a: 95-118, 1996c: 430-432). Durante o inverno a forma geral do acampamento é aproximadamente poligonal, com a parte frontal das unidades domésticas voltadas para um espaço central, utilizado com diversos propósitos nas atividades cotidianas e de socialização intra e inter-bandos, associadas ao universo ritual do grupo. O padrão observado durante a estação seca é irregular, sendo impreciso os limites entre as áreas habitacionais que se distribuem em função dos suportes naturais disponíveis para as redes, não havendo uma área central definida.

Independente da estação, as áreas de descarte nos acampamentos Nukak se geram principalmente em torno dos fogões das unidades habitacionais e nos locais de entrada e saída da clareira onde está o acampamento. Observa-se ainda que no inverno há uma tendência ao acúmulo de resíduos atrás da área de dormitório, junto à parede de folhas que limita o acampamento. A área em torno dos fogões caracteriza-se por um padrão de descarte primário, acumulando os resíduos das várias atividades realizadas nas redes que se distribuem ao seu redor, como preparação e consumo de alimentos e fabricação de instrumentos ${ }^{16}$. Em geral a limpeza da área doméstica ocorre periodicamente a cada 3 a 6 dias, em função da quantidade de resíduos e da expectativa de permanência no acampamento, sendo recolhidos os dejetos maiores que são descartados nos depósitos secundários situados junto aos acessos. Os dejetos menores, em geral, são deslocados para uma segunda área de depósito secundário, situada na periferia da área de dormitório. As áreas de depósito secundário no interior da habitação apresentam-se de forma mais esparsa, gerando acúmulos de 6 x $1 \mathrm{~m}$, com 10 a $15 \mathrm{~cm}$ de altura. Os depósitos secundários junto aos acessos do acampamento apresentam, por sua vez, uma estrutura mais formal que aumenta de tamanho regularmente ao longo da ocupação, podendo atingir até $2 \mathrm{~m}$ de diâmetro e $1 \mathrm{~m}$ de altura.

das distintas áreas domésticas. No inverno, toda a área do acampamento é coberta por folhas para proteção contra as chuvas (Politis, 1996a: 87-95).

${ }^{16}$ Estas áreas de deposição primária em torno da fogueira apresentam correspondência com os dados registrados por Binford ([1978] 1983c) para os Nunamiut, estando associados a dois atos manipulativos: deposição acidental de um elemento que se desprende de um item que está na mão de alguém (dropping zone), como por exemplo as lascas de um osso quebrado para extrair tutano; e deposição intencional do que resta deste item depois de completada a atividade, sendo este jogando na periferia da fogueira (tossing zone), como por exemplo as terminações articulares de um osso quebrado para extração de tutano. Este modelo foi utilizado por Stevenson $(1985,1991)$ para interpretar padrões de dispersão de resíduos de lascamento na identificação de áreas de atividade doméstica associada à deposição primária para sítios arqueológicos de caçadores coletores. 
Durante a estação seca, os padrões de produção, distribuição e acumulação de lixo apresentam-se distintos devido à estrutura mais irregular do acampamento, no qual as paredes e o teto de folhas estão ausentes. Desta forma, ocorre uma zona de depósito primário em torno das fogueiras e áreas de dormitório, que passam a se dispersar no perímetro do acampamento. Também se forma uma zona de depósito secundário junto aos acessos, porém sua densidade é menor se comparada a dos acampamentos de inverno, apresentando limites mais difusos, tendo em vista o menor tempo de permanência. Um padrão similar de descarte foi observado por Jones (1993: 104) e Borrero e Yacobaccio (1989: 16-20) para os acampamentos de curta duração associados às expedições Aché para a caça e a coleta, apresentando-se os vestígios descartados em torno das fogueiras em contexto primário já que os acampamentos não sofrem nenhum tipo de limpeza antes do abandono.

Destaca-se que os acampamentos Nukak nunca são abandonados com o piso limpo, ou seja, a tendência é encontrar-se depósitos primários junto às áreas domésticas quando do abandono do sítio ${ }^{17}$. O pisoteio ocasiona nestas áreas um deslocamento horizontal limitado dos resíduos de atividades, não gerando o enterramento das peças em função do tipo de solo, compacto e argiloso. Igualmente, alguns objetos ou matérias primas são deixados no acampamento para uso posterior, como morteiros ou matérias primas associadas à confecção de dardos e zarabatanas (site furniture). Quando do abandono do acampamento, a maioria dos elementos que se encontram em deposição primária junto às áreas domésticas correspondem a restos alimentares e, em menor quantidade, aos resíduos de produção de artefatos, estando também presentes, em menor concentração, artefatos inteiros ou fragmentados como cestas, recipientes de metal ou cerâmica, percutores, dardos e zarabatanas, lanças, artefatos de madeira dura com depressão central utilizados para partir frutos (quebra-coquinhos), entre outros. Em geral, os artefatos são descartados quando se encerra sua vida útil ou quando se fraturam acidentalmente, durante o uso, ou intencionalmente, em função de brigas domésticas. Também são abandonados artefatos expeditivos que ainda possuem vida útil, mas cujos

\footnotetext{
17 Buscando avaliar a relação entre depósitos primários e secundários com o sistema de mobilidade e assentamento entre caçadores coletores e horticultores, Murray empreendeu um estudo intercultural abrangendo 79 distintos grupos. Os resultados sugeriram que só há coincidência entre local de uso e descarte em sítios habitacionais relacionados a populações com alta mobilidade que apresentam acampamentos de curta duração. Independente do tipo de sistema de subsistência predominante, populações sedentárias ou semi-sedentárias que residem em um sítio por pelo menos uma estação descartam elementos sempre fora da área doméstica onde são utilizados (Murray, 1980: 497).
} 
custos de transporte seriam maiores que os de sua produção no próximo acampamento. Partindo destas características, o autor sugere que quanto mais prolongada a ocupação, maior a tendência à formação de depósitos secundários, sendo os depósitos primários relacionados a atividades que se desenvolveram poucos dias antes do abandono do acampamento (Politis, 1996a: 331-333; 1996c: 436-437).

Entre os Nukak, os ossos das espécies habitualmente consumidas como macacos, porcos do mato, tatus, aves, peixes e tartarugas, entre outros, são encontrados desarticulados, fraturados, dispersos e associados às estruturas formais de descarte, apresentando em geral marcas de queima, corte e de dentes ${ }^{18}$. Contudo, observa-se pelo menos dois padrões espaciais distintos para o descarte destes ossos, um associado ao porco do mato e outro relacionado aos demais animais de menor porte.

No caso do porco do mato observa-se pelo menos três áreas de descarte relacionadas as etapas de abate, preparo e consumo do animal. A cabeça e algumas vísceras são descartadas próximas ao local de abate, quando o pelo é queimado e o animal é cortado em partes para o transporte até o acampamento. A carne é assada e consumida somente pelo grupo masculino, constituindo tabu alimentar para mulheres e crianças, situando-se o local de preparo fora do perímetro do acampamento. Neste são descartadas as costelas, vértebras, pélvis e escápulas, além de alguns ossos largos, como úmeros e fêmures, freqüentemente faturados para obtenção de tutano. São levados para o acampamento residencial e lá descartados outros ossos largos como tíbias, fíbulas, ulnas, bem como ossos associados à terminação das patas que ingressam aderidos ao couro ressecado, pendurado acima dos fogões familiares.

No caso de animais de menor porte, como os macacos, a carcaça é levada inteira para o acampamento, sendo os ossos descartados no local de preparo e consumo, geralmente junto às fogueiras familiares. É nesta área que o animal terá seu pelo queimado, sendo posteriormente cortado em partes, para então ser cozido. A unidade doméstica onde se cozinha a presa e a distribuição de suas partes varia de acordo com seu tamanho e a quantidade de animais abatidos. Quando são caçados apenas um ou dois animais, estes são cozidos na unidade doméstica do caçador e divididos de forma

\footnotetext{
${ }^{18}$ Animais selvagens tomados como mascotes, como macacos e aves, ou animais domésticos, como os cachorros, são sepultados no piso dos acampamentos a semelhança dos demais membros do grupo. Os restos faunísticos de espécies consideradas sagradas, sobre as quais incidem tabus alimentares (como as onças, veados e antas) só são encontrados nos assentamentos associados a objetos ritualísticos ou de conteúdo simbólico (Politis, 1996c: 439).
} 
igualitária entre os membros do bando, levando à distribuição de partes distintas de um mesmo animal entre as diferentes unidades domésticas do acampamento. Por outro lado, quando vários animais são caçados, estes são distribuídos inteiros entre as famílias, sendo cozinhados e consumidos individualmente em cada unidade doméstica. Em geral, os ossos destes animais são fraturados para a obtenção de tutano, sendo causada a maior parte do dano sobre as unidades anatômicas neste último estágio do consumo. A cabeça é a última parte consumida, permanecendo geralmente na unidade doméstica do caçador, podendo ser transportada para um novo acampamento (Politis, 1996a: 259-280; 1996c: 439).

O padrão de caça, consumo e descarte de partes anatômicas entre os Aché apresenta-se muito semelhante ao caso Nukak, sendo os animais abatidos e carregados inteiros para o acampamento, onde são desmembrados, preparados (assados ou cozidos) e imediatamente consumidos, incluindo-se neste processo também animais de maior porte como os porcos do mato. Em geral, os ossos de animais de menos de 15 kg são fraturados para extração de tutano. Estes são abertos nas terminações articulares com os dentes ou com uma faca, para se sugar ou retirar o tutano, remanescendo, geralmente, apenas as diáfises cilíndricas dos ossos longos nas áreas de descarte primário, junto às fogueiras. Os ossos longos de animais de maior porte são também fraturados para extração de tutano, gerando uma grande quantidade de pequenos fragmentos. Em geral, os restos faunísticos se concentram no perímetro das fogueiras domésticas, dispersos por uma área de até $1 \mathrm{~m}$ de diâmetro a partir destas (Jones, 1993: 105-110).

Partindo do modelo de sistema de assentamento desenvolvido no capítulo anterior, sugerimos a hipótese de que os sítios em abrigo sob rocha identificados no Alto Vale do Rio dos Sinos, foram utilizados, preferencialmente, como unidades habitacionais. Estas foram ocupadas por breves períodos de tempo ao longo dos ciclos de mobilidade dos caçadores coletores, deixando um registro arqueológico discreto, compatível com o modelo forrageiro para áreas tropicais, caracterizado principalmente por depósitos primários em torno das fogueiras domésticas. Partindo do pressuposto de que a estrutura espacial das unidades habitacionais corresponde à materialização de um modelo mental de organização e uso do espaço, espera-se que as ocupações reveladas nas escavações destes abrigos sob rocha apresentem padrões recorrentes no tempo e no espaço. Contudo, deve-se considerar as características estruturais e deposicionais próprias a cada abrigo sob rocha como um elemento chave para a compreensão da variabilidade intra e inter-sítios em um mesmo sistema de assentamento relacionado à 
Tradição Umbu. Destaca-se ainda que o estudo arqueológico deste tipo de contexto apresenta vantagens para a caracterização destas unidades habitacionais, tanto em termos sincrônicos quanto diacrônicos, na medida em que possui melhores condições de preservação de resíduos orgânicos e estruturas se comparados com os sítios a céu aberto, nos quais preservam-se, em geral, somente as evidências líticas como índices para o estudo de áreas de atividade.

A fim de testar o modelo acima proposto, realizamos escavações em três distintos sítios em abrigo sob rocha da área estudada, contrastando-se os dados obtidos com o modelo de estrutura habitacional derivado do estudo etnoarqueológico de grupos caçadores coletores de floresta tropical. A seguir, caracterizamos a metodologia empregada nas escavações e os aspectos de ordem deposicional e pós-deposicional que afetaram a variabilidade observada nestes contextos. É com base nestes dados que estabelecemos os critérios analíticos pertinentes para a interpretação funcional da variabilidade espacial e temporal observada entre os sítios escavados, a serem tratados na última parte deste capítulo.

\subsection{Escavando Abrigos sob Rocha: Problemas Geoarqueológicos e}

\section{Propostas Metodológicas}

Abrigos sob rocha e cavernas podem ocorrer em uma variedade de litologias, desenvolvendo-se geralmente em formações calcárias e arenitícas, podendo também se formar através de fraturas ou tubos em leitos rochosos de lava basáltica. A gênese de um abrigo arenítico, em geral, resulta da infiltração e escoamento de águas superficiais nas proximidades das escarpas, ao longo dos planos de diaclasiamento, com conseqüente remoção e dissolução do material arenoso. Obtido um alargamento inicial, segue-se uma evolução por abatimento, sendo o escoamento das águas de infiltração controlado por níveis menos permeáveis no arenito, marcados por horizontes mais argilosos, silicificados ou ferruginosos, pela ocorrência de corpos magmáticos, por variações internas de granulometria do leito rochoso ou ainda por intersecções da topografia e do nível freático (Wernick et al, 1973: 63-65). 
Os estudos da dinâmica de formação e degradação dos abrigos correspondem a fatores importantes na interpretação da formação do registro arqueológico. Deve-se considerar que os abrigos, como parte da paisagem, evoluem através do tempo, podendo erodir ou entrar em colapso em função dos processos naturais que afetam o leito rochoso (Collins, 1991; Rapp \& Hill, 1998: 66-71; Schiffer, [1987]1996: 102; Strauss, 1990:258-259; Waters, 1992: 241-246).

Dependendo da morfologia da boca do abrigo, da topografia do local onde se situa e do conjunto de detritos que se acumulam em sua entrada, a água da linha de goteira pode escorrer para seu interior ou descer pela encosta. O principal processo responsável pelo pacote sedimentar que se forma em seu interior se dá em função das alterações físicas e químicas que agem sobre seu teto e paredes. Os abrigos areníticos são dominados por uma sedimentação clástica endógena, podendo os sedimentos de fora do abrigo (exógenos) encontrar uma via de acesso, seja pela abertura principal, seja pelas fissuras das paredes e do teto.

Em geral, os sedimentos exógenos derivam de processos fluviais, eólicos, coluviais, lacustres, glaciais e marinhos, dependendo sua acumulação de três fatores principais: 1) da forma, tamanho e orientação da entrada do abrigo ou de outras aberturas; 2) das características do ambiente deposicional dominante na área externa do abrigo; e 3) da posição e altura da entrada do abrigo com relação aos agentes deposicionais ativos na sua parte externa. Outros tipos de sedimentos presentes em abrigos sob rocha e cavernas incluem materiais de origem humana (vestígios arqueológicos) e de origem animal (restos ósseos, guano, coprólitos, entre outros).

Desta forma, a seqüência estratigráfica de qualquer abrigo sob rocha ou caverna é única em função das diferenças em sua litologia, dinâmica de formação e ambiente deposicional no qual se insere. Em geral corresponde a combinação variada de sedimentos endógenos e exógenos que se depositam de forma continua ou descontínua na superfície do solo, com ritmos distintos através do tempo. A história da decomposição, erosão e estabilidade de um abrigo influenciam a integridade e a separação vertical e horizontal do registro arqueológico. Quanto maior a taxa de acumulação sedimentar, maior a separação entre as distintas ocupações. Porém, durante períodos de estabilidade, ocupações temporalmente distintas podem se sobrepor, formando palimpsestos. Por outro lado, aparentes hiatos entre ocupações contemporâneas podem ser criados durante episódios de erosão. Igualmente, distúrbios pós-deposicionais na composição dos pacotes sedimentares podem ser gerados por 
distintos processos alheios à dinâmica sedimentar do abrigo, como por exemplo bioturbações geradas por galerias de animais cavadores (como tatus, minhocas, cupins, formigas, entre outros agentes) ou pela presença de raízes (Rapp \& Hill, 1998: 82-85; Schiffer, [1987]1996: 199-234; Waters, 1992: 293-316).

Os abrigos sob rocha não são estruturas estáticas, pois, por um lado, sofrem processos de degradação acelerados pela presença humana e, por outro, suas características estruturais também afetam a escala, a distribuição, a organização e a natureza das atividades que neles ocorrem. Escavar um abrigo sob rocha, portanto, pressupõe a utilização de metodologias que combinem técnicas de controle horizontal e vertical que permitam registrar os processos naturais que agiram para criação do pacote sedimentar, bem como compreender como a dinâmica de formação do contexto deposicional e pós-deposicional afetou a integridade dos conjuntos artefatuais identificados. A interpretação da variabilidade intra-sítio observada ao longo das escavações, por sua vez, demanda perceber os abrigos estudados em seu contexto regional, resgatando suas "histórias de formação" específicas e como estas se relacionam com o sistema de assentamento do qual fazem parte (Galanidou, 2000: 272273; Strauss, 1990: 268-278).

Tendo em vista as questões acima apontadas optou-se por realizar escavações amplas em 3 sítios em abrigo sob rocha, dos quais dois já haviam sido escavados durante o PRONAPA. Três etapas de escavações ocorreram entre 3 e 31 de janeiro de 2001, 1 e 31 de julho de 2001 e 3 e 31 de janeiro de 2002, totalizando 88 dias de atividades. Os métodos de escavação empregados orientam-se para o entendimento da organização do uso do espaço intra-sítio, proporcionando amostragens que permitissem comparações inter-sítios associadas ao sistema de assentamento de caçadores coletores identificados no Alto Vale do Rio dos Sinos.

Como os abrigos sob rocha correspondem a sítios com limites naturais fixos, o sistema de quadriculamento empregado obedeceu à orientação geográfica de suas aberturas, sendo estabelecido por metro quadrado. As malhas de quadriculamento foram orientadas para o interior dos abrigos a partir de uma linha mestra estabelecida junto à linha de goteira, também utilizada para realização de croqui e orientação dos sistemas de sondagens. Na nominação das quadrículas considerou-se a linha mestra como representado a linha “A”, recebendo as linhas verticais numeração correspondente a sua divisão por metros. A designação das quadrículas se deu pela intersecção das linhas horizontais e verticais em seu canto esquerdo inferior. O ponto zero das escavações foi 
estabelecido dentro da área dos abrigos, tendo em vista a possibilidade de visualização total de possíveis locais a serem escavadas, sendo todas as medidas de altura tomadas ao longo das escavações correlacionadas a este. Este foi marcado na parede dos abrigos, à direita da sua entrada, com tinta acrílica vermelha, tendo sido registrado em croqui, quanto a sua posição e altura.

$\mathrm{Na}$ medida em que as sondagens dos sítios em abrigo sob rocha evidenciaram pacotes estratigráficos homogêneos e profundos, porém com baixa densidade de materiais, para o controle estratigráfico vertical optou-se por escava-los através de níveis arbitrário de $5 \mathrm{~cm}$ que obedecessem à declividade natural do terreno. Antes do início da escavação de uma quadricula foram tomadas às medidas das alturas, a partir do ponto zero, do seu centro e quatro cantos, sendo utilizado este controle de profundidade ao longo da escavação de todos os níveis. Também foram realizados croquis dos perfis remanescentes das áreas escavadas para auxiliar na interpretação dos mapas planimétricos e das características sedimentares registradas por nível artificiais (Anexo 5). Este procedimento agilizou o ritmo das escavações e facilitou a interpretação de concentração de materiais, em função da topografia dos sítios, permitindo correlacionar, com o auxílio das datações obtidas e análise dos perfis estratigráficos, os níveis artificiais entre as diferentes áreas escavadas.

Para o controle horizontal, as evidências arqueológicas (artefatos, ecofatos e estruturas), bem como alterações na composição dos sedimentos observadas ao longo das escavações, foram plotadas e registradas em fichas individualizadas por quadrícula e nível estratigráfico. Nesta ficha consta uma planilha, em escala padrão, na qual as evidências arqueológicas foram plotadas e registradas, com numeração individual, quanto ao tipo de material, altura da peça em relação ao ponto zero e distâncias das paredes norte e leste da quadrícula. Estas informações também foram registradas em uma etiqueta que acompanhou as peças em embalagens individuais. A presença de estruturas ou de alterações na composição dos sedimentos também foi registrada nestas fichas. Este procedimento permitiu a elaboração, em laboratório, de mapas planimétricos de distribuição de materiais e estruturas, por níveis artificiais, revelados ao longo das escavações, servindo como referência para as análises de variabilidade intra-sítio e para as comparações inter-sítios (Anexo 6).

Todos os sedimentos foram peneirados em malha de $2 \mathrm{~mm}$ e para dois dos sítios escavados amostras de solo remanescentes nas peneiras foram selecionadas para lavagem em laboratório, a fim de resgatar micro vestígios líticos e arqueofaunísticos. O 
material arqueológico resgatado nas escavações encontra-se atualmente sob guarda do Museu Arqueológico do Rio Grande do Sul (MARSUL), recebendo a numeração de catálogo correspondente aos sítios arqueológicos do vale do rio dos Sinos, associada à numeração individual das peças registradas nas fichas de escavação.

Ao término das atividades, todas as áreas escavadas, incluindo os perfis preservados, foram revestidas com lonas plásticas e posteriormente cobertas com os sedimentos restantes das peneiras. Este procedimento foi realizado com o objetivo de preservar da erosão as áreas não escavadas e facilitar sua localização em caso de novas intervenções.

4.3. Três Versões sobre o Mesmo Tema: Aspectos da Variabilidade Intrasítio para os Abrigo sob Rocha do Alto Rio dos Sinos

\subsubsection{Sítio RS-S-360: Marimbondo}

Tendo em vistas suas características de implantação, de preservação e de acervo relativo a pesquisas anteriores, o sítio RS-S-360: Marimbondo foi selecionado para novas escavações entre 3 e 31 de janeiro de 2001. Em 1970 havia sido escavada uma área 24,5 m² neste sítio, distribuída em 11 quadrículas de 1,5 x 1,5 m No setor sul do sítio foram realizadas duas quadrículas, escavadas até a profundidade de $30 \mathrm{~cm}$, apresentando baixa densidade de material (35 peças líticas). As demais se distribuíram na forma de trincheira a partir da parede norte do abrigo, apresentando material lítico entre profundidades que variaram entre 20 e $70 \mathrm{~cm}$, revelando um conjunto de 2725 peças líticas. Embora esta coleção lítica apresente amplo potencial para discussão sobre variabilidade artefactual, as características dos métodos de escavações anteriormente utilizados e a inexistência de documentações de campo referentes aos aspectos contextuais dos conjuntos líticos resgatados, influenciou diretamente a escolha deste sítio para novas intervenções. A definição das novas áreas para escavação foi determinada em função dos resultados das sondagens, descritas no capítulo anterior, e do inventário de acervo das escavações anteriores neste sítio. Optou-se por estabelecer um novo sistema de quadriculamento, dividido em dois setores (sul e norte), sendo 
escavada uma área total de $29 \mathrm{~m}^{2}$. Em conjunto com as intervenções já realizadas, este sítio atualmente possui uma área de $53,5 \mathrm{~m}^{2}$ escavados.

No setor sul do abrigo foi estabelecida uma área de escavação de $8 \mathrm{~m}^{2}$ (4 x $2 \mathrm{~m}$ ), ao lado das sondagens de 1970, junto à parede leste. Esta malha se distribuiu em torno do trado de número 12 que havia revelado sedimentos arenosos, de coloração acinzentada, associados a fragmentos de carvão, que interpretamos, inicialmente, como relacionados à presença de estruturas de fogueiras. Esta área foi escavada até os $50 \mathrm{~cm}$ de profundidade, não apresentando nenhum tipo de evidência arqueológica na forma de estruturas ou artefatos. A medida em que as escavações prosseguiam revelou-se um pacote de sedimentos de coloração marrom escura e consistência argilosa, associado às infiltrações da linha de goteira. Estes estavam intercalados por manchas de sedimentos arenosos e acinzentados e/ou argilosos de coloração alaranjada, distribuídos de forma irregular ao longo das quadrículas e níveis, que correlacionamos à decomposição, em função de infiltração de umidade da linha de goteira, de blocos de arenito desprendidos do teto e paredes do abrigo ${ }^{19}$ (foto 1 ).

A fim de testar esta hipótese, uma das quadrículas do setor sul (L19) foi escavada até 1,5 m de profundidade, quando atingiu a rocha matriz do abrigo. Esta revelou um pacote sedimentar com alto índice de umidade, de coloração alaranjada e consistência argilosa, confirmando a ação de decomposição da rocha matriz por ação de infiltrações subterrâneas associadas à linha de goteira ${ }^{20}$ (foto 2). Para complementar a visão do setor sul do abrigo foi escavada uma sondagem (quadrícula E4), junto à parede sul. Esta estendeu-se até a profundidade de $80 \mathrm{~cm}$, sem apresentar evidências arqueologias associadas, atingindo um lençol d'água relacionado à linha de goteira. $\mathrm{O}$ pacote sedimentar mostrou-se semelhante ao das demais quadrículas escavadas no setor sul do sítio, com sedimentos homogêneos e argilosos, de coloração marrom-escura (foto 3).

Os fragmentos de carvão resgatados nas tradagens desta área, estavam associados à presença de uma estaca de madeira queimada, evidenciada entre 10 e 50 cm de profundidade, na quadrícula J18. Em superfície também foram identificadas duas

\footnotetext{
19 As quadrículas próximas à parede (M18 e M19) apresentavam sedimentos arenosos associados à deposição eólica e perturbações decorrentes da presença de uma galeria de tatu.

${ }^{20}$ Como o abrigo foi escavado em época de chuvas intensas foi possível observar a formação de uma queda d'água em frente à área escavada que se manteve ativa ao longo de todo o mês, movimentando um volume significativo de água.
} 
moedas da década de 1970 e fragmentos de plástico. Os proprietários informaram que o sítio havia sido utilizado anos atrás como área de pernoite por um trabalhador rural que havia construído uma pequena cabana situada sobre esta área. Igualmente, os filhos pequenos do proprietário utilizam o abrigo como área de lazer, ocasionalmente acampando em seu interior durante a noite, o que pode explicar a presença de carvão nesta área. Destaca-se que o sítio também é utilizado atualmente como depósito e curral, estando presente ao lado da área escavada a caçamba de uma camionete.

No setor norte do sítio foram estabelecidas 20 quadrículas, em uma malha de 7 x 3 m, entre a parede leste e a zona escavada em 1970. Sua orientação foi determinada pela presença de materiais arqueológicos em três das tradagens realizadas nesta área. Observa-se que a linha mestra situa-se onde hoje há um declive acentuado de pelo menos $3 \mathrm{~m}$ de profundidade, pelo qual escoa a água da linha de goteira e que corresponderia ao local original da trincheira escavada em 1970. Segundo os proprietários, esta erosão foi acentuada pelo pisoteio do gado, pois este se constitui no ponto de acesso dos animais. Ressalta-se que nesta área o solo encontrava-se coberto por estrume que se misturava aos sedimentos do primeiro nível da escavação, o que garantiu que parte dos vestígios de superfície não sofresse com a ação da erosão. Por outro lado, o pisoteio do gado influenciou as características dos sedimentos, tornando-os soltos nos primeiros centímetros e extremamente compactos até a rocha matriz, sendo necessário o uso de espátulas na escavação (fotos 4 e 5).

Em contraste com o setor sul do abrigo, esta área apresentou-se pouco afetada pela ação da umidade, revelando um pacote sedimentar de caráter arenoso, com granulação mais grossa e coloração marrom clara, bastante homogêneo e de pouca profundidade (Anexo 5 - perfis 1 e 2). O piso arenítico mostrou-se evidente nesta área entre 45 e $20 \mathrm{~cm}$ de profundidade, confirmando as hipóteses quanto à formação do pacote sedimentar do setor sul, e possibilitando a ampliação da malha de escavação, originalmente idealizada em $8 \mathrm{~m}^{2}$. Este dado permitiu compreender o sistema de registro da escavação de 1970, uma vez que as tomadas de medidas para o controle estratigráfico naquela época foram feitas aleatoriamente a partir do solo original. Assim, as quadrículas da trincheira de 1970 que atingiram profundidades entre 60 e 70 cm estão associadas à parede norte do abrigo que apresenta acúmulo de areia, associada à ação eólica. Por sua vez, as que se distribuíam em torno da área escavada em 2001 chegaram a profundidades entre 10 e $40 \mathrm{~cm}$, sendo possível perceber que atingiram o piso arenítico, informação não disponível até então (foto 6). 
No setor norte do sítio o material arqueológico distribuiu-se predominantemente entre a superfície e as profundidades de 20 e 30 cm, com baixa densidade de materiais, indicando episódios discretos de ocupação. Estas características também indicam que apesar das dimensões do abrigo, sua ocupação obedeceu a critérios de habitabilidade, sendo eleita para ocupação apenas à área que apresentava maior insolação e menor exposição à umidade. Em função do tipo de sedimentos e da quantidade de evidências coletadas na peneira, optou-se por não coletar sedimentos para lavagem em laboratório, pois a metodologia de escavação empregada foi suficiente para o resgate total de material nas áreas que sofreram intervenções (Anexo 6 - planos 1 a 8).

As quadrículas C51, C52, B51 e B52 apresentaram maior concentração de material lítico e ósseo, associados a uma estrutura de fogueira, evidente entre os níveis 2 e 4, situadas sobre o piso arenítico, que se encontrava com marcas de queima (foto 7). $\mathrm{O}$ material arqueofaunístico se deu em baixa densidade, apresentando-se extremamente queimado e fragmentado. Igualmente, as amostras de carvão apresentaram-se muito esparsas na área da fogueira, impedindo coleta para datação. Estes aspectos podem ser entendidos tendo em vista a topografia e as características sedimentares do abrigo nesta área. Por apresentar pouca profundidade de aba, o setor norte está mais exposto à ação destrutiva das chuvas e da insolação sobre o material orgânico, levando a deterioração das amostras. Em função destas características, foi possível realizar somente uma datação em AMS para este sítio a partir de uma amostra de osso associada à fogueira sobre o piso arenítico da quadrícula B51 $(10-15 \mathrm{~cm})$. Foi obtido um resultado de $920 \pm$ 40 AP (Beta Analytics 154354), com calibração de 2 sigma 960 a 790 AP (Anexo 6 plano 3).

Quanto aos processos pós-deposicionais que afetaram a integridade deste contexto, observa-se que as quadrículas B46, C46 e D46 estão associadas ao ponto terminal de um extenso cupinzeiro, visível em superfície na área central do abrigo, estendendo-se ao longo de uma área de $20 \mathrm{~m}$. Este cupinzeiro já havia sido registrado na planta original da escavação de 1970 e afetou de forma intensa a área central do abrigo ao longo dos últimos 30 anos, erodindo seus sedimentos. Sua parte visível estava a $5 \mathrm{~m}$ ao sul da área de escavação, mostrado-se ativo a poucos centímetros da superfície quando do início da escavação. A ação dos cupins causou perturbação nas quadrículas contíguas, caracterizadas por sedimentos arenosos de granulação fina, associado à decomposição do arenito, com baixa densidade de material arqueológico. Esta área também apresentou concentração de quedas de blocos do teto, abaixo de um dos quais 
foi identificada uma concentração de 5 artefatos líticos, entre este um micro-raspador associado a lascas de retoque de matéria-prima silicosa de origem alógena (foto 8 e anexo 6 - plano 5).

A coleção proveniente das escavações de 2001 totalizou 428 peças líticas, das quais $48 \%$ correspondem a evidências registradas nos mapas planimétricos da escavação e 52\% foram resgatados nas peneiras. Do conjunto total de peças líticas, pelo menos 70\% corresponde a lascas unipolares inteiras ou fragmentadas em arenito silicificado e basalto, sendo o conjunto restante caracterizado por lascas bipolares, fragmentos térmicos e fragmentos de placas de basalto. Os artefatos correspondem a apenas $4 \%$ do conjunto lítico, estando representados por pontas de projétil, peças bifaciais, lascas retocadas, entre outros, cuja análise será tratada no capítulo 6. O conjunto de fragmentos ósseos e conchíferos plotados corresponde a 113 peças, sendo resgatados nas peneiras outros 459 fragmentos, totalizando um conjunto de 572 peças. Este, contudo, apresenta-se extremamente fragmentado, inviabilizando a análise zooarqueológica ou mesmo tafonômica. Destaca-se nesta coleção a presença de 2 fragmentos ósseos humanos (um astrágalo e uma falange) e 8 dentes humanos, distribuídos em torno da área da fogueira. 


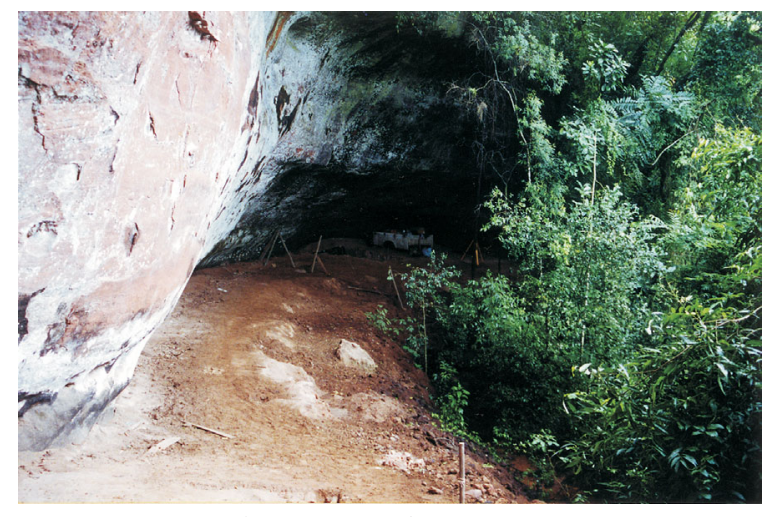

1. RS-S-360 - Vista setor sul. Foto: Adriana Dias

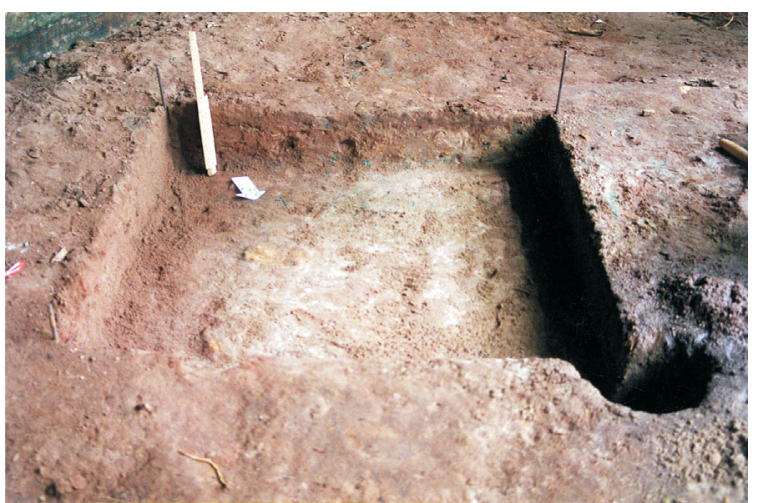

3. RS-S-360 - Poço teste (E4) no setor sul. Foto: Adriana Dias

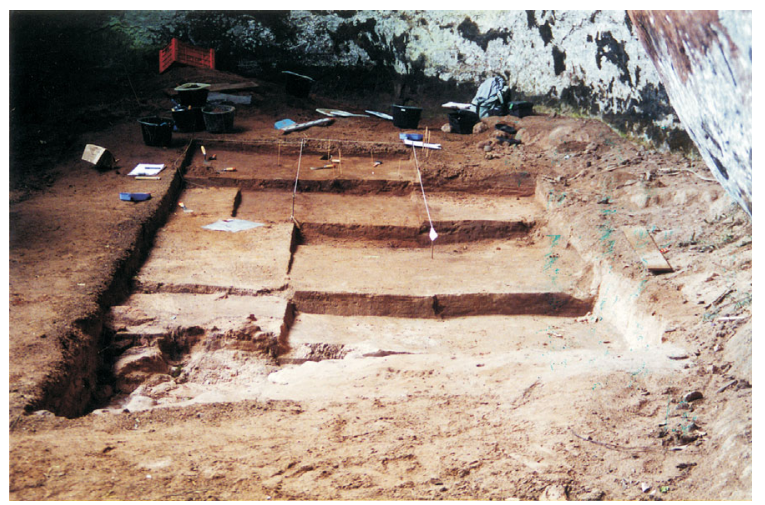

5. RS-S-360 - Detalhe da área escavada no setor norte, término da escavação. Foto: Adriana Dias

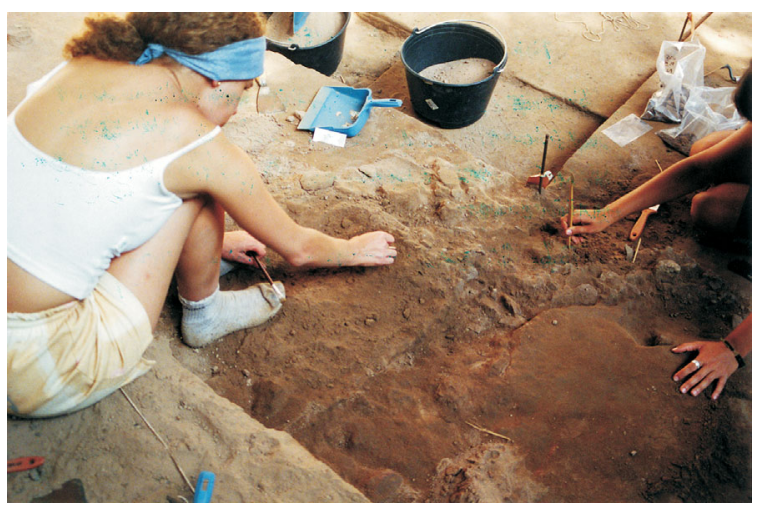

7. RS-S-360 - Detalhe de escavação de fogueira no setor norte. Foto: Adriana Dias

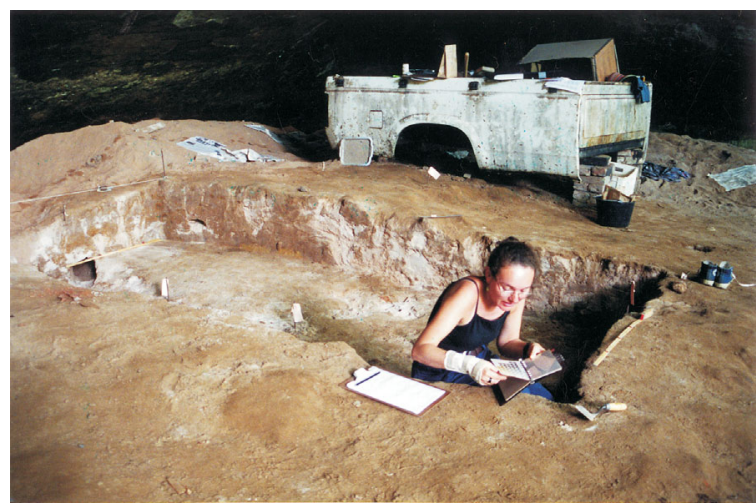

2. RS-S-360 - Detalhe do registro dos perfis no setor sul. Foto: Adriana Dias

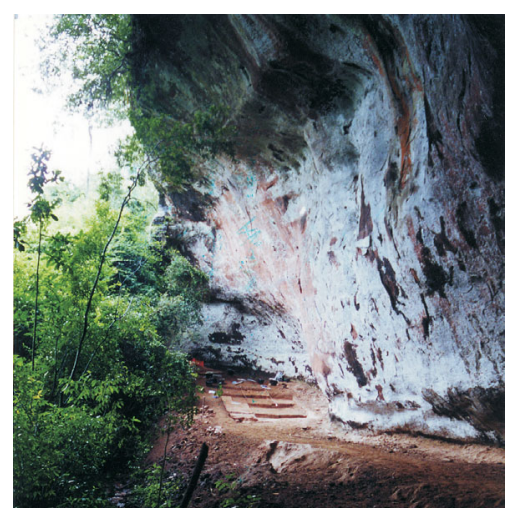

4. RS-S-360 - Vista geral da área escavada no setor norte. Foto: Adriana Dias

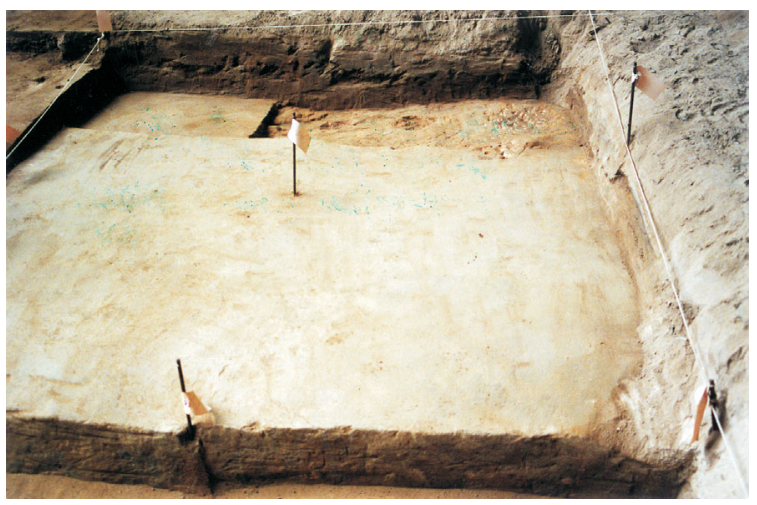

6. RS-S-360 - Detalhe do piso do abrigo no setor norte. Foto: Adriana Dias

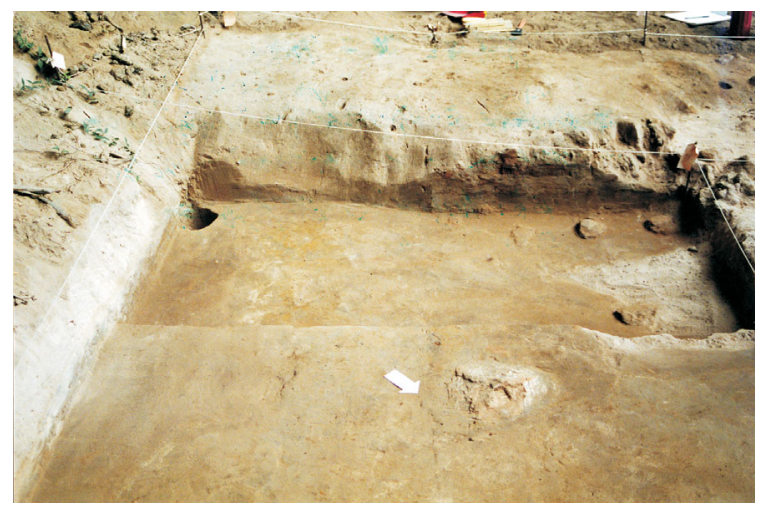

8. RS-S-360 - Detalhe do cupinzeiro e do piso arenítico no setor norte. Foto: Adriana Dias 


\subsubsection{Sítio RS-S-327: Sangão}

O sítio RS-S-327: Sangão já havia sido escavado em duas etapas de campo em 1966 e 1970, tendo sido realizadas 12 quadrículas de 1,5 x 1,5 metros, em níveis artificiais de $10 \mathrm{~cm}$, totalizando uma área de 29,25 $\mathrm{m}^{2}$ escavados. Estas quadrículas distribuíram na forma de duas trincheiras: 7 ao longo da parede norte, com orientação leste-oeste, e 5 estendendo-se em direção sul a partir do centro da primeira trincheira, cortando a área central do sítio. Foi preservado um testemunho na parede norte, que corresponderia às quadrículas 12A e 12B do quadriculamento original. O conjunto lítico das escavações de 1966/1970 corresponde a 791 peças, das quais 69\%, encontram-se associadas à trincheira junto à parede norte do abrigo. Em função da ausência de registros quanto às características estratigráficas e associação entre material arqueológico e estruturas nas escavações anteriores, bem como dos resultados das novas sondagens realizadas, descritas no capítulo anterior, este sítio foi selecionado para novas escavações. Foi escavada uma área de $13 \mathrm{~m}^{2}$ que em conjunto com as intervenções anteriormente feitas totalizam uma área escavada de 42,25 $\mathrm{m}^{2}$.

As escavações ocorreram entre $1^{\circ}$ e 31 de julho de 2001, distribuindo-se em torno das sondagens e trincheiras anteriormente escavadas com o objetivo de contextualização de suas coleções. Foram escavadas 3 quadrículas em torno da sondagem D13/D14 (quadrículas D12, E12 e E13; Anexo 6 - planos 9 a 21), 2 quadrículas junto à parede norte (quadrículas F16 e F15; Anexo 6 - planos 22 a 33) no limite da área afetada pelas escavações de 1966/1970, bem como o testemunho ${ }^{21}$ deixado pelo PRONAPA (quadrículas G8, G9, H8, H9, I8 e I9; Anexo 6 - planos 34 a 48). Retomaram-se ainda as escavações da quadrícula F8, para contextualização dos materiais associados à sondagem E8 e a trincheira central realizada durante o PRONAPA (fotos 9 a 13).

\footnotetext{
${ }^{21}$ Quanto às escavações do testemunho, este apresentava uma superfície irregular devido ao desmoronamento dos seus perfis e ao acúmulo de sedimentos junto à parede do abrigo, tornando impossível determinar sua altura original. Assim, os sedimentos das capas iniciais foram retirados e peneirados até a superfície atingir uma altura aproximada ao primeiro nível da quadrícula G8, sendo então escavado em níveis artificiais de $5 \mathrm{~cm}$. Esta estratégia mostrou-se adequada para o controle cronológico, tendo em vista a associação das estruturas de fogueiras evidenciadas para as quadrículas H8, G8, H9 e G9 e a sequiência de datações obtidas. Também foi realizada a limpeza dos perfis das escavações anteriores, sendo os sedimentos peneirados e o material arqueológico resgatado acondicionado de acordo com seu local de origem.
} 
O pacote sedimentar revelado pelas escavações apresentou-se muito homogêneo, com granulação fina e coloração marrom escura, estando a rocha matriz situada a profundidades entre 50 e $80 \mathrm{~cm}$. O material arqueológico distribui-se com freqüência constate ao longo de toda a estratigrafia, estando as alterações observadas no pacote sedimentar relacionadas à presença de fogueiras e de galerias de tatu (Anexo 5 - perfis 3 a 11). As estruturas de fogueiras estão presentes em todas as quadrículas, distribuindose desde a superfície até o piso arenítico, estando dispersos em seu entorno restos arqueofaunísticos relativamente bem preservados e resíduos de lascamento (fotos 14 e 15). Sugere-se que este pacote sedimentar apresenta características de formação predominantemente endógena, em função das características estruturais e forma de implantação do abrigo, que também garantiram boas condições de preservação para o material orgânico. A abertura do abrigo está voltada para um declive acentuado sobre o rio dos Sinos, escoando a água da linha de goteira, e a forma da sua aba impede que a chuva atinja seu interior. Por sua vez, por possuir orientação sul, o abrigo não recebe insolação direta e encontra-se também relativamente protegido da ação do vento, mesmo durante o inverno, por uma mata ciliar fechada. A coloração escura e a consistência fina do pacote sedimentar relacionam-se as boas condições de preservação das evidências orgânicas, principalmente o carvão e as cinzas associadas às fogueiras.

A dificuldade de acesso ao sítio para o gado, por sua vez, também contribuiu para sua preservação, sendo o principal fator de distúrbio antrópico atual o hábito de depositar lixo no rio a partir do platô que se situa na parte superior do abrigo, gerando acúmulos de carcaças de animais, como vacas e ovelhas, e outros detritos presos às árvores que se projetam junto a sua abertura. O principal fator pós-deposicional que contribui para afetar a integridade do sítio corresponde à ação de galerias de tatus, cujas tocas de 20 a $30 \mathrm{~cm}$ de diâmetro afetaram diversos níveis de distintas quadrícula, sendo mais ativas no setor leste do sítio. As galerias, em geral, encontram-se preenchidas ${ }^{22}$, porém tendo em vista a homogeneidade do pacote sedimentar, ao longo das escavações só puderam ser percebidas em função de alterações na textura dos sedimentos ou quando afetavam diretamente as estruturas de fogueiras, sendo sua presença confirmada

\footnotetext{
${ }^{22}$ Evidências de soterramento de galerias de tatu podem ou não ser detectadas ao longo das escavações. Em caso de colapso, a galeria pode ser preenchida tanto pelos sedimentos puxados pelo animal quando pelos sedimentos dos níveis superiores, criando-se uma krotovina (galeria preenchida por sedimento) que pode ser identificada em campo pelas diferenças de textura e coloração dos sedimentos. Porém, em matrizes sedimentares muito homogêneas estas diferenças podem não ser observáveis (Waters, 1992: 312).
} 
através da análise dos perfis das quadrículas. Com exceção das quadrículas E12 e D12, todas as demais foram afetadas em maior ou menor grau pela ação das galerias de tatu (foto16).

Praticamente todas as estruturas de fogueiras identificadas formaram-se a partir de vários episódios de reutilização que deram origem a lentes de carvões e cinzas concrecionada pela ação da umidade, entendendo-se por vários níveis, com espessuras variadas, entre 20 e $55 \mathrm{~cm}$. As estruturas de cinza e carvão que apresentaram uma distribuição praticamente contínua ao longo da estratigrafia foram identificadas junto às quadrículas E12, E13, D13, G9, G8, estendendo-se entre 40 e 55 cm, indicando um intenso processo de reocupação destas áreas centrais do abrigo ao longo de diferentes momentos da ocupação.

Com o objetivo de compreender a correlação cronológica entre as diferentes estruturas evidenciadas e avaliar a metodologia de escavação empregada, amostras de carvão destas fogueiras foram selecionadas para datação nas quadrículas F8 (nível 4 15 a 20 cm), G9 (nível 5 - 20 a 25 cm), F16 (nível 6 - 25 a 30 cm), D13 (nível 6 - 25 a 30 cm; nível 8 - 35 a 40 cm; e nível 10 - 45 a 50 cm) e E13 (nível 13 - 60 a 65 cm). Para a quadrícula F8, nível 4, foi obtida uma datação radiométrica de 3730+60 AP (Beta Analytics 160846), com calibração de 2 sigmas de 4250 a 3900 AP. Para a quadrícula G9, nível 5, foi obtida uma datação por AMS de 3940+40 AP (Beta Analytics 160849) com calibração de 2 sigmas de 4510 a 4480 AP e 4440 a 4260 AP. Para a quadrícula F16, nível 6, foi obtida uma datação radiométrica de 4610+140 AP (Beta Analytics 160847), com calibração 2 sigmas de 5610 a 4860 AP. Para a quadrícula D13 selecionamos 3 amostras de carvão de distintos níveis de uma mesma estrutura de fogueira, a fim de avaliar a continuidade de sua utilização e comparar com as outras datações obtidas. No nível 6 foi realizada uma datação radiométrica padrão sobre amostra de carvão com os seguintes resultados: 4160+100 AP (Beta Analytics 154351), com calibração de 2 sigmas 4870 a 4420 AP. No nível 8 da mesma estrutura de fogueira foi retirada outra amostra de carvão datado por AMS em 4710+40 AP (Beta Analytics 154352), com calibrações de 2 sigmas 5580 a 5520 AP e 5480 a 5310 AP. Uma última amostra de carvão do nível 10, recebeu uma datação em AMS de 7390 土 40 AP (Beta Analytics 154353), com calibração de 2 sigmas 8330 a 8150 AP. Por fim, para a quadrícula E13, nível 13, foi obtida uma datação por AMS de 8800+40 AP (Beta Analytics 160845) com calibração de 2 sigmas de 10110 a 10080 AP e 9930 a 9680 AP. 
As sete datações obtidas para os diferentes níveis deste sítio permitem comprovar um baixo índice de perturbação pós-deposicional e oferecem uma baliza cronológica para os estudos de variabilidade intra-sítio, abrangendo um período de pelo menos 5.000 anos. A seqüência de datações também permite observar que a variação nos ritmos de formação do pacote sedimentar deste abrigo não se deu de forma constante ao longo do tempo. Observa-se que da superfície até os $20 \mathrm{~cm}$ de profundidade teríamos uma taxa de sedimentação aproximada de $1 \mathrm{~cm}$ de acúmulo a cada 90 anos. As datações obtidas entre os 20 e $40 \mathrm{~cm}$ de profundidade (entre 3730 e 4710 AP), indicariam uma acumulação sedimentar mais rápida de $1 \mathrm{~cm}$, em média, a cada 48 anos. Este processo se torna mais lento entre os 40 e $50 \mathrm{~cm}$ de profundidade (entre 4710 e 7390 AP), podendo-se sugerir um acúmulo médio de $1 \mathrm{~cm}$ de sedimento a cada 268 anos. Esta taxa seria mais acelerada entre os 50 e 65 cm (entre 7390 e 8800 AP), com uma variação de $1 \mathrm{~cm}$ de acumulação sedimentar, em média, a cada 95 anos, semelhantes aos níveis mais recentes.

Levando-se em consideração que a composição sedimentar deste abrigo é representada principalmente por sedimentos endógenos formados pela decomposição das paredes e teto do abrigo, pode-se sugerir que estas variações nos ritmos de deposição sedimentar estejam relacionadas diretamente as alterações paleoclimáticas do Holoceno, associando-se os ritmos mais acelerados de sedimentação a períodos de maior umidade e temperaturas mais elevadas. Por fim, este tipo de controle cronológico permite sugerir que a análise de áreas de atividade neste sítio deve considerar uma maior probabilidade quanto à presença de palimpsestos de ocupação se comparado aos demais sítios escavados, tendo em vista as características do processo sedimentar, em geral bastante lento, reforçados pela tendência a sobreposição das estruturas de fogueira por períodos bastante longos de tempo.

Os sedimentos levados às peneiras apresentaram grande quantidade de vestígios líticos, arqueofaunísticos e carvão, porém as baixas condições de luminosidade do abrigo $^{23}$ e coloração escura dos sedimentos tornavam lenta a atividade de triagem do material durante as escavações. Em função destas características e das possibilidades de existência de micro-vestígios não perceptíveis em campo optou-se por acondicionar

\footnotetext{
${ }^{23}$ A baixa incidência solar no abrigo, em função de sua orientação, a coloração escura dos sedimentos em decorrência da grande quantidade de carvão, a profundidade das quadrículas e as condições climáticas de intensas chuvas durante o inverno, dificultaram a visibilidade durante as escavações, sendo necessário, em alguns momentos, a utilização de luz artificial.
} 
todos os sedimentos restantes nas peneiras para lavagem e triagem em laboratório. Ressalta-se ainda que as amostras de carvão resgatadas in situ e em laboratório apresentam alto potencial, tendo em vista sua preservação, para futuros estudos antracológico, bem como novas datações.

Em termos gerais, foram plotados nos mapas planimétricos das escavações 2321 peças, das quais 75\% representam fragmentos arqueofaunísticos, totalizando uma coleção de 693 fragmentos ósseos, 504 fragmentos de carapaças de gastrópodes terrestres e 539 fragmentos de carapaças de bivalves de rio, além daqueles associados aos sedimentos das peneiras cuja quantificação não foi efetuada. O bom estado de preservação desta coleção arqueofaunística apresenta alto potencial para estudos zooarqueológicos, que vem sendo realizados por André Jacobus ${ }^{24}$. Dados preliminares desta análise ${ }^{25}$, indicam uma grande diversidade de espécies, todas associadas à ambiente florestal, estando também representadas 3 peças que indicam a exploração esporádica de recursos marinhos. Foram identificadas as seguintes espécies: gastrópodes terrestres, como o aruá-do-mato (Megalobulimus oblongus) e aruá-do-brejo (Pomacea cf canaliculata); gastrópodes marinhos, como o caramujinho-da-praia (Olivella $c f$ verreauxi) e o linguarudo (Olivancillaria vesica auricularia); bivalves fluviais, como o marisco de água doce ou itã (Diplodon sp) e a tarioba (Iphigenia brasiliana); peixes cartilaginosos, como o tubarão ${ }^{26}$ (gênero Charcharinus); peixes ósseos sem escamas, como o mandi (Pimelodella laticeps), o guitarreiro (Bunocephalus iheringi), o tamboatá (Hoplosternum littorale) e o muçum (Symbranchus marmoratus), entre outras espécies indeterminadas; répteis, como o cágado ( $c f$ Chrysemis sp), o lagarto teiú (Tupinambis teguixin) e o jacaré (Caiman sp); e as aves como a saracura (família Rallidae) e o jacu (Penélope sp), além de pássaros pequenos e espécies indeterminadas. Foi identificada na amostra analisada uma grande variedade de mamíferos de porte variado ${ }^{27}$. Para os mamíferos de pequeno porte, com peso superior a $1 \mathrm{Kg}$, foram identificados o gambá (Didelphis sp), o tatu mulita (Dasypus septemcinctus), o gato maracajá (Leopardus

\footnotetext{
${ }^{24}$ As coleções arqueofaunísticas dos sítios RS-S-327: Sangão e RS-S-395: Deobaldino Marques fazem parte do objeto de tese de doutoramento junto ao MAE/USP de André Luiz Jacobus (2000), intitulado Caçadores coletores na mata atlântica: um estudo de caso na região hidrográfica da Bacia do Lago Guaíba e Planície Litorânea adjacente (RS), com defesa prevista para 2003.

${ }^{25} \mathrm{~A}$ amostragem de material que foi analisada está associada às quadrículas E8, F8, D13 e D12.

${ }^{26}$ No sítio RS-S-327: Sangão foi identificado um dente de tubarão do gênero Charcharinus, tendo sido identificado na coleção do sítio RS-S-358: Toca Grande outro dente de tubarão do gênero Galeocerdo.
} 
wiedii), entre outras espécies indeterminadas. Para os mamíferos de médio porte foram identificados o tatu galinha (Dasypus novemcinctus), o tatu de rabo mole (Cabassous tatouay), o porco cateto (Pecari tajacu), a paca (Agouti paca) e o ratão do banhado (Myocastor coypus), entre outras espécies indeterminadas. Entre os mamíferos de grande porte foram identificados a anta (Tapirus terrestris), o veado mateiro (Mazama americana) e a capivara (Hydrochaeris hydrochaeris), além de outras espécies indeterminadas.

Para avaliar o potencial da coleção para estudos tafonômicos foi registrada, quando possível, ao longo das atividades de limpeza e numeração das peças em laboratório, informações referentes ao tipo de fragmento ósseo documentado nas fichas de plotagem. Com base nestes dados preliminares, observa-se que do conjunto de fragmentos ósseos plotados nas escavações, 36,6\% da amostra corresponde a fragmentos de diáfises de ossos longos, 13,4\% são fragmentos de mandíbulas, 11,25\% são fragmentos de epífises de ossos longos, 7,35\% são fragmentos de costelas, 4,04\% são fragmentos de crânios, 3,46\% são fragmentos ósseos relacionados às terminações das patas de animais de médio porte e $2,74 \%$ são fragmentos de vértebras. Do conjunto restante, $17,7 \%$ são fragmentos não classificados (possivelmente associados a ossos chatos das bacias, pelvis ou omoplatas) e 0,86\% corresponde a dentes. Destaca-se ainda que a presença de fragmentos ósseos de pequenos roedores encontra-se, em sua maioria, associada às quadrículas E8 e F8 que se situam sob uma aba no teto do abrigo, correspondendo, possivelmente, a restos alimentares de corujas que se alojavam nesta cavidade natural (Payne, 1983).

A coleção deste sítio apresentou ainda 3 artefatos ósseos (pontas polidas) e 6 carapaças de moluscos com perfuração, sendo 5 sobre bivalves de água doce e uma sobre gastrópode marinho. As escavações do testemunho das atividades de campo de 1966/1970 permitiram ainda a identificação de restos ósseos humanos, distribuídos juntos à parede norte entre os $35 \mathrm{~cm}$ de profundidade e o piso do abrigo, indicando a possível presença de uma estrutura de cova. Correspondem a 30 fragmentos ósseos póscranianos de indivíduo(s) infante(s), com idade estimada em menos de 12 anos distribuídos de forma dispersa (Anexo 6 - planos 40 a 46). Sugere-se que o restante deste esqueleto estivesse associado às quadrículas contíguas ao testemunho, escavadas $27 \mathrm{Na}$ análise da coleção arqueofaunística do sítio RS-S-395: Deobaldino Marques também foram
identificados entre as aves, fragmentos ósseos de tucano (Ramphastos dicolorus), e entre os mamíferos, 
durante o PRONAPA ou jaziam em associação a partes desmoronadas do testemunho, talvez também afetadas por galerias de tatu. Foi ainda resgatado um dente humano associado à quadrícula D12 (nível 2), cujo contexto de associação não é claro (Anexo 6 - plano 10). Ao longo das escavações, foram resgatados também 10 fragmentos carbonizados de coquinhos, possivelmente de jerivá, associados às estruturas de fogueiras. Nos níveis 9 e 10 da quadrícula D12 foi identificada a presença de um buraco de $15 \mathrm{~cm}$ de diâmetro e $5 \mathrm{~cm}$ de profundidade escavado no piso arenítico, no interior do qual foram identificados limbos de folhas (Anexo 6 - planos 17 e 18).

O material lítico corresponde a um conjunto de 5037 peças, das quais 477 encontram-se registradas nos mapas planimétricos. Tendo em vista a composição e coloração escura dos sedimentos, a dimensão das peças e o tipo de matéria prima predominante (basalto), a identificação destes micro-vestígios de lascamento só foi possível após a lavagem dos sedimentos em laboratório. Este tipo de procedimento de coleta posterior à escavação permitiu resgatar 90,5\% dos vestígios líticos, indicando que a metodologia empregada nas escavações de 1966/1970 apresentou-se inadequada tendo em vista as características sedimentares deste sítio, gerando uma coleção com informações parciais sobre a realidade do conjunto lítico.

Assim como no sítio RS-S-360: Marimbondo, 85\% do material lítico corresponde a lascas unipolares inteiras e fragmentadas, apresentando a maioria dimensões inferiores a $2 \mathrm{~cm}$. O restante da coleção lítica é composto por lascas bipolares, fragmentos térmicos e placas de basalto utilizadas como suporte de lascamento. A quantidade de artefatos é proporcionalmente menor se comparada ao sítio anterior, representando menos de $1 \%$ da amostra de peças líticas, sendo representadas por peças bifaciais, pontas de projétil e lascas retocadas, entre outras, cuja análise será tratada no capítulo 6. 


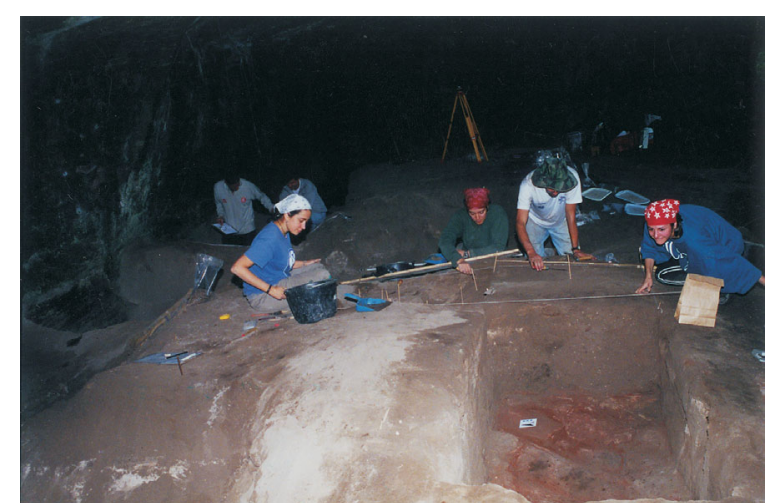

9. RS-S-327 - Piso arenítico base da sondagem e início da escavação do entorno. Foto: Adriana Dias

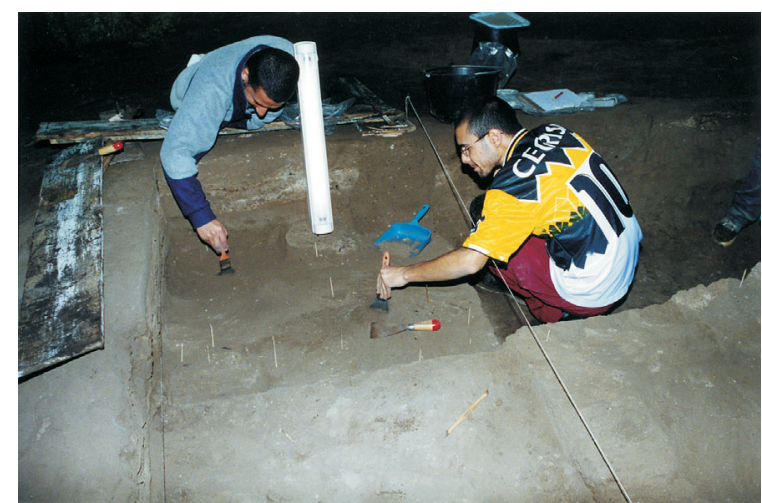

11. RS-S-327 - Utilização de luz artificial para escavação da quadrícula D12. Foto: Adriana Dias

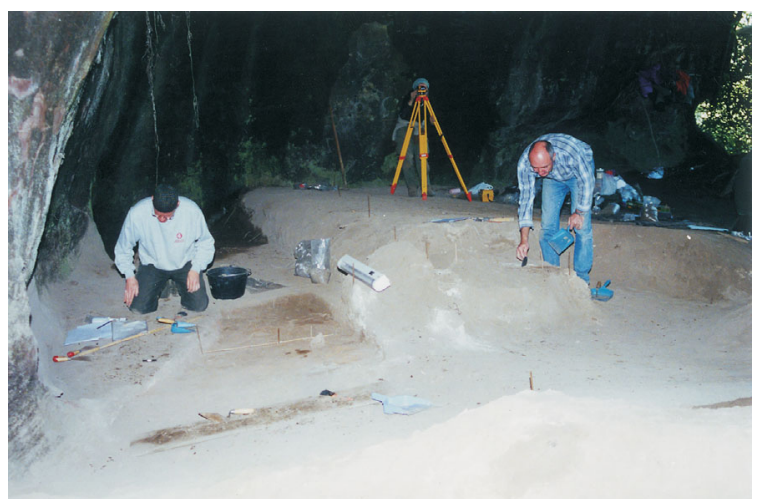

13. RS-S-327 - Escavações do testemunho e das quadrículas G8 e F8. Foto: Adriana Dias

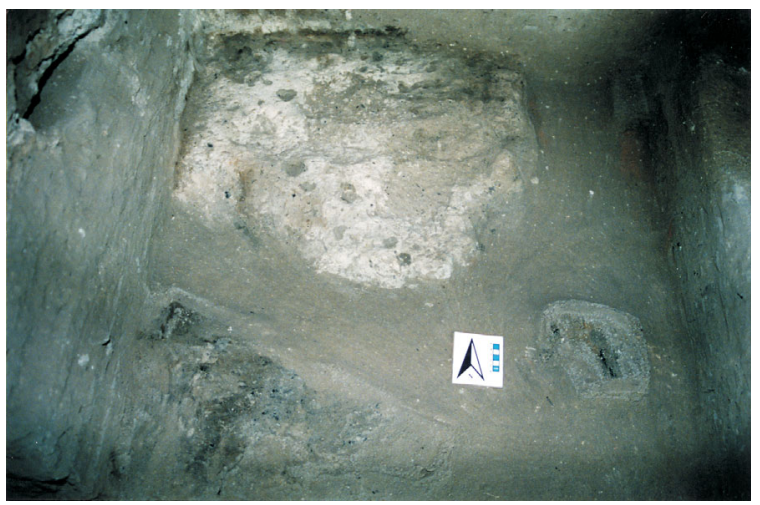

15. RS-S-327 - Detalhe de fogueira e lente de carvões na quadrícula E13. Foto: Adriana Dias

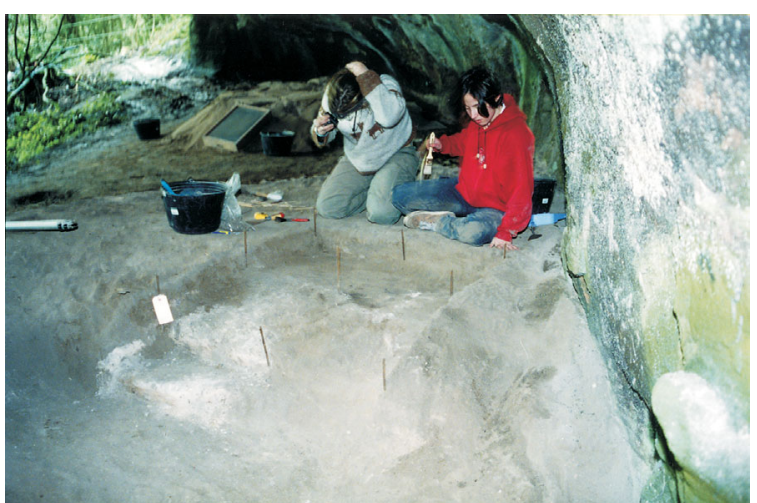

10. RS-S-327 - Detalhe da fogueira na quadrícula F16. Foto: Adriana Dias

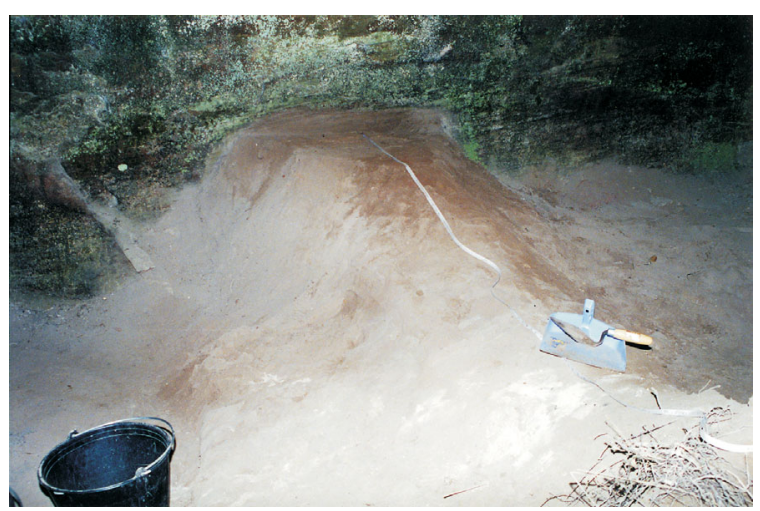

12. RS-S-327 - Testemunho das escavações do

PRONAPA junto à parede norte. Foto: Adriana Dias

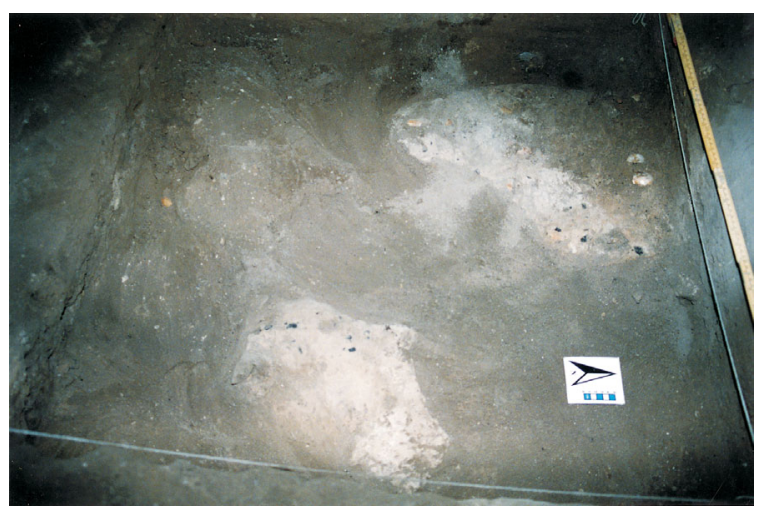

14. RS-S-327 - Detalhes de fogueiras da quadrícula E12. Foto: Adriana Dias

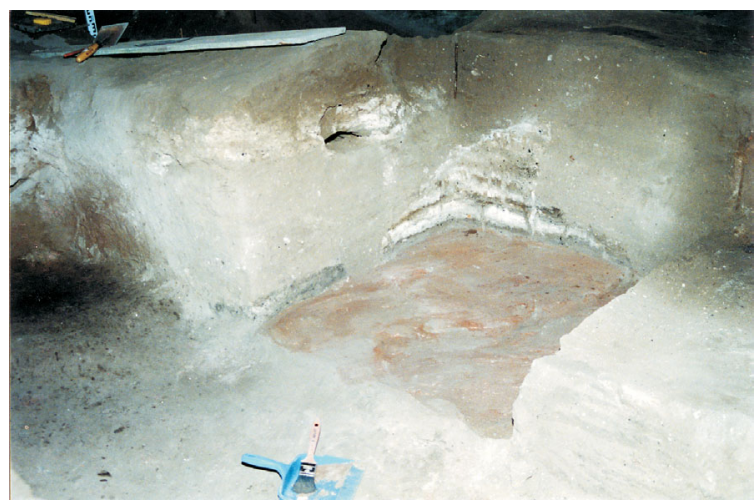

16. RS-S-327 - Detalhe do perfil e evidência do piso na quadrícula E13. Foto: Adriana Dias 


\subsubsection{Sítio RS-S-337: Monjolo}

As escavações do sítio RS-S-337: Monjolo ocorreram em duas etapas de campo entre 3 e 31 de julho de 2001 e 3 e 31 de janeiro de 2002. Na primeira etapa foi escavada uma área de $12 \mathrm{~m}^{2}$, sendo realizadas 6 quadrículas em torno da sondagem efetuada em fevereiro de 2000, e o restante distribuindo-se entre as sondagens da área central do abrigo, descritas no capítulo anterior. A ampliação das escavações revelou uma ocupação histórica sobreposta a um bloco de arenito de $8 \mathrm{~m}$ de extensão, situado a uma profundidade entre 20 e $45 \mathrm{~cm}$. Os sedimentos mostraram-se arenosos, de coloração marrom clara e consistência compacta em função do pisoteio pelo gado, já que o sítio foi utilizado por vários anos como curral, apresentando o primeiro nível uma camada orgânica, associada a estrume. Foram identificadas 3 zonas de fogueiras, com concentração de carvões e ossos associadas à cerâmica do século XVIII, entre profundidades de 10 a $20 \mathrm{~cm}$ (foto 17).

Ao todo foram registrados nas fichas de plotagem 138 fragmentos de cerâmica neobrasileira (fase Monjolo), 1 fragmento de cachimbo de cerâmica, 421 fragmentos ósseos (na maioria, bovídeos), 91 fragmentos líticos (em geral, placas de basalto e fragmentos térmicos associados às fogueiras), 1 pederneira em sílex, 3 fragmentos de metal (ferro), 1 brinco (ouro e topázio) e 3 fragmentos de faiança portuguesa. A semelhança deste conjunto com a coleção do sítio RS-S-263: Guarda Velha 2, situado a aproximadamente $4 \mathrm{Km}$ do abrigo, na margem direita do rio dos Sinos, permite levantar duas hipótese preliminares quanto a esta ocupação, podendo estar relacionada a acampamentos de tropeiros em trânsito pela Guarda de Viamão ou corresponder a um possível refúgio de escravos foragidos ${ }^{28}$.

Na segunda etapa dos trabalhos, foi escavada uma área de $19 \mathrm{~m}^{2}$ distribuída em dois setores em torno das sondagens realizadas em julho de 2001, tendo por objetivo à caracterização da ocupação caçadora coletora deste sítio e obtenção de amostras para datação a fim de observar sua correlação com os demais abrigos escavados na área (fotos 18, 19 e 20). Optou-se também por recolher os sedimentos das peneiras para lavagem em laboratório, a fim de resgatar micro-vestígios arqueofaunísticos e líticos.

\footnotetext{
${ }^{28}$ A contextualização histórica da ocupação do sítio RS-S-337: Monjolo encontra-se no próximo capítulo, sendo que os aspectos da ocupação histórica deste sítio fazem parte do projeto de tese de doutorado de Cláudio Carle (2001), junto ao Programa de Pós-graduação em Arqueologia da PUCRS, com defesa prevista em agosto de 2004.
} 
Contudo, este procedimento mostrou-se pouco produtivo se comparado a sítio anterior, não contribuindo significativamente esta atividade de laboratório para a ampliação da amostra de material já coletada nas peneiras durante as escavações.

Um primeiro setor da escavação corresponde a 8 quadrículas distribuídas em torno da sondagem B11/B12, junto à linha de goteira do abrigo (Anexo 5 - perfis 12 a 16; Anexo 6 - planos 49 a 68). Estas revelaram uma interface entre as ocupações históricas e caçadoras coletoras, distribuída em torno de uma área de queda de blocos. A ocupação histórica está relacionada às quadrículas A12, A13, A14, B14, B13 e C13, associada à face leste e sul da área de queda de blocos do teto identificada durante as escavações. A ocupação caçadora coletora está relacionada à face oeste desta zona de queda de blocos, compreendendo as quadrículas B12, B11, C11 e C12 (fotos 21 e 22).

O setor leste da área de queda de blocos está voltado para a abertura do abrigo, sendo a composição sedimentar representada por duas camadas distintas e de deposição recente, associados à ação eólica e à decomposição dos blocos. A primeira é caracterizada por apresentar sedimentos arenosos, de origem eólica, granulação fina, consistência compacta e coloração marrom clara, atingindo profundidades entre 5 e 25 cm. Sua compactação está relacionada ao pisoteio pelo gado, apresentando vestígios orgânicos de estrume e perturbações causadas pela presença de tocas de insetos (besouros). Estes sedimentos assumem progressivamente uma granulação mais grossa e uma coloração marrom mais escura, relacionados à decomposição dos blocos de arenito, atingindo uma profundidade máxima de $50 \mathrm{~cm}$ (foto 23). Nesta área observa-se, associada à primeira camada sedimentar, a presença de áreas de concentração de carvão distribuídas entre as quadrículas A12, A13 e B14, estando a maior parte das evidências arqueológicas deste setor relacionados a estas estruturas. Dos 30 aos $50 \mathrm{~cm}$ de profundidade, a presença de material arqueológico nesta área é bastante escassa, apresentando padrões de dispersão aleatórios. Amostras de carvão do nível 5 da quadrícula B14 foram datadas, em associação com uma costela de bovídeo identificada no nível 6, obtendo-se uma datação de 180+40 AP (Beta Analytics 165624), com calibração de 2 sigmas de 290 a 0 AP. Esta datação permite associar esta primeira camada sedimentar com o contexto histórico do século XVIII, oferecendo bases cronológicas para a interpretação da seqüência estratigráfica do setor oeste da área de queda de blocos (anexo 6 - planos 49 a 58).

A ocupação caçadora coletora apresenta-se relacionada às quadrículas B11, B12, C11 e C12, na face oeste da zona de queda de blocos, atingindo uma profundidade de 1 
m. A mesma camada arenosa fina e compacta que caracteriza os níveis ocupacionais do século XVIII nas quadrículas escavadas na porção leste está representada nesta área, com profundidades variadas entre 5 e $30 \mathrm{~cm}$, indicando intervenções da ocupação histórica sobre os conjuntos associados à ocupação caçadora coletora. Esta, por sua vez, está relacionada a um pacote sedimentar de características complexas e granulação mais grossa, que atinge profundidades entre $50 \mathrm{~cm}$ e $1 \mathrm{~m}$, até alcançar o piso arenítico do abrigo. Esta camada encontra-se distribuída diferencialmente sobre os blocos, com variação de coloração entre o marrom acinzentado e o marrom muito escuro, apresentando também uma granulação fina (foto 24). A ocupação caçadora coletora pode ser identificada mais claramente nas quadrículas B11 e C11 a partir dos 35 cm de profundidade, estando as quadrículas B12 e C12 ocupadas por blocos areníticos. Entre os 35 e os $60 \mathrm{~cm}$ de profundidade observa-se, principalmente na quadrícula B11, a presença de estruturas de fogueiras, representadas por concentrações de carvão, em torno das quais distribuem-se fragmentos ósseos e resíduos de lascamento atingindo também as quadrículas C11 e C12. Foi coletada uma amostra ${ }^{29}$ de carvão para datação a $90 \mathrm{~cm}$ de profundidade (nível 18) na quadrícula C11, apresentando uma datação de 7330+40 AP (Beta Analytics 165626) com calibração de 2 sigmas de 8160 a 7960 AP, correspondendo esta ao limite temporal mais antigo para a ocupação caçadora coletora neste sítio (Anexo 6 - plano 55 a 68).

As distinções entre as ocupações histórica e caçadora coletora neste setor da escavação também se evidenciam na composição e distribuição dos conjuntos arqueológicos. Foram registrados nos mapas planimétricos de escavação deste setor 3234 peças, das quais 65\% estão relacionadas às quadrículas do setor oeste da área de queda de blocos. Este conjunto é composto por 1418 fragmentos ósseos, 625 fragmentos de carapaças de gastrópodes terrestres, 190 fragmentos de carapaça de bivalves de rio, 804 fragmentos líticos, 12 fragmentos de cerâmica neo-brasileira (fase Monjolo), 12 fragmentos de metal (ferro), 48 dentes de animais, 6 dentes de felino perfurados, 14 fragmentos de coquinho de jerivá carbonizados e 105 fragmentos de carvão coletados como amostras para datação. Deste conjunto, 74\% dos fragmentos ósseos, 61\% dos fragmentos de bivalves e $72 \%$ dos fragmentos de gastrópodes concentram-se no setor oeste, relacionando-se a ocupação caçadora coletora. O conjunto total de peças líticas,

\footnotetext{
${ }^{29}$ Uma amostra de osso do nível 6 da quadrícula B11 foi enviada para datação por AMS, contudo não apresentou colágeno suficiente para análise.
} 
incluindo àquelas coletadas na peneira, é formado por 1806 evidências, das quais 55,5\% estão associadas às quadrículas do setor oeste. Observam-se também diferenças na composição dos conjuntos líticos entre as distintas áreas. Embora as lascas unipolares inteiras ou fragmentadas representem $52 \%$ do conjunto lítico das quadrículas relacionadas à ocupação histórica, estas não apresentam artefatos e possuem uma maior concentração de placas de basalto (22,\%) e fragmentos térmicos (24,5\%) em comparação com o setor oeste. Este, por sua vez, caracteriza-se por apresentar $75 \%$ de sua coleção lítica representada por lascas unipolares inteiras ou fragmentadas, estando também presentes, em menores proporções, núcleos $(0,2 \%)$ e artefatos $(0,8 \%)$, destacando-se uma ponta de projétil. As placas de basalto (11,3\%) e os fragmentos térmicos $(11,1 \%)$ representam o restante do conjunto lítico destas quadrículas, porém estão relacionadas mais intensamente aos primeiros níveis ocupacionais que sofreram intervenção da ocupação histórica do século XVIII.

A segunda área escavada correspondeu a 9 quadrículas distribuídas em torno da sondagem G16, na área central do abrigo, revelando igualmente uma sobreposição de ocupações históricas e pré-históricas (Anexo 5 - perfis 17 a 23). Observa-se para as quadrículas D17, E17, F17, G17, F16 e G16 a presença, entre a superfície os $40 \mathrm{~cm}$ de profundidade, de uma estrutura de material vegetal, possivelmente um teto de cabana, sob a qual foi evidenciada uma lente espessa de carvões e folhas, associada a uma estrutura de fogueira e vestígios arqueofaunísticos variados, destacando-se a presença de ossos de bovídeos (fotos 25 a 28). Foi realizada a datação de uma amostra de carvão do nível 4 da quadrícula F16, associada à fogueira localizada abaixo do teto de cabana. Esta indicou uma datação de $60 \pm 50$ AP (Beta Analytics 165622), apontando uma ocupação do início do século passado.

Logo abaixo desta estrutura, estendendo-se até os $75 \mathrm{~cm}$ de profundidade observa-se um pacote sedimentar homogêneo e marrom escuro, associado a vestígios arqueofaunísticos e líticos. Estes, porém, apresentam um padrão de distribuição aleatória, não se observando a presença de nenhum tipo de estrutura de fogueira como as registradas na escavação das quadrículas B11 e C11. Estas características, associadas à análise dos perfis de escavação relacionados às quadrículas G17, G16, G15 e G14, indicam que, possivelmente, esta área teria sido aterrada durante a ocupação histórica do século XIX, a fim de retificar o piso sobre o qual foi construída a cabana, já que o solo 
original também se apresentava irregular pela presença de grandes blocos desprendidos do teto, distribuídos entre as quadrículas F14, G14, G15, G16 e F16 (foto 29). Os sedimentos utilizados para este aterro seriam, possivelmente, provenientes do fundo do abrigo, onde se situa um buraco de 10 x $5 \mathrm{~m}$, com $50 \mathrm{~cm}$ de profundidade, caracterizando-se pela mistura de materiais históricos do século XVIII e pré-históricos que estavam associados a ocupações pretéritas junto à parede oeste do abrigo.

A fim de testar esta hipótese, uma sondagem de $2 \mathrm{~m}^{2}$ foi escavada junto à parede oeste ao lado deste buraco (quadrículas M25 e M26), evidenciando uma estrutura de fossa culinária altamente preservada estendendo-se até uma profundidade de $75 \mathrm{~cm}$ (fotos 30 e 31). Esta apresentou alta densidade de carvão, materiais arqueofaunísticos, como restos de bovídeos, suínos e caça selvagem, além de grande quantidade de cerâmica associada à tradição Neo-brasileira (fase Monjolo). Igualmente, a fim de compreender as características sedimentares deste aterro foi datada uma amostra de calcâneo de veado associado ao nível 20 da quadrícula G17 que confirmaram as perturbações antrópicas recentes deste contexto, sendo obtido um resultado de $220 \pm 40$ AP (Beta Analytics 165627), com calibração de 2 sigmas de 310 a 260 AP, 220 a 140 AP e 20 a 0 AP. Os resultados desta sondagem, associada à datação obtida para a quadrícula G17 e a análise das plantas de escavação e dos perfis, confirmam a presença deste aterro histórico até $75 \mathrm{~cm}$ de profundidade

Nesta área central do abrigo uma ocupação caçadora coletora mais clara só foi evidenciada nas quadrículas G16, F16, G15 e G14, entre os 75 cm e 1,20 m de profundidade, quando surgem resíduos de lascamento e estruturas de fogueira a semelhança das identificadas nas quadrículas C11 e B11 (Anexo 6 - planos 69 a 78). Para amostras de carvão associadas ao nível 15 das quadrículas F16 e G16, obteve-se, respectivamente, as datações de $520 \pm 70$ AP (Beta Analytics 165623), com calibração de 2 sigmas de 650 a 470 AP, e $440 \pm 90$ AP (Beta Analytics 165621), com calibração de 2 sigmas de 640 a 590 AP e 560 a 300 AP (Anexo 6 - plano 69). Ambas datações correspondem ao limite mais recente da ocupação caçadora coletora no Alto Vale do Rio dos Sinos e estão associadas a duas áreas de fogueira contíguas. Estas 4 quadrículas foram escavadas até $1 \mathrm{~m}$ de profundidade, tendo sido aprofundado apenas um setor de 50 x $50 \mathrm{~cm}$ da quadrícula G16 até ser evidenciado o piso arenítico a uma profundidade de 1,2 m. Nesta foi obtida uma amostra de carvão datado por AMS, com um resultado de $5230 \pm 40$ AP (Beta Analytics 165625) com calibração de 2 sigmas de 6100 a 6070 AP e 6020 a 5920 AP (anexo 6 - plano 78). 
Em termos gerais, este abrigo apresenta características estruturais distintas dos demais da área, apresentando sua aba evidências de processos intensos de queda de blocos associados aos planos de diaclasiamento do arenito (foto 32). Estas características tornaram-se evidentes ao longo das escavações que revelaram, em distintos pontos do abrigo, a presença de concentrações de blocos de arenito derivados do teto, cuja decomposição contribuiu para a formação do pacote sedimentar. A altura da aba (em torno de 20 m), a extensão da abertura, sua posição topográfica no topo de um morro testemunho e sua orientação leste, determinam também que a ação eólica contribuísse intensamente para a formação do pacote sedimentar.

A presença destes blocos, por sua vez, também influenciou a forma de ocupação do espaço do abrigo ao longo do tempo. Observa-se que a ocupação caçadora coletora preferencialmente ocorre junto a faces de áreas de queda de blocos protegidas dos ventos que vêem do sul e do nordeste. Por sua vez, o comportamento das ocupações históricas identificadas apresenta-se distinto, optando as ocupações do século XVIII por ocupar áreas mais regulares do piso, mesmo expostas ao vento, ou realizar aterros sobre as áreas de concentrações de blocos com o objetivo de regularizar o piso, como foi observado para a ocupação do século XIX. Portanto, o principal processo de distúrbio pós-deposicional que afetou as ocupações caçadoras coletoras estão relacionadas às ocupações históricas dos séculos XVIII e XIX. A utilização deste abrigo como curral nas últimas décadas acelerou os processos erosivos dos sedimentos no seu setor sul e sua utilização recente como templo da comunidade católica do Monjolo tem contribuído para afetar as características estruturais do sítio através da instalação de bancos e outras estruturas, como altar, canteiros de plantas, entre outros.

Em função destas características deposicionais e pós-deposicionais, este abrigo caracteriza-se por apresentar uma estratigrafia complexa, sendo difícil correlacionar as ocupações caçadoras coletoras nas distintas áreas unicamente através da comparação entre as seqüências estratigráficas identificadas e sua relação com as datações obtidas. Desta forma sugere-se que as ocupações de caçadores coletores identificadas representam distintos episódios que ocorreram ao longo de aproximadamente 7000 anos e que se distribuíram espacialmente em função da topografia original do sítio. Esta, por sua vez, encontra-se “mascarada” pelas alterações antrópicas sofridas ao longo dos últimos 250 anos que produziram um aplainamento artificial da superfície do sítio. 


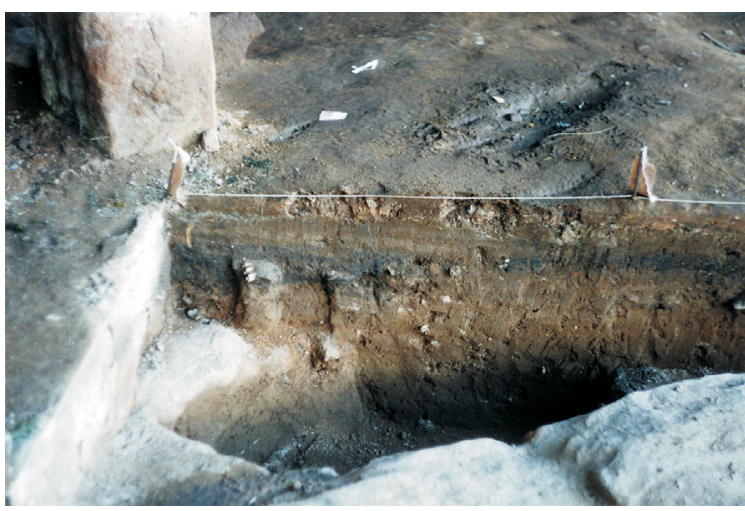

17. RS-S-337 - Detalhe do perfil de fogueira do século XVIII na quadrícula E6. Foto: Claudio Carle

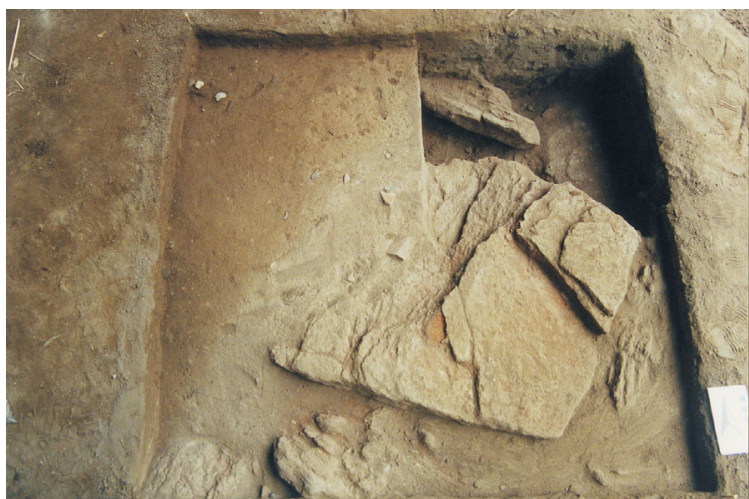

19. RS-S-337 - Detalhe da área de queda de blocos, sondagem B12. Foto: Claudio Carle

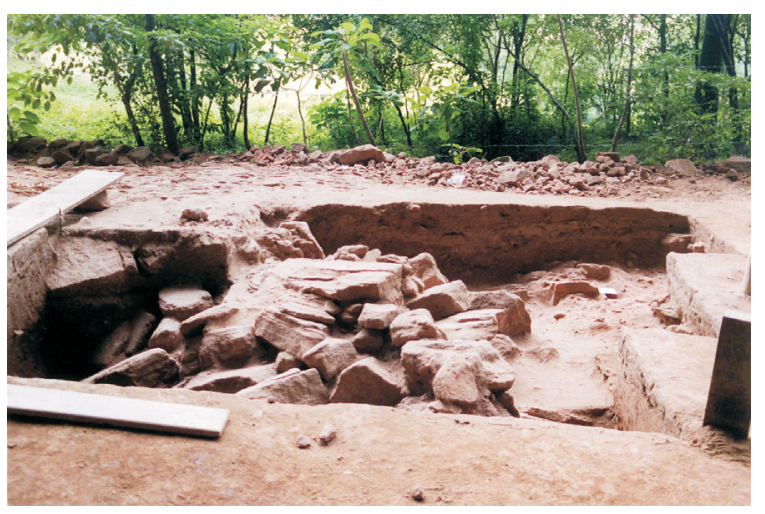

21. RS-S-337 - Escavação junto à abertura, associada à ocupação caçadora-coletora. Foto: Adriana Dias

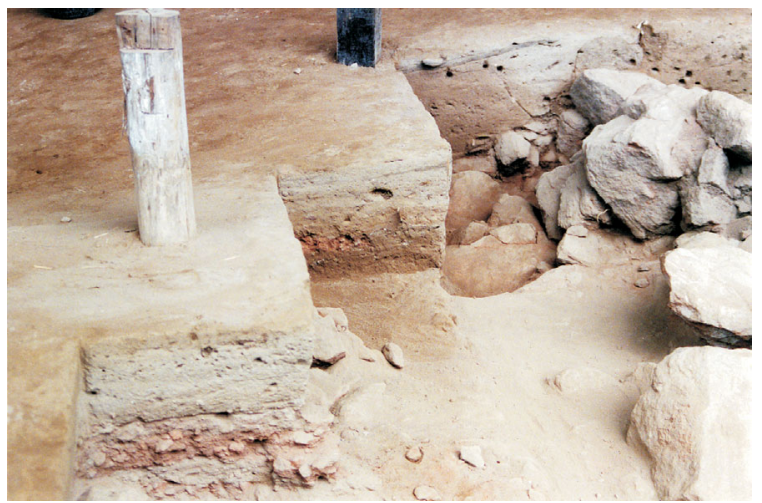

23. RS-S-337 - Detalhe do perfil oeste, quadrículas A14 e B14. Foto: Adriana Dias

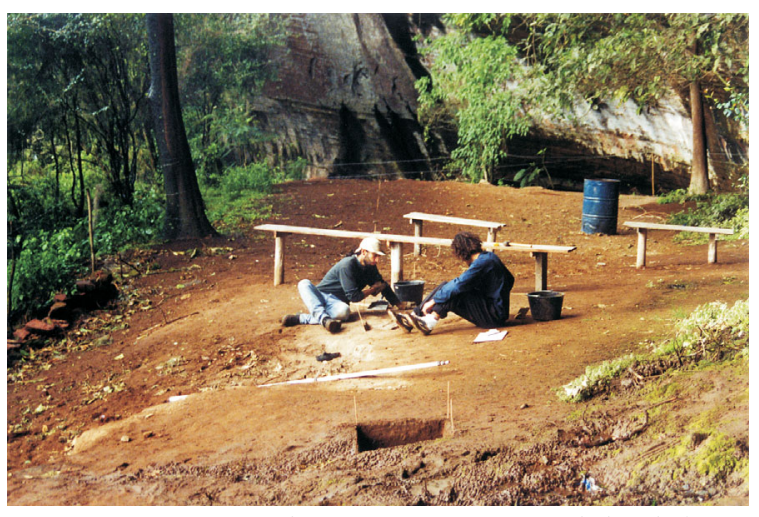

18. RS-S-337 - Sondagens na área central do abrigo. Foto: Claudio Carle

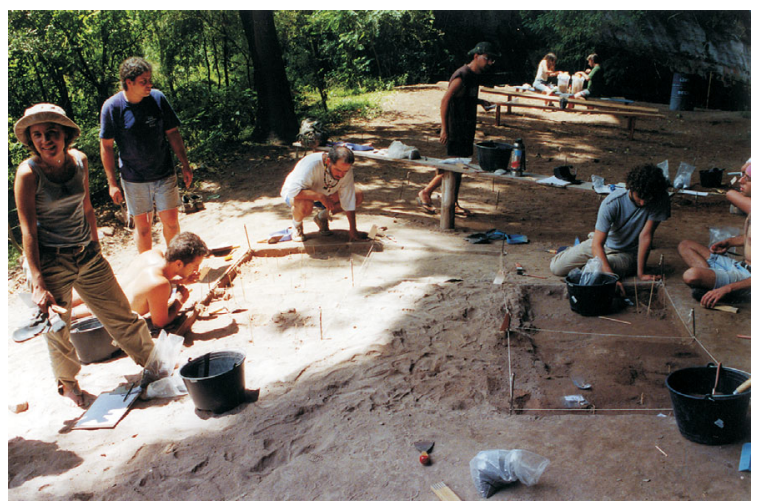

20. RS-S-337 - Ampliação das escavações em torno da sondagem. Foto: Adriana Dias

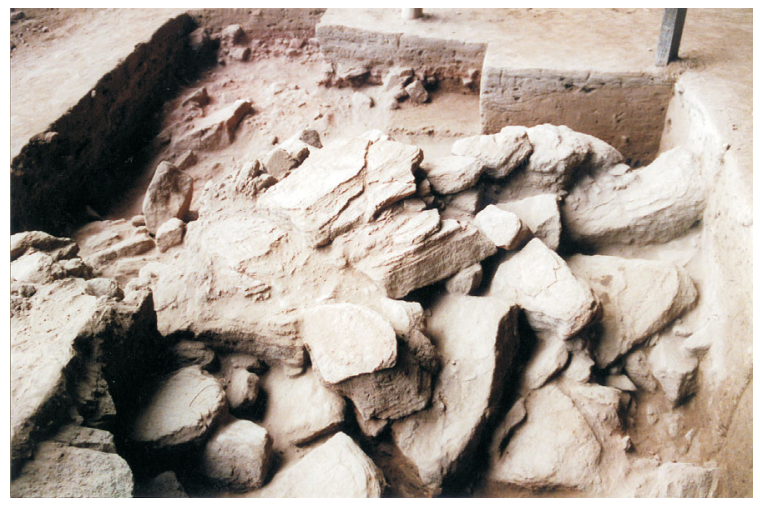

22. RS-S-337 - Detalhe da área da queda de blocos, porção oeste. Foto: Adriana Dias

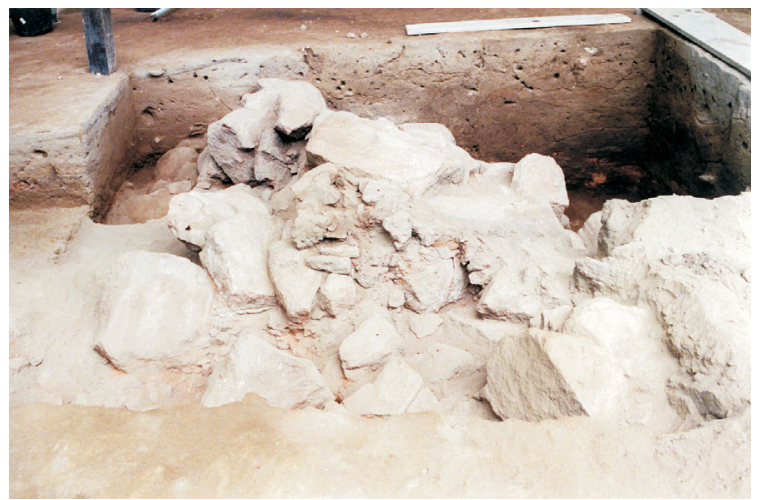

24. RS-S-337 - Perfil oeste das quadrículas C13,.C12 e C11. Foto: Adriana Dias 


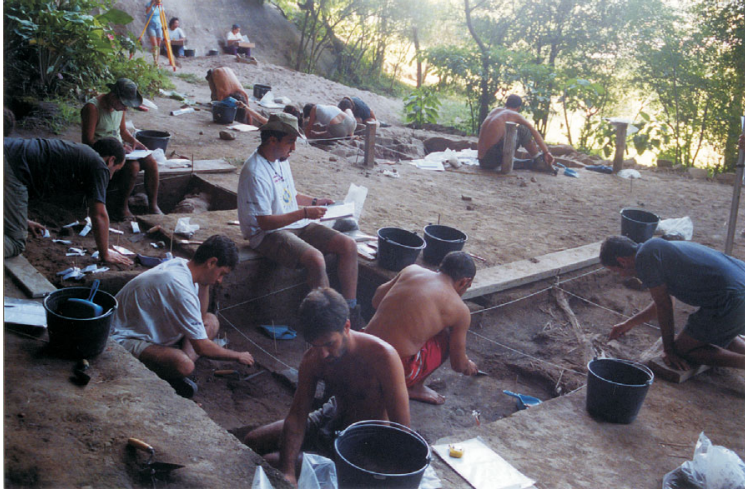

25. RS-S-337 - Detalhe das escavações na área central do abrigo. Foto: Adriana Dias

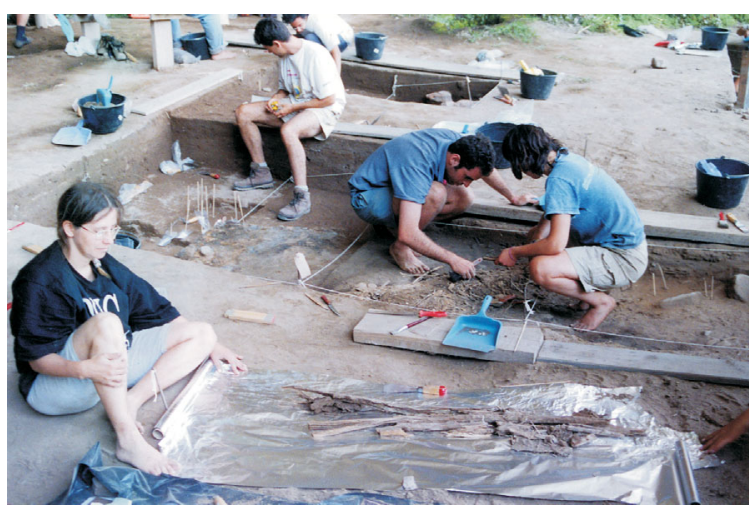

27. RS-S-337 - Escavação de estrutura (possível teto de cabana) do século XIX. Foto: Adriana Dias

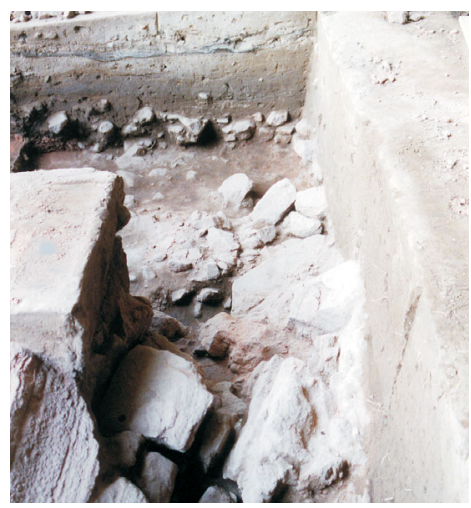

29. RS-S-337 - Área de queda de blocos do teto. Foto: Adriana Dias

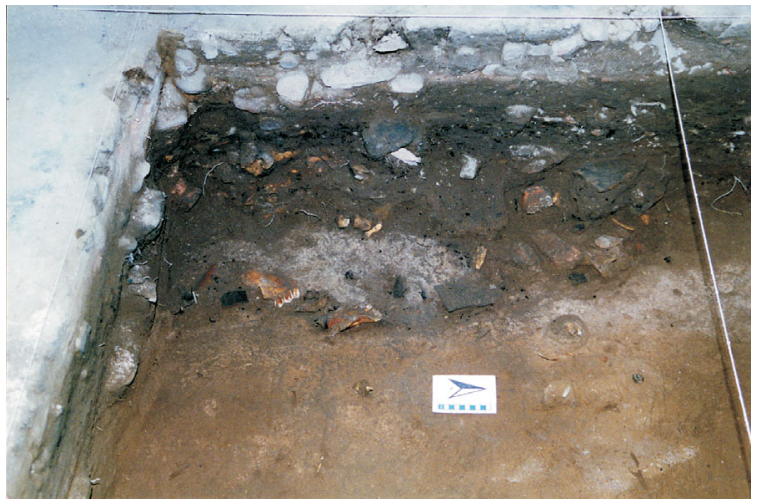

31. RS-S-337 - Detalhe de fossa culinária do século XVIII. Foto: Adriana Dias

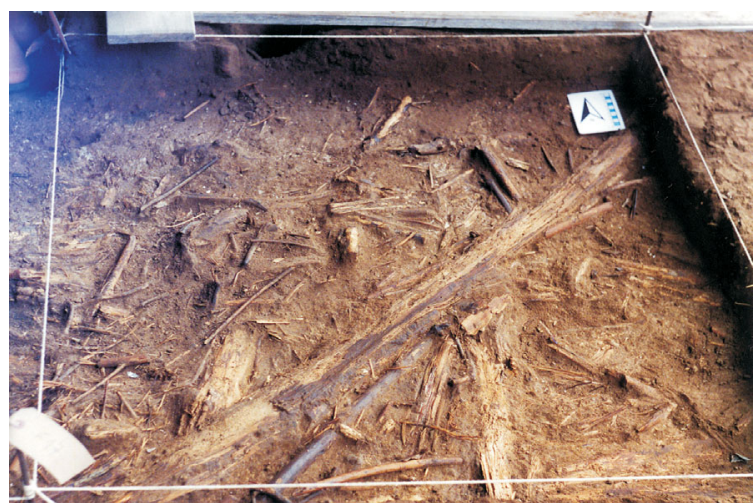

26. RS-S-337 - Detalhe de esteio central de estrutura de teto cabana do século XIX. Foto: Adriana Dias

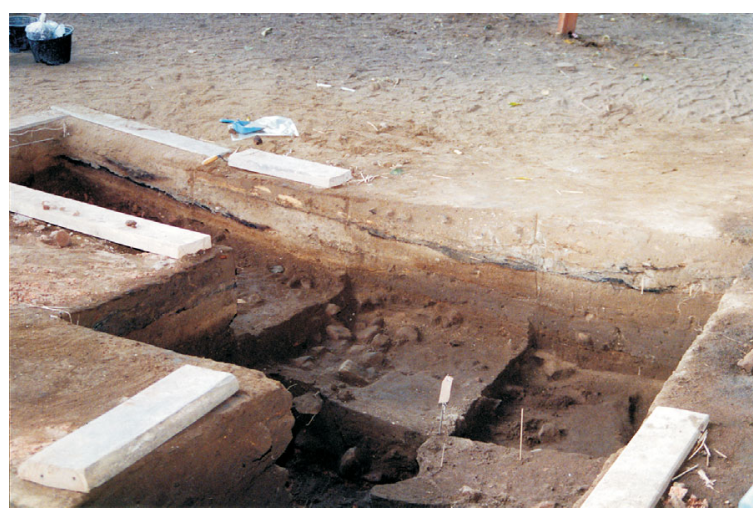

28. RS-S-337 - Detalhe da lente de carvão associada à ocupação do século XIX. Foto: Adriana Dias

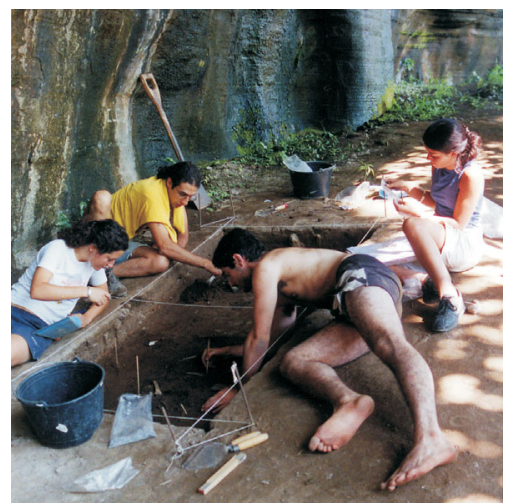

30. RS-S-337 - Sondagem M25 e M26. Foto: Adriana Dias

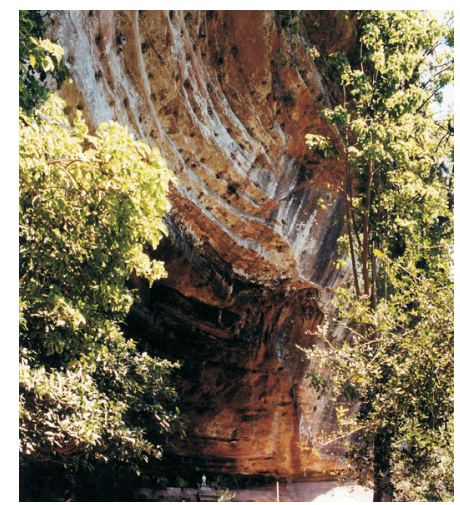

32. RS-S-337 - Vista do diaclasiamento da aba do sitio. Foto: Adriana Dias 


\subsection{Os Abrigos sob Rocha como Áreas de Atividades Domésticas: Aspectos da Variabilidade Inter-sítios para os Caçadores Coletores do Alto Vale do Rio dos Sinos}

As escavações realizadas nestes três sítios orientaram-se a fim de testar a hipótese de que as ocupações de abrigos sob rocha na região do Alto Vale do Rio dos Sinos corresponderiam predominantemente a unidades habitacionais, sendo os conjuntos artefatuais e estruturas resgatados característicos de áreas de atividade domésticas. Estes sítios fariam parte de um sistema de assentamento que abrangeria a região nordeste do Estado, tendo sido ocupados de forma continuada ao longo de 8.000 anos. Partindo do modelo de mobilidade assumido, estes abrigos teriam sido ocupados como bases residenciais por breves períodos de tempo pelos bandos locais que percorriam o território regional do grupo ao longo do seu ciclo anual de mobilidade. A curta permanência nos sítio redundaria em uma baixa densidade de material arqueológico, sendo estes caracterizados, predominantemente, por unidades de deposição primária. Devido a grande disponibilidade de abrigos na região estudada, os sítios teriam sido ocupados em diferentes momentos pelos grupos co-residentes, sendo que dificilmente mais de um abrigo teria sido utilizado em um mesmo momento.

Analisando os mapas de distribuição de artefatos e estruturas gerados pelas escavações dos três sítios acima descritos (Anexo 6), observa-se que há redundâncias de associação entre estruturas associadas a fogueiras e conjuntos de vestígios arqueofaunísticos e líticos. Embora as características estruturais e pós-deposicionais de cada abrigo tenham gerado variações no padrão de distribuição destes conjuntos arqueológicos numa perspectiva inter-sítio, há redundâncias intra-sítio nas formas de ocupação dos abrigos, com padrões repetitivos de sobreposição de áreas de atividade representadas pelas fogueiras. Em todos os abrigos escavados observa-se um padrão recorrente de associação entre estruturas de fogueiras que apresentam em sua periferia conjuntos de fragmentos arqueofaunísiticos e resíduos de lascamento, indicando um padrão de descarte primário, interpretados como evidências de ocupações rápidas, sendo baixo o índice de descarte de artefatos formais.

Tomando por base a literatura etnoarqueológica para caçadores coletores de floresta tropical, partimos do princípio que cada fogueira identificada nas escavações representa uma unidade doméstica relacionada a um dos grupos familiares que compõem o bando local, sendo o padrão de descarte primário associado à fogueira 
doméstica característico de sítios de ocupação breve. Os vestígios arqueológicos destas ocupações estariam relacionados, principalmente, a atividades cotidianas de preparação, distribuição e consumo de alimentos, bem como produção e manutenção de artefatos. Em termos gerais, dentre os conjuntos líticos descartados junto às unidades domésticas haveria uma maior tendência à concentração de resíduos associados à produção e manutenção de artefatos formais (tecnologia de curadoria) relacionados às atividades de caça, como as pontas de projétil. Estes, por sua vez, seriam descartados em baixa freqüência, em geral, quando fraturados ou quando se mostraram inadequados durante do processo de produção/manutenção. Os artefatos informais (tecnologia expediente) produzidos sobre lascas unipolares ou bipolares e utilizados em atividades cotidianas variadas tanto na preparação e consumo dos alimentos, quanto na produção de outros artefatos sobre material perecível, apresentariam, por sua vez, uma maior freqüência de descarte junto às unidades domésticas. Observaria-se também uma tendência a deposição junto às unidades domésticas de conjuntos de artefatos de maior porte (como núcleos, percutores, morteiros ou bifaces) e acúmulos intencionais de matérias primas de boa qualidade para lascamento ali deixados em antecipação a usos futuros quando houvesse a possibilidade de re-ocupação do sítio (site furniture).

A estrutura e tipos de vestígios arqueológicos associados aos sítios habitacionais relacionados a um sistema de assentamento relacionado à Tradição Umbu seria semelhante tanto a céu aberto, quanto em abrigo sob rocha, pois obedeceria ao mesmo modelo simbólico de apropriação e uso do espaço. As variações intra-sítio observadas na ocupação de abrigos resultariam, portanto, de adaptações à utilização destes espaços restritos. Por sua vez, as condições mais favoráveis de preservação de vestígios orgânicos em abrigos sob rocha são um indicador importante de atividades domésticas, que geralmente encontram-se ausentes em sítios a céu aberto. Desta forma, a caracterização das indústrias dos sítios escavados, a ser tratada no capítulo 6, pode trazer subsídios fundamentais para a interpretação funcional de contextos domésticos similares a céu aberto, distribuídos em outras áreas da região sul nos quais estas condições de preservação estão ausentes.

Quanto aos vestígios arqueofaunísticos observados nos três sítios escavados, estes apresentam semelhança em termos de contexto de deposição e padrão de fratura descritos para os Nukak e os Aché. Com exceção do porco do mato no caso Nukak, em geral, os animais abatidos são levados inteiros para o acampamento residencial, onde são preparados, distribuídos, consumidos e descartados junto às unidades domésticas, 
sendo os ossos fraturados para a extração de tutano. Embora até o presente não tenha sido realizado um estudo tafonômico detalhado dos conjuntos arqueofaunísticos associados aos sítios escavados que possa indicar um padrão de fragmentação intencional dos ossos para extração de tutano ou mesmo produção de artefatos, observase o predomínio de um padrão de descarte primário dos fragmentos ósseos sempre associado à periferia imediata ou interior das fogueiras, indicando ausência de manutenção ou limpeza nas áreas domésticas. A associação em torno das fogueiras de micro-vestígios de lascamento e concentrações intencionais de matéria prima na forma de placas de basalto coletadas nos cursos de água próximos aos abrigos reforçam a interpretação destes sítios como áreas de atividade doméstica.

Como estes abrigos sofreram vários episódios de reocupação e possuem ritmos variados de sedimentação, não se pode definir, com base nos dados disponíveis, limites claros entre distintas unidades domésticas, tanto em termos diacrônicos quanto sincrônicos. Os dados registrados ao longo das escavações apontam para uma tendência de palimpsestos arqueológicos, sendo provável que as sucessivas ocupações ao longo do tempo mesclaram suas evidências, tendo em vista a tendência à reutilização de certos locais preferenciais nos abrigos para localização das fogueiras. Porém, de acordo com o modelo adotado é provável que os abrigos escavados abrigassem mais de uma família por vez, cada qual com sua unidade doméstica própria, distribuindo-se as fogueiras familiares próximas entre si com um padrão de dispersão determinado pela topografia de cada abrigo. Este padrão pode ser evidenciado no sítio RS-S-360: Marimbondo, no qual se observa a distribuição das evidências arqueológicas concentradas em uma área de aproximadamente $50 \mathrm{~m}^{2}$ que correspondem a menos de $20 \%$ da área coberta do abrigo. A proximidade entre as fogueiras identificadas no sítio RS-S-327: Sangão também apontam para esta tendência, embora não seja possível definir a contemporaneidade entre estas. Ressaltamos ainda que ao longo das escavações não foi identificado nenhum indício quanto à presença de depósitos secundários, contudo sua possível existência em sítios em abrigo sob rocha não necessariamente indica ocupações mais prolongadas. Episódios de limpeza que gerariam este padrão de deposição de lixo somente em determinadas áreas do sítio podem ser resultantes de episódios de reocupação de abrigos com taxas de sedimentação mais lenta ou freqüências mais constantes de visita, aspecto que só pode ser analisado tomando por base conjuntos arqueológicos escavados através de uma metodologia adequada. 
Em termos gerais, observa-se que apenas alguns abrigos da região foram selecionados para serem ocupados pelos grupos caçadores coletores, sendo esta escolha determinada primeiramente em função de sua implantação na paisagem e condições de habitabilidade, desempenhando um papel secundário aspectos relacionados ao seu tamanho e a orientação. Estes fatores igualmente condicionam outros aspectos relacionados à variabilidade intra-sítio quanto à distribuição das áreas de atividade no espaço circunscrito do abrigo, bem como quanto às características dos conjuntos arqueológicos relacionados a sucessivos episódios de reocupação. Dentre os abrigos escavados, o sítio RS-S-360: Marimbondo é o que apresenta maior área disponível para ocupação humana, com aproximadamente $350 \mathrm{~m}^{2}$, porém apenas sua porção norte foi ocupada por possuir melhores condições de insolação e proteção contra a umidade (Anexo 7 - mapas de densidade ${ }^{30}$ de 1 a 4). O sítio RS-S-337: Monjolo também apresenta uma área ampla para ocupação humana, com aproximadamente $330 \mathrm{~m}^{2}$, no entanto suas condições de implantação na paisagem (topo de morro testemunho) e características estruturais (altura e orientação da abertura), tornam a área do abrigo muito exposta à ação do vento e do sol, circunscrevendo o estabelecimento das unidades habitacionais à proteção dos blocos que se desprenderam do teto. Embora as áreas escavadas tenham sido amplas neste sítio, observa-se recorrência de ocupação em apenas dois locais situados na proteção de blocos, associadas às quadrículas B11, C11, G16 e F16. Portanto, em ambos os sítios, os conjuntos arqueológicos registrados nas escavações caracterizam-se por episódios discretos de ocupação, restritos somente a determinadas áreas dos abrigos que apresentam melhores condições de habitabilidade.

O sítio RS-S-327: Sangão, por sua vez, possui a metade da área dos demais e orientação sul, contudo do conjunto de sítios da área parece ser o que apresenta maiores indícios de uma ocupação recorrente ao longo do tempo, com maior densidade de material arqueológico por $\mathrm{m}^{2}$ dispersos de forma homogênea por toda sua área (Anexo 7 - mapas de densidade 5 a 12). Tendo por base os dados obtidos, sugerimos que a escolha dos três sítios para ocupação humana esteja associada a sua área de implantação junto à várzea do rio dos Sinos, próximos a áreas de confluência, que corresponderiam a locais com maior concentração de caça. Contudo, a preferência pela ocupação do sítio RS-S-327: Sangão desde um período bastante recuado parece estar relacionada a sua

\footnotetext{
${ }^{30}$ Para a elaboração destes mapas de densidade para os sítios RS-S-360 e RS-S-327, optamos por avaliar as concentrações de conjuntos lítico do PRONAPA e das novas intervenções, em níveis de $10 \mathrm{~cm}$.
} 
maior proximidade com o rio, estando sua utilização sistemática associada a uma maior facilidade para atividades de coleta de bivalves e gastrópodes, bem como a pesca. Igualmente, este último abrigo apresenta melhores condições de proteção contra a chuva e o vento e sua orientação sul pode também ter representado um fator de atração, oferecendo proteção contra insolação acentuada no verão.

Os dados resultantes das escavações sugerem que para a região do Alto Vale do Rio dos Sinos a variabilidade intra e inter-sítios observada relaciona-se mais propriamente a aspectos de ordem deposicional e pós-deposicional específica a cada abrigo. Os tipos de evidências documentadas, apontam para um padrão similar de ocupação do espaço dos abrigos, marcado pela presença de áreas de atividade domésticas definidas a partir dos modelos etnoarqueológicos disponíveis para caçadores coletores de florestas tropicais (Anexo 6). Igualmente, sugerimos que não haja grandes distinções em termos de distribuição espacial e composição das indústrias lítica entre os conjuntos observados em nosso estudo de caso e as ocupações a céu aberto funcionalmente equivalentes, relacionadas a sistemas de assentamento da Tradição Umbu em outras áreas da região sul-brasileira, devendo esta hipótese ser testada através de estudos comparativos entre industrias líticas. No capítulo 6 buscamos testar esta hipótese através do estudo das coleções líticas de sete abrigos sob rocha da área piloto, derivadas das pesquisas do PRONAPA e das intervenções recentes, comparando estes dados com os resultados obtidos por Hoeltz e Hilbert (2000) na análise da coleção lítica do sítio a céu aberto RS-LC-76, também associada à Tradição Umbu.

O padrão de ocupação do espaço observado para a Região do Alto Rio dos Sinos interpretado a luz de um modelo de mobilidade para caçadores coletores também pode servir como referência para a análise interpretativa de contextos arqueológicos caracterizados por uma maior densidade de material arqueológico a céu aberto. Sítios a céu aberto com alta densidade de materiais em sistemas de assentamento marcados pela alta mobilidade podem estar relacionados à reocupação recorrente de pontos estratégicos na paisagem, que concentram determinados tipos de recursos com disponibilidade sazonal ou não, obedecendo a reutilização destes espaços aos mesmos critérios que levam a ocupação recorrente de abrigos. Sítios a céu aberto associados a áreas litorâneas, lacustres ou alagadiças, bem como cursos fluviais de grande porte, podem estar associados a pesca, a coleta ou a caça de espécies migratórias, devendo a interpretação do seu conjunto arqueológico ser mediada pela análise de suas características de implantação na paisagem. Este tipo de estratégia também pode estar 
relacionado aos processos que deram origem às especializações adaptativas voltadas à exploração de recursos costeiros, observados no litoral sul-brasileiro, bem como lacustres e de áreas alagadiças observadas nos cerritos ou aterros do Rio Grande do Sul e do Uruguai.

Uma alta densidade de material lítico pode estar relacionada também a uma funcionalidade de sítio distinta da habitacional, associada à extração e preparação inicial de matérias primas, cujas coleções apresentariam características específicas a este tipo de atividade, passíveis de serem observadas através de análise comparativa com conjuntos líticos associados a unidades habitacionais. Por outro lado, uma alta densidade de materiais líticos característicos de unidades habitacionais pode estar associada ainda ao sistema ritual do grupo ou a contextos onde ocorreram restrições aos modelos de mobilidade tradicional em função da presença de outras populações nas mesmas áreas de domínio.

No primeiro caso, a presença de sítios associados ao contexto ritual, marcados por locais que apresentam arte rupestre ou concentração de sepultamentos, pode representar um fator de concentração periódica de distintos bandos locais, gerando concentrações de unidades habitacionais, não necessariamente sincrônicas, em suas nas proximidades. Este não parece ser o caso dos sítios a céu aberto relacionados aos sistemas de assentamento da Tradição Umbu no sul do Brasil, mas pode ser uma hipótese a ser testada para outros contextos da região sudeste, centro-oeste e nordeste do país.

No segundo caso, tendo em vista as cronologias atualmente disponíveis para a Tradição Umbu no sul do país, observamos a contemporaneidade destes grupos caçadores coletores com populações horticultoras das Tradições Taquara e Guarani. O contato com estes grupos e as disputas pelas áreas tradicionais de forragem podem ter afetado os modelos de mobilidade tradicionais dos grupos caçadores coletores, levando a restrições nos sistemas de mobilidade, com ocupações mais recorrentes dos mesmos espaços a céu aberto ou ainda maior permanência nos sítios.

Por fim, o modelo assumido para nosso estudo de caso relaciona-se a um ambiente de floresta sub-tropical que apresenta uma distribuição homogênea de recursos ao longo do ciclo anual, sendo a disponibilidade de matéria prima também regular na paisagem. Porém, este modelo pode apresentar variações para ambientes com produtividade sazonal ou disponibilidades de matérias primas mais restritas, como por exemplo às regiões de cerrado e floresta tropical do centro e norte do país. 


\section{Capítulo 5}

\section{Sistemas de Assentamento de Horticultores no Alto Vale do Rio dos Sinos: As Tradições Guarani e Taquara}

\subsection{Os Horticultores da Tradição Guarani no Alto Vale do Rio dos Sinos}

\subsubsection{Por um Modelo Etnoarqueológico do Sistema de Assentamento Guarani Pré-colonial do Sul do Brasil}

A arqueologia Guarani desenvolvida no sul do Brasil nas últimas quatro décadas pode ser dividida em duas tradições de pesquisa. A primeira está relacionada ao enfoque históricocultural associado à atuação do PRONAPA que enquadrou os contextos arqueológicos Guarani na Sub-tradição Corrugada que caracterizaria os sítios meridionais da Tradição Cerâmica Tupiguarani, estendendo-se ao longo da costa atlântica até o nordeste do país ${ }^{1}$. Uma segunda vertente da arqueologia Guarani deriva da revisão das propostas do PRONAPA, iniciada a partir do final da década de 1970, por José Justiniano Proenza Brochado. Participante do PRONAPA em sua fase de implantação, Brochado foi um dos primeiros a questionar os resultados do Programa referentes à interpretação dos contextos arqueológicos Guarani. Embora em termos teóricos suas propostas bebam das mesmas fontes do PRONAPA, a influência de Donald Lathrap em seu trabalho trouxe novas luzes para a elaboração de um modelo ecológico sob a dinâmica populacional Guarani, a partir de sua origem Amazônica (Brochado, 1984).

Baseado na relação entre estudos lingüísticos e arqueológicos, o autor propõe que a origem das proto-línguas da família Tupi-guarani teria se dado há aproximadamente 5.000 anos atrás na Amazônia Central. Por sua vez, esta diferenciação lingüística apresentaria correlação na cultura material, representada pelo surgimento de diversas tradições cerâmicas a

\footnotetext{
${ }^{1}$ Críticas ao modelo proposto pelo PRONAPA referente à arqueologia Guarani podem ser encontradas em Noelli (1993, 1999/2000) e Soares $(1997,1999)$.
} 
partir da Tradição Policrômica Amazônica ${ }^{2}$, sendo o processo de expansão destas tradições resultante de migrações associadas à pressão demográfica. O modelo de dispersão populacional de Brochado segue uma lógica de colonização dos espaços dos principais cursos fluviais, sempre motivada por causas demográficas e centrada em ambientes florestais relacionados a concepção de sistema de assentamento amazônico original.

No início da era Cristã, estas migrações teriam resultado em dois grandes blocos culturais, de origem comum, mas com características materiais distintas. A sub-tradição Guarani $^{3}$ teria se expandido desde a Amazônia até a foz do Rio da Prata, seguindo os cursos dos rios Paraguai, Paraná e Uruguai, circundando o planalto central brasileiro, em sua porção oeste e sul. A dispersão proto-Guarani em direção ao sul, possivelmente, deu-se através dos rios Madeira e Guaporé, com perdas das formas originais dos vasilhames e técnicas decorativas, relacionadas à sub-tradição Guarita, e aquisição de novas formas e tratamentos de superfície, como o corrugado, através de contato com as populações do leste boliviano e peruano. Uma segunda leva migratória, por sua vez, estendeu-se da Amazônia Central em direção à foz do Amazonas, onde em contato com as populações do baixo Amazonas a cerâmica adquiriu as características da sub-tradição Tupinambá que ocupou a costa atlântica, do nordeste ao litoral paulista.

Os trabalhos desenvolvidos por Brochado e colaboradores, entre as décadas de 1970 e 1990, proporcionaram um novo olhar sobre a cerâmica da Tradição Guarani, incorporando à análise destes conjuntos referenciais etnoarqueológicos, baseados em fontes etno-históricas do período do contato, para a interpretação funcional da variabilidade formal e decorativa dos vasilhames (Brochado, 1977; Brochado et al, 1990; Brochado \& Monticelli, 1994; La Salvia \& Brochado, 1989; Noelli \& Brochado, 1998). Esta linha de pesquisa frutificou ao longo da década de 1990, gerando uma série de modelos interpretativos para a arqueologia Guarani, voltados ao estudo da cultura material, da organização social e das formas de uso do espaço (Assis, 1995; Garlet \& Soares, 1998; Landa, 1995, 1999; Monticelli, 1995, 1999; Noelli, 1993; Noelli \& Dias, 1995; Soares, 1997; Tochetto, 1996; entre outros). Dentre estes destacamos o modelo ecológico proposto por Noelli (1993) como ferramenta fundamental

\footnotetext{
${ }^{2}$ Para um aprofundamento nas discussões lingüísticas e arqueológicas sobre o centro de origem dos Tupi ver Noelli (1993, 1996a, 1996b, 1998a), Urban (1996) e Viveiros de Castro (1996).

${ }^{3}$ A influência do modelo proposto por Brochado na arqueologia do sul do Brasil, fez com que nas duas últimas décadas, se tornasse de uso comum entre as novas gerações de pesquisadores referir-se a esta cerâmica como pertencente à Tradição Guarani, termo que incorporamos neste trabalho, embora não haja uma definição formal neste sentido em nenhuma publicação do autor.
} 
para a interpretação dos sistemas de assentamento da Tradição Guarani ${ }^{4}$. Baseado em uma extensa revisão da bibliografia dos cronistas do século XVI a XIX, com ênfase no Tesoro de la Lengua Guarani, escrito por Montoya entre 1612 e 1617. Noelli propõe um modelo que busca dar subsídios históricos e arqueológicos para a interpretação de aspectos espaciais das estruturas do assentamento Guarani e sobre as estratégias de captação de recursos para a subsistência e elaboração da cultura material ${ }^{5}$.

Segundo Noelli (1993: 247-250), as categorias que classificam os domínios territoriais entre os Guarani pré-coloniais refletiriam os laços de parentesco e reciprocidade em três níveis espaciais inclusivos: guará, tekohá e teii. O Guará é um conceito sócio-político que determina uma região definida, geralmente delimitada por rios. Neste, era assegurado o pleno direito do usufruto da terra para o uso exclusivo de seus habitantes, representado pela prática da roça e pela independência das áreas de pesca e caça. Para garantir a manutenção dos territórios conquistados, os Guará seriam formados por alianças entre várias aldeias, mantidas através de laços de parentesco e reciprocidade. De acordo com os jesuítas, alguns Guará seriam compostos por até 40 aldeias refletindo um modelo de ocupação e manutenção territorial baseado na reciprocidade, na guerra e na antropofagia. Os Guará, de acordo com os informes de vários jesuítas, estariam sob a liderança de uma pessoa de grande prestígio político e espiritual que dominava extensos trechos das bacias hidrográficas. É provável,

\footnotetext{
${ }^{4}$ Outras propostas interpretativas sobre os sistemas de assentamento Guarani foram sugeridas por Schmitz (1985b) e Rogge (1996), de acordo com uma orientação teórico-metodológica aliada à ecologia cultural. Em ambos os casos, interpreta-se o deslocamento de sedes de aldeia em função do esgotamento dos recursos naturais, a semelhança do modelo defendido por Meggers para a Amazônia (teoria dos fatores limitantes).

5 "Quase todas as informações históricas, etnográficas, ecológicas e arqueológicas nos conduzem a uma conclusão: haveria uma perseguição constante do ñande reko, modo de ser, 'ser o mais Guarani entre os Guarani', manifestado principalmente nas situações de conflito e de contato. Segundo Metraux, os Guarani seriam antes 'melhores difusores' de suas coisas do que inventores, atestando a priori as repetições apontadas historicamente e deduzidas para o período anterior ao contato com os europeus. (...) Os Guarani seriam representantes de uma sociedade etnocêntrica, impositora de comportamento, colonizadora e conquistadora de regiões e outras sociedades. Os Guarani, principalmente os anteriores ao século XVII, devem ser enquadrados entre as sociedades chamadas por Sahlins de 'prescritivas', ou seja, aquelas em que nada é novo, onde os acontecimentos são valorizados pela sua similaridade com a ordem vigente. (...) Tudo era efetivação e repetição. Tudo deveria ser conforme o 'estilo de vida aprovado'. (...) Desta forma, o habitus destas sociedades Guarani 'prescritivas' seriam o bem reproduzir das palavras e das coisas, linguagem igual, cultura material idêntica. (...) Como centro, foco fundamental do habitus e da prescrição, a educação é o meio pelo qual se dá a perpetração simbólica e material da ordem estabelecida. A palavra é o veículo primordial para estabelecer as bases necessárias à reprodução da ordem social Guarani. (...) A educação entre os Guarani visava e visa, sobretudo, a manutenção da tradição do ñande reko, nosso modo de ser, isto é, do teko, 'ser, estado de vida, condição, estar, costume, lei, hábito”” (Noelli, 1993: 15-16).
} 
portanto, que os rios principais da bacia Platina e da costa atlântica fossem subdivididos em vários Guará6.

Os Guará são compostos por unidades sócio-econômicas aliadas, denominadas tekohá, onde vão coexistir as multi-linhagens, ordenadas por laços de parentesco e reciprocidade. Sua área era bem definida, delimitada por arroios ou rios, e utilizada de forma comunal e exclusiva pelo grupo local, significando que estranhos só entravam com permissão. Era o espaço onde se reproduziam as relações econômicas, sociais e político-religiosas essenciais a vida Guarani. "Se o tekó era o modo de ser, o sistema, a cultura, a lei e os costumes, o tekohá era o lugar, o meio em que se davam as condições que possibilitavam a subsistência e o modo de ser dos Guarani” (Noelli, 1993: 249-250).

Por fim, os tekohá eram formados por teii isolados ou agrupados, em função das condições locais e políticas. O teii corresponde à parcialidade ou família extensa, sendo designada de teii oga a casa onde vivia a linhagem e de amundá o local da aldeia ou sede do tekohá. O teii corresponde à representação concreta da macrofamília ou linhagem ${ }^{7}$, por sua vez, subdividida em famílias constituídas, em média, por 6 pessoas, sendo a poligamia, aparentemente restrita a uma posição de prestígio no âmbito da aldeia. Uma teii oga poderia abrigar até 60 famílias nucleares, podendo as aldeias de grande porte possuir até 6 teii oga, sendo habitada por, aproximadamente, 2000 pessoas $^{8}$. Estima-se que, em função de alianças, um Guará de grande porte poderia conjugar em torno de 40 tekohá, sendo sua população total superior a 80.000 habitantes.

\footnotetext{
${ }^{6}$ A partir do mapa etnográfico de Teschauer (de 1918) e das fontes jesuíticas para o Rio Grande do Sul no período do contato com o europeu, Soares (1997: 191-202) aponta para a existência de cinco parcialidades (possíveis Guará) representados pelas regiões habitadas pelos Guarani, Tape, Caágua, Carijó e Arachane. Os Guarani, ocupariam a região das Missões, nas bacias dos rios Ijuí, Piratini e I-Camaquã, a noroeste do Estado, tendo sua área por limite sul o vale do rio Ibicuí. A região habitada pelos Tape teria como limites naturais a oeste o alto rio Ibicuí, ao norte a Serra Geral, a leste o vale do rio Caí e ao sul a Serra dos Tapes. O território dos Tape corresponderia à parte leste da Depressão Central e as regiões mais altas do planalto, a oeste do Alto rio Taquari. Os territórios dos Guarani e Tape seriam os com maior densidade demográfica quando do contato com os jesuítas. Os Caágua teriam sofrido mais intensamente a ação das bandeiras paulistas, com intensos deslocamentos populacionais, sendo possivelmente seu território original delimitado pela bacia do rio Jacuí ao sul, pelo rio Taquari, a oeste, e pela Serra do Mar, a leste. Por fim, a planície costeira abrigaria outras duas parcialidades, estando os Carijó na porção norte do litoral atlântico e os Arachane nas margens da Lagoa dos Patos, ao sul, sendo os primeiros também fortemente afetados pela ação das bandeiras.

7 Segundo Soares (1997: 82-83), o sistema de localidade que ordenaria as relações de parentesco entre os Guarani seria do tipo kindred, ou seja, famílias extensas que agregavam diversas famílias nucleares reunidas em torno de uma liderança política e/ou religiosa através de laços de parentesco sangüíneos e/ou político e/ou adotivos.

${ }^{8}$ As teii ogas eram instaladas próximas entre si na sede da aldeia (amundá) a fim de estreitar os laços de reciprocidade e parentesco, bem como para a proteção e segurança da coletividade (Soares, 1997: 126)
} 
O tekohá comporta um jogo entre três espaços distintos: a aldeia (amundá), as roças $(\operatorname{cog})$ e a vegetação circundante (caa). As roças ( $\operatorname{cog})$ iniciam-se fora do perímetro da aldeia, localizando-se a diferentes distâncias, de acordo com a sua antiguidade. Além das roças, inicia-se o espaço das matas, genericamente denominadas caa, no qual situam-se as áreas de pesca, coleta e caça e as jazidas litológicas e de argila. Nestas também estão outras áreas de manejo que podem refletir antigas ocupações ou a preparação para futuros assentamentos, levando a crer que o raio de ação do ambiente humanizado estendia-se por muitos quilômetros a partir da sede do tekohá (Noelli, 1993: 266). O tamanho da área de captação de recursos de um tekohá pode variar em função do grau de reciprocidade do conjunto multi-comunitário pertencente a um mesmo Guará, não sendo incomum a sobreposição de áreas de ação entre distintos tekohá. A partir dos dados etno-históricos e arqueológicos, estima-se em torno de 50 Km a área de captação de recursos de um tekohá ao longo do ciclo anual, a partir da sede da aldeia $^{9}$ (Noelli,1993: 252).

As roças eram divididas em lotes para cada família, cuja posição e tamanho eram definidos a partir do consenso com os demais ou arbitrado pelo chefe da linhagem (teiiru ou tuvichá), obedecendo a critérios relativos a sua posição hierárquica na família extensa. A relação cog-teii determinava a área total coberta pelas roças de um determinado tekohá. Através das fontes etno-históricas estima-se os lotes de roça para cada família entre 0,5 e 2 hectares, resultando em uma área cultivada de 30 a 120 hectares para uma teii oga de 60 famílias, não sendo possível determinar se as roças eram continuas ou interligadas (Noelli, 1993: 275-276). A formação de pomares, hortas medicinais e o cultivo plantas manufatureira também era desenvolvida em outros lugares além da roça, podendo situar-se junto às casas, no perímetro da aldeia, nas trilhas ${ }^{10}$ que ligam aldeias e roças entre si e em clareiras naturais ou artificiais associadas à derrubada de árvores para a coleta de madeira, mel ou insetos (Noelli, 1993: 265).

\footnotetext{
${ }^{9}$ Baseado em fontes históricas do período dos primeiros contatos, Soares (1997: 128) estima que as distâncias entre as aldeias seriam variáveis, desde um dia de viagem até $600 \mathrm{Km}$, ainda dentro dos limites do Guará. Dados etnográficos atuais apontam uma distância média de $50 \mathrm{Km}$ entre os povoados, apresentando compatibilidade com as estimativas de Noelli.

${ }^{10}$ As trilhas abertas na mata serviam para interligar a aldeia com as roças, o porto das canoas, os pesqueiros e outras aldeias, recebendo o nome de pê (caminho). Os Guarani tinham uma ampla rede de caminhos entre suas aldeias no Brasil meridional, que recebeu a designação histórica de peabirú, utilizada intensamente no início da ocupação européia, unindo o interior da bacia platina à costa Atlântica (Noelli 1993: 270-271).
} 
O desenvolvimento das roças possui características semelhantes às da vegetação sucessional natural. O cultivo de vegetais baseava-se no princípio de consorciamento de diferentes espécies, resultando na competição diferencial dos nutrientes por $\mathrm{m}^{2}$, criando resistência à disseminação de pragas e a diminuição dos impactos da erosão. A área de uma roça era utilizada por vários anos, na medida em que nela, além dos cultígenos de ciclo fenológico curto (2 a 3 anos), eram introduzidas também árvores frutíferas e plantas medicinais ou fornecedoras de matérias primas (Noelli, 1993: 262). Portanto, a evolução e distinção funcional das roças se alteravam de acordo com a sucessão secundária. Quando o número de plantas cultivadas diminuía, novas roças eram abertas em outros pontos, passando as antigas a corresponder a locais onde predominam atividades de coleta. Estes, por sua vez, ficariam em repouso por um período de no mínimo 20 anos, até que houvesse um estrato arbóreo característico de matas jovens, de mais fácil derrubada com machados líticos, para novamente ser transformados em roça (Noelli, 1993: 293).

Na prática, o processo de abandono da roça traduz a conversão de um sistema de cultivo de curto prazo, em um sistema de agricultura agroflorestal de longo prazo, resultando na possibilidade de ocupação permanente do mesmo assentamento sem esgotar a capacidade produtiva dos solos, da flora e da fauna. Dentro dos limites do tekohá haveria florestas primárias, não manejadas, e áreas de florestas secundárias, antropogênicas, com distintas idades e funções, sendo que algumas das antigas roças poderiam ser utilizadas por até 35 anos quando suas árvores frutíferas estivessem quase completamente desaparecidas no meio da densa vegetação sucessional. O manejo pode iniciar dentro da roça, com a preservação de árvores úteis durante a derrubada ou com o transplante de espécies da floresta primária e secundária para os locais de cultivo. Com esta contínua atividade, diversas áreas de cultivo em torno do raio de ação da aldeia são criadas para minimizar a procura de plantas úteis e maximizar a oferta de alimentos e matérias primas vegetais durante todo o ano. Gradativamente, o local da roça passa de um local exclusivo da agricultura de plantas anuais para um espaço de plantas perenes, a serem usadas até que os processos de sucessão secundária fechem as clareiras abertas na mata. Acompanhando o processo natural de sucessão secundária da vegetação, os cultivares deixam de ser o principal foco da atenção, para dar lugar ao uso de árvores frutíferas ou plantas manufatureiras que foram cultivadas desde a primeira semeadura já que seus ciclos fenológicos se iniciam alguns anos após o plantio (Noelli, 1993: 295-298). Igualmente, as áreas de roça, em seus diferentes estágios de 
desenvolvimento, são locais de atração de caça, sendo pontos preferenciais para a instalação de armadilhas (Noelli, 1993: 262).

As fontes etno-históricas e etno-botânicas consultadas por Noelli, permitiram o levantamento de 180 tipos de cultivares de ciclo anual variável para as roças Guarani no século XVI (distribuídos em 36 gêneros de plantas) e de pelo menos 307 tipos de plantas alimentícias ou com outros fins passíveis de ser coletadas pelos Guarani em suas florestas antropogênicas, garantindo um abastecimento anual de recursos vegetais variado, que permitiria a sustentação de ocupações de longa duração (Noelli, 1993: 278 e 294). Recursos advindos da caça, pesca e coleta de moluscos, insetos e mel complementariam o quadro de necessidades alimentares do grupo, sendo outro sustentáculo para a manutenção alimentar de assentamentos de longa duração para os Guarani. Portanto, a mudança de local de uma aldeia se daria mais por razões culturais do que em função do esgotamento dos recursos (Noelli, 1993: 262).

Na medida em que a floresta secundária representa a área majoritariamente utilizada para a subsistência Guarani, Noelli sugere que uma aldeia não seria instalada em um local que não fosse previamente manejado. O padrão de ocupação e colonização territorial dos Guarani seria temporal e espacialmente contíguo, refletindo um modelo de mudança de sede de aldeia dentro de locais anteriormente manejados no tekohá. Igualmente, uma aldeia poderia dividirse em função do crescimento populacional ou por dissidência interna, ocupando a nova aldeia a área mais externa dos locais manejados e a original permanecendo no mesmo sítio (Noelli, 1993: 301-303). Nas palavras de Noelli:

Baseado nas informações dos cronistas e etnógrafos pode-se constatar que o tekohá mantém-se enquanto área de domínio, mas sua sede (sítio arqueológico, aldeia) é que circula (...). As fontes de alimentação vegetais e animais contribuem para transformar o sítio arqueológico no epicentro de um domínio, em princípio, muito amplo, conquistado e conservado pela força da guerra, e mantido cotidianamente pela força do trabalho de uma sociedade que fez questão de reproduzir culturalmente o seu bom modo de viver, seu tekó, até quando lhe foi possível (Noelli, 1993: 381).

Por fim, a prática da guerra, associada a captura de prisioneiros para o ritual antropofágico, representaria a necessidade de expansão das fronteiras territoriais e de manutenção das áreas já ocupadas. A guerra de expansão de fronteiras seria a primeira etapa da conquista territorial, com a desagregação dos habitantes originais e instalação das 
primeiras áreas de manejo. O contínuo processo de expansão de fronteiras deixaria para trás os territórios colonizados por uma população estável com condições de manter e manejar suas terras. Se no momento de expansão de fronteiras era desenvolvida a guerra contra grupos nãoGuarani, posteriormente, a manutenção dos espaços já conquistados desencadeava entre os grupos Guarani, disputas pela instalação e manutenção das melhores áreas ${ }^{11}$. O aumento demográfico contribui neste processo, levando a instalação gradativa em locais cada vez menos propícios. No caso do Rio Grande do Sul este ritmo de expansão paulatinamente se dirigiria para os rios que tem suas nascentes no planalto, enquanto o ângulo de inclinação do solo mantém-se favorável à agricultura, obedecendo a um limite de 400 m de altitude (Noelli, 1993: 305-306).

É a partir do modelo de sistema de assentamento de Noelli que buscamos subsídios para interpretar o padrão de distribuição dos sítios da Tradição Guarani localizados no Alto Rio dos Sinos. Inicialmente descreveremos os contextos arqueológicos identificados e a seguir desenvolveremos nossas considerações sobre o modelo de implantação que representam.

\subsubsection{Os Sítios da Tradição Guarani do Alto Vale do Rio dos Sinos:}

\section{Características de Implantação}

Os 30 sítios da Tradição Guarani identificados distribuem-se, preferencialmente, nas meias encostas que circundam a drenagem do rio dos Sinos e de seus afluentes de maior volume de água, abrangendo uma área em torno de $120 \mathrm{Km}^{2}$ (tabelas 1 e 2). As altitudes médias estão em torno de 100 m, situando-se os sítios a uma distância entre 50 e 300 m dos cursos de água. Os sítios distribuem-se de forma praticamente contínua ao longo do curso do rio dos Sinos e de seus principais afluentes, podendo ser divididos em 11 conjuntos distintos de acordo com seu local de implantação (Anexo 3).

\footnotetext{
${ }^{11}$ Soares (1997: 168) destaca que a guerra é também um veículo de promoção na hierarquia social Guarani, pois é nela que a liderança temporária das chefias locais (tuvichá) se faz sentir, aumentando seu prestígio no teii através da possibilidade de manifestar valentia e capacidade de reunir pessoas pelos convites intercomunitários para formação das alianças de guerra ou ampliar a família extensa, seja pelas alianças de casamento, seja pelo rapto das mulheres dos inimigos.
} 
O primeiro conjunto está próximo às nascentes do Rio dos Sinos, na sua confluência com o arroio Pedra Branca, estando representados pelos Sinos RS-S-400: Alto Rio dos Sinos I (UTM 22 J 563 400/6705 620) e RS-S-401: Alto Rio dos Sinos II (UTM 22 J 561 188/ 6707 023), marcando o limite leste da distribuição de sítios deste sistema de assentamento, próximo às nascentes do rio dos Sinos. Estes sítios estão fora da abrangência da área piloto, tendo sido localizados nas vistorias extensivas prévias para definição da metodologia a ser empregada nas prospecções. Desta forma, as prospecções nesta área não foram intensas, justificando a baixa densidade de sítios, porém diagnosticam seu potencial para futuras pesquisas. O primeiro sítio está associado a um platô de meia encosta, a $200 \mathrm{~m}$ do rio dos Sinos, não atingido pelas cheias. Apresentou fragmentos cerâmicos esparsos, em baixa densidade, e dois bifaces de grande porte, coletados para diagnóstico, associados a uma área de cultivo de cana de 500 × 300 m, com baixa visibilidade de solo. O segundo sítio situa-se 2,5 Km a noroeste e apresenta um padrão de implantação semelhante ao anterior, estando associado à área de cultivo de milho de 200 x 300 m, com baixa visibilidade de solo, onde foi localizado um biface, semelhante tipologicamente aos demais coletados.

A $4 \mathrm{Km}$ a oeste deste conjunto, seguindo o curso do rio dos Sinos, próximo a sua confluência com o arroio Sertão, localizam-se os sítios RS-S-402: Rio dos Sinos-1 (UTM 22J 557 076/ 6707 382) e RS-S-403: Rio dos Sinos-2 (UTM 22 J 556 609/ 6707 100). O primeiro sítio apresenta somente evidências cerâmicas, em baixa densidade, associadas a uma área lavrada por arado mecânico para plantação de cana (300 x 100 m). O sítio dista 100 m da margem esquerda do Rio dos Sinos e está a uma altitude de 45 m, situando-se no centro urbano da localidade de Rio dos Sinos, com alto índice de perturbação de solo em função da densidade da malha urbana. O proprietário deste sítio informou que a $800 \mathrm{~m}$ ao sul, em uma meia encosta de morro, coberta atualmente por pastagens, encontrava-se até 15 anos atrás uma grande quantidade de cerâmica Guarani, quando a área era arada, tendo sido identificado na época uma vasilha inteira que foi descartada (Indicação de Sítio Guarani 5 - UTM 22J 557 044/ 6706 530). Embora o proprietário atual não recorde pesquisas arqueológicas anteriores neste último local, as análises do acervo documental do MARSUL referente às pesquisas de Eurico Miller na região indicam que este pode provavelmente corresponder, em função de seu local de implantação, ao sítio RS-S-290: Mont Serrat-2, onde foram realizadas coletas de 
superfície em 7/1/1966 (Anexo 4 - croqui 13). Este sítio correspondia a uma mancha de terra preta com uma extensão de 120 x 60 m, no sentido leste-oeste, na qual foi feita uma coleta de superfície de um conjunto de 254 fragmentos cerâmicos e 3 artefatos lítico da Tradição Guarani (nº de catálogo junto ao MARSUL: 471).

O sítio RS-S-403: Rio dos Sinos-2, dista 150 m da confluência de um pequeno arroio com a margem esquerda do rio dos Sinos. Na outra margem deste arroio está o sítio RS-S-402 a uma distância aproximada de $500 \mathrm{~m}$. O sítio RS-S-403 está a uma altitude de $45 \mathrm{~m}$ e corresponde a um sítio lítico associado a uma área preparada para cultivo de milho por arado de boi (200 x 100 m). A vistoria do terreno permitiu a localização de 3 bifaces sobre seixo e 3 lascas de basalto, distribuídas de forma esparsa ao longo de toda área. As características da sua indústria e a proximidade com o sítio RS-S-402 justificaram a associação deste sítio lítico à Tradição Guarani. Embora não haja confirmação de pesquisas arqueológicas anteriores pelos proprietários atuais, pode corresponder a uma possível sinonímia do sítio RS-S-289: Mont Serrat-1, no qual foram feitas coletas de superfície por Eurico Miller em 6/1/1966. Na época o sítio estava associado a uma área de plantação de milho e fumo, na meia encosta, com aproximadamente 200 × $100 \mathrm{~m}$. O sítio apresentava 3 manchas de terra preta de pequenas dimensões, estando o material arqueológico disperso por toda a área arada (Anexo 4 - croqui 14). Ao todo foram coletados 165 fragmentos cerâmicos Guarani e 58 artefatos líticos, cuja tipologia é semelhante ao do sítio RS-S-403: Rio dos Sinos-2. (nº de catálogo no MARSUL: 470).

Segundo informações de um morador local, teria sido localizada há 30 anos atrás nas proximidades desta área uma vasilha Guarani inteira (Informação de Sítio Guarani 6 - UTM 22J 556 004/ 6707 368) na várzea do interflúvio entre o arroio Sertão e o rio dos Sinos. O local foi vistoriado, não sendo identificadas evidências arqueológicas em superfície. Esta vasilha foi fotografada, correspondendo a um cambuchi (panela) com decoração ungulada, e encontra-se na residência de Francisco Machado da Silva. A 400 m ao norte dos dois sítios acima descritos, também foram identificados dois afloramentos rochosos, sendo um de arenito silicificado (UTM 22J 556 944/ 6707 674) e o outro de basalto (UTM 22J 556 969/ 6707 837).

\footnotetext{
${ }^{12}$ A localidade de Rio dos Sinos recebeu esta designação quando da emancipação do município de Caraá, chamando-se Mont Serrat na época do PRONAPA.
} 
Seguindo o curso do rio dos Sinos, a $3 \mathrm{Km}$ a leste dos sítios acima descritos situa-se o sítio Guarani RS-S-407: Quebrada Rio dos Sinos (UTM 22J 553 861/ 6706 678). Situado em um platô da meia encosta, a 118 m de altitude, está associado a uma plantação mista, com aproximadamente 300 x 200 m de extensão, no sentido norte-sul, com baixa visibilidade de solo. O sítio situa-se a 400 metros da confluência de dois braços do rio dos Sinos e foram localizados fragmentos esparsos de cerâmica estendendo-se da meia encosta até o topo do morro, associado a grande quantidade de blocos rolados de basalto, indicando a existência de afloramento nas proximidades, identificado a $1,5 \mathrm{Km}$ a nordeste do sítio. Foram coletadas amostras desta cerâmica e não foi localizado nenhum tipo de resíduo de lascamento ou artefato lítico em superfície. A cobertura vegetal por mato secundário encobre praticamente toda esta área, sendo possível à existência de outros sítios a este relacionado que não foram detectados.

A $2 \mathrm{Km}$ a sudeste do conjunto de sítios da localidade de Rio dos Sinos situa-se um conjunto de 3 sítios Guarani relacionados à planície de inundação do arroio Caraá, situados no centro do município de Caraá. O sítio RS-S-404: Caraá-1 (UTM 22 J 555 523/ 6703 775) situa-se em uma meia encosta associada a áreas de cultivo misto, intercaladas com pasto, com uma extensão de 300 x 300 m. Está a 300 m da margem esquerda do arroio Caraá, a uma altitude de 114 m. Foram identificados fragmentos de cerâmica distribuídos de forma esparsa ao longo das áreas aradas, bem como um afloramento misto de arenito silicificado e basalto, junto ao qual foram coletados dois bifaces e um núcleo unipolar. O proprietário da área informou a presença de cerâmica e artefatos líticos associados a uma plantação de alfafa próxima ao rio (Informação de Sítio Guarani 8 - UTM 22J 555 557/6704 069), 200 m ao norte da concentração de cerâmica observada. Contudo, este material foi descartado no rio quando a terra foi preparada há uns anos atrás, pois quando da colheita, "estragava o fio da foice e machucava os pés” dos agricultores. Entrevistas com os moradores locais apontam para a existência de outras duas ocorrências de cerâmica Guarani nas proximidades deste sítio. A primeira está a uma altitude de $200 \mathrm{~m}$ e situa-se a $500 \mathrm{~m}$ ao norte do sítio (Informação de Sítio Guarani 7 - UTM 22J 554 822/ 6702 979), em uma área coberta por pasto e mato secundário, fora dos limites da área piloto. A segunda situa-se $1,5 \mathrm{Km}$ a oeste do sítio, a 200 m da margem esquerda do arroio Caraá e 70 m de altitude, em área de meia encosta, atualmente coberta por pasto (Informação de Sítio Guarani 9 - UTM 22J 553 865/6703 879).

O sítio RS-S-405: Caraá-2 (UTM 22J 555 622/ 6705 046) está situado a 1 Km ao norte do sítio anterior, em uma meia encosta com altitude de $85 \mathrm{~m}$, distando $500 \mathrm{~m}$ da 
margem direita do arroio Caraá. Está associado a uma plantação mista (300 x 100 m) onde foram coletadas 5 lascas de basalto e 1 biface. Segundo informações do proprietário, esta área apresentava há anos atrás fragmentos de cerâmica Guarani que desapareceram em função da erosão. A área do sítio apresentava, em superfície, grande quantidade de blocos rolados de basalto, indicando a presença de afloramento nas proximidades, não localizado nas prospecções.

A 300 m ao sul deste último, foi localizado o sítio RS-S-406: Caraá-3 (UTM 22J 554 942/ 6704 976), na continuidade do mesmo platô da meia encosta. Estava associado a uma área recém-arada (100 x 50 m) onde foi coletado um fragmento cerâmico de superfície lisa, dois bifaces sobre seixo e três lascas unipolares. Segundo informações dos proprietários, há aproximadamente 30 anos atrás a área do sítio foi desmatada pela primeira vez para cultivo. Nas primeiras vezes em que foi trabalhada apresentou grande quantidade de cerâmica Guarani, porém como esta vem sendo arada desde então, os fragmentos cerâmicos têm se mostrado cada vez mais raros. Tendo em vista a proximidade e semelhanças entre os sítios, ambos podem corresponder a duas concentrações de material arqueológico de um único sítio de maiores dimensões, atualmente destruído.

Por fim, o sítio RS-S-422: Caraá-4 (UTM 22J 552 740/ 6704 449) localiza-se próximo à confluência do arroio Caraá com o rio dos Sinos. Situado em uma meia encosta, com altitude de 74 m, está a 200 m a sudoeste do arroio Caraá. Neste foi identificado fragmentos esparsos de cerâmica Guarani associada a uma plantação abandonada de milho e mandioca (150 x 50 m), atualmente coberta por gramíneas e vassoural, com baixa visibilidade de solo. Segundo o proprietário, a área quando arada apresenta uma densidade relativamente maior de cerâmica. Também há informações sobre a presença de cerâmica Guarani em área coberta por pasto (Informação de Sítio Guarani 13 - UTM 22J 552 150/ 6704 300) a aproximadamente $1 \mathrm{Km}$ a leste do sítio RS-S-422: Caraá 4. Segundo os proprietários, esta área corresponderia a um sítio arqueológico pesquisado por Miller na década de 1960. Em função das suas características topográficas, proximidade com outros sítios também pesquisados na área e documentação disponível no MARSUL, possivelmente corresponde ao sítio RS-S-286: Castelhano, pesquisado 2/1/1966, durante o PRONAPA. Na época das pesquisas o sítio distribuía-se por uma área cultivada de 70 × 35 m, no sentido leste oeste, apresentando uma mancha de terra preta de $10 \mathrm{~m}$ de diâmetro. As coletas de superfície produziram uma coleção de 19 fragmentos cerâmicos da Tradição Guarani, associada a 3 
artefatos líticos ( ${ }^{\circ}$ de catálogo junto ao MARSUL: 467). Nas proximidades desta área também foi localizado um afloramento de arenito silicificado (UTM 22J 551 718/ 6704 275).

Na confluência do arroio Caraá com o rio dos Sinos, aproximadamente $3 \mathrm{Km}$ a leste dos sítios acima descritos, situa-se um outro conjunto composto por 3 sítios Guarani. O primeiro sítio distribuía-se em duas concentrações, a 60 m a leste da margem esquerda do Rio dos Sinos. A primeira foi localizada em meio a uma plantação de mandioca (UTM 22J 550 535/6704 918), onde foram evidenciados fragmentos cerâmicos e um biface de basalto. A segunda associa-se a uma plantação mista de cana e mandioca, onde foram localizados fragmentos cerâmicos (UTM 22J 550 424/6704 976). O sítio situa-se em um pequeno platô elevado sobre planície de inundação do rio dos Sinos, estando a $25 \mathrm{~m}$ de altitude. Os proprietários informaram que teria havido pesquisas arqueológicas neste sítio há mais de 30 anos atrás e consultas à documentação do MARSUL, indicaram que pelo padrão de implantação este corresponderia ao sítio RS-S-285: Passo da Forquilha-1, pesquisado em 1/1/1966 por Eurico Miller. Na época o sítio apresentava três manchas de terra preta, estando a cerâmica dispersa em uma área de 40 x 20 m no sentido nordeste-sudoeste (Anexo 4 croqui 15). Naquela ocasião foram realizadas coletas de superfície totalizando uma coleção de 10 artefatos líticos e 191 fragmentos de cerâmica ( ${ }^{\circ}$ de catálogo junto ao MARSUL: 466).

A nordeste, distante 1,5 Km deste sítio, foi localizado um biface de basalto em uma área com pouca visibilidade de solo, coberta por gramíneas e vassoural. O sítio situa-se em um platô de meia encosta, a uma altitude de 60 m, acima da planície de inundação da margem direita do rio dos Sinos, do qual dista 200 m. Entrevistas com o proprietário também confirmaram que pesquisas arqueológicas haviam sido realizadas naquele local há mais de 30 anos atrás. Através de pesquisas no acervo documental do MARSUL, confirmamos que este corresponde ao sítio RS-S-287: Passo da Forquilha-2 (UTM 22J 552 063/6705 346) pesquisado por Eurico Miller em 3/1/1966. Na época o sítio foi caracterizado por uma grande quantidade de artefatos líticos bifaciais associados a roças de milho, arroz, feijão e potreiros, dispersos por uma área de 120 x 60 m, no sentido leste-oeste. O sítio foi associado à Tradição Humaitá, apesar de estar a 30 m ao sul do sítio Guarani RS-S-288: Passo da Forquilha-3 (Anexo 4 - croqui 16). A coleta de superfície realizada em 1966 produziu uma coleção de 69 artefatos líticos e 3 fragmentos cerâmicos ( $\mathrm{n}^{\circ}$ de catálogo junto ao MARSUL: 468), que associamos à Tradição Guarani.

A 200 m a norte deste último sítio foi identificada uma concentração de cerâmica Guarani associada a linhas de erosão em uma área atualmente coberta por pasto. Entrevistas 
com o antigo proprietário confirmaram que este sítio também havia sido pesquisado por Eurico Miller em 1966. Corresponde ao sítio RS-S-288: Passo da Forquilha-3 (UTM 22J 551 920/ 6705 315) descrito na ocasião como possuindo uma concentração de cerâmica Guarani associada a uma roça de milho, dispersas entre duas manchas de terra preta $(40 \times 20$ m no sentido leste-oeste), situadas a 20 m ao sul do sítio RS-S-287: Passo da Forquilha-2. O sítio se encontra em um platô de meia encosta, acima de planície de inundação do rio dos Sinos, a uma altitude de $60 \mathrm{~m}$, estando a $30 \mathrm{~m}$ de um braço do rio dos Sinos (Anexo 4 croqui 16). A coleta de superfície realizada em 4/1/1966 formou uma coleção de 9 artefatos líticos e 319 fragmentos cerâmicos (nº de catálogo junto ao MARSUL: 469).

Foram registradas outras informações sobre ocorrências de sítios Guarani nas proximidades dos sítios acima descritos em áreas atualmente cobertas por pasto e mato secundário. Uma primeira (Informação de Sítio Guarani 10 - UTM 22 J 552 448/ 6705 435) situa-se 500 m a leste dos sítios RS-S-287 e RS-S-288. O proprietário da área informou sobre a presença fragmentos de cerâmica Guarani em um local atualmente coberto por pastagens para criação de gado que era lavrado até 15 anos atrás. Informação semelhante foi registrada em outro local (Informação de Sítio Guarani 11 - UTM 22J 552 615/ 6705 655) cultivado há 20 anos atrás e atualmente coberto por mato secundário, situada a aproximadamente $600 \mathrm{~m}$ ao norte dos sítios RS-S-287 e RS-S-288. Nesta mesma área foi também localizado um pequeno abrigo sob rocha (Abrigo 27 - UTM 22J 552 449/ 6706 249), a 71 m de altitude, com menos de $1,5 \mathrm{~m}$ de altura e $2 \mathrm{~m}$ de profundidade, em cujo interior teria sido localizada uma vasilha inteira Guarani, segundo o proprietário (Informação de Sítio Guarani 12 - UTM 22 J 552 449/ 6706 249).

Seguindo o curso do rio dos Sinos, na confluência com o arroio Carvalho, $1 \mathrm{Km}$ a sudeste dos sítios da localidade de Passo da Forquilha situa-se um outro conjunto composto por três sítios. O sítio RS-S-421: Rincão do Herval-3 situa-se em uma meia encosta, distando 250 m da confluência do arroio Carvalho com o rio dos Sinos, apresentando duas concentrações esparsas de fragmentos cerâmicos. A primeira está situada em meio a uma pequena plantação de milho e mandioca, a uma altitude de $52 \mathrm{~m}$, apresentando menos de uma dezena de fragmentos cerâmicos (UTM 22J 550 166/6703 947). A 200 m desta primeira concentração foi identificado um afloramento de arenito. A segunda concentração apresenta maior quantidade de fragmentos cerâmicos e está associada a uma área de cultivo de milho (UTM 22J 550 203/ 673 919) a uma altitude de 53 m. Por sua localização, o sítio pode corresponder a uma sinonímia do sítio RS-S-284: Carvalho, pesquisado por Eurico Miller em 
28/12/1965. Este estava associado na época a uma área agrícola de 90 x 45 m, no sentido norte-sul, associadas a 3 manchas de terra preta, com 10 m, 20 m e 7 m de diâmetro (anexo 4

- croqui 17). As coletas de superfície produziram uma coleção de 140 fragmentos cerâmicos e 6 artefatos líticos associados à tradição Guarani (nº catálogo MARSUL: 465).

Distante 1,5 Km a sudoeste deste último sítio, fora da abrangência da área piloto, foram localizados dois sítios Guarani. O sítio RS-S-414: Rincão do Herval-1 (UTM 22J 549 091/ 6703 183) apresenta fragmentos de cerâmica esparsos e está localizado em um topo de morro, a uma altitude entre 93 e 116 m, associado a uma plantação mista de, aproximadamente, 100 x 100 m. O sítio dista 100 m de um braço do rio dos Sinos e está associada a dois afloramentos de arenito silicificado, o primeiro a $80 \mathrm{~m}$ de altitude, na meia encosta (UTM 22J 549 065/6703 222), e o segundo no topo do morro, a 116 m de altitude (UTM 22J 549 008/ 6703 149). O sítio RS-S-415: Rincão do Herval-2 (UTM 22J 548 684/6703 521) possivelmente apresenta relação com o sítio anterior, pois se situa na meia encosta do mesmo morro, a uma altitude de $56 \mathrm{~m}$. Corresponde a uma pequena concentração de cerâmica Guarani identificada a 300 m do sítio anterior em uma área de plantação mista, com 20 x 10 m.

Ao longo do médio curso do Arroio Grande, afluente do rio dos Sinos, encontra-se uma concentração de 6 sítios Guarani, situada a 1,5 Km ao norte do conjunto de sítios da localidade de Passo da Forquilha. O primeiro sítio, RS-S-396: Evaristo-1 (UTM 22J 552 700 /6708 500), situa-se na base de uma meia encosta, a uma altitude de 40 m, distando 200 m de uma das nascentes da Sanga do Bugre, tributário da margem esquerda do arroio Grande. Apresentou fragmentos cerâmicos esparsos associados a uma pequena plantação de milho, com dimensões de 10 x 20 m.

O sítio seguinte, RS-S-411: Evaristo-4 (UTM 22J 552 539/6707 607), situa-se 500 $\mathrm{m}$ a sudoeste do anterior, já na meia encosta, em uma área atualmente coberta por pasto, em uma altitude de 100 m. Na vistoria do terreno não foram observadas evidências em superfície, porém o sítio foi identificado pelo proprietário quando arava a terra para plantação de milho e amostras de cerâmica e de um machado polido foram coletadas. Este material foi fotografado e amostras de cerâmica doadas para a equipe (fotos 1 e 2). O proprietário também nos indicou outra área cultivada até alguns anos atrás, onde haveria evidencias de cerâmica, próxima a nascente da Sanga do Bugre (Indicação de Sítio Guarani 14 - UTM 22J 552 663/ 6707 166), mas a baixa visibilidade do solo, coberto por vassourais, impediu a detecção de novas evidências. 
O sítio RS-S-412: Evaristo-5 (UTM 22J 552 199/6707 064) está a 500 m do sítio anterior, em um topo de morro, a uma altitude de $160 \mathrm{~m}$. Foram identificados fragmentos de cerâmica na vistoria de boçorocas situadas numa área coberta por pasto, utilizada até 5 anos atrás para cultivo de milho e mandioca. O sítio situa-se a $1 \mathrm{Km}$ ao norte de um braço do arroio Grande (foto 3).

O sítio RS-S-413: Fenda (UTM 22J 551 705/6707 035) está localizado na base de uma meia encosta, a uma altitude de 60 m. Está a 500 m ao sul da confluência da Sanga do Bugre com o arroio Grande, distando 500 m do sítio anterior. Assim como este, também se situa em área de pasto utilizado na criação de gado cortada por boçorocas, cuja vistoria permitiu a localização de um fragmento de cerâmica corrugada e de um biface de basalto. $\mathrm{O}$ sítio situa-se em frente à entrada inferior de uma Fenda Arenítica, atração turística da localidade de Evaristo, que corresponde a dois paredões de arenito de $8 \mathrm{~m}$ de altura e distantes entre si em torno de 2,5 m (UTM 22J 551 870/ 6707 047). Entrevistas com os moradores locais apontam que teria sido encontrada há anos atrás uma vasilha Guarani inteira no interior da Fenda.

O sítio RS-S-409: Evaristo-2 (UTM 22J 551 466/6708 353) situa-se na margem direita do arroio Grande, $1 \mathrm{Km}$ a noroeste do conjunto de sítios acima descrito. Está localizado em uma meia encosta, a $250 \mathrm{~m}$ do arroio Grande, a uma altitude de $100 \mathrm{~m}$. As evidências correspondem a artefatos líticos e fragmentos cerâmicos esparsos em meio a áreas lavradas, de extensões variadas, circundadas por capões de mato secundário e eucalipto. Segundo o proprietário, a cerâmica era abundante até pelo menos 10 anos atrás, contudo em função da erosão tornou-se a cada ano mais escassa. O sítio está associado a um afloramento de arenito silicificado, encoberto por mato secundário (UTM 22J 551 343/ 6708 246).

A 2,5 Km ao norte do conjunto acima descrito foi localizado o sítio RS-S-428: Evaristo 6 (UTM 22J 554 400/6710 064). Este seria a manifestação mais ao norte dos sítios da localidade de Evaristo, porém como não foram vistoriadas as encostas na faixa que os separam, há uma alta probabilidade que o padrão de distribuição de sítios observado ao sul se prolongue até este limite. Este sítio está situado em uma meia encosta, com altitude de 224 m, em uma área de cultivo misto, com extensão de 250 x 150 m. A área apresenta alto índice de erosão, sendo localizados em superfície um fragmento de cerâmica pintada e um biface de basalto. Toda a área apresenta construções de taipa para fixação dos platôs de cultivo e o proprietário informou que, nos últimos 20 anos, durante o preparo da terra, sistematicamente, 
vem descartando a cerâmica encontrada e retirando blocos de basalto, dentre estes possíveis artefatos, para a construção das taipas.

A aproximadamente $2 \mathrm{Km}$ a noroeste do conjunto de sítios da localidade de Evaristo, foram localizados 3 outros sítios Guarani na confluência dos arroios Pinheiros e Grande. O sítio RS-S-410: Evaristo-3 (UTM 22J 550 372/ 6707 847) está localizado no topo do mesmo morro testemunho, onde se situa o sítio em abrigo sob rocha RS-S-395: Deobaldino Marques (associado à Tradição Umbu), a uma altitude de 95 m. Este morro está localizado em meio à planície de inundação da confluência dos arroios Pinheiros e Grande, estando o material arqueológico distribuído entre duas plantações mistas, separadas por uma área de pasto, com uma extensão total de 300 x 50 m, no sentido leste-oeste. Foram localizados além de fragmentos cerâmicos, um núcleo unipolar e dois bifaces de basalto (foto 4).

Distando 1,5 Km a nordeste deste último, situa-se o sítio RS-S-427: Pinheiros (UTM 22J 550 748/ 6708 827) em um platô de meia encosta associado à várzea do arroio Pinheiros, a uma altitude de $30 \mathrm{~m}$. O sítio está a $250 \mathrm{~m}$ da margem esquerda do arroio e foram identificados poucos fragmentos cerâmicos associados a uma pequena horta de 30 x 20 m. O proprietário informou que haveria maior densidade de cerâmica em uma área contígua, atualmente coberta por pasto para criação de gado, cultivada pela última vez há 20 anos atrás.

Por sua vez, o sítio RS-S-423: Bom Retiro 1 (UTM 22J 549 913/ 6709 071) situa-se na margem do arroio Bom Retiro, estando a $1 \mathrm{Km}$ a leste do sítio anterior. Neste foi identificado um artefato lítico bifacial em calcedônia associado a uma área arada 50 x 50 m, junto a uma plantação cana. O restante da área está coberto por pastagens, contudo o proprietário informou que quando lavrada apresenta fragmentos de cerâmica, justificando a classificação desta ocorrência como um sítio lítico Guarani.

Na margem direta do arroio Bom Retiro foram localizados 3 sítios Guarani, situados 1,5 Km a leste do conjunto acima descrito. Próximo às nascentes do arroio situa-se o sítio RSS-425: Bom Retiro 3 (UTM 22J 548 061/ 6709 235). Localizado em uma meia encosta, a 90 m de altitude, o sítio apresentou cerâmica associada a uma área de cultivo misto, com extensão total de 350 x 150 m. Em associação a este foi localizado um afloramento misto de basalto e arenito silicificado (UTM 22J 547 942/ 6709 357).

O sítio RS-S-424: Bom Retiro 2 está a $1 \mathrm{Km}$ ao sul do sítio anterior, em uma meia encosta, entre 58 e $70 \mathrm{~m}$ de altitude. Está dividido entre duas concentrações, associadas a áreas recém aradas preparadas para plantio de mandioca, cortadas por uma estrada vicinal. A primeira possui dimensões de 50 x $50 \mathrm{~m}$, apresentando 3 lascas bipolares de quartzo e uma 
lasca unipolar de basalto (UTM 22J 548 212/ 6708 132). A segunda concentração está a menos de 200 m da anterior, e apresentou uma concentração de cerâmica Guarani, em área recém-arada de 100 x 50 m (UTM 22J 548 199/ 6708 445) (foto 5).

A $500 \mathrm{~m}$ ao sul deste último, está o sítio RS-S-426: Bom Retiro 4 (UTM 22J 548 129-6707 655), situado no topo de um morro testemunho, próximo à confluência do arroio Bom Retiro com o rio dos Sinos, a uma altitude de $47 \mathrm{~m}$. O sítio localiza-se atrás do cemitério da localidade, em uma plantação mista, com dimensões de 150 x 150 m, circundada por pastagens para o gado e por um capão de eucaliptos, apresentando unicamente fragmentos cerâmicos.

A $3 \mathrm{Km}$ a leste deste último conjunto, encontra-se dois sítios Guarani que apresentam um padrão de implantação atípico, se comparado aos demais, representando a fronteira oeste de expansão dos sítios Guarani na área piloto. O sítio RS-S-399: Campestre Novo-1 (UTM 544 565/6708 992) situa-se em um topo de morro, a uma altitude de 213 m, em meio à área lavrada de 300 x 200 m. O material cerâmico é abundante em superfície e o sítio está associado a um afloramento misto de arenito silicificado e basalto (UTM 22J 544 038/6708 718), onde foram localizados dois bifaces em basalto. Este sítio está a $1 \mathrm{~km}$ ao sul de um braço do arroio Campestre e a 500 metros ao norte de 2 nascentes do arroio Restinga. Como é o sítio Guarani com maior densidade de material cerâmico localizado na área piloto, optouse por não realizar coletas superficiais a fim de preservar a integridade espacial dos vestígios para futuras pesquisas. Amostras diagnósticas desta cerâmica foram doadas a equipe pelo proprietário, que as havia recolhido de forma aleatória.

Neste sítio foi realizado um poço teste de 1 x $1 \mathrm{~m}$, controlado por níveis artificiais de $10 \mathrm{~cm}$, até a profundidade de $50 \mathrm{~cm}$ com o objetivo de observar a estratigrafia e coletar amostras para datação por termoluminescencia (UTM 22J 544 542/6709 040). Este evidenciou um pacote de sedimentos compactos, homogêneos e argilosos, de coloração avermelhada, com baixa densidade de material em sub-superfície, tendo sido localizado dois fragmentos cerâmicos nos níveis 1 e 2, respectivamente, e uma lasca de basalto a profundidade de $40 \mathrm{~cm}$. Também foram coletadas 4 amostras de sedimentos das paredes da sondagem entre as profundidades de $10-20 \mathrm{~cm}, 20-30 \mathrm{~cm}, 30-40 \mathrm{~cm}$ e $40-50 \mathrm{~cm}$. Para complementar esta sondagem, foram realizadas 13 tradagens com cavadeira, produzindo intervenções de $30 \mathrm{~cm}$ de diâmetro, até a profundidade de $50 \mathrm{~cm}$. Estas tradagens foram estabelecidas em duas linhas orientadas a partir do poço-teste. A primeira linha foi realizada com orientação de $0^{\circ}$ da sondagem, tendo a extensão de $12 \mathrm{~m}$, na qual foram realizadas 6 
tradagens, distanciados $2 \mathrm{~m}$ entre si. Os sedimentos mostraram-se semelhantes aos revelados pelo poço-teste, não havendo materiais arqueológicos associados. A segunda linha de tradagens orientou-se a $45^{\circ}$ do poço-teste com uma extensão de $14 \mathrm{~m}$, sendo realizadas 7 tradagens, distantes entre si $2 \mathrm{~m}$. As características sedimentares são semelhantes às anteriormente observadas, não apresentando também evidencias arqueológicas associadas. Tendo em vista a composição argilosa do pacote sedimentar, não foi possível utilizar peneira para a triagem dos sedimentos que foram inspecionados com colher de pedreiro.

Tendo em vista a baixa densidade de material em sub-superfície foram coletadas 3 amostras de cerâmica superficial que foram encaminhadas juntamente com os sedimentos da sondagem ao laboratório de vidros da FATEC para datação. As datações obtidas para a cerâmica foram as seguintes: 165+20 AP (LVD 594) e 205+25 AP (LVD 595). Estas apresentam compatibilidade com as datações radiocarbônicas para sítios da Tradição Guarani nos vales dos rios Jacuí, Vacacaí, Pardo e Caí, indicando contemporaneidade com o início da presença portuguesa na área. Destaca-se ainda que deste sítio é possível avistar o local onde se situava o Registro de Viamão, cujo início da ocupação é contemporânea as datações obtidas (fotos 6 a 8).

O sítio RS-S-416: Campestre Novo-2 (UTM 22J 545 185/6709 180) situa-se a 200 m a noroeste do sítio anterior, a uma altitude de $176 \mathrm{~m}$. Este sítio lito-cerâmico está associado a uma extensa plantação mista, intercalada por pastos naturais, onde foram identificados um fragmento cerâmico e uma lasca unipolar de basalto. Possivelmente este corresponde a um prolongamento do sítio RS-S-399 para a vertente norte do morro. Também foi localizado nesta encosta, associado a boçorocas, um veio de arenito silicificado (UTM 22J 545 081/ 6709 214). Entrevistas com os moradores indicam ainda a presença de uma ocorrência de cerâmica Guarani nas proximidades do sítio, em área atualmente coberta por pasto a $150 \mathrm{~m}$ de altitude (Indicação de Sítio Guarani 1 - UTM 22J 544 963/6709 202). O sítio RS-S-416 e a ocorrência Guarani 1 podem corresponder à sinonímia do sítio RS-S-338: Campestre-3, registrado por Eurico Miller em 1969. Não existe documentação nem acervo no MARSUL relativo a este sítio, o que dificulta a confirmação desta sinonímia, porém foi doado à equipe, por um morador local, um machado polido, cuja tipologia é típica Guarani, que haveria sido encontrado nesta localidade.

Um último conjunto de sítios Guarani foi localizado a 6,5 $\mathrm{Km}$ ao norte dos conjuntos acima descritos, associados ao limite norte da área piloto, junto às meias encostas que limitam o vale do arroio Rolantinho. O sítio RS-S-408: Alto Rolantinho (UTM 22J 543 396/ 6715 
310) está associado a uma meia encosta coberta por plantações mistas e capões de mato secundário. As evidências arqueológicas são esparsas e em baixa densidade em superfície, tendo sido localizados, em meio a uma plantação de mandioca, dois fragmentos cerâmicos e um biface em basalto. O sítio situa-se a 100 m de altitude e está a 200 metros ao sul do arroio Rolantinho.

Entrevistas com os moradores locais apontam para a existência de duas outras ocorrências de sítios Guarani correlacionadas ao sítio RS-S-408: Alto Rolantinho em áreas atualmente com baixa visibilidade de solo. A primeira está a $500 \mathrm{~m}$ a nordeste do sítio (Informação de Sítio Guarani 3 - UTM 22J 543 962/ 6715 337) em área com plantações de cana e mato secundário, cuja vistoria não evidenciou material em superfície, devido à baixa visibilidade. A segunda situa-se a $1,5 \mathrm{Km}$ a nordeste do sítio, em uma área ocupada por plantações de cana e capões de pinheiros, sem visibilidade de solo (Informação de Sítio Guarani 2 - 544 590/ 6716 053). Por fim, a 3 Km a sudoeste do conjunto de sítios acima descrito, registrou-se a informação de ocorrência de um sítio Guarani em área coberta por pasto. Segundo o proprietário, encontrava-se cerâmica nesta área há 20 anos atrás quando se lavrava a terra (Informação de Sítio Guarani 4 - UTM 22J 540 400/ 6714 400). Esta ocorrência pode corresponder ao sítio RS-S-343: Rolantinho da Figueira, registrado por Eurico Miller em 1969, cujo acervo e documentação de campo não foram localizados junto ao MARSUL. Vistorias nesta encosta e nas áreas adjacentes não permitiram a identificação de material arqueológico em superfície, porém foi registrado um afloramento de basalto nas proximidades da ocorrência mencionada (UTM 22J 540 705/ 6714 812). 


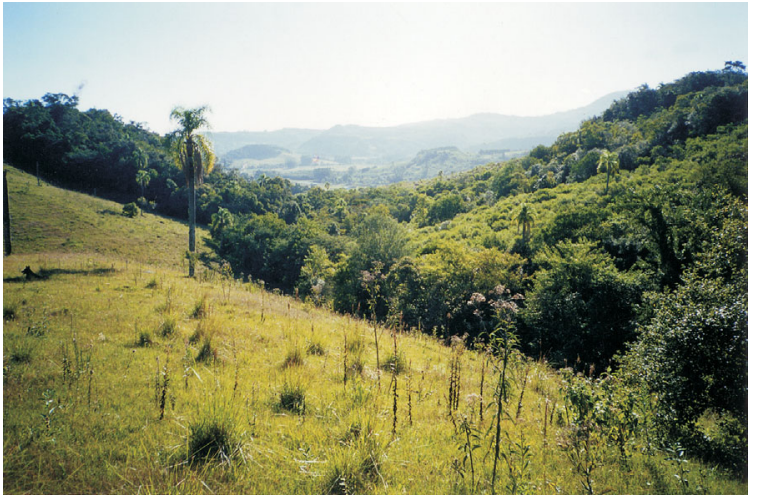

1. Sítio RS-S-411, atualmente coberto por pasto. Foto: Adriana Dias

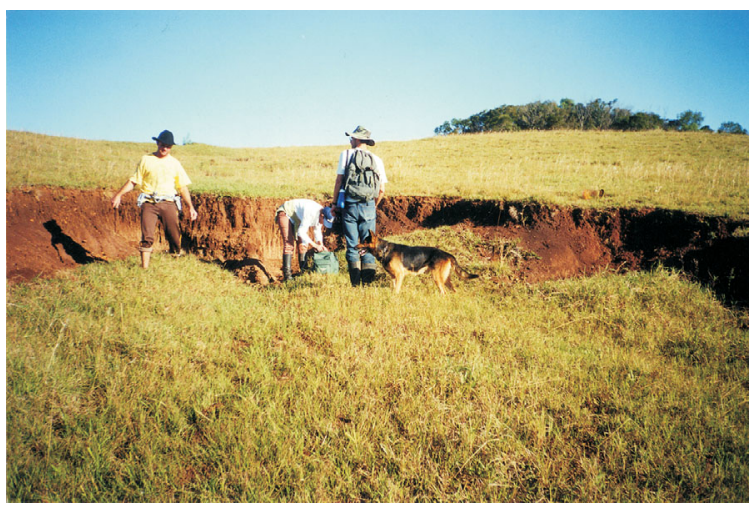

3. Sítio RS-S-412, localizado em vistoria de Boçoroca. Foto: Adriana Dias

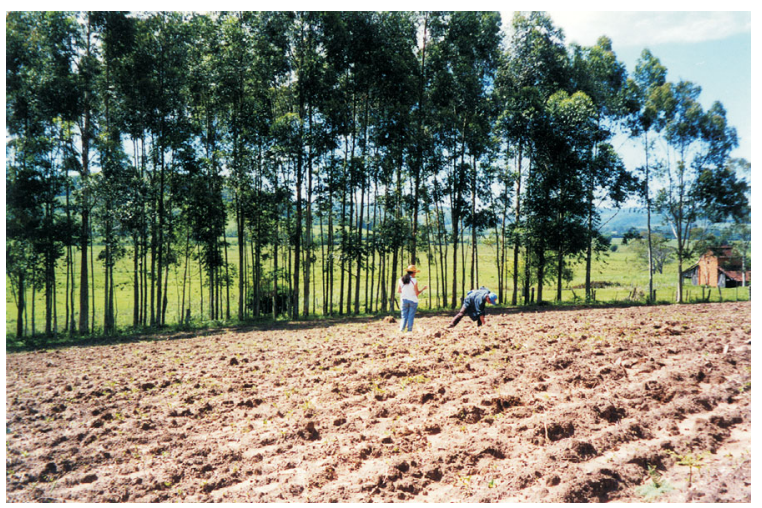

5. RS-S-424, sítio em área arada com boa visibilidade de solo. Foto: Adriana Dias

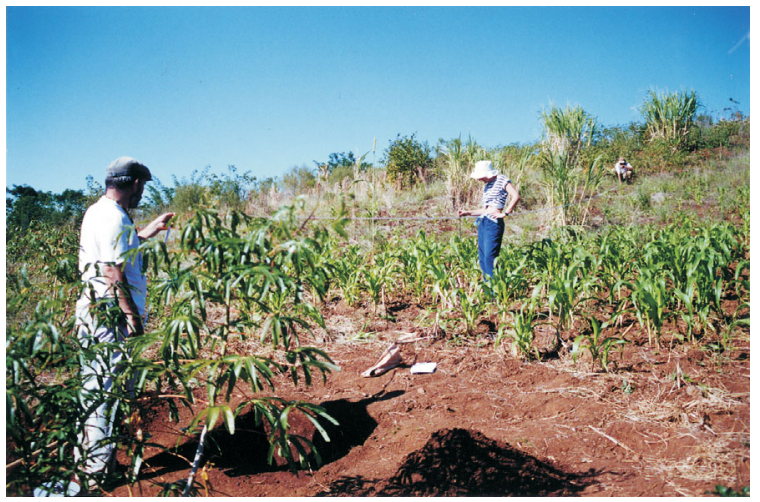

7. Sítio RS-S-399, detalhe das sondagens com trado. Foto: Adriana Dias

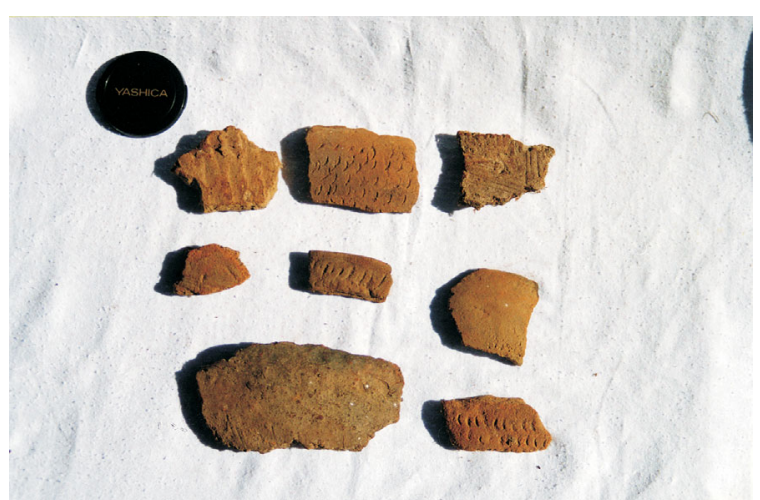

2. Amostra de cerâmica coletada pelo proprietário no sítio RS-S-411. Foto: Adriana Dias

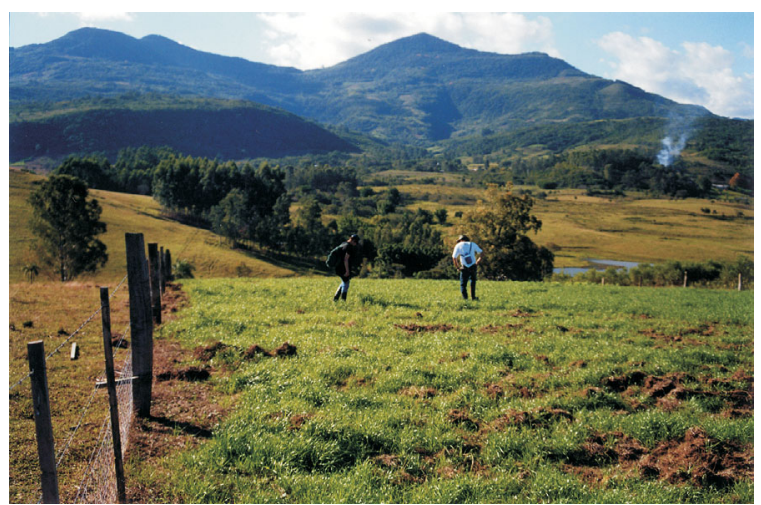

4. RS-S-410, sítio em área cultivada com visibilidade regular. Foto: Adriana Dias

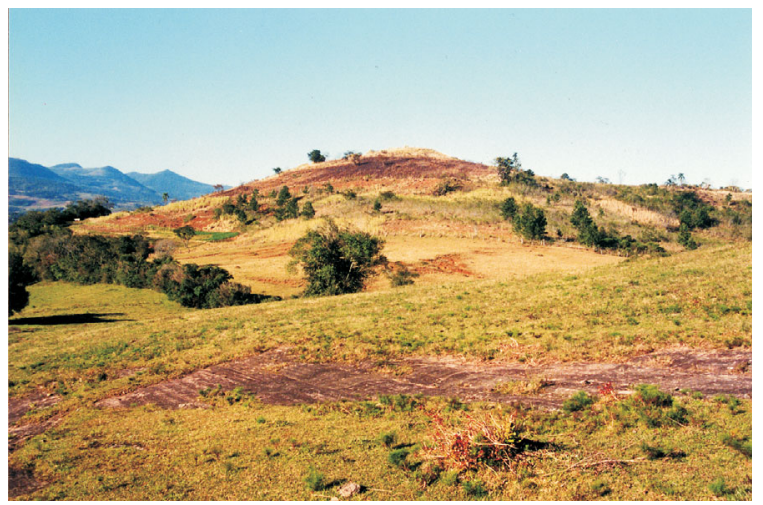

6. Sítio RS-S-399, vista geral. Foto: Adriana Dias

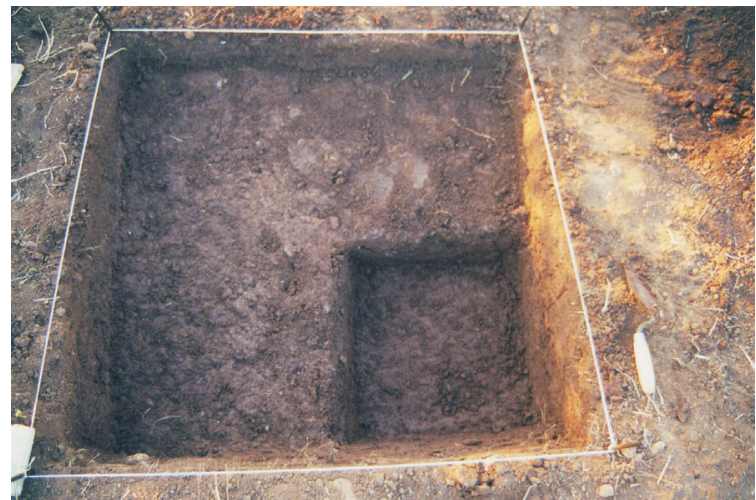

8. Sítio RS-S-399, detalhe do poço teste. Foto: Adriana Dias 


\subsubsection{O Tekohá do Alto Vale do Rio dos Sinos: Um Modelo Interpretativo para o Sistema de Assentamento da Tradição Guarani}

Partindo dos modelos etnoarqueológicos referentes ao sistema de assentamento Guarani no século XVI, consideramos a distribuição de sítios arqueológicos observados no Alto Vale do Rio dos Sinos como representando o deslocamento das sedes de aldeias (amundá) na área de domínio de pelo menos dois tekohá. O primeiro está representado pela concentração de sítios no setor sudeste da área piloto, acompanhando os cursos do rio dos Sinos e dos arroios Caraá, Grande, Pinheiros e Bom Retiro, estando representado também no vale do arroio Campestre por uma ocupação periférica e provavelmente mais tardia. O segundo tekohá situa-se a noroeste da área piloto, associado ao vale do arroio Rolantinho, em altitudes mais elevadas em relação ao grupo anterior de sítios, em um ambiente menos favorável à ocupação Guarani tradicional.

Analisando o padrão de sítios no espaço da área piloto podemos distinguir 4 agrupamentos de sítios (Anexo 3). O primeiro conjunto estaria representado por 25 sítios Guarani, distribuídos em vários agrupamentos, situados na confluência do arroio Sertão com o rio dos $\operatorname{Sinos}^{13}$ (3 sítios), na confluência do arroio Caraá com o rio dos $\operatorname{Sinos}^{14}$ (10 sítios) e nas proximidades da confluência do arroio Grande com os arroios Pinheiros e Bom Retiro ${ }^{15}$ (12 sítios). Estes conjuntos de sítios representariam, de acordo com o modelo adotado, o deslocamento da sede da aldeia principal (amundá) pela área de domínio do tekohá, partindo de um núcleo original e deslocando-se a uma distância média de $2 \mathrm{Km}$ entre os assentamentos. Seguindo o curso do rio dos Sinos, e dos arroios Caraá e Grande, as aldeias instalaram-se, preferencialmente, nas meias encostas, com altitude em torno de $100 \mathrm{~m}$, nas proximidades de zonas de confluência de corpos de água e de fontes de matéria prima lítica e argilosa.

A proximidade entre os núcleos de sítios, entre 3 e $1,5 \mathrm{Km}$, representaria o deslocamento periódico da sede de uma mesma aldeia no tekohá do Alto Rio dos Sinos movida por motivos sanitários (necessidade de manutenção das estruturas), simbólicos

\footnotetext{
${ }^{13}$ Sítios RS-S-402: Rio dos Sinos 1, RS-S-403: Rio dos Sinos 2 e RS-S-407: Quebrada Rio dos Sinos.

${ }^{14}$ Sítios RS-S-404: Caraá 1, RS-S-405: Caraá 2, RS-S-406: Caraá 3, RS-S-422: Caraá 4, RS-S-285: Passo da Forquilha 1, RS-S-287: Passo da Forquilha 2, RS-S-288: Passo da Forquilha 3, RS-S-414: Rincão do Herval 1, RS-S-415: Rincão do Herval 2, RS-S-421: Rincão do Herval 3.
} 
(mortes ou doenças) ou mesmo acidentais (incêndios). Contudo, subentende uma ocupação de longa duração, associada ao manejo das florestas primárias decorrentes do sistema de cultivo, com roças em diferentes estágios de desenvolvimento.

O segundo conjunto representaria uma aldeia periférica ao núcleo central acima descrito, relacionado ao limite leste da área piloto, mais próximo às nascentes do rio dos Sinos, em associação com a confluência do arroio Pedra Branca. Este conjunto está representado por apenas dois sítios ${ }^{16}$, porém como não foram realizadas prospecções intensivas neste local, na medida em que se situa fora dos limites da área piloto, a densidade de sítios original pode ser maior. Este conjunto apresentaria características de implantação de uma aldeia periférica ao núcleo central de ocupação do tekohá, acima caracterizado. De acordo com os modelos propostos por Brochado (1994), Noelli (1993) e Soares (1997), esta poderia corresponder a um desdobramento da aldeia central, por questões demográficas ou de ordem social decorrente de conflitos internos, apresentando menor prestígio com relação à aldeia original. Ocuparia áreas já manejadas do tekohá, porém menos favoráveis ao desenvolvimento do modo de ser tradicional (tekó), na medida em que está próximo às nascentes do rio dos Sinos, cuja topografia não se mostra ideal para o desenvolvimento pleno das roças.

Um terceiro conjunto de sítios também periférico ao núcleo principal do tekohá do Alto Rio dos Sinos esta representado por dois sítios situados no vale do arroio Campestre ${ }^{17}$, marcando o limite oeste da presença Guarani na área piloto. O padrão de implantação destes sítios é distinto dos demais, situando-se a uma altitude mais elevada, a uma maior distância dos cursos de água e em um ambiente menos propício para o tipo de cultivo tradicional. As datações obtidas para um destes sítios apresentam-se contemporâneas ao início da ocupação portuguesa na área piloto, representada pelo sítio RS-S-263: Guarda Velha 2, local onde estava instalado o Registro de Viamão, entre 1738 e 1808, início oficial da Estrada das Tropas que seguia pelo planalto até Sorocaba, São Paulo. Representa, portanto, um momento terminal da ocupação Guarani na área, no qual os espaços tradicionais de instalação das aldeias passam a ser ocupado pelos portugueses. Em detrimento do sistema tradicional de implantação, adotase estratégias mais defensivas, pois é possível visualizar o Registro de Viamão do topo do

\footnotetext{
15 Sítios RS-S-396: Evaristo 1, RS-S-409: Evaristo 2, RS-S-410: Evaristo 3, RS-S-411: Evaristo 4, RS-S-412: Evaristo 5, RS-S-428: Evaristo 6, RS-S-413: Fenda Arenítica, RS-S-427: Pinheiros, RS-S-423: Bom Retiro 1, RS-S-424: Bom Retiro 2, RS-S-425: Bom Retiro 3, RS-S-426: Bom Retiro 4.

16 Sítios RS-S-400: Alto Rio dos Sinos 1 e RS-S-401: Alto Rio dos Sinos 2.
} 
morro onde se situam os sítios em questão, e dali observar possíveis movimentos dos novos inimigos.

Um último conjunto de sítios está distribuído no limite norte da área piloto, a aproximadamente $7 \mathrm{Km}$ a noroeste do tekohá do Alto Rio dos Sinos, junto ao curso do arroio Rolantinho, em um ambiente com topografia acidentada e altitudes elevadas, relacionado mais diretamente com a encosta do planalto. Um único sítio foi localizado nesta área ${ }^{18}$, porém as informações relativas à existência de outros sítios Guarani em locais atualmente sem visibilidade de solo, indicam um padrão de distribuição similar ao observado ao sul da área piloto. Estes dados sugerem a existência de um outro tekohá ao norte da região estudada, cuja área de captação de recursos pode apresentar relação de sobreposição com as florestas antropogênicas do tekohá da porção sul. Como não possuímos datações para esta área, tornase impossível determinar se corresponde a uma área de domínio contemporânea, hierarquicamente subordinada ao tekohá do Alto Rio dos Sinos ou um padrão de implantação posterior, decorrente da pressão da frente colonial a partir do início do século XVIII, implantada junto aos cursos de rios e arroios ocupados tradicionalmente. No caso da segunda hipótese, os sítios da localidade de Campestre poderiam representar uma aldeia periférica a este tekohá do norte, instalada naquele local para controlar o movimento dos portugueses junto ao vale do rio dos Sinos.

Um aspecto a ser destacado quanto ao modelo etnoarqueológico adotado diz respeito às possibilidades de estimativas demográficas e temporais para a ocupação Guarani no tekohá do Alto Rio dos Sinos. A área ocupada pelos sítios Guarani na porção sul da área piloto possui aproximadamente 12 hectares. Baseando-se nas estimativas mínimas apresentadas por Noelli (1993) de área de roça por família de 6 pessoas (0,5 hectares), sugerimos que o tekohá da porção sul da área piloto poderia ter sido habitado por, no mínimo, 24 famílias ou 144 pessoas, pertencentes a uma mesma família extensa. Esta hipótese pode ser contrastada com as características dos sítios identificados nas prospecções.

Todos os sítios Guarani identificados apresentaram, em geral, uma baixa densidade de materiais, com exceção do sítio RS-S-399: Campestre Novo 1. Os fragmentos cerâmicos são de pequenas dimensões e encontram-se esparsos ao longo das áreas aradas, sem formar concentrações, não ultrapassando, em geral, uma dezena de peças. Os artefatos líticos, por sua

\footnotetext{
${ }^{17}$ Sítios RS-S-399: Campestre Novo 1 e RS-S-416: Campestre Novo 2.

${ }^{18}$ Sítio RS-S-408: Alto Rolantinho.
} 
vez, apresentam grandes dimensões, representados preferencialmente por peças bifaciais, estando também presentes, em menores proporções, núcleos e resíduos de lascamento unipolares. Em nenhum dos casos estudados foi possível identificar a presença de manchas pretas elipsoidais ou arredondadas que na literatura Guarani são identificadas como produto da decomposição dos materiais orgânicos utilizados na edificação das teii oga. No entanto, entrevistas com os proprietários dos sítios permitiram resgatar o histórico dos processos pósdeposicionais que vem afetando estes contextos arqueológicos por várias décadas.

A possibilidade de localização dos sítios arqueológicos na área estudada, tendo em vista a baixa visibilidade de solo, em geral, dependeu da presença de áreas cultivadas. Contudo, a baixa densidade de materiais identificada é decorrente da alta intensidade da perturbação antrópica recente, associadas à ação dos desmatamentos e do cultivo de subsistência contínuo ao longo de pelos menos 40 anos. O caso do sítio RS-S-399: Campestre Novo 1 é um exemplo desta situação, pois a alta densidade de materiais observada decorre do fato de que o local onde se situa só passou a ser cultivado de forma mais intensa há poucos anos atrás, tendo em vista seu difícil acesso ${ }^{19}$. Para os casos estudados, observa-se que o preparo da terra com arado de boi causa menor perturbação dos estratos arqueológicos se comparado com a ação do arado mecânico, atingindo uma profundidade máxima de $30 \mathrm{~cm}$ de solo e proporcionando deslocamentos laterais pouco significativos das peças ${ }^{20}$. Contudo, são freqüentes os casos relatados pelos moradores quanto à retirada e descarte intencional de materiais arqueológicos durante o preparo da terra, pois estes “machucam os pés e arruínam o fio das foices quando da colheita da cana” ou "atrapalham o arado de boi quando do preparo da terra”. Por outro lado, o tipo de cultivo mais freqüente na região, a mandioca e milho, contribui para a destruição dos sítios arqueológicos, através de floraturbações causadas pelo crescimento das raízes e, principalmente, pelo sistema de colheita da mandioca que demanda a arrancada dos pés, deslocando grande quantidade de terra e, conseqüentemente, materiais arqueológicos (Wood \& Jonhson, 1978: 328-333; Schiffer, [1987] 1996: 210-212).

Igualmente, este tipo de atividade agrícola acaba por “mascarar” os conjuntos arqueológicos remanescente, pois tem o efeito de selecionar os materiais por tamanho (size

\footnotetext{
${ }^{19}$ O sítio está localizado em uma chácara de lazer recentemente adquirida e o proprietário informou que escolheu àquele local para cultivar pois queria um lugar para trabalhar "com uma vista bonita”, mesmo que para isto tivesse que caminhar quase 40 minutos desde sua casa para atingir o topo do morro onde o sítio se situa.

20 Araújo (2001) oferece uma rica revisão bibliográfica sobre métodos actualísticos desenvolvidos pela arqueologia norte americana, a partir da década de 1980, para interpretação de sítios sujeitos à ação de arado (plowzone archaeology).
} 
effect). Em geral, os artefatos maiores são trazidos à superfície pelo arado com mais freqüência do que as peças pequenas e dificilmente são reincorporados ao depósito quando a terra é arada novamente. Também, os artefatos grandes sofrem um maior deslocamento lateral sob a ação do arado do que as peças menores, que tendem a permanecer mais próximas de seus locais de deposição primária (Baker, 1978; Schiffer, [1987] 1996). Do conjunto de sítios Guarani da área, 13 apresentaram associação entre evidências líticas e cerâmicas (sendo a cerâmica sempre mais escassa que o lítico) e 5 apresentaram apenas artefatos líticos. Porém, os proprietários dos sítios lito-cerâmicos e líticos foram unânimes em afirmar que "quando do início do cultivo os fragmentos de cerâmica eram abundantes, mas tornaram-se escassos ao longo dos anos, sobrando só as pedras", exemplificando de forma clara o "efeito de tamanho" representado pelos sítios líticos Guarani na área. Outro aspecto que pode ser relacionado ao “efeito tamanho" diz respeito ao padrão de implantação dos sítios Guarani. Situadas geralmente em platôs na meia encosta, estas áreas sofreram um intenso desmatamento ao longo dos anos para serem aproveitadas para plantações ou pastagens, sendo atualmente afetadas por intensa erosão pluvial que contribui para o arraste na torrente dos artefatos menores, como os fragmentos cerâmicos e resíduos de lascamento de menor porte como as lascas bipolares (Schiffer, [1987] 1996: 251-252).

Apesar do alto índice de perturbação antrópica atual dos sítios, os documentos de campo decorrentes das pesquisas de Eurico Miller na área mostram um quadro distinto que permite inferências relativas à densidade e organização original das aldeias que ocuparam o tekohá do Alto Rio dos Sinos. Quatro dos conjuntos de sítios da área nuclear do tekohá apresentavam, há 37 anos atrás, "manchas pretas" que podem ser interpretadas como remanescentes de casas extensas (teii oga). A maior das manchas pretas registradas por Miller está associada ao sítio RS-S-290: Mont Serrat 2, com 120 x 60 m. A 500 m desta, na outra margem do rio dos Sinos, foi identificado no sítio RS-S-289: Mont Serrat-1, um conjunto de três manchas circulares menores, cujo diâmetro não foi registrado. Este padrão pode representar uma aldeia com uma grande teii oga em uma posição central que abrigaria uma família extensa e na periferia desta, três casas menores ocupadas por famílias de menor prestígio, porém também relacionadas por afinidade sangüínea ou política à linhagem original. Outra possibilidade seria a de que as casas menores teriam sido construídas em um momento posterior ao abandono da casa grande, podendo ter sido aproveitadas as matérias primas construtivas ainda úteis, como os esteios centrais da casa original. O padrão de três casas poderia ser decorrente de uma queda demográfica ou de uma desagregação da linhagem 
original (teii). Outra hipótese pode relacionar as três manchas menores a áreas de atividade específicas, representando a mancha maior à área de habitação e as menores locais de trabalho em madeira, pois o sítio RS-S-289: Mont Serrat-1, apresentou grande densidade de material lítico $^{21}$.

Os três sítios pesquisados por Miller na confluência do arroio Caraá com o rio dos Sinos apresentaram também conjuntos de "manchas pretas” a semelhança dos acima descritos. O sítio RS-S-285: Passo da Forquilha-1, apresentava três manchas de terra preta, cujas dimensões foram estimadas pelo pesquisador em 40 × 20 m. A 1,5 Km deste último situava-se o sítio RS-S-287: Passo da Forquilha-2, onde foi coletada uma grande quantidade de artefatos líticos bifaciais dispersos por uma área de 120 x 60 m. Este último sítio distanciase apenas $30 \mathrm{~m}$ do sítio RS-S-288: Passo da Forquilha-3, descrito na ocasião como correspondendo a uma concentração de cerâmica Guarani dispersa entre duas manchas de terra preta, com dimensões também estimadas em 40 x 20 m. Sugerimos para este caso um modelo de implantação semelhante ao observado para os sítios da localidade de Rio dos Sinos, representando os sítios RS-S-285: Passo da Forquilha 1 e RS-S-288: Passo da Forquilha 3, dois momentos de ocupação de uma mesma aldeia, com o curto deslocamento das casas, de uma margem do rio para a outra ${ }^{22}$. Por sua vez, o sítio RS-S-287: Passo da Forquilha 2 representaria uma área de atividade específica próxima ao rio comum as duas ocupações, associada à extração de matéria prima e a produção de artefatos líticos de grande porte, possivelmente utilizados na construção das casas, na confecção de canoas ou nas atividades agrícolas e de manejo agroflorestal (Noelli e Dias, 1995).

Infelizmente, as atuais condições de degradação dos sítios na área e a falta de informações contextuais quanto às coleções decorrentes das pesquisas do PRONAPA, resultantes de coletas de superfície assistemáticas, impedem a possibilidade de estudos de áreas de atividade relacionada às estruturas habitacionais ${ }^{23}$. A literatura arqueológica Guarani também é pobre em estudos do gênero que pudessem servir de subsídio para a interpretação das unidades habitacionais relacionadas aos sítios identificados na área. Até o presente foram

\footnotetext{
${ }^{21}$ O sítio RS-S-407: Quebrada Rio dos Sinos apresenta uma posição periferia ao conjunto de sítios acima descritos, porém apresenta uma dispersão e densidade de material de relativamente alta que talvez possibilitasse testar as hipóteses acima levantadas.

${ }^{22}$ Também foram identificadas “manchas pretas” pelas pesquisas do PRONAPA nos sítios RS-S-284 e RS-S286.

${ }^{23}$ Exceção a este quadro é apresentada pelo sítio RS-S-399: Campestre Novo 1, que pode oferecer subsídios interessantes para futuras pesquisas sobre espacialidade dos assentamentos Guarani na área.
} 
publicados apenas dois estudos descritivos de estruturas habitacionais de sítios Guarani ${ }^{24}$ para o Rio Grande do Sul (Schmitz et al, 1990; Carle, 2003). Contudo, acreditamos que em um curto espaço de tempo esta deficiência interpretativa pode ser superada em novas pesquisas de campo, tendo em vista a possibilidade de elaboração de modelos interpretativos baseados nos dados etnoarqueológicos hoje disponíveis, tanto relacionados à analogia histórica direta para os Guarani (Landa, 1995; Soares, 1997), quando a modelos gerais para os Tupinambá do século XVI (Assis, 1995) e grupos Tupi contemporâneos, como os Mbyá-Guarani (Assis, 1999) e os Assuriní do Xingu (Silva, 2000).

Embora haja limitações interpretativas tendo em vista as fontes bibliográficas disponíveis para a arqueologia Guarani, podemos observar a partir dos dados de Miller uma permanência do modelo de três casas representadas por “manchas pretas” ao longo do curso do Alto Rio dos Sinos. Iniciando com uma casa de grandes dimensões, próxima a confluência do rio dos Sinos com o arroio Sertão, porém, o diâmetro das “manchas pretas” diminui a medida em que se aproximam da confluência do rio dos Sinos com o Arroio Grande. Tendo por base o modelo de Noelli (1993), podemos sugerir que o padrão observado representaria uma tendência de deslocamento de uma sede de aldeia (amundá) no território de domínio manejado por longa data (tekohá). Estes deslocamentos, contudo, poderiam estar associados a uma queda demográfica, representada pela diminuição do diâmetro das casas.

As cronologias disponíveis para a ocupação Guarani nos vales dos rios Jacuí, Vacacaí, Pardo e Caí apontam a presença Guarani na área nordeste do Estado, por pelo menos 2.000 $\operatorname{anos}^{25}$. As datas mais antigas estão associadas à bacia hidrográfica do Alto Jacuí, remontando o início da era Cristã, estendendo-se as datações nas bacias hidrográficas dos rios Vacacaí, Pardo, Baixo Jacuí e Caí até o século XVIII, período compatível as datas por nós obtidas para o Alto Vale do Rio dos Sinos (Jacobus, 2000; Noelli, 1999/2000). Este padrão apresenta correspondência com o modelo de “colonização” de novas áreas pelos Guarani pré-coloniais, sugerido por Brochado (1984), concentrando-se as ocupações mais antigas nos vales maiores, como o caso do Jacuí, e paulatinamente estendendo-se as novas aldeias para os vales dos principais afluentes, como é o caso do Vacacaí, Pardo, Caí e Sinos. Esta expansão, contudo,

\footnotetext{
${ }^{24}$ No vale do rio Pardo foi escavado o sítio Candelária 1, sem datações (Schmitz et al 1990), e no município de Rio Grande, próximo a Lagoa dos Patos, foi escavado o sítio RS-002-2: Povo Novo, com datações de $580 \pm 50$ AP e 510 + 60 AP, sem referencia ao laboratório (Carle, 2003; Noelli, 1999/2000: 253).

${ }^{25}$ As datações apresentadas por Noelli como relacionadas à sítios Guarani (Noelli, 1999/2000: 250-253), apontam para os Estados de São Paulo datações entre 1870 e 470 AP, para o Paraná, entre 2010 e 85 AP, para o Mato Grosso do Sul, entre 1493 e 240 AP e para Santa Catarina, entre 1070 e 420 AP.
} 
prevê a manutenção das áreas inicialmente ocupadas, como pode ser atestado pelas cronologias dos sítios do médio Jacuí, estudados por Rogge (1996), que apontam uma permanência Guarani nesta região por pelo menos 1200 anos $^{26}$.

Jacobus (2000) destaca que o processo inicial de expansão Guarani na região nordeste do Estado apresenta contemporaneidade com as ocupações de caçadores coletores apenas nas regiões hidrográficas do Alto Jacuí e das Bacias Litorâneas. No restante da área observa-se que as datações para as ocupações caçadoras coletoras limitam-se a faixa temporal de 500 anos AP, momento em que se tornam mais freqüentes as datações para sítios Guarani. Com base nestes dados, sugerimos que no vale do rio dos Sinos a ocupação Guarani se sobrepõe à caçadora coletora, cuja datação mais recente está em torno de 500 AP, não sendo, portanto, anterior a este limite temporal e estendendo-se até a segunda metade do século XVIII.

O mesmo processo observa-se quanto às cronologias disponíveis para sítios da Tradição Taquara na região nordeste do Estado, com datações distribuídas entre $1520 \pm 90$ AP (SI 607) e $620 \pm 90$ AP (SI 608) para a bacia hidrográfica dos rios das Antas e Taquari. Para o caso da Bacia Hidrográfica do rio dos Sinos as duas datações disponíveis para a Tradição Taquara são anteriores em pelo menos mil anos a presença Guarani, apresentando correlação com as datações do rio Caí ${ }^{27}$. Em ambos os casos, as evidências de contato entre as distintas populações que ocuparam o vale dos Sinos são inexistentes até o presente, apontando para um padrão de conquista Guarani da área sem assimilação das populações precedentes, exterminadas pela guerra ou expulsas para outros ambientes não explorados pelos Guarani.

Se estabelecermos as balizas cronológicas da ocupação Guarani do Alto Rio dos Sinos entre 1450 e 1750 AD, teríamos um período de ocupação de pelos menos 300 anos da área. Retomando os padrões de distribuição de sítios identificados sob o prisma do modelo de Noelli (1993), podemos sugerir que cada um dos conjuntos de sítios identificados ao longo do vale do Alto rio dos Sinos poderia ter sido ocupado por aproximadamente 50 anos. Considerando que cada um destes núcleos é formado, em média, por 3 a 4 sítios arqueológicos considerados como unidades habitacionais, podemos estimar uma ocupação das casas por um período de 10 a 15 anos, compatível com as projeções da literatura etnográfica

\footnotetext{
${ }^{26}$ A datação mais antiga na área é a do sítio RS-MJ-60, de 1475 + 80 AP (SI 2203), e a mais recente é para o sítio RS-MJ-71, 265 + 90 AP (SI 2199). Outras três datações em sítios no mesmo vale apontam uma continuidade de ocupação: RS-MJ-101 com datação de $1255 \pm 100$ AP (SI 2201), RS-MJ-98 com datação de $775 \pm 65$ AP (SI 2198) e RS-MJ-87 com datação de $695 \pm 55$ AP (SI 2200).
} 
atual para os Guarani que aponta uma média de 6 anos para mudança de residência (Noelli, 1993).

Embora não tenhamos um controle cronológico preciso para a área de estudo, os padrões de sítios observados ao norte da área piloto e o padrão de implantação dos sítios no vale do arroio Campestre levam a crer que estes estejam associados a um tekohá estabelecido em um período contemporâneo a presença européia na área, representando um deslocamento populacional das áreas tradicionalmente manejadas para posições defensivas periféricas. Este estratégia corresponderia a uma última tentativa de resistência ao avanço das frentes coloniais, ativas desde o século XVI, com as expedições das bandeiras paulistas no território riograndense, e concretizada pela instalação do Registro de Viamão, junto ao Rio dos Sinos, no início do século XVIII. Os impactos causados pelos primeiros contatos levam a desestruturação, em menos de um século, dos modos de vida tradicional Guarani mantidos ao longo de dois milênios ${ }^{28}$.

\footnotetext{
${ }^{27}$ Correspondem a dois sítios a céu aberto: RS-S-282 com datação de $1380 \pm 110$ AP (SI 414) e sítio RS-S-61 $1190 \pm 100$ AP (SI 409). Para a bacia hidrográfica do rio Caí foram obtidas 5 datações para uma casa subterrânea (sítio RS-37/127), entre 1480 + 70 AP (SI 603) e 630 + 70 AP (SI 604).

${ }^{28}$ Segundo Schmitz (1991:313-321), o Guarani do sul do Brasil e regiões vizinhas foi colhido no século XVI pelas tenazes opostas de duas etnias altamente expansivas: a escravista portuguesa, por um lado, e a missionária espanhola, por outro. Das frentes portuguesas, a das plantations (fazendas de cultivo para a exportação) de São Vicente, Piratininga e Rio de Janeiro começam a atuar em 1585, contra os Guarani do litoral catarinense e norte do Rio Grande do Sul, iniciando a partir de 1600 as descidas para predação dos índios do sul do Brasil. Paralelo ao movimento escravista de São Vicente, inicia a frente missionária jesuítica em terras da coroa de Portugal, com ponto de apoio no Rio de Janeiro. Tentativas de fixar reduções no sul do Brasil, na costa, ocorrem entre 1605 e 1637, mas os atritos com as bandeiras são grandes e a iniciativa abandonada, retornando os jesuítas para o Rio de Janeiro com os índios cristianizados durante este primeiro período missionário. Em 1635, conseqüência do comércio escravista da costa e das bandeiras do interior, os Guarani livres praticamente desaparecem no Rio Grande do Sul. Pelo lado espanhol, a expansão missionária de Assunción vai congregar a maior parte dos Guarani remanescentes dos ataques portugueses. A partir de 1609, a maior parte dos Guarani do oeste do Paraná, do centro e oeste do Rio Grande do Sul, do nordeste da Argentina e sudeste do Paraguai foram incorporados às reduções e transformados em cidadãos da Coroa de Espanha. Contudo, a ação das bandeiras paulistas é intensa sobre estas reduções no período entre 1611 e 1639, conduzindo ao deslocamento dos índios reduzidos no Rio Grande do Sul para a outra margem do rio Uruguai. Os índios transmigrados voltam a se instalar no noroeste do Rio Grande do Sul a partir de 1687, construindo os Sete Povos, que abrigava entre 100.000 a 300.000 Guarani sobreviventes aos primeiros séculos de contato,entrando em decadência cem anos mais tarde, em função da redefinição das linhas de fronteira do sul do Brasil entre as coroas de Espanha e Portugal, com o Tratado de Madrid.
} 


\subsection{Os Horticultores da Tradição Taquara no Alto Vale do Rio dos Sinos}

\subsubsection{Modelo de Mobilidade e Sistema de Assentamento Jê Pré-colonial no Sul do} Brasil: Um Objeto em Construção

Os primeiros estudos relativos à caracterização de coleções cerâmicas pré-coloniais distintas das Guarani no sul do Brasil foram realizados por Schmitz, em finais da década de 1950, no município de Osório, no litoral norte sul-rio-grandense. Porém, foi somente a partir do PRONAPA que pesquisas de maior amplitude quanto a estes contextos passaram a ser realizados no sul do Brasil. Em finais da década de 1960, os estudos prospectivos e as escavações realizadas pelas equipes do Instituto Anchietano de Pesquisas (IAP/UNISINOS) e da Universidade de Caxias do Sul (UCS), bem como pelos integrantes do PRONAPA nos três estados do sul do Brasil permitiram a identificação de distintos padrões de implantação correlacionada a esta cerâmica, destacando-se os sítios com estruturas subterrâneas localizadas no alto do Planalto sul-brasileiro (Schmitz \& Becker, 1991). A variabilidade regional dos padrões de tratamento de superfície, bem como da composição da pasta desta cerâmica, por sua vez, levou a definição pelo PRONAPA de três tradições regionais. A Tradição Taquara, abrigaria as fases cerâmicas definidas para o Rio Grande do Sul e sul de Santa Catarina, correspondendo as fases cerâmicas do Paraná e região central e litorânea de Santa Catarina à Tradição Itararé. Por fim, as fases cerâmicas definidas para o sul do Paraná e planalto catarinense seriam congregadas na Tradição Casa de Pedra (Schmitz, 1988).

As datações disponíveis para estes contextos arqueológicos apontam uma ocupação de longa duração para estas Tradições, contemporânea ao início da presença Guarani na região. No planalto sul-rio-grandense encontramos datações entre 1810+85 AP (SI 813) e 355+50 AP (SI 6559) para o vale do rio Pelotas, entre 830+60 AP (SI 598) e 160_70 AP (SI 599) para o vale do rio da Várzea e entre 1515_105 AP (SI 805) e 700_60 AP (SI 2343) para o vale do rio das Antas $^{29}$ (Noelli, 1999/2000: 244-245). Para as bacias hidrográficas dos rios Caí e dos

\footnotetext{
${ }^{29}$ Para Santa Catarina a quantidade de datações é menor se comparada às pesquisas no Rio Grande do Sul, mas também se observa uma profundidade temporal semelhante, sendo a datação mais antiga de 1920+50 AP (SI 811) e a mais recente de 330+90 AP (SI 997). O mesmo se aplica para o Estado do Paraná, sendo a datação mais antiga da região de 1475+65 AP (SI 2197) e a mais recente de 255+100 AP (SI 692) (Noelli 1999/2000:244245).
} 
Sinos também se observa uma ocupação de longa duração, iniciada em torno de 1500 anos $\mathrm{AP}^{30}$ e, possivelmente, interrompida com a intensificação da ocupação Guarani na área, por volta de 500 anos atrás. Na bacia hidrográfica do rio Caí, o sítio RS-127 apresentou uma seqüência de 5 datações para duas estruturas subterrâneas e uma estrutura monticular com datas entre 1480+70 AP (SI 603) e 630+70 AP (SI 604). O intervalo de 850 anos entre as datações mais antigas e recentes para este sítio indica um padrão de manutenção de território pelas populações da Tradição Taquara, representado possivelmente processos de abandono e reocupação de um mesmo sítio associado a uma área de domínio mais ampla. Por sua vez, os dois únicos sítios a céu aberto datados para a Tradição Taquara no vale do rio dos Sinos também apontam para uma ocupação antiga da área com resultados entre 1380+110 AP (SI 414) e 1190+100 AP (SI 409) (Jacobus, 2000).

Comparando os dados arqueológicos concernentes às fases e sítios que compõe as três Tradições cerâmicas do Planalto Sul Brasileiro, Schmitz (1988) conclui que embora haja variabilidade restrita a alguns aspectos da produção cerâmica, todas compartilham características comuns quanto aos padrões de assentamento observados, em sua inter-relação com tipos de ambientes distintos. Com base nestas observações, Schmitz propõe um modelo de assentamento e subsistência para estas populações, baseado no domínio vertical de três estratos topográficos: planalto, encosta e litoral. O abastecimento anual destas populações se daria através de exploração sazonal dos recursos destes distintos ambientes, organizando-se a partir de sistemas de mobilidade populacional e/ou de intercâmbio de recursos entre populações relativamente fixas (Schmitz, 1988: 118-120; Schmitz \& Becker, 1991: 267-270).

O autor observa que nos três Estados da região sul, os sítios arqueológicos com estruturas subterrâneas e monticulares concentram-se nas cotas mais elevadas do planalto sulbrasileiro, associadas às florestas de araucária, entremeadas por campos. Neste tipo de ambiente os sítios a céu aberto são mais raros, estando a ocupação dos abrigos sob rocha relacionadas a sepultamentos ${ }^{31}$. Avaliando os dados descritivos disponíveis para os sítios

\footnotetext{
30 Duas das datações apontadas para sítios da Tradição Taquara no Rio Grande do Sul por Noelli (1999/2000:245), correspondem a sítios em abrigo sob rocha associados à Tradição Umbu. O sítio RS-S-359: Aterrado, situado em nossa área de pesquisa, não apresenta nenhum tipo de associação com material cerâmico histórico ou pré-histórico. O sítio RS-C-12: Viradouro apresenta fragmentos de cerâmica da Tradição Taquara em superfície, contudo a datação referida por Noelli está associada à ocupação caçadora coletora do sítio.

${ }^{31}$ O abrigo sob rocha “do Matemático”, no município de Bom Jesus, no Rio Grande do Sul, é destacado por Schmitz \& Becker (1991:258-259) como típico para este padrão de sítio, tendo sido pesquisado no início da década de 1970 pela equipe do IAP/UNISINOS e por Eurico Miller, como membro do PRONAPA. Este corresponde a uma gruta que se abre entre duas camadas de basalto, em meio a escarpas de difícil acesso. A gruta possui pequena abertura, de $80 \mathrm{~cm}$, dando acesso a um salão de $40 \mathrm{~m}$ de largura, por $9 \mathrm{~m}$ de profundidade e
} 
desta região, Schmitz e Becker (1991) concluem que as estruturas subterrâneas corresponderiam a unidades habitacionais ${ }^{32}$ adaptadas às baixas temperaturas do planalto. Estes tipos de estruturas encontram-se geralmente agrupadas, podendo chegar a dezenas de casas, com dimensões variadas. Analisando de forma comparativa os conjuntos de casas subterrâneas da região de Vacaria e Bom Jesus (fase Guatambu), os autores destacam que estas formam conjuntos de no máximo 22 casas, com diâmetros entre 2,5 e 18 m, atingindo profundidades entre 2 e 6 m. Contudo, a ocupação destas casas subterrâneas dificilmente seria simultânea, representando povoados semi-dispersos, abandonados e reocupados por centenas de anos, sempre localizados próximos a fontes de água perenes como nascentes de rios ou pequenos córregos.

As áreas de menor altitude, como os altos vales de rios e as encostas do planalto da região sul, relacionados a ambiente de floresta sub-tropical, apresentam, predominantemente, sítios a céu aberto de dimensões variadas, em geral com alta densidade de artefatos cerâmicos e líticos, sendo ocasionais as ocupações em abrigos sob rocha, também utilizados para sepultamentos. Estes possivelmente representariam ocupações permanentes, contemporâneas às aldeias de casas subterrâneas do planalto, atingindo a área de dispersão de materiais nos maiores sítios até $4.000 \mathrm{~m}^{2}$. Os sítios da encosta estariam relacionados ao cultivo, estando também representados neste assentamento pequenos acampamentos estacionais relacionados à caça, pesca e coleta.

Por fim, na planície litorânea dos três estados da região sul também são freqüentes a presença de sítios a céu aberto, muitas vezes relacionados a acúmulos de conchas e restos arqueofaunísticos associados a atividades de pesca e a caça (concheiros). Numerosos sepultamentos estão associados aos sítios do litoral central e norte de Santa Catarina e do litoral paranaense, indicando ocupações mais permanentes onde há associação entre vegetação litorânea e mata atlântica (Schmitz, 1988; ver também Izidro, 2001).

de 2,1 m de altura máxima. O solo apresentava perturbações devido, possivelmente, a ação de “caçadores de tesouros”, estando dispersos em superfície fragmentos ósseos humanos em grande quantidade, além de fragmentos de cerâmicas da Tradição Taquara e restos de milho, pinhão e fragmentos de taquara utilizados para cestaria. Não há dados relativos ao número mínimo de indivíduos para os restos humanos, porém haveria informações locais quanto à existência de 12 a 15 crânios, levados por visitantes ocasionais. Notícias quanto à identificação de sítios semelhantes na região de Vacaria, são apresentados por Krever e Haubert (2001), Rogge (1999a), Rosa (1998, 1999) e Schmitz e colaboradores (2002).

${ }^{32}$ Ver críticas de Reis $(1997,2002)$ quanto à associação funcional direta entre estruturas subterrâneas e unidades habitacionais nos sistemas de assentamento relacionados à Tradição Taquara. 
O modelo de domínio vertical entre estes três ambientes prevê um abastecimento diferencial ao longo do ano, reforçado por um sistema de estocagem de alimentos, garantindo, desta forma, a estabilidade habitacional dos assentamentos. Esta, por sua vez, poderia se dar tanto através de migrações estacionais individuais, familiares ou plurifamiliares pelos diferentes ambientes que compõe o sistema de assentamento do grupo ou ocorrer através do intercâmbio de bens e pessoas para complementação dos recursos da área residencial central (Schmitz, 1988; Schmitz \& Becker, 1991).

Avaliando as implicações de seu modelo para a compreensão das seqüências históricoculturais disponíveis no final da década de 1980, Schmitz conclui que:

"pelas diferenças regionais observadas pode-se inferir que lidamos com populações que tem um fundo tecnológico e cultural comum, mas que se divide em territórios sobre os quais mantém domínio por séculos. Sobre o deslocamento destas populações dentro do próprio espaço e com relação ao território de outros grupos não sabemos quase nada". (1988:121)

As linhas de pesquisa que se desenvolveram a partir de meados da década de 1990 sobre o tema vêem suprir as deficiências apontadas por Schmitz. Nos últimos anos, projetos regionais desenvolvidos nos municípios de Vacaria e Bom Jesus, no vale do rio Pelotas, pelas equipes do IAP/UNISINOS e NUPArq/UFRGS, respectivamente, tem desenvolvido estudos arqueológicos de caráter contextual, voltados a compreender a variabilidade intra e inter-sítios relacionados a estruturas subterrâneas da área. Simultaneamente, a equipe do IAP/UNISINOS tem desenvolvido projetos no litoral sul catarinense, no município de Içara, e central gaúcho, no município de Quintão, a fim de melhor compreender a funcionalidade e a variabilidade entre sítios litorâneos com características de implantação semelhantes associados às Tradições Itararé e Taquara. Estes projetos vêem desenvolvendo preocupações concernentes aos sistemas de subsistência, aos processos de formação dos sítios, à cronologia dos assentamentos, à caracterização de áreas de atividade e variabilidade funcional entre os assentamentos de uma mesma área, às distinções tecnológicas entre os conjuntos de distintas regiões, bem como quanto às características antropo-biológicas destas populações, e em um curto espaço de tempo contribuirão para superação das lacunas existentes quanto ao conhecimento arqueológico dos horticultores do planalto sul-brasileiro (Copé, 1999; Copé \& Saldanha, 2002; Copé et al, 2002; Izidro, 2001; Krever et al, 1998; Krever \& Haubert, 2001; 
Rogge, 1999a; 1999b; Rosa, 1998, 1999; Schmitz, 1999; Saldanha \& Copé, 1998; Schmitz et al, 2002).

Outra linha de pesquisa que vem se desenvolvendo diz respeito às possibilidades de estudos etnoarqueológicos, baseados nas fontes etno-históricas para as populações do planalto, como geradora de modelos interpretativos para os dados arqueológicos disponíveis. Schmitz e Becker, procurando avaliar os processos históricos que afetaram as populações da Tradição Taquara no Rio Grande do Sul, sugerem que

Hoje há uma idéia absolutamente dominante que a população sobreviveu [a conquista européia](...), embora com nomes cambiantes (Guaianá, Coroado, Kaingang) e em condições cada vez menos satisfatórias devido à progressiva redução de seu território e, com isto, de seu potencial de abastecimento, estando representada hoje por grupos Kaingang das reservas indígenas do nordeste e noroeste do Estado (Schmitz \& Becker, 1991: 252).

Partindo deste pressuposto, os autores buscam nas fontes etno-históricas ${ }^{33}$ do século XIX para os Kaingang, subsídios para complementar o modelo de domínio vertical para a ocupação pré-colonial. Desta forma, esboçam um ciclo anual de abastecimento das populações do planalto, estando o verão e o outono representado pelos cultivos na área de encosta, o inverno pela coleta do pinhão no planalto, estando o abastecimento através da coleta de moluscos e a pesca na área litorânea disponível ao longo de todo o ano.

Os dados coligidos junto às fontes etno-históricas e etnográficas por Noelli (1999/2000: 245-247) reforçam as propostas de Schmitz \& Becker (1991), demonstrando uma adaptação integrada aos variados ecótonos do sul do Brasil pelos Kaingang, tanto através do manejo agroflorestal, quanto pelas atividades de caça e pesca. As fontes etno-históricas também registram as estratégias de circulação no território de domínio, em diferentes áreas satélites da aldeia principal, onde predominam certos tipos de ofertas de alimentos. A agricultura documentada seria desenvolvida através de técnicas de cultivo em clareias na floresta, sendo alguns dos cultivares registrados a mandioca, as batatas doce e inglesa, o cará,

\footnotetext{
${ }^{33}$ Os autores, também sugerem correlação entre a área de dispersão de algumas fases cerâmicas da Tradição Taquara a locais de implantação de parcialidades indígenas Kaingang do século XIX, no intuito de oferecer um possível quadro de divisão territorial pré-colonial das áreas representadas pelas fases desta Tradição. "No século XIX, quando da ocupação definitiva pelos colonizadores europeus, os Campos de Cima da Serra eram dominados pelos Botocudos, adversários férreos dos Kaingang do cacique Braga, que ocupava os campos e
} 
o milho, os feijões e o amendoim. O início do ciclo anual parece ter sido regido pelo cultivo das roças, havendo a dispersão dos grupos afins após a colheita para áreas com concentração de diversas plantas de coleta, como o pinhão, que, provavelmente, correspondem a antigos locais de manejo agroflorestal. Estas florestas antropogênicas, por sua vez, também atraiam determinadas espécies animais, como o porco do mato, constituindo-se também em reservas de caça de exploração sazonal. O mesmo tipo de comportamento extrativo sazonal foi registrado quanto às atividades de pesca com o uso de armadilhas (pari) que podem servir de parâmetro para a compreensão dos sítios litorâneos com acúmulos de conchas e restos arqueofaunísticos associados à ocupação pré-colonial de grupos ceramistas. Estas atividades extrativas intensivas, concentradas em um determinado período do ano, garantiriam o abastecimento anual através de diversas técnicas de preservação de alimentos, tanto de origem vegetal como animal, para estocagem. As carnes, tanto provenientes da caça e da pesca, quanto da coleta de moluscos, poderiam ser desidratadas no moquém ou sob o sol e o pinhão, coletado no inverno, podia ser hidratado e depositado em silos subterrâneos e cestas em locais úmidos, permitindo seu consumo por vários meses.

Exercícios de análise cerâmica das Tradições do sul do Brasil, buscando relaciona-las as populações historicamente conhecidas da área já haviam sido propostos no fim da década de 1970, por Tom Miller Jr (1978). Contudo, o predomínio do modelo histórico-cultural proposto pelo PRONAPA, avesso a comparações entre contextos arqueológicos e etnográficos, desencorajou o desenvolvimento deste tipo de exercício interpretativo até recentemente. Este tipo de postura, de certa forma, criou barreiras para a compreensão da origem e desdobramentos históricos das populações representadas pelas Tradições cerâmicas do planalto sul-brasileiro, cristalizando a idéia de que estes grupos seriam autóctones e representaria uma evolução local do horizonte caçador coletor para o horticultor ${ }^{34}$, através do

pinheirais de São Francisco de Paula, Caxias do Sul e arredores, território da fase Taquara” (Schmitz \& Becker, 1991: 260).

${ }^{34}$ Segundo Schmitz, "o surgimento das tradições ceramistas é obscuro. Diversos arqueólogos registram que o material lítico de certas fases do planalto é muito semelhante ao das fases pré-cerâmicas locais. (...) Assim, nos parece que, ao menos em parte, populações pré-cerâmicas locais se transformaram em populações ceramistas. Como? Por modernização a partir de horizonte tecnológico e cultural do continente sul-americano? Ou através da migração de populações ceramistas e cultivadoras que teriam produzido um notável e rápido movimento renovador nas populações pré-existentes? (...) Não que imaginemos que, por exemplo, toda a Tradição Humaitá se tenha transformado na Tradição Taquara; os pescadores coletores litorâneos, na Tradição Itararé; ou os caçadores da Tradição Umbu do planalto catarinense, na Tradição Casa de Pedra. A situação é bem mais complexa e complicada pelo fato de as sistematizações aplicadas aos materiais e sítios arqueológicos produzirem resultados notavelmente ambíguos” (Schmitz, 1988: 121-122). Noelli (1999, 1999/2000) imputa este modelo interpretativo quanto à origem das populações ceramistas do planalto sul-brasileiro à assimilação acrítica, por 
contato com o Guarani (Schmitz, 1988; Schmitz \& Becker, 1991; Ribeiro, 1979; entre outros).

Tendo por base estudos lingüísticos, biológicos e antropológicos, Noelli (1999/2000: 240) advoga que as Tradições tecnológicas Casa de Pedra, Itararé e Taquara representam os antecedentes das populações Xokleng e Kaingang que ocupam a área, de matriz cultural Macro-Jê, originárias do Centro-Oeste brasileiro. As relações internas na família lingüística Jê colocam a língua Kaingang no conjunto Akwén (Xakriabá, Xavante e Xerente) e Apinayé, nos estados de Minas Gerais, Mato Grosso e Goiás, ocupando continuamente as terras mais altas do planalto brasileiro desde o Centro-Oeste do Brasil, nas bacias dos rios Tocantins e Araguaia e nos altos cursos dos rios São Francisco e Paraná. Os Xokleng estão associados ao grupo das línguas Kayapó, Timbia, Kren-akarôn e Suyá, ocupando as bacias dos rios Xingu e Paraná, baixo Tocantins e médio curso do rio São Manuel.

Na opinião de Noelli (1999/2000:241-242), as variações que se observa entre registro arqueológico e fontes etno-históricas são decorrentes dos processos de invasão e conquista dos territórios originais destas populações. Inicialmente o processo de expansão dos Jê pelo planalto brasileiro e sua diversificação regional em termos de cultura material e sistema de assentamento no sul do Brasil decorre das pressões sofridas pelas invasões Guarani, a partir do início da Era Cristã.

Em um segundo momento, a partir do século XVI, já em função da presença européia, observa-se uma redistribuição das populações Jê do Sul, tendo em vista que os grupos mais afetados pelas frentes coloniais em um primeiro momento correspondem às populações Guarani. Segundo Noelli (1999/2000: 261), nos 150 primeiros anos da presença européia houve um sucessivo processo de redução demográfica Guarani, esvaziando o interior e o litoral, do Paraná ao Rio Grande do Sul. Embora os Guarani tenham conseguido manter uma população nas reduções jesuíticas acima da média de 80.000 pessoas até 1750-60, a população não reduzida declinou até sobrarem dois bolsões principais no Paraguai e no Mato Grosso do Sul. Este processo, por sua vez, provocou uma remodelação na distribuição dos povos Kaingang e Xokleng, entre os século XVII e XX, com um possível aumento demográfico decorrente da ocupação dos antigos territórios abandonados pelos Guarani no interior e litoral dos três Estados do sul do Brasil. 
Do final do século XVIII a princípios do século XX, as terras tradicionais destas populações passam a sofrer novos impactos das frentes coloniais, através da instalação de imigrantes alemães, italianos e de outras nacionalidades européias em suas áreas de domínio no sul do Brasil. A depopulação é intensa em função deste último impacto, através de epidemias, incapacidade de reprodução dos sistemas de vida tradicionais pela redução e descaracterização dos territórios tradicionais, ou ainda, pela ação de grupos de extermínio financiados pelos governos provinciais, passando os remanescentes destes grupos a se submeter às políticas de confinamento dos povos indígenas em reservas restritas, a partir da fundação do Serviço de Proteção ao Índio (atual FUNAI) (Noelli, 1999/2000:261). Estima-se, pelas fontes etno-históricos, um contingente populacional para os Kaingang do século XIX, em torno de 2.000 a 3.000 pessoas para as áreas que passam a ser ocupadas pela colonização alemã e italiana do Rio Grande do Sul (Schmitz \& Becker, 1991: 270).

Tendo por base os processos históricos que afetaram as populações Jê do Sul do Brasil, Noelli (1999/2000: 242) sugere que os descompassos que encontramos entre fontes etno-históricas e arqueológicas representam o produto de um processo contínuo de guerras e desterritorialização que causou mudanças significativas na demografia, na cultura material, na organização sócio-política e nos sistemas de subsistência e assentamento. Estes processos teriam levado ao abandono definitivo de certos tipos de assentamento (como as aldeias de casas subterrâneas), de técnicas tradicionais de produção de artefatos (como a produção de cerâmica e de artefatos líticos) ou práticas de subsistência (como a agricultura no caso Xokleng, criando uma falsa imagem de um sistema caçador coletor ancestral) que demandam padrões tradicionais em equilíbrio, dependentes de territorialidade fixa. Contudo, observados os processos históricos que afetaram estas populações, a documentação etno-histórica pode ser uma fonte inesgotável para a elaboração de modelos interpretativos sobre a organização sócio-política e econômica, comum às populações Jê do Sul, bem como um referencial significativo para compreender as diferenças regionais de longa duração observadas no registro arqueológico (para tanto ver Becker, [1976] 1995; Lavina, 1994; Noelli, 1998b; Silva \& Noelli, 1996).

Um exemplo das possibilidades interpretativas desta linha de pesquisa para a análise cerâmica é oferecido por Silva (1999) a partir do estudo comparativo quanto à organização da tecnologia de produção de cerâmica entre Kaingang e Xokleng, baseada em dados dispersos em distintas fontes etno-históricas. Retomando a proposta de Miller Jr. (1978), a autora constata a manutenção de elementos técnicos comuns a ambos os grupos, indicando que 
compartilhavam em muitos aspectos uma mesma tradição tecnológica ${ }^{35}$. Este aspecto indicaria uma origem cultural comum ou uma maior interação destas populações em um dado período de sua história, questões estas que poderiam ser respondidas pela arqueologia, “desde que haja um compromisso explícito em estabelecer as inter-relações entre as populações ceramistas pré-históricas e estas populações Jê e, neste caso, considerando com profundidade as informações históricas sobre os mesmos” (Silva,1999: 67).

\subsubsection{Os Sítios da Tradição Taquara do Alto Vale do Rio dos Sinos:}

\section{Características de Implantação}

Os sítios relacionados ao sistema de assentamento da Tradição Taquara estão concentrados à nordeste da área piloto, junto às nascentes e ao curso médio dos arroios Grande e Sertão, em área de encosta e meia encosta, com altitudes médias entre 100 e 400 m (Anexo 3).

Junto às nascentes do arroio Grande situa-se um conjunto representado por três sítios. O sítio RS-S-429: Furna 1 situa-se em um platô na encosta, com altitude de 329 m, estando a $100 \mathrm{~m}$ das nascentes do arroio Grande. O sítio está dividido em três concentrações, intercaladas por mato secundário, estando as duas primeiras separadas pela estrada FurnaRiozinho que possivelmente cortou o sítio. A primeira concentração está associada a uma plantação mista de 70 x 50 m de extensão no sentido leste-oeste, apresentando fragmentos esparsos de cerâmica, associado a lascas e peças bifacias, relacionadas a um afloramento de basalto (UTM 22J 554 564/ 6713 796). A segunda concentração apresentou apenas peças líticas bifaciais e lascas, associadas a uma plantação de cana de 100 x 50 m (UTM 22J 554 535/ 6713 809). Uma terceira concentração de material lítico foi localizada a aproximadamente $200 \mathrm{~m}$ dos dois primeiros conjuntos, em meio a uma plantação mista de

\footnotetext{
${ }^{35}$ Um aspecto interessante a destacar no trabalho da autora, diz respeito às técnicas de tratamento de superfície, que representam a maior distinção entre os conjuntos cerâmicos analisados, apresentando a cerâmica Kaingang tratamentos de superfície semelhantes ao encontrado na cerâmica da Tradição Taquara e a cerâmica Xokleng grande afinidade com os tratamentos de superfície descritos para a Tradição Itararé/Casa de Pedra. As diferenças no tratamento da argila, relacionadas ao tipo de antiplástico, parecem mais ser o resultado de adaptações tecnológicas as matérias primas disponíveis em termos locais do que, propriamente, prescritividades culturais a serem consideradas como indicadores fidedignos para a definição de tradições tecnológicas (Silva, 1999: 60-65).
} 
pequenas dimensões, sendo coletado um biface e uma lasca de basalto (UTM 22J 554 344/ 6713 716) (foto 10).

O sítio RS-S-430: Furna 2 (UTM 22J 554129 - 6713 162) situa-se a 700 m ao sul do anterior, em uma meia encosta, a altitude de $260 \mathrm{~m}$. O sítio está associado a uma plantação mista com extensão de 250 x 100 m, na qual foi também identificado um afloramento de basalto de boa qualidade. A densidade de material é baixa, tendo sido localizados poucos fragmentos cerâmicos em superfície e nenhum artefato lítico. Entrevistas com o proprietário indicam que a concentração de cerâmica era alta até 30 anos atrás, tendo sido localizadas na época até mesmo vasilhas inteiras. Esta quantidade diminuiu consideravelmente ao longo dos anos em decorrência da ação agrícola e da erosão (foto 11).

O sítio RS-S-431: Furna 3 (UTM 22 J 554 057/ 6712 406) está a 600 m ao sul do sítio acima descrito, seguindo o curso do arroio Grande. Corresponde a um sítio lítico a céu aberto associado à Tradição Taquara tendo em vista sua proximidade com sítios cerâmicos acima descritos e a semelhança tecno-tipológica com o material lítico coletado no sítio RS-S429: Furna 1. O sítio situa-se em um platô de meia encosta, a uma altitude de $171 \mathrm{~m}$, a $100 \mathrm{~m}$ ao norte da confluência de dois braços do arroio Grande, estando associado a um afloramento de basalto de boa qualidade. O material arqueológico aflora em uma área de cultivo misto, com 150 x 150 m, tendo sido identificada alta densidade de lascas e núcleos unipolares e peças bifaciais (fotos 12 a 14).

Nas nascentes do arroio Sertão, a 3,5 Km a leste do conjunto de sítios acima descritos, foi localizado um sítio lítico, cujo material apresenta semelhanças tecno-tipológicas com as indústrias dos demais sítios da Tradição Taquara na área. O sítio RS-S-433: Morro das Flores (UTM 22J 558 069/ 6712 868) está associado a um afloramento de basalto, em uma área preparada para o cultivo de mandioca de 100 x $50 \mathrm{~m}$, em meio a capões de mato secundário. Situa-se em uma meia encosta, a altitude de $410 \mathrm{~m}$, distando $50 \mathrm{~m}$ de uma das nascentes do arroio Sertão. A densidade de material em superfície é baixa, correspondendo a lascas e núcleos unipolares. A 4,5 Km a sudeste deste, foi identificado outro sítio lítico a 400 m da margem esquerda do arroio Sertão, cuja indústria também apresenta semelhanças com os demais sítios da Tradição Taquara da área. O sítio RS-S-432: Sertão Rio dos Sinos (UTM 22J 556 203/ 6709 920) está associado a um afloramento de basalto, apresentando uma densidade de material baixa em superfície. Está em meio a áreas não contíguas de cultivo de mandioca, intercaladas por capões de mato secundário, com uma extensão total aproximada 
de 250 x $150 \mathrm{~m}$. Situado em uma meia encosta, a altitude de $101 \mathrm{~m}$, dista $400 \mathrm{~m}$ da confluência de uma pequena sanga com o curso médio do arroio Sertão.

A 1,5 Km a nordeste deste último sítio localiza-se o abrigo sob rocha RS-S-328: Caipora (UTM 22J 557 804/6709 448), na vertente leste do Morro das Flores. O sítio está a uma altitude de 300 m e corresponde a uma fenda no basalto, com orientação sudeste, tendo difícil acesso. O sítio foi pesquisado por Eurico Miller em 1968, quando foram realizadas coletas de superfície. A coleção é predominantemente composta por fragmentos ósseos humanos, com um número mínimo de 23 indivíduos, estando ausentes os crânios $\left(\mathrm{n}^{\circ}\right.$ de catálogo junto ao MARSUL: 453 e 983 a 985). Moradores mais antigos do local afirmam que há mais de 50 anos atrás o proprietário do abrigo teria retirado os crânios, enterrando-os em local desconhecido, pois as crianças da localidade costumavam utiliza-los em suas brincadeiras. Uma destas amostras de osso foi datada na época, obtendo-se o resultado de 1655+65 AP (SI 2345), indicando contemporaneidade com o sistema de assentamento caçador coletora que ocupa a porção leste da área piloto. Em função da datação obtida e da ausência de outros marcadores culturais além de algumas lascas de basalto, o sítio foi classificado por Miller como associado à Tradição Humaitá. Porém, o sítio apresenta maior correlação espacial com os sítios da Tradição Taquara, além de apresentar um padrão de sepultamento compatível ao identificado para esta Tradição no planalto sul-rio-grandense. Igualmente, a datação obtida também é compatível com as cronologias disponíveis para esta Tradição no planalto, bem como nos vales dos rios Caí e dos Sinos. Estas evidências colaboram para associar o sítio RS-S-358: Caipora ao sistema de assentamento da Tradição Taquara na área piloto, oferecendo uma referência cronológica para esta, uma vez que os sítios cerâmicos identificados mostraram-se pouco densos para a realização de datações ${ }^{36}$ (foto 9).

\footnotetext{
${ }^{36}$ Recentemente, a equipe do IAP/UNISINOS iniciou um estudo antropo-biológico desta coleção esqueletal ao fim de compará-la com os conjuntos similares que vem sendo estudados pelo Projeto Vacaria, coordenado por Pedro Ignácio Schmitz. Os resultados desta pesquisa, por sua vez, contribuirão significativamente para reforçar a hipótese de afiliação cultural deste sítio à Tradição Taquara.
} 


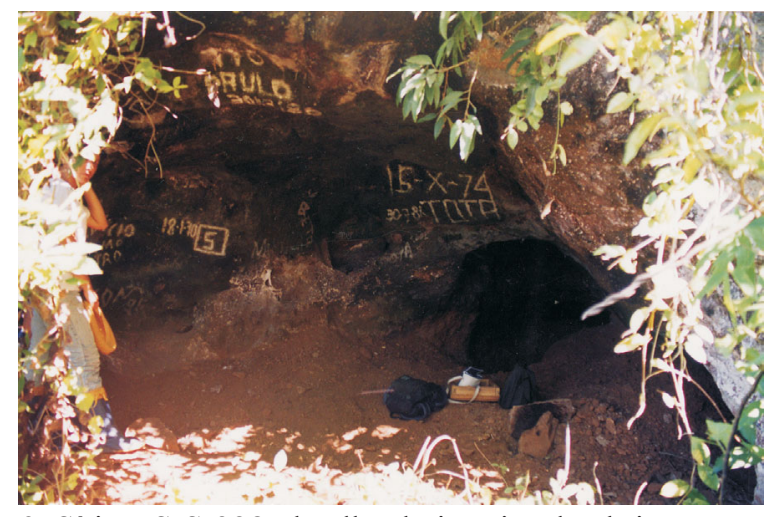

9. Sítio RS-S-328, detalhe do interior do abrigo. Foto: Adriana Dias

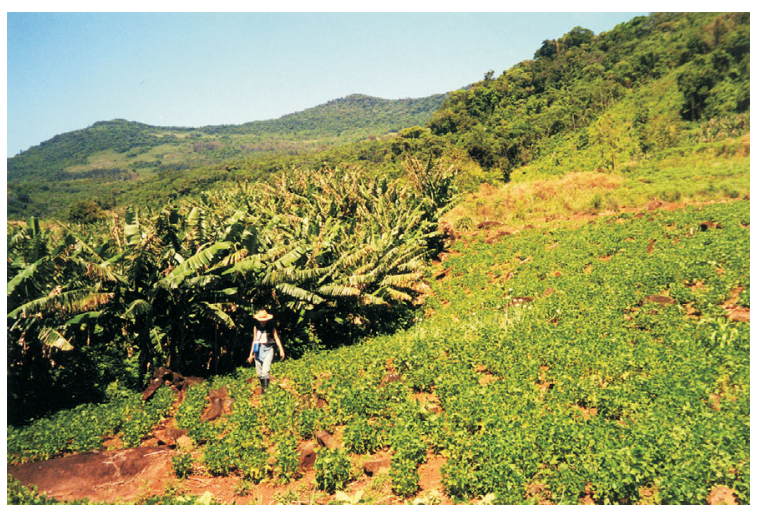

11. RS-S-430, sítio com baixa visibilidade de solo. Foto: Adriana Dias

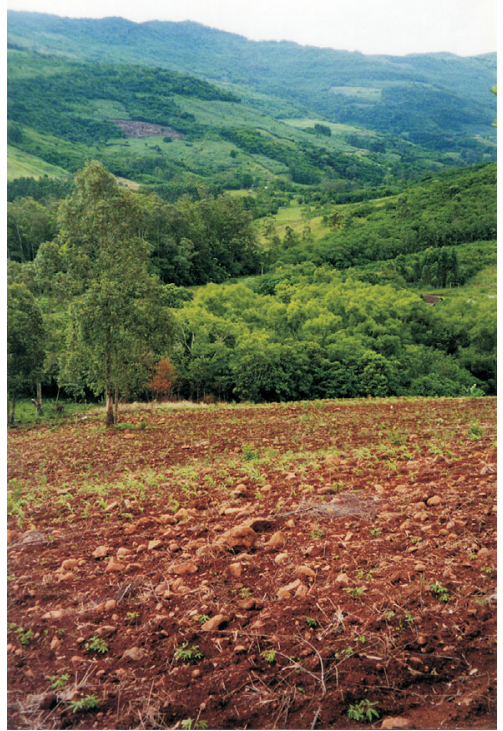

13. Sítio RS-S-431, concentração de material lítico em superfície. Foto: Adriana Dias

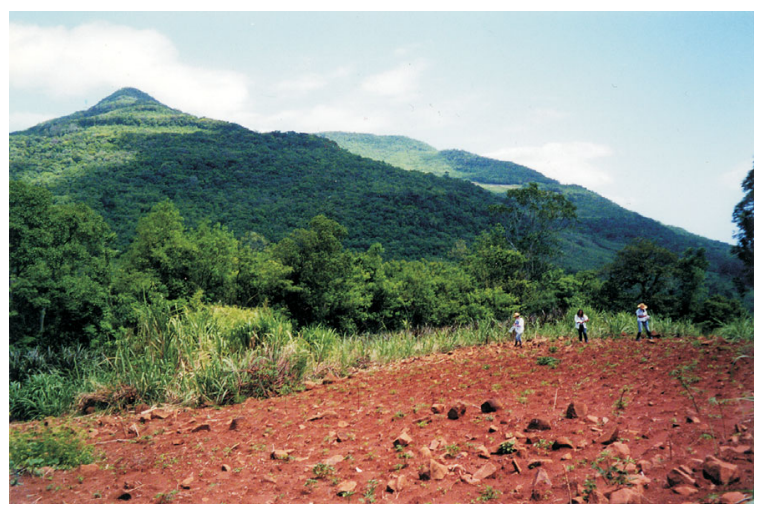

10. RS-S-429, sítio em área recém arada. Foto: Adriana Dias

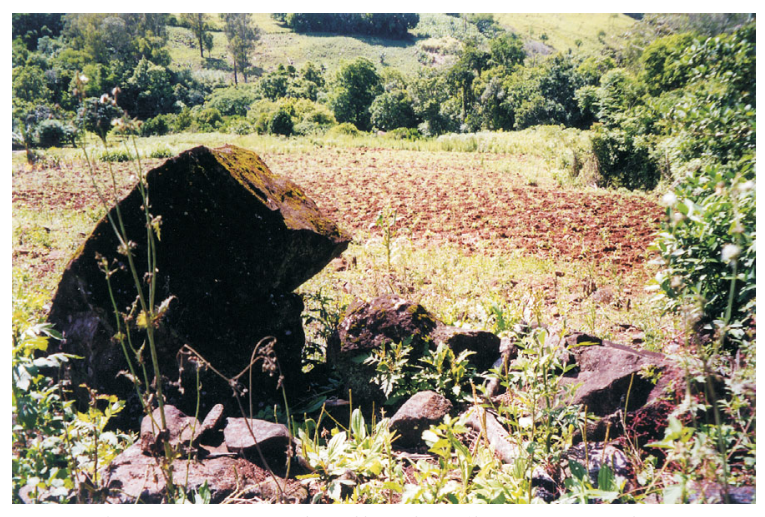

12. Sítio RS-S-431, detalhe de afloramento de basalto associado ao sítio. Foto: Adriana Dias

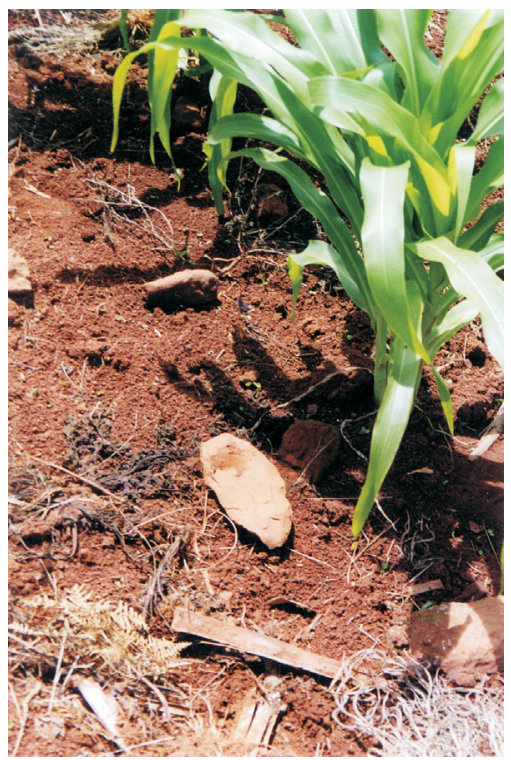

14. Sítio RS-S-431, detalhe de biface associado à roça de milho. Foto: Adriana Dias 


\subsubsection{Uma Primeira Aproximação sobre o Sistema de Assentamento Jê no Alto} Vale do Rio dos Sinos

Avaliando a distribuição de sítios associados à Tradição Taquara na área piloto a luz do modelo de mobilidade e assentamento proposto por Schmitz (1988) e Schmitz e Becker (1991), podemos levantar a hipótese de que este conjunto representa parte de um sistema de assentamento mais amplo que se estende para o norte, abrangendo as terras mais altas do planalto, e para o leste, explorando os recursos das lagoas litorâneas. O modelo de domínio vertical proposto pelos autores prevê a exploração diferencial destes três pacotes ambientais de forma sazonal a fim de garantir a subsistência do grupo ao longo do ciclo anual, sendo o sistema de cultivo, nas áreas de encosta, suplementado por estratégias de estocagem de alimentos de origem animal e vegetal, obtidos através de caça e coleta em áreas florestais previamente manejadas no planalto e pesca e coleta de moluscos no litoral.

A estabilidade econômica proporcionada por estas estratégias, por sua vez, tem como conseqüência uma alta mobilidade habitacional que gera uma variabilidade de tipos de sítios adaptados às características ambientais das distintas áreas. Desta forma, as estruturas subterrâneas seriam utilizadas predominantemente no final do outono e no inverno, durante a coleta e processamento do pinhão, e os sítios a céu aberto da encosta seriam ocupados mais intensamente durante a primavera e o verão, em função dos ciclos de cultivos. Os sítios litorâneos, por sua vez, poderiam ser explorados em qualquer estação do ano, por grupos de tarefas que realizariam a coleta de moluscos e a pesca de forma intensiva para consumo nos sítios de ocupação mais estável da encosta e do planalto, após processamento por desidratação. Os concheiros associados à Tradição Taquara, identificados na costa atlântica do Rio Grande do Sul entre Torres (litoral norte) e Quintão (litoral central), seriam decorrentes de ocupações rápidas, associadas a estratégias extrativas voltadas ao processamento de alimentos para estocagem e consumo em outros locais do assentamento, possivelmente na encosta, durante o verão.

Tendo por base este modelo, podemos sugerir que as estratégias de mobilidade desenvolvidas por estas populações Jê que ocuparam a região nordeste do Rio Grande do Sul a partir de 1500 anos atrás eram representadas por migrações estacionais pluri-familiares, abrangendo os diferentes ambientes que compõe o sistema de assentamento do grupo, e voltando a ocupar os mesmos assentamentos a cada estação. Indicadores deste padrão podem estar representados nas seqüências de datações para as estruturas subterrâneas do planalto que, 
por vezes, abrangem centenas de anos, bem como na alta densidade de materiais registrados nos sítios a céu aberto da encosta na década de 1960 (fase taquara). Outro índice desta estabilidade habitacional de caráter sazonal estaria representado pela quantidade de sepultamentos associados a determinados tipos de sítios, como os abrigos sob rocha, para o Rio Grande do Sul, ou os concheiros, para o litoral de Santa Catarina. Neste último caso, o modelo de mobilidade associado à Tradição Itararé pode apresentar distinções ao da Tradição Taquara, no nordeste do Rio Grande do Sul, sendo caracterizado pela circulação de grupos familiares entre assentamentos mais permanentes.

Este sistema teria se estruturado de forma paralela ao sistema de mobilidade caçador coletor que lhe é contemporâneo no nordeste do Estado, sem maiores competições pelos recursos. Contudo, entraria em colapso com a presença Guarani na região, intensificada a partir de 500 anos atrás, levando a concentração das populações Jê no planalto e ao progressivo abandono dos assentamentos da encosta e do litoral. Embora os assentamentos Guarani, preferencialmente, ocupem áreas de menores altitudes, próximas ao curso de rios de maior porte, sua noção defensiva de território acaba por limitar a circulação das populações Jê pelas diferentes ambientes explorados. A presença de sítios Guarani no litoral norte e central do Rio Grande do Sul (Schmitz et al, 1988; Rogge, 1999b), possivelmente impediria, limitaria ou regularia o acesso para os Jê aos recursos litorâneos, levando ao progressivo abandono desta estratégia de subsistência. O mesmo processo teria se dado em relação às áreas de cultivo na encosta que pela proximidade com os assentamentos Guarani teriam sido abandonadas a fim de evitar agressões representadas pela expansão de territórios dos tekohá para áreas mais próximas às nascentes dos rios de maior porte por volta de 500 anos atrás. Há evidências de contato entre estes dois grupos, através da presença de cerâmica Guarani em sítios com estruturas subterrâneas do planalto (Ribeiro e Ribeiro, 1985; Schmitz et al 1988). Este dado pode indicar intercâmbios de produtos do planalto (como o pinhão), por cultígenos produzidos pelas populações das várzeas dos grandes rios. Porém, as formas bélicas de conquista e manutenção dos territórios de domínio desenvolvidas pelos Guarani, sugerem que conflitos e disputas com os Jê pelas áreas de cultivo da encosta e extração de recursos litorâneos marcariam a tônica do tipo de relação predominante.

A pressão Guarani, em um primeiro momento, e das frentes coloniais, de forma mais direta a partir do século XVII e XIX, teriam restringido as estratégias de mobilidade dos Jê do sul, mantendo-se apenas um dos três pilares que sustentavam a subsistência tradicional, representado pelos assentamentos do planalto. A pressão cada vez maior exercida pelas 
frentes de imigração alemã e italiana, ao longo do século XIX, levaria ao abandono definitivo da utilização das estruturas subterrâneas e da produção de cerâmica e artefatos líticos (e no caso dos Xokleng, dos cultivos), reduzindo os Jê do sul ao padrão de alta mobilidade em áreas restritas caracterizado pelas fontes etno-históricas.

Os sítios arqueológicos associados à Tradição Taquara identificados no Alto Rio dos Sinos podem ser interpretados como parte de um sistema de assentamento mais amplo. Os dois sítios que apresentam cerâmica (RS-S-429: Furna 1 e RS-S-430: Furna 2), associados as nascentes do arroio Grande, poderiam representar uma única aldeia, sucessivamente reocupada na época de cultivo (primavera, verão e início do outono). A baixa densidade de materiais cerâmicos nestes sítios não pode diretamente ser interpretada como um índice de ocupações de curta duração, pois resulta de processos pós-deposicionais semelhantes aos identificados nos sítios Guarani. O sítio RS-S-431: Furna 3, por sua vez, representaria uma área de atividade específica, próxima a sede da aldeia, associada a um afloramento de boa qualidade e relacionada à extração de matérias primas e confecção de artefatos líticos. Os artefatos produzidos poderiam ser utilizados nas atividades domésticas, bem como nas atividades desenvolvidas próximas ao assentamento principal como abertura de clareiras na mata e preparo da terra para o cultivo. A estabilidade destas ocupações seria atestada pela quantidade de sepultamentos presentes no sítio RS-S-328: Caipora. Sua datação atestaria a longa duração da ocupação desta área pelas populações Jê, possivelmente encerrando-se antes da ocupação efetiva deste território pelas populações Guarani por volta de 500 anos atrás. Esta datação estaria entre as mais antigas do Estado e apresentaria correlação com as demais datações existentes para a Tradição Taquara nos vales dos rios dos Sinos e Caí. Igualmente, estudos comparativos destes restos esqueletais com as coleções do planalto e do litoral catarinense podem contribuir para a confirmação positiva de sua associação ao sistema de assentamento Jê na área. Os outros dois sítios líticos identificados ao longo do Alto curso do arroio Sertão (RS-S-433: Morro das Flores e RS-S-432: Arroio Sertão), seriam indicadores da presença de um padrão de aldeia semelhante e relacionado ao acima descrito. Contudo, a detecção de outros sítios lito-cerâmicos nesta área demandaria a aplicação de métodos de prospecção distintos dos utilizados, voltadas a sondagens de sub-superfície, tendo em vista a baixa visibilidade de solo em função da presença predominante de mato secundário.

A relação dos sítios da Tradição Taquara identificados no Alto Rio dos Sinos com os modelos de mobilidade e assentamento propostos por Schmitz, são aspectos que poderiam ser explorados através de projetos específicos para a área. Além da ampliação das prospecções na 
área, há informações a serem confirmadas quanto à presença de sítios com estruturas subterrâneas ao norte da área piloto, na localidade de Borrússia, município de Caraá. Igualmente, o sítio RS-LC-76 (UTM 22J 561 150/6681 800), situado na margem sul da Lagoa dos Barros, no município de Osório apresenta evidências de ocupação caçadora coletora, bem como fragmentos cerâmicos das Tradições Guarani e Taquara, podendo representar um sítio de atividade específica voltada a extração de recursos costeiros explorados pelos distintos sistemas de assentamento pré-coloniais presentes em nossa área de estudo. As hipóteses aqui levantadas quanto ao sistema de assentamento da Tradição Taquara no Alto Vale do Rio dos Sinos poderiam ser testadas através de uma ampliação do estudo regional aqui desenvolvido, voltado a compreender especificamente a relação entre estes distintos conjuntos de sítios com o modelo de domínio vertical de Schmitz (1988). Igualmente, os aspectos sócio-políticos e econômicos implicados por este sistema de assentamento poderiam ser aprofundados através do uso explicito de modelos etnoarqueológicos gerais, gerados a partir de fontes etnohistóricas e etnográficas disponíveis para as populações Jê do Sul.

\subsection{Uma Estrada para a Conquista do Sul: O Início do Povoamento Luso-africano} no Alto Vale do Rio dos Sinos

Embora a presença européia tenha sido sentida na região nordeste do Estado desde o início do século XVI, sua ocupação efetiva por populações de origem euro-africana se dá apenas no início do século XVIII, com a instalação do Registro de Viamão, situado ao sul da área piloto estudada por este projeto. Este se constituía no início oficial da Estrada das Tropas que seguia pelo planalto até Sorocaba, São Paulo. Ao longo dela existiam outros Registros: o de Santa Vitória, em Bom Jesus (RS), o de São Jorge, em Lages (SC), e o de Curitiba (PR) (Jacobus, 1998).

O início do ciclo minerador no centro do país aumenta a demanda por animais de tração, intensificando o interesse pela exploração do gado crioulo criado nas Vacarias Missioneiras, desde o século XVII. A Guarda de Viamão foi fundada, entre 1737 e 1738, para controlar o fluxo das tropas de gado originárias das Vacarias "do Mar” e dos "Pinhais", vendidos na feira de Sorocaba, em São Paulo. A população inicial do Registro comportava um tenente, um sargento e 20 soldados dragões responsáveis pelo controle do fluxo de tropas de animais. Um pedágio sobre estas tropas de gado passa a ser cobrado pela coroa portuguesa a 
partir de 1739 e em 1752 a Guarda passa a categoria de "registro" cabendo ao seu administrador controlar o contrabando de gado na região. As tropas que passam pelo Registro eram mistas, possuindo entre 30 e 250 animais, em sua maioria cavalos e mulas, sendo também comercializado gado bovino (Jacobus, 1996a: 23). As instalações do Registro eram compostas por três currais, que abrigavam separadamente os animais da Guarda, as tropas em trânsito e o gado aprendido, bem como por três ranchos ocupados pela Administração do Registro, pelo corpo da Guarda e pelo depósito de couros (Jacobus, 1996b: 8).

Além de sua importância para a economia da colônia, o Registro de Viamão viabiliza o início da ocupação permanente do território gaúcho por luso-brasileiros que a partir de sua fundação passam a instalar estâncias de criação de gado. Em 1728 é concedida a primeira sesmaria no território sul-rio-grandense e até a década de 1750 várias outras são concedidas na região de Viamão que comportava originalmente toda a porção nordeste do Estado. A partir de 1750 o núcleo do povoamento inicial, do que no início do século XIX será a Vila de Santo Antônio da Guarda Velha, passa a se formar em torno do Registro Viamão, podendo esta população ser estimada em torno de mil habitantes em 1780, dos quais mais de $20 \%$ eram representados por negros escravizados. Uma parcela da população branca é representada por imigrantes açorianos ali instalados em 1770 , sendo o restante da população possivelmente oriunda de Rio Grande, ocupada pelos espanhóis em 1763. Uma pequena parcela desta população inicial é representada por “índios Guarani administrados”, oriundos da região missioneira e instalados pela coroa portuguesa a partir de 1753 nas proximidades do Registro de Viamão, na localidade de Aldeia Velha, e na Aldeia dos Anjos, atual município de Gravataí (Jacobus, 1996b: 10-13).

Em função da decadência do ciclo minerador, a economia regional passa a se direcionar a indústria do charque. Este processo leva a diminuição do fluxo de tropas pelo Registro de Viamão, passando o gado a ser adquirido pelos tropeiros a oeste do Estado, acessado através do “Caminho Novo da Vacaria”, culminando no seu abandono em 1808 (Jacobus, 1996b: 9).

O sítio RS-S-263: Guarda Velha-2 (UTM 22J 544 450/6705 000) corresponde a sede do Registro de Viamão e está localizado sobre um pequeno morro testemunho, a $52 \mathrm{~m}$ de altitude, em meio à várzea da margem esquerda do rio dos Sinos, a cerca de $6 \mathrm{Km}$ da sede atual do município de Santo Antônio da Patrulha. Atualmente o sítio é coberto por pastagens utilizadas para a criação de gado, e não apresenta estruturas arquitetônicas ou evidências arqueológicas em superfície. Este sítio foi inicialmente pesquisado por Eurico Miller em 
1965, quando foram feitas duas coletas de superfície e três cortes estratigráficos de 1,5 x 1,5 m. Na época havia 3 manchas escuras, de forma elíptica, dispostas no sentido noroestesudeste com as seguintes dimensões: 25 x 17 m, 40 x 30 m e 50 x 35 m. Os vestígios arqueológicos distribuíam-se sobre elas até uma extensão de 150 x 70 m, cobrindo uma área de $8200 \mathrm{~m}^{2}$. A cerâmica deste sítio foi relacionada por Miller à fase Monjolo da Tradição Neo-brasileira, com cronologia estimada do início do século XVIII ( $\mathrm{n}^{\circ}$ de catálogo junto ao MARSUL: 390 a 399).

As atividades do PASAP, entre 1995 e 1997, ampliaram a área escavada deste sítio em $63 \mathrm{~m}^{2}$ sendo o resultado destas atividades analisado por Jacobus (1996a, 1996b e 1998). As novas pesquisas de campo identificaram o traçado do caminho dos tropeiros para o Registro, a partir do vale da Aldeia Velha, alcançando a Guarda Velha por sua encosta à direita e ali fazendo uma curva para, em seguida, subir a colina do registro (Jacobus, 1996b:20). Próximas ao traçado da antiga estrada dos tropeiros foram evidenciadas duas estruturas habitacionais de pau-a-pique e cobertura de telhas, possivelmente relacionadas a uma lixeira, escavada por Miller na década de 1960. Também foram escavadas duas fogueiras, possivelmente relacionadas aos acampamentos de tropeiros em trânsito nas proximidades dos currais.

As duas intervenções arqueológicas produziram uma coleção de 5274 vestígios arqueológicos compostos por fragmentos de cerâmica (49,5\%) e de telhas (23,8\%), restos faunísticos de gado bovino (9,9\%), fragmentos de louças (6,7\%), de massas de barro associadas às construções de pau-a-pique (5,3\%), fragmentos de metais $(2,3 \%)$ e de vidros (1,9\%), artefatos líticos (0,2\%) e madeira carbonizada (0,04\%) (Jacobus, 1998: 65 e 73-76).

Destaca-se nesta coleção os conjuntos cerâmicos associados à fase Monjolo da Tradição Neo-brasileira, definida pelo PRONAPA como representando a cerâmica confeccionada pelos grupos familiares, neo-brasileiros ou caboclos, para uso doméstico, com técnicas indígenas e de outras procedências. A cerâmica da fase Monjolo é caracterizada pela queima redutora e por um padrão decorativo de superfície representado por incisões, aspectos distintivos das técnicas indígenas tradicionais, que poderiam representar uma possível influência africana. Tomado este último aspecto como ponto de partida, Jacobus (1996a, 1996b) analisou a cerâmica do Registro de Viamão, comparando seus resultados com dados bibliográficos disponíveis para os grupos falantes de língua Bantu, do oeste africano (Angola, Congo, Benin e Nigéria).

Embora correspondesse a uma amostra muito fragmentada, quanto às técnicas de produção, a maioria dos fragmentos apresentou queima redutora e decoração de superfície 
alisada, e a amostra de peças com decoração plástica indicou a presença de técnicas incisas, pinçadas e aplicadas. Também foi identificada a presença de asas e alças nas panelas, bem como bases planas e bordas de lábios reforçados, arredondados, planos ou ungulados, características ausentes na cerâmica indígena (Jacobus, 1996b: 36-38). As formas reconstituídas das vasilhas cerâmicas indicam uso e produção doméstica, relacionada a atividades de cozinhar (cuscuzeiro, panela, torrador de beiju), servir (alguidar e tigela) e consumir alimentos (pratos) (Jacobus, 1998). Tendo por base os resultados obtidos na análise, o autor conclui que:

A cerâmica Monjolo foi produzida, predominantemente, por mulheres que habitavam os locais onde ela foi identificada. Em uma sociedade escravista é muito provável que mulheres brancas não se dedicassem a tarefas braçais, em especial a produção de cerâmica para uso doméstico. (...) [Portanto] a cerâmica Monjolo foi produzida predominantemente por negras escravizadas (Jacobus, 1996b: 41).

Nas prospecções realizadas na área piloto foram identificadas evidencias de ocupação do século XVIII somente no sítio em abrigo sob rocha RS-S-337: Monjolo. Os demais sítios históricos localizados na área piloto correspondem a um momento de ocupação mais recentes, datados do final do século XIX e início do século XX. As escavações que realizamos no sítio RS-S-337: Monjolo evidenciaram estruturas de fogueiras e uma cova culinária, cujo material associado apresenta grande semelhança com a identificada no Registro de Viamão, sendo abundante e bem preservada a cerâmica Monjolo associada a estas estruturas, complementado os dados inicialmente tratados por Jacobus e possibilitando o teste de suas hipóteses. 


\section{Tabela 1 . Sítios Arqueológicos a Céu Aberto}

\begin{tabular}{|c|c|c|c|c|c|c|c|c|}
\hline Nome do Sítio & $\begin{array}{l}\text { Coordenadas } \\
\text { UTM 22J }\end{array}$ & Dimensões & Intervenções & Material arqueológico & Localidade & Altitude & $\begin{array}{l}\text { Distância de } \\
\text { água }\end{array}$ & Topografia \\
\hline $\begin{array}{l}\text { RS-S-263: Guarda } \\
\text { Velha } 2\end{array}$ & $\begin{array}{l}544450-6705 \\
000\end{array}$ & $8200 \mathrm{~m}^{2}$ & $\begin{array}{l}\text { Coletas de superfície, } \\
67 \text { quadrículas ( } 67 \mathrm{~m}^{2} \\
\text { escavados) }\end{array}$ & Histórico - Século XVIII & $\begin{array}{l}\text { Guarda } \\
\text { Velha }\end{array}$ & $52 \mathrm{~m}$ & $250 \mathrm{~m}$ & Várzea \\
\hline $\begin{array}{l}\text { RS-S-285: Passo da } \\
\text { Forquilha } 1\end{array}$ & $\begin{array}{l}550535-6704 \\
918 \\
550424-6704 \\
976\end{array}$ & $40 \times 20 \mathrm{~m}$ & Coletas superficiais & $\begin{array}{l}\text { Cerâmica e lítico da } \\
\text { Tradição Guarani }\end{array}$ & $\begin{array}{l}\text { Passo da } \\
\text { Forquilha }\end{array}$ & $25 \mathrm{~m}$ & $60 \mathrm{~m}$ & Meia-encosta \\
\hline $\begin{array}{l}\text { RS-S-287: Passo da } \\
\text { Forquilha } 2\end{array}$ & $\begin{array}{l}552063-6705 \\
346\end{array}$ & $120 \times 60 \mathrm{~m}$ & Coletas superficiais & $\begin{array}{l}\text { Cerâmica e lítico da } \\
\text { Tradição Guarani }\end{array}$ & $\begin{array}{l}\text { Passo da } \\
\text { Forquilha }\end{array}$ & $60 \mathrm{~m}$ & $60 \mathrm{~m}$ & Meia-encosta \\
\hline $\begin{array}{l}\text { RS-S-288: Passo da } \\
\text { Forquilha } 3\end{array}$ & $\begin{array}{l}551920-6705 \\
315\end{array}$ & $40 \times 20 \mathrm{~m}$ & Coletas superficiais & $\begin{array}{l}\text { Cerâmica e lítico da } \\
\text { Tradição Guarani }\end{array}$ & $\begin{array}{l}\text { Passo da } \\
\text { Forquilha }\end{array}$ & $60 \mathrm{~m}$ & $30 \mathrm{~m}$ & Meia-encosta \\
\hline $\begin{array}{l}\text { RS-S-386: Guarda } \\
\text { Velha } 4\end{array}$ & $\begin{array}{ll}544 & 300 \\
6704450\end{array}$ & Indeterminada & Coleta de superfície & Histórico - Século XIX & $\begin{array}{l}\text { Guarda } \\
\text { Velha }\end{array}$ & $40 \mathrm{~m}$ & $1000 \mathrm{~m}$ & Meia-encosta \\
\hline $\begin{array}{l}\text { RS-S-387: Guarda } \\
\text { Velha } 5\end{array}$ & $\begin{array}{l}543300-6704 \\
400\end{array}$ & Indeterminada & Coleta de superfície & Histórico - Século XIX & $\begin{array}{l}\text { Guarda } \\
\text { Velha }\end{array}$ & $40 \mathrm{~m}$ & $1000 \mathrm{~m}$ & Meia-encosta \\
\hline $\begin{array}{l}\text { RS-S-389: Guarda } \\
\text { Velha } 7\end{array}$ & $\begin{array}{l}544 / 750 \\
6704 / 800\end{array}$ & Indeterminada & Coleta de superfície & Histórico - Século XIX & $\begin{array}{l}\text { Guarda } \\
\text { Velha }\end{array}$ & $40 \mathrm{~m}$ & $300 \mathrm{~m}$ & Meia-encosta \\
\hline RS-S-392: Fonte & $\begin{array}{l}543550-6706 \\
550\end{array}$ & Indeterminada & & $\begin{array}{lll}\text { Histórico } & - & \text { Início } \\
\text { Século XX } & & \end{array}$ & $\begin{array}{l}\text { Campestre } \\
\text { Novo }\end{array}$ & $18 \mathrm{~m}$ & $50 \mathrm{~m}$ & Várzea \\
\hline RS-S-396: Evaristo I & $\begin{array}{l}552972-6708 \\
097\end{array}$ & Indeterminada & & $\begin{array}{l}\text { Cerâmica da Tradição } \\
\text { Guarani }\end{array}$ & Evaristo & $40 \mathrm{~m}$ & $100 \mathrm{~m}$ & Várzea \\
\hline $\begin{array}{l}\text { RS-S-397: } \\
\text { Genari }\end{array}$ & $\begin{array}{l}548500-6708 \\
650\end{array}$ & Indeterminada & $\begin{array}{l}9 \text { tradagens até } 40 \mathrm{~cm} \\
\text { de profundidade }\end{array}$ & Histórico - Século XIX & Bom Retiro & $40 \mathrm{~m}$ & $50 \mathrm{~m}$ & Várzea \\
\hline $\begin{array}{l}\text { RS-S-398: Casa } \\
\text { Açoriana }\end{array}$ & $\begin{array}{l}546250-6707 \\
300\end{array}$ & Indeterminada & & Histórico - Século XIX & Monjolo & $40 \mathrm{~m}$ & $1000 \mathrm{~m}$ & Meia-encosta \\
\hline RS-S-399: & $544565-6708$ & Indeterminada & 1 auadrícula e 13 & Cerâmica e lítico da & Campestre & $213 \mathrm{~m}$ & $500 \mathrm{~m}$ & Encosta \\
\hline
\end{tabular}




\begin{tabular}{|c|c|c|c|c|c|c|c|c|}
\hline Campestre Novo I & 992 & & $\begin{array}{l}\text { tradagens até } 50 \mathrm{~cm} \text { de } \\
\text { profundidade }\left(1 \quad \mathrm{~m}^{2}\right. \\
\text { escavado). }\end{array}$ & Tradição Guarani & Novo & & & \\
\hline $\begin{array}{l}\text { RS-S-400: Alto Rio } \\
\text { dos Sinos I* }\end{array}$ & $\begin{array}{l}563400- \\
6705620\end{array}$ & Indeterminada & & $\begin{array}{l}\text { Cerâmica e lítico da } \\
\text { Tradição Guarani }\end{array}$ & $\begin{array}{l}\text { Alto Rio dos } \\
\text { Sinos }\end{array}$ & $100 \mathrm{~m}$ & $200 \mathrm{~m}$ & Meia-encosta \\
\hline $\begin{array}{l}\text { RS-S-401: Alto Rio } \\
\text { dos Sinos II* }\end{array}$ & $\begin{array}{l}561 / 188 \\
6707 / 023\end{array}$ & Indeterminada & & $\begin{array}{l}\text { Lítico da Tradição } \\
\text { Guarani }\end{array}$ & $\begin{array}{l}\text { Alto Rio dos } \\
\text { Sinos }\end{array}$ & $100 \mathrm{~m}$ & $100 \mathrm{~m}$ & Meia-encosta \\
\hline $\begin{array}{l}\text { RS-S-402: Rio dos } \\
\text { Sinos I }\end{array}$ & $\begin{array}{lll}557 \quad 076 \quad- \\
6707382\end{array}$ & Indeterminado & $\begin{array}{l}\text { Possível sinonímia do } \\
\text { sítio RS-S-290: Mont } \\
\text { Serrat } 2 \text { onde foram } \\
\text { feitas coletas de } \\
\text { superfície }\end{array}$ & $\begin{array}{l}\text { Cerâmica da Tradição } \\
\text { Guarani }\end{array}$ & $\begin{array}{l}\text { Rio dos } \\
\text { Sinos }\end{array}$ & $48 \mathrm{~m}$ & $100 \mathrm{~m}$ & Várzea \\
\hline $\begin{array}{l}\text { RS-S-403: Rio dos } \\
\text { Sinos II }\end{array}$ & $\begin{array}{lll}556 & 609 \quad- \\
6707 / 100\end{array}$ & Indeterminado & $\begin{array}{l}\text { Possível sinonímia do } \\
\text { sítio RS-S-289: Mont } \\
\text { Serrat } 1 \text { onde foram } \\
\text { feitas coletas de } \\
\text { superfície }\end{array}$ & $\begin{array}{lll}\text { Lítico da } & \text { Tradição } \\
\text { Guarani } & & \end{array}$ & $\begin{array}{l}\text { Rio dos } \\
\text { Sinos }\end{array}$ & $45 \mathrm{~m}$ & $150 \mathrm{~m}$ & Várzea \\
\hline RS-S-404: Caraá I & $\begin{array}{l}555523-6703 \\
775\end{array}$ & Indeterminada & & $\begin{array}{l}\text { Cerâmica e lítico da } \\
\text { Tradição Guarani }\end{array}$ & $\begin{array}{l}\text { Centro } \\
\text { municipal de } \\
\text { Caraá }\end{array}$ & $114 \mathrm{~m}$ & $300 \mathrm{~m}$ & Meia-encosta \\
\hline RS-S-405: Caraá II & $\begin{array}{lll}555 & 622 & - \\
6705 / 046 & \end{array}$ & Indeterminado & & $\begin{array}{lll}\text { Lítico da Tradição } \\
\text { Guarani }\end{array}$ & $\begin{array}{l}\text { Centro } \\
\text { municipal de } \\
\text { Caraá }\end{array}$ & $85 \mathrm{~m}$ & $500 \mathrm{~m}$ & Meia-encosta \\
\hline RS-S-406: Caraá III & $\begin{array}{ll}554 \quad 942 \quad- \\
6704 / 976\end{array}$ & Indeterminado & & $\begin{array}{lll}\text { Lítico da } & \text { Tradição } \\
\text { Guarani } & & \end{array}$ & $\begin{array}{l}\text { Centro } \\
\text { municipal de } \\
\text { Caraá }\end{array}$ & $85 \mathrm{~m}$ & $800 \mathrm{~m}$ & Meia-encosta \\
\hline $\begin{array}{l}\text { RS-S-407: Quebrada } \\
\text { Rio dos Sinos }\end{array}$ & $\begin{array}{ll}553 / 861 & - \\
6706 / 678\end{array}$ & Indeterminado & & $\begin{array}{l}\text { Cerâmica da Tradição } \\
\text { Guarani }\end{array}$ & $\begin{array}{l}\text { Quebrada } \\
\text { Rio dos } \\
\text { Sinos }\end{array}$ & $118 \mathrm{~m}$ & $400 \mathrm{~m}$ & Meia-encosta \\
\hline $\begin{array}{l}\text { RS-S-408: } \quad \text { Alto } \\
\text { Rolantinho }\end{array}$ & $\begin{array}{l}543396-6715 \\
310\end{array}$ & Indeterminado & & $\begin{array}{l}\text { Cerâmica e lítico da } \\
\text { Tradição Guarani }\end{array}$ & $\begin{array}{l}\text { Alto } \\
\text { Rolantinho }\end{array}$ & $100 \mathrm{~m}$ & $200 \mathrm{~m}$ & Meia-encosta \\
\hline $\begin{array}{l}\text { RS-S-409: Evaristo } \\
\text { II }\end{array}$ & $\begin{array}{l}551 / 466 \\
6708 / 353\end{array}$ & Indeterminada & & $\begin{array}{l}\text { Cerâmica e lítico da } \\
\text { Tradição Guarani }\end{array}$ & Evaristo & $100 \mathrm{~m}$ & $250 \mathrm{~m}$ & Meia-encosta \\
\hline $\begin{array}{l}\text { RS-S-410: Evaristo } \\
\text { III }\end{array}$ & $\begin{array}{l}550372- \\
6707847\end{array}$ & Indeterminado & & $\begin{array}{l}\text { Cerâmica e lítico da } \\
\text { Tradição Guarani }\end{array}$ & Evaristo & $95 \mathrm{~m}$ & $700 \mathrm{~m}$ & Meia-encosta \\
\hline
\end{tabular}




\begin{tabular}{|c|c|c|c|c|c|c|c|c|}
\hline $\begin{array}{l}\text { RS-S-411: Evaristo } \\
\text { IV }\end{array}$ & $\begin{array}{ll}552 & 539 \\
6707 & 607\end{array}$ & Indeterminada & & $\begin{array}{l}\text { Cerâmica e lítico da } \\
\text { Tradição Guarani }\end{array}$ & Evaristo & $100 \mathrm{~m}$ & $500 \mathrm{~m}$ & Meia-encosta \\
\hline $\begin{array}{l}\text { RS-S-412: Evaristo } \\
\text { V }\end{array}$ & $\begin{array}{l}552 / 199 \\
6707 / 064\end{array}$ & Indeterminada & & $\begin{array}{l}\text { Cerâmica da Tradição } \\
\text { Guarani }\end{array}$ & Evaristo & $160 \mathrm{~m}$ & $1000 \mathrm{~m}$ & Meia-encosta \\
\hline $\begin{array}{l}\text { RS-S-413: Fenda } \\
\text { Arenítica }\end{array}$ & $\begin{array}{ll}551 & 705 \\
6707035\end{array}$ & Indeterminada & & $\begin{array}{l}\text { Cerâmica e lítico da } \\
\text { Tradição Guarani }\end{array}$ & Evaristo & $60 \mathrm{~m}$ & $500 \mathrm{~m}$ & Meia-encosta \\
\hline $\begin{array}{l}\text { RS-S-414: Rincão } \\
\text { do Herval I* }\end{array}$ & $\begin{array}{l}549 / 091 \\
6703 / 183\end{array}$ & Indeterminada & & $\begin{array}{l}\text { Cerâmica da Tradição } \\
\text { Guarani }\end{array}$ & $\begin{array}{l}\text { Rincão do } \\
\text { Herval }\end{array}$ & $93 \mathrm{~m}$ & $100 \mathrm{~m}$ & Meia-encosta \\
\hline $\begin{array}{l}\text { RS-S-415: Rincão } \\
\text { do Herval II* }\end{array}$ & $\begin{array}{lr}548 & 684 \\
6703 & 521\end{array}$ & Indeterminada & & $\begin{array}{l}\text { Cerâmica da Tradição } \\
\text { Guarani }\end{array}$ & $\begin{array}{l}\text { Rincão do } \\
\text { Herval }\end{array}$ & $56 \mathrm{~m}$ & $200 \mathrm{~m}$ & Meia-encosta \\
\hline $\begin{array}{l}\text { RS-S-416: } \\
\text { Campestre Novo II }\end{array}$ & $\begin{array}{ll}545 & 185 \\
6709 & 180\end{array}$ & Indeterminada & $\begin{array}{l}\text { Possível sinonímia do } \\
\text { sítio } \quad \text { RS-S-338: } \\
\text { Campestre } 3\end{array}$ & $\begin{array}{l}\text { Cerâmica da Tradição } \\
\text { Guarani }\end{array}$ & $\begin{array}{l}\text { Campestre } \\
\text { Novo }\end{array}$ & $176 \mathrm{~m}$ & $500 \mathrm{~m}$ & Encosta \\
\hline RS-S-420: Boçoroca & $\begin{array}{l}543 \quad 066 \\
6709856\end{array}$ & Indeterminado & Coleta superficial & $\begin{array}{l}\text { Lítico possivelmente da } \\
\text { Tradição Umbu }\end{array}$ & $\begin{array}{l}\text { Campestre } \\
\text { Novo }\end{array}$ & $26 \mathrm{~m}$ & $200 \mathrm{~m}$ & Várzea \\
\hline $\begin{array}{l}\text { RS-S-421: Rincão } \\
\text { do Herval III }\end{array}$ & $\begin{array}{l}550203-673 \\
919\end{array}$ & Indeterminado & $\begin{array}{l}\text { Possível sinonímia do } \\
\text { sítio RS-S-284: Arroio } \\
\text { Carvalho onde foram } \\
\text { feitas coletas de } \\
\text { superfície }\end{array}$ & $\begin{array}{l}\text { Cerâmica da Tradição } \\
\text { Guarani }\end{array}$ & $\begin{array}{l}\text { Rincão do } \\
\text { Herval }\end{array}$ & $52 \mathrm{~m}$ & $250 \mathrm{~m}$ & Meia-encosta \\
\hline RS-S-422: Caraá IV & $\begin{array}{ll}552 & 740 \\
6704 & 449\end{array}$ & Indeterminado & & $\begin{array}{l}\text { Cerâmica da Tradição } \\
\text { Guarani }\end{array}$ & $\begin{array}{l}\text { Centro } \\
\text { municipal de } \\
\text { Caraá }\end{array}$ & $74 \mathrm{~m}$ & $200 \mathrm{~m}$ & Meia-encosta \\
\hline $\begin{array}{l}\text { RS-S-423: } \\
\text { Retiro I }\end{array}$ & $\begin{array}{l}549913- \\
6709071\end{array}$ & Indeterminada & Coleta superficial & $\begin{array}{l}\text { Lítico provavelmente } \\
\text { relacionado à Tradição } \\
\text { Guarani }\end{array}$ & Bom Retiro & $61 \mathrm{~m}$ & $150 \mathrm{~m}$ & Meia-encosta \\
\hline $\begin{array}{l}\text { RS-S-424: } \quad \text { Bom } \\
\text { Retiro II }\end{array}$ & $\begin{array}{ll}548 & 212 \\
6708 & 132\end{array}$ & Indeterminado & & $\begin{array}{l}\text { Cerâmica e lítico da } \\
\text { Tradição Guarani }\end{array}$ & Bom Retiro & $70 \mathrm{~m}$ & $300 \mathrm{~m}$ & Meia-encosta \\
\hline $\begin{array}{l}\text { RS-S-425: } \\
\text { Retiro III }\end{array}$ & $\begin{array}{ll}548 & 061 \\
6709 & 235\end{array}$ & - Indeterminado & & $\begin{array}{l}\text { Cerâmica da Tradição } \\
\text { Guarani }\end{array}$ & Bom Retiro & $90 \mathrm{~m}$ & $50 \mathrm{~m}$ & Meia-encosta \\
\hline $\begin{array}{l}\text { RS-S-426: } \quad \text { Bom } \\
\text { Retiro IV }\end{array}$ & $\begin{array}{ll}548 & 129 \\
6707 & 655\end{array}$ & Indeterminado & & $\begin{array}{l}\text { Cerâmica da Tradição } \\
\text { Guarani }\end{array}$ & Bom Retiro & $47 \mathrm{~m}$ & $300 \mathrm{~m}$ & Meia-encosta \\
\hline RS-S-427: Pinheiros & $\begin{array}{ll}550 & 748 \\
6708 & 827\end{array}$ & - Indeterminado & & $\begin{array}{l}\text { Cerâmica da Tradição } \\
\text { Guarani }\end{array}$ & Pinheiros & $30 \mathrm{~m}$ & $250 \mathrm{~m}$ & Várzea \\
\hline $\begin{array}{l}\text { RS-S-428: Evaristo } \\
\text { VI }\end{array}$ & $\begin{array}{ll}554 & 400 \\
6710 & 064\end{array}$ & Indeterminado & & $\begin{array}{l}\text { Cerâmica e lítico da } \\
\text { Tradição Guarani }\end{array}$ & Evaristo & $224 \mathrm{~m}$ & $300 \mathrm{~m}$ & Encosta \\
\hline
\end{tabular}




\begin{tabular}{|c|c|c|c|c|c|c|c|c|c|}
\hline RS-S-429: Furna I & $\begin{array}{lc}554 & 564 \\
6713 & 796\end{array}$ & - & Indeterminado & Coleta superficial & $\begin{array}{l}\text { Cerâmica e lítico da } \\
\text { Tradição Taquara }\end{array}$ & Furna & $229 \mathrm{~m}$ & $100 \mathrm{~m}$ & Encosta \\
\hline RS-S-430: Furna II & $\begin{array}{lc}554 & 129 \\
6713 & 162\end{array}$ & - & Indeterminado & Coleta superficial & $\begin{array}{l}\text { Cerâmica da Tradição } \\
\text { Taquara }\end{array}$ & Furna & $260 \mathrm{~m}$ & $400 \mathrm{~m}$ & Meia Encosta \\
\hline RS-S-431: Furna III & $\begin{array}{ll}554 & 057 \\
6712 & 406\end{array}$ & - & Indeterminado & Coleta superficial & $\begin{array}{l}\text { Lítico da Tradição } \\
\text { Taquara }\end{array}$ & Furna & $171 \mathrm{~m}$ & $100 \mathrm{~m}$ & Meia Encosta \\
\hline $\begin{array}{l}\text { RS-S-432: Sertão } \\
\text { Rio dos Sinos }\end{array}$ & $\begin{array}{ll}556 & 203 \\
6709 & 920\end{array}$ & - & Indeterminado & Coleta superficial & $\begin{array}{l}\text { Lítico possivelmente da } \\
\text { Tradição Taquara }\end{array}$ & $\begin{array}{l}\text { Sertão Rio } \\
\text { dos Sinos }\end{array}$ & $101 \mathrm{~m}$ & $400 \mathrm{~m}$ & Meia Encosta \\
\hline $\begin{array}{l}\text { RS-S-433: } \quad \text { Morro } \\
\text { das Flores }\end{array}$ & $\begin{array}{l}558069- \\
6712868\end{array}$ & & Indeterminada & Coleta superficial & $\begin{array}{l}\text { Lítico possivelmente da } \\
\text { Tradição Taquara }\end{array}$ & $\begin{array}{l}\text { Morro das } \\
\text { Flores }\end{array}$ & $410 \mathrm{~m}$ & $50 \mathrm{~m}$ & Meia Encosta \\
\hline
\end{tabular}

*Sítios arqueológicos situados na periferia da área piloto, localizados durante as vistorias extensivas de áreas aradas fora das unidades amostrais de prospecção. 
Tabela 2. Indicações de Sítios Guarani em Áreas sem Visibilidade de Solo

\begin{tabular}{|c|c|c|c|c|c|c|}
\hline Número da indicação & $\begin{array}{l}\text { Coordenadas } \\
\text { UTM 22J }\end{array}$ & $\begin{array}{l}\text { Informação sobre o tipo de } \\
\text { material arqueológico }\end{array}$ & Possíveis Sinonímias & Localidade & Altitude & Topografia \\
\hline Sítio Guarani 1 & $\begin{array}{l}544963-6709 \\
202\end{array}$ & Fragmentos de cerâmica & & $\begin{array}{l}\text { Campestre } \\
\text { Novo }\end{array}$ & $150 \mathrm{~m}$ & Meia-encosta \\
\hline Sítio Guarani 2 & $\begin{array}{l}544590-6716 \\
053\end{array}$ & Fragmentos de cerâmica & & $\begin{array}{l}\text { Alto } \\
\text { Rolantinho }\end{array}$ & $100 \mathrm{~m}$ & Meia-encosta \\
\hline Sítio Guarani 3 & $\begin{array}{l}543962-6715 \\
337\end{array}$ & Fragmentos de cerâmica & & $\begin{array}{l}\text { Alto } \\
\text { Rolantinho }\end{array}$ & $100 \mathrm{~m}$ & Meia-encosta \\
\hline Sítio Guarani 4 & $\begin{array}{l}540400-6714 \\
400\end{array}$ & Fragmentos de cerâmica & $\begin{array}{l}\text { RS-S-343: Rolantinho da } \\
\text { Figueira }\end{array}$ & $\begin{array}{l}\text { Rolantinho da } \\
\text { Figueira }\end{array}$ & $200 \mathrm{~m}$ & Meia-encosta \\
\hline Sítio Guarani 5 & $\begin{array}{lll}557 & 044 & 6706 \\
530 & & \end{array}$ & Fragmentos de cerâmica & & Rio dos Sinos & $100 \mathrm{~m}$ & Meia-encosta \\
\hline Sítio Guarani 6 & $\begin{array}{l}556044-6707 \\
368\end{array}$ & Vasilha inteira isolada & & Rio dos Sinos & $45 \mathrm{~m}$ & Várzea \\
\hline Sítio Guarani 7 & $\begin{array}{l}554822-6702 \\
979\end{array}$ & Fragmentos de cerâmica & & $\begin{array}{l}\text { Centro urbano } \\
\text { de Caraá }\end{array}$ & $200 \mathrm{~m}$ & Encosta \\
\hline Sítio Guarani 8 & $\begin{array}{l}555557-6704 \\
069\end{array}$ & Fragmentos de cerâmica & & $\begin{array}{l}\text { Centro urbano } \\
\text { de Caraá }\end{array}$ & $100 \mathrm{~m}$ & Meia-encosta \\
\hline Sítio Guarani 9 & $\begin{array}{l}553865-6703 \\
879\end{array}$ & Fragmentos de cerâmica & & $\begin{array}{l}\text { Centro urbano } \\
\text { de Caraá }\end{array}$ & $70 \mathrm{~m}$ & Meia-encosta \\
\hline Sítio Guarani 10 & $\begin{array}{l}552448-6705 \\
435\end{array}$ & Fragmentos de cerâmica & & $\begin{array}{ll}\text { Passo da } \\
\text { Forquilha }\end{array}$ & $60 \mathrm{~m}$ & Meia-encosta \\
\hline Sítio Guarani 11 & $\begin{array}{l}552615-6705 \\
655\end{array}$ & Fragmentos de cerâmica & & $\begin{array}{ll}\text { Passo da } \\
\text { Forquilha }\end{array}$ & $60 \mathrm{~m}$ & Meia-encosta \\
\hline Sítio Guarani 12 & $\begin{array}{l}552449-6706 \\
249\end{array}$ & Vasilha inteira isolada & & $\begin{array}{ll}\text { Passo da } \\
\text { Forquilha }\end{array}$ & $70 \mathrm{~m}$ & Meia-encosta \\
\hline Sítio Guarani 13 & $\begin{array}{l}552150-6704 \\
300\end{array}$ & Fragmentos de cerâmica & $\begin{array}{l}\text { RS-S-286: } \\
\text { Castelhano }\end{array}$ & $\begin{array}{l}\text { Passo da } \\
\text { Forquilha }\end{array}$ & $70 \mathrm{~m}$ & Meia-encosta \\
\hline Sítio Guarani 14 & $\begin{array}{l}552663-6707 \\
166\end{array}$ & Fragmentos de cerâmica & & Evaristo & $100 \mathrm{~m}$ & Meia-encosta \\
\hline
\end{tabular}




\section{Capítulo 6}

\section{Estilo Tecnológico e as Indústrias Líticas do Alto Vale do Rio dos Sinos: Variabilidade Artefatual entre Sistemas de Assentamentos Pré- coloniais}

\subsection{Artefatos Líticos como Índices de Comportamento: Propostas Metodológicas para Implementação de Estudos de Estilo Tecnológico}

Compreender os mecanismos que condicionam a variabilidade de conjuntos artefatos tem sido o tópico central de discussão dos estudos de tecnologia lítica. Esta preocupação gerou nos últimos cinqüenta anos linhas de pesquisa variadas em termos de estudos tecno-tipológicos e funcionais, estimuladas pelos resultados da arqueologia experimental e da etnoarqueologia.

Os estudos experimentais caracterizam-se, desde as primeiras décadas do século passado, por uma preocupação contínua em compreender e dominar os mecanismos de produção dos artefatos líticos na pré-história. Nos últimos vinte anos observa-se que a maioria dos trabalhos experimentais tem se voltado a estudar como a variabilidade dos conjuntos líticos, com destaque para os resíduos de lascamento, pode fornecer informações sobre o comportamento cultural no passado (Kooyman, 2001; Jonhson, 1978). Nas décadas de 1950 e 1960, a arqueologia experimental lítica centrou-se em esclarecer os processos mecânicos que levam à produção de lascas diferenciadas a partir de uma origem tecnológica distinta, oferecendo subsídios empíricos para o desenvolvimento de modelos de análise lítica orientados pela noção de cadeia operatória ou sequiência de produção. Baseadas nestes dados, as propostas metodológicas de Collins (1975) desempenharam um papel fundamental no desenvolvimento desta linha de pesquisa na arqueologia norte americana, ao entender a redução lítica enquanto meio para inferências processuais (Andrefsky, 1998; Kooyman, 2001; Johnson, 1978; Shott, 1994).

Para Collins (1975: 16-19), a manufatura de artefatos líticos é uma tecnologia redutiva, limitada pela mecânica de fratura das matérias primas e pelas habilidades culturais em exercer e controlar a força aplicada no lascamento. Em função destas restrições, existem procedimentos redutivos básicos que envolvem a produção de um artefato e quanto mais complexa esta for, maior a quantidade de redução requerida. 
Embora este processo seja linear, o autor sugere dividi-lo em uma série de passos, que não são estritamente delimitados entre si, mas suficientemente distintos em termos de procedimentos técnicos e resultados de produção em um dado processo de manufatura. Collins define cinco passos técnicos fundamentais ao processo de produção lítica: a aquisição de matéria-prima, a preparação do núcleo ou a redução inicial, a redução primária opcional (redução bifacial ou unifacial de artefatos), a redução secundária opcional (retoque) e a manutenção ou modificação opcional dos artefatos (reativação). A idéia central é a de que cada um destes passos é composto por um ou mais conjuntos de atividades e resulta em um grupo de produtos e de artefatos: resíduos de lascamento e artefatos destinados ao uso ou redução posterior. Os grupos de artefatos produzidos em cada etapa de produção podem ser descritos em termos de seus atributos tecnológicos e inferências podem ser traçadas com relação às atividades específicas que cada passo de manufatura particular compreendeu. Desta noção sistêmica da tecnologia, deriva a importância do estudo dos resíduos de lascamento ou debitagem na arqueologia contemporânea, enquanto índice de informação sobre o processo tecnológico, ausente na análise isolada do artefato acabado.

Shott (1994: 70-71) salienta a influência do modelo de seqüência de redução desenvolvido por Collins nos estudos líticos contemporâneos, na medida em que este permite enfocar a variabilidade lítica em termos funcionais, enquanto produto do uso diferenciado do espaço por sistemas de assentamento pré-históricos, enfoque estimulado pelos trabalhos etnoarqueológicos de Binford (argumento funcional). A partir desta noção passou-se a compreender a variabilidade lítica enquanto produto de fatores de ordem social, permitindo sua análise inferir a natureza e a freqüência de atividades pelo tamanho e composição dos conjuntos líticos.

Este enfoque estimulou o desenvolvido de modelos analíticos sobre a variabilidade da debitagem, envolvendo a relação entre atributos métricos e formais. Contudo, para Shott (1994: 71) o resultado destas análises levou a um certo desencanto quanto às promessas da análise da debitagem, na medida em que a variabilidade observada na arqueologia experimental, parece estar associada à mecânica de fratura, ao tipo de matéria prima e às variações individuais entre os produtores. Analisando a mesma questão Andrefsky, conclui que "muitos estudos de debitagem enfatizam por que os atributos são importantes para compreender o comportamento tecnológico, mas nunca mostram como registrar estes atributos de forma consistente e confiável" (Andrefsky, 1998: 85). 
As críticas mais contundentes às tipologias derivadas da noção de seqüência de estágios de debitagem foram elaboradas por Sullivan e Rozen (1985). Prentiss reconhece que nos últimos 25 anos, poucos autores geraram tanto debate nos estudos líticos, sendo sua proposta metodológica utilizada em várias pesquisas como instrumento para medir os efeitos da redução de núcleos contra a produção de bifaces na análise de conjuntos de debitagem (Prentiss, 1998: 635).

A proposta metodológica de Sullivan e Rozen pode ser classificada como uma tipologia de "livre de categorias" (Andrefsky, 1998: 122-125), por centrar-se em aspectos alheios ao processo de produção, destacando o padrão de fratura das lascas ${ }^{1}$. Para os autores este seria um indicador mais significativo para inferir comportamento tecnológico do que uma tipologia de lascas, derivada da arqueologia experimental e orientada pela noção de seqüências de redução, uma vez que "as origens tecnológicas da debitagem não podem, na maioria dos casos, ser inferida de atributos chaves, observados em espécimes individuais, e que a manufatura de artefatos de pedra lascada é mais realisticamente vista como um continuum, do que como um conjunto de eventos tecnológicos distintos". Basicamente, a proposta dos autores visa instrumentalizar o pesquisador a observar, através da debitagem, aspectos associados à interpretação da funcionalidade de sítios relacionados à variabilidade tecnológica (Sullivan \& Rozen, 1985: 755).

As críticas ao modelo foram múltiplas (Amick \& Maulden, 1989; Enzor e Roemer, 1989; Prentiss, 1998), estimulando grande quantidade de estudos experimentais voltados a avaliar a composição e a variabilidade de conjuntos de debitagem em função das atividades que lhes deram origem. As conclusões apontam que as freqüentes exceções ao modelo de Sullivan e Rozen comprometem seu valor interpretativo, principalmente no que concerne à matéria prima empregada e à variabilidade nas categorias de tamanho dos resíduos (Prentiss, 1998; Shott, 1994). Contudo, seu aspecto positivo na análise lítica foi tornar explícita a necessidade de clareza terminológica, e de replicabilidade de atributos nas tipologias de debitagem, bem como permitiu selecionar critérios mais objetivos para testar

1 O modelo está centrado na distinção da freqüência de padrões de fratura de lascas, na medida em que resíduos morfologicamente caracterizados como etapas de produção diferentes poderiam ser originados no mesmo episódio de lascamento. Em suas conclusões, os autores sugerem que sítios onde a análise da debitagem aponta uma maior concentração de lascas quebradas (terminações proximais) e fragmentos de lasca (terminações distais), as atividades predominantes seriam a produção de instrumentos, enquanto sítios que apresentam maior proporção de lascas inteiras e debris (fragmentos de lascamento distintos das terminações proximais e distais) estariam associados à redução de núcleos (Sullivan \& Rozen, 1985). 
funcionalidade de sítios a partir de análise de resíduos de lascamento (Andrefsky, 1998: 123).

Avaliando estas questões, Andrefsky conclui que a produção da debitagem é sensível a um número variado de diferentes tipos de comportamento tecnológico e a combinação de seus atributos pode variar dependendo das limitações associadas à produção, uso, manutenção e descarte dos artefatos. Não existe uma fórmula do tipo "livro de receitas" para a escala de análise que deve ser conduzida para o estudo da debitagem, para se obter um tipo específico de interpretação de comportamento. Para o autor as interpretações mais convincentes são aquelas que usam resultados derivados de diferentes atributos de debitagem e/ou tipos de debitagem. Contudo, quando possível, a análise deve ser conduzida em combinação com outras evidências do sitio que possam suportar interpretações (tipo de acesso à matéria prima, relação com artefatos, entre outros aspectos), devendo levar em conta aspectos gerais da organização da tecnologia lítica (Andrefsky, 1998: 134-135).

O estudo da organização tecnológica compreende a seleção e integração de estratégias e meios materiais para fazer, usar, transportar, manter e descartar artefatos. A ênfase destes estudos concentra-se na dinâmica do comportamento tecnológico, ou seja, nos planos e estratégias que guiam as escolhas tecnológicas. Corresponde, portanto, a uma resposta às condições do ambiente natural e social que incluem a previsão, a distribuição, a periodicidade, a produtividade e a mobilidade dos recursos, bem como seus riscos potenciais de exploração (Nelson, 1991: 57-59). O objetivo de um estudo de organização tecnológica centra-se na determinação de quais estratégias tecnológicas ou combinação de estratégias foram usadas no passado e como estas se relacionam com o comportamento humano e a mudança cultural (Carr, 1994: 35). As estratégias tecnológicas identificam tipos de planejamentos que facilitam o uso do ambiente e que podem ser desenvolvidos em uma variedade de formas, em respostas a uma multiplicidade de condições. A forma dos artefatos e a composição dos conjuntos líticos são, portanto, as conseqüências de diferentes modos de implementação destas estratégias (Nelson, 1991: 62).

Os estudos de organização tecnológica derivam das reflexões de Binford, baseados em seus estudos etnoarqueológicos quanto à relação entre variabilidade lítica e padrões de assentamento caçador coletor, a partir dos quais foram definidos os conceitos de estratégias tecnológicas de curadoria e expediente (Binford [1973] 1983a, [1976] 1983b, 1979, 1980, [1984] 1989c, [1986] 1989d, Binford e O’Connel, [1984] 1989). De acordo com a definição original de Binford, uma organização tecnológica baseada em estratégias de 
curadoria, proporciona um aumento da expectativa de vida dos artefatos, apresentando altos índices de reciclagem das peças quebradas para produção de outros itens materiais. Uma organização tecnológica baseada em estratégias expedientes, por sua vez, associa-se à produção de artefatos em função de necessidades imediatas, com o posterior descarte das peças nas áreas de atividade. As conseqüências materiais de uma organização tecnológica de curadoria centram-se na ausência de relação direta entre artefatos e áreas de atividade específicas e em altos índices de investimentos tecnológicos na produção e manutenção dos artefatos, que são produzidos em antecipação ao uso e descartados em baixa freqüência. Por outro lado, organizações tecnológicas expedientes apresentam uma relação mais positiva entre área de atividade e descarte nos sítios. Portanto, a distribuição, a associação e a freqüência dos artefatos são amplamente afetadas pelo caráter da organização tecnológica, não sendo possível fazer nenhuma correlação simples entre artefato e tarefa ou freqüência e popularidade no estudo da funcionalidade de sítios líticos (Binford [1976]1983b: 268). Igualmente, Binford aponta que diferentes tipos de sistema de assentamento e subsistência entre caçadores coletores (forrageiros ou coletores) podem produzir variados tipos de sítios, com organizações tecnológicas diferenciadas. As implicações disto para os estudos de organização tecnológica correspondem ao fato de que os artefatos produzidos por um mesmo grupo podem ser diferencialmente manufaturados, usados e descartados, dependendo de seu papel na organização tecnológica e de sua relação com as atividades realizadas nos diferentes sítios ocupados por um mesmo sistema cultural, envolvendo tanto atividades de curadoria como expedientes ${ }^{2}$ (Binford, 1979, 1980).

O teste do modelo etnoarqueológico de Binford relativo à organização tecnológica gerou, ao longo das décadas de 1980 e 1990, diversos estudos centrados em sua relação com aspectos das estratégias de mobilidade caçadora coletora (Amick, 1994; Carr, 1994; Lurie, [1989] 1998; Odell, 1994, 1996; Shott, 1986, entre outros) e da economia de matéria

\footnotetext{
${ }^{2}$ Andrefsky (1994: 21-23) apresenta uma apropriação mais flexível da organização tecnológica de indústrias líticas, através da distinção entre conjuntos de artefatos formais e informais. A primeira categoria corresponderia a artefatos com formas pré-concebidas, modelares e recorrentes, que possuem uma vida útil maior em função dos procedimentos técnicos complexos, associados a sua produção e reciclagem. Seriam caracterizados como artefatos flexíveis ou projetados para serem rejuvenescidos ou potencialmente redesenhados para uso em várias funções. Os artefatos formais que respondem a estas especificidades incluem peças bifaciais, núcleos preparados e artefatos sobre lascas retocadas, que podem ser usados em diferentes tarefas. Os artefatos informais corresponderiam a peças produzidas de forma simplificada para uso imediato de acordo com as necessidades do artesão, sendo rapidamente descartadas. Apresentam formas casuais e despadronizadas, sendo geralmente caracterizados pelas lascas sem retoque e pelos sub-produtos de bipolaridade.
} 
prima disponível em termos locais (Andrefsky, 1994; Bamforth 1986, 1991; Jeske [1989] 1998; Kunh, 1991, 1992; Morrow \& Jefferies, [1989] 1998). A maioria das discussões quanto à aplicabilidade deste modelo centra-se em quais aspectos determinam as escolhas das estratégias tecnológicas: se a conservação/retenção do artefato em termos de uso ou utilidade no sistema cultural (Odell 1996, Shott 1996) ou a preparação dos artefatos em antecipação ao uso, afetada pela natureza e distribuição dos recursos líticos (Bamforth, 1986; Carr, 1994; Nelson, 1991).

Contudo, deve-se destacar que as estratégias tecnológicas de curadoria e expediente fazem parte de um contínuo e identificam tipos de planos para facilitar o uso do ambiente. Portanto, podem ser desenvolvidas como resposta a uma variedade de condições, estando as diferenças na forma e composição dos conjuntos de artefatos relacionados aos diferentes modos de implementação de ambas estratégias tecnológicas (Bamforth, 1986; Carr, 1994; Magne, 1989; Nelson, 1991). Para a compreensão do comportamento tecnológico, torna-se necessário ver os artefatos no contexto dinâmico de produção, uso e descarte, na medida em que são os fatores locais (ambientais e sociais) que condicionam as escolhas tecnológicas (Amick, 1994; Bamforth, 1991). Portanto, deve-se ressaltar que a variabilidade lítica observada nos estudos de organização tecnológica só pode ser entendida enquanto parte de um sistema tecnológico que compreende todas as atividades com as quais o lítico se relaciona.

Trabalhar a variabilidade das lascas isoladas do sistema tecnológico é incorrer no mesmo erro das tipologias tradicionais que consideram apenas a variabilidade dos artefatos. Concordamos com Perlés quando esta afirma que a variação tipológica é somente a ponta visível do iceberg. Muito da variabilidade nas indústrias líticas ocorre seguindo vários pontos ao longo do processo de produção: a modalidade de exploração da matériaprima, o esquema conceitual que é subjacente à manufatura dos conjuntos de artefatos, aos métodos e técnicas de produção e, finalmente, ao gerenciamento dos conjuntos de artefatos. Como a variabilidade não é exclusivamente tipológica, mas simultaneamente conceitual, social e econômica, seus fatores causais também são múltiplos por natureza, pois, como todo fenômeno humano, resultam da interação de fatores variados (Perlés, 1992: 223-224).

O objetivo da análise das indústrias líticas aqui apresentada centrou-se em avaliar a partir do conceito de estilo tecnológico a variabilidade e as distinções da organização tecnológica entre os conjuntos líticos de caçadores coletores e horticultores, estes últimos relacionados a dois grupos lingüísticos distintos (Tupi-guarani e Jê). Para tanto, os 
conjuntos líticos foram analisados de forma comparativa, observando-se a relação entre as distintas estratégias de escolha e obtenção de matérias primas, sua relação com as tecnologias de produção empregadas e com os tipos de artefatos resultantes destas escolhas. É o conjunto destas escolhas que refletem os estilos tecnológicos, servindo com índice para a definição de identidades culturais ou sociais a partir da análise lítica.

A fim de atingir estes objetivos, utilizou-se uma metodologia de análise comparativa que conjuga duas estratégias de pesquisa complementares. Em um primeiro momento, as coleções foram analisadas a partir de critérios quantitativos a partir de categorias tecno-tipológicas gerais, relacionadas aos distintos tipos de matérias primas (Dias, 1994). A partir dos resultados desta análise exploratória, os resíduos de lascamento e artefatos de determinados sítios foram selecionados para análise qualitativa, segundo a metodologia proposta por Dias e Hoeltz (1997). Baseando-se nas propostas de Collins (1975), as autoras sugerem um conjunto de indicadores para a análise de resíduos de lascamento e conjuntos artefatuais, que procuram refletir diferentes aspectos dos processos de produção das peças, distribuídas em três listas de análise relativas aos resíduos de lascamento (lascas e núcleos), aos artefatos bifaciais e unifaciais e aos artefatos brutos e polidos. Cada lista de análise é sistematizada em quatro blocos de registro de informações relativas à identificação individual da peça (numeração de catálogo, sigla do sítio, sigla da quadrícula e posição estratigráfica), às suas características gerais (tipo de matéria prima, estado de preservação da peça, presença e tipo de córtex, alterações de superfície relacionados a agentes pós-deposicionais e dimensões), aos aspectos relacionados a sua modificação primária ${ }^{3}$ (origem tecnológica das peças) e às características da modificação

\footnotetext{
${ }^{3}$ Para a análise das lascas selecionamos do conjunto de indicadores propostos pelas autoras os seguintes: 1) tipo de lasca (lascas unipolares iniciais ou corticais, lascas unipolares primárias ou de preparação, lascas unipolares secundárias ou de redução de bifaces, microlascas ou escamas de retoque, lâminas unipolares, lascas unipolares de borda de biface e lascas bipolares); 2) quantidade de superfície natural na face dorsal (total, $1 / 4$ do total, $1 / 2$ do total e $1 / 3$ do total); 3) tipo de plano de percussão direto (cortical, acortical liso, acortical facetado e puntiforme); 4) tipo de plano de percussão indireto (com ponto de percussão indireto, sem ponto de percussão indireto, com vestígio de quartzo e em forma de vértice); 5) canto dorsal do ponto de percussão direto (sem redução dorsal, com redução dorsal, com retoque, com desgaste, com córtex); e 6) canto ventral do plano de percussão direto (sem formação de lábio e com formação de lábio) (Dias e Hoeltz, 1997: 30-34). Para a análise dos núcleos foram selecionados os seguintes indicadores: 1) tipo de núcleos (núcleos unipolares com uma plataforma definida, núcleos unipolares com duas plataformas bidirecionais opostas, núcleos unipolares com duas plataformas em ângulo, núcleos unipolares com várias plataformas em outras posições, núcleos unipolares poliédricos ou sem plataforma definida e núcleos bipolares); 2) tipo de plataforma de percussão (cortical, acortical liso, acortical facetado, ventral ou sobre lasca unipolar e plataformas de percussão direta/indireta opostas) ; 3) canto da plataforma de percussão (sem redução, com redução, com retoque e com desgaste) e 4) quantidade de superfície natural (sem superfície natural, só na plataforma de percussão, $1 / 4$ do total, $1 / 2$ do total e 1/3 do total) (Dias e Hoeltz, 1997: 35-36). Para os artefatos bifaciais e unifaciais foram selecionados os seguintes indicadores: 1) base de modificação primária (lasca unipolar, lasca bipolar, núcleo unipolar, núcleo bipolar, placa, bloco, seixo); 2) sentido de utilização da lasca
} 
secundária $^{4}$ (causadas pelo retoque) e possível uso. Os dados registrados foram tabulados, por sua vez, em planilhas de cálculo a partir das quais foram geradas estatísticas descritivas utilizadas nas comparações entre coleções.

\subsection{Indústrias Líticas dos Sítios de Caçadores Coletores da Região do Alto Rio}

\section{dos Sinos: a Tradição Umbu}

Para a definição do estilo tecnológico relacionado à ocupação caçadora coletora no Alto Vale do Rio dos Sinos e a interpretação da variabilidade intra-sítio representada por suas indústrias, estudamos de forma comparativa as coleções de sete sítios arqueológicos em abrigos sob rocha, distribuídos junto ao vale do arroio Campestre (RS-S-358: Toca Grande e RS-S-359: Aterrado) e à várzea do rio dos Sinos (RS-S-265: Campestre, RS-S327: Sangão, RS-S-337: Monjolo, RS-S-360: Marimbondo e RS-S-361: Mato da Toca) ${ }^{5}$. As coleções líticas foram analisadas a partir de critérios quantitativos gerais, sendo selecionados para análise qualitativa os resíduos de lascamento dos sítios RS-S-360, RS-S327 e RS-S-337 e o conjunto artefatual dos sítios RS-S-358, RS-S-360 e RS-S-327.

Embora as coleções analisadas tenham sido geradas por metodologias de pesquisa distintas, não se observou diferenças quantitativas na composição geral das indústrias ${ }^{6}$ entre os conjuntos produzidos pelo PRONAPA e aqueles associados às novas intervenções realizadas nos sítios RS-S-360 e RS-S-327. Este aspecto justificou a realização de um estudo comparativo que incorporasse outras coleções relacionadas às pesquisas das décadas de 1960 e 1970, a fim de ampliar a amostragem estudada. Igualmente, não foram detectadas variações temporais na composição das indústrias dos sítios RS-S-360 e RS-S327 nas novas intervenções realizadas, o mesmo observando-se nos conjuntos líticos produzidos pelo PRONAPA para estes sítios. Desta forma, optou-se por analisar os

(lateral, oblíqua, distal e proximal); 3) extensão das cicatrizes de modificação primária (ausente, massiva e reduzida) (Dias e Hoeltz, 1997:36-38).

${ }^{4}$ Os indicadores relacionados à modificação secundária de artefatos líticos lascados selecionados para esta análise são os seguintes: 1) extensão do retoque (marginal, invasor e envolvente); 2) posição do retoque (direto, indireto, alterno, alternante e bifacial); 3) ângulo de inclinação do retoque (abrupto, semi-abrupto e rasante); 4) padrão de ocorrência do retoque (contínuo, descontínuo e em grupos); 5) localização do retoque; 6) tipos de desgaste de borda causados por uso (micro-lascamentos, estrias e arredondamento); 7) direção do desgaste em relação ao gume da peça (paralelo, perpendicular e diagonal); e 8) localização das marcas de uso. As modificações em artefatos brutos e polidos foram analisadas a partir dos seguintes indicadores: 1 ) tipo de suporte (seixo, bloco, placa e lasca); 2) tipo de artefato bruto ou polido; 2) tipo de modificação (picoteado, polido, macerado, lascado, ranhuras de raspagem, marcas de percussão direta, marcas de percussão indireta, depressão semi-esférica); e 3) localização da modificação (Dias e Hoeltz, 1997: 38-46). 
conjuntos líticos de forma geral, independente do tipo de controle estratigráfico e cronológico empregado nas escavações. Tal procedimento partiu da hipótese de que os conjuntos líticos representados pelas distintas ocupações ao longo do tempo seriam semelhantes em termos de composição, tendo em vista a equivalência funcional destes sítios enquanto unidades habitacionais, pertencentes a um sistema de assentamento caçador coletor relacionado à Tradição Umbu.

Os resultados destas análises, por sua vez, foram comparados aos dados obtidos por Hoeltz e Hilbert (2000) para a análise da coleção lítica do sítio a céu aberto RS-LC-76. Este sítio está associado a paleodunas situadas a $500 \mathrm{~m}$ da margem sul da Lagoa dos Barros (UTM 22J 561 150/ 6681 800), no município de Osório, estando, por sua vez, a aproximadamente $25 \mathrm{Km}$ do limite sudeste da área piloto do Alto Vale do Rio dos Sinos. As pesquisas arqueológicas foram coordenadas por Klaus Hilbert, tendo sido escavada uma área de $221 \mathrm{~m}^{2}$ e estando em superfície a maior parte do material lítico associado à Tradição $\mathrm{Umbu}^{7}$ (1654 peças).

\footnotetext{
${ }^{5}$ Os sítios RS-S-358: Toca Grande, RS-S-359: Aterrado, RS-S-265: Campestre e RS-S-361: Mato da Toca foram escavados durante o PRONAPA. Parte das coleções dos sítios RS-S-327: Sangão e RS-S-360: Marimbondo foram produzidas pelo PRONAPA, sendo a amostragem de material ampliada por novas escavações associadas a este projeto. A coleção do sítio RS-S-337 está associada às escavações realizadas em julho de 2000 e janeiro de 2001 e relaciona-se apenas ao material das quadrículas que apresentaram evidências de associação com áreas de atividade relacionadas à ocupação caçadora coletora (quadrículas A12, A13, A14, B11, B12, B13, B14, C11, C12, C13, bem como o material situados abaixo dos $75 \mathrm{~cm}$ de profundidade das quadrículas G16, G15, G14 e F16). Para este sítio também não foram considerados na análise os materiais líticos de superfície que podem estar também associados à ocupação histórica.

${ }^{6}$ A única exceção está relacionada à amostragem de microlascas no sítio RS-S-327, ampliada pelas novas intervenções.

${ }^{7}$ Do topo da duna para a base, a estratigrafia do sítio é composta por 4 camadas. A primeira apresenta um sedimento arenoso, de coloração amarela escura, com espessura de $80 \mathrm{~cm}$. O segundo estrato, $c 0 \mathrm{~m} 50 \mathrm{~cm}$ de espessura, apresenta sedimento arenoso, amarelo claro, associado a concreções de ferro e magnésio. $\mathrm{O}$ terceiro estrato tem $60 \mathrm{~cm}$ de espessura e compõe-se de uma areia esbranquiçada, com pequenas concreções de ferro. O último estrato, na base da duna, tem $70 \mathrm{~cm}$ de espessura e corresponde a um paleosolo formado por uma areia cinza escura, tendo $70 \mathrm{~cm}$ de espessura. A erosão eólica e alterações de curso de um pequeno arroio nas proximidades do sítio causaram deslocamentos dos estratos mais recentes da duna, evidenciando o estrato mais antigo de paleosolo cinzento sobre o qual distribuía-se o material da Tradição Umbu. As pesquisas de campo desenvolvidas em 2000 evidenciaram também a presença de cerâmica das Tradições Taquara e Guarani associada aos níveis mais recentes desta zona de dispersão de dunas, a exemplo dos dados
} 


\subsubsection{Estratégias de Seleção de Matérias Primas}

A utilização das matérias primas foi estudada de forma comparativa através da análise dos resíduos de lascamento das coleções. Todas as matérias primas identificadas são abundantes e de origem local, sendo seu aproveitamento diferencial condicionado pelas estratégias tecnológicas predominantes em cada sítio. A escolha das matérias primas apresenta relação positiva com as tecnologias de produção empregadas nos sítios, sendo o arenito silicificado e o basalto processados predominantemente através da tecnologia de produção unipolar e a calcedônia e o quartzo, processados pela tecnologia bipolar. As mesmas características foram observadas no estudo de outras coleções líticas da Tradição Umbu associadas à região nordeste do Estado, em sítios em abrigos sob rocha nos vales dos rios Caí e Maquiné (Dias, 1994, 1999b) e no sítio a céu aberto RS-LC-76 junto a Lagoa dos Barros (Hoeltz \& Hilbert, 2000).

Embora tenham sido localizados ao longo das prospecções vários afloramentos de basalto na área de implantação dos sítios, a seleção deste tipo de matéria prima está relacionada, principalmente, à coleta junto aos cursos de água de fragmentos de basalto colunar, trazido por arraste fluvial das encostas. Nos sítios próximos à várzea do rio dos Sinos observa-se a utilização preferencial desta matéria prima, correspondendo entre $97 \%$ e $61 \%$ do conjunto dos resíduos de lascamento, estando seus índices de utilização nos sítios do vale do arroio Campestre, entre 36\% e 27\% dos resíduos de lascamento.

A participação relativa do arenito silicificado nas indústrias do conjunto total de sítios mantém-se estável, variando entre 12\% e 32\%, com exceção do sítio RS-S-358 que apresenta o menor valor (5\%). As maiores quantidades desta matéria prima são observadas nos sítios RS-S-360 e RS-S-327 associados à várzea do rio dos Sinos, representando 27\% a 32\% dos conjuntos analisados. Em ambas as áreas, a procedência do arenito silicificado está associada a afloramentos, tendo sido identificado no local de implantação dos abrigos pelo menos um afloramento de arenito silicificado que pode representar a fonte principal para esta matéria prima na localidade de Campestre.

A origem da calcedônia e do quartzo ocorre na área piloto na forma de geodos associados ao arraste fluvial das encostas ou, no caso do quartzo leitoso, associados a veios nos afloramentos de basalto. A utilização da calcedônia é preferencial nos sítios localizados junto ao vale do arroio Campestre, correspondendo a 50\% das matérias primas 
empregadas nos sítios RS-S-358 e RS-S-359. Sua maior ocorrência nesta área pode estar relacionada a uma maior disponibilidade de seixos de calcedônia junto aos arroios de pequeno porte, situados em locais de topografia mais encaixada. Contudo, também pode decorrer da tecnologia de produção relacionada a sua transformação, a bipolaridade, que gera grande quantidade de resíduos de pequeno porte, influenciando a quantificação do conjunto estudado. Quanto ao quartzo sua utilização mantém-se estável entre 9\% e 1\% para a amostragem total dos sítios, sendo, porém, mais freqüente também entre sítios do vale do arroio Campestre. Como todas as matérias primas associadas aos sítios de caçadores coletores apresentam-se dispersas na paisagem, sua coleta possivelmente se caracterizou como uma estratégia “encaixada” em outras atividades associadas à subsistência do grupo, como sugere Binford (1979) (fotos 1 a 6).

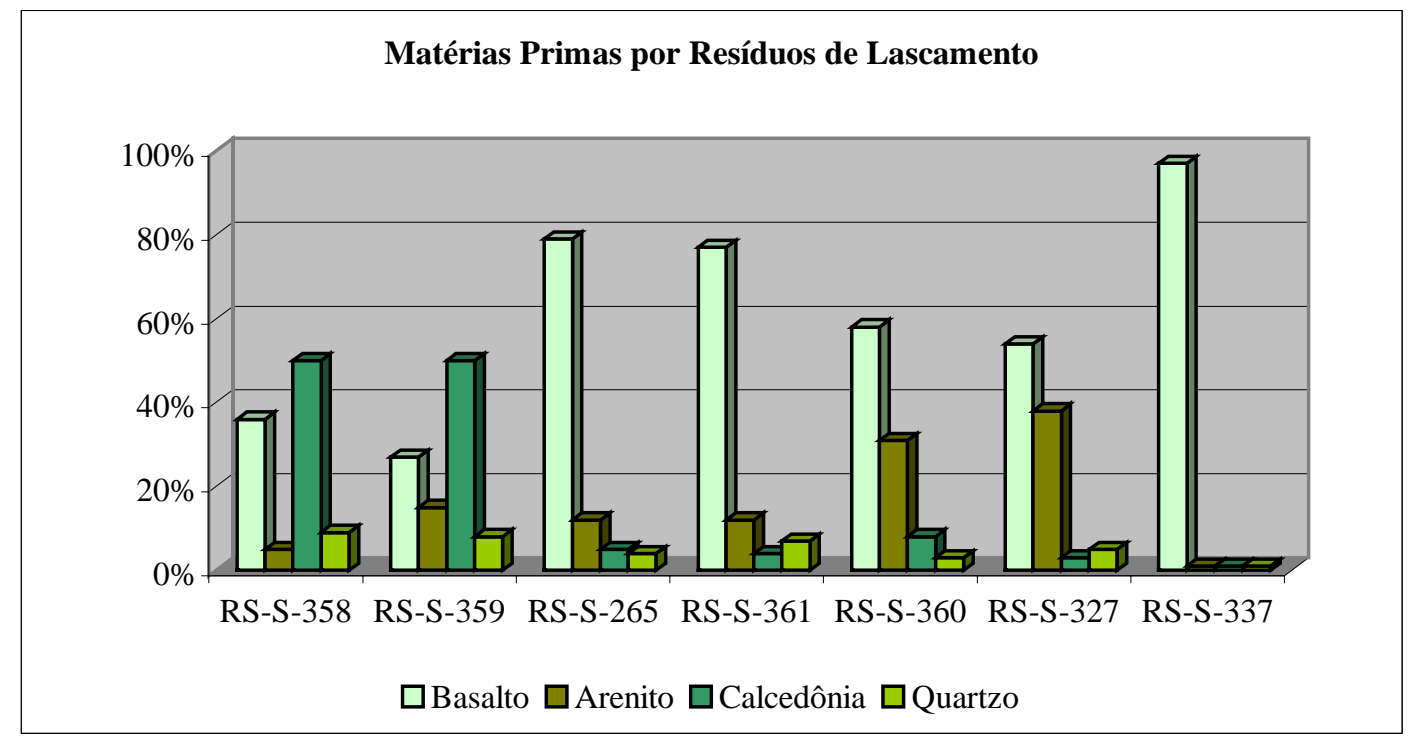




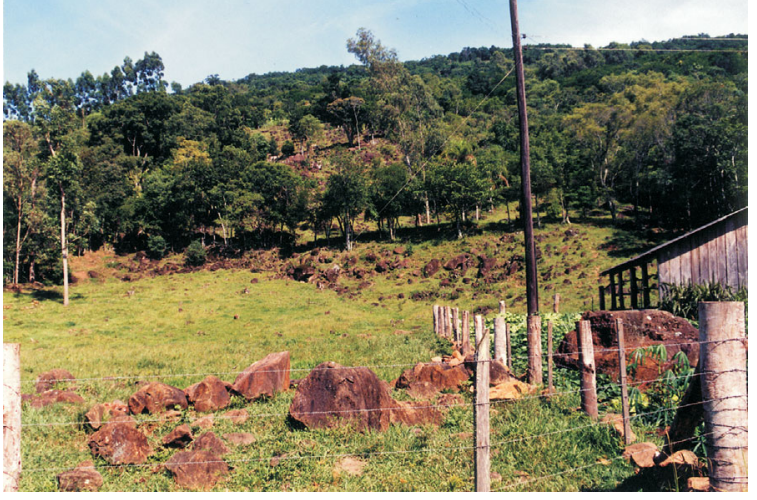

1. Afloramento de basalto no Arroio Sertão. Foto: Adriana Dias

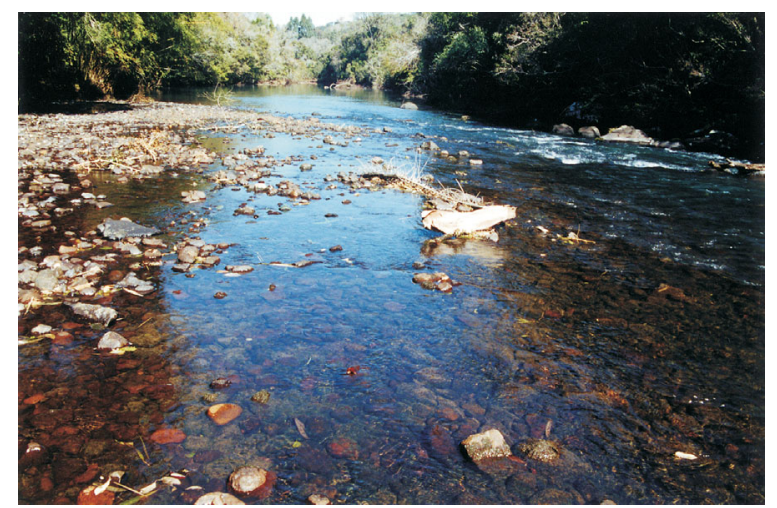

3. Concentração de seixos na confluência dos rios dos Sinos com Arroio Sertão. Foto: Adriana Dias

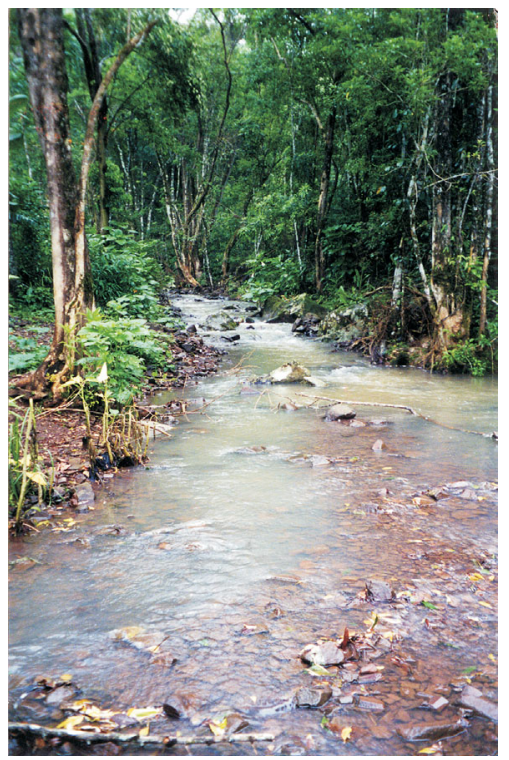

5. Placas de basalto colunar no Arroio Pinheiros. Foto: Adriana Dias

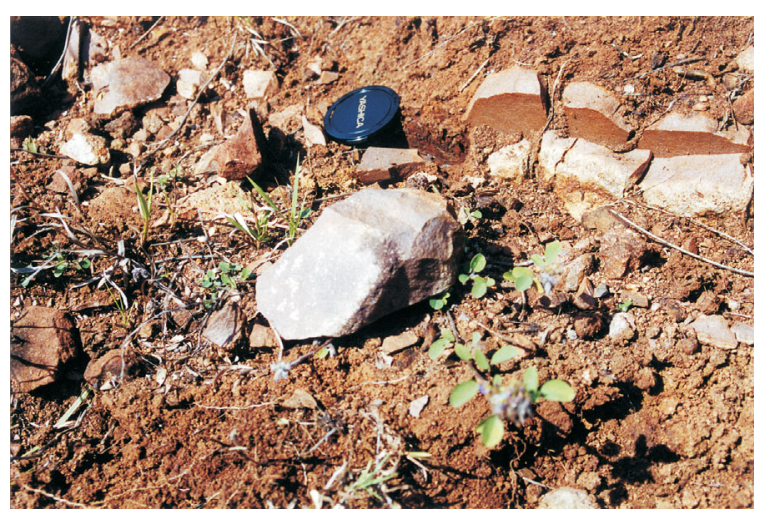

2. Veio de arenito silicificado associado à afloramento de basalto, Campestre Novo. Foto: Adriana Dias

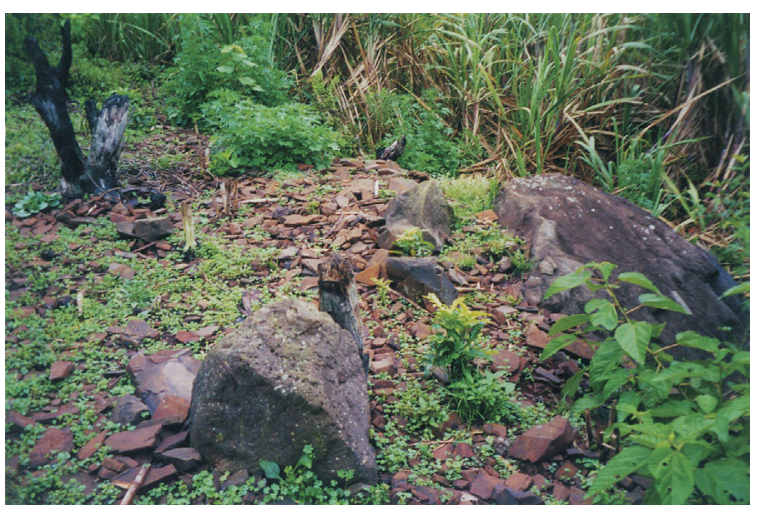

4. Afloramento de basalto colunar associada à pedreira moderna, Pinheiros. Foto: Adriana Dias

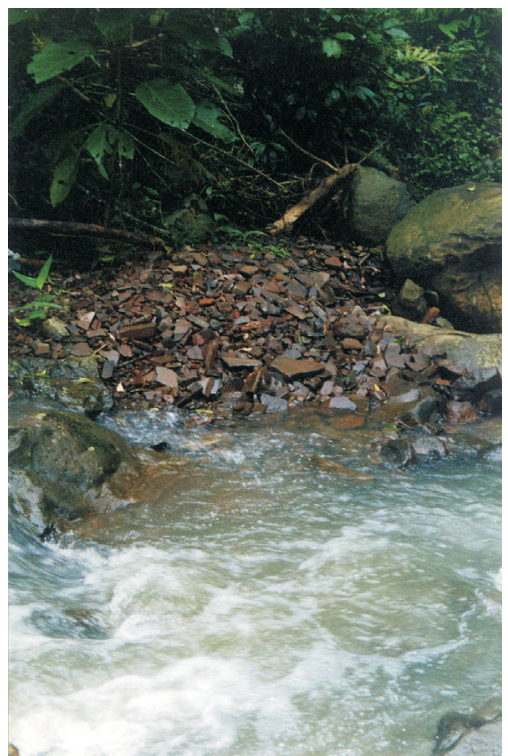

6. Detalhe da concentração de placas de basalto de arraste fluvial no Arroio Pinheiros. Foto: Adriana Dias 


\subsubsection{Estratégias de Redução e Composição dos Conjuntos Líticos:}

A fim de caracterizar as estratégias gerais de organização tecnológica representadas nos sítios e sua relação com as estratégias de seleção de matérias primas, suas coleções foram inicialmente analisadas por categorias tecno-tipológicas, utilizadas em trabalhos anteriores para análise de coleções similares (Dias, 1994). As coleções totalizaram um conjunto de 21.491 peças, classificadas a partir das seguintes categorias gerais:

1) microlascas, com dimensões inferiores a $1 \mathrm{~cm}$;

2) lascas e núcleos unipolares sem ou com modificação através de retoque;

3) lascas e núcleos bipolares sem ou com modificação através de retoque;

4) fragmentos de lascas (sem as terminações proximais) e fragmentos de núcleos;

5) fragmentos naturais, sem modificação ou com fratura térmica;

6) fragmentos naturais com modificação, também chamados de artefatos brutos, como percutores, polidores manuais, hematitas com marcas de raspagem para extração de pigmento e peças com depressões semi-esféricas, utilizadas como suporte para quebrar cocos de jerivá ou butiá (quebra-coquinhos);

7) artefatos polidos como boleadeiras, almofarizes e lascas que apresentam polimento na face externa, decorrentes da redução de artefatos polidos;

8) artefatos bifaciais característicos às coleções da Tradição Umbu, tais como peças unifaciais ou bifaciais elaboradas sobre lascas e núcleos unipolares ou bipolares através de redução primária, préformas de pontas de projétil ${ }^{8}$, pontas de projétil pedunculadas ou lanceoladas de origem tecnológica variada e micro-raspadores pedunculados, associados à reciclagem de fragmentos de pedúnculos ou elaborados sobre lascas unipolares ou bipolares e núcleos bipolares;

\footnotetext{
${ }^{8}$ As pré-formas correspondem a formas inacabadas e não utilizadas de um artefato proposto. Seriam maiores, mais espessas e sem o refinamento do instrumento completo, apresentando profundas cicatrizes bulbares e bordas geralmente irregulares. Uma pré-forma deve ter uma morfologia potencial para ser modificada em somente um tipo de implemento no conjunto da indústria, podendo existir assim diferentes categorias de préformas em uma única indústria, de acordo com o tipo de artefato que dará origem. As pré-formas de pontas de projétil originam-se a partir da modificação primária bifacial de uma lasca ou biface que lhes confere uma forma triangular através de retoque por percussão direta com percutor brando. Após adquirir essa forma triangular, que será preservada no corpo da ponta de projétil, a pré-forma recebe o retoque por pressão, que dá origem as aletas e ao pedúnculo. Nesta etapa de produção, a pré-forma pode sofrer também modificação em sua espessura através de retoques invasores que tornarão a futura ponta de projétil mais delgada e leve, facilitando seu encabamento e melhorando sua amplitude de vôo (Crabtree, 1972: 49; Bradley, 1975: 6-9; Shott, 1993: 435-436).
} 
9) fragmentos de bordas de artefatos bifaciais ou de pontas de projétil (pedúnculos, ápices e aletas).

Tabela 1 - Distribuição de categorias tecno-tipológicas por sítios arqueológico

\begin{tabular}{|c|c|c|c|c|c|c|c|c|}
\hline Categorias Tecno-tipológicas & RS-S-359 & RS-S-358 I & RS-S-265 & RS-S-361 I & RS-S-360 I & RS-S-327 I & RS-S-337 & Total \\
\hline Microlascas & 33 & 398 & 19 & 2 & 302 & 1257 & 290 & 2301 \\
\hline Lascas unipolares & 707 & 1025 & 163 & 79 & 1055 & 1353 & 372 & 4512 \\
\hline Lascas unipolares retocadas & 15 & 62 & 1 & 0 & 3 & 4 & 0 & 85 \\
\hline Lascas bipolares & 1089 & 1620 & 10 & 10 & 136 & 211 & 9 & 3085 \\
\hline Lascas bipolares retocadas & 67 & 46 & 0 & 0 & 3 & 4 & 0 & 120 \\
\hline Núcleos unipolares & 6 & 8 & 1 & 1 & 15 & 8 & 1 & 4 \\
\hline Núcleos bipolares & 26 & 18 & 0 & 0 & 4 & 5 & 1 & 56 \\
\hline Fragmentos de lascamento & 1739 & 805 & 297 & 166 & 1152 & 1798 & 605 & 6804 \\
\hline Fragmentos nucleiformes & 11 & 95 & 3 & 1 & 34 & 16 & 4 & 164 \\
\hline $\begin{array}{l}\text { Fragmentos naturais sem ou com } \\
\text { fratura térmica }\end{array}$ & 168 & 432 & 270 & 85 & 439 & 815 & 665 & 2874 \\
\hline $\begin{array}{l}\text { Fragmentos de hematita raspados } \\
\text { para extração de pigmento }\end{array}$ & 6 & 14 & 0 & 4 & 4 & 8 & 2 & 38 \\
\hline Percutores & 1 & 3 & 0 & 0 & 1 & 0 & 2 & 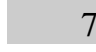 \\
\hline Polidores & 0 & 3 & 0 & 0 & 3 & 6 & 0 & 12 \\
\hline Quebra-cocos & 0 & 2 & 0 & 0 & 0 & 0 & 0 & 2 \\
\hline Boleadeiras & 0 & 1 & 0 & 0 & 0 & 1 & 0 & 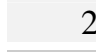 \\
\hline Almofarizes & 0 & 1 & 0 & 0 & 0 & 0 & 0 & . \\
\hline Lascas com face externa polida & 6 & 36 & 2 & 9 & 8 & 19 & 7 & 87 \\
\hline Bifaces & 20 & 37 & 1 & 0 & 5 & 3 & 0 & 66 \\
\hline Unifaces & 4 & 3 & 1 & 1 & 1 & 0 & 0 & 10 \\
\hline Préformas & 146 & 171 & 0 & 0 & 4 & 7 & 1 & 329 \\
\hline Micro-raspadores & 14 & 16 & 2 & 0 & 1 & 1 & 0 & 34 \\
\hline Pontas de projétil & 331 & 259 & 9 & 2 & 4 & 11 & 1 & 617 \\
\hline Fragmentos de pontas de projétil & 9 & 54 & 0 & 1 & 1 & 7 & 0 & 72 \\
\hline $\begin{array}{l}\text { Fragmentos de bordas de } \\
\text { artefatos bifaciais }\end{array}$ & 53 & 90 & 3 & 2 & 13 & 9 & 0 & 170 \\
\hline Fragmentos naturais polidos & 0 & 0 & 0 & 0 & 0 & 3 & 0 & \\
\hline otais & 4451 & 5199 & 782 & 363 & 3188 & 5548 & 1960 & 21491 \\
\hline
\end{tabular}


RS-S-358: Toca Grande

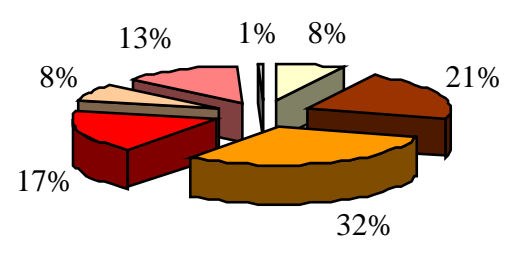

$\square$ Microlascas

$\square$ Lascas bipolares

口núcleos

\section{RS-S-265: Campestre}

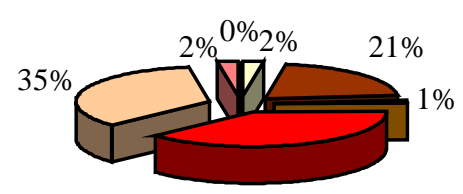

$39 \%$

\begin{abstract}
$\square$ Microlascas
$\square$ Lascas bipolares
$\square$ Frag. Naturais
\end{abstract}

$\square$ Núcleos

$\square$ Lascas unipolares

Grag. de lascamento

$\square$ Artefatos

Frag. de lascamento

Artefatos
RS-S-359: Aterrado

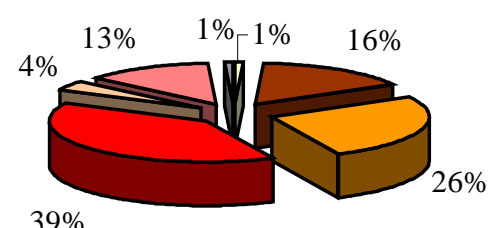

Microlascas

$\square$ Lascas bipolares

Frag. Naturais

पnúcleos

Lascas unipolares

Frag. de lascamento

$\square$ Artefatos

(1)

\section{RS-S-361: Mato da Toca}

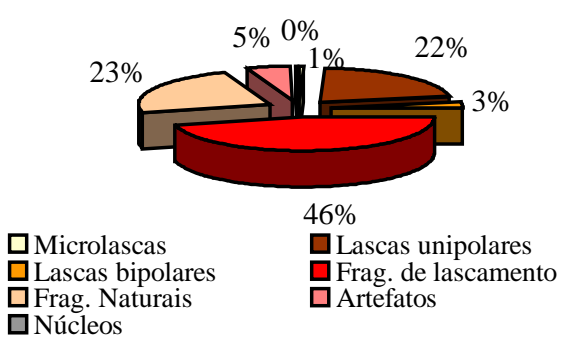

RS-S-327: Sangão

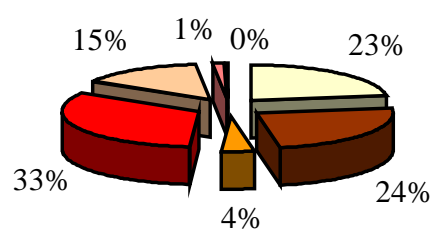

Microlascas

LLascas bipolares

Frag. Naturais

口Núcleos

Lascas unipolares

Gragm. de lascamento

$\square$ Artefatos

$\square$ Frag. Naturais

Frag. de lascamento

$\square$ Núcleos

$\square$ Artefatos

RS-S-337: Monjolo

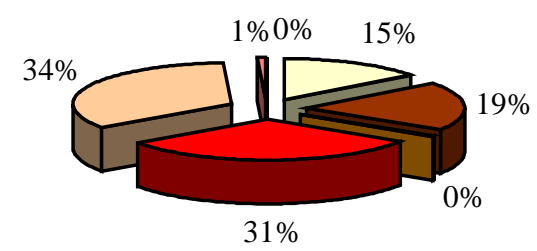

$\square$ Microlascas

$\square$ Lascas unipolares

$\square$ Lascas bipolares

$\square$ Frag. Naturais

$\square$ Frag. de lascamento

$\square$ Núcleos

口Artefatos 
O estudo da participação relativa das categorias tecno-tipológicas no conjunto lítico dos sítios permite observar uma distinção em termos de organização tecnológica entre os sítios associados ao vale do arroio Campestre e os sítios da várzea dos Sinos, cujas características associam-se a utilização diferencial das matérias primas já mencionadas (Anexo 3).

Os sítios RS-S-358 e RS-S-359 são os únicos que apresentam vestígios de lascamento bipolar em termos elevados, correspondendo a 32,04\% e 25,97\% da composição geral do conjunto lítico, respectivamente. Nos demais sítios associados ao vale do rio dos Sinos, os resíduos de bipolaridade variam entre 4,36\% e 0,45\% da composição geral da indústria, sendo o menor índice apresentado pelo sítio RS-S-337. Uma situação inversa observa-se quanto à participação relativa das lascas unipolares nos conjuntos analisados, estando os menores índices associados aos sítios do vale do arroio Campestre, que apresentam entre 20,90\% e 16,22\% de suas coleções compostas por esta categoria de resíduos. Nos sítios associados ao vale do rio dos Sinos as lascas unipolares distribuem-se entre 33,18\% e 18,97\% da composição geral das indústrias. A indústria lítica do sítio a céu aberto RS-LC-76 apresenta índices semelhantes aos sítios em abrigo associados à várzea rio dos Sinos. Esta coleção apresenta 1029 lascas que representam 62\% do conjunto total de peças, das quais 64,9\% são unipolares e 4,3\% bipolares (Hoeltz \& Hilbert, 2000).

A participação relativa de lascas unipolares ou bipolares com retoque é pequena para todos os conjuntos analisados. Sua maior freqüência relaciona-se aos sítios do vale do arroio Campestre, com índices entre 2,07\% e 1,8\%, estando o retoque preferencialmente associado às lascas bipolares. Nas coleções dos sítios associados à várzea do rio dos Sinos, as lascas retocadas representam entre $0,12 \%$ e $0,18 \%$ dos conjuntos líticos, estando ausentes nas coleções dos sítios RS-S-361 e RS-S-337. Os fragmentos de lascas sem as terminações proximais e os fragmentos de núcleos apresentam em geral uma participação relativa similar entre os sítios analisados, variando entre 39,3\% e 31,07\%. As exceções são representadas pelo sítio RS-S-358, associado ao vale do arroio Campestre, com os menores valores $(17,31 \%)$ e o sítio RS-S-361, associado à várzea do rio dos Sinos, com os índices mais elevados (46\%).

Todas as lascas que apresentavam dimensões inferiores a $1 \mathrm{~cm}$ foram incorporadas à categoria de microlascas, cuja origem tecnológica pode ser variada, podendo originar-se tanto da bipolaridade, quanto do lascamento unipolar primário ou secundário, associado ao retoque. Sua presença nas coleções variou entre $0,65 \%$ e 22,65\%, estando os maiores índices relacionados aos sítios RS-S-327 e RS-S-337. As diferenças nas metodologias de 
escavação que geraram as distintas coleções analisadas, bem como os processos de formação particulares a cada sítio, podem corresponder aos fatores que influenciam a variação entre os conjuntos analisados quanto à categoria microlascas. Por exemplo, a coleção do sítio RS-S-359 apresenta um dos índices mais altos de produção de artefatos bifaciais, porém do conjunto de coleções analisadas é a que apresenta um dos índices mais baixos relativos à presença de microlascas $(0,74 \%)$. Uma situação inversa é observada para o sítio RS-S-327, cuja metodologia de escavação permitiu ampliar significativamente a amostra desta categoria de resíduos (22,65\%), em comparação a coleção produzida pelas intervenções do PRONAPA, embora os índices relativos à presença de artefatos bifaciais, em geral, sejam relativamente baixos (1,35\%).

Outro fator que pode influenciar a variação observada para esta categoria de resíduos está relacionado à variabilidade intra-sítio, associada tanto a áreas de atividade, quanto às características físicas de cada abrigo que influenciaram a ocupação. Independente dos métodos de escavação, observa-se semelhanças entre os índices de microlascas apresentados pelas coleções dos sítios RS-S-358 (7,65\%), escavado durante o PRONAPA, e RS-S-360 (9,47\%), que sofreu novas intervenções. Ambos correspondem aos maiores abrigos pesquisados na área, e os índices de microlascas parecem indicar uma semelhança nos padrões de descarte relacionados a áreas de atividade doméstica mais dispersas. A recorrência de ocupações em áreas mais restritas características dos sítios RSS-327 e RS-S-337, por sua vez, pode ter influenciado a maior quantidade de vestígios com dimensões inferiores a $1 \mathrm{~cm}$ resgatados nas novas intervenções.

A fim de explorar em detalhe as características da organização tecnológica dos sítios de caçadores coletores, selecionamos para análise qualitativa os conjuntos de lascas unipolares dos sítios RS-S-360, RS-S-327 e RS-S 337. As lascas unipolares maiores de 1 $\mathrm{cm}$ de comprimento foram divididas a priori em três grupos que poderiam apresentar significância em termos de seqüência de produção, analisadas de forma comparativa. $\mathrm{O}$ primeiro grupo diz respeito às lascas unipolares corticais ou iniciais, que corresponderiam a primeira retirada de um núcleo ou base de redução que apresenta córtex. O segundo grupo comporta as lascas unipolares primárias ou de preparação de núcleos, retiradas após o desbaste inicial da massa de matéria prima, caracterizando-se por apresentar cicatrizes de lascamento na face dorsal e um plano de percussão espesso. Por fim, teríamos as lascas unipolares secundárias ou de redução de bifaces, que apresentariam pequena espessura e perfil longitudinal ligeiramente curvo, planos de percussão estreitos e, por vezes, com lábios no canto ventral (Dias e Hoeltz, 1997: 32). 
A participação relativa de lascas unipolares corticais ou iniciais nos sítios estudados distribui-se entre $12,5 \%$ e $20,81 \%$. O basalto de origem colunar representa a matéria prima predominante em todos os sítios, entre $76,6 \%$ e $51,1 \%$, estando o arenito silicificado procedente de afloramentos também representado nas amostra do sítio RS-S-360 (43,6\%) e RS-S-327 (34,58\%). O tamanho médio das lascas corticais apresenta seus maiores valores no sítio RS-S-360 ( 3 x 2,7 x 0,85 cm), seguindo uma ordem decrescente para os sítios RSS-337 $(2,42 \times 2,12 \times 0,6 \mathrm{~cm})$ e RS-S-327 $(1,75 \times 1,9 \times 0,73 \mathrm{~cm})$. A cobertura cortical predominante é pouco extensa para todos os sítios, variando de $1 / 2$ a $1 / 4$ da face externa entre 49\% e 57\% das amostras estudadas. Este aspecto indica intensa redução das bases de lascamento que geram este tipo de resíduo, aspecto confirmado pela variação encontrada entre os tipos de plataformas de percussão direta para os três sítios analisados. Os talões corticais predominam na amostra do sítio RS-S-337 (31,16\%), enquanto os acorticais lisos dominam as amostras dos sítios RS-S-360 (33,05\%) e RS-S-327 (40,22\%). Porém, em todos os sítios também estão presentes para esta categoria de lascas unipolares, os talões acorticais facetados e puntiformes. Quanto ao canto dorsal das plataformas de percussão encontramos, igualmente, grande variação entre as coleções, predominado a presença de córtex nos sítios RS-S-360 (38,34\%) e RS-S-327 (41,7\%), enquanto no sítio RS-S-337 podem apresentar-se com ou sem redução (72\%). Em geral, os lábios estão ausentes no canto ventral do plano de percussão direto entre $73 \%$ e 59\% das lascas corticais ${ }^{9}$.

As lascas unipolares primárias ou de preparação de núcleos correspondem a 15,3\% da coleção do sítio RS-S-360, sendo menos freqüentes nos sítios RS-S-327 (6,25\%) e RSS-337 (8,64\%). O basalto representa a matéria prima predominante para esta categoria de lascas, distribuindo-se sua participação relativa entre $76,68 \%$ e $90,62 \%$ dos conjuntos analisados. O tamanho médio das lascas unipolares primárias apresenta valores mais elevados em comparação com a categoria anterior para todos os sítios, apresentando maiores valores no sítio RS-S-360 (3,96 x 3,8 x 1,1 cm), seguindo uma ordem decrescente para os sítios RS-S-337 (3,11 x 2,7x 1,25 cm) e RS-S-327 (2,4 x 1,83 x 0,9 cm). Para todas as amostras estudadas predominam para esta categoria de lascas as superfícies dorsais acortical com cicatrizes de lascamento anterior, entre $81,17 \%$ e 90,62\% dos conjuntos. Entre 59,5\% e 38,82\% dos casos, os tipos de planos de percussão direta são lisos, podendo

\footnotetext{
${ }^{9}$ Análises qualitativas similares realizadas para uma amostragem das lascas unipolares da coleção do sítio RS-S-358: Toca Grande indicam que para as lascas corticais correspondem a 17\% do conjunto. Predomina o córtex liso, associado às placas de basalto de origem colunar em 65\% da amostra analisada. Os tamanhos médios são de 3,4 x 3,0 x 0,9 cm e a cobertura cortical predominante não excede a 1/4 da superfície externa,
} 
também se apresentar corticais, entre 35,29\% e 31,25\% dos casos. Os cantos dorsais dos talões não apresentam redução entre 57,66\% e 65,62\% dos casos. Por fim a ausência de lábios no canto ventral dos talões é mais característica desta categoria de lascas se comparada às demais, representando entre $90,18 \%$ e $65,8 \%$ dos casos analisados ${ }^{10}$.

As lascas unipolares secundárias ou de redução de peças bifaciais predominam em todas as coleções analisadas, representando entre 74,17\% e 70,54\% das amostras analisadas. O basalto representa a matéria prima predominante na coleção do sítio RS-S337, correspondendo a 51,24\% e 57,04\% das lascas deste tipo para os sítios RS-S-360 e RS-S-327, sendo o restante representado, principalmente, pelo arenito silicificado. As dimensões médias destas lascas são menores que a categoria anterior, apresentando valores similares para os sítios RS-S-360 (1,95 x 1,73 x 0,45 cm) e RS-S-337 (1,9 x 1,83 x 0,42 $\mathrm{cm})$ e um pouco inferiores as do sítio RS-S-327 (1,61 x 1,47 x 0,40 cm). Para todos os sítios as faces dorsais apresentam-se, em geral, acorticais com cicatrizes de lascamento anterior, com índices entre 85,84\% e 90,8\%, a semelhança da categoria de lascas anterior. No entanto, as lascas de redução secundária apresentam maior variação quanto ao tipo de plano de percussão direta se comparada às lascas primárias, embora as proporções sejam semelhantes entre os sítios. Para todas os conjuntos os talões acorticais lisos predominam, representando entre 44,29\% e 47,2\% das amostras, porém também estão representados os talões acorticais facetados (entre 28,04\% e 21,92\%) e os puntiformes (entre 29,6\% e $25,28 \%)$. As variações internas entre os conjuntos apresentam-se mais evidentes quanto às características dos cantos dorsais dos planos de percussão. Dentre as coleções, a que apresentou maiores índices de redução no canto dorsal é a do sítio RS-S-360, com 52,3\%, estando as mesmas características presentes em 39,08\% e 34,25\% das lascas secundárias dos sítios RS-S-337 e RS-S-327, respectivamente. Entre 59,12\% e 43,51\% do conjunto restante não apresentou redução no canto dorsal, estando os desgastes do canto dorsal melhor representados entre as lascas secundárias se comparadas as demais categorias, distribuindo-se entre 5,35\% e 1,14\% dos conjuntos. Por fim, a ausência de lábios no canto ventral da plataforma de percussão também caracteriza a maioria das lascas secundárias de todos os conjuntos analisados, entre $65,13 \%$ e 53,76\% dos casos, embora os índices sejam

podendo atingir até metade. Também se observa um predomínio de talões acorticais e facetados e ausência de redução dorsal e de lábio nestes talões (Dias, 1999b).

${ }^{10}$ As lascas unipolares de redução primárias representam $22 \%$ da amostragem analisada para o sítio RS-S358: Toca Grande. Apresentaram dimensões médias de 3,6 x 3,5 x 0,9 cm, possuindo faces externas acorticais e facetadas. Quanto aos tipos de talão, estes podem ser facetados ou lisos, não sendo significativa sua redução no canto dorsal, nem a presença de lábios no canto ventral (Dias, 1999b). 
menos elevados que nas demais categorias ${ }^{11}$. Deve-se destacar que este indicador parece apresentar uma relação forte com o tipo de matéria prima, sendo mais freqüentes em lascas de arenito silicificado ${ }^{12}$

Partindo dos dados acima apresentados, concluímos que a baixa extensão da cobertura cortical e as variações quanto às dimensões e características dos planos de percussão, parecem indicar que as lascas corticais podem decorrer tanto da preparação de núcleos quanto da redução de bifaces ${ }^{13}$. Esta hipótese confirma-se na comparação entre participação relativa de lascas unipolares acorticais e corticais para o conjunto de sítios da área do Alto Vale do Rio dos Sinos, sendo a presença de córtex sempre inferior a 20\% do conjunto. O mesmo padrão é observado no sítio a céu aberto RS-LC-76, no qual somente 6,5\% das lascas unipolares apresentam córtex, com uma distribuição na face externa, em geral, inferior a 1/3 da peça (Hoeltz \& Hilbert, 2000).

Por sua vez, a análise qualitativa permitiu observar que as principais diferenças entre as lascas primárias ou de redução de núcleos e secundárias ou de redução de bifaces para os sítios da Tradição Umbu estariam relacionadas às categorias de tamanho ${ }^{14}$. $\mathrm{O}$ primeiro grupo possuiria comprimentos médios maiores, entre 4 e 2,5 cm e espessura média entre 1,25 e 0,9 cm, predominando os planos de percussão lisos ou corticais, com cantos dorsais sem redução e ventrais sem lábio, indicando etapas iniciais de redução. As lascas secundárias ou de redução de peças bifaciais de pequeno porte, possuem dimensões médias menores, entre 2 e 1,5 cm de comprimento e 0,4 cm de espessura, possuindo planos de percussão variados (lisos, facetados ou puntiformes), com maior tendência a apresentar redução e desgaste no canto dorsal e lábios no canto ventral, aspectos relacionados à

\footnotetext{
${ }^{11}$ As lascas unipolares secundárias ou de redução de biface do sítio RS-S-358 representam 61\% da amostra analisada, com dimensões médias de $2,7 \times 2,5$ x 0,6 cm. Quanto à face externa predominam as lascas acorticais facetadas, bem como os talões facetados. Contudo, os índices de redução dorsal dos talões continuam baixos, ocorrendo também à presença de desgaste, sendo baixa a presença de lábios no canto ventral dos talões (Dias, 1999b).

${ }^{12}$ Do conjunto de lascas secundárias do sítio RS-S-327 que apresentaram lábio no canto ventral do talão, $67,6 \%$ são de arenito silicificado. O mesmo tipo de padrão foi identificado para o sítio RS-S-360, onde $57,5 \%$ das lascas secundárias que apresentavam lábio no canto dorsal também são de arenito silicificado.

${ }^{13}$ Estes dados são sustentados por estudos experimentais que apontam que a quantidade e as características das lascas corticais em um determinado conjunto lítico depende tanto da técnica de lascamento empregada, quanto do tipo de artefato produzido, podendo estar presente em várias etapas da produção diferenciadas (Andrefsky, 1998: 102). Esperaria-se, portanto, que as coleções líticas de caçadores coletores relacionados à Tradição Umbu apresentassem, em geral, baixos índices de lascas corticais.

${ }^{14}$ Estudos experimentais para rochas silicosas tem apontado que há uma tendência de a debitagem ser menor quando os artefatos individuais tornam-se progressivamente próximos ao termino e similarmente a quantidade de córtex tende a ser menor durante estágios finais de redução (Andrefsky, 1998 : 108-109; Shott, 1994:90).
} 
preparação de plataformas para refinamento de bifaces, a utilização de percutores brandos e ao emprego de retoque.

Tomando por base esta generalização derivada da análise qualitativa, sugerimos que os sítios da Tradição Umbu caracterizam-se por apresentar, predominantemente, lascas pequenas, com dimensões inferiores a 2,5 cm de comprimento indicando um predomínio de atividades relacionadas à redução de peças bifaciais de pequeno porte, sendo pouco representativas as lascas com dimensões maiores, relacionadas à preparação de núcleos. Para testar esta hipótese, dividimos os conjuntos de lascas unipolares dos sete sítios estudados, independente da presença de córtex, em três categorias de tamanho. As lascas com comprimento entre 1 e 2,5 cm estariam associadas à redução de bifaces e as com dimensões entre 2,5 e 4 cm à redução de núcleos. Lascas com dimensões maiores de 4 cm estariam associadas a bases de produção de pontas de projétil, sendo obtidas junto às fontes de matéria prima e transportadas para os sítios. Para todos os sítios predominou a presença de lascas pequenas, confirmando a hipótese inicial, estando as lascas do segundo e terceiro tipo representadas por menos de $30 \%$ da amostra. Estas últimas estão mais freqüentemente associadas aos sítios do vale do arroio Campestre, nos quais a presença de artefatos bifaciais é mais significativa.

Um padrão similar também foi identificado para o sítio a céu aberto RS-LC-76, no qual predomina lascas unipolares com dimensões inferiores a $3 \mathrm{~cm}$ de comprimento. Do total de lascas unipolares deste sítio, 71,8\% possuem comprimento entre 1 e 3 cm, 8,8\% apresentam dimensões entre 3 e $5 \mathrm{~cm}$ de comprimento e somente $2 \%$ apresentam tamanhos superiores a $5 \mathrm{~cm}$. O restante da coleção de lascas unipolares é formado por peças cujas dimensões são inferiores a $1 \mathrm{~cm}$ de comprimento $(17,4 \%)$, apresentando valores equivalentes à participação relativa das microlascas para os sítios em abrigo sob rocha do Alto Vale do Rio dos Sinos. Quanto às características do conjunto de lascas unipolares, a análise qualitativa da coleção deste sítio indicou uma variedade de planos de percussão semelhante à observada para as lascas de redução de biface dos sítios em abrigo sob rocha. Os planos de percussão apresentaram-se acorticais facetados (42,8\%), puntiformes (33,6\%) ou lisos $(21,4 \%)$, com cantos dorsais sem redução $(65,6 \%)$ e cantos ventrais com ausência de lábio (91,2\%) (Hoeltz \& Hilbert, 2000). 
Tipos de lascas

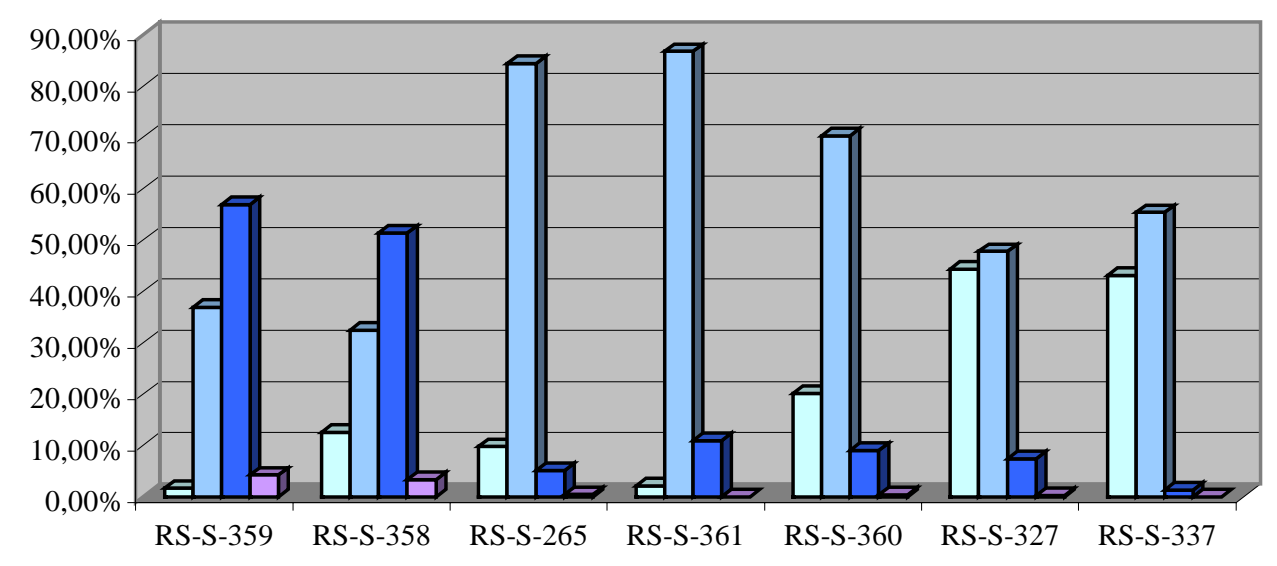

$\square$ Microlascas $\quad \square$ Lascas unipolares $\quad \square$ Lascas bipolares $\square$ Lascas retocadas

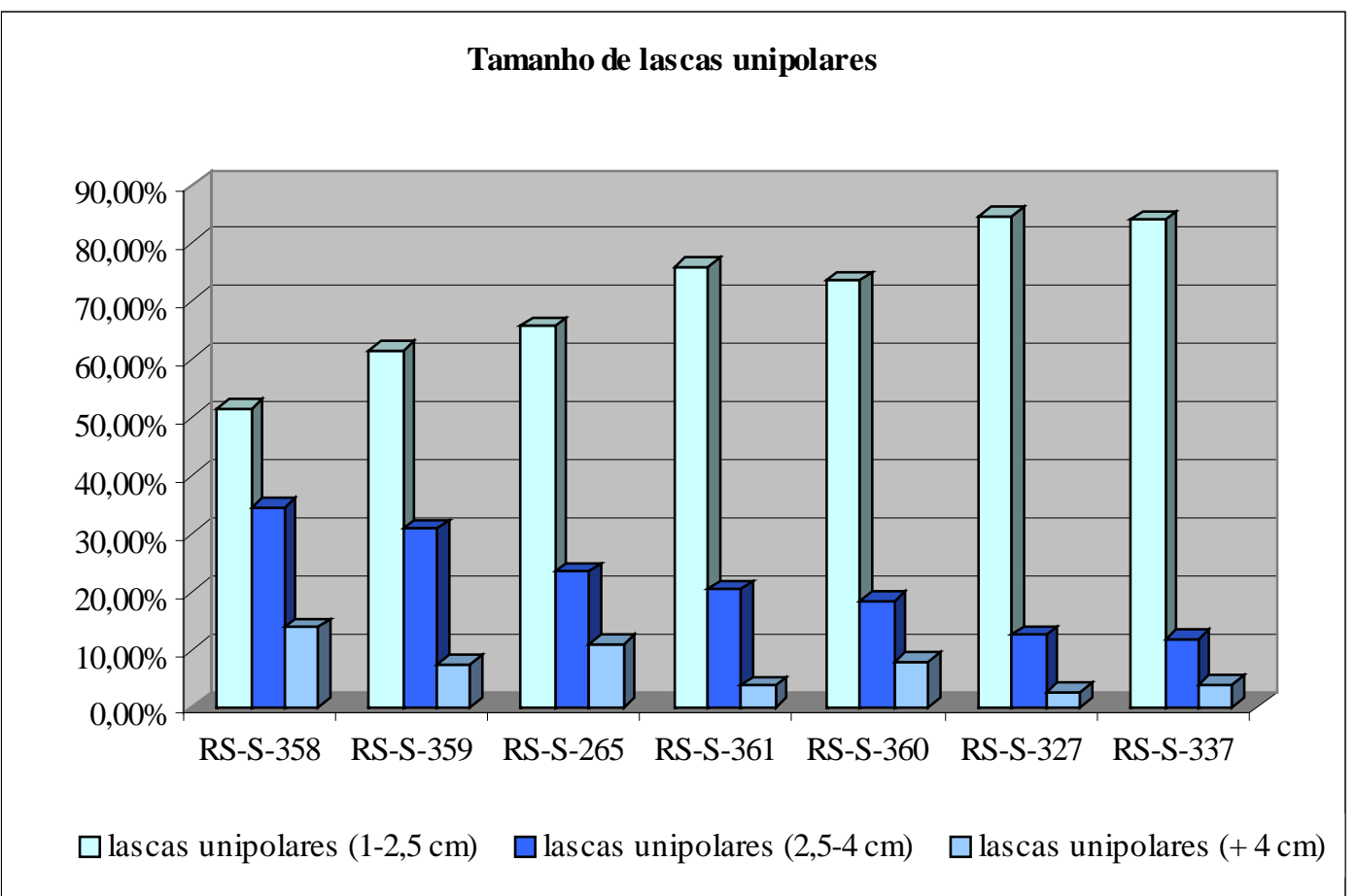

Como as lascas bipolares apresentaram grande semelhança entre todos os sítios estudados, foi realizado um estudo qualitativo mais detalhado das lascas bipolares dos sítios RS-S-327 e RS-S-360, cujos resultados podem ser estendidos às amostras dos demais sítios. Estas apresentaram uma grande homogeneidade, independente do tipo de matéria prima, predominando a calcedônia no sítio RS-S-360 (80,6\%) e o quartzo no sítio RS-S- 
327 (51,63\%). As dimensões médias das lascas bipolares são similares, com valores entre 1,76 x 1,25 x 0,55 cm e 1,92 x 1,44 x 0,49 cm, respectivamente, e em ambas as coleções a superfície da face externa é acortical com cicatrizes de lascamento anteriores. O plano de percussão direto é, em geral, puntiforme (entre 36,6\% e 37,2\%) ou acortical facetado (27,35\% e 30,6\%), apresentando metade das amostras de ambos os sítios evidências de maceração de canto dorsal de plataforma. As terminações distais, em geral, possuem forma variada, predominando as em forma de vértice, e não apresentam pontos de percussão indireta entre $86 \%$ e $91 \%$ dos casos analisados. É característica para as lascas bipolares a presença de faces ventrais retas, observadas entre $90 \%$ e $98 \%$ das peças analisadas.

A presença de núcleos, seja estes bipolares ou unipolares, para o conjunto total de sítios do Alto vale do Rio dos Sinos apresentaram-se sempre baixa, com índices entre 0,71\% e 0,10\%. Características semelhantes também foram observadas na análise de outras coleções da Tradição Umbu da região nordeste do Estado, tanto em abrigos sob rocha dos vales dos rios Caí e Maquiné (Dias, 1994, 1999b), quanto no sítio a céu aberto RS-LC-76 (Hoeltz e Hilbert, 2000) A maior concentração de núcleos bipolares de calcedônia e quartzo, está associada aos sítios RS-S-358 (18 peças) e RS-S-359 (26 peças), apresentando relação com a maior proporção de lascas bipolares nestes sítios.

A maior concentração de núcleos unipolares relaciona-se ao sítio RS-S-360 (15 peças), sendo estes representados em sua maioria por placas de basalto colunar que apresentam retiradas, sem preparação de plataformas. Os núcleos unipolares formais associados a todos os sítios, em geral, são pequenos, com dimensões inferiores a $10 \mathrm{~cm}$, e apresentam baixa cobertura cortical. Possuem, em geral, mais de três plataformas de percussão, distribuídas em várias posições, indicando processos intensos de redução para extração de lascas de uso expeditivo. Um padrão similar foi observado na análise dos núcleos unipolares associados à coleção do sítio RS-LC-76 (0,48\% do conjunto lítico), predominando os tipos com várias plataformas e dimensões máximas entre 5 e $10 \mathrm{~cm}$ (Hoeltz \& Hilbert, 2000). Quanto aos núcleos bipolares das coleções líticas da Tradição Umbu para o Alto Vale do rio dos Sinos, estes também são pequenos, em geral com menos de $4 \mathrm{~cm}$ de comprimento, apresentando planos de percussão direto e indiretos opostos. A presença de córtex está geralmente associada apenas à plataforma de percussão direta que se caracteriza por apresentar vários pontos de impacto.

Com base nos estudos qualitativos das lascas unipolares e bipolares e das características dos tipos de núcleos observa-se que tanto a tecnologia bipolar, quanto a unipolar não demandam uma preparação inicial das matérias primas coletadas para 
extração de córtex, indicando que a organização tecnológica associada à Tradição Umbu para a área não se caracteriza por apresentar investimentos na redução inicial. A ausência de estratégias de preparação de núcleos apresenta, por sua vez, uma correlação positiva com a presença de fragmentos naturais em todos os sítios estudados, indicando estratégias de coleta e estocagem de matérias primas para redução junto às unidades habitacionais. A participação relativa desta categoria para as coleções estudadas varia entre 3,77\% e 33,92\% dos conjuntos, estando os menores valores associados aos sítios do vale do arroio Campestre, com índices entre 8,3\% e 3,77\%, aspecto que se relaciona com as variações locais quanto às estratégias de redução das matérias primas. Para os sítios associados à várzea do rio dos Sinos os índices de participação relativa para os fragmentos naturais se dão entre $13,77 \%$ e $34,72 \%$. Para todos os sítios analisados, o basalto corresponde à matéria prima predominante entre os fragmentos naturais, sendo os fragmentos de basalto colunar o tipo mais freqüente nas coleções dos sítios RS-S-360, RS-S-327 e RS-S-337. A coleção lítica do sítio a céu aberto RS-LC-46 também apresenta um comportamento similar quanto à presença e tipos de fragmentos naturais, correspondendo estes a 15\% do conjunto analisado. O basalto corresponde a 63\% da matéria prima dos fragmentos naturais, porém seu tipo varia em relação às disponibilidades locais no entorno do sítio, sendo mais freqüentes os fragmentos de basalto originários de afloramentos (65\%), seguidos pelas placas de basalto colunar (35\%) (Hoeltz \& Hilbert, 2000).

\subsubsection{Relação entre Estratégias de Redução e Produção de Artefatos:}

Assim como para os resíduos de lascamento, observa-se uma diferenciação entre os conjuntos de sítios do Alto Vale do Rio dos Sinos quanto à participação relativa de artefatos em suas coleções. Ambos sítios do vale do arroio Campestre apresentam 13\% de sua indústria composta por artefatos, enquanto os demais apresentaram uma composição que varia entre $1 \%$ a $5 \%$. A distribuição dos tipos de artefatos, por sua vez, apresenta igualmente variações entre os sítios. Para os sítios do vale do arroio Campestre, as peças bifaciais representam entre 98\% e 95\% dos conjuntos de artefatos. Sua representação nos sítios da várzea dos Sinos, no entanto, é mais variada, atingindo entre 89\% e 51\% dos conjuntos dos sítios RS-S-265, RS-S-360 e RS-S-327. Nos dois sítios restantes, RS-S-361 e RS-S-337, predominam os artefatos polidos e brutos em relação à participação relativa de artefatos bifaciais. 
As pontas de projétil representam entre 57\% e 41\% dos artefatos bifaciais dos sítios do vale do arroio Campestre, predominando em suas coleções também a presença de préformas de pontas de projétil (27 a 25\%) e os fragmentos de pontas de projétil e bordas de peças bifaciais (23 a 11\%). Dentre os sítios associados à várzea do rio dos Sinos, observase um padrão semelhante em termos de participação relativa para os sítios RS-S-265 e RSS-337, embora a amostragem de materiais seja significativamente menor. Nos demais se observa um predomínio dos fragmentos de artefatos bifaciais, entre $42 \%$ e $50 \%$ dos conjuntos, destacando-se, em um segundo plano, a presença de pontas de projétil.
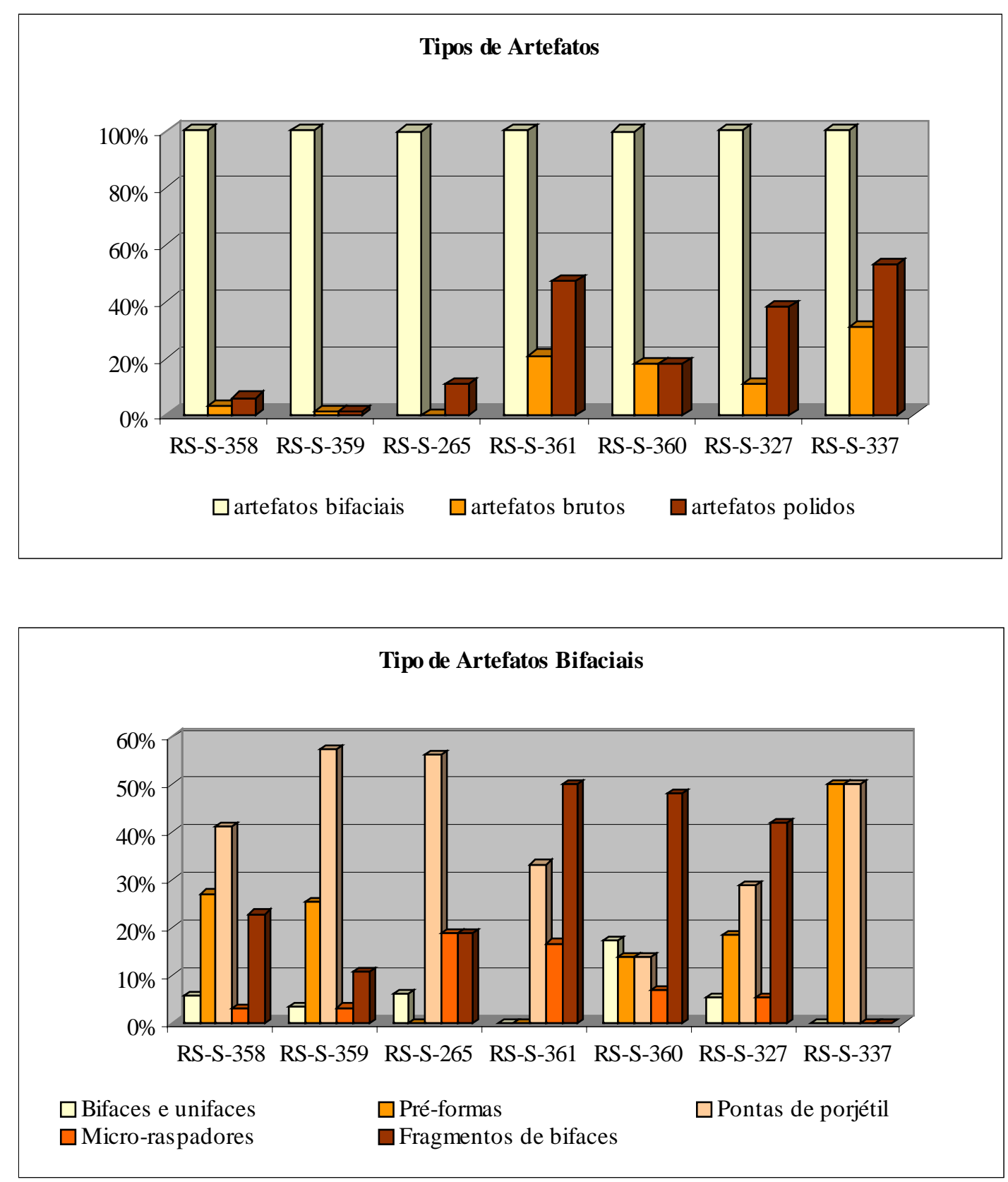
O comportamento dos resíduos de lascamento pode ser melhor compreendido a partir da análise qualitativa dos conjuntos de artefatos bifaciais. Para tanto foram selecionadas para a análise as coleções dos sítios RS-S-360 e RS-S-327, sendo seus resultados comparados com uma amostragem de artefatos bifaciais do sítio RS-S-358 ${ }^{15}$. A coleção de artefatos bifaciais estudados para o sítio RS-S-358 é composta por 76 peças, havendo um predomínio das pontas de projétil lanceoladas (41\%), seguidas das préformas (33\%), das pontas de projétil de pedúnculo bifurcado (8\%) e reto (7\%), das pontas de projétil de bordas serrilhadas (4\%), dos micro-raspadores (4\%) e dos bifaces sobre lasca (3\%). Para o sítio RS-S-327 foi estudada uma coleção de 23 artefatos, predominando neste conjunto as pré-formas $(30,43 \%)$, as pontas de projétil com base de pedúnculo reto $(17,39 \%)$ e bifurcado $(13,04 \%)$ e as pontas de projétil lanceoladas (13,04\%), estando também presentes os bifaces (8,69\%), os micro-raspadores (8,69\%), as pontas de projétil pedunculadas com bordas serrilhadas $(4,3 \%)$ e as peças unifaciais $(4,3 \%)$. Na participação relativa dos artefatos bifaciais para o conjunto de 16 peças associadas ao sítio RS-S-360, predominam os bifaces (37\%) e as pré-formas (25\%), sendo também representadas as pontas de projétil com pedúnculo reto (12,5\%) e bifurcado (6,25\%), os micro-raspadores (6,25\%), as pontas de projétil lanceoladas (6,25\%) e os unifaces (6,25\%).

Este comportamento, quando observado a luz da análise qualitativa demonstra a relação entre pontas lanceoladas e tecnologia bipolar sobre a calcedônia no sítio RS-S-358. Por sua vez, a unipolaridade se relaciona de forma estreita com as demais categorias de artefatos para os três sítios estudados, sendo representada pela maior representatividade de bifaces, pré-formas e pontas pedunculadas elaboradas em basalto ou arenito silicificado ${ }^{16}$.

Os bifaces do sítio RS-S-358 correspondem a 3 peças inteiras com dimensões média de 8,1x 6,1 x 2,6 cm. Duas das peças são elaboradas em basalto e uma em arenito silicificado, apresentando todas superfícies corticais em menos de 1/4 ou 1/2 da superfície total da peça. Em dois casos pode-se identificar a base de redução primária como correspondendo a lascas unipolares, utilizadas no sentido proximal e com redução massiva. O sítio RS-S-360 apresentou 6 bifaces em sua coleção, dos quais 4 foram elaborados sobre lascas unipolares e 2 sobre placas, sendo a matéria prima o basalto. Os bifaces elaborados

\footnotetext{
${ }^{15}$ Foram selecionados para análise qualitativa os artefatos bifaciais associados às quadrículas D20, D19, E20, E19, E18, E17 que apresentavam maior densidade de materiais líticos para o total da área escavada do sítio RS-S-358. As fotos presentes neste capítulo são de peças significativas selecionadas de todo o conjunto da coelção deste sítio.

${ }^{16}$ Destaca-se a grande similaridade nas estratégias de produção de artefatos observadas entre os sítios do Alto Vale do Rio dos Sinos e os sítios RS-C-43: Picada Capivara, associado ao vale do rio Caí (Dias, 1994) e RSLN-01: Cerrito Dalpiaz, associado ao vale do rio Maquiné (Dias, 1999b).
} 
sobre lascas unipolares apresentaram dimensões médias de 4,5 x 3,2 x 1,4 cm, não apresentando cobertura cortical. O sentido de utilização destas lascas foi predominantemente proximal, havendo um caso de utilização lateral, sendo a extensão das cicatrizes primárias marginal para todas as peças. Os dois bifaces elaborados sobre placa apresentaram dimensões maiores se comparados à categoria anterior com uma média de 15,6 x 7,1 x 2,7 cm. A cobertura cortical está presente em ambas às peças, podendo ser total ou restrita a apenas uma extremidade, distribuindo-se os lascamentos primários de forma marginal por todo o contorno dos artefatos. Os dois bifaces presentes na coleção do sítio RS-S-327 possuem dimensões médias de 3,85 x 3 x 1,2 cm e foram elaborados basalto e arenito silicificado. A base do lascamento inicial corresponde a lascas unipolares e em um dos casos observa-se a presença de córtex, cuja extensão não excede $1 / 4$ da superfície de uma das faces da peça. O sentido de utilização das lascas foi proximal ou lateral, distribuindo-se as cicatrizes de lascamento primário de forma marginal em ambas às faces das peças. Destaca-se que nenhum dos bifaces analisado nas três coleções apresentou evidências de modificação secundária por retoque ou marcas de uso.

Foram identificados dois artefatos unifaciais para as coleções dos sítios RS-S-360 e RS-S-327. Para o primeiro sítio a peça possui 3,5 x 2,5 x 1,8 cm, sendo a sua matéria prima o basalto. A base de modificação primária corresponde a uma lasca unipolar de basalto que apresenta córtex até a $1 \frac{1}{2}$ de sua superfície dorsal. Esta peça apresentou retoque direto e marginal regular, distribuído em todo o contorno da face dorsal, sendo seu ângulo abrupto. Para o segundo sítio, a matéria prima do artefato unifacial é a calcedônia, com dimensões de $3 \times 2 \times 1,2$ cm. A peça não apresenta córtex, sendo a base da modificação primária um núcleo bipolar. O retoque direto se distribui em todo o contorno de apenas uma das faces, sendo invasor regular, contínuo e aplicado em um ângulo abrupto.

As pré-formas do sítio RS-S-358 correspondem a 25 peças com dimensões médias de 4,0 × 2,7 x 0,9 cm, estando inteiras em 56\% dos casos ou apresentando apenas as terminações proximais (24\%) ou distais (16\%). A matéria prima predominante é o basalto (68\%), estando também presente o arenito silicificado (12\%) e a calcedônia (20\%), este último caso associado à pré-formas de menores dimensões elaboradas sobre lascas e núcleos bipolares para produção de pontas de projétil lanceoladas. Predominam as superfícies acorticais, com cicatrizes em ambas as faces (76\%) ou em uma das faces (20\%), apresentando apenas uma peça córtex em menos de 1/4 da superfície total. Nas peças nas quais foi possível identificar a base de redução primária, nota-se o predomínio de lascas unipolares, de orientação proximal e extensão de cicatrizes massiva. Apenas 8 peças 
apresentaram retoque, predominantemente marginal regular, distribuído de forma bifacial ou direta. O ângulo predominante de aplicação do retoque é semi-abrupto, com padrão de ocorrência contínuo, localizado em todo o contorno bifacial (50\%) ou nas terminações proximais ou distais (50\%). A coleção do sítio RS-S-360 apresentou 4 pré-formas, das quais 3 em basalto e 1 em arenito silicificado. Apenas uma das peças encontra-se inteira, com dimensões de $3 \times 2 \times 0,9 \mathrm{~cm}$, sendo as demais representadas por terminações proximais, não havendo evidências de retoque em nenhum dos casos. Nenhuma das peças apresentou córtex, sendo possível identificar a base de modificação primária em apenas um caso, tendo em vista a extensão massiva das cicatrizes de redução primária, correspondendo esta a uma lasca unipolar cujo sentido de utilização foi proximal. Das 7 pré-formas da coleção do sítio RS-S-327, apenas uma apresenta-se inteira, com dimensões de 4,5 x 2,7 x $1 \mathrm{~cm}$, correspondendo as demais peças a terminações proximais (28\%) ou distais (58\%). A matéria prima de 70 \% destas é o basalto, sendo o restante em arenito silicificado, nenhuma apresentando evidências de córtex. Foi possível identificar as lascas unipolares como base da redução primária em duas peças, cuja orientação é proximal, sendo a extensão das cicatrizes primárias massiva em 85\% dos casos. Duas das peças apresentam retoque bifacial, aplicado em ângulo semi-abrupto e distribuído de forma marginal e contínua. Nenhuma das pré-formas estudadas apresentou evidências de desgaste de bordas.

Os micro-raspadores pedunculados do sítio RS-S-358 apresentam dimensões médias de 2,0 x 2,0 x 0,7 cm, correspondendo a um total de 3 peças inteiras. Todos são elaborados em calcedônia, apresentando superfície acortical com cicatrizes de lascamento anterior em ambas as faces. A base de redução primária só pode ser identificada em uma peça, como sendo uma lasca bipolar com orientação proximal, sendo a extensão das cicatrizes primárias massiva em todos os casos. Todas as peças apresentam retoque bifacial com padrão de ocorrência contínuo, variando sua extensão em cada caso entre marginal regular, invasor regular e envolvente regular. O ângulo do retoque foi semi-abrupto em dois casos e abrupto no outro, estando localizado em todo contorno bifacial para todas as peças. A coleção de artefatos bifaciais do sítio RS-S-360 apresenta um micro-raspador em calcedônia, com dimensões de 2,2 x 2,5 x 0, 7 cm. As cicatrizes de retoque são bifaciais e distribuem-se de forma envolvente e regular, impedindo a identificação da base de modificação primária, sendo o ângulo de aplicação abrupto. Os dois micro-raspadores do sítio RS-S-327 também são em calcedônia, com dimensões médias de 1,95 x 1,65 x 0,75 cm. A base de redução primária foi identificada para uma das peças, correspondendo a um 
núcleo bipolar. O retoque é direto em ambos os casos, distribuindo-se de forma regular ou marginal em todo o contorno de apenas uma das faces, sendo seu ângulo abrupto. Para nenhuma das peças analisadas foi possível identificar evidências de desgaste nas bordas (foto 7).

As pontas de projétil com base de pedúnculo reto estão representadas por 5 peças na coleção do sítio RS-S-358. Apresentam dimensões médias entre 3,9 x 2,0 x 0,7 cm, sendo à maioria inteira e elaboradas sobre matérias primas variadas, predominando as de arenito silicificado (3 peças), seguidas pelo basalto e a calcedônia. Em todos os casos as superfícies são acorticais, estando em somente um caso as cicatrizes de lascamento concentradas em apenas uma das faces. A base de redução pode ser identificada em 3 peças, sendo esta lascas unipolares com orientação proximal. A extensão das cicatrizes de redução primária é massiva e o retoque é invasor regular na maioria nos casos, podendo também ser marginal regular ou envolvente regular. A posição de retoque bifacial é predominante, com um caso apenas de retoque direto localizado em todo o contorno da peça de forma contínua, sendo, em geral, o ângulo de aplicação semi-abrupto, com um caso de ângulo rasante. A coleção do sítio RS-S-360 apresenta duas pontas de projétil deste tipo, sendo uma em basalto e a outra em arenito silicificado. As dimensões são de 2,7 x 1,75 x 0,6 cm, apresentando uma destas fratura distal. A base da modificação primária foi identificada para uma delas como sendo uma lasca unipolar, não sendo possível identificar o sentido de sua utilização em função da presença de retoque bifacial invasor regular ou envolvente regular, aplicado em ângulo semi-abrupto. As pontas de pedúnculo reto estão representadas por 4 peças para o sítio RS-S-327, sendo 3 em basalto e 1 em arenito silicificado. As dimensões médias são de 4 x 2,2 x 0,8 cm, sendo possível identificar a base de redução inicial para duas destas como sendo lascas unipolares, com sentido de utilização proximal. Na maioria das peças o retoque se deu de forma envolvente, podendo apresentar-se também de forma marginal ou invasora. Para todas as peças a posição do retoque é bifacial, com ângulo semi-abrupto e padrão de ocorrência contínuo (fotos 8 e 9).

As pontas com base de pedúnculo bifurcado correspondem a 6 peças inteiras para 0 sítio RS-S-358, apresentando dimensões médias menores do que a categoria anterior (2,9 x 1,7 x 0,6 cm). A matéria prima que predomina é o basalto, sendo duas ocorrências em arenito silicificado. Só foi possível identificar a base de redução primária em um dos casos, sendo esta uma lasca unipolar, contudo a presença massiva de cicatrizes de redução primária e de retoque, impediu observar seu sentido de utilização. O retoque presente em todas as peças é predominantemente bifacial, com um único caso de retoque alterno. Em 
metade dos casos sua extensão é invasora regular ou envolvente regular, só apresentando um caso marginal. Predominam os retoques aplicados em ângulo semi-abrupto, com padrão de ocorrência contínua e localização em todo contorno bifacial. Foi identificada apenas uma ponta deste tipo na coleção do sítio RS-S-360, elaborada em basalto. Suas dimensões são de 4 × 2 x 0,8 cm, sendo elaborada a partir de uma lasca unipolar. O retoque é envolvente, distribuindo-se de forma contínua em ambas as faces da peça, sendo seu ângulo semi-abrupto. A coleção do sítio RS-S-327 apresenta 3 pontas de projétil de pedúnculo bifurcado, sendo todas em basalto. As dimensões médias são de 3 x 1,6 x 0,7 cm, podendo ser identificada a base de lascamento em uma das peças como correspondendo a uma lasca unipolar, com orientação proximal. A extensão do retoque bifacial se dá de forma contínua, invasora ou envolvente, sendo seu ângulo de aplicação semi-abrupto (fotos 10 e 11).

As pontas de projétil de formato lanceolado e sem pedúnculos correspondem a 32 peças para o sítio RS-S-358. Do conjunto de peças, apenas uma apresenta fratura longitudinal, estando todas as demais inteiras. Suas dimensões médias são de 2,2 x 1 x 0,5 cm, sendo a calcedônia a matéria prima predominante em 96,8\% dos casos, ocorrendo apenas uma peça em basalto. Na maioria, as pontas apresentam cicatrizes de redução primária em apenas uma das faces $(56,4 \%)$, sendo a base de redução predominante as lascas bipolares (93,7\%), com exceção da única peça em basalto elaborada sobre lasca unipolar. Independente da tecnologia de produção, as lascas foram reduzidas a partir de uma orientação proximal (93,7\%), havendo somente um caso de orientação lateral. A posição do retoque para 59,3\% dos casos é direto, podendo ser também bifacial (31,2\%) ou alterno (9,3\%). O ângulo do retoque varia entre semi-abrupto (56,2\%) e abrupto (40,6\%), havendo apenas um caso de retoque rasante. A extensão do retoque pode ser tanto invasora regular $(37,5 \%)$ quanto envolvente regular $(37,5 \%)$, havendo também casos de retoque marginal regular (25\%). O padrão de ocorrência é contínuo na maioria das peças (68,7\%), mas também pode ser encontrado em grupos $(21,8 \%)$, sendo mais raramente descontínuo $(9,3 \%)$. Na maioria das peças o retoque encontra-se na região proximal ou cobrindo todo contorno bifacial, havendo apenas dois casos de distribuição na área distal. No sítio RS-S-360 foi identificada apenas uma ponta lanceolada em calcedônia, com dimensões de 3,6 x 1,4 x 0,7 cm . A base da modificação primária é uma lasca bipolar, com orientação proximal, apresentando córtex no talão. O retoque é envolvente regular, distribuindo-se de forma bifacial e contínua, sendo aplicado em ângulo semi-abrupto. Foram identificadas três pontas lanceoladas na coleção do sítio RS-S-327, cujas 
características tecnológicas são menos homogêneas em função da variação dos tipos de matéria prima (quartzo, basalto e arenito silicificado). As dimensões médias são de 3 x 2,1 x 0,7 cm, sendo a base de redução da ponta de quartzo uma lasca bipolar e das pontas de outras matérias primas, lascas unipolares. O sentido de utilização das lascas foi identificado em apenas um caso como sendo oblíquo. No caso da ponta de quartzo o retoque se dá de forma marginal e direta, sendo invasor e bifacial nas demais peças, distribuindo-se em todos os casos em todo o contorno das pontas. Por fim, o ângulo de aplicação do retoque é variado podendo ser abrupto, semi-abrupto ou rasante (fotos 12 e 13).

As pontas de projétil pedunculadas que apresentam bordas serrilhadas estão representadas no sítio RS-S-358 por duas peças inteiras em basalto com dimensões médias de 2,3 x 1,2 x 0,5 cm. Ambas apresentam superfície acortical em ambas as faces, cuja base de redução não pode ser identificada. O retoque é bifacial, estendendo-se de forma envolvente regular ou marginal regular, aplicado em ângulo abrupto ou semi-abrupto. O padrão de ocorrência é contínuo, localizando-se em todo o contorno bifacial. Nas demais coleções só foi identificada uma ponta de projétil deste tipo na coleção do sítio RS-S-327. Confeccionada em basalto, possui dimensões de 2,8 x 1,4 x 0,8 cm. A presença de retoque bifacial, envolvente e regular impediu a identificação da base de redução inicial, sendo o ângulo de aplicação semi-abrupto (foto 14).

Quanto aos artefatos brutos associados aos sítios da Tradição Umbu do Alto Vale do Rio dos Sinos, o tipo mais popular é representado por pequenos fragmentos naturais de hematita, em geral com menos de $3 \mathrm{~cm}$ de comprimento, que apresentam marcas de raspagem em suas faces para extração de pigmentos. Estes compõem entre $45 \%$ a $100 \%$ da amostragem para este tipo de artefato nas coleções analisadas, estando ausentes apenas no sítio RS-S-265 que não apresenta artefatos brutos. Destaca-se no conjunto do sítio RS-S327 uma placa de basalto oxidada que apresenta marcas de raspagem em uma das faces, possivelmente também relacionada obtenção de pigmentos.

Fragmentos naturais de arenito friável que apresentam marcas de alisamento em uma ou ambas as faces também estão presentes na maioria das coleções, com exceção dos sítios RS-S-265 e RS-S-361, representando entre 20\% e 40\% das amostras para este tipo de artefatos. Geralmente designados de polidores manuais, estas peças apresentam pequenas dimensões e teriam sido utilizadas como superfícies abrasivas. A pressão difusa exercida sobre suas faces provocou a formação de áreas mais regulares sobre a superfície granular, gerando um polimento “passivo” (Dias e Hoeltz, 1997: 44). 
Foram também identificados percutores nos conjuntos líticos dos sítios RS-S-359, RS-S-358, RS-S-360 e RS-S-337. Estes correspondem a fragmentos de seixos arredondados de basalto, cujas extremidades apresentaram marcas pontuais relacionadas aos locais de impacto. Uma última categoria de artefatos brutos, representada pelas peças com depressões semi-esféricas ou quebra-coquinhos, foi identificada apenas na coleção do sítio RS-S-358.

Pequenas lascas unipolares de basalto com a face externa polida correspondem entre $80 \%$ e $100 \%$ dos tipos de artefatos polidos presentes em todos as coleções analisadas. Estas estão associadas a processos de redução de artefatos polidos com faces planas, sendo características também a presença de lascas de redução de gume polido. Machados ou outros tipos de artefatos com o gume polido não foram identificados nas coleções estudadas, embora esteja representado no único sítio a céu aberto identificado na área piloto (RS-S-420: Boçoroca).

Dentre os demais artefatos polidos identificados, destacam-se duas boleadeiras associadas aos sítios RS-S-327 e RS-S-358. Ambas são confeccionadas em basalto e apresentam formato esférico, sulco periférico produzido por picoteamento e polimento total de superfície. Também foi identificado um fragmento de almofariz em basalto na coleção do sítio RS-S-358. Elaborado a partir de picoteamento e polimento, foi possivelmente utilizado como suporte para trituração de pigmentos ou grãos. Na coleção do sítio RS-S-327 foram também identificados 2 fragmentos naturais que apresentaram evidencias de polimento. O primeiro corresponde a um pequeno seixo esférico de basalto e o segundo a um fragmento de calcedônia com formato circular, ambos podendo representar pré-formas de artefatos ou adornos. 


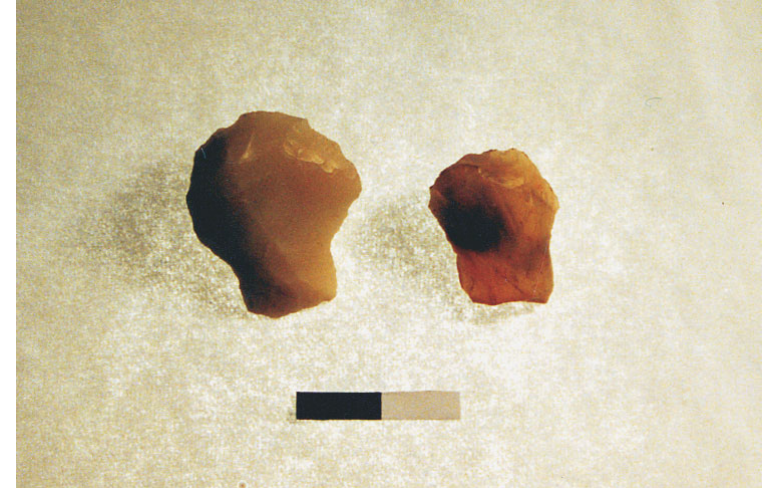

7. RS-S-358 - Micro-raspadores pedunculados em calcedônia. Foto: Mariana Cabral

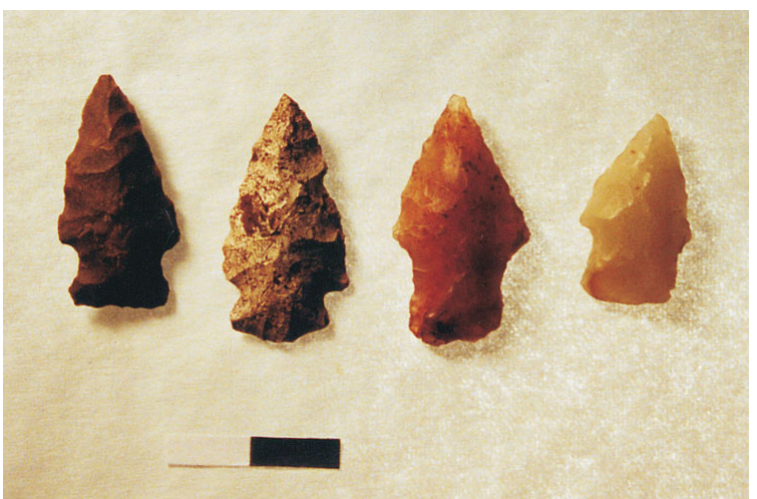

9. RS-S-358 - Pontas de projétil com pedúnculo reto em basalto e calcedônia. Foto: Mariana Cabral

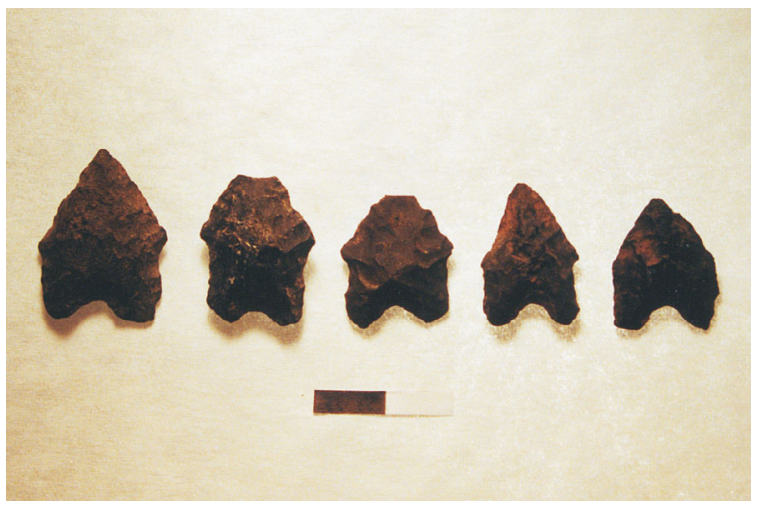

11. RS-S-358 - Pontas de projétil "reativadas" com pedúnculo bifurcado. Foto: Mariana Cabral

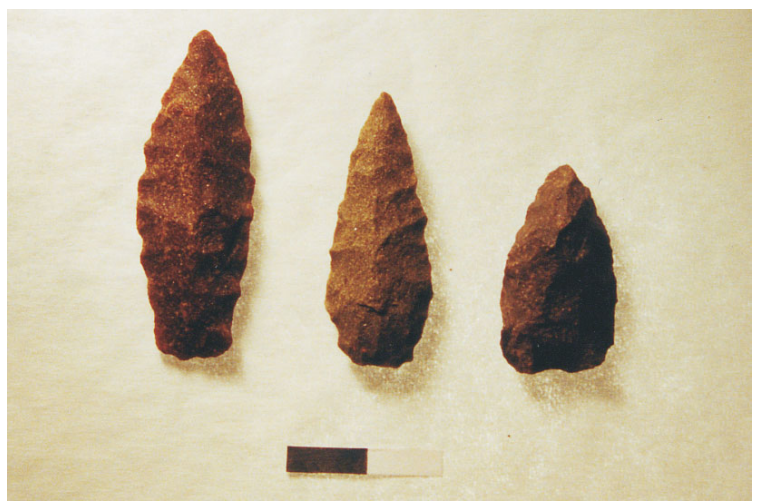

13. RS-S-358 - Pontas de projétil lanceoladas em arenito. Foto: Mariana Cabral

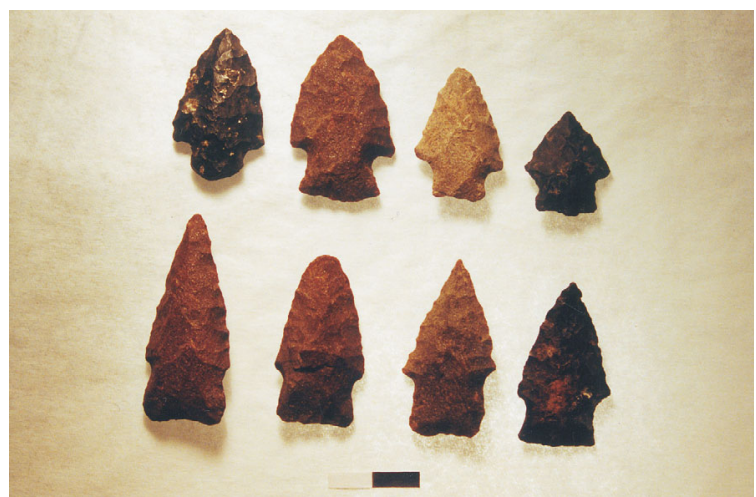

8. RS-S-358 - Pontas de projétil com pedúnculo reto em arenito e basalto. Foto: Mariana Cabral

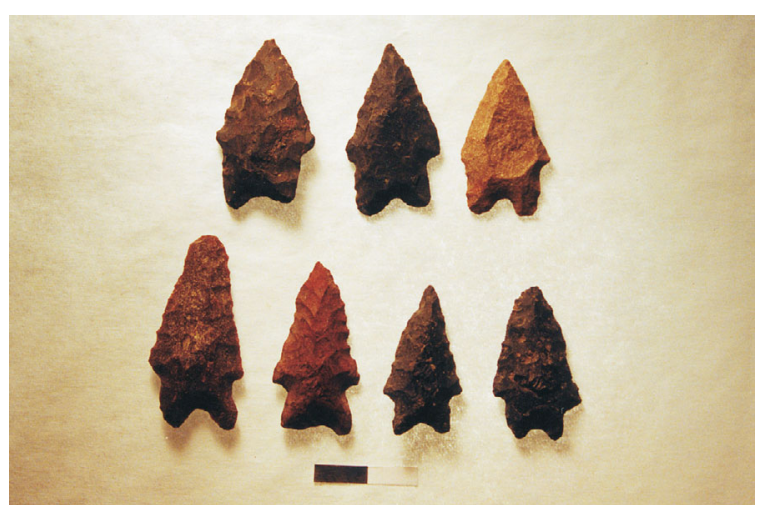

10. RS-S-358 - Pontas de projétil com pedúnculo bifurcado em basalto e arenito. Foto: Mariana Cabral

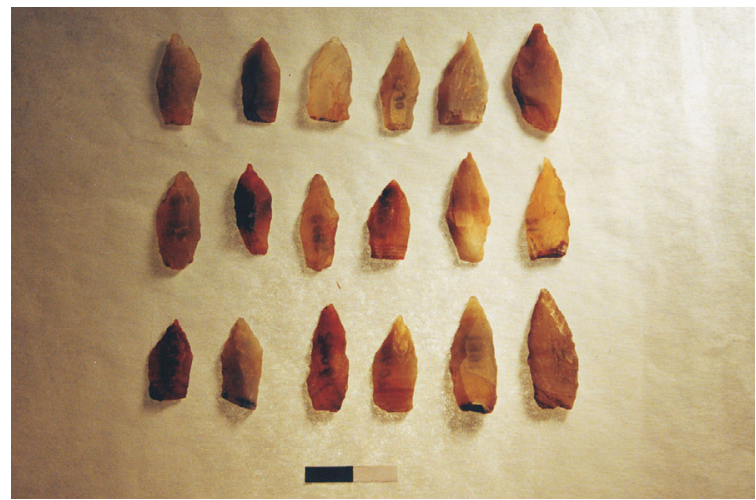

12. RS-S-358 - Pontas de projétil lanceoladas em calcedônia. Foto: Mariana Cabral

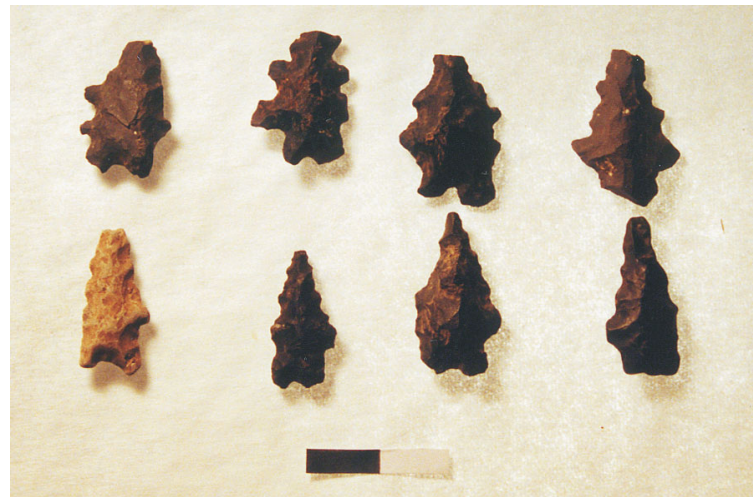

14. RS-S-358 - Pontas de projétil com bordas serrilhadas em basalto. Foto: Mariana Cabral 


\subsection{As Indústrias Líticas de Horticultores da Região do Alto Vale do Rio dos} Sinos

As características das indústrias líticas da Tradição Guarani foram definidas a partir da análise de um conjunto de 200 peças líticas associadas a 24 sítios arqueológicos localizados na área piloto. A maior parte da coleção provém de coletas de superfície realizadas na década de 1960 nos sítios RS-S-287: Passo da Forquilha 2 (34\%) e RS-S289: Mont Serrat 1 (30,6\%). A análise qualitativa realizada para as coleções destes dois sítios indicou resultados similares (Dias, 2001b), sendo seus resultados utilizados como referência para a classificação e análise dos demais conjuntos líticos coletados nas novas pesquisas de campo ${ }^{1}$. Por sua vez, os conjuntos líticos da Tradição Taquara totalizam 112 peças relacionadas a quatro sítios arqueológicos. A maioria do material lítico provém dos sítios RS-S-429: Furna 1 (55,35\%) e RS-S-431: Furna 3 (36,6\%), cuja análise prévia indicou também grande similaridade na composição das coleções, sendo utilizados seus resultados como referência para a classificação dos demais conjuntos artefatuais associados à Tradição Taquara (Dias \& Hoeltz, 2002).

A análise do material lítico seguiu os mesmos critérios metodológicos aplicados ao estudo das coleções da Tradição Umbu, sendo os conjuntos artefatuais dos dois grupos horticultores comparados entre si quanto às estratégias diferenciais de aproveitamento das matérias primas, de organização diferencial das estratégias de redução e de produção de artefatos.

\subsubsection{Estratégias de Seleção de Matérias Primas}

Quanto à obtenção de matérias primas relacionadas às indústrias líticas da Tradição Guarani, 93,4\% do total das peças foram confeccionadas em basalto, sendo o restante representado pelo arenito silicificado (5\%), a calcedônia (1\%) e o quartzo (0,5\%). Em 81\% do conjunto das peças analisadas foi possível identificar a origem da matéria prima, sendo esta predominantemente representada por seixos de arraste fluvial $(65,43 \%)$ obtidos nas

\footnotetext{
${ }^{1}$ As novas pesquisas de campo não identificaram novas coleções com a mesma densidade tendo em vista a intensidade da ação erosiva sobre os sítios decorrente da ação agrícola nos últimos 30 anos, descritos no capítulo 5.
} 
proximidades do assentamento. $\mathrm{O}$ restante do conjunto tem sua origem relacionada a placas de basalto colunar (12,34\%) ou blocos de afloramento também associados, em alguns casos, ao próprio assentamento (22,2\%).

As indústrias líticas dos sítios da Tradição Taquara apresentam os mesmos índices de participação relativa para o basalto (93,7\%) que o conjunto anterior, sendo o restante representado pelo quartzo (5,3\%) e pela calcedônia (1\%). Foi possível identificar a procedência da matéria prima para 54\% do conjunto analisado, predominando os blocos de afloramentos de basalto (65,5\%) aos quais todos sítios da Tradição Taquara estão associados. Os seixos (14,75\%) e placas (9,83\%) de basalto, originários de arraste fluvial, também estão representados nesta amostra, bem como cristais de quartzo $(9,83 \%)$.

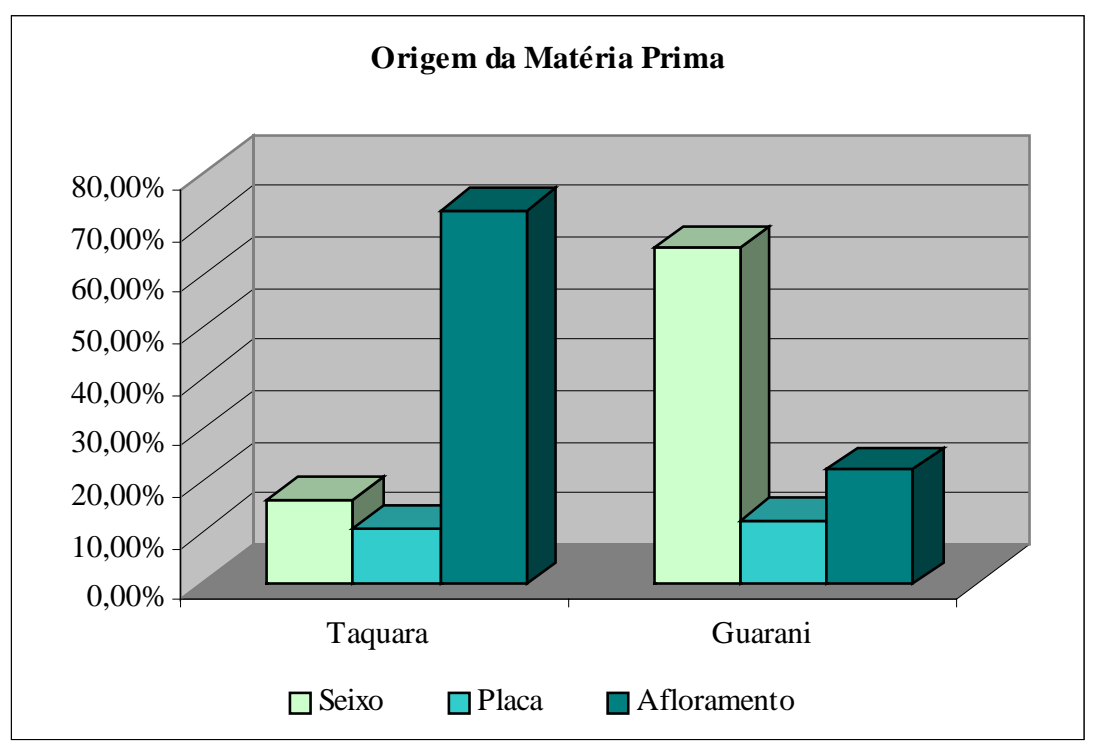

\subsubsection{Estratégias de Redução e Composição dos Conjuntos Líticos}

Para caracterizar as estratégias de organização tecnológica entre os conjuntos líticos das Tradições Guarani e Taquara e observar sua relação com as estratégias de seleção de matérias primas, os conjuntos tecnológicos em geral foram quantificados a partir das mesmas categorias tecno-tipológicas empregadas na análise das coleções líticas da Tradição Umbu. A análise qualitativa do conjunto total de lascas, núcleos e artefatos também obedeceu aos mesmos critérios de análise dos conjuntos líticos da Tradição Umbu. 
Nos conjuntos líticos da Tradição Guarani predominam os artefatos unifaciais e bifaciais, que correspondem a 42\% da amostra analisada. Quanto aos resíduos de lascamento, predominam as lascas uniplares (28\%) e os núcleos unipolares (8\%), sendo raros os fragmentos de lascamento (3\%) e resíduos de bipolaridade (1\%) representados por apenas um núcleo. O restante da amostra é formado por fragmentos naturais com ou sem evidências de fratura térmica (16\%), destacando-se três peças associadas ao sítio RS-S-287 que apresentaram evidências de modificação, na forma de um prisma de basalto polido e dois fragmentos de seixo que apresentaram evidências de modificação na forma de cicatrizes de lascamento de redução primária associadas à área fraturada (fotos 15 a 22).

As indústrias líticas da Tradição Taquara apresentam uma composição diferenciada, na qual destaca-se a participação relativa dos resíduos de lascamento. Predomina a presença de lascas unipolares (47\%), núcleos unipolares (21\%) e fragmentos de lascamento (11\%), estando também representadas, em baixa proporção, as lascas bipolares (3\%). Os artefatos bifaciais correspondem a 8\% do conjunto analisado, estando também presentes os artefatos brutos, na forma de percutores (2\%) e os artefatos polidos, representados por fragmentos de mãos de pilão (2\%). O restante das coleções é composto por fragmentos naturais (6\%) (fotos 23 a 30).

A análise qualitativa dos núcleos e lascas unipolares apontou para uma diferenciação quanto às estratégias de organização tecnológica entre as indústrias das Tradições Guarani e Taquara. Quanto às características dos núcleos unipolares observamos diferenças significativas entre as indústrias líticas das Tradições Guarani e Taquara, relacionadas aos tipos e à posição das plataformas de percussão, indicando variações na organização da tecnologia entre ambos conjuntos. 
Tabela 2. Conjuntos Líticos dos Sítios da Tradição Guarani do Alto Vale do Rio dos Sinos

\section{Categorias Tecno-tipológicas}

Núcleos unipolares

Núcleo bipolar

Lascas unipolares

Lascas unipolares modificadas

Fragmentos de lascamento

Fragmentos naturais com ou sem fratura térmica

Fragmentos naturais modificados

Artefatos Bifaciais

Artefatos Unifaciais

Fragmentos de borda de artefato bifacial

Totais
S289 S287 S285 S288 S290 S399 S400 S401 S403 S404 S405 S406 S408 S409 S410 S413 S414 S416 S423 Total

\begin{tabular}{|c|c|c|c|c|c|c|c|c|c|c|c|c|c|c|c|c|c|c|c|}
\hline 5 & 5 & 2 & 0 & 0 & 1 & 0 & 0 & 1 & 1 & 0 & 0 & 0 & 0 & 1 & 0 & 0 & 0 & 0 & 16 \\
\hline 1 & 0 & 0 & 0 & 0 & 0 & 0 & 0 & 0 & 0 & 0 & 0 & 0 & 0 & 0 & 0 & 0 & 0 & 0 & 1 \\
\hline 11 & 13 & 3 & 3 & 3 & 2 & 1 & 0 & 3 & 0 & 6 & 2 & 0 & 0 & 2 & 0 & 1 & 2 & 0 & 52 \\
\hline 4 & 0 & 0 & 0 & 0 & 0 & 0 & 0 & 0 & 0 & 0 & 0 & 0 & 0 & 0 & 0 & 0 & 0 & 0 & 4 \\
\hline 2 & 2 & 0 & 0 & 0 & 0 & 0 & 0 & 0 & 0 & 0 & 0 & 0 & 1 & 1 & 0 & 0 & 0 & 0 & 6 \\
\hline 6 & 17 & 5 & 4 & 0 & 0 & 0 & 0 & 0 & 0 & 0 & 0 & 0 & 0 & 0 & 0 & 0 & 0 & 0 & 32 \\
\hline 0 & 3 & 0 & 0 & 0 & 0 & 0 & 0 & 0 & 0 & 0 & 0 & 0 & 0 & 0 & 0 & 0 & 0 & 0 & 3 \\
\hline 23 & 20 & 5 & 1 & 0 & 3 & 3 & 1 & 2 & 0 & 1 & 2 & 1 & 1 & 2 & 1 & 0 & 0 & 0 & 66 \\
\hline 9 & 5 & 0 & 0 & 0 & 0 & 0 & 0 & 1 & 0 & 0 & 0 & 0 & 0 & 0 & 0 & 0 & 0 & 1 & 16 \\
\hline 0 & 3 & 0 & 0 & 0 & 0 & 0 & 0 & 0 & 0 & 0 & 0 & 0 & 1 & 0 & 0 & 0 & 0 & 0 & 4 \\
\hline 61 & 68 & 15 & 8 & 3 & 6 & 4 & 1 & 7 & 1 & 7 & 4 & 1 & 3 & 6 & 1 & 1 & 2 & 1 & 200 \\
\hline
\end{tabular}

Tabela 3 - Conjuntos Líticos dos Sítios da Tradição Taquara do Alto Vale do Rio dos Sinos

\begin{tabular}{|c|c|c|c|c|c|}
\hline Categorias Tecno-tipológicas & S-429 & S-431 & S-432 & S-433 & Total \\
\hline Núcleos unipolares & 11 & 10 & 0 & 2 & 23 \\
\hline Lascas unipolares & 26 & 16 & 2 & 3 & 47 \\
\hline Lascas unipolares modificadas & 5 & 1 & 0 & c & 6 \\
\hline Lascas bipolares & 3 & 0 & 0 & c & 3 \\
\hline Fragmentos de lascamento & 10 & 2 & 0 & c & 12 \\
\hline Fragmentos naturais com ou sem fratura térmica & 5 & 1 & 0 & ) & 7 \\
\hline Percutores & 0 & 2 & 0 & c & 2 \\
\hline Mãos de pilão & 0 & 3 & 0 & ) & 3 \\
\hline Artefatos Bifaciais & 2 & 6 & 0 & ) & 9 \\
\hline Totais & 62 & 41 & 2 & 2 & 112 \\
\hline
\end{tabular}




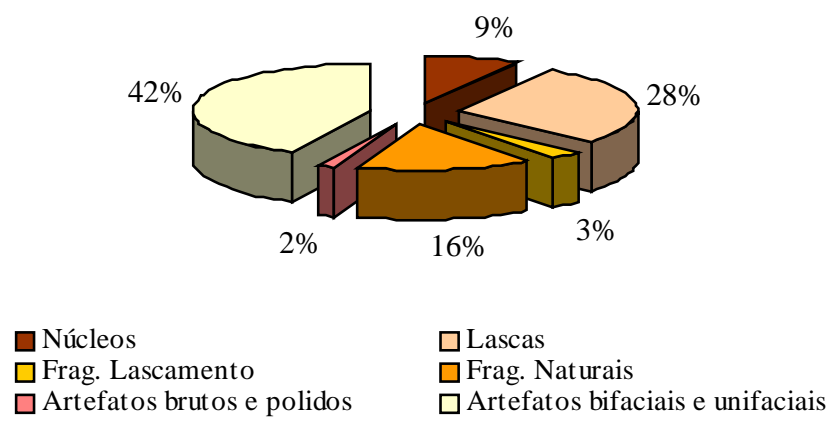

\section{Conjuntos Líticos da Tradição Taquara}

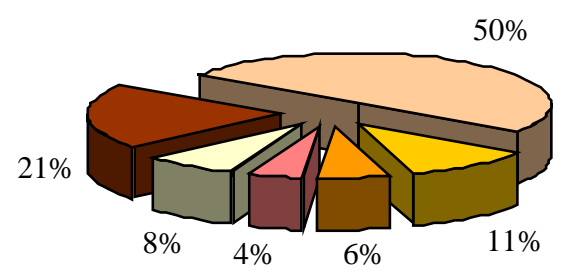

$\square$ Núcleos

$\square$ Lascas

$\square$ Frag. Lascamento

$\square$ Frag. Naturais

$\square$ Artefatos brutos e polidos

$\square$ Artefatos bifaciais e unifaciais

Nos conjuntos líticos da Tradição Guarani os núcleos unipolares têm dimensões médias de 12,75 x 10,43 x 6,15 cm. Predominam os tipos que apresentam duas plataformas bidirecionais opostas (47\%) e os com duas plataformas em ângulo (33\%), sendo menos freqüentes os núcleos unipolares com uma plataforma definida (13\%) ou com três a quatro plataformas em várias posições (7\%).

Nos conjuntos líticos da Tradição Taquara o tamanho médio dos núcleos unipolares é de 11,47 x 9,36 x 5,6 cm, havendo uma grande variabilidade de formas, relacionada às distintas posições de suas plataformas de percussão. Predominam os núcleos com uma plataforma ventral (39\%), que utilizam a face ventral de uma lasca espessa e de grande porte como plataforma de percussão, seguidos por núcleos com duas plataformas em ângulo (33\%). Neste conjunto estão presentes também, em proporções relativamente menores, núcleos unipolares com duas plataformas bidirecionais opostas (13\%), com três a 
quatro plataformas em várias posições, geralmente formando ângulos entre si (13\%), e com apenas uma plataforma definida (9\%).

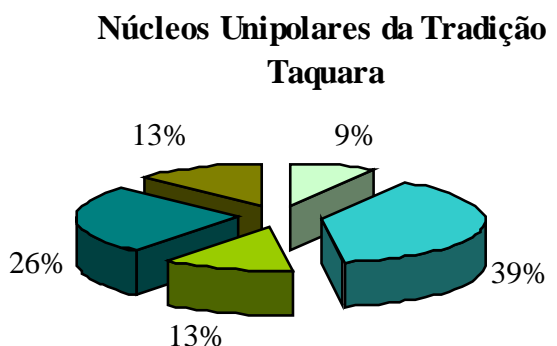

$\square 1$ plataforma definida

$\square 2$ plataformas bidirecionais opostas

$\square 3$ a 4 plataformas em várias posições

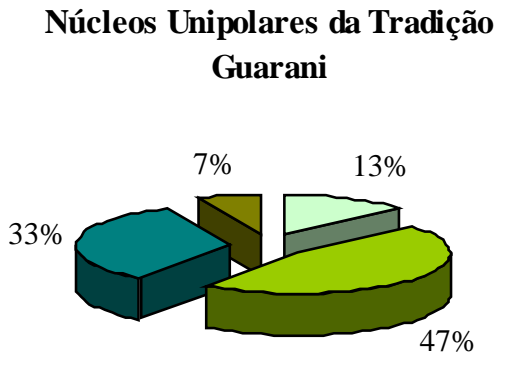
$\square$ plataforma definida
$\square 2$ plataformas bidirecionais opostas
$\square 2$ plataformas em ângulo

3 a 4 plataformas em várias posições

Os dados relativos à análise qualitativa dos tipos de suporte de lascamento e das plataformas de percussão permitem compreender as distinções nas estratégias de redução de núcleos unipolares entre os dois conjuntos. Quanto ao tipo de suporte de lascamento utilizado constata-se que os blocos de afloramento de basalto foram predominantes em ambos os conjuntos para a redução de núcleos unipolares, representando 53,3\% da fonte de matéria prima para o conjunto lítico da Tradição Guarani e 60\% para a Tradição Taquara. A utilização dos seixos de basalto como suporte de lascamento de núcleos unipolares é mais freqüente nos conjuntos líticos da Tradição Guarani (33,3\%) do que entre os da Tradição Taquara (13\%).

Analisando-se a quantidade de córtex observa-se também uma maior tendência a redução mais intensa dos núcleos nas coleções da Tradição Taquara, apresentando 48\% das peças cobertura cortical igual ou inferior a $1 / 4$ e $39 \%$ igual ou inferior a $1 / 2$ da superfície total, possuindo o restante ausência total de córtex (4,3\%) ou cobertura cortical igual ou superior a $3 / 4$ da superfície total da peça (8,6\%). Uma cobertura cortical que atinge entre $3 / 4$ (19\%) a $1 / 2(44 \%)$ da superfície total da peça representa a maioria dos núcleos unipolares da Tradição Guarani, podendo o restante apresentar até 1/4 de córtex (25\%) ou ausência de cobertura cortical (12\%).

No que se refere aos tipos de plataforma de percussão dos núcleos unipolares, os tipos mais freqüentes nas indústrias líticas da Tradição Guarani são corticais (60\%) ou lisos (20\%), indicando a seleção de suportes de lascamento, sejam estes blocos ou seixos, que já apresentavam planos de percussão naturais. O investimento na preparação das 
plataformas de percussão nas industrias Guarani é baixo, sendo representado por poucas peças que apresentam associação de plataformas lisas e facetadas $(13,3 \%)$ ou somente plataformas facetadas (6,6\%). Nas indústrias líticas da Tradição Taquara, o predomínio de núcleos unipolares com uma plataforma ventral relaciona-se a maior freqüência de plataformas de percussão lisas (56,6\%). Porém, observa-se neste conjunto um investimento maior no preparo das plataformas de percussão representadas pelos tipos que conjugam plataformas lisas e corticais $(17,3 \%)$, pelos que apresentam apenas plataformas facetadas (8,6\%), pelos que possuem associação entre plataformas facetadas e corticais (8,6\%) e por aqueles que apresentam tanto plataformas lisas, quanto facetadas $(4,3 \%)$, sendo mais raros os que apresentam plataformas unicamente corticais (4,3\%).

Por fim, quanto ao preparo das plataformas de percussão dos núcleos unipolares, observamos entre os conjuntos líticos da Tradição Taquara maior incidência de maceração em seus cantos (87\%) do que entre os conjuntos líticos da Tradição Guarani (60\%), processo também relacionado a um investimento mais intenso no primeiro caso quanto ao preparo dos planos de percussão.

A análise qualitativa da amostragem de lascas unipolares associadas aos conjuntos líticos de ambas Tradições apresentou relação positiva com as características das estratégias de redução de núcleos e produção de artefatos. Para o conjunto associado à Tradição Guarani, 44,6\% da amostra é representada por lascas corticais, com dimensões médias de 8,39 x 7, 89 × 2,73 cm. A maior parte das lascas corticais (52\%) provém de seixos, apresentando o restante córtex de afloramento (40\%) ou placa (8\%). A cobertura cortical é, em geral, baixa, distribuindo-se entre $1 / 2$ (48\%) ou $1 / 4$ (32\%) das faces externas das lascas, sendo poucas as peças que apresentaram cobertura até 3/4 da face dorsal (12\%) ou cobertura cortical total (8\%). Predominam os planos de percussão direta acorticais lisos (48\%) ou corticais (28\%), podendo apresentarem-se também facetados (24\%). Em geral, os cantos dorsais dos planos de percussão não apresentam nenhuma alteração (48\%), podendo encontrar-se macerados em alguns casos (28\%) ou apresentar córtex (24\%). Para o canto ventral do plano de percussão, apenas uma lasca desta categoria apresentou lábio (4\%).

As lascas corticais dos conjuntos líticos da Tradição Taquara representam 28,3\% da amostra, sendo procedentes da redução de blocos de afloramento. As dimensões médias são de $6,49 \times 6,28 \times 2 \mathrm{~cm}$ e a quantidade de córtex, em geral, atinge até $1 \frac{1}{2}$ da face dorsal (40\%), mas também podem apresentar cobertura total (20\%), até 3/4 (13\%) ou até $1 / 4$ da face dorsal (9,86\%). Os planos de percussão direto são, em sua maioria, acorticais lisos (40\%) ou corticais (33,3\%), também se apresentando, em menor proporção, facetados 
(26,6\%). Os cantos dorsais, em geral, são macerados (53,3\%) ou corticais $(26,6 \%)$ e a presença de lábios no canto ventral também se restringe a apenas uma peça.

As lascas de redução de núcleos representam 39,28\% da amostra deste tipo de resíduo para os conjuntos líticos da Tradição Guarani, apresentando dimensões médias menores que a categoria anterior $(6,7 \times 5,7 \times 2 \mathrm{~cm})$, reforçando a idéia de seqüência produtiva. Todas as lascas apresentam a face dorsal acortical com cicatrizes de lascamento anterior, predominando os planos de percussão lisos (86,3\%), sendo pouco significativos os talões facetados (13,63\%). Os cantos das plataformas de percussão não apresentam alterações em sua face dorsal para $68,2 \%$ das lascas desta categoria, sendo o restante macerado (31,8\%), havendo somente um caso com lábio no canto ventral.

Por sua vez, as lascas desta categoria predominam para a amostragem da Tradição Taquara (56,6\%), apresentando dimensões médias de 6,47 x 5,98 x 3 cm. Todas apresentam a face dorsal acortical com cicatrizes de lascamento anterior, possuindo a maioria o plano de percussão direta liso (56,6\%), sendo o restante facetado (43,3\%), com canto dorsal macerado (53,3\%) ou sem alteração (46,66\%), não apresentando lábio no canto ventral. Observa-se uma correlação positiva para esta categoria de lascas com as estratégias de redução de núcleos observados para os conjuntos da Tradição Taquara caracterizados por apresentar uma maior intensidade de preparação de plataformas de lascamento, se comparado ao conjunto lítico da Tradição Guarani.

As lascas de redução de artefatos bifaciais foram definidas a partir dos mesmos critérios utilizados para a análise das coleções líticas da Tradição Umbu. Foram identificados no conjunto de lascas da Tradição Guarani apenas 5 peças que se enquadravam nesta categoria, correspondendo a 8,9\% da amostra. As dimensões médias são menores se comparadas às demais categorias $(6 \times 4$ x 1,3 cm), destacando-se a menor espessura, porém não apresenta relação com o padrão de tamanho para as lascas do mesmo tipo para os conjuntos líticos da Tradição Umbu. As superfícies dorsais são acorticais com cicatrizes de lascamento anterior, predominando os planos de percussão lisos (80\%) em relação aos facetados (20\%), sendo os cantos dorsais sem alteração e os ventrais sem lábio.

As lascas de redução de biface para os conjuntos líticos da Tradição Taquara também estão representadas em baixas proporções, correspondendo a 3,75\% da amostra analisada. As dimensões médias são de 1,4 x 1,5 x 0,5 cm, sendo menores que as apresentadas pelo conjunto da Tradição Guarani e aproximando-se mais do padrão observado para as lascas deste tipo entre os conjuntos líticos da Tradição Umbu. Todas as peças apresentaram faces dorsais acorticais facetadas, com planos de percussão lisos e 
cantos ventrais com lábios, podendo os cantos dorsais apresentar-se com ou sem maceração.

Para os conjuntos líticos das Tradições Guarani e Taquara, as lascas que apresentaram evidências de modificação relacionadas à presença de cicatrizes de redução primárias estão relacionadas tanto às categorias corticais quanto às de redução de núcleos, sendo semelhantes entre as duas indústrias. As lascas unipolares modificadas correspondem a 7,14\% da amostra para a Tradição Guarani, apresentando as maiores dimensões médias do conjunto, com 11,8 x 9,7 x 4,3 cm. Em geral, apresentam cobertura cortical entre $1 / 2$ e $1 / 4$ da peça, sendo a origem da matéria prima predominante os blocos de afloramento. O plano de percussão direto é, na maioria dos casos, facetado, com canto dorsal cortical, sendo a posição das cicatrizes de redução primária direta, com padrão descontínuo, sendo representado por 3 a 8 retiradas.

As lascas modificadas correspondem a 11,32\% da amostra da Tradição Taquara, possuindo também as maiores dimensões médias para o conjunto de lascas analisadas, com 10,4 x 8,4 x 3,7 cm. Metade do conjunto apresenta córtex de afloramento, distribuído entre $1 / 2$ e $1 / 4$ da face dorsal. O plano de percussão direto é para $50 \%$ dos casos cortical, podendo também ser liso (33, 3\%) ou facetado (16,6\%). Os cantos dorsais podem ser macerados ou sem alteração, apresentando apenas uma lasca lábio no canto ventral. Em 83,3\% dos casos as cicatrizes de redução primária possuem posição direta e padrão descontínuo, sendo representado por uma média entre 4 a 7 retiradas na face dorsal. Somente um caso apresentou retoque bifacial em todo o contorno do da peça.

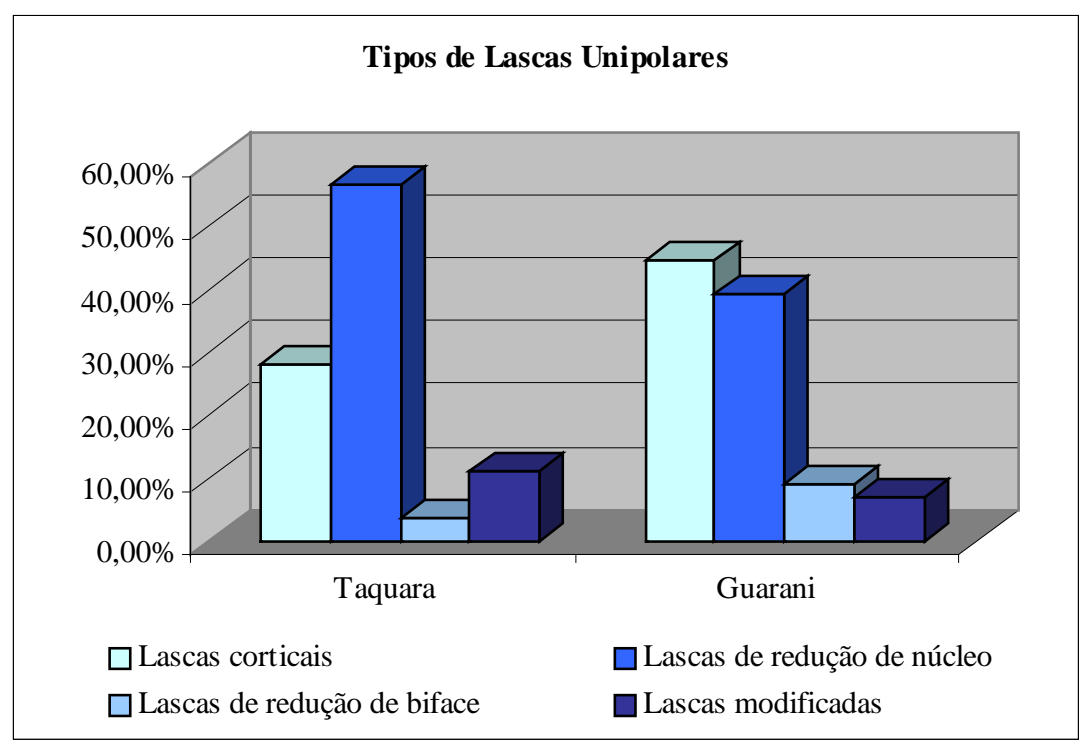




\subsubsection{Relação entre Estratégias de Redução e Produção de Artefatos}

O conjunto de artefatos bifaciais e unifaciais correspondem a 40,5\% da indústria lítica das Tradições Guarani e 8\% da amostra relativa à Tradição Taquara, não havendo evidências de redução secundária (retoque) em nenhuma das peças. Predomina em ambos os casos artefatos de grande porte, que poderiam ser classificados como fósseis guia da Tradição Humaitá. A revisão deste enfoque analítico realizado por Hoeltz (1995, 1997a, 1997b) para coleções líticas da Tradição Humaitá e as reflexões de Dias e Silva (2001) serviram com base para o estabelecimento de uma proposta alternativa para classificação desta categoria de artefatos baseada na concepção de cadeia operatória.

Foram definidas 6 categorias tecno-tipológicas para a análise quantitativa deste conjunto de artefatos, privilegiando as diferenças na intensidade da redução unifacial ou bifacial das peças e a posição das cicatrizes de redução primária. Considerando as peculiaridades destes conjuntos de artefatos em relação às indústrias da Tradição Umbu, optou-se para a análise qualitativa selecionar alguns indicadores que complementassem aspectos da cadeia operatória relacionados à sua produção, como tipos de suporte de lascamento inicial selecionado, quantidade de córtex remanescente na superfície total da peça, dimensões médias por categoria tecno-tipológica e quantidade de cicatrizes de redução primária.

As duas primeiras categorias tecno-tipológicas de artefatos para este conjunto foram elaboradas a partir de seixos ou placas e diferenciam-se por apresentam redução primária unifacial ou bifacial em apenas uma das extremidades, estando até 3/4 da superfície total da peça coberta por córtex. Um terceiro grupo conjuga os artefatos bifaciais, também elaborados sobre seixos ou placas, que apresentam cicatrizes de redução primária associadas a apenas uma extremidade da peça, estando entre $3 / 4$ a $1 / 2$ de sua superfície coberta por córtex. O lascamento, porém, é mais intenso que nas categorias anteriores, produzindo uma terminação em ponta e um gume bifacial que se entende até $1 / 2$ da peça, apresentando-se a terminação oposta cortical. A quarta categoria tecno-tipológica agrupa os artefatos bifaciais, elaborados sobre suportes variados, que apresentam redução primária em ambas as extremidades, produzindo terminações opostas em forma de ponta, intercalada por uma faixa central cortical. A redução primária, a semelhança da categoria anterior também é intensa e a cobertura cortical se estende entre $1 / 2$ e $1 \frac{1}{4}$ da superfície total da peça. Uma quinta categoria de artefatos bifaciais caracteriza-se por apresentar redução 
primária em todo o contorno da peça, gerando um gume periférico, sendo os tipos de suporte de lascamento variados. A quantidade de cicatrizes de redução primária pode ser mais intensa em uma das faces, contudo sua extensão, geralmente, é marginal e reduzida, permanecendo até $1 / 2$ das faces da peça cobertas com córtex. Por fim, a sexta categoria tecno-tipológica diz respeito aos bifaces elaborados sobre lascas unipolares, cujas características assemelham-se aos artefatos bifaciais das indústrias líticas de caçadores coletores.

A análise comparativa entre os conjuntos de artefatos das Tradições Guarani e Taquara apresentou distinções quanto à distribuição das categorias tecno-tipológicas acima descritas. Nos conjuntos de artefatos da Tradição Guarani, todas as seis categorias estão representadas, predominando os bifaces com redução primária em apenas uma extremidade (40\%) ou atingindo até $1 / 2$ da peça (23\%), sendo também significativa à participação relativa das peças unifaciais com redução primária em apenas uma das extremidades (19\%) e dos artefatos com redução bifacial em todo contorno da peça, formando gume periférico (12\%). O restante da amostra é composto por bifaces elaborados sobre lascas unipolares (5\%), sendo raros os artefatos com redução primária bifacial em ambas extremidades (1\%) (fotos 16 a 21).

Os conjuntos de artefatos bifaciais da Tradição Taquara variam entre 4 categorias tecno-tipológicas, predominando os bifaces com redução primária em ambas extremidades (34\%) ou em todo contorno da peça (33\%), formando um gume periférico. O restante da amostra é representado por artefatos que possuem redução primária em uma extremidade formando um gume que se estende até $1 / 2$ da peça (22\%), sendo o restante do conjunto representado por artefatos que possuem redução primária bifacial em apenas uma extremidade (11\%) (fotos 27 a 30). 
Posição dos Lascamentos nos Artefatos da Tradição

Guarani

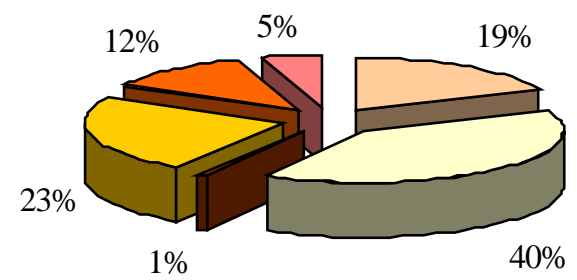

$\begin{array}{ll}\square \text { Unifacial em uma extremidade } & \square \text { Bifacial em uma extremidade } \\ \text { 口Bifacial em ambas extremidades } & \square \text { Bifacial até 1/2 da peça } \\ \square \text { Bifacial em todo contorno } & \square \text { Biface sobre lasca }\end{array}$

\section{Posição dos Lascamentos nos Artefatos da Tradição \\ Taquara}

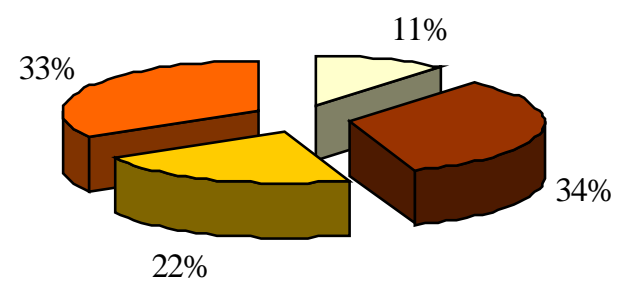

$\square$ Bifacial em uma extremidade

Bifacial em ambas extremidades

$\square$ Bifacial até $1 / 2$ da peça

$\square$ Bifacial em todo contorno

A distinção entre a composição dos conjuntos de artefatos relacionam-se as diferenças entre ambas Tradições quanto ao tipo de suporte de lascamento inicial selecionado para a produção do artefato. No caso dos conjuntos líticos da Tradição Guarani a maioria dos artefatos foi produzida a partir de seixos de rio, com morfologia original geralmente alongada ou esférica, sendo menos comum a utilização de placas ou blocos de afloramento como suporte inicial de lascamento. Para os artefatos líticos da Tradição Taquara, observa-se uma maior variabilidade na seleção dos tipos de base de redução inicial, predominando os blocos de afloramento (40\%), embora também estejam representados os seixos e as placas de basalto colunar. 


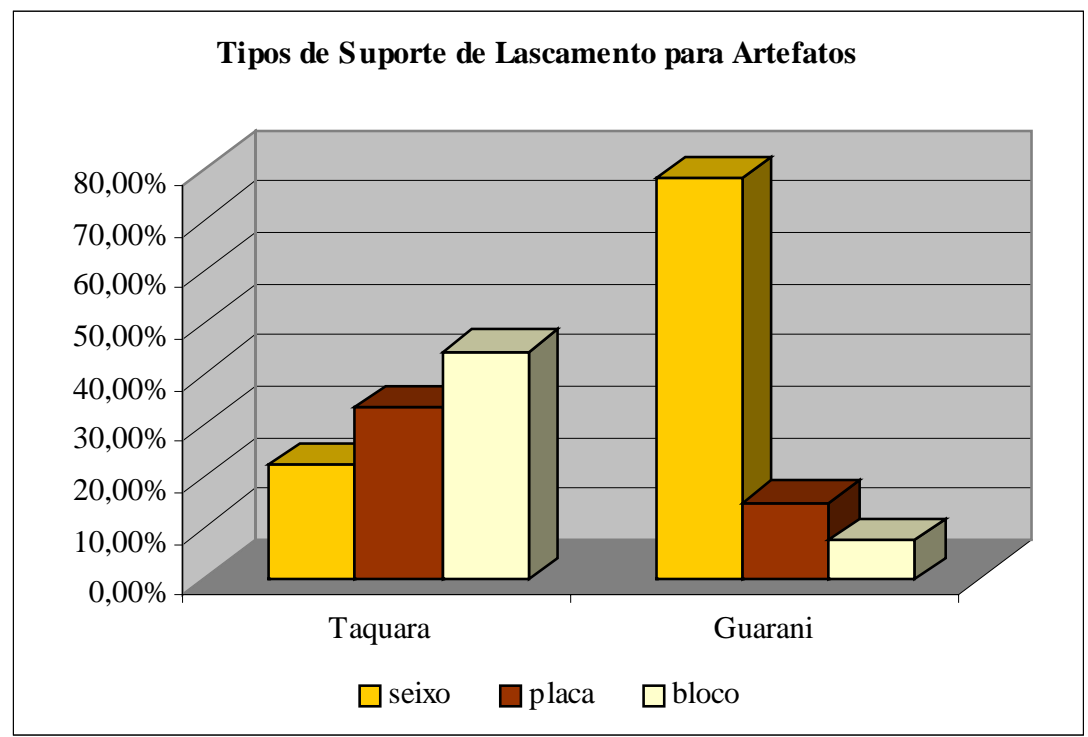

No que se refere à quantidade de córtex, os artefatos da Tradição Guarani apresentam maior cobertura cortical do que os das indústrias líticas da Tradição Taquara, indicando baixo investimento técnico na produção. Nos artefatos da Tradição Guarani a cobertura cortical atinge, em geral, mais de $3 / 4$ da peça (67,5\%), apresentando a maioria dos artefatos da Tradição Taquara córtex até $1 \frac{1}{2}$ da superfície total (55,5\%). Estas diferenças justificam-se tendo em vista que os artefatos mais freqüentes nas indústrias líticas da Tradição Guarani são os tipos nos quais predominam lascamentos primários em apenas uma das extremidades, permanecendo o restante da peça coberta por córtex.

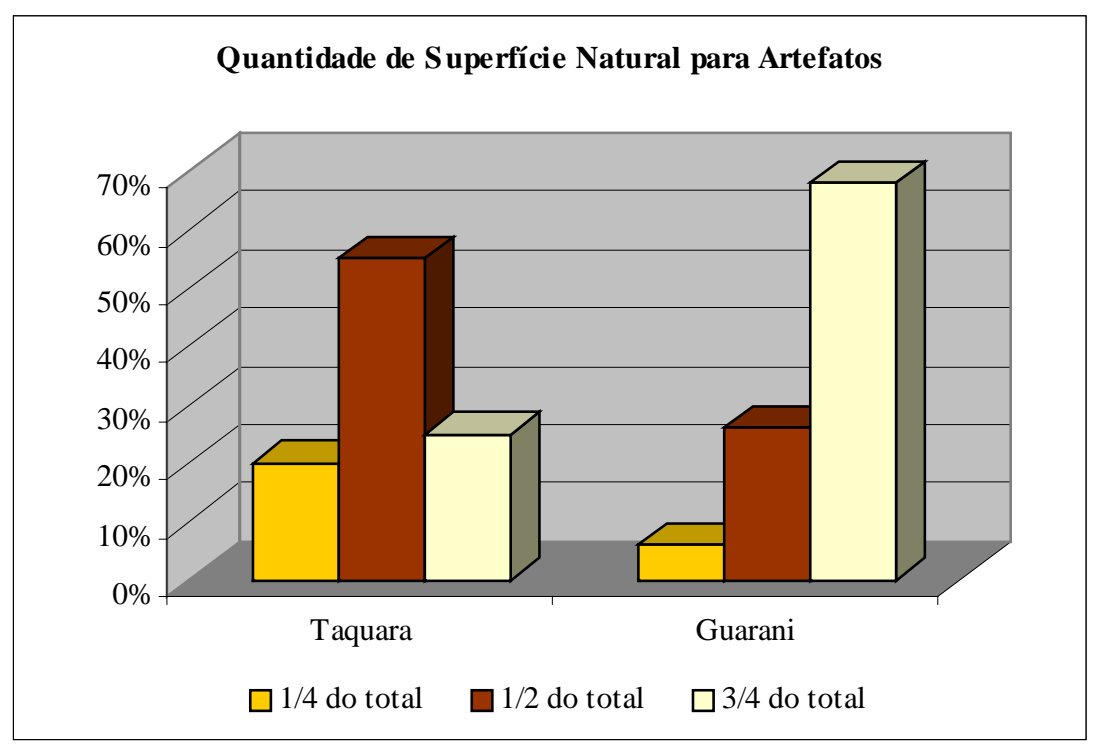


Os resultados da análise qualitativa demonstram diferenças claras entre as categorias tecno-tipológicas de artefatos entre ambas Tradições que representam distinções em termos de seqüência de produção. Os artefatos com retiradas unifaciais em apenas uma das extremidades estão presentes apenas nos conjuntos líticos da Tradição Guarani, sendo representados por 15 artefatos que possuem dimensões médias de 14,1 x 8,2 x 4,2 cm. Estes foram elaborados preferencialmente sobre seixos redondos (40\%) ou irregulares (33,3\%), podendo também ser utilizados como suportes de lascamento os seixos alongados $(13,3 \%)$ ou as placas de basalto colunar (13,3\%). A extensão da cobertura cortical atinge em todos os casos 3/4 da superfície total da peça, apresentando as peças entre 1 e 4 cicatrizes de redução primária, predominando 2 cicatrizes em $60 \%$ do conjunto. Estas características indicam que em relação à cadeia operatória da Tradição Guarani, este tipo de artefatos pode representar testes de matéria-prima (seguidos de abandono da peça pela presença de irregularidades), uma etapa produtiva inicial de uma peça bifacial ou corresponder a um artefato expeditivo acabado, já que os lascamentos unifaciais produzem um gume funcional.

Os artefatos bifaciais que apresentam cicatrizes de redução primária em apenas uma extremidade estão presentes em ambos conjuntos líticos, apresentando grande semelhança que decorre do tipo de suporte selecionado para sua produção. Para o conjunto de artefatos da Tradição Guarani foram analisados 31 bifaces desta categoria, com dimensões médias de 13,3 x 8,5 x 3,9 cm. As bases de redução primária predominantes são os seixos alongados (51,6\%) ou arredondados (26,6\%), podendo também ser utilizados placas de basalto colunar $(9,6 \%)$, seixos com formato irregular $(12,6 \%)$ ou blocos $(1,2 \%)$. Apresentam, em geral, de 1 a 6 retiradas em ambas às faces, predominando 2 a 3 em uma face $(53,3 \%)$ e 1 a 2 na outra (66,6\%), apresentando todas as peças analisadas 3/4 de sua superfície total cobertas por córtex. A quantidade de lascamento é suficiente para criar um gume bifacial numa das extremidades da peça, permanecendo a outra cortical, reforçando a idéia de um contínuo produtivo em relação à categoria de artefatos anterior. Os conjuntos líticos da Tradição Taquara apresentaram uma peça com estas características, elaborada sobre um seixo alongado, com dimensões de 16 x 10 x 3,5 cm. O córtex esta presente em 3/4 da superfície total do artefato, apresentando 3 cicatrizes de redução primária em uma das faces e 2 na outra.

Os artefatos bifaciais da Tradição Guarani que apresentam cicatrizes de redução primária até a $1 / 2$ da peça, apresentando uma terminação em forma de ponta e outra cortical, são representados por 19 peças com dimensões médias de 17,1 x 8,8 x 4,97 cm. A maioria 
também é elaborada a partir de seixos alongados (68,42\%) ou placas $(26,31 \%)$, ocorrendo só um caso no qual foi utilizado um seixo redondo como base de redução inicial $(5,26 \%)$. Predomina o córtex até $1 \frac{1}{2}$ da peça $(57,48 \%)$, apresentando o restante do conjunto cobertura cortical até 3/4 da superfície total. Em $70 \%$ das peças analisadas observa-se entre 4 a 7 cicatrizes de redução primária por face (70\%), podendo registrar-se até 15 cicatrizes por face em 15,78\% dos casos. Porém, em todas as peças a redução primária se concentra mais intensamente em apenas uma das faces, podendo-se relacionar estes bifaces como um contínuo produtivo da categoria anterior. Esta categoria de artefatos é representada por duas peças associadas às coleções da Tradição Taquara. Os suportes de lascamento selecionados foram blocos ou placas de basalto colunar, sendo as dimensões médias de 21,2 x 8,5 x $7 \mathrm{~cm}$. A quantidade de córtex varia entre 3/4 e 1/2 da superfície total das peças, apresentando-se a distribuição das cicatrizes de redução primária distribuídas de forma mais intensa para uma das faces, com 4 a 5 retiradas, apresentando a outra face apenas uma cicatriz.

Os bifaces que apresentam lascamento bifacial em todo o contorno da peça, formando gume periférico, estão representados por 10 artefatos para o conjunto lítico da Tradição Guarani, com dimensões médias de 15,3 x 8,3 x 4,7 cm. Os seixos alongados predominam como tipo de suporte de lascamento selecionado para produção destes artefatos (50\%), estando também representados na amostra os seixos redondos (20\%) ou irregulares (10\%) e as placas de basalto colunar (20\%). Em 90\% do conjunto foi registrada a presença de córtex cobrindo até $1 / 2$ da superfície total da peça, restrito a área central de suas faces. Foram registradas entre 6 a 16 cicatrizes de redução primária em uma das faces, contra 1 a 10 cicatrizes na face oposta, cuja extensão em geral é marginal e reduzida, predominando para 50\% da amostra um padrão de 6 cicatrizes para uma face e uma para a face oposta. Observa-se uma tendência a redução total de uma das faces da peça, voltada à formação de um gume periférico, antes de iniciar-se a redução da face oposta, apresentando este tipo de biface uma relação de continuidade com as estratégias de produção da categoria anterior. Esta categoria está representada por três artefatos nos conjuntos líticos da Tradição Taquara, com dimensões médias de 21,1 x 9 x 5,5 cm. O suporte de lascamento predominante corresponde às placas de basalto colunar, também sendo utilizado para um dos casos um seixo alongado. A cobertura cortical, em geral corresponde a $1 / 2$ da superfície total da peça, podendo também atingir $1 / 4$. A distribuição das cicatrizes de redução primária entre as faces das peças é mais homogenia nos bifaces da 
Tradição Taquara, apresentando um padrão entre 8 a 16 cicatrizes por face, com extensão invasora.

Os bifaces que apresentam redução primária em ambas as extremidades, produzindo terminações opostas em forma de ponta, intercaladas por uma faixa central cortical são representados por dois artefatos na coleção lítica da Tradição Guarani, sendo o suporte de lascamento os blocos de afloramento. Suas dimensões médias são de 15,7 x 8,8 x 4,6 cm e a cobertura cortical pode se estender entre 1/2 e 1/4 da superfície total da peça. Ambas apresentam um padrão de redução primária intensa, mas distribuído de forma diferencial entre as faces, apresentando mais de 10 cicatrizes em uma face contra 6 na oposta. Esta categoria, por sua vez, predomina na amostra de bifaces da Tradição Taquara sendo representada por 4 peças. As dimensões médias são de 12,5 x 8,5 x 6,1 cm, sendo o suporte de lascamento utilizado também os blocos de afloramento. Em geral, o córtex recobre entre $1 / 2$ a $1 / 4$ da superfície total da peça e a extensão das cicatrizes de lascamento é invasora, apresentando, em média, entre 6 e 12 cicatrizes de redução primária para uma face e 6 a 5 cicatrizes para a face oposta. Estas características parecem apontar que este tipo de biface corresponderia a uma etapa de produção anterior a categoria de bifaces anterior para o caso da Tradição Taquara.

Por fim, os bifaces elaborados sobre lascas unipolares estão representados somente por 5 artefatos associados às indústrias líticas da Tradição Guarani, com dimensões médias de 12 x 10 × $4 \mathrm{~cm}$. A origem da matéria prima predominante das lascas unipolares utilizadas como suporte de lascamento corresponde aos blocos de afloramento de basalto, havendo um caso de utilização de uma lasca de calcedônia. A cobertura cortical, em geral, atinge até $1 / 4$ da superfície total das peças, restringindo-se a apenas uma das faces. A redução primária distribui-se de forma mais homogênea entre as faces do artefato, predominado um padrão de mais de 10 cicatrizes numa face e entre 5 a 8 cicatrizes na face oposta. Esta categoria de artefato apresenta correlação para esta indústria com as lascas unipolares que apresentam modificação, que podem corresponder a uma etapa de produção inicial desta categoria de artefatos bifacial para as indústrias líticas da Tradição Guarani. 


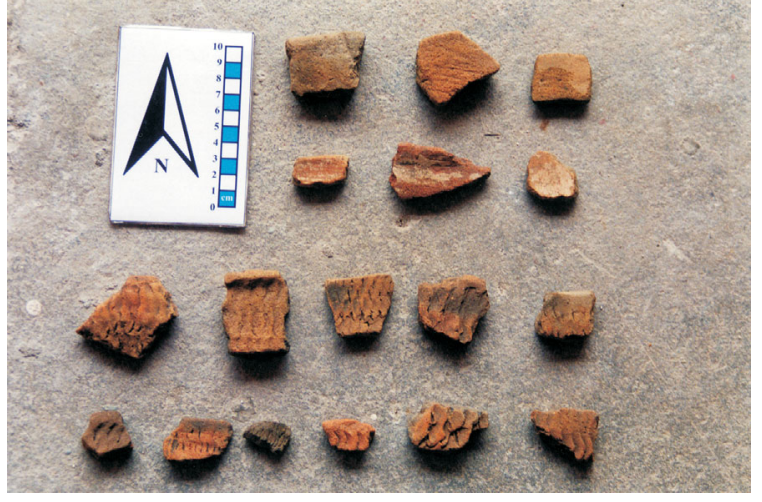

15. Cerâmica da Tradição Guarani, sítio RS-S-285. Foto: Adriana Dias

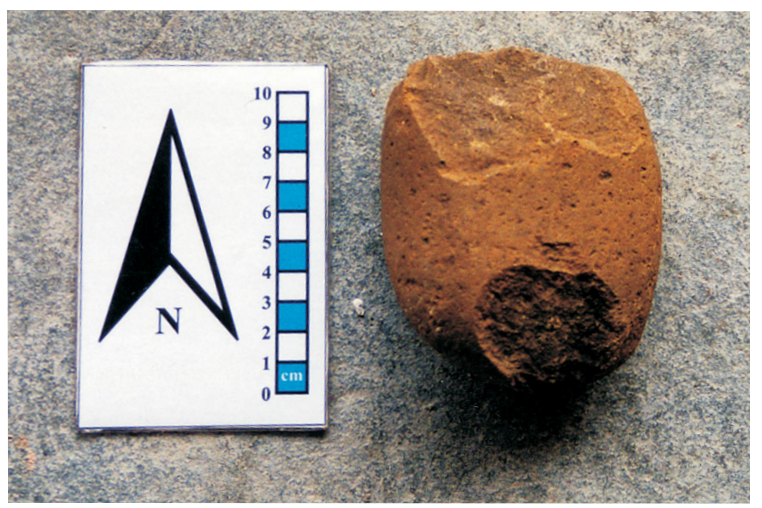

17. Artefato unificial sobre seixo. Foto: Adriana Dias

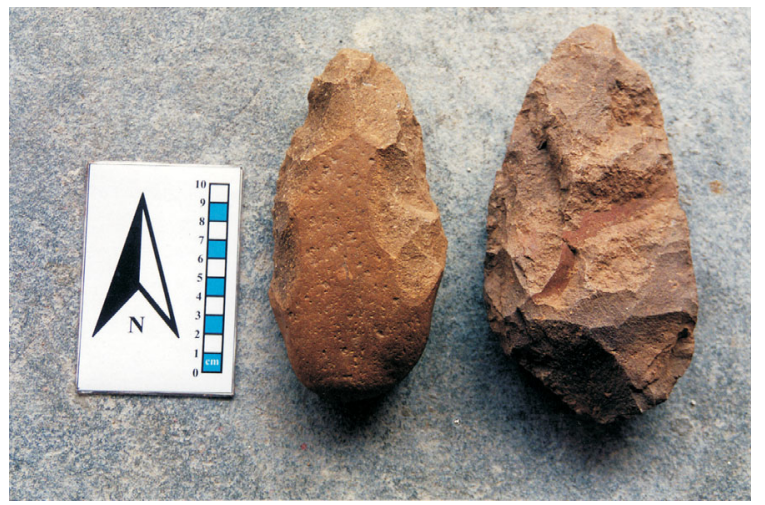

19. Biface sobre seixo. Foto: Adriana Dias

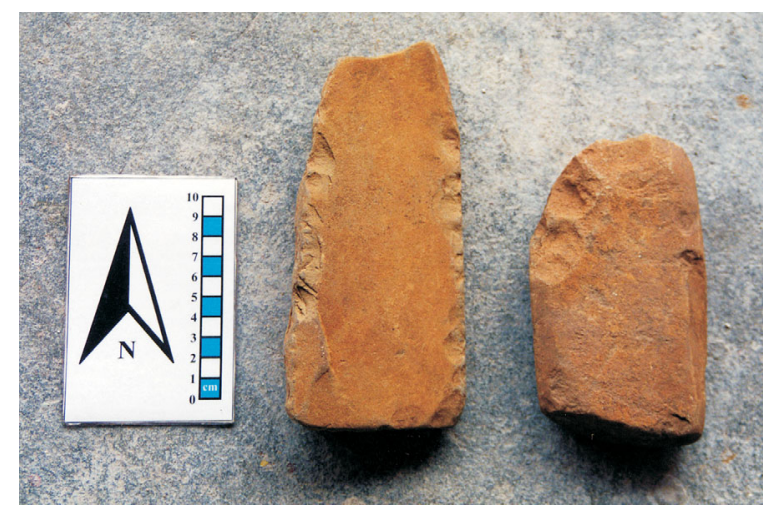

21. Biface sobre placa. Foto: Adriana Dias

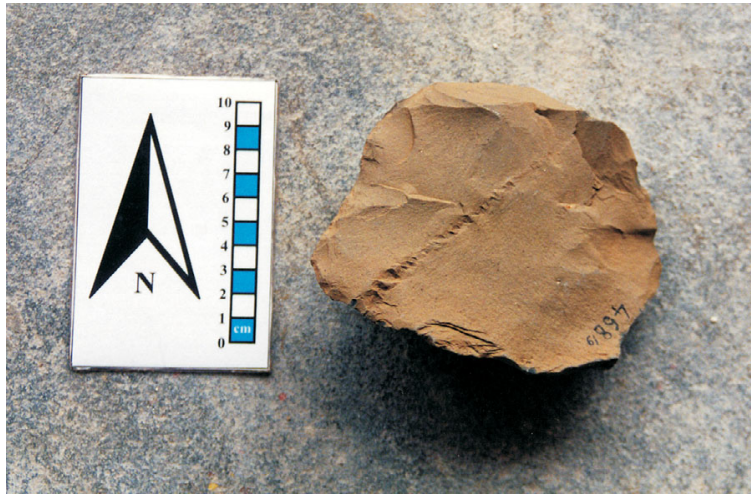

16. Biface sobre lasca de basalto. Foto: Adriana Dias

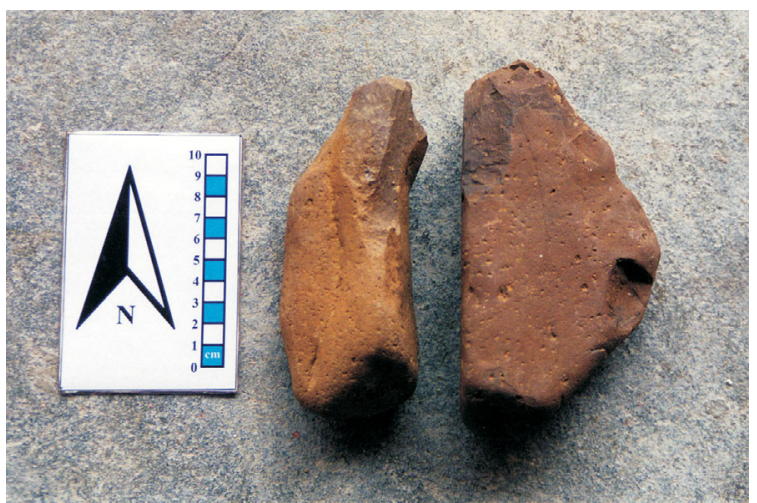

18. Biface sobre seixo. Foto: Adriana Dias

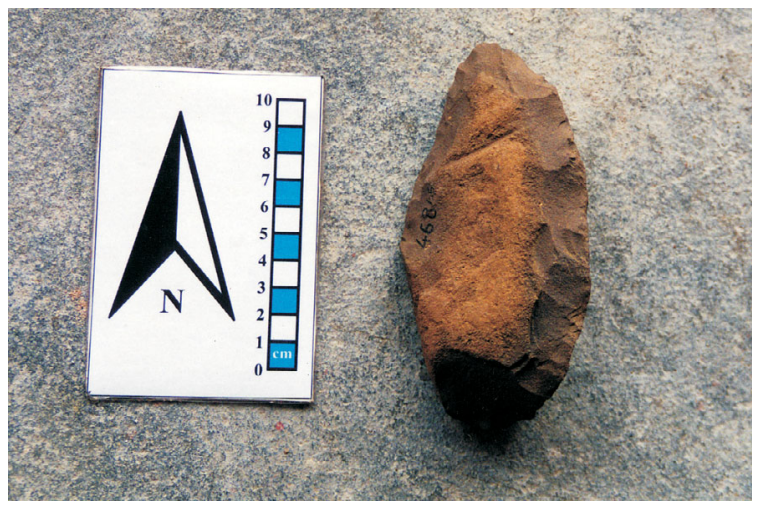

20. Biface sobre seixo. Foto: Adriana Dias

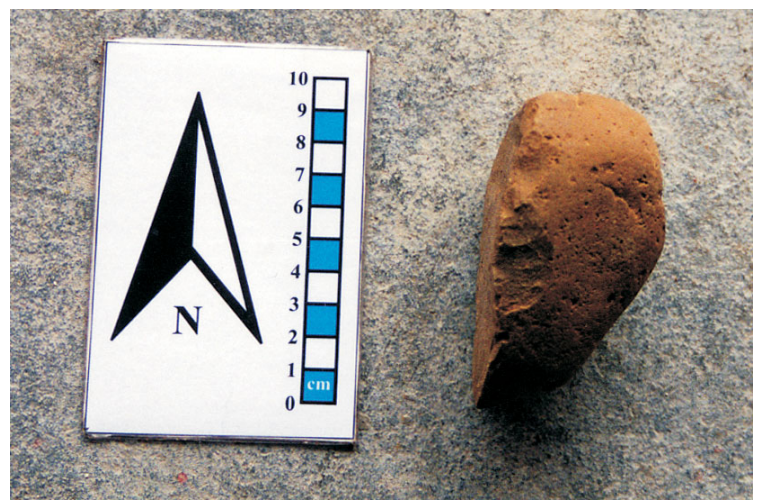

22. Seixo fraturado com retiradas. Foto: Adriana Dias 


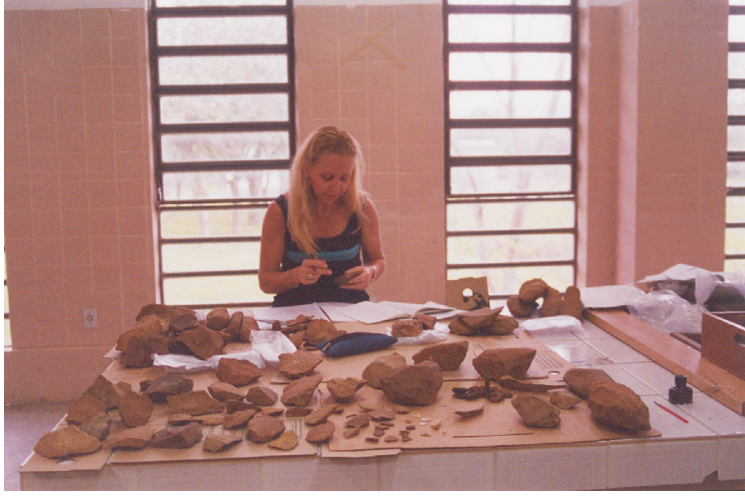

23. Variedade de núcleos da Tradição Taquara, analisado por Sirlei Hoeltz. Foto: Adriana Dias

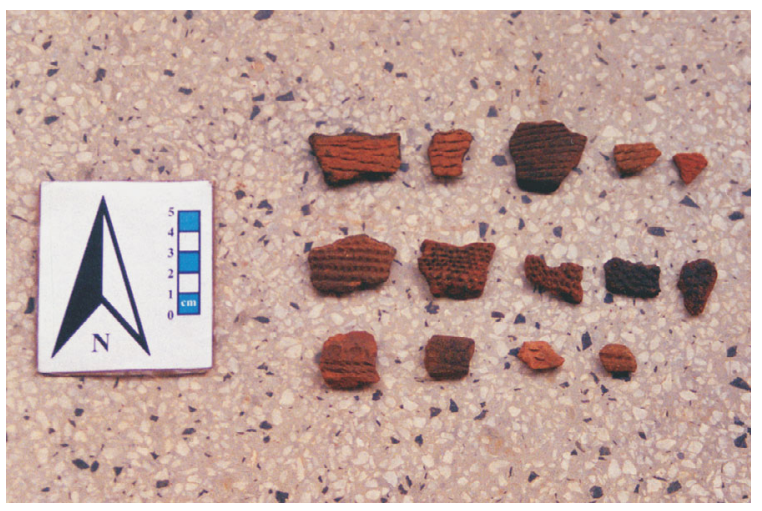

25. Cerâmica da Tradição Taquara do sítio RS-S-429. Foto: Adriana Dias

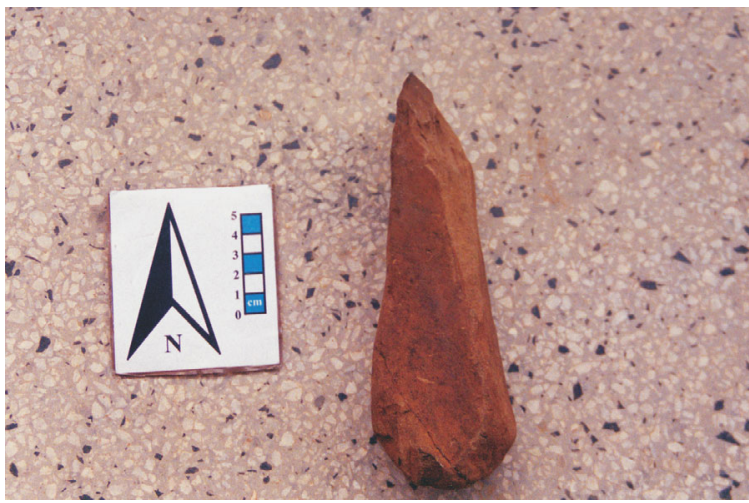

27. Biface sobre placa. Foto: Adriana Dias

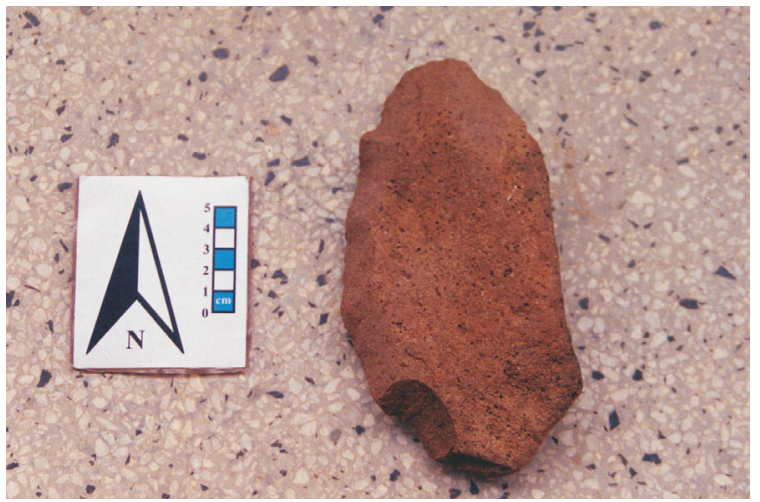

29. Biface sobre seixo. Foto: Adriana Dias

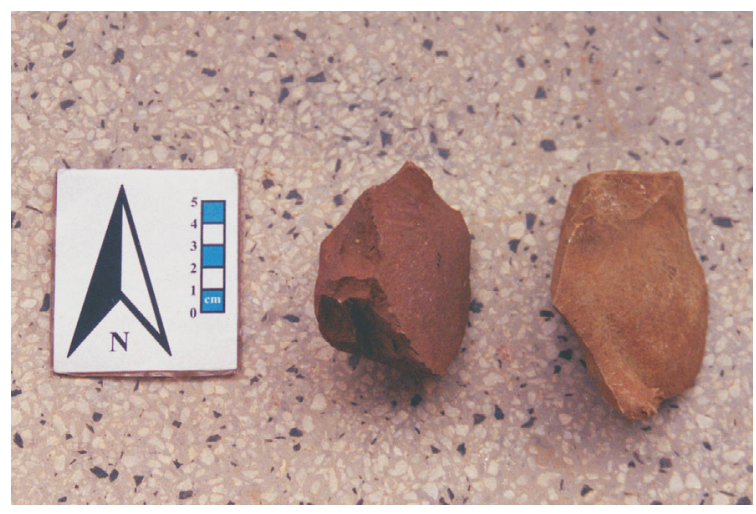

24. Núcleos com plataforma ventral. Foto: Adriana Dias

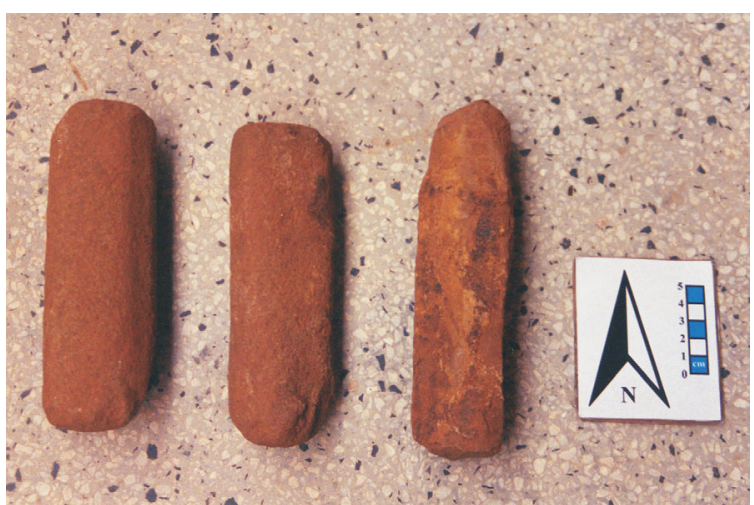

26. Mãos de pilão. Foto: Adriana Dias

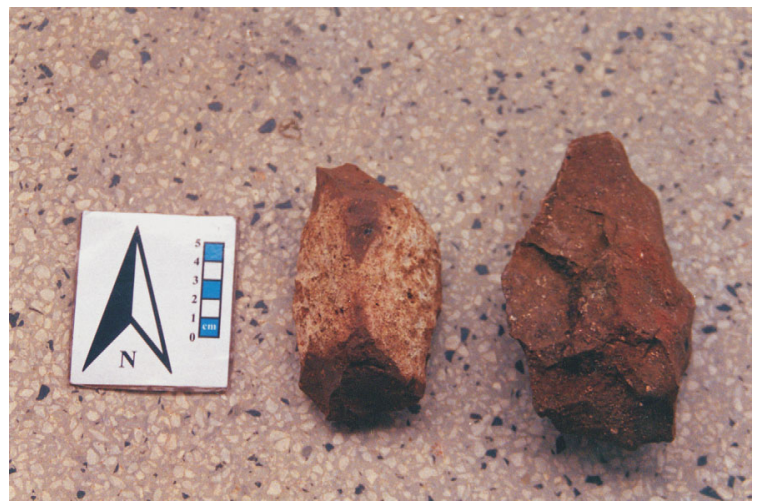

28. Biface sobre bloco. Foto: Adriana Dias

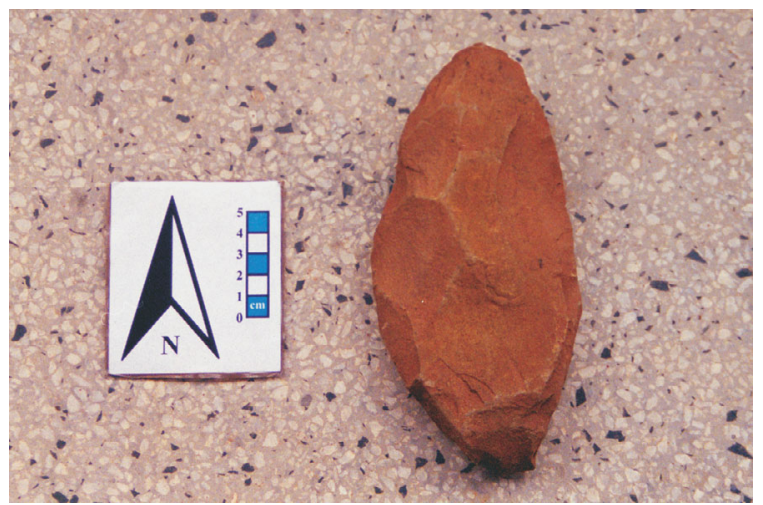

30. Biface. Foto: Adriana Dias 


\subsection{A Relação entre Estilo Tecnológico e Variabilidade Artefatual no Estudo} das Indústrias Líticas do Alto Vale do Rio dos Sinos

A análise das coleções líticas dos sítios em abrigo sob rocha do Alto Vale do rio dos Sinos indica um estilo tecnológico comum, sendo a variabilidade observada, produto de uma intensidade diferencial na exploração das matérias primas disponíveis em termos locais. A estratégia de obtenção de matérias primas característica relaciona-se à coleta de fragmentos de basalto colunar ou pequenos geodos de calcedônia e quartzo junto aos cursos de água da região, sendo a exploração de afloramentos relacionada unicamente ao arenito silicificado. Como todas as matérias primas associadas aos sítios de caçadores coletores apresentam-se dispersas na paisagem, sua coleta possivelmente se caracterizou como uma estratégia “encaixada” em outras atividades associadas à subsistência do grupo.

A escolha das matérias primas apresenta relação positiva com as tecnologias de produção empregadas nos sítios, incidindo a tecnologia unipolar sobre o basalto e o arenito silicificado e a tecnologia bipolar sobre a calcedônia e o quartzo. A variabilidade observada em termos de organização tecnológica entre os sítios corresponde a um produto de uma intensidade diferencial na exploração das matérias primas, tratadas através de duas estratégias tecnológicas distintas.

Por sua vez, a variabilidade observada entre os sítios de caçadores coletores quanto à participação relativa de artefatos em suas coleções, está relacionada também as estratégias tecnológicas predominantes em cada conjunto. Os conjuntos artefatuais que apresentam maior abundância de artefatos relacionam-se aos sítios do vale do arrio Campestre, sendo estes representados em sua maioria por pontas de projétil lanceoladas produzidas a partir de lascas bipolares de calcedônia. Por sua vez, a unipolaridade se relaciona de forma estreita com as demais categorias de artefatos para os todos os sítios estudados, estando associada à produção de bifaces sobre lascas, pré-formas e pontas pedunculadas elaboradas em basalto ou arenito silicificado, aspecto atestado pelo predomínio em todos os conjuntos de lascas unipolares de redução de biface.

As distinções morfológicas apresentadas pelas pontas de projétil também decorrem da tecnologia de produção, podendo distinguir-se dois conjuntos: pontas de projétil pedunculadas e de corpo triangular produzidas a partir de uma base de redução primária unipolar e pontas de projétil apedunculadas e de corpo lanceolado produzidas a partir de uma base de redução primária bipolar. 
Tomando por base estas características sugerimos para os sítios de caçadores coletores um predomínio de atividades relacionadas à redução de peças bifaciais de pequeno porte. A baixa freqüência de núcleos unipolares e lascas corticais nas coleções indica que o arenito silicificado e o basalto sofreram processamento inicial, preferencialmente nos próprios locais de coleta, a fim de produzir bifaces elaborados sobre lascas unipolares com dimensões médias de 6,5 × 4,5 x 2 cm e núcleos unipolares pequenos de fácil transporte para as unidades habitacionais. Lascas para a produção de artefatos bifaciais ou uso expeditivo também poderiam ser obtidas através do uso de pequenas placas de basalto colunar coletadas nos cursos de água situados nas proximidades dos sítios. Os bifaces elaborados sobre lascas unipolares poderiam ser utilizados para atividades variadas, servirem como base para a obtenção de lascas expeditivas ou sofrerem redução primária com o objetivo de produzir pré-formas de pontas de projétil pedunculadas.

As pontas de projétil de corpo triangular e base de pedúnculo reta foram produzidas a partir de lascas unipolares ou de pré-formas. Na produção de pontas de projétil pedunculadas sobre lascas unipolares, o talão da lasca original foi utilizado enquanto suporte para a produção do pedúnculo, indicando suas dimensões médias (3,5 x 1,98 x 0,7 cm) uma tendência à escolha de lascas de redução de núcleos. Neste caso, as lascas originais, após extração de um núcleo pequeno foram diretamente retocadas dando origem à ponta de projétil. Por sua vez, as pré-formas foram produzidas através da redução bifacial de lascas ou bifaces com retoque por percussão, assumindo uma forma inicial triangular. Posteriormente, foram retocadas por pressão, sendo assim confeccionados o pedúnculo e as aletas da ponta de projétil. A aplicação de retoque sobre pontas de projétil pedunculadas também apresenta técnicas padronizadas, com uma extensão envolvente ou invasora e posição bifacial, que se localiza de forma contínua ao longo da borda da peça, aplicado em ângulo semi-abrupto. Suas aletas foram produzidas simultaneamente ao retoque de borda, formando um ângulo reto ou reto-circular em relação ao corpo do pedúnculo.

A única distinção significativa entre o grupo de pontas pedunculadas diz respeito à preparação do pedúnculo, justificando uma subdivisão entre pontas de pedúnculo reto e bifurcado, sendo estas últimas caracterizadas por uma retirada invasora sobreposta ao retoque de borda. A característica bifurcada do pedúnculo pode estar relacionada à facilidade de encabamento ou a atividades de reativação do pedúnculo fraturado durante o uso. As pontas pedunculadas de bordas serrilhadas, por sua vez, são menos freqüentes e 
apresentam dimensões médias inferiores às categorias anteriores $(2,5 \times 1,3 \times 0,6)$, sugerindo o padrão de retoque também processos de reativação.

A calcedônia e o quartzo foram destinados à redução bipolar em função das pequenas dimensões originais destas matérias primas disponíveis localmente na forma de seixos ou prismas. A análise dos fragmentos natural e das peças presente no sítio aponta que o tratamento inicial desta matéria prima, para abertura do nódulo e retirada do córtex, também se deu nos locais de coleta. Os núcleos pré-formatados de calcedônia foram levados para os abrigos para produção de lascas de uso expeditivo ou utilizadas como suporte para produção de pontas de projétil lanceoladas através de redução secundária.

As pontas de projétil produzidas a partir de modificação primária bipolar correspondem a peças apedunculadas de formato lanceolado, produzidas a partir de lascas bipolares de calcedônia, com dimensões médias de 2,9 x 1,2 x 0,6 cm. Para a produção destes artefatos foram selecionadas lascas cuja morfologia aproximadamente cônica foi aproveitada na produção da ponta, sem o desenvolvimento de processos de redução intermediários. Neste caso, observa-se que o talão da lasca bipolar original foi aproveitado, como terminação proximal da ponta de projétil, enquanto sua terminação distal, em forma de vértice, recebeu retoque para formar o ápice da peça. O retoque sofrido por esta categoria de pontas distribui-se de forma envolvente ou invasora, sendo comum a posição do retoque ser direta, embora também seja freqüente o retoque bifacial, em ângulo abrupto ou semi-abrupto de acordo com as características da base original de redução. Fogem deste padrão as pontas produzidas em arenito silicificado e basalto, cujas características indicam corresponderem à reativação de pontas pedunculadas com fraturas de pedúnculo e aletas.

A varibilidade das formas de pontas de projétil relaciona-se tanto aos processos tecnológicos de produção e reativação quanto às possibilidades de uso distinto relacionadas aos tipos de animais abatidos por estes artefatos (Flenniken \& Raymond, 1986). Por outro lado, a maior incidência de descarte de pontas lanceoladas nos sítios do vale do arroio Campestre pode ser explicada em função dos passos técnicos reduzidos que envolvem a sua produção o que condicionaria uma maior propensão ao descarte. As pontas pedunculadas tenderiam a ter uma média de vida útil mais longa em função do maior investimento tecnológico envolvido na sua produção, sendo descartadas em menor freqüência e sofrendo um maior índice de reativação, o que daria origem à variabilidade de formas observadas.

As indústrias líticas da Tradição Guarani apresentam uma preferência pela utilização do basalto, cuja origem relaciona-se preferencialmente a seixos de arraste fluvial 
ou blocos de afloramento, sendo rara a utilização de placas de basalto colunar. A escolha diferencial é determinada pela abundância de matéria prima no local de implantação do sítio, sendo escolhidos os seixos em sítios localizados nas proximidades de cursos de água de maior volume, como o arroio Caraá. Os sítios situados em meia-encosta e maiores altitudes, geralmente estão associados a afloramentos de basalto e arenito silicificado que são explorados como recurso principal de matéria prima.

Os artefatos unifaciais e bifacias predominam nas indústrias líticas da Tradição Guarani, estando o restante do conjunto representado, principalmente, por lascas e núcleos unipolares. Os blocos de afloramento são o tipo de suporte de lascamento predominante entre os núcleos unipolares, sendo ocasionalmente também utilizados seixos. Independente do tipo de suporte, predominam os tipos que apresentam duas plataformas bidirecionais opostas e os com duas plataformas em ângulo, apresentando cobertura cortical entre 3/4 e 1/2 da superfície total da peça, geralmente associada às plataformas de percussão. Estas características indicam uma preferência pela seleção de suportes de lascamento, sejam estes blocos ou seixos, que apresentem planos de percussão naturais, havendo um baixo investimento na preparação das plataformas de percussão. O baixo investimento técnico, associado a suas dimensões médias relativamente pequenas para o conjunto da indústria aponta que seu papel na organização da tecnologia está relacionado principalmente à produção de lascas para uso expeditivo.

A maior parte da amostra de lascas unipolares do conjunto lítico da Tradição Guarani é do tipo cortical, seguida pelas lascas de redução de núcleos, podendo ambas categorias apresentar modificação primárias, relacionadas à produção de bifaces elaborados sobre lasca unipolar. A maioria das lascas corticais do conjunto está associada à redução de seixos e relaciona-se à produção de artefatos unifaciais e bifaciais, sendo o restante associado à redução inicial de núcleos unipolares a partir de blocos de afloramento.

A classificação dos artefatos da indústria lítica Guarani em categorias tecnotipológicas que privilegiam a intensidade das estratégias de redução, em detrimento da morfologia dos artefatos, aponta para uma relação de seqüência de produção entre os tipos. Os seixos de morfologia alongada e, mais raramente, as placas de basalto colunar, foram selecionados como suporte preferencial para a produção de artefatos bifaciais, sendo mais freqüentes nas coleções as categorias relacionadas às primeiras etapas da cadeia operatória que seriam descartados em maior freqüência. 
As características deste conjunto artefatual indicam que as faces planas originais do seixo selecionado para a produção do artefato serviriam como plataforma inicial para o lascamento. O lascamento primário inicia-se, em geral, por duas retiradas em uma das faces da peça, para teste da matéria prima, centrando-se em apenas uma das suas extremidades. Esta etapa de produção gera um gume funcional, podendo o artefato ser utilizado, abandono em função da presença de irregularidades na matéria prima ou sofrer de dois a três lascamentos na face oposta, produzindo um gume bifacial, com terminação em ponta. Intensificando-se a redução primária em uma das faces do artefato, com mais duas retiradas, pode-se ampliar o gume bifacial até a metade da peça. Também pode-se optar nesta etapa da produção por estender a redução primária por todo o contorno da peça, formando um gume periférico, assumindo a redução primária um padrão mais homogêneo entre as faces, realizando-se entre 8 a 16 retiradas invasoras por face.

Outros tipos de artefatos bifaciais podem também ser produzidos utilizando-se matérias primas provenientes de blocos de afloramento. Neste caso, observa-se a seleção de suportes de lascamento que apresentam originalmente superfícies regulares que possam ser utilizadas como planos de percussão. Os gestos técnicos variam para esta categoria de artefatos, havendo uma tendência à redução primária intensa em ambas extremidades da peça, produzindo duas terminações em ponta, intercaladas por uma faixa de córtex.

Para as indústrias líticas da Tradição Taquara o basalto foi também a matéria prima preferencial, sendo selecionados principalmente os blocos de afloramento aos quais os sítios estão associados, sendo também utilizados, em menor escala, seixos e placas de basalto coletados junto aos cursos de água situados nas proximidades. A composição geral da indústria está relacionada à presença de lascas e núcleos unipolares, sendo mais raros os artefatos bifaciais e polidos, representados pelas mãos de pilão.

Os blocos de afloramento correspondem ao tipo de suporte de lascamento preferencial para os núcleos unipolares. Estes, em geral, apresentam evidências de intensa redução, sendo a cobertura cortical ausente ou inferior a $1 / 4$ da superfície total da peça em mais da metade do conjunto analisado. As plataformas de percussão raramente apresentam córtex, podendo possuir a mesma peça combinação de plataformas lisas e facetadas, com grande incidência de cantos macerados, características que indicam investimentos em atividades de preparação de núcleos. Estas características geram uma grande variabilidade na posição das plataformas de percussão, de acordo com as características originais de cada bloco, predominando os núcleos unipolares que utilizam a face ventral de uma lasca espessa e de grande porte como plataforma de percussão, seguidos dos núcleos que 
apresentam duas plataformas em ângulo. Estão também representados, em menor proporções, os núcleos que apresentam duas plataformas bidirecionais opostas, os que possuem três a quatro plataformas em várias posições, geralmente formando ângulos entre si, e àqueles com apenas uma plataforma definida. Para o conjunto das lascas unipolares, predominam àquelas relacionadas à redução de núcleos e as corticais, também associadas predominantemente a esta atividade, sendo mais rara as lascas de redução de bifaces.

As características gerais do conjunto lítico apontam que a indústria lítica da Tradição Taquara está voltada predominantemente para a redução de núcleos voltados a obtenção de lascas para uso expeditivo, podendo estas ser utilizadas sem nenhuma modificação ou sofrerem redução secundária. As lascas modificadas, no entanto, não apresentam um padrão de distribuição de cicatrizes de redução primária, indicando uma tendência a multi-funcionalidade destes artefatos. A maior representatividade na amostra estudada de núcleos unipolares com uma plataforma ventral, pode indicar que sua redução preferencial esteja associada a sua utilização enquanto artefatos junto às unidades domésticas do assentamento, gerando formas plano convexas que apresentam gume utilitário em todo o contorno da plataforma de percussão.

A produção de artefatos bifaciais de grande porte teriam um papel secundário nas indústrias da Tradição Taquara. Por sua vez, observa-se nas indústrias da Tradição Taquara três estratégias associadas à produção de artefatos bifaciais relacionadas a variações dos tipos de suporte de lascamento selecionados. Os blocos de afloramento podem ser reduzidos inicialmente em uma extremidade, formando um gume bifacial até a $1 / 2$ da peça, estendendo-se a redução primária, posteriormente, a outra extremidade. Em função das irregularidades dos blocos originais, estes bifaces, em geral, apresentam uma faixa central coberta por córtex. Os mesmos passos técnicos são observados na redução de placas de basalto colunar, dando a redução primária, inicialmente, em uma extremidade da peça. Neste caso, os planos naturais da placa são utilizados como plataforma de percussão, podendo a redução estender-se por todo o contorno da peça, gerando um gume periférico. Por fim, podem também ser utilizados, em menor freqüência, seixos alongados para a produção de bifaces, com lascamentos em apenas uma das extremidades. 


\section{Conclusões}

O conceito de estilo tecnológico é um instrumento para o entendimento dos conjuntos tecnológicos de diferentes grupos culturais, podendo ser definido como o "modo como as pessoas realizam os seus trabalhos, incluindo as escolhas feitas por eles no que se refere aos materiais e às técnicas de produção” (Reedy \& Reedy, 1994:304) . Esta noção permite compreender o estilo como algo que é inerente e subjacente aos processos de produção a partir dos quais a forma dos artefatos é uma resultante. O estilo tecnológico não é um fenômeno unidimensional, integrando várias concepções e, ao mesmo tempo, apresentando uma multi-funcionalidade em diferentes contextos sócioculturais. As diferentes perspectivas analíticas sobre este conceito compartilham, no entanto, alguns princípios básicos, centrados na noção de que o estilo refere-se a um determinado modo de fazer algo ou alguma coisa que implica em escolhas dentre possibilidades alternativas, próprias a um determinado tempo e lugar.

Nosso interesse nesta categoria conceitual reside nas possibilidades que oferece ao ser incorporada ao estudo da variabilidade das indústrias líticas do sul do Brasil. Partindo do conceito de estilo tecnológico, podemos compreender a variabilidade dos conjuntos líticos como o resultado de escolhas tecnológicas, culturalmente determinadas, representadas na seleção das matérias primas, nas técnicas e seqüências de produção e nos resultados materiais destas escolhas. Os estilos tecnológicos são, portanto, o produto de uma tradição cultural, servindo como indicadores de identidades sociais.

É da comparação entre estilos tecnológicos de indústrias líticas dos sítios de uma mesma região que podemos antever a possibilidade de distinção entre identidades sociais ou culturais no registro arqueológico. Contudo, esta percepção nunca pode estar dissociada de uma análise contextual, na medida em que o estilo tecnológico só adquire sentido quando compreendido como parte de um sistema cultural. Assim, o resgate das cadeias operatórias de uma determinada indústria lítica deve ser compreendido em conjunto e associado ao contexto situacional da região estudada a fim de possibilitar a interpretação da variabilidade artefatual. 
Com base nas referências teóricas e nos problemas de pesquisa acima expostos, procuramos avaliar a variabilidade das indústrias líticas do sul do Brasil a partir das seguintes hipóteses de trabalho:

1. As cadeias operatórias relacionadas à produção de diferentes categorias de artefatos associadas a sítios arqueológicos relacionados em um determinado sistema de assentamento manifestam um estilo tecnológico que possui significado cultural em termos de identidade social.

2. A partir da identificação de padrões tecno-estilísticos pela comparação da organização tecnológica das indústrias de diferentes sítios líticos de uma mesma área, pode-se avaliar se a variabilidade nos conjuntos representa variações regionais e/ou temporais de uma ampla tradição tecnológica ou correspondem a categorias funcionais vinculadas ao uso diferenciado do espaço, em função do padrão de assentamento representado pelos sítios arqueológicos.

Partindo destas hipóteses, buscamos compreender a variabilidade das indústrias líticas associadas à ocupação pré-colonial da região do Alto Vale do Rio dos Sinos, situada na vertente nordeste do planalto sul-brasileiro. Através dos trabalhos de campo desenvolvidos e da análise das coleções líticas buscamos definir o perfil tecnológico das distintas ocupações relacionadas aos sítios arqueológicos localizados nesta área piloto. A partir dos resultados obtidos, procuramos compreender em que medida os padrões estilístico-tecnológicos identificados relacionam-se a identidades sociais distintas e a aspectos funcionais associados às formas de estruturação do uso do espaço regional por distintas populações pré-coloniais.

Em um primeiro momento, nosso estudo estava direcionado para a análise de contextos arqueológicos relacionados exclusivamente a ocupação caçadora coletora da área estudada, associada à Tradição Umbu. Tendo em vista esta orientação inicial, optou-se por trabalhar uma região, cujos resultados de pesquisas anteriores apontavam para um grande potencial arqueológico para a exploração desta temática. Contudo, tendo em vista a orientação regional deste estudo, o desenvolvimento das pesquisas de campo acabaram também por revelar conjuntos líticos identificados em vários sítios da área, associados a sistemas de assentamento de grupos horticultores Guarani e Jê, que correspondiam aos fósseis guia clássicos da Tradição Humaitá (choppers, chopping tools, talhadores e bifaces de grande porte). Desta forma, ampliamos nossa análise a fim de incorporar à proposta original problemáticas também relacionadas à Tradição 
Humaitá, cujos conjuntos líticos, pelo menos na região estudada, apresentam uma forte correlação contextual com os sistemas de assentamento de grupos horticultores.

A definição do tamanho da área a ser prospectada deu-se em função de um padrão mínimo derivado do modelo etnoarqueológico de mobilidade caçadora coletora em área de floresta tropical. Tendo por base este critério, foram selecionados como limites naturais para a área piloto os principais cursos de água associados à drenagem do Alto Rio dos Sinos, sendo sua área total definida em $216 \mathrm{Km}^{2}$. Levando-se em consideração o tipo de contexto arqueológico conhecido para a região, o tamanho da área piloto e os resultados das vistorias extensivas previamente realizadas nesta área, organizamos nosso plano de prospecção combinando estratégias de levantamento por amostragem probabilística estratificada com estratégias de levantamento abrangente extensivo. Optou-se por estabelecer unidades amostrais de prospecção com limites arbitrários, na forma de quadrados de $1 \mathrm{Km}^{2}$, subdivididos em 4 quadrantes de 500 metros de lado.

Em função das características do relevo, da cobertura vegetal e do sistema hidrográfico, decidiu-se distribuir as unidades amostrais entre os dois estratos geomorfológicos distintos que caracterizam a área piloto, compreendendo as planícies de inundação ao sul e as meias encostas e encostas que marcam sua paisagem ao norte. Para estabelecer a quantidade de unidades amostrais a serem prospectadas e garantir uma padronização na sua distribuição entre os estratos ambientais selecionados, elegeuse as áreas de confluência de corpos de água como locais preferenciais para a sua localização. Foram selecionadas a partir deste critério 56 unidades amostrais para prospecção que corresponderam a uma fração de 25\% da área piloto.

A vistoria geral do terreno se deu através de levantamentos abrangentes extensivos, utilizando como táticas básicas à vistoria dos locais onde ocorre exposição natural ou artificial do solo e a prospecção sistemática intensiva em terrenos arados. Para testar a eficiência do sistema de prospecções por unidades amostrais, foram também realizados levantamentos extensivos nas áreas situadas no entorno dos limites das unidades amostrais de prospecção, realizando-se prospecções sistemáticas intensivas nas áreas com visibilidade de solo. Entrevistas com os moradores locais complementaram esta atividade, oferecendo informações sobre os processo de formação que afetaram os sítios detectados, sobre as pesquisas arqueológicas anteriormente realizadas na área e sobre a existência de sítios em áreas atualmente sem visibilidade de solo devido à cobertura vegetal. 
Apenas 7,9\% da área coberta por unidades amostrais de prospecção apresentou relativa visibilidade de solo associada às áreas aradas, relacionadas ao cultivo misto de pequena extensão e, em menor escala, à agricultura extensiva de arroz e milho. A maior parte da área prospectada encontra-se coberta por pastagens utilizadas para criação de gado, nas zonas de várzea, ou pastagens associadas a mato secundário, nas áreas de meia encosta. A presença de cobertura vegetal total por mato secundário e plantações de banana também são expressivas, relacionadas às zonas de meia encosta e encosta.

A implementação dos métodos de prospecção propostos resultou na localização de 61 sítios arqueológicos, concentrados principalmente na porção sul da área piloto, junto à várzea do rio dos Sinos. Ao todo foram localizados 50 abrigos sob rocha, em sua maioria na porção oeste da área piloto, sendo 18 destes confirmados como sítios arqueológicos. Do total de sítios arqueológicos em abrigos sob rocha, 14 estão associados à ocupação de caçadores coletores da Tradição Umbu, sendo o restante relacionado a ocupações históricas ou apresentando afiliação cultural indeterminada. Dentre os 43 sítios arqueológicos a céu aberto localizados, 30 estão associados à Tradição Guarani e 5 estão vinculados à Tradição Taquara. Apenas um dos sítios a céu aberto identificado associa-se ao sistema de assentamento da Tradição Umbu, sendo os demais históricos.

A fim de avaliar, em termos comparativos, os resultados das prospecções subdividimos a área piloto em quatro setores. O setor nordeste da área piloto, corresponde a uma área de encosta com declividade acentuada, cortada por vales encaixados associados às nascentes do arroio Rolantinho e dos arroios Sertão, Grande e Pinheiros, afluentes da margem direita do rio dos Sinos. As altitudes deste setor são as mais elevadas da área piloto, estando entre 100 e $850 \mathrm{~m}$. Os 5 sítios a céu aberto da Tradição Taquara identificados nas prospecções situam-se neste setor, apresentando três destes apenas evidências líticas. Estes sítios estão associados às nascentes e ao curso médio dos arroios Grande e Sertão, em área de encosta e meia encosta, com altitudes médias entre 100 e $400 \mathrm{~m}$. Um dos abrigos sob rocha localizado neste setor também foi associado a este sistema de assentamento, em função das características de seu acervo e de seu padrão de implantação.

O setor sudeste da área piloto caracteriza-se pela intersecção entre várzea e meia encosta, relacionada ao início do curso do rio dos Sinos. Na sua porção oeste, as várzeas do rio dos Sinos e de seus afluentes, arroios Caraá e Sertão, seguem um curso encaixado em uma encosta montanhosa, correspondendo a uma várzea mais elevada, com altitudes 
médias entre 30 e $50 \mathrm{~m}$. A meia encosta que acompanha os principais cursos de água possui altitudes entre 80 e $120 \mathrm{~m}$, formando platôs elevados com declividade suave sobre a área de inundação. A porção leste deste setor é marcada por uma várzea extensa, com altitudes entre 19 e $38 \mathrm{~m}$, que caracteriza o interflúvio entre o rio dos Sinos e o arroio Grande e a confluência do arroio Pinheiros com o arroio Grande. A maioria dos sítios a céu aberto da Tradição Guarani situa-se neste setor da área piloto, associados a meia encosta que acompanha os cursos de água de maior porte, em platôs abrigados das enchentes. Do total de sítios Guarani localizados, 13 são lito-cerâmicos, 12 apresentam somente evidencias cerâmicas e 5 estão representados apenas por material lítico.

Os 15 sítios de caçadores coletores localizados na área piloto estão relacionados, em sua maioria, a abrigos sob rocha e concentram-se nos setores noroeste e sudoeste da área piloto, em torno da várzea do rio dos Sinos e de seus afluentes, arroios Restinga, Campestre e Pinheiros. As altitudes mais baixas situam-se no setor sudoeste, sendo esta área caracterizada pelas várzeas do rio dos Sinos e dos arroios Grande e Restinga, com altitudes médias entre 10 e 20 m. Formações de morros testemunhos areníticos se destacam nesta paisagem de várzea, com altitudes médias entre 50 e 70 m, apresentando formações de abrigos sob rocha. A meia encosta que circunda o eixo principal do rio dos Sinos possui altitudes entre 60 e $160 \mathrm{~m}$, apresentando também a formação de abrigos sob rocha. Por sua vez, a porção sul do setor noroeste da área piloto é caracterizada pela várzea do arroio Campestre, com altitude média de $48 \mathrm{~m}$. A meia encosta onde se situam suas nascentes tem altitudes médias entre 100 e $160 \mathrm{~m}$, estando os topos de morros da área entre 200 e 230 m. As características topográficas deste setor acompanham a tendência do setor sudoeste da área piloto, sendo grande a quantidade de abrigos sob rocha associados às áreas de meia encosta. A porção norte deste setor corresponde ao vale encaixado do arroio Rolantinho, com altitudes médias entre 100 e $160 \mathrm{~m}$, estando os pontos mais elevados associados a cotas entre 250 e $400 \mathrm{~m}$.

A fim de compreendermos as características do sistema de assentamento caçador coletor identificado na área piloto utilizamos como referência teórica o modelo forrageiro proposto por Binford, associado aos dados etnoarqueológicos para caçadores coletores de floresta tropical e às tendências da literatura antropológica contemporânea sobre o tema. Partindo deste modelo teórico sugerimos que o sistema de assentamento relacionado à Tradição Umbu para a área estudada seria caracterizado por três princípios ordenadores gerais. Em primeiro lugar, destaca-se a idéia de que a manutenção de um sistema de assentamento caçador coletor adaptado a áreas florestais 
é mediado pela alta mobilidade, demandando, portanto, um território amplo. Este território, por sua vez, comportaria duas dimensões distintas: uma regional, associada ao grupo de afiliação, e uma local, associada às áreas de forragem dos bandos que compõe o grupo de afiliação, cujas fronteiras são marcadas pela alta fluidez. Uma segunda característica estaria associada às estratégias de mobilidade que correspondem ao marco estrutural deste tipo de organização social. A alta mobilidade agiria de forma a potencializar a capacidade produtiva do ambiente e manter os vínculos sociais e o fluxo de informação entre os distintos bandos locais que fazem parte de um grupo de afiliação e que compartilham o mesmo território regional. Por fim, os sítios arqueológicos derivados de um sistema de assentamento caracterizado pela alta mobilidade seriam o produto de intervalos breves de ocupação, gerando vestígios materiais pouco densos e altamente dispersos na paisagem. Estes sítios possuiriam baixa variabilidade funcional e alta probabilidade de apresentar depósitos primários, podendo variar entre dois tipos: unidades habitacionais e locações relacionadas a atividades específicas.

Seguindo este modelo, podemos sugerir que a área piloto do Alto Vale do Rio dos Sinos representaria um território de forragem de um bando local, correspondendo a uma porção mínima de um território regional mais amplo, associado a um grupo de afiliação. Este abrangeria a borda nordeste do planalto sul-rio-grandense, compreendendo os vales dos rios Taquari, Caí, Sinos e Maquiné, bem como a planície litorânea adjacente. Este território regional comportaria vários territórios de forragem de bandos locais, cujos membros poderiam mover-se sem restrição em função de objetivos de ordem social e econômica. A fluidez da organização social e do uso do espaço, por sua vez, implicaria em uma organização tecnológica homogênea para a área deste território regional, em função do fluxo constante de informações e pessoas, características estas que podem ser percebidas através dos estudos de coleções líticas da Tradição Umbu na área piloto, bem como em estudos já realizados para os vales dos rios Caí e Maquiné.

A partir dos dados paleoclimáticos e paleoambientais disponíveis para a região estudada, podemos sugerir que a borda nordeste do planalto sul-brasileiro apresentou características ambientais estáveis marcada pela presença de floresta sub-tropical desde o início de sua ocupação por populações caçadoras coletoras, por volta de 9.000 anos atrás. Diferente das áreas tropicais, nas florestas sub-tropicais a produtividade da flora é constante ao longo do ano, possuindo ciclos fenológicos distintos de acordo com as estações, sendo o regime de chuvas igualmente distribuído ao longo do ano. Portanto, os 
sistemas de mobilidade que caracterizariam os caçadores coletores de floresta subtropical associados à Tradição Umbu não estaria tão estritamente relacionados à presença concentrada de determinados recursos em função de ciclos sazonais de chuvas. Por sua vez, as características mais restritas das florestas sub-tropicais quanto à disponibilidade de vegetais para coleta parecem indicar que a caça, possivelmente, representou um papel importante para obtenção de recursos alimentares, desempenhando a pesca um papel secundário nos sistemas de subsistência destes grupos de acordo com os dados zooarqueológicos atualmente disponíveis. Estes fatores conjugados refletiriam-se na necessidade de áreas de forragem mais amplas do que observado nos modelos etnoarqueológicos para os caçadores coletores de floresta tropical a fim de preservar os recursos disponíveis, tendo em vista o padrão disperso da caça neste tipo de ambiente e o retorno a longo prazo das estratégias de manejo das espécies arbóreas exploradas.

Os recursos costeiros, provavelmente, também exerceram um fator de atração para as populações caçadoras coletoras da Tradição Umbu que ocuparam o Alto Vale do Rio dos Sinos e evidências de uma exploração ocasional podem ser observadas na coleção de dois sítios da área piloto. Contudo, ressaltamos que a exploração sazonal dos recursos costeiros só teria se tornado mais efetiva para as populações caçadoras coletoras da região nordeste do Rio Grande do Sul a partir da estabilização da linha de costa, por volta de 2.000 anos AP, quando estes ambientes tornaram-se mais produtivos em função da formação dos sistema de lagoas e banhados do litoral norte que passam a concentrar recursos de caça e pesca na primavera e no verão.

As datações disponíveis para a região nordeste permitem sugerir uma ocupação constante deste território regional ao longo de pelo menos 9.000 anos, sendo freqüente a ocupação de abrigos sob rocha, associados a morros testemunho areníticos, formações geológicas comuns na paisagem da porção leste da Depressão Central Gaúcha. Portanto, sugerimos que os abrigos sob rocha desta área representavam marcos na paisagem, sistematicamente re-ocupados como bases residenciais ao longo do ciclo anual de forragem por distintos grupos locais. O sistema de assentamento de caçadores coletores neste território regional também comportaria sítios a céu aberto, de igual funcionalidade, porém estes apresentariam um padrão de distribuição mais disperso na paisagem, sendo sua preservação mais rara.

Os sítios em abrigo sob rocha identificados para o Alto Vale do Rio dos Sinos estariam relacionados a este sistema de assentamento regional, tendo sido ocupados de 
forma continuada ao longo de 8.000 anos, segundo as datações obtidas. Partindo do modelo de mobilidade assumido, estes abrigos teriam sido ocupados como bases residenciais por breves períodos de tempo pelos bandos locais que percorriam a área ao longo do seu ciclo anual de mobilidade. A curta permanência nos sítio redundaria na baixa densidade de material arqueológico observada nas sondagens realizadas nestes sítios, porém as ocupações teriam se dado de forma recorrente ao longo do tempo. Devido a grande disponibilidade de abrigos na área piloto, os sítios teriam sido ocupados em diferentes ocasiões pelos grupos co-residentes. Igualmente, observa-se que houve uma preferência na escolha de determinados sítios para o estabelecimento das bases residenciais, pois dos 50 abrigos sob rocha identificados na área piloto, apenas 8 apresentaram uma densidade de materiais arqueológicos mais significativa o que indicaria uma utilização mais freqüente, estando a maior concentração de sítios com estas características próximos à várzea do rio dos Sinos. Esta escolha parece ser determinada, primeiramente, em função do local de implantação do abrigo na paisagem e das suas condições de habitabilidade, desempenhando um papel secundário aspectos relacionados ao seu tamanho e a orientação.

Sugerimos que o sistema de assentamento de caçadores coletores do Alto Vale do Rio dos Sinos, também comportaria uma quantidade significativa de sítios a céu aberto que corresponderiam a unidades habitacionais, porém a alta mobilidade e a curta duração das ocupações produziria um conjunto de vestígios materiais pouco densos, a exemplo das características ocupacionais identificadas nos abrigos sob rocha sondados. Portanto, os sítios a céu aberto teriam pouca visibilidade e da alta dispersão na paisagem, na medida em que não sofreriam episódios de re-ocupação. Por sua vez, a reocupação constante dos abrigos redundaria em uma concentração ainda menor de sítios a céu aberto. A detecção destes sítios a céu aberto seria menos favorável na área piloto tendo em vista a intensidade da ação agrícola contemporânea e a baixa visibilidade de solo relacionada à cobertura vegetal predominante.

O modelo de sistema de assentamento adotado prevê também a presença de sítios associados a atividades específicas (locations) que poderiam ser de dois tipos: locais associados à extração de matérias primas e locais relacionados ao sistema simbólico do grupo, demarcados pela presença de gravações rupestre (petroglifos). As prospecções na área piloto não permitiram a identificação de sítios do primeiro tipo tendo em vista as características da organização tecnológica que privilegiou a coleta de matérias primas disponíveis nas proximidades dos sítios. Por outro lado, foi localizado 
um sítio de atividade específica associado ao universo simbólico dos grupos de caçadores coletores que ocuparam a região, relacionado a gravuras rupestres, sendo a ausência de evidências arqueológicas nas sondagens realizadas um indicador das características funcionais específicas deste sítio no sistema de assentamento da área.

A fim de testar a hipótese de que os sítios de caçadores coletores identificados no Alto Vale do Rio dos Sinos correspondem a unidades habitacionais foram realizadas escavações em três sítios arqueológicos em abrigos sob rocha. Embora as características estruturais e pós-deposicionais de cada abrigo tenham gerado variações no padrão de distribuição dos conjuntos arqueológicos numa perspectiva inter-sítios, há redundâncias intra-sítio nas formas de ocupação dos abrigos, com padrões repetitivos de sobreposição de áreas de atividade representadas pelas fogueiras. Em todos os abrigos escavados observa-se um padrão recorrente de associação entre estruturas de fogueiras que apresentam em sua periferia conjuntos de fragmentos arqueofaunísiticos e resíduos de lascamento, indicando um padrão de descarte primário, interpretados como evidências de ocupações rápidas, sendo baixo o índice de descarte de artefatos formais.

Tomando por base a literatura etnoarqueológica para caçadores coletores de floresta tropical, partimos do princípio que cada fogueira identificada nas escavações representa uma unidade doméstica relacionada a um dos grupos familiares que compõem o bando local, sendo o padrão de descarte primário associado à fogueira doméstica característico de sítios de ocupação breve. Os vestígios arqueológicos destas ocupações estariam relacionados, principalmente, a atividades cotidianas de preparação, distribuição e consumo de alimentos, bem como produção e manutenção de artefatos. Como estes abrigos sofreram vários episódios de re-ocupação e possuem ritmos variados de sedimentação, não foi possível definir limites claros entre as distintas unidades domésticas, tanto em termos diacrônicos, quanto sincrônicos. Os dados registrados ao longo das escavações apontam para uma tendência de palimpsestos arqueológicos, sendo provável que as sucessivas ocupações ao longo do tempo mesclaram suas evidências, tendo em vista a tendência à reutilização de certos locais preferenciais nos abrigos para localização das fogueiras. Porém, de acordo com o modelo adotado é provável que os abrigos abrigassem mais de uma família por vez, cada qual com sua unidade doméstica própria, distribuindo-se as fogueiras familiares próximas entre si, com um padrão de dispersão determinado pela topografia de cada abrigo. 
Partindo do modelo etnoarqueológico adotado, para os conjuntos líticos descartados junto às unidades domésticas haveria uma maior tendência à concentração de resíduos associados à produção e manutenção de artefatos formais (tecnologia de curadoria) relacionados às atividades de caça, como as pontas de projétil. Estas, por sua vez, seriam descartadas em baixa freqüência, em geral, quando fraturadas em função do uso ou quando se mostraram inadequados durante do processo de produção ou manutenção da peça. Os artefatos informais (tecnologia expediente) produzidos sobre lascas unipolares ou bipolares e utilizados em atividades cotidianas variadas, tanto na preparação e consumo dos alimentos, quanto na produção de outros artefatos sobre materiais perecíveis, apresentariam, por sua vez, uma maior freqüência de descarte junto às unidades domésticas. Observaria-se também uma tendência a deposição junto às unidades domésticas de conjuntos de artefatos de maior porte (como núcleos, percutores, morteiros ou bifaces) e acúmulos intencionais de matérias primas de boa qualidade para lascamento ali deixados em antecipação a usos futuros quando houvesse a possibilidade de re-ocupação do sítio (site furniture).

Os resultados do estudo comparativo das coleções líticas de sete dos sítios em abrigos sob rocha associados à área piloto confirmam o modelo proposto. Observa-se na organização tecnológica dos conjuntos líticos da Tradição Umbu para os sítios estudados um estilo tecnológico comum, sendo a variabilidade observada, produto de uma intensidade de exploração diferenciada das matérias primas disponíveis em termos locais. As matérias primas exploradas preferencialmente encontram-se dispersas na paisagem, sendo sua coleta uma estratégia “encaixada” em outras atividades associadas à subsistência do grupo. Os distintos tipos de matérias primas selecionadas, por sua vez, foram tratados de forma diferenciada, sendo a calcedônia e o quartzo trabalhados por tecnologia bipolar e o basalto e o arenito silicificado tratados a partir de tecnologia unipolar.

Em termos gerais, a análise quantitativa e qualitativa das coleções líticas apontam para um predomínio de atividades relacionadas à produção e manutenção de artefatos bifaciais de pequeno porte. Para todos os sítios observamos uma baixa freqüência de descarte de artefatos formais, sendo a maior parte das coleções representadas por lascas unipolares pequenas relacionadas à redução de peças bifaciais, lascas bipolares e fragmentos de lascamentos associados a ambas estratégias tecnológicas. A baixa freqüência de núcleos unipolares e lascas unipolares corticais e de redução de núcleos nas coleções dos sítios indica que o arenito silicificado e o basalto 
sofreram processamento inicial preferencialmente nos próprios locais de coleta, a fim de produzir bifaces elaborados sobre lascas unipolares de fácil transporte para as unidades habitacionais. Lascas para a produção de artefatos bifaciais ou uso expeditivo também poderiam ser obtidas para utilização nas unidades domésticas através do uso de pequenas placas de basalto colunar coletadas nos cursos de água situados nas proximidades dos sítios. Os bifaces elaborados sobre lascas unipolares poderiam ser utilizados para atividades variadas, servirem como base para a obtenção de lascas expeditivas ou sofrerem redução primária com o objetivo de produzir pré-formas de pontas de projétil pedunculadas.

A calcedônia e o quartzo foram destinados à redução bipolar em função das pequenas dimensões originais destas matérias primas disponíveis localmente na forma de seixos ou prismas. A baixa freqüência de peças com córtex, indica que os núcleos bipolares de calcedônia foram pré-formatados nos locais de coleta e transportados para as unidades domésticas, sendo utilizados para a produção de lascas de uso expeditivo que também poderiam ser usadas como suporte para produção de pontas de projétil lanceoladas.

A variabilidade observada entre os sítios de caçadores coletores quanto à participação relativa de artefatos em suas coleções, está relacionada também as estratégias tecnológicas predominantes em cada conjunto. Os conjuntos artefatuais que apresentam maior abundância de artefatos relacionam-se aos sítios do vale do arroio Campestre, sendo estes representados em sua maioria por pontas de projétil lanceoladas produzidas a partir de lascas bipolares de calcedônia. Por sua vez, a unipolaridade se relaciona de forma estreita com as demais categorias de artefatos para os todos os sítios estudados, estando associada à produção de bifaces sobre lascas, pré-formas e pontas de projétil pedunculadas, elaboradas preferencialmente em basalto e arenito silicificado. A varibilidade das formas de pontas de projétil relaciona-se tanto aos processos tecnológicos de produção e reativação quanto às possibilidades de uso distinto relacionadas aos tipos de animais abatidos por estes artefatos. Por outro lado, a maior incidência de descarte de pontas lanceoladas nos sítios do vale do arroio Campestre pode ser explicada em função dos passos técnicos reduzidos que envolvem a sua produção o que condicionaria uma maior propensão ao descarte. As pontas pedunculadas tenderiam a ter uma média de vida útil mais longa em função do maior investimento tecnológico envolvido na sua produção, sendo descartadas em menor 
freqüência e sofrendo um maior índice de reativação, o que daria origem a uma variabilidade de formas.

Quanto aos vestígios arqueofaunísticos observados nos três sítios escavados, estes também apresentam semelhança com os dados etnoarqueológica para caçadores coletores de floresta tropical em termos de contexto de deposição e padrão de fratura. De acordo com o modelo etnoarqueológico, a tendência seria de que os animais abatidos sejam levados inteiros para o acampamento residencial, onde são preparados, distribuídos, consumidos e descartados junto às unidades domésticas, sendo os ossos fraturados para a extração de tutano. Embora até o presente não tenha sido realizado um estudo tafonômico detalhado dos conjuntos arqueofaunísticos associados aos sítios escavados, observa-se um padrão recorrente de descarte primário associado à periferia imediata ou interior das fogueiras, reforçando a interpretação destes sítios como unidades domésticas. Ressaltamos ainda que ao longo das escavações não foi identificado nenhum indício quanto à presença de depósitos secundários, contudo sua possível existência em sítios em abrigo sob rocha não necessariamente indica ocupações mais prolongadas. Episódios de limpeza que gerariam este padrão de deposição de lixo somente em determinadas áreas do sítio podem ser resultantes de episódios de reocupação de abrigos com taxas de sedimentação mais lenta ou freqüências mais constantes de visita.

Os dados resultantes das escavações sugerem que para a região do Alto Vale do Rio dos Sinos a variabilidade intra e inter-sítios observada relaciona-se mais propriamente a aspectos de ordem deposicional e pós-deposicional específica a cada abrigo. Partindo dos resultados das escavações e da análise das coleções líticas dos sítios em abrigo sob rocha da área piloto, sugerimos que a estrutura e tipos de vestígios arqueológicos associados aos sítios habitacionais relacionados a um sistema de assentamento relacionado à Tradição Umbu seria semelhante tanto a céu aberto, quanto em abrigo sob rocha, pois obedeceriam ao mesmo modelo simbólico de apropriação e uso do espaço. Uma primeira aproximação sobre esta questão pode ser atestada pelas semelhanças entre os conjuntos líticos dos sítios em abrigo sob rocha e os do sítio céu aberto RS-LC-76.

O padrão de ocupação do espaço observado para a Região do Alto Rio dos Sinos interpretado a luz de um modelo de mobilidade para caçadores coletores também pode servir como referência para a análise interpretativa de sítios de caçadores coletores a céu aberto caracterizados por uma alta densidade de material arqueológico. Sítios com estas 
características podem estar relacionados à re-ocupação recorrente de pontos estratégicos na paisagem, que concentram determinados tipos de recursos com disponibilidade sazonal ou não, obedecendo à reutilização destes espaços aos mesmos critérios que levam a ocupação recorrente de abrigos. Sítios a céu aberto associados a áreas litorâneas, lacustres ou alagadiças, bem como cursos fluviais de grande porte, podem estar associados a atividades relacionadas a pesca, coleta ou caça de espécies migratórias, devendo a interpretação de seus conjuntos arqueológicos ser mediada pela análise do tipo de implantação na paisagem.

Por outro lado, uma alta densidade de materiais líticos em sítios a céu aberto pode estar associada ainda ao sistema ritual do grupo ou a contextos onde ocorreram restrições aos modelos de mobilidade tradicional em função da presença de outras populações nas mesmas áreas de domínio. No primeiro caso, a presença de sítios associados ao contexto ritual, marcados por locais que apresentam arte rupestre ou concentração de sepultamentos, pode representar um fator de concentração periódica de distintos bandos locais, gerando concentrações de unidades habitacionais, não necessariamente sincrônicas, em suas nas proximidades. No segundo caso, as disputas pelas áreas de forragem com grupos horticultores pode ter afetado os modelos de assentamento tradicionais, levando a restrições nos sistemas de mobilidade e, conseqüentemente, à ocupação mais recorrente ou permanente dos mesmos espaços a céu aberto.

Por fim, o modelo de sistema de assentamento proposto para a Tradição Umbu na região nordeste do Estado coloca em questão a coerência do esquema históricocultural tradicionalmente aceito para a área, segundo o qual esta teria sido compartilhada, por pelo menos 6.000 anos, por dois diferentes grupos de caçadores coletores, portadores de indústrias líticas distintas, relacionados às Tradições Umbu e Humaitá. O modelo teórico adotado para o entendimento das formas de organização de uma sociedade caçadora coletora inviabiliza a possibilidade de dois distintos grupos de afiliação compartilharem o mesmo território regional, o que causaria um desequilíbrio no arranjo dos territórios de forragem dos diferentes bandos locais. Isto se daria em função da pressão demográfica sobre os recursos, já que a manutenção do sistema de subsistência em um modelo de assentamento forrageiro demanda uma densidade populacional baixa e dispersa na paisagem. Igualmente, espera-se que grupos que compartilham o mesmo território regional apresentem-se conectados por laços sociais, representados em um padrão homogêneo para a cultura material que refletiria, em 
última instância, o fluxo constante na área de informações e pessoas. Os dados arqueológicos e datações produzidas nos últimos 40 anos para a região nordeste do Estado e os resultados das pesquisas de campo desenvolvidas no Alto Vale do Rio dos Sinos, reforçam esta hipótese, sugerindo que um único grupo caçador coletor, associado à Tradição Umbu, ocupou esta área, pertencendo os sítios líticos identificados como associados à Tradição Humaitá aos sistemas de assentamento de horticultores.

Os sítios arqueológicos associados à Tradição Taquara na área piloto representam parte de um sistema de assentamento mais amplo que se estende para o norte, abrangendo as terras mais altas do planalto, e para o leste, explorando os recursos das lagoas litorâneas. Este modelo de domínio vertical prevê a exploração diferencial destes três pacotes ambientais de forma sazonal a fim de garantir a subsistência do grupo ao longo do ciclo anual. O sistema de cultivo, nas áreas de encosta, seria suplementado por estratégias de estocagem de alimentos, obtidos através da caça e coleta nas áreas florestais manejadas do planalto e da pesca e coleta de moluscos no litoral.

A estabilidade econômica proporcionada por estas estratégias, por sua vez, tem como conseqüência uma alta mobilidade habitacional que gera uma variabilidade de tipos de sítios adaptados às características ambientais das distintas áreas. Desta forma, as estruturas subterrâneas do planalto seriam utilizadas, predominantemente, no final do outono e no inverno, durante a coleta e processamento do pinhão, e os sítios a céu aberto da encosta seriam ocupados, mais intensamente, durante a primavera e o verão, em função dos ciclos dos cultivos. Os concheiros associados à Tradição Taquara, identificados na costa atlântica do Rio Grande do Sul, seriam decorrentes de ocupações rápidas, associadas a estratégias extrativas voltadas ao processamento de alimentos para estocagem e consumo em outros locais do assentamento, possivelmente na encosta, durante o verão.

Tendo por base este modelo, podemos sugerir que as estratégias de mobilidade desenvolvidas pelas populações Jê pré-coloniais eram representadas por migrações estacionais pluri-familiares, abrangendo os diferentes ambientes que compõe o sistema de assentamento do grupo, havendo uma tendência a re-ocupação dos mesmos assentamentos a cada estação. Indicadores deste padrão podem estar representados nas seqüências de datações para as estruturas subterrâneas do planalto que, por vezes, abrangem centenas de anos, bem como na alta densidade de materiais registrados nos sítios a céu aberto da encosta na década de 1960. Outro índice desta estabilidade habitacional de caráter sazonal estaria representado pela quantidade de sepultamentos 
associados a determinados tipos de sítios, como os abrigos sob rocha, para o Rio Grande do Sul, ou os concheiros, para o litoral de Santa Catarina.

Os três sítios arqueológicos associados à Tradição Taquara identificados na área piloto junto às nascentes do arroio Grande representariam uma única aldeia, sucessivamente reocupada na época dos cultivos (primavera, verão e início do outono). As concentrações de artefatos líticos identificadas representariam áreas de atividades específicas, próxima a sede da aldeia, associada a afloramentos de boa qualidade e relacionada à extração de matérias primas e confecção de artefatos líticos. Os artefatos produzidos poderiam ser utilizados nas atividades domésticas, bem como nas atividades desenvolvidas próximas ao assentamento principal como abertura de clareiras na mata e preparo da terra para o cultivo. Os outros dois sítios líticos identificados ao longo do alto curso do arroio Sertão, seriam indicadores da presença de um padrão de aldeia semelhante, cuja detecção se viu inviabilizada tendo em vista a densa cobertura vegetal por mato secundário nesta área.

Para as indústrias líticas da Tradição Taquara o basalto foi a matéria prima preferencial, sendo selecionados principalmente os blocos de afloramento aos quais os sítios estão associados, e, em menor escala, seixos e placas de basalto coletados junto aos cursos de água situados nas proximidades. A composição geral da indústria está relacionada à presença de lascas e núcleos unipolares, sendo mais raros os artefatos bifaciais e polidos, representados pelas mãos de pilão. Os núcleos unipolares apresentam evidências de intenso lascamento e investimento na preparação de plataformas, gerando uma grande variabilidade de tipos e uma alta concentração de lascas unipolares associadas a sua redução. As características gerais do conjunto lítico apontam que esta indústria estava caracterizada, predominantemente, pela redução de núcleos voltados a obtenção de lascas para uso expeditivo junto às unidades domésticas da aldeia, podendo estas ser utilizadas sem nenhuma modificação ou sofrerem redução secundária. As lascas modificadas, no entanto, não apresentam um padrão de distribuição de cicatrizes de redução primária, indicando uma tendência a multifuncionalidade destes artefatos. A maior representatividade na amostra estudada de núcleos unipolares com uma plataforma ventral, pode indicar que sua redução preferencial esteja associada a sua utilização enquanto artefatos junto às unidades domésticas do assentamento, gerando formas plano convexas que apresentam gume utilitário em todo o contorno da plataforma de percussão. 
A produção de artefatos bifaciais de grande porte teria um papel secundário nas indústrias da Tradição Taquara no Alto Vale do Rio dos Sinos, sendo sua produção relacionada a três distintas estratégias em função dos tipos de suporte de lascamento selecionados. Os blocos de afloramento poderiam ser reduzidos, inicialmente, em uma extremidade, formando um gume bifacial até a $1 / 2$ da peça, estendendo-se a redução primária, posteriormente, a outra extremidade. Em função das irregularidades dos blocos originais, estes bifaces, em geral, apresentam uma faixa central coberta por córtex. Os mesmos passos técnicos são observados na redução de placas de basalto colunar, dando-se a redução primária, inicialmente, em uma extremidade da peça. Neste caso, os planos naturais da placa são utilizados como plataforma de percussão, podendo a redução estender-se por todo o contorno da peça, gerando um gume periférico. Por fim, podem também ser utilizados, em menor freqüência, seixos alongados para a produção de bifaces, com lascamentos em apenas uma das extremidades.

A estabilidade da ocupação representada pelo sistema de assentamento da Tradição Taquara na área piloto seria atestada pela quantidade de sepultamentos presentes no sítio RS-S-328: Caipora. Sua datação atestaria a longa duração da ocupação desta área pelas populações Jê que teria se estruturado contemporaneamente ao sistema de mobilidade caçador coletor, porém, entraria em colapso com a presença Guarani na região nordeste do Estado, intensificada a partir de 500 anos atrás. Embora os assentamentos Guarani, preferencialmente, ocupem áreas de menores altitudes, próximas ao curso de rios de maior porte, sua noção defensiva de território acaba por limitar a circulação das populações Jê pelas diferentes ambientes explorados. A presença de sítios Guarani no litoral norte e central do Rio Grande do Sul, possivelmente impediria, limitaria ou regularia o acesso para os Jê aos recursos litorâneos, levando ao progressivo abandono desta estratégia de subsistência. O mesmo processo teria se dado em relação às áreas de cultivo na encosta que pela proximidade com os assentamentos Guarani teriam sido abandonadas a fim de evitar agressões representadas pela expansão de territórios dos tekohá para áreas mais próximas às nascentes dos rios de maior porte por volta de 500 anos atrás. Embora haja evidências arqueológicas de contato entre estes dois grupos, as formas bélicas de conquista e manutenção dos territórios de domínio desenvolvidas pelos Guarani, sugerem que conflitos e disputas com os caçadores coletores e os horticultores Jê pelas áreas de cultivo da encosta e extração de recursos litorâneos marcariam a tônica do tipo de relação predominante na região nordeste do Estado. 
Partindo do modelo etnoarqueológico referente ao sistema de assentamento Guarani, consideramos a distribuição de sítios arqueológicos observados no Alto Vale do Rio dos Sinos como representando o deslocamento das sedes de aldeias (amundá) na área de domínio de pelo menos dois tekohá. O primeiro está representado pela concentração de sítios no setor sudeste da área piloto, acompanhando os cursos do rio dos Sinos e dos arroios Caraá, Grande, Pinheiros e Bom Retiro. Um segundo tekohá situaria-se a noroeste da área piloto, associado ao vale do arroio Rolantinho, em altitudes mais elevadas em relação ao grupo anterior de sítios, em um ambiente menos favorável à ocupação Guarani tradicional.

O primeiro tekohá estaria representado pela maioria dos sítios identificados, distribuídos em vários agrupamentos, nas proximidades das confluências do arroio Sertão com o rio dos Sinos, do arroio Caraá com o rio dos Sinos e do arroio Grande com os arroios Pinheiros e Bom Retiro. Estes conjuntos de sítios representariam, de acordo com o modelo etnoarqueológico, o deslocamento da sede da aldeia principal (amundá) pela área de domínio do tekohá, partindo de um núcleo original e deslocando-se a uma distância média de $2 \mathrm{Km}$ entre os assentamentos. Seguindo o curso do rio dos Sinos, e dos arroios Caraá e Grande, as aldeias instalaram-se, preferencialmente, nas meias encostas, com altitude em torno de 100 m, nas proximidades de zonas de confluência de corpos de água e de fontes de matéria prima lítica e argilosa.

Se estabelecermos as balizas cronológicas do assentamento Guarani na área piloto entre 1450 e $1750 \mathrm{AD}$, teríamos um período de ocupação de pelos menos 300 anos da região, associado ao manejo das florestas primárias decorrentes do sistema de cultivo, com roças em diferentes estágios de desenvolvimento. Com base nesta projeção, podemos sugerir que cada um dos conjuntos de sítios identificados no tekohá do Alto Rio dos Sinos poderia ter sido ocupado por aproximadamente 50 anos. Considerando que cada um destes núcleos é formado, em média, por 3 a 4 sítios arqueológicos considerados como unidades habitacionais, podemos estimar uma ocupação das casas por um período de 10 a 15 anos.

Apesar do alto índice de perturbação antrópica atual dos sítios, a análise da documentação de campo das pesquisas realizadas a mais de trinta anos na área piloto permite inferências relativas à densidade e organização original destas aldeias. Quatro dos conjuntos de sítios da área nuclear do tekohá apresentavam na época "manchas pretas” que podem ser interpretadas como remanescentes de casas extensas (teii oga). O padrão observado foi de uma casa alongada grande, com dimensões aproximadas de 120 
x 60 m, ou padrões de associação de três casas circulares menores, em média, com dimensões de 40 x 20 m. Estes dados podem ser interpretados como representando uma aldeia com uma grande teii oga em uma posição central, estando distribuídas no seu entorno aldeias compostas por três casas menores ocupadas por famílias de menor prestígio, porém relacionadas por afinidade sangüínea ou política à linhagem original. Outra possibilidade seria a de que o padrão de três casas poderia ser decorrente de uma queda demográfica ou de uma desagregação da linhagem original representada pela grande teii oga alongada.

Em associação às unidades habitacionais em alguns destes sítios pode-se observar a presença de áreas de atividade específicas, com concentração de artefatos líticos, associadas à extração de matérias primas e à produção de artefatos líticos de grande porte, possivelmente utilizados na construção das casas, na confecção de canoas ou nas atividades agrícolas e de manejo agroflorestal. A maior parte do conjunto lítico da Tradição Guarani está associada a dois sítios, sugerindo que estas duas áreas correspondem aos principais locais de extração e preparação inicial de artefatos líticos do tekohá do Alto Vale do Rio dos Sinos. A produção inicial dos artefatos ocorreria nestes dois sítios de atividade específica, sendo as peças acabadas transportadas para as sedes de aldeias ou para os locais de roças, justificando os sítios lito-cerâmicos identificados e os sítios líticos com baixa densidade de materiais localizados nas prospecções.

Em geral observou-se uma preferência pela utilização do basalto, cuja origem relaciona-se preferencialmente a seixos de arraste fluvial ou blocos de afloramento, sendo a escolha diferencial determinada pela abundância da matéria prima no local de implantação do sítio. Os artefatos unifaciais e bifacias predominam na indústria lítica, estando o restante do conjunto representado, principalmente, por lascas e núcleos unipolares. Os blocos de afloramento são o tipo de suporte de lascamento predominante entre os núcleos unipolares, apresentando, em geral, planos de percussão naturais o que indica um baixo investimento na preparação das plataformas de percussão. Seu papel na organização da tecnologia está relacionado principalmente à produção de lascas para uso expeditivo junto às unidades habitacionais. A maior parte da amostra de lascas unipolares do conjunto lítico da Tradição Guarani é do tipo cortical, associadas à redução de seixos para a produção de artefatos unifaciais e bifaciais. Lascas de redução de núcleos, por sua vez, também podem sofrer redução primária associadas à produção de artefatos bifaciais. 
Os seixos de morfologia alongada e, mais raramente, as placas de basalto colunar, foram selecionados como suporte preferencial para a produção de artefatos unifaciais e bifaciais, sendo mais freqüentes nas coleções as categorias relacionadas às primeiras etapas da cadeia operatória que seriam descartados em maior freqüência junto aos locais de produção de artefatos. As características deste conjunto artefatual indicam que as faces planas originais do seixo selecionado para a produção do artefato serviriam como plataforma inicial para o lascamento. O lascamento primário inicia-se, em geral, por duas retiradas em uma das faces da peça, para teste da matéria prima, centrando-se em apenas uma das suas extremidades. Esta etapa de produção gera um gume funcional, podendo o artefato ser utilizado, abandono em função da presença de irregularidades na matéria prima ou sofrer de dois a três lascamentos na face oposta, produzindo um gume bifacial, com terminação em ponta. Intensificando-se a redução primária em uma das faces do artefato, com mais duas retiradas, pode-se ampliar o gume bifacial até a metade da peça. Nesta etapa da produção pode-se também optar por estender a redução primária por todo o contorno da peça, formando um gume periférico. Outros tipos de artefatos bifaciais podem ser produzidos utilizando-se matérias primas provenientes de blocos de afloramento. Neste caso, observa-se a seleção de suportes de lascamento que apresentam originalmente superfícies regulares que possam ser utilizadas como planos de percussão. Os gestos técnicos variam para esta categoria de artefatos, havendo uma tendência à redução primária intensa em ambas extremidades da peça, produzindo duas terminações em ponta, intercaladas por uma faixa de córtex.

O tekohá do arroio Rolantinho situa-se $7 \mathrm{Km}$ a noroeste do núcleo principal de sítios Guarani do Alto Rio dos Sinos, em um ambiente com topografia acidentada e altitudes elevadas, relacionado mais diretamente com a encosta do planalto. A ausência de datações torna impossível determinar se este corresponde a uma área de domínio contemporânea, hierarquicamente subordinada ao tekohá do Alto Rio dos Sinos, ou se deriva de um padrão de implantação posterior, decorrente da pressão da frente colonial a partir do início do século XVIII, implantada junto aos cursos dos rios e arroios ocupados tradicionalmente. No caso da segunda hipótese, os sítios da localidade de Campestre poderiam representar uma aldeia periférica a este tekohá do norte, instalada naquele local para controlar o movimento dos portugueses junto ao vale do rio dos Sinos, cuja contemporaneidade de ocupações é atestada pelas datações obtidas para o sítio RS-S-399. O padrão de implantação deste sítio é distinto dos demais, situando-se a uma altitude mais elevada, a uma maior distância dos cursos de água e em um ambiente 
menos propício para o tipo de cultivo tradicional. Representaria, portanto, um momento terminal da ocupação Guarani caracterizado por um deslocamento populacional das áreas tradicionalmente manejadas para posições defensivas periféricas. Este estratégia corresponderia a uma última tentativa de resistência ao avanço das frentes coloniais, ativas desde o século XVI, com as expedições das bandeiras paulistas, e efetivadas na área do Alto Vale do Rio dos Sinos pela instalação do Registro de Viamão, no início do século XVIII. 


\section{REFERÊNCIAS BIBLIOGRÁFICAS}

AMICK, D. 1994 Technological organization and the structure of inference in lithic analysis: an examination of Folsom hunting behavior in the American Southwest. In: CARR, P. (Ed.) The organization of North American prehistoric chipped stone tool technologies. International Monographs in Prehistory, Archaeological Series 7. Ann Arbor, University of Michican Press. 9-34 pp.

AMICK, D. \& MAULDIN, R. 1989 Comments on Sullivan and Rozen's debitage analysis and archaeological interpretation. American Antiquity, 54 (1): 166-168.

ANDREFSKY, W. 1994 Raw material availability and the organization of technology. American Antiquity, 59 (1): 21-34.

ANDREFSKY, W. 1998 Lithics: macroscopic approachs to analysis. Cambridge, Cambridge University Press. 258 p.

ARAÚJO, A. 2001 Teoria e método em arqueologia regional: um estudo de caso no Alto Paranapanema, Estado de São Paulo. Tese de doutorado. Universidade de São Paulo, São Paulo.

ARAÚJO, A.; NEVES, W. \& PILO, L. 2003 Holocene dryness and human occupation in South America: understanding the "Archaic Gap". Datiloscrito. São Paulo, Universidade de São Paulo.

ARNOLD, J. 1996 The archaeology of complex hunter-gatherers. Journal of Archaeological Method and Theory, 3 (2): 77-126.

ASSIS, V. 1995 Da espacialidade Tupinambá. Dissertação de mestrado. Porto Alegre, Pontifícia Universidade Católica do Rio Grande do Sul.

ASSIS, V. 1999 Questões etnoarqueológicas para pesquisas em registros arqueológicos Guarani. Revista do CEPA, 23 (29): 228-232.

BAHUCHET, S.; McKEY, D. \& GARINE, I. 1991 Wild yams revisited: is independence from agriculture possible for rain forest hunther-gatherers? Human Ecology, 19 (2): 213-243.

BAILEY, R.; HEAD, G.; JENIKE, M; OWEN, B.; RECHTMAN, R. \& ZECHENTER, E. 1989 Hunting and gathering in tropical rain forest: is it possible? American Anthropologist, 91: 59-82.

BAILEY, R. \& HEADLAND, T. 1991 The tropical rain forest: is it a productive environment for human foragers? Human Ecology, 19 (2): 261-285.

BAILLY, A. 1990 Dictionnaire Grec Français. Paris, Hachette. 2154 pp.

BAKER, C. 1978 The size effect: an explanation of variability in surface artifact assemblage content. American Antiquity, 43 (2): 288-293. 
BAMFORTH, D. 1986 Technological efficiency and tool curation. American Antiquity, 51 (1): 38-50.

BAMFORTH, D. 1991 Technological organization and hunter-gatherer land use: a California example. American Antiquity, 56 (2): 216-234.

BARNARD, A 1983 Contemporary hunter-gatherers: current theoretical issues in ecology and social organization. Annual Review os Anthropology, 12: 193-214.

BARNARD, A. 1999 Images of hunters and gatherers in european social thought. In: LEE, R. \& DALY, R. (Eds.) The Cambridge Encyclopedia of Hunters and Gatheres. Cambridge, Cambridge University Press. 375-383 pp.

BARRETO, C. 1999 Arqueologia brasileira: uma perspectiva histórica e comparada. In: FUNARI, P. P.; NEVES, E. G. \& PODGORNY, I. (Org.) Anais da I Reunião Internacional de Teoria Arqueológica na América do Sul - Revista do Museu de Arqueologia e Etnologia - Suplementos 3: 201-212.

BARRETO, C. 1999/2000 A construção de um passado pré-colonial: uma breve história da arqueologia no Brasil. Revista da USP, 44 (1): 32-51.

BARROS, M. L. 1996 Tapera da Figueira: um estudo de caso sobre o processo ocupacional da Aldeia Velha no século XIX (Santo Antônio da Patrulha, Rio Grande do Sul, BR). Dissertação de mestrado. Porto Alegre, Pontifícia Universidade Católica do Rio Grande do Sul.

BARTRAM, L.; KROLL, E. \& BUNN, H. 1991 Variability in camp structure and bone food refuse patterning at Kua San hunter-gatherer camps. In: KROLL, E. \& PRICE, T. (Eds.) The interpretation of archaeological spatial patterning. New York, Plenum Press. 77-148 pp.

BECKER, I. [1976] 1995 O índio Kaingang no Rio Grande do Sul. São Leopoldo, Editora Unisinos. 334 p.

BEHLING, H. \& NEGRELLE, R. 2001 Tropical rain forest climate dynamics of the atlantic lowland, southern Brazil, during the late Quaternary. Quaternary Research, 56: 383-389.

BENDER, B. \& MORRIS, B. 1988 Twenty years of history, evolution and social change in gatherer-hunter studies. In: INGOLD, T.; RICHES, D. \& WOODBURN, J. (Eds.). Hunters and gatherers 1: history, evolution and social change. Oxford, Berg. 4-14 pp.

BETTINGER, R. 1987 Archaeological approaches to hunter-gatherers. Annual Review of Anthropology, 16: 121-142.

BETTINGER, R. 1991 Hunter-gatherers: archaeological and evolutionary theory. New York, Plennum Press. 257 p.

BINFORD, L. 1962 Archaeology as anthropology. American Antiquity, 28 (2): 217-225. 
BINFORD, L. 1964 A consideration of archaeological research design. American Antiquity, 29 (4): 425-461.

BINFORD, L. 1965 Archaeological systematics and the study of cultural process. American Antiquity, 31 (2): 203-210.

BINFORD, L. [1968] 1972a Methodological considerations of the archaeological use of ethnographic data In: BINFORD, L. An archaeological perspective. New York, Seminar Press. 59-67 pp.

BINFORD, L. 1972b Model building, paradigms and the current state of Paleolithic research. In: BINFORD, L. An archaeological perspective. New York, Seminar Press. 252-294 pp.

BINFORD, L. 1978 Nunamiut etnoarchaeology. New York, Academic Press. 509 p.

BINFORD, L. 1979 Organization and formation process: looking at curated technologies. Journal of Anthropological Research, 35 (3): 255-272.

BINFORD, L. 1980 Willow smoke and dogs' tails: hunter-gatherer settlement systems and archaeological site formation. American Antiquity, 45 (1): 4-20.

BINFORD, L. 1981 Bones: ancient man and modern myths. New York, Academic Press.

BINFORD, L. 1983a Working at archaeology: the late 60s and early 70s. In: BINFORD, L. Working at archaeology. New York, Academic Press. 3-20 pp.

BINFORD, L. [1977] 1983b Forty seven trips: a case study in the character of archaeological formation process. In: BINFORD, L. Working at archaeology. New York, Academic Press. 243-268 pp.

BINFORD, L. [1978] 1983c Dimensional analysis of behavior and site structure: learning from na eskimo hunting stand. In: BINFORD, L. Working at archaeology. New York, Academic Press. 287-324 pp.

BINFORD, L. [1978] 1983d Evidences for diferences between residential and special purpose sites. In: BINFORD, L. Working at archaeology. New York, Academic Press. 325-338 pp.

BINFORD, L. [1982] 1983e The archaeology of place. In: BINFORD, L. Working at archaeology. New York, Academic Press. 357-378 pp.

BINFORD, L. [1981] 1983f Long-term land-use patterning: some implications for archaeology. In: BINFORD, L. Working at archaeology. New York, Academic Press. 379-386 pp.

BINFORD, L. [1973] 1983g Interassemblage variability: the Mousterian and the functional argument. In: BINFORD, L. Working at archaeology. New York, Academic Press. 131-156 pp. 
BINFORD, L. [1987] 1989a Researching ambiguity: frames of reference and site structure. In: BINFORD, L. Debating archaeology. New York, Academic Press. 223-265 pp.

BINFORD, L. 1989b Styles of style. Journal of Anthropological Archaeology, 8 : 5167.

BINFORD, L. [1984] 1989c An Alyawara day: flour, spinifex gum and shifting perspectives. In: BINFORD, L. Debating archaeology. New York, Academic Press. 147-171 pp.

BINFORD, L. [1986] 1989d An Alyawara day: making man's knive and beyond. In: BINFORD, L. Debating archaeology. New York, Academic Press. 172-189 pp.

BINFORD, L. 1990 Mobility, housing and environment. Journal of Anthropological Research, 46 (1): 119-152.

BINFORD, L. 1991a When the going gets tough, the tough get going: Nunamiut local groups, camping patterns and economic organisation. In: GAMBLE, C. \& BOISMIER, W. (Eds.) Ethnoarchaeological approaches to mobile campsites: hunter-gatherer and pastoralist case studies. International Monographs in Prehistory - Ethnoarchaeological Series 1. Ann Arbor, University of Michican Press. 25-137 pp.

BINFORD, L. 1991b Is Australian site structure explained by the absence of predators? Journal of Anthropological Archaeology, 10: 255-282.

BINFORD, L. [1983] 1994 En busca del pasado. Barcelona, Editorial Crítica. 283 p.

BINFORD, L. 2001 Constructing frames of reference: an analytical method for archaeological theory building using ethnographic and environmental data sets. Berkeley, University of California Press. 563 p.

BINFORD, L. \& BINFORD, S. [1966] 1983 A preliminary analysis of funtional variability in the Mousterian of Levalloi facies In: BINFORD, L. Working at archaeology. New York, Academic Press. 71-124 pp.

BINFORD, L. \& O’CONNELL, J. [1984] 1989 An Alyawara day: the stone quarry. In: BINFORD, L. Debating archaeology. New York, Academic Press. 121-146 pp.

BINFORD, S. 1968 Variability and change in the Near Eastern Mousterian of Levalloi facies. In: BINFORD, L. \& BINFORD, S. (Eds.) New perspectives in archaeology. New York, Aldine Publishers. 49-60 pp.

BIRD-DAVID, N. 1988 Hunters and gatherers and other people: a re-examination. In: INGOLD, T.; RICHES, D. \& WOODBURN, J. (Eds.). Hunters and gatherers 1: history, evolution and social change. Oxford, Berg. 17-30 pp.

BIRD-DAVID, N. 1996 Hunter-gatherer research and cultural diversity. In: KENT, S. (Ed.) Cultural diversity among twentieth-century foragers. Cambridge, Cambridge University Press. 297-304 pp. 
BIRD-DAVID, N. [1992] 1998 Beyond "the original affluent society": a culturalist reformulation. In: GOWDY, J. (Ed.) Limited wants, unlimited means. Washington, Island Press. 115-137 pp.

BODLEY, J. 1999 Hunter-gatherers and the colonial encounter. In: LEE, R. \& DALY, R. (Eds.) The Cambridge Encyclopedia of Hunters and Gatheres. Cambridge, Cambridge University Press. 465-472 pp.

BORRERO, L. \& YACOBBACIO, H. 1989 Etnoarqueología de asentamientos Aché, cazadores-recolectores del Paraguay oriental. Journal de La Société des Americanistes, 75: 7-83.

BRADLEY, B. 1975 Lithic reduction sequences: a glossary and discussion. In: SWANSON, E. (Ed.). Lithic technology: making and using stone tools. Chicago, Mouton Publishers. 5-13 pp.

BROCHADO, J. 1977 Alimentação na floresta tropical. Porto Alegre, Cadernos n 2, IFCH/UFRGS. 103 p.

BROCHADO, J. 1984 An ecological model to the spread of pottery and agriculture into Eastern South América. Tese de doutorado. Urbana-Champaign, University of Illinois.

BROCHADO, J.; MONTICELLI, G. \& NEUMANN, E. 1990 Analogia etnográfica na reconstrução gráfica das vasilhas Guarani arqueológicas. Veritas, 35 (140): 727743.

BROCHADO, J. \& MONTICELLI, G. 1994 Regras práticas na reconstrução gráfica da cerâmica Guarani por comparação com vasilhas inteiras. Estudos IberoAmericanos, 20 (2): 107-118.

BROSIUS, J. 1991 Foraging in tropical rain forests: the case of the Penan of Sarawak, East Malaysia. Human Ecology, 19 (2): 123-149.

BUNN, H.; BARTRAM, L. \& KROLL, E. 1988 Variability in bone assemblage formation from Hazda hunting, scavenging, and carcass processing. Journal of Anthropological Archaeology, 7: 412-457.

BURCH, E. 1996 The future of hunter-gatherer research. In: BURCH, E. \& ELLANNA, L. Key issues in hunter-gatherer research. Oxford, Berg. 441-455 pp.

CABRERA-BECERRA, G.; FRANKY-CALVO, C. \& MAHECHA-RUBIO, D. 2001 Los Nûkak: nômadas de la Amazonia Colombiana. Bogotá, Universidad Nacional de Colombia/Unibiblos Editorial. 423 p.

CAMERON, C. \& TOMKA, S. (Eds.) 1996 Abandonment of settlements and regions: ethnoarchaeological and archaeological approaches. New York, Cambridge University Press. 201 p.

CARLE, C. 2001 Assentamento de negros no Rio Grande do Sul. Projeto de tese de doutorado. Porto Alegre, Pontifícia Universidade Católica do Rio Grande do Sul. 
CARLE, M. 2003 Investigação arqueológica em Rio Grande: uma proposta da ocupação Guarani pré-histórica no Rio Grande do Sul. Dissertação de mestrado. Porto Alegre, Pontifícia Universidade Católica do Rio Grande do Sul.

CARR, C. 1984 The nature of organization of intrasite archaeological records and spatial analytic approaches to their investigation. In: SCHIFFER, M. (Ed.) Advances in archaeological method and theory - Vol 7. London, Academic Press. 103-222 pp.

CARR, C. 1987 Dissecting intrasite artifact palimpsests using fourier methods. In: KENT, S. (Ed.) Method and theory for activity area research: an ethnoarchaeological approach. New York, Columbia University Press. 236-291 pp.

CARR, C. 1991 Left in the dust: contextual information in model-focused archaeology. In: KROLL, E. \& PRICE, T. (Eds.) The interpretation of archaeological spatial patterning. New York, Plenum Press. 221-256 pp.

CARR, P. 1994 Technological organization and prehistoric hunter-gatherer mobility: examination of the Hayes site. In: CARR, P. (Ed.) The organization of North American prehistoric chipped stone tool technologies. International Monographs in Prehistory, Archaeological Series 7. Ann Arbor, University of Michigan Press. 9$34 \mathrm{pp}$.

CASTELHANO, L. 2003 Ocupação pré-histórica do abrigo do Barreiro na borda do planalto meridional, Ivorá, RS. Dissertação de mestrado. Porto Alegre, Pontifícia Universidade Católica do Rio Grande do Sul.

CHAMPION, T.; GAMBLE, C.; SHENNAN, S. \& WHITTLE, A. 1996 Prehistoria de Europa. Barcelona, Editorial Crítica. 475 p.

CHANG, K. 1968 Toward a science of prehistoric society. In: CHANG, K. C. (Ed.). Settlement archaeology. Palo Alto, National Press Books. 1-9 pp.

CHATTERS, J. 1987 Hunter-gatherer adaptations and assemblage structure. Journal of Anthropological Archaeology, 6: 336-375.

CHMYZ, I. 1966 Terminologia arqueológica brasileira para a cerâmica. Manuais de Arqueologia, ${ }^{\circ}$ 1. Curitiba, CEPA/ UFPR. 34 p.

CLARKE, D. 1977 Spatial information in archaeology. In: CLARKE, D. (Ed.) Spatial archaeology. London, Academic Press. 1-32 pp.

COHEN, M. 1995 Prehistoric hunter-gatherers: the meaning of social complexity. In: PRICE, D. \& BROWN, J. (Eds.) Prehistoric hunter-gatherers: the emergence of cultural complexity. London, Academic Press. 99-119 pp.

COLLINS, M. 1975 Lithic technology as a mean of processual inference. In: SWANSON, E. (Ed.). Lithic technology: making and using stone tools. Chicago, Mouton Publishers. 15-34 pp. 
COLLINS, M. 1991 Rockshelters and the early archaeological record in the Americas. In: DILLEHAY, T. \& MELTZER, D. (Eds.) The first americans: search and research. Boca Raton, CRC Press. 157-182 pp.

COPÉ, S. 1999 Arqueologia pré-histórica do planalto: os grupos ceramistas da Tradição Taquara. Revista do CEPA, 23 (29): 180-188.

COPÉ, S. \& SALDANHA, J. D. 2002 Em busca de um sistema de assentamento para o planalto sul riograndense: escavações no sítio RS-AN-03, Bom Jesus, RS. In: SCHMITZ, P. I. (Ed.) Casas subterrâneas nas terras altas do sul do Brasil. Pesquisas - Antropologia, 58:107-120.

COPÉ, S.; SALDANHA, J. D. \& CABRAL, M. 2002 Contribuições para a pré-história do planalto: estudo da variabilidade de sítios arqueológicos de Pinhal da Serra, RS. In: SCHMITZ, P. I. (Ed.) Casas subterrâneas nas terras altas do sul do Brasil. Pesquisas - Antropologia, 58: 121-138.

COSTA, C. 2000 Indústrias líticas no alto Uruguai: um exemplo de análise tecnotipológica em arqueologia de salvamento. Dissertação de mestrado. Porto Alegre, Pontifícia Universidade Católica do Rio Grande do Sul.

CRABTREE, D. 1972 An introduction to flintwork. Ocassional Papers of Idaho State University Museum, $\mathrm{n}^{\circ} 28.99 \mathrm{p}$.

DANA, J. \& HURLBUT, C. 1976 Manual de mineralogia. Rio de Janeiro, Livros Técnicos e Científicos, S.A. 642 p.

DAVID, N. \& KRAMER, C. 2001 Ethnoarchaeology in action. Cambridge, Cambridge University Press. 476 p.

DE BLASIS, P. 1988 A ocupação pré-colonial do vale do Ribeira de Iguape, SP: os sítios líticos do médio curso. Dissertação de Mestrado. Universidade de São Paulo, São Paulo.

DE BLASIS, P. 1989 A indústria dos sítios líticos do médio vale do Ribeira do Iguape, SP: um ensaio tipológico. Revista de Pré-história, 7: 89-111.

DE BLASIS, P. 1990 Padrão de assentamento dos sítios líticos do médio vale do Ribeira de Iguape, S. Paulo. In: RIBEIRO, P. A. M. (Ed.) Anais da V Reunião Científica da Sociedade Brasileira de Arqueologia - Revista do CEPA, 17 (20): 87-100.

DE BLASIS, P. 1996 Bairro da Serra em três tempos: arqueologia, uso do espaço regional e continuidade cultural no médio vale do Ribeira. Tese de Doutorado. Universidade de São Paulo, São Paulo.

DE BLASIS, P. 1999 Indicadores da transição do Arcaico para o Formativo na região montanhosa do médio vale do Ribeira, SP. In: TENÓRIO, M. C. (Org.) Préhistória da Terra Brasilis. Editora UFRJ, Rio de Janeiro. 273-284 pp.

DE MASI, M. A 2001 Pescadores coletores da costa sul do Brasil. PesquisasAntropologia, 57: 1-136. 
DE MASI, M. A. \& SCHMITZ, P. I. 1987 Análise dos artefatos líticos de fases da Tradição Tupiguarani do Rio Grande do Sul. Arqueologia do Rio Grande do Sul Série Documentos, 1: 49-98.

DIAS, A. S. 1994 Repensando a Tradição Umbu através de um estudo de caso. Dissertação de Mestrado. Porto Alegre, Pontifícia Universidade Católica do Rio Grande do Sul.

DIAS, A. S. 1995a Um projeto para a arqueologia brasileira: breve histórico da implementação do PRONAPA. Revista do CEPA, 19 (22): 24-39.

DIAS, A. S. 1995b Análise tecno-tipológica da indústria lítica do abrigo sob rocha RSC-43: Capivara (Ivoti, RS). In: CONSENS, M.; LOPEZ-MAZZ, J. \& CURBELO, M. C. (Eds.) Arqueología en Uruguay - Anais do VIII Congresso Nacional de Arqueología Uruguaya. Editorial Surcos, Montevideo. 423-427 pp.

DIAS, A. S. 1996 Estudo da representatividade de pontas de projétil líticas enquanto marcadores temporais para a Tradição Umbu. In: KERN, A A (Org.) Anais da VIII Reunião Científica da Sociedade de Arqueologia Brasileira. Porto Alegre, Edipucrs. 309-332 pp.

DIAS, A. S. 1999a Painel dos últimos trinta anos de pesquisas arqueológicas dos caçadores coletores do sul do Brasil. Revista do CEPA, 23 (29): 52-59.

DIAS, A. S. 1999b Discutindo a variabilidade de indústrias líticas a partir da análise comparativa de coleções da Tradição Umbu. Comunicação apresentada no $X$ Congresso da Sociedade de Arqueologia Brasileira, Recife.

DIAS, A. S. 2000a A questão da variabilidade na obra de Lewis R. Binford e sua contribuição para a construção de uma teoria arqueológica. Revista do CEPA, 24 (31): 7-42.

DIAS, A. S. 2000b Resgate da coleção lítica do sítio arqueológico RS-S-358: Toca Grande, Santo Antônio da Patrulha (RS). In: MENDONÇA DE SOUZA, S. (Org). Arqueologia e suas interfaces disciplinares - Anais do IX Congresso da Sociedade de Arqueologia Brasileira. CDROM. SAB, Rio de Janeiro.

DIAS, A. S. 2000c Variabilidade lítica entre sítios caçadores coletores na região sul do Brasil: o caso de Santo Antônio da Patrulha, Rio Grande do Sul. Comunicação apresentada na II Reunião Internacional de Teoria Arqueológica na América do Sul. Universidad Nacional del Centro de la Provincia de Buenos Aires (UNCPBA), Olavarria.

DIAS, A S. 2001a Trajetórias e perspectivas teórico-metodológicas da arqueologia brasileira. Comunicação apresentada no XI Congresso da Sociedade de Arqueologia Brasileira, Rio de Janeiro.

DIAS, A S. 2001b Variabilidade lítica e o conceito de Tradição tecnológica: novos aportes para uma arqueologia de caçadores coletores no sul do Brasil. Comunicação apresentada no XI Congresso da Sociedade de Arqueologia Brasileira, Rio de Janeiro. 
DIAS, A. S. \& HOELTZ, S. 1997 Proposta metodológica para o estudo das indústrias líticas do sul do Brasil. Revista do CEPA, 21 (25): 21-62.

DIAS, A S. \& HOELTZ, S. 2002 Havia uma pedra no meio do caminho: indústrias líticas das Tradições Taquara e Guarani na região do alto rio dos Sinos. Comunicação apresentada no III Encontro da Regional da Sociedade de Arqueologia Brasileira (SAB/Sul), Porto Alegre.

DIAS, A. S. \& SILVA, F. 2001 Sistema tecnológico e estilo: as implicações desta inter-relação no estudo das indústrias líticas do sul do Brasil. Revista do Museu de Arqueologia e Etnologia, 11: 95-108.

DIBBLE, H.; CHASE, P.; McPHERRON, S. \& TUFFREAU, A. 1998 Testing the reality of a "living floor" with arcaheological data. American Antiquity, 62 (4): 629-651.

DUNNEL, R. \& DANCEY, W. 1983 The siteless survey: a regional scale data collection strategy. In: SCHIFFER, M. B. (Ed.) Advances in archaeological method and theory - Vol. 6. New York, Academic Press. 267-287 pp.

DWYER, P. \& MINNEGAL, M. 1991 Hunting in lowland, tropical rain forest: towards a model of non-agricultural subsistence. Human Ecology, 19 (2): 187-212.

ENDICOTT, K. 1997 Property, power and conflict among the Batek of Malaysia. In: INGOLD, T.; RICHES, D. \& WOODBURN, J. (Eds.) Hunters and gatherers 2: property, power and ideology. Oxford, Berg. 110-128 pp.

ENDICOTT, K. 1999 Gender relations in hunter-gatherer societies. In: LEE, R. \& DALY, R. (Eds.) The Cambridge Encyclopedia of Hunters and Gatheres. Cambridge, Cambridge University Press. 411-418 pp.

ENDICOTT, K. \& BELLWOOD, P. 1991 The possibility of independent foraging in the rain forest of peninsular Malaysia. Human Ecology, 19 (2): 151-185.

ENSOR, H. \& ROEMER, E. 1989 Comments on Sullivan and Rozen's debitage analysis and archaeological interpretations. American Antiquity, 54 (1): 175-178

EVANS, C. \& MEGGERS, B. 1965 Guia para a prospecção arqueológica no Brasil. Belém, Museu Paranaense Emílio Goeldi. 63 p.

FISH, S. \& KOWALEWSKI, S. (Eds.) 1990 The archaeology of regions: a case for full-coverage survey. Washington, Smithsonian Institution Press. 276 p.

FLENNIKEN, J. \& RAYMOND, A. 1986 Morphological projectile points tipology: replication, experimentation and technological analysis. American Antiquity, 51 (3): 603-614.

FORD, J. 1962 Método cuantitativo para establecer cronologías culturales. Washington, União Panamericana. 122 p.

FUNARI, P. P. 1994 Arqueologia brasileira: visão geral e reavaliação. Revista de História da Arte e Arqueologia, 1: 23-41. 
GALANIDOU, N. 2000 Patterns in caves: foragers, horticulturalists, and use of space. Journal of Anthropological Archaeology, 19: 243-275.

GALLAY, A. 1986 L’archéologie demain. Paris, Belfond. 319 p.

GAMBLE, C. 1990 El poblamiento Paleolítico de Europa. Barcelona, Editorial Crítica. $519 \mathrm{p}$.

GAMBLE, C. 2000 The Paleolithic societies of Europe. Cambridge, Cambridge University Press. 505 p.

GAMBLE, C. \& BOISMIER, W. (Eds.) 1991 Ethnoarchaeological approaches to mobile campsites: hunter-gatherer and pastoralist case studies. International Monographs in Prehistory - Ethnoarchaeological Series, $\mathrm{n}^{\circ}$ 1. Ann Arbor, University of Michigan Press. 420 p.

GARGETT, R. \& HAYDEN, B. 1991 Site structure, kinship, and sharing in aboriginal Australia: implications for archaeology. In: KROLL, E. \& PRICE, T. The interpretation of archaeological spatial patterning. New York, Plenum Press. 61$76 \mathrm{pp}$.

GARLET, I. \& SOARES, A. 1998 Cachimbos Mbyá-Guarani: aportes etnográficos para uma arqueologia Guarani. In: FUNARI, P. P. (Org.) Cultura material e arqueologia histórica. Campinas, IFCH/Unicamp. 251-274 pp.

GIBSON, T. 1997 Meat sharing as a political ritual: forms of transaction versus modes of subsistence. In: INGOLD, T.; RICHES, D. \& WOODBURN, J. (Eds.) Hunters and gatherers 2: property, power and ideology. Oxford, Berg. 165-180 pp.

GIFFORD-GONZALEZ, D.; DAMROSCH, D.; DAMROSCH, D.; PRYOR, J. \& THUNEN, R. 1985 The third dimension in site structure: an experiment in trampling and vertical dispersal. American Antiquity 50 (4): 803-818.

GOLDMEIER, V. \& SCHMITZ, P. I. 1989 A utilização da matéria-prima em sítios précerâmicos. In: SCATAMACCHIA, M. C. \& FLEMING, M. C. (Eds.). Anais da IV Reunião Científica da Sociedade Brasileira de Arqueologia - Dédalo, Publicações Avulsas, $n^{0}$ 1: 388-408.

GORECKI, P. 1991 Horticulturalists as hunter-gatherers: rock shelter usage in Papua New Guinea. In: GAMBLE, C. \& BOISMIER, W. (Eds) Ethnoarchaeological approaches to mobile campsites: hunter-gatherer and pastoralist case studies. International Monographs in Prehistory - Ethnoarchaeological Series, $\mathrm{n}^{0}{ }^{1}$. Ann Arbor, University of Michigan Press. 237-262 pp.

GOULD, R. 1971 The archaeologist as ethnographer: a case study from the western desert of Australia. World Archaeology, 3: 143-177.

GOULD, R. 1978 The anthropology of human residues. American Anthropologist, 86: 815-835.

GOULD, R. 1980 Living Archaeology. Cambridge, Cambridge University Press. 270 pp. 
GOULD, R. 1995 “Now let's invent agriculture...”: a critical review of concepts of complexity among hunter-gatherers. In: PRICE, D. \& BROWN, J. (Eds.) Prehistoric hunter-gatherers: the emergence of cultural complexity. London, Academic Press. 427-435 pp.

GOULD, R. \& YELLEN, J. 1987 Man the hunted: determinants of household spacing in desert and tropical foraging societies. Journal of Anthropological Archaeology, 6: 77-103.

GOULD, R. \& YELLEN, J. 1991 Misreading the past: a reply to Binford concerning hunter-gatherer site structure. Journal of Anthropological Archaeology, 10: 283298.

GOWDY, J. 1998 Back to the future and forward to the past. In: GOWDY, J. (Ed.) Limited wants, unlimited means. Washington, Island Press. 15-31 pp.

GOWDY, J. 1999 Hunter-gatherers and the mythology of the market. In: LEE, R. \& DALY, R. (Eds.) The Cambridge Encyclopedia of hunters and gatherers. Cambridge, Cambridge University Press. 391-398 pp.

GRALA, M. \& LORCHEIDER, M. L. 2001 Paleoambientes em Serra Velha, RS, Brasil, durante do Holoceno. Boletim de Resumos do VIII Congresso da ABEQUA: 393-394.

GREGG, S.; KINTIGH, K. \& WHALLON, R. 1991 Linking ethnoarchaeological interpretation and archaeological data: the sensitivity of spatial analytical methods to postdepositional disturbance. In: KROLL, E. \& PRICE, T. (Eds.) The interpretation of archaeological spatial patterning. New York, Plenum Press. 149196 pp.

GREHS, S. 1976 Mapeamento geológico preliminar de Santa Cruz do Sul visando obter informações básicas ao planejamento integrado. Acta Geológica Leopoldense Estudos Tecnológicos, 1: 121-175.

HAYDEN, B. 1996 Competition, labor, and complex hunter-gatherers. In: BURCH, E. \& ELLANNA, L. (Eds.) Key issues in hunter-gatherer research. Oxford, Berg. 223-239 pp.

HAYDEN, B.; ELDRIDGE, M.; ELDRIDGE, A. \& CANNON, A. 1995 Complex hunter-gatherers in interior British Columbia. In: PRICE, D. \& BROWN, J. (Eds.) Prehistoric hunter-gatherers: the emergence of cultural complexity. London, Academic Press. 181-199 pp.

HEADLAND, T. 1987 The wild yam question: how well could independent huntergatherers live in a tropical rain forest ecosystem? Human Ecology, 15 (4): 463-491.

HEADLAND, T. \& REID, L. 1989 Hunter-gatherers and their neighbours from prehistory to the present. Current Anthropology, 30 (1): 43-66.

HEADLAND, T. \& BAILEY, R. 1991 Introduction: have hunther-gatherers ever lived in tropical rain forest independently of agriculture? Human Ecology, 19 (2): 115122. 
HEGMON, M. 1992 Archaeological research on style. Annual Review in Anthropology, 21: 517-536.

HENRIQUES, G. 2002 O material lítico da UHE Quebra-Queixo. In: CALDARELLI, S. (Org.) Projeto de resgate arqueológico na área diretamente afetada da UHE Quebra-Queixo, SC. Relatório final. Florianópolis, Scientia Ambiental.

HENRIQUES, G. \& PASSOS, J. L. 2001 Análise tecno-tipológica do material lítico de um sítio da Tradição Itararé localizado no noroeste de Santa Catarina. Comunicação apresentada no XI Congresso da Sociedade de Arqueologia Brasileira, Rio de Janeiro.

HIETALA, H. 1984 Variations on a categorical data theme: local and global considerations with Near-eastern Paleolithic applications. In: HIETALA, H. (Ed.) Intrasite spatial analysis in archaeology. Cambridge, Cambridge University Press. 44-53 pp.

HITCHCOCK, R. 1999 Indigenous peoples' rights and the struggle for survival. In: LEE, R. \& DALY, R. (Eds.) The Cambridge Encyclopedia of Hunters and Gatheres. Cambridge, Cambridge University Press. 480-486 pp.

HILBERT, K. 1994 Caçadores-coletores pré-históricos no sul do Brasil: um projeto para uma redefinição das Tradições líticas Umbu e Humaitá. In: FLORES, M. (Org.). Negros e índios: literatura e história. Porto Alegre, Edipucrs. 9-24 pp.

HILBERT, K.; HOELTZ, S. \& COSTA, C. 1999 Estudo tecno-tipológico e funcional do material lítico. In: MONTICELLI, G. \& BERTOLLETTI, J. (Orgs.) Relatório técnico semestral: salvamento arqueológico nas áreas do canteiro de obras e estruturas da UHE Machadinho (fases 1 e 2). Porto Alegre, MCT/PUCRS.

HILBERT, K.; HOELTZ, S. \& COSTA, C. 2000 Resultado da análise tecno-tipológica da indústria lítica dos sítios arqueológicos localizados na área da UHE Machadinho - fase 3. In: MONTICELLI, G. \& BERTOLLETTI, J. (Orgs.) Salvamento arqueológico em área do futuro reservatório da UHE Machadinho (fase 3): análise do material lítico e fito-faunístico - Vol. 3. Porto Alegre, MCT/PUCRS.

HIVERNEL, F. \& HODDER, I. 1984 Analysis of artifact distribution at Ngenyn (Kenya): depositional and post depositional effects. In: HIETALA, H. (Ed.) Intrasite spatial analysis in archaeology. Cambridge, Cambridge University Press. 97-115 pp.

HODDER, I. 1977 Some new directions in the spatial analysis of archaeological data at the regional scale (macro). In: CLARKE, D. (Ed.) Spatial archaeology. London, Academic Press. 223-352 pp.

HODDER, I. \& ORTON, C. [1976] 1990 Análisis espacial en arqueología. Barcelona, Editorial Crítica. 295 p.

HOELTZ, S. 1995 As Tradições Umbu e Humaitá: releitura das indústrias líticas das fases Rio Pardinho e Pinhal através de uma proposta alternativa de investigação. Dissertação de mestrado. Porto Alegre, Pontifícia Universidade Católica do Rio Grande do Sul. 
HOELTZ, S. 1997a Artesãos e artefatos pré-históricos do vale do rio Pardo. Santa Cruz do Sul, Edunisc. 180 p.

HOELTZ, S. 1997b As Tradições Umbu e Humaitá: sítios Bom Jardim Velho (RS-C14) e Boa Vista 2 (RS-Vz-25): características tecno-tipológicas. In: MENDONÇA DE SOUZA, S. (org). Arqueologia e suas interfaces disciplinares: Anais do IX Congresso da Sociedade de Arqueologia Brasileira. CDROM. Rio de Janeiro.

HOELTZ, S. \& HILBERT, K. 2000 Análise da indústria lítica do sítio RS-LC-76. In: HILBERT, K. P.; MONTICELLI, G.; CARLE, C.; DIMICKS, J.; HOELTZ, S. \& CAPPELLETTI, A. Pesquisas arqueológicas no sítio arqueológico RS-LC-76, Osório, RS - Relatório de arqueologia de salvamento relativo ao oleoduto OsórioCanoas para a Empresa Copesul. Porto Alegre, CEPA/PUCRS.

HOELTZ, S. \& BRÜGGEMANN, A. 2003 Análise das indústrias líticas da margem direita do rio Pelotas da UHE Barra Grande. In: CALDARELLI, S. (Org.) Projeto de levantamento arqueológico na área de inundação e salvamento arqueológico no canteiro de obras da UHE Barra Grande, SC/RS - Relatório final 2: salvamento arqueológico no canteiro de obras, margem direita e esquerda do rio Pelotas. Resultado dos trabalhos laboratoriais, Vol. 1. Florianópolis, Scientia Ambiental.

HUDSON, J. (Ed.) 1993 From bones to behavior: ethnoarchaeological and experimental contributions to the interpretation of faunal remains. Center for Archaeological Investigations Occasional Paper, $n^{0}$ 21. Carbondale, South Illinois University Press. 353 p.

IBGE 1986 Levantamento de recursos naturais: geologia, geomorfologia, pedologia, vegetação e uso potencial da terra (V. 33, folha SH 22, Porto Alegre e parte das folhas SH 21, Uruguaiana, e SI 22, Lagoa Mirim). Rio de Janeiro, Fundação Instituto Brasileiro de Geografia e Estatística. 791 pp.

INGOLD, T. 1986 The appropriation of nature: essays in human ecology and social relations. Manchester, Manchester University Press.

INGOLD, T. 1988 Notes on foraging mode of prodution. In: INGOLD, T.; RICHES, D. \& WOODBURN, J. (Eds.) Hunters and gatherers 1: history, evolution and social change. Oxford, Berg. 269-285 pp.

INGOLD, T. 1992 Foraging for data, camping with theories: hunter-gatherers and nomadic pastoralists in archaeology and anthropology. Antiquity, 66: 790-803.

INGOLD, T. 1999 On the social relations of the hunter-gatherer band. In: LEE, R. \& DALY, R. (Ed.) The Cambridge Encyclopedia of Hunters and Gatheres. Cambridge, Cambridge University Press. 399-410 pp.

INGOLD, T. 2000 The perception of the environment: essays on livehood, dwelling and skill. London, Routledge. 464 p.

IZIDRO, J. 2001 O jazigo funerário de Içara no contexto litorâneo catarinense. Dissertação de mestrado. São Leopoldo, Universidade do Vale do Rio dos Sinos. 
JACOBUS, A. 1994a Projeto Arqueológico de Santo Antônio da Patrulha (PASAP). Taquara, Museu Arqueológico do Rio Grande do Sul.

JACOBUS, A 1994b Relatório de prospecção arqueológica em Santo Antônio da Patrulha. Taquara, Museu Arqueológico do Rio Grande do Sul.

JACOBUS, A. 1996a Resgate arqueológico e histórico do Registro de Viamão (Guarda Velha, Santo Antônio da Patrulha, Rio Grande do Sul). Dissertação de mestrado. Porto Alegre, Pontifícia Universidade Católica do Rio Grande do Sul.

JACOBUS, A. 1996b Louças e cerâmicas no sul do Brasil no século XVIII: o Registro de Viamão como estudo de caso. Revista do CEPA, 20 (23): 7-58.

JACOBUS, A. 1998 O Registro de Viamão: um pedágio do século VIII na América Portuguesa. Revista do CEPA, 22 (27/28): 63-76.

JACOBUS, A 2000 Caçadores coletores na mata atlântica: um estudo de caso na região hidrográfica da bacia do Lago Guaíba e Planície Litorânea Adjacente (RS). Memorial de qualificação de doutorado. São Paulo, Universidade de São Paulo.

JACOBUS, A.; DIAS, A. S. \& THADDEU, V. 1995 Projeto arqueológico no município de Santo Antônio da Patrulha (Rio Grande do Sul). In: CONSENS, M.; LOPEZ-MAZZ, J. \& CURBELO, M. C. (Eds.) Arqueología en Uruguay - Anais do VIII Congresso Nacional de Arqueología Uruguaya. Editorial Surcos, Montevideo. 428-431 pp.

JELINEK, A. 1976 Form, function, and style in lithic analysis. In: CLELAND, C. (Ed.) Cultural change and continuity. New York, Academic Press. 19-33 pp.

JESKE, R. [1989] 1998 Economies in raw material use by prehistoric hunter-gatherers. In: TORRENCE, R. (Ed.) Time, energy and stone tools. Cambridge, Cambridge University Press. 34-45 pp.

JOHNSON, I. 1984 Cell frequency recording and analysis of artifact distributions. In: HIETALA, H. (Ed.) Intrasite spatial analysis in archaeology. Cambridge, Cambridge University Press. 75-96 pp.

JOHNSON, L. 1978 A history of flint-knapping experimentattion, 1838-1976. Current Anthropology, 19 (2): 337-372.

JONES, K. 1993 The archaeological structure of a short-term camp. In: HUDSON, J. (Ed.) From bones to behavior: ethnoarchaeological and experimental contributions to the interpretation of faunal remains. Center for Archaeological Investigations Occasional Paper, $n^{\circ} 21$. Carbondale, South Illinois University Press. 101-116 pp.

KAARE, B. 1996 The impact of modernization policies on the hunter-gatherer Hazdabe: the case of education and language policies of postindependence Tanzania. In: BURCH, E. \& ELLANNA, L. (Eds.) Key issues in hunter-gatherer research. Oxford, Berg. 315-331 pp. 
KEELEY, L. 1991 Tool use and spatial patterning: complications and solutions. In: KROLL, E. \& PRICE, T. (Eds.) The interpretation of archaeological spatial patterning. New York, Plenum Press. 257-268 pp.

KEENE, A. 1983 Biology, behavior and borrowing: a critical examination of optimal foraging theory in archaeology. In: MOORE, J. \& KEENE, A. (Eds.) Archaeological hammers and theories. New York, Academic Press. 137-155 pp.

KELLY, R. 1995 The foraging spectrum: diversity in hunter-gatherer lifeways. Washington, Smithsonian Institution Press. 446 p.

KELLY, R. 2000 Elements of a behavioral ecological paradigm for the study of prehistoric hunter-gatherers. In: SCHIFFER, M. (Ed.) Social theory in archaeology. Salt Lake City, The University of Utah Press. 63-78 pp.

KENT, S. 1984 Analyzing activity areas: an ethnoarchaeological study of the use of space. New Mexico, University of New Mexico Press. 259 p.

KENT, S. 1987 Understanding the use of space: an ethnoarchaeolgical approach. In: KENT, S. (Ed.) Method and theory for activity area research: an ethnoarchaeological approach. New York, Columbia University Press. 1-60 pp.

KENT, S. 1991 The relationship between mobility strategies and site structure. In: KROLL, E. \& PRICE, T. (Eds.) The interpretation of archaeological spatial patterning. New York, Plenum Press. 33-60 pp.

KENT, S. (Ed.) 1993a Domestic architecture and the use of space: an interdisciplinary cross-cultural study. New York, Cambridge University Press. 192 p.

KENT, S. 1993b Variability in faunal assemblages: the influence of hunting skill, sharing, dogs, and mode of cooking on faunal remains at a sedentary Kalahari community. Journal of Anthropological Archaeology, 12: 323-385.

KENT, S. 1996 Cultural diversity among african foragers: causes and implications. In: KENT, S. (Ed.) Cultural diversity among twentieth-century foragers. Cambridge, Cambridge University Press. 1-18 pp.

KERN, A. 1981 Le Précéramique du Plateau Sud-Brésilien. Tese de doutorado. Paris, École des Hautes Étude en Sciences Sociales.

KERN, A. 1983 Variáveis para a definição e caracterização das Tradições précerâmicas Umbu e Humaitá. Revista do IFCH-UFRGS, 11/12: 105-115.

KERN, A. 1991a Grupos pré-históricos de caçadores-coletores da floresta subtropical. In: KERN, A. (Org.). Arqueologia pré-histórica do Rio Grande do Sul. Porto Alegre, Mercado Aberto. 135-166 pp.

KERN, A. 1991b Paleopaisagens e povoamento pré-histórico do Rio Grande do Sul. In: KERN, A. (Org.). Arqueologia pré-histórica do Rio Grande do Sul. Porto Alegre, Mercado Aberto. 13-61 pp. 
KINTIGH, K. 1988 The effectiveness of subsurface testing: a simulation approach. American Antiquity, 53 (4): 686-707.

KIPNIS, R. 2002 Foraging societies of eastern Central Brazil: an evolutionary ecological study of subsistence strategies during the terminal Pleistocene and early/middle Holocene. Tese de doutorado. Ann Arbor, University of Michigan.

KOOYMAN, B. 2001 Understanding stone tools and the archaeological sites. Albuquerque, University of New Mexico Press. 206 pp.

KRAKKER, J.; SHOTT, M. \& WELCH, P. 1983 Design and evaluation of shovel-test in regional archaeological survey. Journal of Field Archaeology, 10: 469-480.

KREVER, M. L.; GOMES, J. \& HAUBERT, F. 1998 Os sepultamentos de Içara: resultados. Comunicação apresentada no I Encontro da Regional Sul da SAB (SAB/SUL). São Leopoldo, IAP/UNISINOS.

KREVER, M. L. \& HAUBERT, F. 2001 Estudo dos remanescentes humanos do planalto sul-riograndense: projeto Vacaria. Comunicação apresentada no $X I$ Congresso da Sociedade de Arqueologia Brasileira, Rio de Janeiro.

KROLL, E. \& PRICE, T. 1991 Introduction. In: KROLL, E. \& PRICE, T. (Eds.) The interpretation of archaeological spatial patterning. New York, Plenum Press. 1-6 pp.

KUNH, S. 1991 “Unpacking” reduction: lithic raw material economy in the Mousterian of West-central Italy. Journal of Anthropological Archaeology, 10: 76-106.

KUNH, S. 1992 On planning and curated technologies in the Middle Paleolithic. Journal of Anthropological Research, 48(3): 185-214.

LAMING-EMPERAIRE, A. 1967 Guia para o estudo das indústrias líticas da América do Sul. Curitiba, CEPA/UFPR. 155 p.

LANATA, J. 1997 Los componientes del paisaje arqueológico. Revista de Arqueología Americana, 13: 151-165.

LANDA, B. 1995 A mulher Guarani: atividades e cultura material. Dissertação de mestrado. Porto Alegre, Pontifícia Universidade Católica do Rio Grande do Sul.

LANDA, B. 1999 Arqueologia Guarani e gênero. Revista do CEPA, 23 (29): 240-244.

LA SALVIA, F. \& BROCHADO, J. 1989 Cerâmica Guarani. Porto Alegre, Posenato Arte e Cultura. 175 p.

LAVINA, R. 1994 Os Xokleng de Santa Catarina: uma etnohistória e sugestões para os arqueólogos. Dissertação de mestrado. São Leopoldo, Universidade do Vale do Rio dos Sinos.

LAYTON, R. 2001 Hunter-gatherers, their neighbours and the nation state. In: PANTER-BRICK; LAYTON, R \& ROWLEY-CONWY, P. (Eds.) Hunter- 
gatherers: an interdisciplinary perspective. Cambridge, Cambridge University Press. 292-321 pp.

LEACOCK, E. [1992] 1998 Women's status in egalitarian society: implications for social evolution. In: GOWDY, J. (Ed.) Limited wants, unlimited means. Washington, Island Press. 139-164 pp.

LEACOCK, E. \& LEE, R. 1982 Introduction. In: LEACOCK, E. \& LEE, R. (Eds.) Politics and history in band societies. Cambridge, Cambridge University Press. 1$19 \mathrm{pp}$.

LEE, R. 1968 What hunters do for a living, or, how to make out on scarce resources. In: LEE, R. \& DeVORE, I. (Eds.) Man, the Hunter. Chicago, Aldine Publishing Company. 30-48 pp.

LEE, R. 1981 Is there a foraging mode of production? Canadian Journal of Anthropology, 2 (1): 13-19.

LEE, R. 1988 Reflections on primitive communism. In: INGOLD, T.; RICHES, D. \& WOODBURN, J. (Eds.) Hunters and gatherers 1: history, evolution and social change. Oxford, Berg. 252-268 pp.

LEE, R. 1991 The !Kung in question: evidence and context in the Kalahari debate. In: MIRACLE, P.; FISHER, L. \& BROWN, J. (Eds.) Foraging in context: long-term, regional, and historical perspectives in hunter-gatherer studies. Michigan discussions in anthropology, vol. 10. Ann Arbor, University of Michican Press. 916 pp.

LEE, R. [1992] 1998 Art, science, or politics? The crisis in hunter-gatherer studies. In: GOWDY, J. (Ed.) Limited wants, unlimited means. Washington, Island Press. 165200 pp.

LEE, R. \& DeVORE, I. 1968 Problems in the study of hunters and gatherers. In: LEE, R. \& DeVORE, I. (Eds.) Man, the Hunter. Chicago, Aldine Publishing Company. 3-12 pp.

LEE, R. \& DeVORE, I. (Eds.) 1998 Kalahari hunter-gatherers: studies of the !Kung San and their neighbors. Cambridge, Harvard University Press. 408 p.

LEE, R. \& DALY, R. 1999 Introdution: foragers and others. In: LEE, R. \& DALY, R. (Eds.) The Cambridge Encyclopedia of Hunters and Gatheres. Cambridge, Cambridge University Press. 1-19 pp.

LEINZ, V. \& AMARAL, S. 1989 Geologia geral. São Paulo, Editora Nacional. 399 p.

LIGHTFOOT, K. 1986 Regional surveys in the Eastern United States: the strenghts and weaknesses of implementing subsurface testing programs. American Antiquity, 51 (3): 484-504.

LIGHTFOOT, K. 1989 A defense of shovel-test sampling: a reply to Shott. American Antiquity, 54 (2): 413-416. 
LINARES, O. 1976 “Garden hunting” in the american tropics. Human Ecology, 4 (4): 331-349.

LURIE, R. [1989] 1998 Lithic technology and mobility strategies: the Koster site Middle Archaic. In: TORRENCE, R. (Ed.) Time, energy and stone tools. Cambridge, Cambridge University Press. 46-56 pp.

MAGNE, M. 1989 Lithic reduction stages and assemblage formation preocess. In: AMICK, D. e MAULDING, R. (Eds.) Experiments in lithic technology. BAR International Series, 528. 15-31 pp.

MARTIN, J. 1983 Optimal foraging theory: a review of some models and their applications. American Anthropologist, 85 (3): 612-629.

MEDEANIC, S.; DILLEMBURG, S. \& TOLDO, E. 2001 Registro palinológico da transgressão marinha pós-glacial e sedimentos da Laguna dos Patos. Boletim de Resumos do VIII Congresso da ABEQUA: 393-394.

MEGGERS, B. \& EVANS, C. 1970 Como interpretar a linguagem cerâmica: guia para arqueólogos. Washington, Smithsonian Institution Press. 111 p.

MEGGERS, B. \& EVANS, C. 1977 Lowlands of South America and Antilles. In: JENNINGS. D (Ed.) Ancient native americans. San Francisco, Freeman and Company. 543-591 pp.

MERCULIEFF, I. 1996 Western society's linear systems and the aboriginal cultures: the need for two-way exchanges for sake of survival. In: BURCH, E. \& ELLANNA, L. (Eds.) Key issues in hunter-gatherer research. Oxford, Berg. 405$415 \mathrm{pp}$.

MILDER, S. 1994 A fase Ibicuí: uma revisão arqueológica, cronológica e estratigráfica. Dissertação de mestrado. Porto Alegre, Pontifícia Universidade Católica do Rio Grande do Sul.

MILDER, S. 1995 Uma breve análise da fase arqueológica Ibicuí. Revista do CEPA 19 (22): 41-63.

MILLER, E. 1967 Pesquisas arqueológicas efetuadas no nordeste do Rio Grande do Sul. In: SIMÕES, M. (Ed.). Programa Nacional de Pesquisas Arqueológicas: resultados preliminares do primeiro ano (1965-1966). Belém, Museu Paranaense Emílio Goeldi. 15-38 pp.

MILLER, E. 1969 Resultados preliminares das escavações no sítio pré-cerâmico RSLN-01: Cerrito Dalpiaz (abrigo-sob-rocha). Iheríngia Antropologia, 1: 43-116.

MILLER, E. 1971 Pesquisas arqueológicas efetuadas no planalto meridional, Rio Grande do Sul. In: SIMÕES, M. (Ed.). Programa Nacional de Pesquisas Arqueológicas: resultados preliminares do quarto ano (1968-1969). Belém, Museu Paranaense Emílio Goeldi. 37-70 pp.

MILLER, E. 1974 Pesquisas arqueológicas em abrigos-sob-rocha no nordeste do Rio Grande do Sul. In: SIMÕES, M. (Ed.). Programa Nacional de Pesquisas 
Arqueológicas: resultados preliminares do quinto ano (1969-1970). Belém, Museu Paraense Emílio Goeldi. 11-24 pp.

MILLER, T. 1978 Tecnologia cerâmica dos Kaingang paulista. Arquivos do Museu Paranaense - Etnologia, 2: 1-51.

MONAHAN, C. 1998 The Hazda carcass transport debate revisited and its archaeological implications. Journal of Archaeological Science, 25: 405-424.

MONTICELLI, G. 1995 Vasilhas cerâmicas Guarani: um resgate da memória entre os Mbyá. Dissertação de mestrado. Porto Alegre, Pontifícia Universidade Católica do Rio Grande do Sul.

MONTICELLI, G. 1999 Análise das informações obtidas com os Mbyá-Guarani sobre suas antigas vasilhas de cerâmica. Revista do CEPA, 23 (29): 233-239.

MORAIS, J. L. 1999 Arqueologia e fator Geo. Revista do Museu de Arqueologia e Etnologia, 9: 3-22.

MORAIS, J. L. 2000 Tópicos de arqueologia da paisagem. Revista do Museu de Arqueologia e Etnologia, 10: 3-30.

MORROW, C. \& JEFFERIES, R. [1989] 1998 Trade or embedded procurement? A test case from southern Illinois. In: TORRENCE, R. (Ed.) Time, energy and stone tools. Cambridge, Cambridge University Press. 27-33 pp.

MUNDAY, F. 1984 Middle Paleolithic intrasite variability and its relationship to regional patterning. In: HIETALA, H. (Ed.) Intrasite spatial analysis in archaeology. Cambridge, Cambridge University Press. 32-43 pp.

MURRAY, P. 1980 Discard location: the ethnographic data. American Antiquity 45 (3): 490-502.

MYERS, F. 1988 Critical trends in the study of hunter-gatherers. Annual Review of Anthropology, 17: 261-282.

MYERS, T. 1992 Agriculture limitations of the Amazon in theory and practice. World Archaeology, 24 (1).

NANCE, J. 1979 Regional subsampling and statistical inference in forested habitats. American Antiquity, 44 (1): 172-176.

NANCE, J. \& BALL, B. 1986 No surprises? The reability and validity of test pit sampling. American Antiquity, 51 (3): 457-483.

NANCE, J. \& BALL, B. 1989 A shot in the dark: a reply to Shott. American Antiquity, 54 (2): 405-412.

NELSON, M. 1991 The study of technological organization. In: SCHFFER, M. (Ed.) Archaeological method and theory - Vol. 3. Tucson, University of Arizona Press. 57-100 pp. 
NEVES, E. G. 1999 O velho e o novo na arqueologia amazônica. Revista da USP, 44 (1): 86-111.

NICHOLSON, A. \& CANE, S. 1991 Desert camps: analysis of australian aboriginal proto-historic campsites. In: GAMBLE, C. \& BOISMIER, W. (Eds.) Ethnoarchaeological approaches to mobile campsites: hunter-gatherer and pastoralist case studies. International Monographs in Prehistory Ethnoarchaeological Series, $n^{0} 1$. Ann Arbor, University of Michigan Press. 263354 pp.

NOELLI, F. 1993 Sem Tekhoa não há Tekó (em busca de um modelo etnoarqueológico da aldeia e da subsistência Guarani e sua aplicação a uma área de domínio no delta do rio Jacuí, Rio Grande do Sul). Dissertação de mestrado. Porto Alegre, Pontifícia Universidade Católica do Rio Grande do Sul.

NOELLI, F. 1996a As hipóteses sobre os centros de origem e as rotas de expansão dos Tupi. Revista de Antropologia, 39 (2): 7-54.

NOELLI, F. 1996b Resposta a Eduardo Viveiros de Castro e Greg Urban. Revista de Antropologia, 39 (2): 105-118.

NOELLI, F. 1998a The Tupi: explaining origin and expansion in terms of archaeology and historical linguistics. Antiquity, 72 (277): 648-663.

NOELLI, F. (Org.) 1998b Bibliografia Kaingang: referências sobre um povo Jê do sul do Brasil. Londrina, Editora da Universidade Estadual de Londrina. 185 p.

NOELLI, F. 1999 Repensando os rótulos e a história dos Jê no sul do Brasil a partir de uma interpretação interdisciplinar. In: FUNARI, P. P.; NEVES, E. G. \& PODGORNY, I. (Orgs.). Teoria arqueológica na América do Sul - Revista do Museu de Arqueologia e Etnologia - Suplementos 3: 285-302.

NOELLI, F. 1999/2000 A ocupação humana na região sul do Brasil: arqueologia, debates e perspectivas - 1872/2000. Revista USP, 44 (2): 218-269.

NOELLI, F. \& DIAS, A. S. 1995 Complementos históricos ao estudo funcional da indútria lítica Guarani. Revista do Cepa, 19(22): 7-32.

NOELLI, F. \& BROCHADO, J. 1998 O cauim e as beberragens dos Guarani e Tupinambá: equipamentos, técnicas de preparação e consumo. Revista do Museu de Arqueologia e Etnologia, 8: 117-128.

O’BRIEN. M. \& LYMAN, L. 2000 Evolutionary archaeology; reconstructing and explaining historical linages. In: SCHIFFER, M. (Ed.) Social theory in archaeology. Salt Lake City, The University of Utah Press. 126-142 pp.

O’BRIEN. M. (Ed.) 1996 Evolutionary archaeology: theory and application. Salt Lake City, University of Utah Press.

O’CONNEL, J. 1987 Alyawara site structure and its archaeological implications. American Antiquity, 52 (1): 74-108. 
O’CONNEL, J.; HAWKES, K. \& JONES, N. 1988 Hazda hunting, butchering, and bone transport and their archaeological implications. Journal of Anthropological Research, 44 (2): 113-161.

O’CONNEL, J.; HAWKES, K. \& JONES, N. 1990 Reanalysis of large mammal body part transport among the Hazda. Journal of Archaeological Science, 17: 301-316.

O’CONNEL, J.; HAWKES, K. \& JONES, N. 1991 Distribution of refuse-producing activities at Hazda residential base camps: implications for analyses of archaeological site structure. In: KROLL, E. \& PRICE, T. (Eds.) The interpretation of archaeological spatial patterning. New York, Plenum Press. 61-76 pp.

O’CONNEL, J.; HAWKES, K. \& JONES, N. 1992 Patterns in the distribution, site structure and assemblage composition of Hazda kill-butchering sites. Journal of Archaeological Science, 19: 319-345.

ODELL, G. 1994 Assessing hunter-gatherer mobility in the Illinois valley: exploring ambiguos results. In: CARR, P. (Ed.) The organization of North American prehistoric chipped stone tool technologies. International Monographs in Prehistory, Archaeological Series 7. Ann Arbor, University of Michigan Press. 9$34 \mathrm{pp}$.

ODELL, G. 1996 Economizing behavior and the concept of “curation”. In: ODELL, G. (Ed.) Stone tools: theoretical insights into human prehistory. New York, Plenum Press. 51-79 pp.

PARKINGTON, J. \& MILLS, G. 1991 From space to place: the architecture and social organisation of southern african mobile communities. In: GAMBLE, C. \& BOISMIER, W. (Eds.). Ethnoarchaeological approaches to mobile campsites: hunter-gatherer and pastoralist case studies. International Monographs in Prehistory - Ethnoarchaeological Series, $\mathrm{n}^{0} 1$. Ann Arbor, University of Michigan Press. 355-370 pp.

PARSONS, J. 1972 Archaeological settlement patterns. Annual Review of Anthropology, 1: 127-150.

PAYNE, S. 1983 Bones from cave sites: who ate what? Problems and a case study. In: CLUTON-BOOCK, J. \& GRIGSON, C. (Eds.). Animals and archaeology: hunters and their preys. Oxford, BAR International Series, 163. 149-162 pp.

PERLÈS, C. 1992 In search of lithic strategies: a cognitive approach to prehistoric chipped stone assemblages. In: GARDIN, J-C \& PEEBLE, C. (Eds.). Representations in archaeology. Indiana University Press. 223-247 pp.

PLOG, F. \& HILL, J. 1971 Explaining variability in the distribution of sites. In: GUMERMAN, G. (Ed.) The distribution of prehistoric agregates. Prescott College Anthropological Reports, 1: 7-36.

PLOG, S. 1976 Relative efficiencies of sampling techniques for archaeological surveys. In: FLANNERY, K. (Ed.) The Early Mesoamerican Village. New York, Academic Press. 136-160 pp. 
PLOG, S.; PLOG, F. \& WAIT, W. 1978 Decision making in modern surveys. In: SCHIFFER, M. (Ed.) Advances in archaeological method and theory - Vol. 1. New York, Academic Press. 383-421 pp.

POLITIS, G. 1996a Nukak. Bogotá, Insituto Amazonico de Investigaciones Científicas. $426 \mathrm{p}$.

POLITIS, G. 1996b Moving to produce: Nukak mobility and settlement patterns in Amazonia. World Archaeology, 27 (3): 492-511.

POLITIS, G. 1996c Un caso de estudio etnoarqueológico: la formación de sitios de cazadores-recolectores en las tierras bajas sudamericanas. In: COIROLO, A. \& BRACCO-BOKSAR, R. (Eds.) Arqueología de las Tierras Bajas. Montivideo, Ministerio de Educación y Cultura/Comisión Nacional de Arqueología. 427-449 pp.

POLITIS, G. 1998 Arqueología de la infancia: una perspectiva etnoarqueológica. Trabajos de prehistoria, 55 (2): 5-19.

POLITIS, G. 2001 Foragers of the Amazon: the last survivors or the first to succed? In: McEWAN, C.; BARRETO, C. \& NEVES, E. (Eds.) Unknown Amazon. London, The British Museum Press. 26-49 pp.

POLITIS, G. 2003 The theoretical landscape and the methodological development of archaeology in Latin America. American Antiquity, 68 (2): 245-272.

POLITIS, G.; MARTINEZ, G. \& RODRÍGUEZ, J. 1997 Caza, recolección y pesca como estrategia de explotación de recursos en florestas tropicales lluviosas: los Nukak de la amozonía colombiana. Revista Española de Antropología Americana, 21: 167-197

POLITIS, G. \& SAUNDERS, N. 2001 Archaeological correlates of ideological activity: food taboos and spirit-animals in an amazonian hunter-gatherer society. In: MIRACLE, P. \& MILNER, N. (Eds.) Consuming passions and patterns of consumption. Cambridge, McDonald Institute Monographs. 113-130 pp.

PRENTISS, W. 1998 The reability and validity of a lithic debitage typology: implications for archaeological interpretation. American Antiquity, 63 (4): 635650.

PRICE, D. \& BROWN, J. 1995 Aspects of hunter-gatherer complexity. In: PRICE, D. \& BROWN, J. (Eds.) Prehistoric hunter-gatherers: the emergence of cultural complexity. London, Academic Press. 3-20 pp.

PROUS, A. 1992 Arqueologia Brasileira. Brasília, Editora UnB. 605 p.

PROUS, A. 1996 Histórico do setor de arqueologia da UFMG e o papel das Missões Franco-brasileiras. In: KERN, A. (Org.) Anais da VIII Reunião Científica da Sociedade de Arqueologia Brasileira. Porto Alegre, EDIPUCRS. 131-150 pp.

PROUS, A. 1999 Arqueologia, pré-história e história. In: TENÓRIO, M. C. Préhistória da Terra Brasilis. Rio de Janeiro, Editora UFRJ. 19-34 pp. 
RAMBO, B. [1956] 1994 A fisionomia do Rio Grande do Sul. São Leopoldo, Editora Unisinos. $472 \mathrm{p}$.

RAPP, G. \& HILL, C. 1998 Geoarchaeology: the earth-science approach to archaeological interpretation. New Haven, Yale University Press. 274 p.

REDMAN, C. 1973 Multistage fieldwork and analytical techniques. American Antiquity, 38 (1): 61-79.

REEDY, C. \& REEDY, T. 1994 Relating visual and technological styles in Tibetan sculpture analysis. World Archaeology, 25 (3): 304-320.

REIS, J. A. 1997 Para uma arqueologia dos buracos de bugre: do sintetizar, do problematizar, do propor. Dissertação de mestrado. Porto Alegre, Pontifícia Universidade Católica do Rio Grande do Sul.

REIS, J. A. 2002 Arqueologia dos buracos de bugre: uma pré-história do planalto meridional. Caxias do Sul, Educs. 228 p.

RENFREW, C. \& BAHN, P. 1995 Arqueologia: teorias, métodos y práctica. Madrid, Akal Editor. 571 p.

RIBEIRO. P. A M. 1978 Arte rupestre no sul do Brasil. Revista do CEPA, 7: 1-27.

RIBEIRO, P. A. M. 1979 Indústrias líticas do sul do Brasil: uma tentativa de esquematização. Veritas, 24 (96): 471-494.

RIBEIRO, P. A. M. 1990 A Tradição Umbu no sul do Brasil. In: RIBEIRO, P. A. M. (Ed.). Anais da V Reunião Científica da Sociedade Brasileira de Arqueologia Revista do CEPA, 17 (20): 129-151.

RIBEIRO, P. A. M. \& FERIS, J. 1984 Sítios com petroglifos na Campanha do Rio Grande do Sul, Brasil. Revista do CEPA, 11 (13): 7-32.

RIBEIRO, P. A M. \& RIBEIRO, C. 1985 Levantamentos arqueológicos no município de Esmeralda, Rio Grande do Sul, Brasil. Revista do CEPA, 12 (14): 50-105.

RIBEIRO, P. A M. \& RIBEIRO, C. 1999 Escavações arqueológicas no sítio RS-TQ-58, Montenegro, RS, Brasil. Documentos da FURG, 10: 1-86.

RIVAL, L. 1999 Introduction: South America. In: LEE, R. \& DALY, R. The Cambridge Encyclopedia of Hunters and Gatherers. Cambridge, Cambridge University Press. 77-85 pp.

ROGGE, J. 1996 Adaptação na floresta subtropical: a Tradição Tupiguarani no médio rio Jacuí e no rio Pardo. Arqueologia do Rio Grande do Sul, Brasil - Série Documentos, 6: 3-156.

ROGGE, J. 1999a A ocupação pré-colonial do planalto: projeto Vacaria. Revista do CEPA, 23 (29): 170-172. 
ROGGE, J. 1999b Assentamentos litorâneos da Tradição Tupiguarani: projeto Quintão. Revista do CEPA, 23 (29): 215-217.

ROSA, A. O 1998 Estudos de sepultamentos indígenas no planalto meridional do Rio Grande do Sul: projeto Vacaria. Comunicação apresentada no I Encontro da Regional Sul da SAB (SAB/SUL). São Leopoldo, IAP/UNISINOS.

ROSA, A. 1999 Sepultamentos indígenas no planalto meridional do Rio Grande do Sul. Comunicação apresentada no $X$ Congresso da Sociedade de Arqueologia Brasileira, Recife.

ROSSIGNOL, J. 1992 Concepts, methods and theory building. In: ROSSIGNOL, J. \& WANDSNIDER, L. (Eds.) Space, time, and archaeological landscapes. New York, Plennum Press. 3-16 pp.

ROWLEY-CONWY, P. 2001 Time, change and the archaeology of hunter-gatherers: how original is the 'original affluent society'? In: PANTER-BRICK; LAYTON, R \& ROWLEY-CONWY, P. (Eds.) Hunter-gatherers: an interdisciplinary perspective. Cambridge, Cambridge University Press. 39-72 pp.

RÜTHSCHILLING, A. L. 1985 Análise do material lítico do sítio arqueológico RSCA-14, Capão Grande, Camaquã. Boletim do MARSUL, 3: 53-60.

RÜTHSCHILLING, A. L. 1987 Uma nova abordagem sobre o material lítico do sítio RS-CA-14: Capão Grande, Rio Grande do Sul. Pré-História do Rio Grande do Sul (Brasil) - Série Documentos, 1: 27-48.

RÜTHSCHILLING, A. L. 1989 Pesquisas arqueológicas no baixo rio Camaquã. PréHistória do Rio Grande do Sul (Brasil)- Série Documentos, 3: 7-106.

RÜTHSCHILLING, A. L. \& SCHMITZ, P. I. 1989 O aproveitamento da matéria-prima em sítios da região de Camaquã, RS. In: SCATAMACCHIA, M. C. \& FLEMING, M. C. (Ed.). Anais da IV Reunião Científica da Sociedade Brasileira de Arqueologia - Dédalo. Publicações Avulsas, nº 1: 381-387.

SACKETT, J. 1977 The meaning of style in archaeology: a general model. American Antiquity, 42 (3): 369-380.

SACKETT, J. 1982 Approaches to style in lithic archaeology. Journal of Anthropological Archaeology, 1: 59-112.

SACKETT, J. 985 Style and ethnicity in the Kalahari: a reply to Wiessner. American Antiquity, 50 (1): 154-159.

SACKETT, J. 1986 Style, function and assemblage variability: a reply to Binford. American Antiquity, 51 (3): 628-634.

SACKETT, J. 1993 Style and ethnicity in arcaheology: the case of isochrestism. In: CONKEY, M. \& HASTORF, C. (Eds). The uses of style in archaeology. Cambridge, Cambridge University Press. 32-43 pp. 
SAHLINS, M. 1968 Notes on the original affluent society. In: LEE, R. \& DEVORE, I. (Eds.) Man, the Hunter. Chicago, Aldine Publishing Company. 85-89 pp.

SAHLINS, M. [1972] 1977 Economia de la Edad de Piedra. Madrid, Akal Editor. 340 p.

SALDANHA, J. D. \& COPÉ, S. 1998 Implicações de estudos estilísticos para a arqueologia do planalto sul-riograndense: um estudo das fases Taquara e Guatambu. Comunicação apresentada no I Encontro da Regional Sul da SAB (SAB/SUL). São Leopoldo, IAP/UNISINOS.

SCHIFFER, M. [1972] 1995a Archaeological context and systemic context. In: SCHIFFER, M. Behavioral Archaeology: first principles. Salt Lake City, University of Utah Press. 25-34 pp.

SCHIFFER, M. [1975] 1995b Archaeology as behavioral science. In: SCHIFFER, M. Behavioral Archaeology: first principles. Salt Lake City, University of Utah Press. 46-54 pp.

SCHIFFER, M. [1976] 1995c A synthetic model of archaeological inference. In: SCHIFFER, M. Behavioral Archaeology: first principles. Salt Lake City, University of Utah Press. 35-45 pp.

SCHIFFER, M. [1985] 1995d Is there a "Pompeii Premisse" in archaeology? In: SCHIFFER, M. Behavioral Archaeology: first principles. Salt lake City, University of Utah Press. 201-218 pp.

SCHIFFER, M. [1987] 1996 Formation processes of the archaeological record. Salt Lake City, University of Utah Press. 428 pp.

SCHIFFER, M.; SULIVAN, A. \& KLINGER, T. 1980 The design of archaeological surveys. World Archaeology, 10 (1): 1-28.

SCHMITZ, P. I. 1981 Indústrias líticas en el sur de Brasil. Pesquisas-Antropologia, 32: 107-130.

SCHMITZ, P. I. 1984 Caçadores e coletores da pré-história do Brasil. São Leopoldo, Instituto Anchietano de Pesquisas. 120 p.

SCHMITZ, P. I. 1985a Estratégias usadas no estudo dos caçadores coletores do sul do Brasil. Pesquisas-Antropologia, 40: 75-97.

SCHMITZ, P. I. 1985b Território de domínio em grupos Tupiguarani. Boletim do MARSUL, 3: 45-52.

SCHMITZ, P. I. 1987 Prehistoric hunters and gatherers of Brazil. Journal of World Prehistory 1 (1): 53-126.

SCHMITZ, P. I. 1988 As tradições ceramistas do planalto sul-brasileiro. Arqueologia do Rio Grande do Sul, Brasil - Série Documentos, 2: 74-130. 
SCHMITZ, P. I. 1991 Migrantes da Amazônia: a Tradição Tupiguarani. In: KERN, A. (Org.) Arqueologia pré-histórica do Rio Grande do Sul. Porto Alegre, Mercado Aberto. 295-330 pp.

SCHMITZ, P. I. 1999 Cerâmica Taquara e Itararé em concheiros. Revista do CEPA, 23 (29): 177-179.

SCHMITZ, P. I. \& BROCHADO, J. 1981a Dados para una secuencia cultural de Rio Grande do Sul (Brasil). Pesquisas-Antropologia, 32: 161-183.

SCHMITZ, P. I. \& BROCHADO, J. 1981b Arqueologia de Rio Grande do Sul, Brasil. Estudos Leopoldenses, 18 (64): 161-184.

SCHMITZ, P. I. \& BROCHADO, J. 1982 Petroglifos do Estilo Pisadas no centro do Rio Grande do Sul. Pesquisas Antropologia, 34: 1-47.

SCHMITZ, P. I.; BECKER, I.; LA SALVIA, F.; LAZZAROTO, D. \& RIBEIRO, P. A M. 1988 Pesquisas sobre a Tradição Taquara no nordeste do Rio Grande do Sul. Arqueologia do Rio Grande do Sul, Brasil - Série Documentos, 2: 5-74.

SCHMITZ, P. I.; ARTUSI, L.; JACOBUS, A.; GAZZANEO, M.; ROGGE, J.; MARTIN, H.; \& BAUMHARDT, G. 1990 Uma aldeia Tupiguarani: projeto Candelária, RS. Arqueologia do Rio Grande do Sul, Brasil - Série Documentos, 4: 7-130.

SCHMITZ, P. I. \& BECKER, I. 1991 Os primitivos engenheiros do planalto e suas estruturas subterrâneas: a Tradição Taquara. In: KERN, A. (Org.) Arqueologia préhistórica do Rio Grande do Sul. Porto Alegre, Mercado Aberto. 251-283 pp.

SCHMITZ, P. I.; ROGGE, J.; ROSA, A.; BEBER, M. V.; MAUHS, J. \& ARNT, F. 2002 O projeto Vacaria: casas subterrâneas no planalto rio-grandense. In: SCHMITZ, P. I. (Ed.) Casas subterrâneas nas terras altas do sul do Brasil. Pesquisas - Antropologia, 58: 11-105.

SCHRIRE, C. (Ed.) 1984 Past and present in hunter-gatherer studies. San Diego, Academic Press. 299 p.

SCHUMANN, W. 1985 Rochas e minerais. Rio de Janeiro, Ao Livro Técnico S.A. 399 p.

SCOTT, C. 1997 Property, practice and aboriginal rights among Quebec Cree hunters. In: INGOLD, T.; RICHES, D. \& WOODBURN, J. (Eds.) Hunters and gatherers 2: property, power and ideology. Oxford, Berg. 35-51 pp.

SEARS, W. 1968 The state and the settlement patterns in the New World. In: CHANG, K. C. Settlement archaeology. Palo Alto, National Press Books. 134-153 pp.

SHOTT, M. 1986 Technological organization ans settlement mobility: an ethnographic examination. Journal of Anthropological Research, 42: 15-51.

SHOTT, M. 1989a Shovel-test sampling in archaeological survey: comments on Nance and Ball, and Lightfoot. American Antiquity, 54 (2): 396-404. 
SHOTT, M. 1989b Diversity, organization, and behavior in the material record. Current Anthropology, 30 (3): 283-315.

SHOTT, M. J. 1993 Spears, darts and arrows: Late Woodland hunting techniques in the Upper Ohio Valley. America Antiquity, 58 (3): 425-443.

SHOTT, M. 1994 Size and form in the analysis of flake debris: review and recent approachs. Journal of Archaeological Method and Theory, 1(1): 69-110.

SHOTT, M. 1996 An exagesis of the curation concept. Journal of Anthropological Research, 52 (3): 259-280.

SILVA, F. 1999 As cerâmicas dos Jê do sul do Brasil e os seus estilos tecnológicos: elementos para uma etnoarqueologia Kaingang e Xokleng. Revista do CEPA, 23 (30): 57-73.

SILVA, F. 2000 As tecnologias e seus significados: um estudo da cerâmica dos Asuriní do Xingu e da cestaria dos Kayapó-Xikrin sob uma perspectiva etnoarqueológica. Tese de doutorado. São Paulo, Universidade de São Paulo.

SILVA, F. \& NOELLI, F. 1996 Para uma síntese dos Jê do Sul: igualdades, diferenças e dúvidas para a etnografia, etno-história e arqueologia. Estudos Ibero-americanos, 22 (1): 5-13.

SIMÕES, M. 1972 Índice das fases arqueológicas brasileiras (1950-1971). Belém, Museu Paraense Emílio Goeldi. 75 p.

SOARES, A. 1997 Guarani: organização social e arqueologia. Porto Alegre, EDIPUCRS. 259 p.

SOARES, A. 1999 Os horticultores Guaranis: modelos, problemáticas e perspectivas. Revista do CEPA, 23 (30): 103-141.

SPURLING, B. \& HAYDEN, B. 1984 Ethnoarchaeology and intrasite spatial analysis: a case study from australian western desert. In: HIETALA, H. (Ed.) Intrasite spatial analysis in archaeology. Cambridge, Cambridge University Press. 224-241 pp.

STEARMAN, A. 1991 Making a living in the tropical forest: Yuquí foragers in the bolivian Amazon. Human Ecology, 19 (2): 245-259.

STEVAUX, J. 2000 Climatic events during the late Pleistocene and Holocne in the upper Paraná river: correlation with NE Argentina and south-central Brazil. Quaternary International, 72: 73-85.

STEVENSON, M. 1985 The formation of artifact assemblages at workshop/habitation sites: models from Peace Point in northern Alberta. American Antiquity, 50 (1): 6381.

STEVENSON, M. 1991 Beyond the formation of hearth-associated artefact assemblages. In: KROLL, E. \& PRICE, T. (Eds.) The interpretation of archaeological spatial patterning. New York, Plenum Press. 269-300 pp. 
STRAUSS, L. 1990 Underground archaeology: perspectives on caves and rockshelters. In: SCHIFFER, M. (Ed.) Archaeological method and theory - Vol. 2. Tucson, University of Arizona Press. 255-304 pp.

SULLIVAN, A. \& ROZEN, K. 1985 Debitage analysis and archaeological interpretation. American Antiquity, 50 (4): 755-779.

TOCCHETTO, F. 1996 Possibilidades de interpretação do conteúdo simbólico da arte gráfica Guarani. Revista do Museu de Arqueologia e Etnologia, 6: 33-45.

TONKINSON, R. 1997 Ideology and domination in aboriginal Australia: a western desert test case. In: INGOLD, T.; RICHES, D. \& WOODBURN, J. (Eds.) Hunters and gatherers 2: property, power and ideology. Oxford, Berg. 150-164 pp.

THOMAS, D. 1975 Non-site sampling in archaeology: up to creek without a site? In: MUELLER, J. (Ed.) Sampling in archaeology. Tucson, University of Arizona Press. 61-81 pp.

TRIGGER, B. 1968 The determinants of settlement patterns. In: CHANG, K. (Ed.) Settlement archaeology. Palo Alto, National Press Books. 53-78 pp.

TRIGGER, B. 1992 A History of archaeological thought. Cambridge, Cambridge University Press. 500 p.

TRIGGER, D. 1999 Hunter-gatherer peoples and nation-states. In: LEE, R. \& DALY, R. (Eds.) The Cambridge Encyclopedia of Hunters and Gatheres. Cambridge, Cambridge University Press. 473-479 pp.

URBAN, G. 1996 On the geographical origins and dispersions of Tupi languages. Revista de Antropologia, 39 (2): 61-104.

VILLA, P. 1982 Conjoinable pieces and site formation process. American Antiquity, 47 (2): 276-290.

VIVEIROS DE CASTRO, E. 1996 Comentários ao artigo de Francisco Noelli. Revista de Antropologia, 39 (2): 55-60.

VOGT, E. 1968 Some aspects of Zinacantan settlement patterns and ceremonial organization. In: CHANG, K. (Ed.) Settlement archaeology. Palo Alto, National Press Books. 154-173 pp.

WAGNER, G. 2001 Estudo paleoambiental e arqueológico do litoral norte do Rio Grande do Sul. Monografia Bacharelado em História. Porto Alegre, Pontifícia Universidade Católica do Rio Grande do Sul.

WALTHALL, J. 1998 Rockshelters and hunter-gatherer adaptation to the Pleistocene/Holocene transition. American Antiquity, 63 (2): 223-238

WANDSNIDER, L. 1992 Archaeological landscape studies. In: ROSSIGNOL, J. \& WANDSNIDER, L. (Eds.) Space, time, and archaeological landscapes. New York, Plennum Press. 285-291 pp. 
WATERS, M. 1992 Principles of geoarchaeology: a North American perspective. Tucson, University of Arizona Press. 398 p.

WERNICK, E.; PASTORES, E. \& PIRES NETO, A. 1973 Cavernas em arenito. Notícias Geomorfológicas da Universidade de Campinas, 13 (26): 33-54.

WHALON, R. 1984 Unconstrained clustering for the analysis of spatial distributions in archaeology. In: HIETALA, H. (Ed.) Intrasite spatial analysis in archaeology. Cambridge, Cambridge University Press. 242-277 pp.

WIESSNER, P. 1982 Beyond willow smoke and dogs' tails: a comment on Binford's analysis of hunter-gatherer settlement systems. American Antiquity, 47 (1): 171178.

WIESSNER, P. 1983 Style and social information in Kalahari San projectile points. American Antiquity, 48 (2): 253-276.

WIESSNER, P. 1985 Style or isochrestic variation? A reply to Sackett. American Antiquity, 50 (1): 160-169.

WIESSNER, P. 1989 Style and changing relations between the individual and society. In: HODDER, I. (Ed.) The meanings of things: material culture and symbolic expression. London, Harper Collins. 56-63 pp.

WIESSNER, P.1993 Is there a unity to style? In: CONKEY, M. \& HASTORF, C. (Eds). The uses of style in archaeology. Cambridge, Cambridge University Press. 105-121 pp.

WINTERHALDER, B. 1981 Optimal foraging strategies and hunter-gatherer research in anthropolgy: theory and models. In: WINTERHALDER, B. \& SMITH, E. (Eds.) Hunter-gatherer foraging strategies: ethnografic and archaeological analyses. Chicago, Chicago University Press. 13-35 pp.

WINTERHALDER, B. 2001 The behavioral ecology of hunter-gatherers. In: PANTERBRICK; LAYTON, R \& ROWLEY-CONWY, P. (Eds.) Hunter-gatherers: an interdisciplinary perspective. Cambridge, Cambridge University Press. 12-38 pp.

WILlEY, G. \& PHILLIPS, P. 1958 Method and theory in american archaeology. Chicago, University of Chicago Press. 269 p.

WOOD, W. \& JOHNSON, D. 1978 A survey of disturbance process in archaeological site formation. In: SCHIFFER, M. (Ed.) Advances in archaeological method and theory - Vol. 1. New York, Academic Press. 315-381 pp.

WOODBURN, J. 1988 African hunter-gatherer social organization: is it best understood as a product of encapsulation? In: INGOLD, T.; RICHES, D. \& WOODBURN, J. (Eds.). Hunters and gatherers 1: history, evolution and social change. Oxford, Berg. 31-64 pp.

WOODBURN, J. [1982] 1998 Egalitarian societies. In: GOWDY, J. (Ed.) Limited wants, unlimited means. Washington, Island Press. 87-110 pp. 
YELLEN, J. 1977a Archaeological approaches to the present: models for reconstructing the past. New York, Academic Press. 259 p.

YELLEN, J. 1977b Cultural patterning in faunal remains: evidence from the !Kung Bushmen. In: INGERSOLL, D.; YELLEN, J. \& MACDONALD, W. (Eds.) Experimental archaeology. New York, Columbia University Press. 271-331 pp.

YELLEN, J. 1990 The present and the future of hunter-gatherer studies. In: LAMBERG-KARLOVSKY, C. (Ed.) Archaeological thought in America. New York, Cambridge University Press. 103-116 pp.

YELLEN, J. 1991a Small mammals: !Kung San utilization and the production of faunal assemblages. Journal of Anthropological Archaeology, 10: 1-26.

YELLEN, J. 1991b Small mammals: post-discard patterning of !Kung San faunal remains. Journal of Anthropological Archaeology, 10: 152-192.

YELLEN, J. [1990] 1998 The transformation of the Kalahari !Kung. In: GOWDY, J. (Ed.) Limited wants, unlimited means. Washington, Island Press. 223-235 pp.

ZUBROW, E. 1996 Knowledge representation and archaeology: a cognitive example using GIS. In: RENFREW, C. \& ZUBROW, E. (Eds.) The ancient mind: elements of cognitive archaeology. New York, Cambridge University Press. 107-118 pp. 
Anexo 1

Mapa geral da região nordeste do Rio Grande do Sul

Escala 1:250.000 


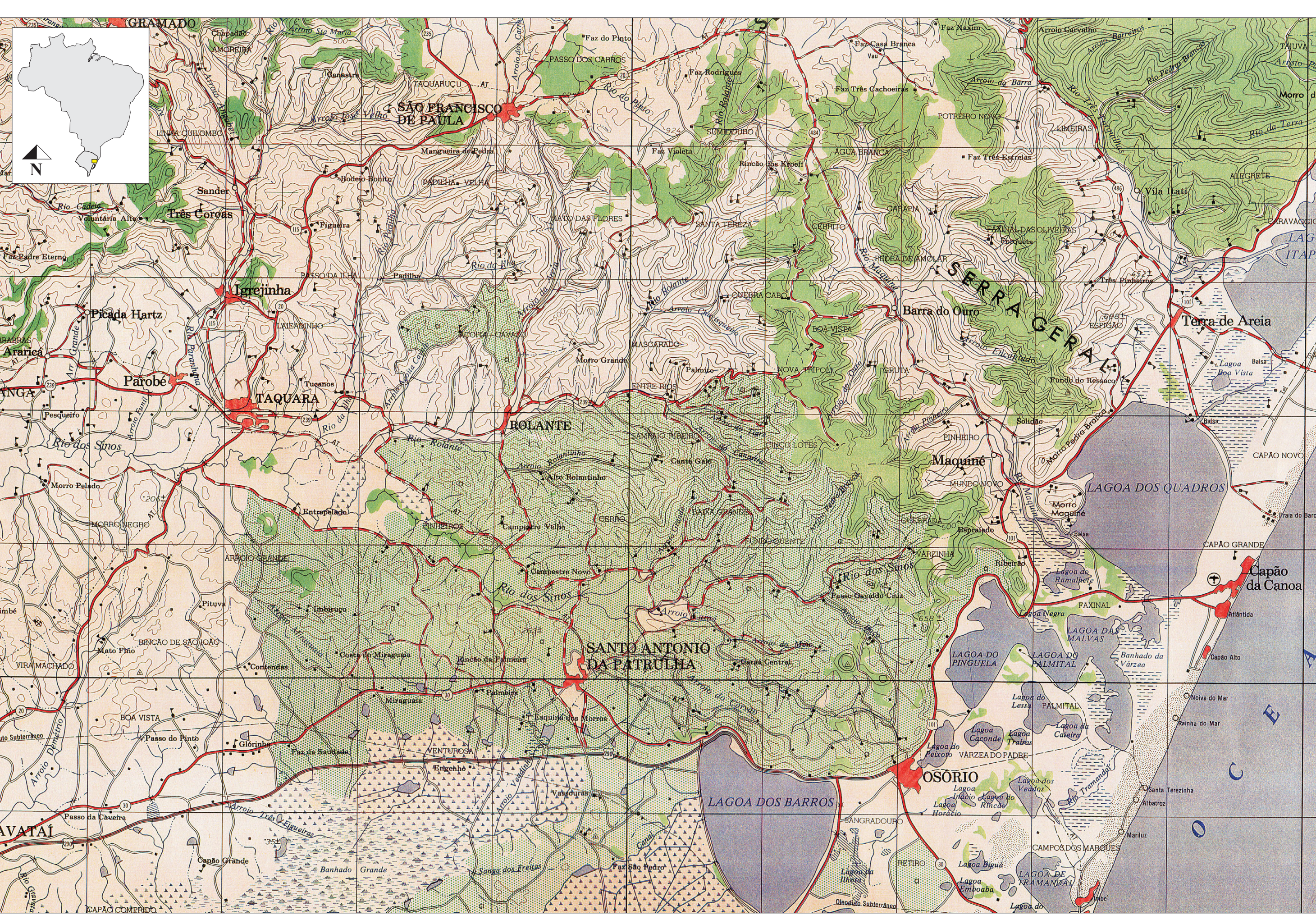


Anexo 2

Mapa da área piloto do alto vale do Rio dos Sinos

Escala 1:50.000 


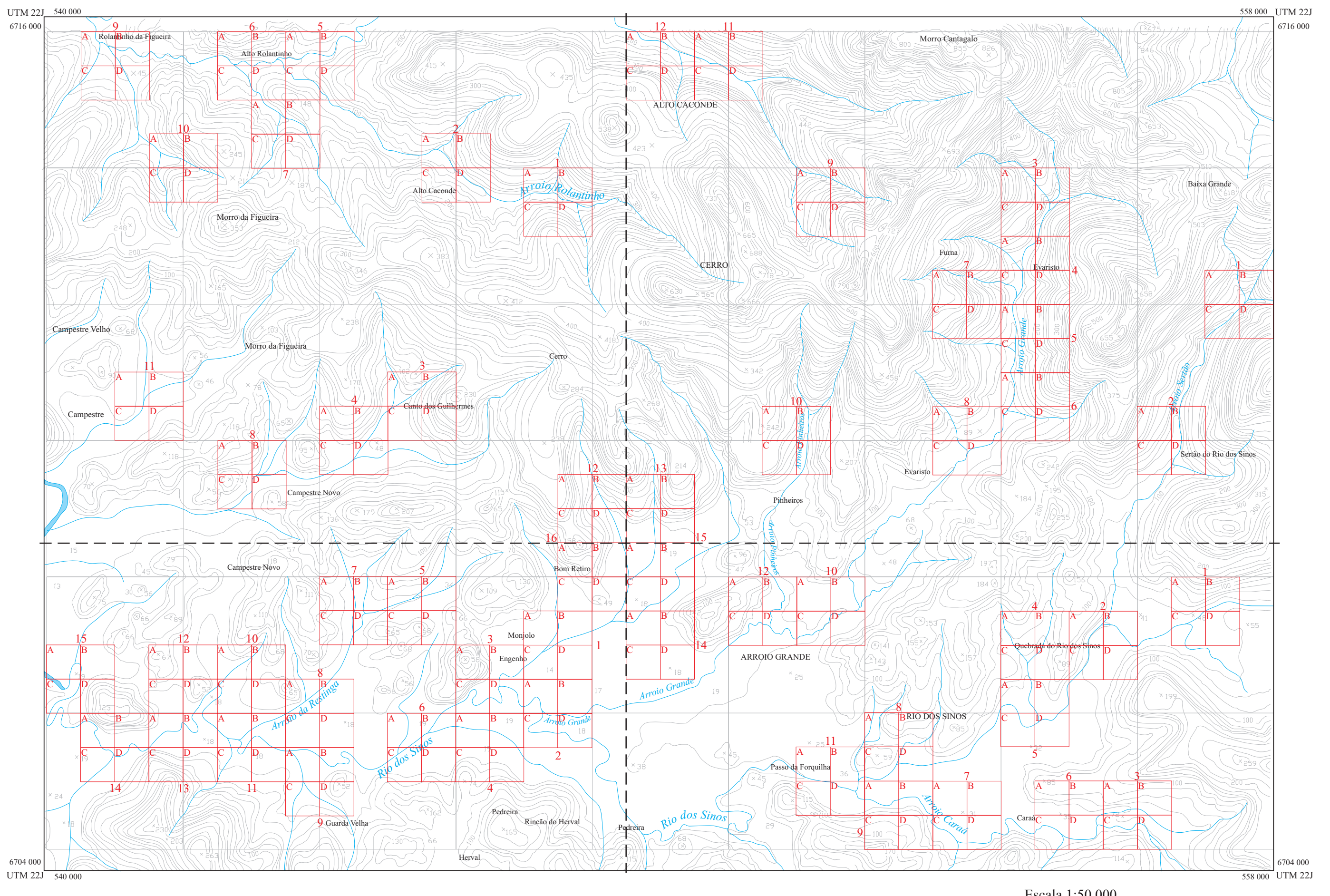


Anexo 3

Mapa da distribuição dos sítios arqueológicos na área piloto

Escala 1:50.000 


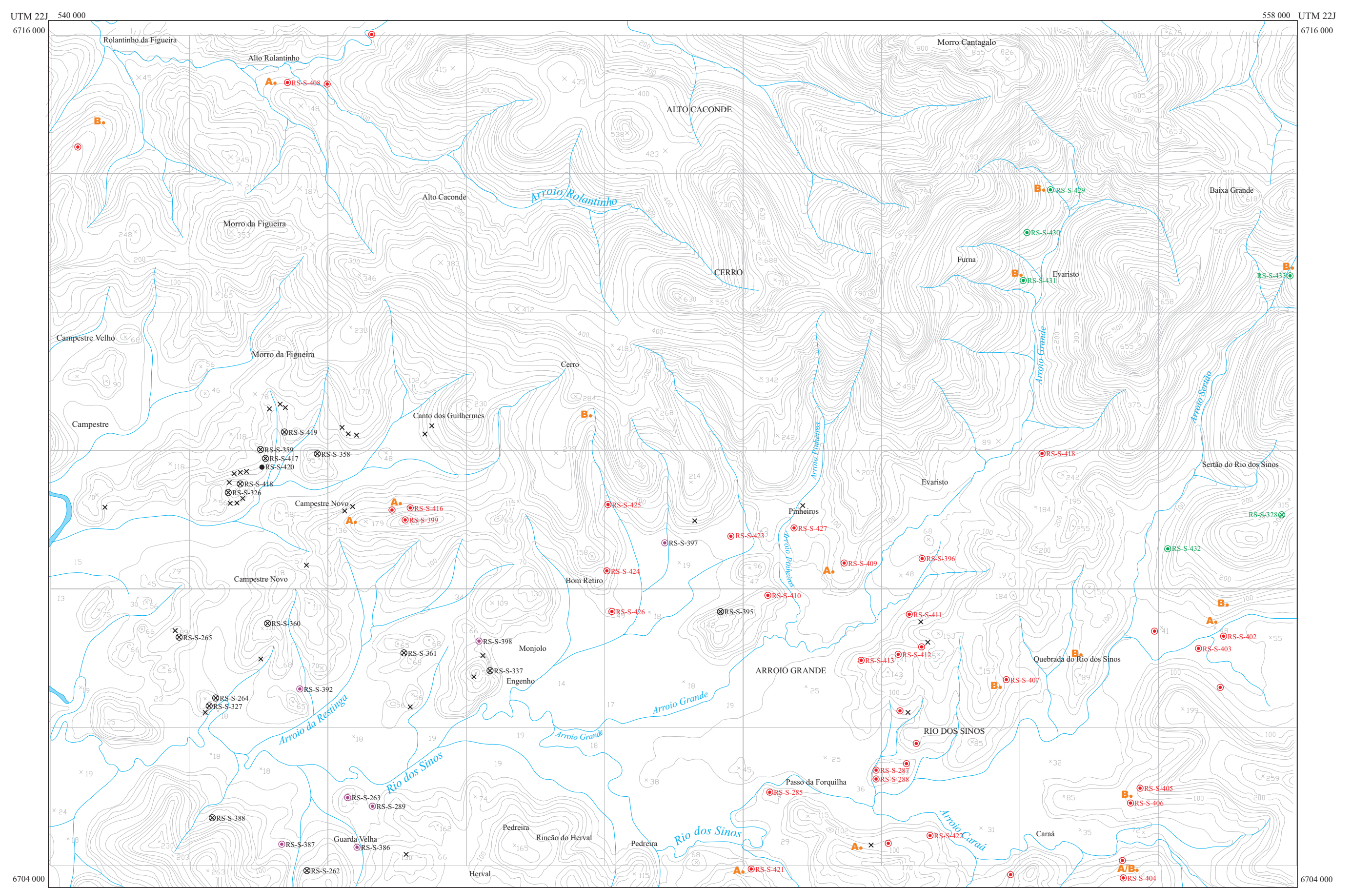

\begin{tabular}{|lll|}
\hline ๑Sítio a céu aberto da Tradição Guarani & • Sítio a céu aberto da Tradição Umbu & ๑Informação sobre sítio a céu aberto da Tradição Guarani \\
$\odot$ Sítio histórico a céu aberto & ๑ Sítio a céu aberto da Tradição Taquara & $\times$ Abrigo sob rocha sem confirmação de ocupação human \\
$\otimes$ Sítio em abrigo sob rocha da Tradição Umbu & A.Afloramento de arenito silicificado \\
$\otimes$ Sítio em abrigo sob rocha da Tradição Taquara & B.Afloramento de basalto \\
\hline
\end{tabular}

Escala 1:50.000

Equidistância das curvas de nível: 20 metros

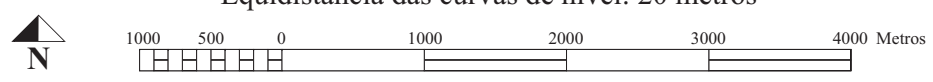


Anexo 4

Croquis dos sítios arqueológicos

Legenda:

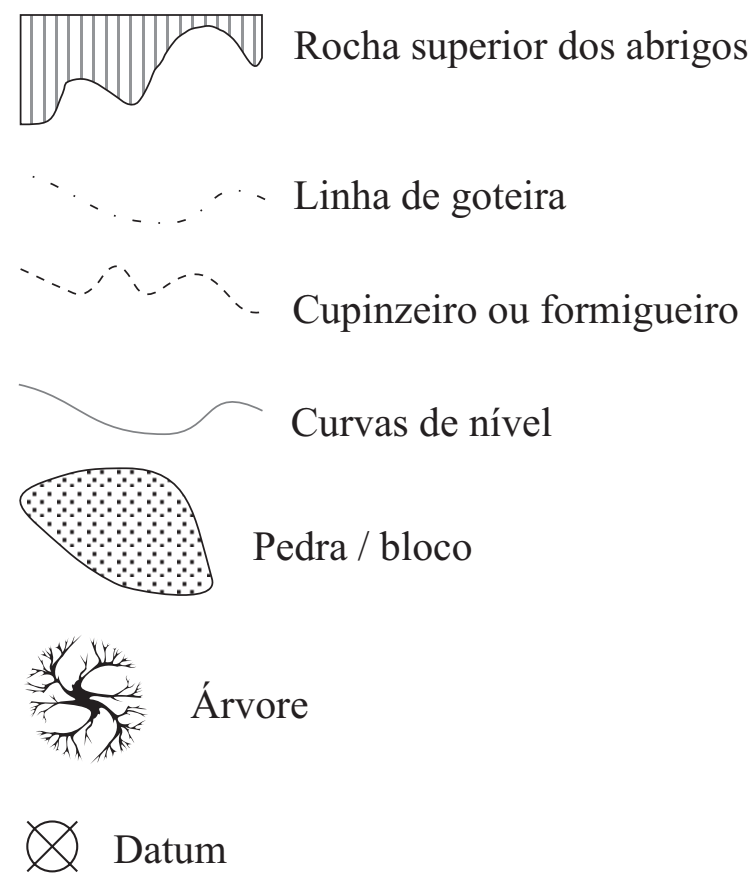

ํo Tradagem

No $\quad$ Escavação 1970

No $\quad$ Escavação 2001 
1. RS-S-395: Deobaldino Marques

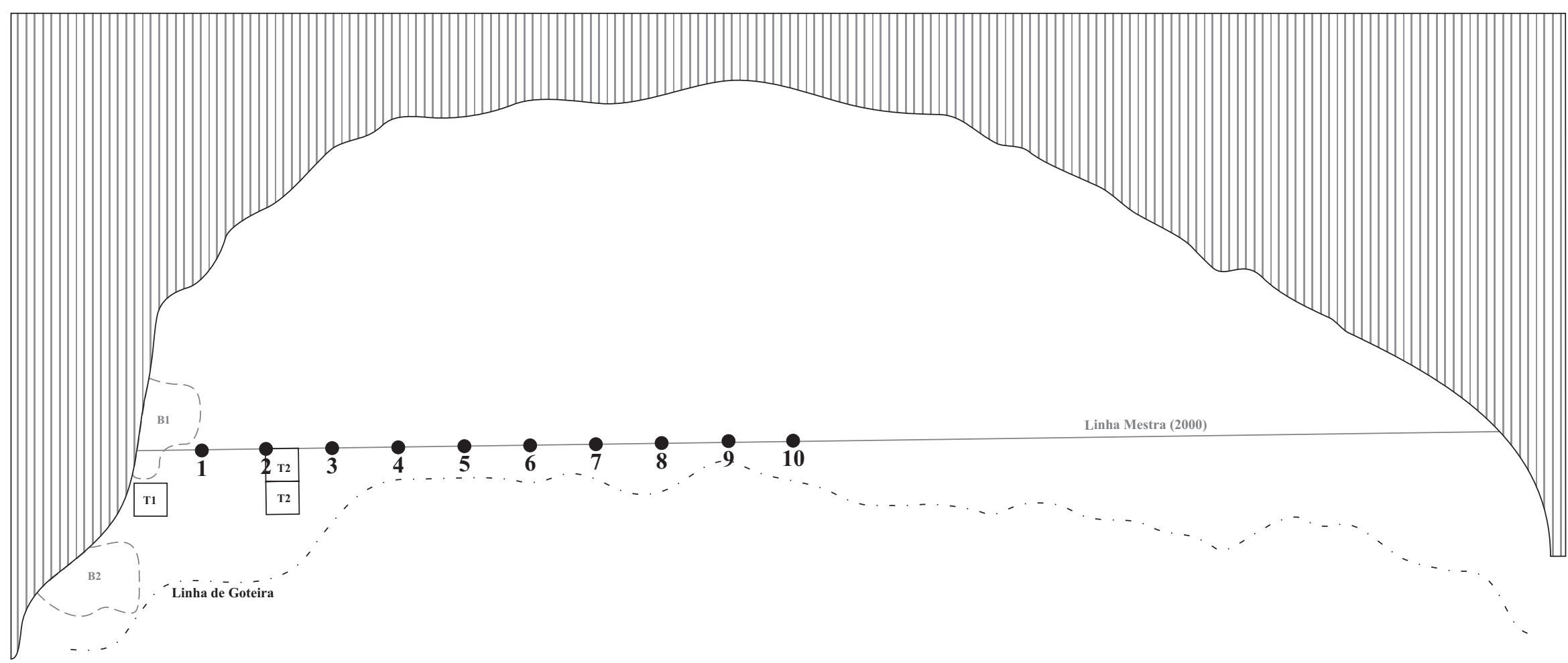

B1 E B2 Buracos de "caçadores de tesouros"

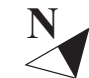

T1 E T2 Poços testes 2000

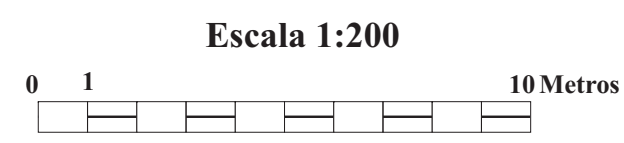


2. RS- S-337: Monjolo
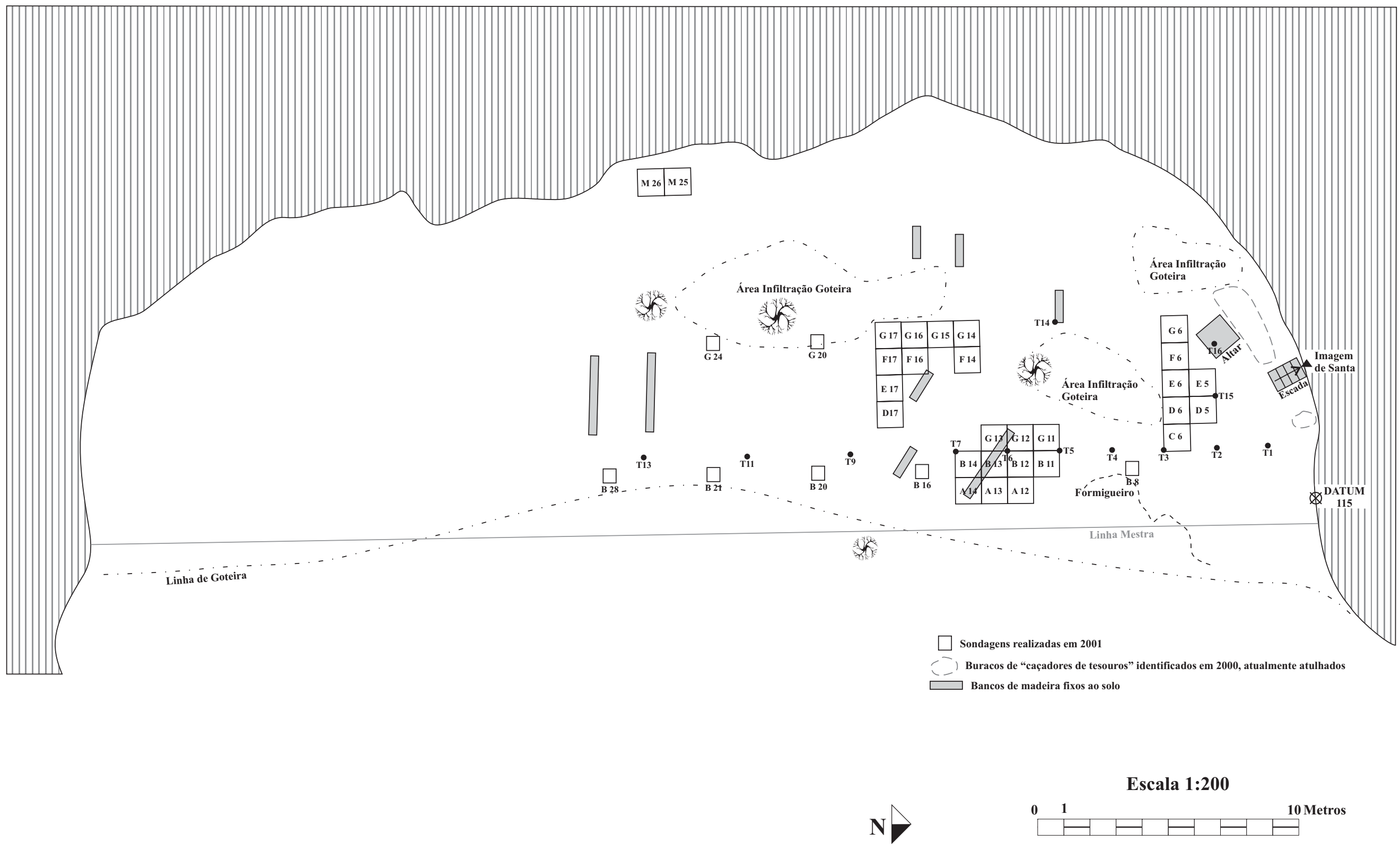
3. RS-S-361: Mato da Toca

Baseado no original de Eurico T. Miller

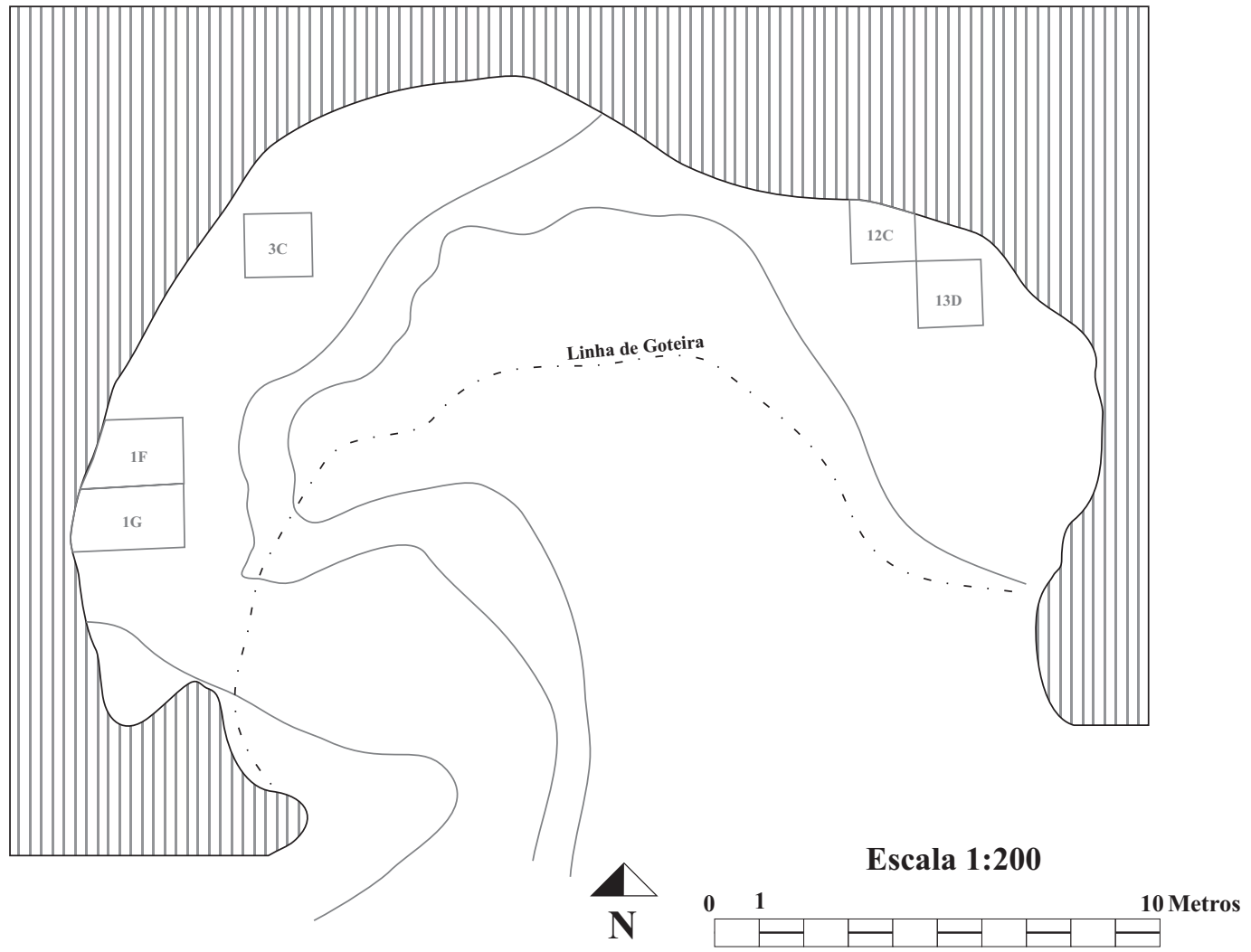

4. RS-S-264: Toca do Sino

Original de Eurico T. Miller (06/11/1965)

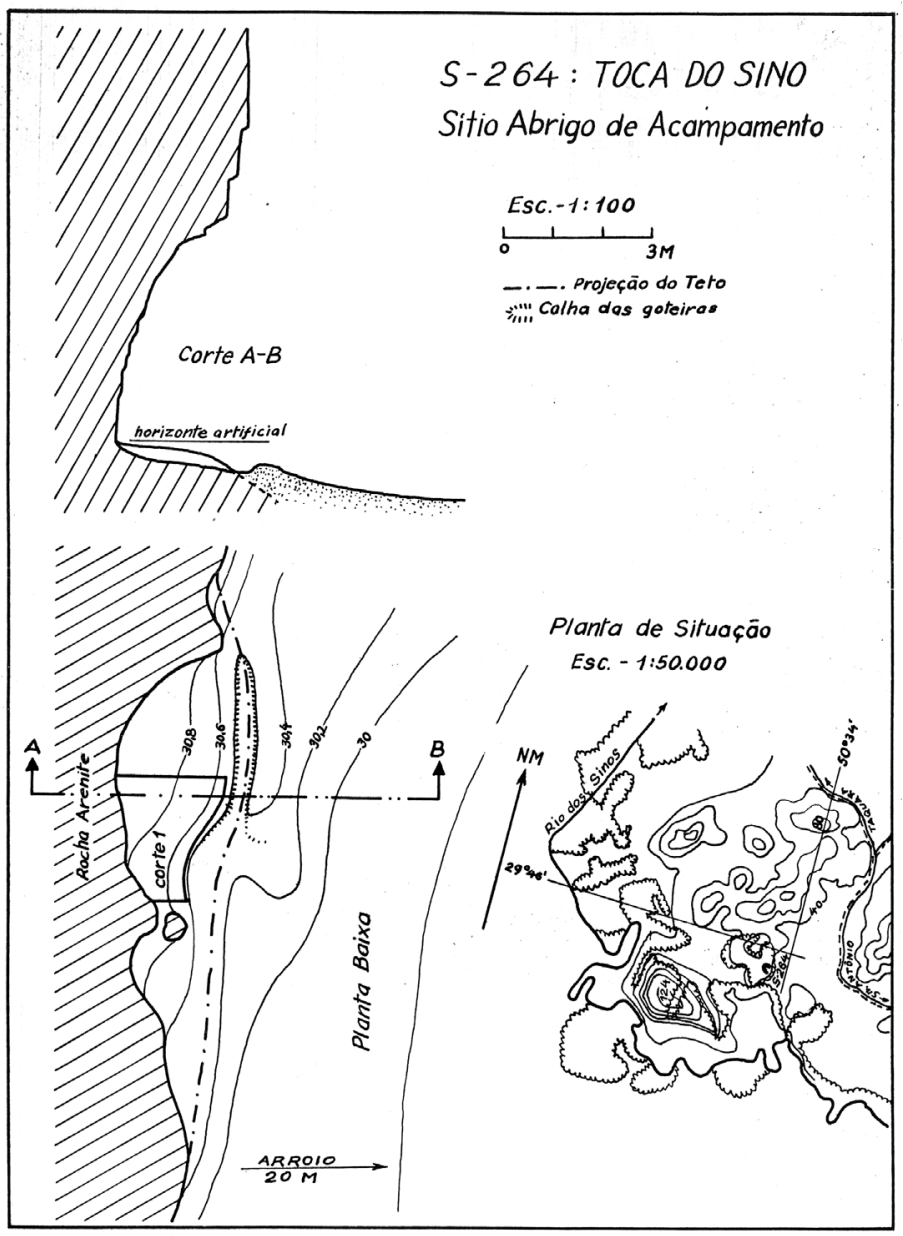


5. RS-S-327: Sangão

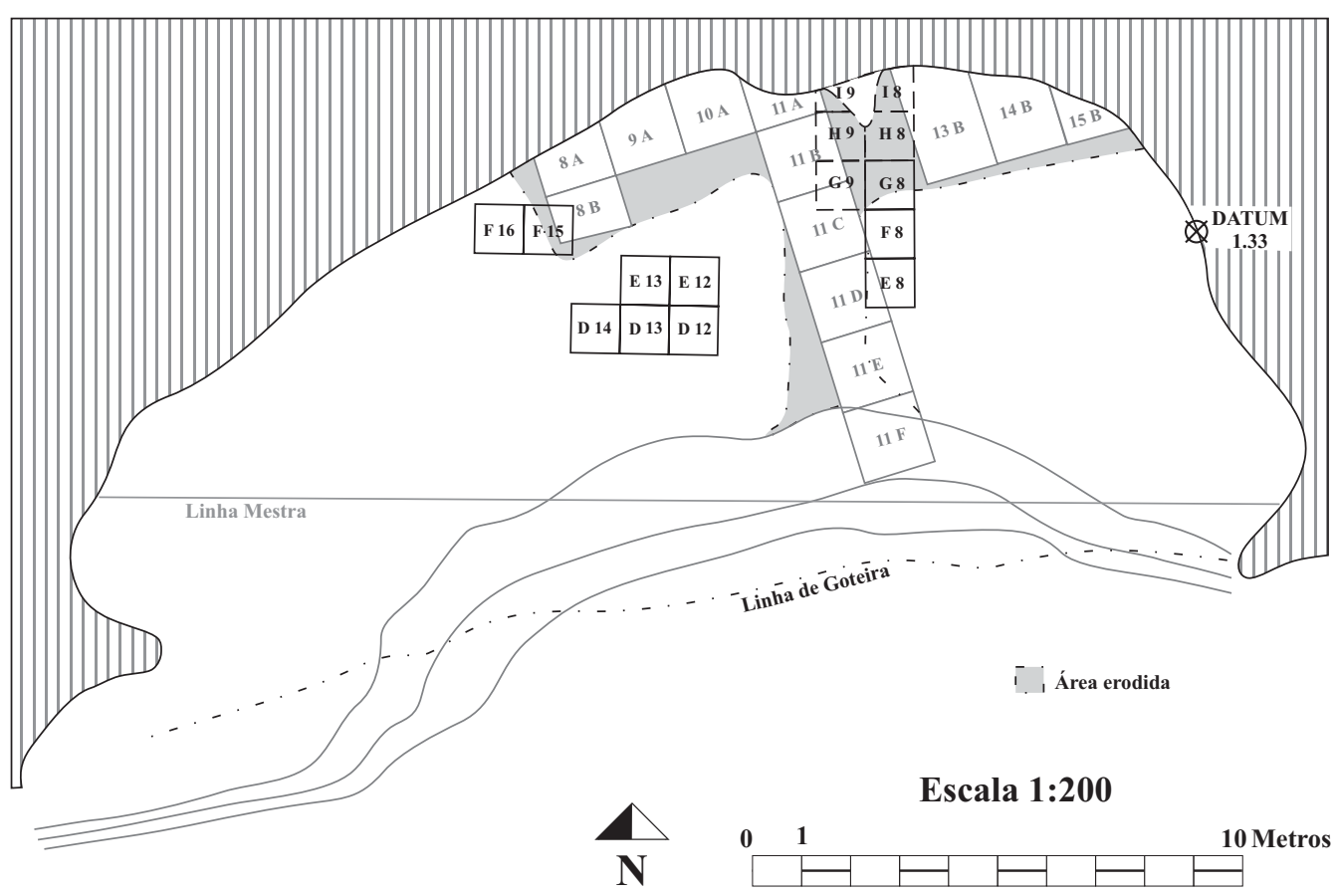


6. RS-S-360: Marimbondo

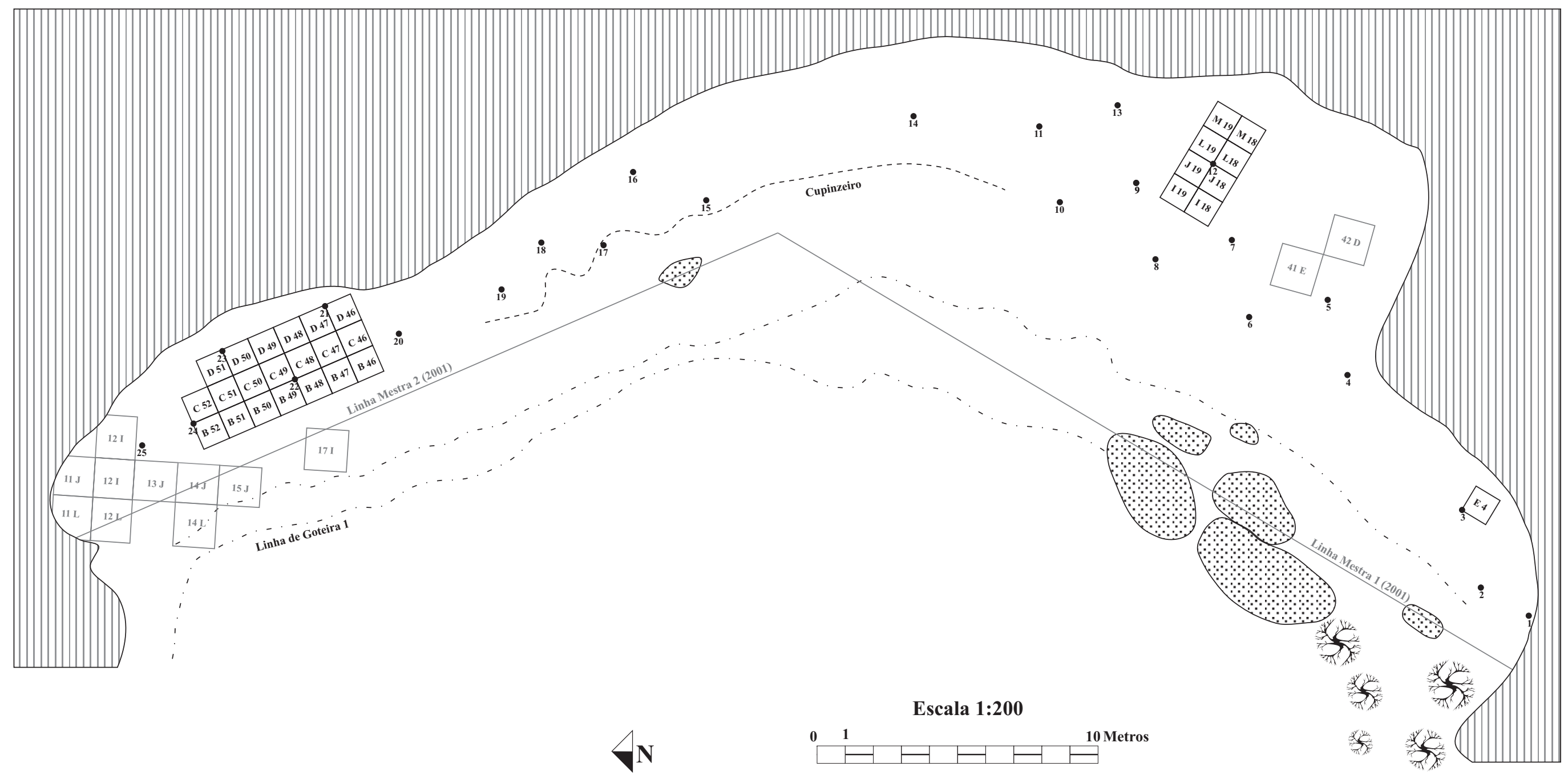


7. RS-S-265: Campestre 1

Baseado no original de Eurico T. Miller

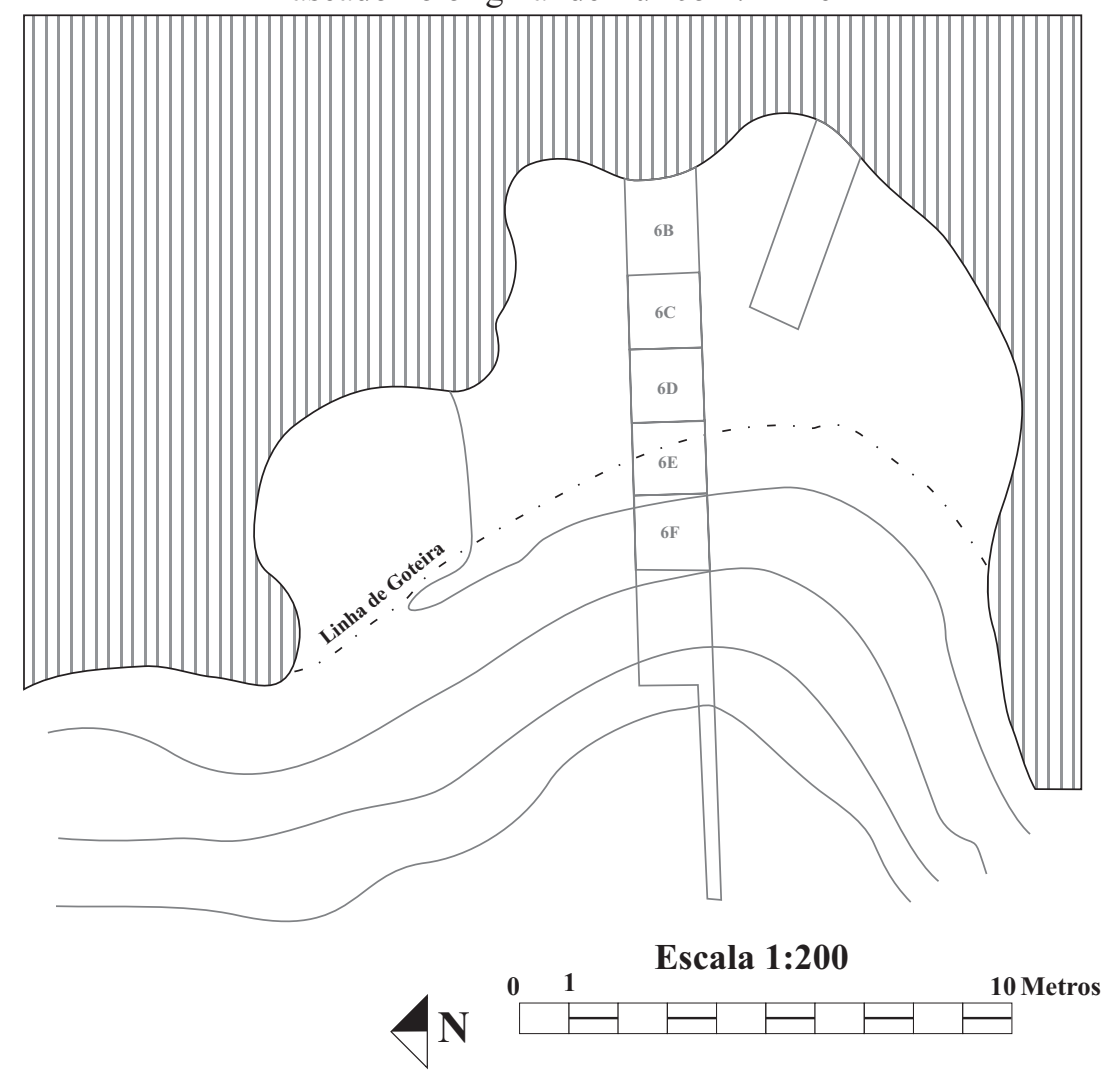


8. RS-S-358: Toca Grande

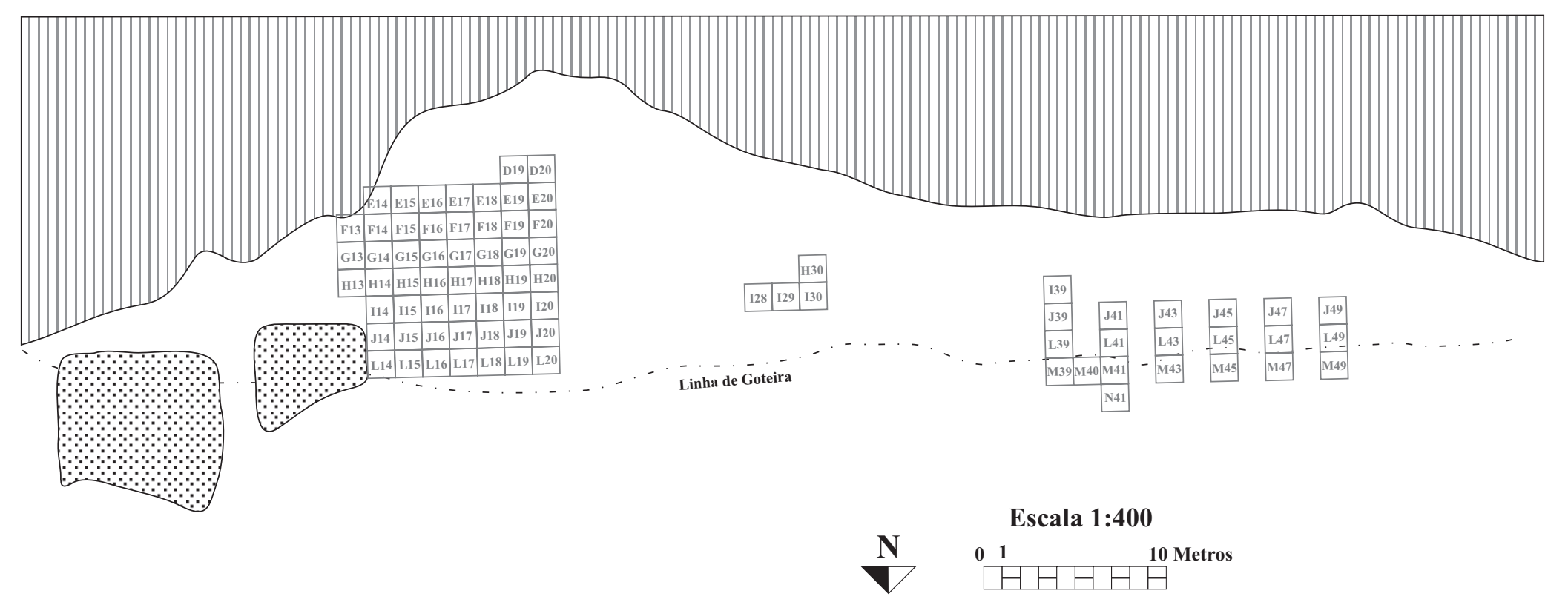


9. RS-S-417: Dirceu Oliveira

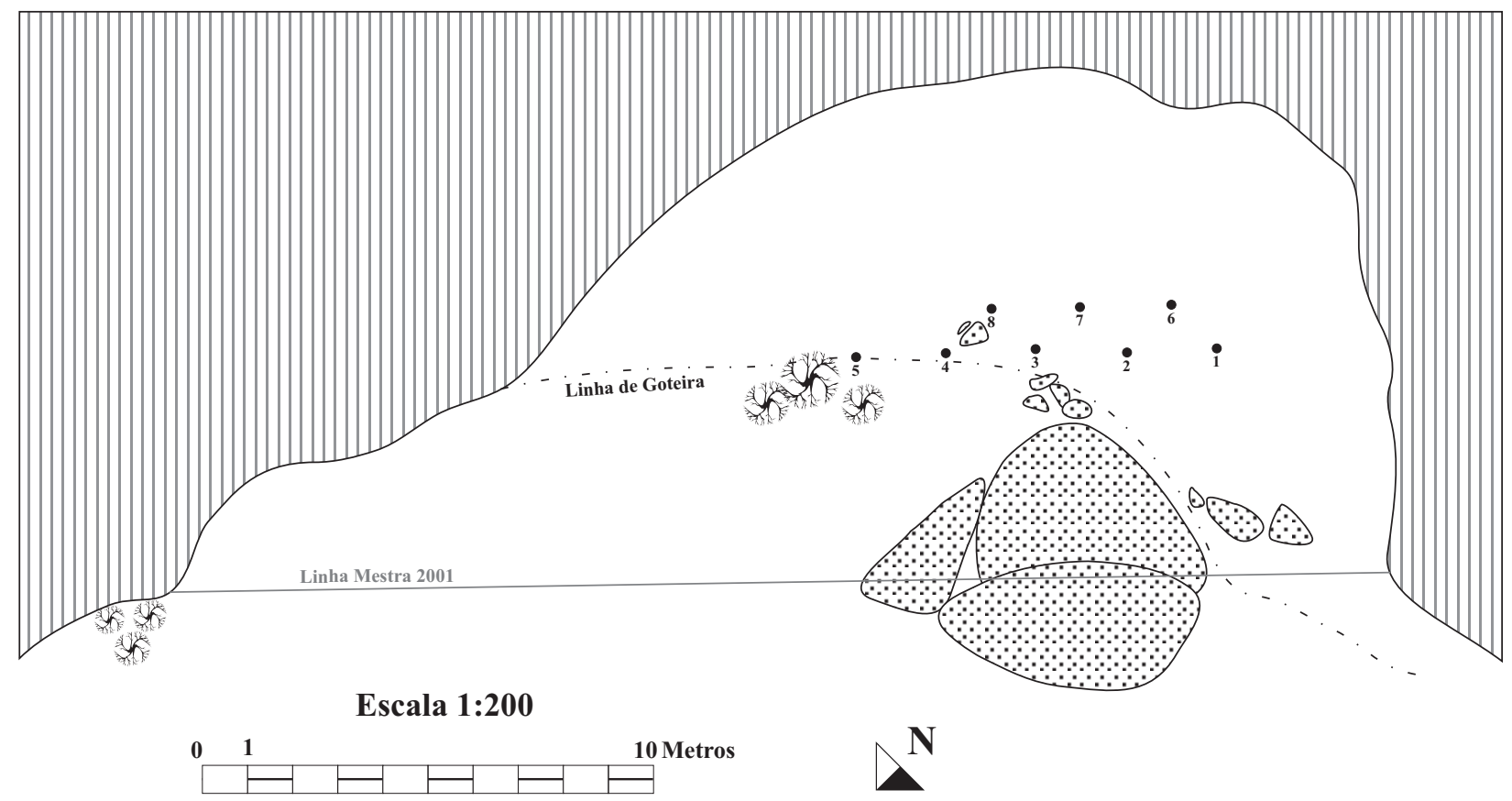

10. RS-S-359: Aterrado

Baseado no original de Eurico T. Miller

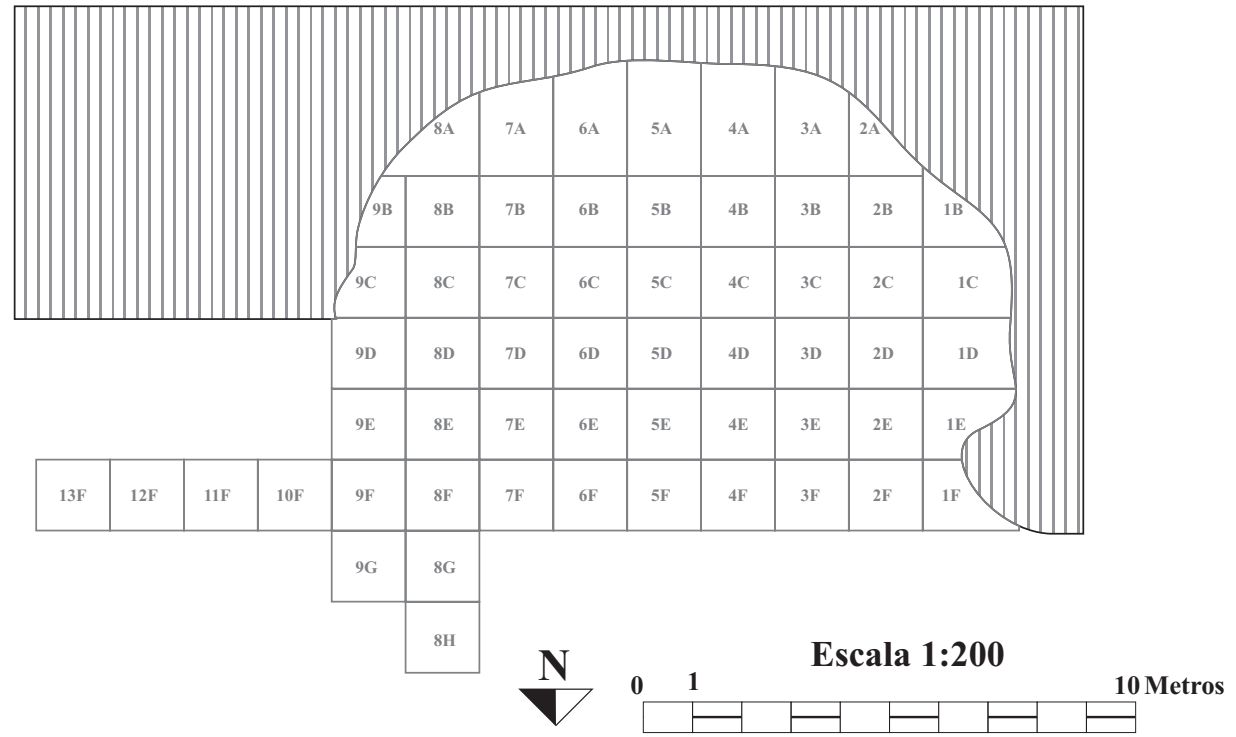


11. RS-S-419: Jair Oliveira

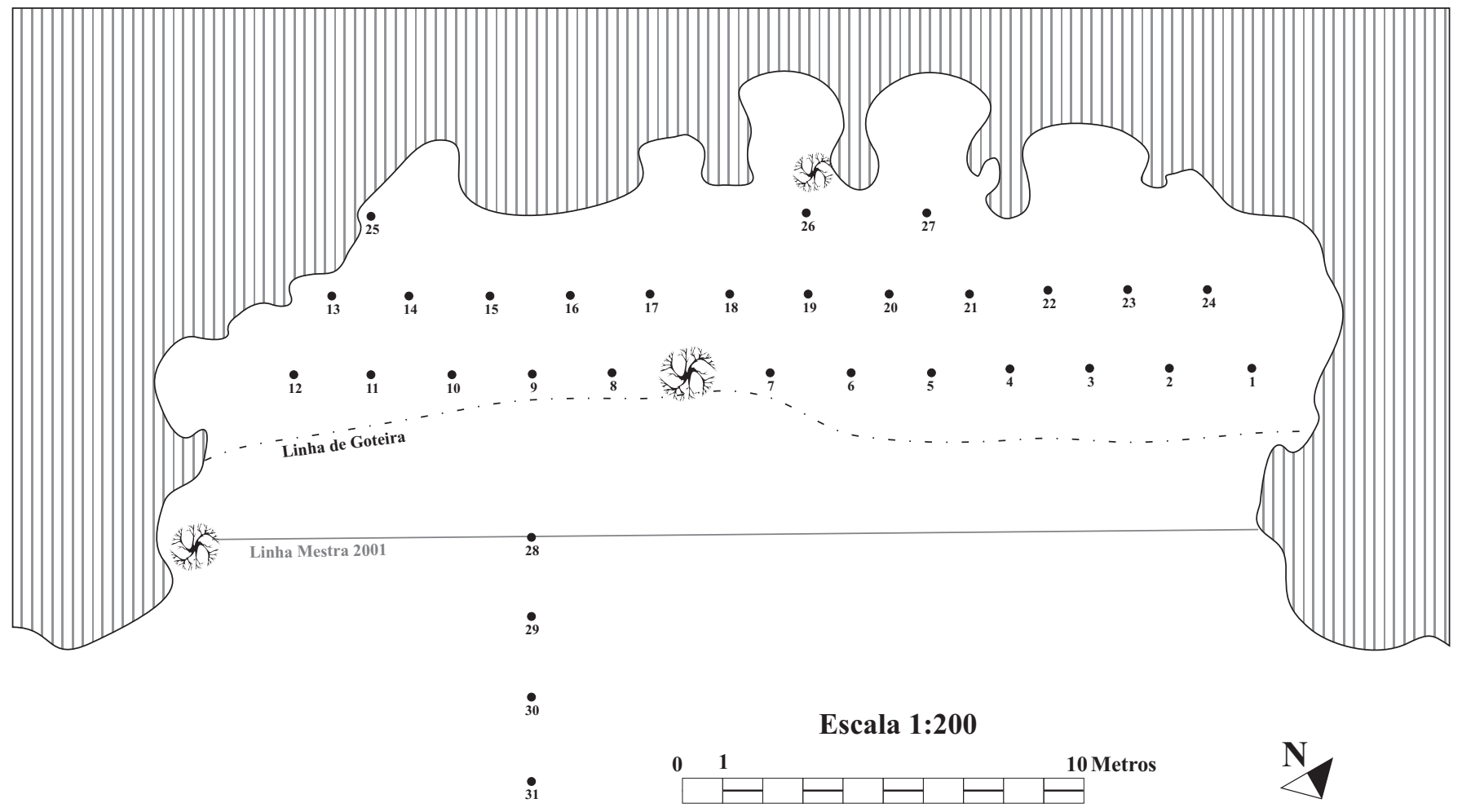

12. RS-S-418: Petroglifo

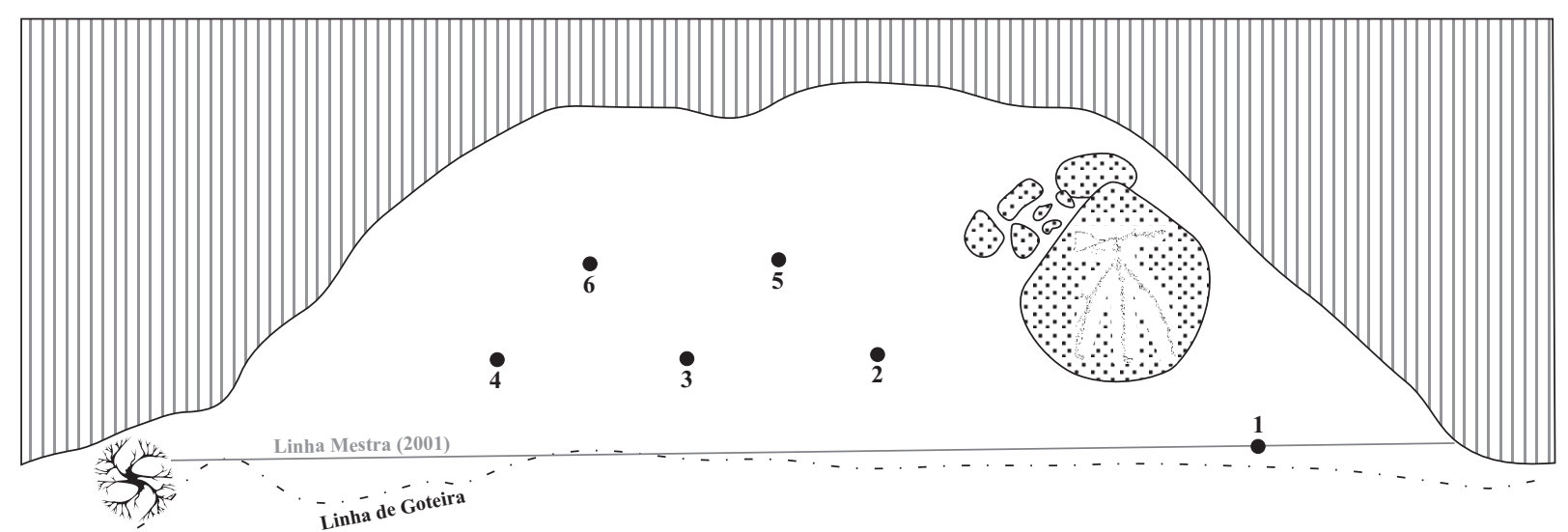

Escala 1:100

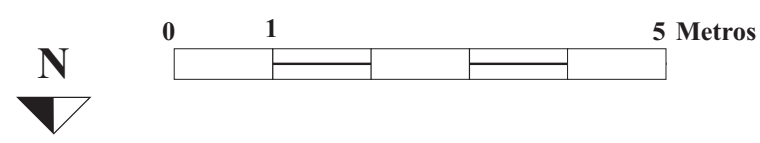


Desenho 1 - Petroglifo

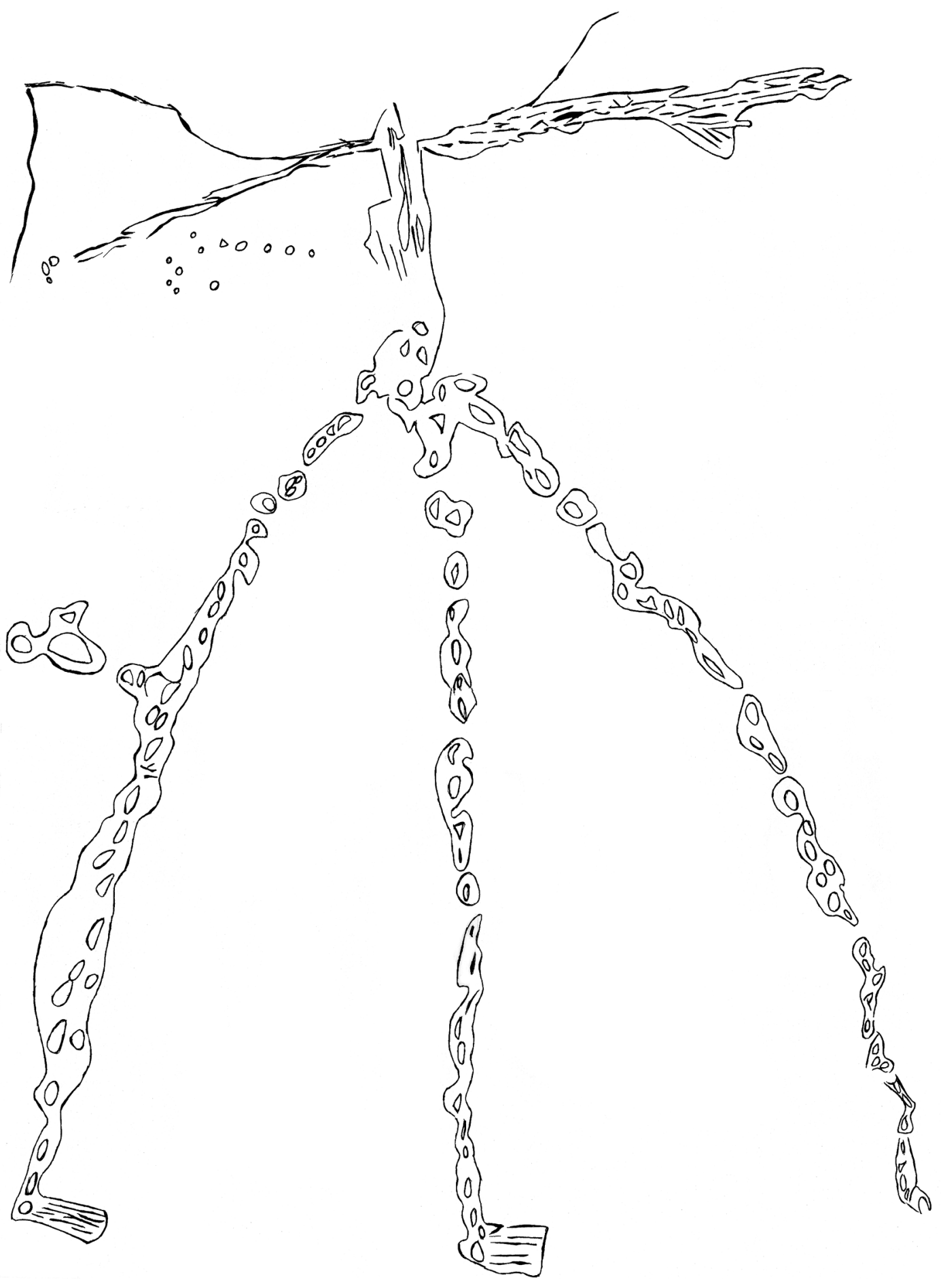

Escala 1:5

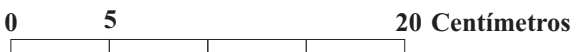




\section{S-290:MONTE SERRAT-2}

ESC. $-1: 1000$

Oـ $30 \mathrm{M}$

- A'REA DO SÍTIO

-D AREA ESCURA

NM

* taquara

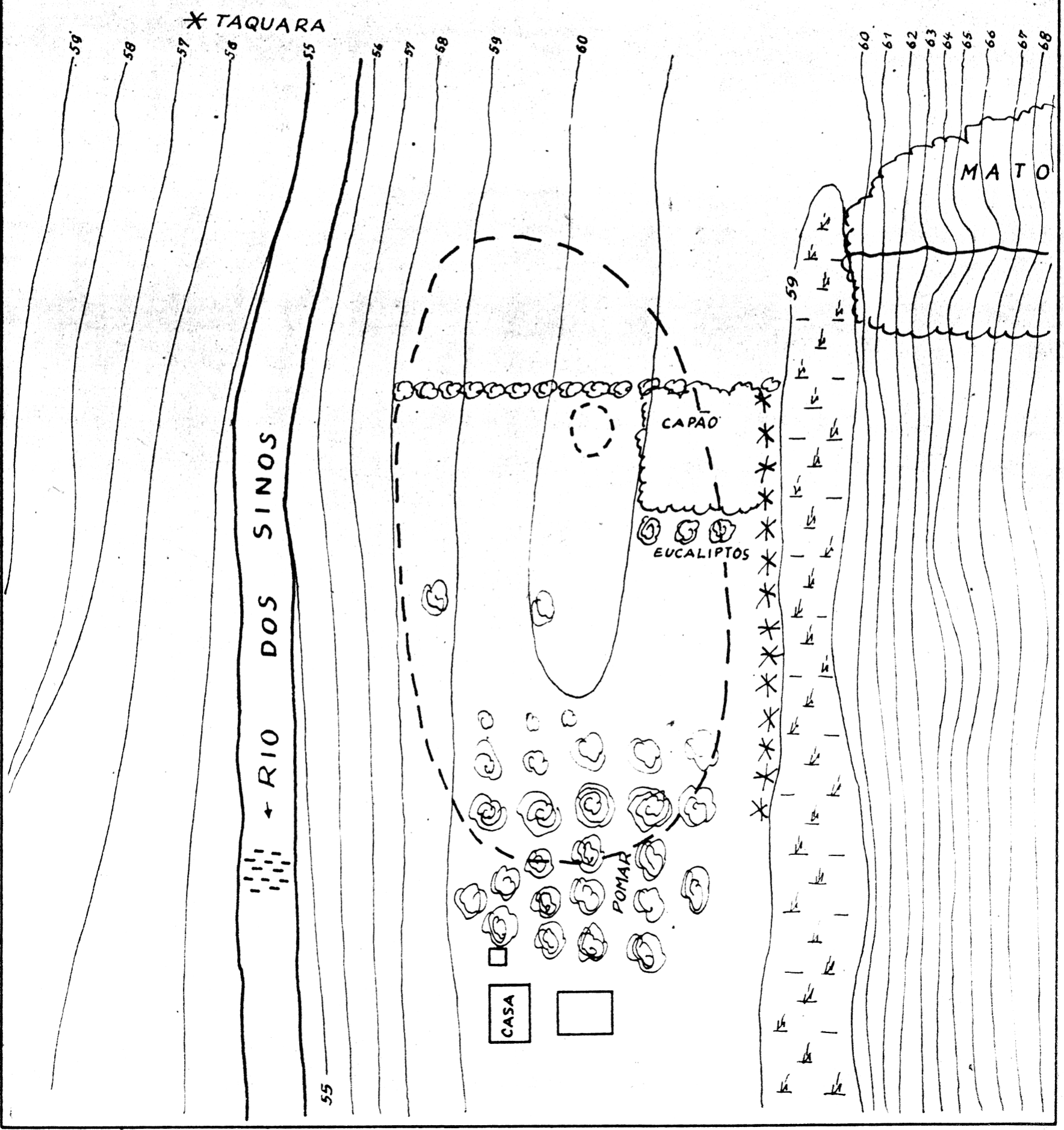




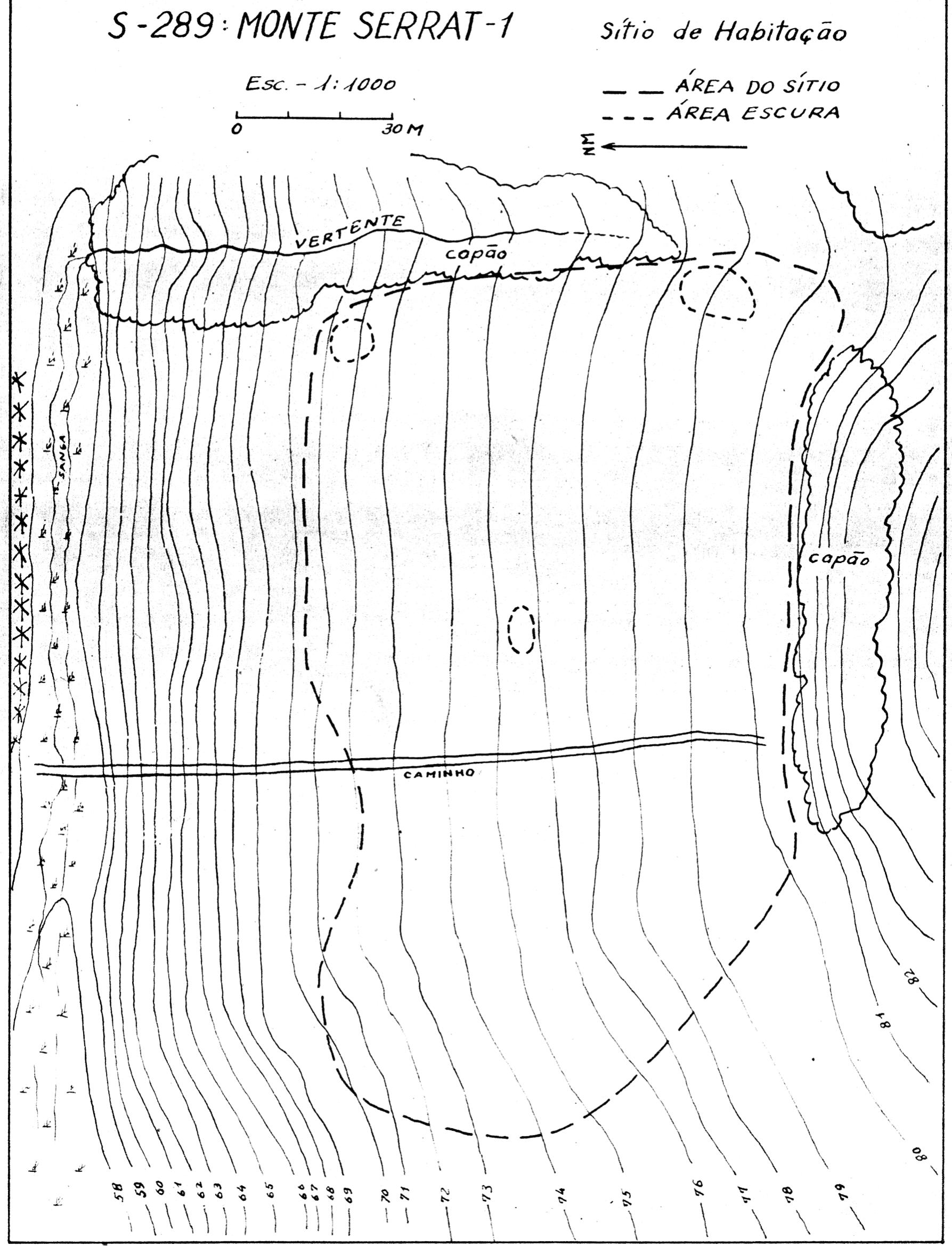


15. RS-S-285: Passo da Forquilha 1

Original de Eurico T. Miller (01/01/1966)

\section{S-285: PASSO DA FORQUILHA sitio de Habitaçäo}
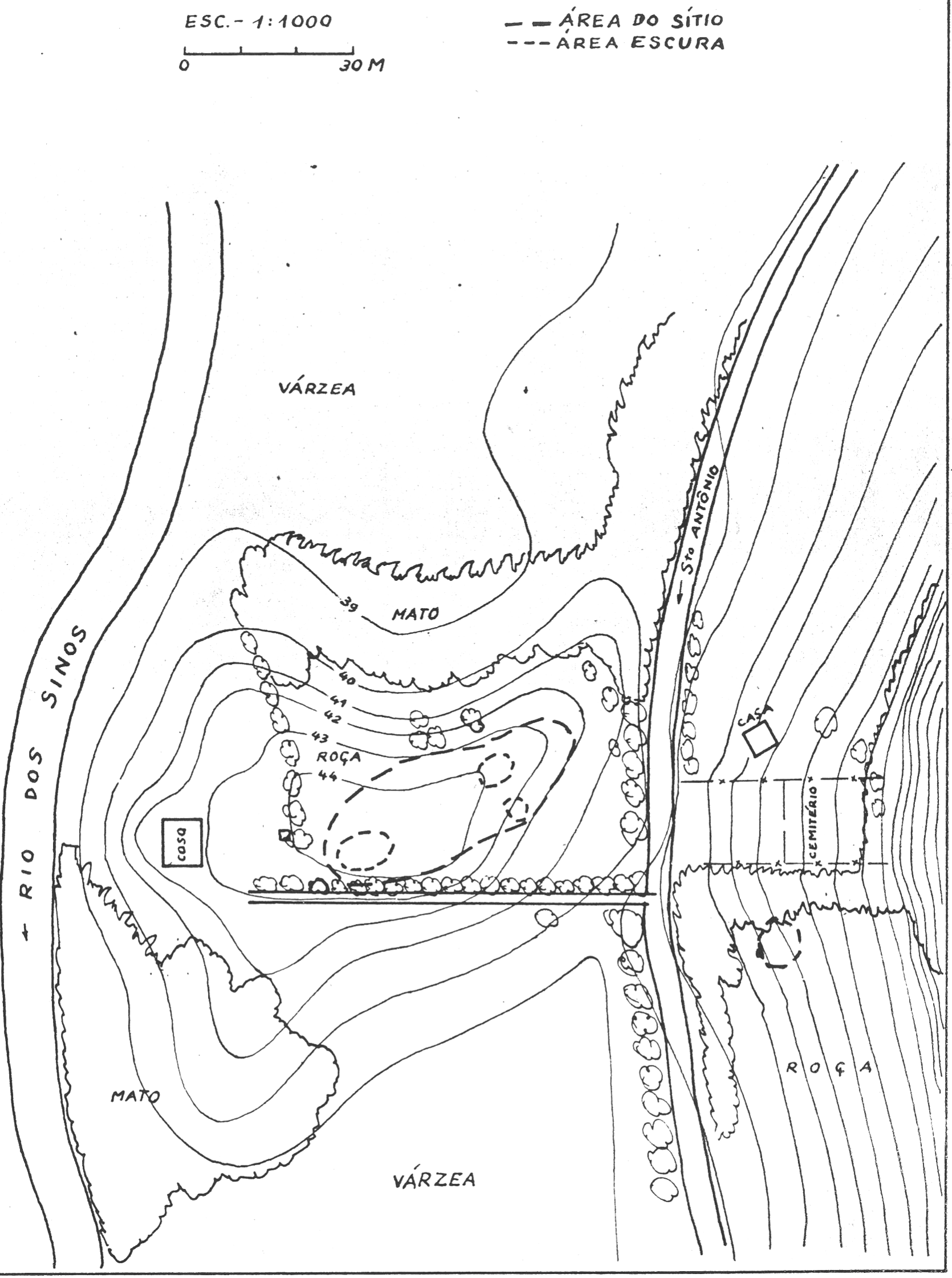
16. RS-S-287: Passo da Forquilha 2 e RS-S-288: Passo da Forquilha 3

Original de Eurico T. Miller (03/01/1966 e 04/01/1966)

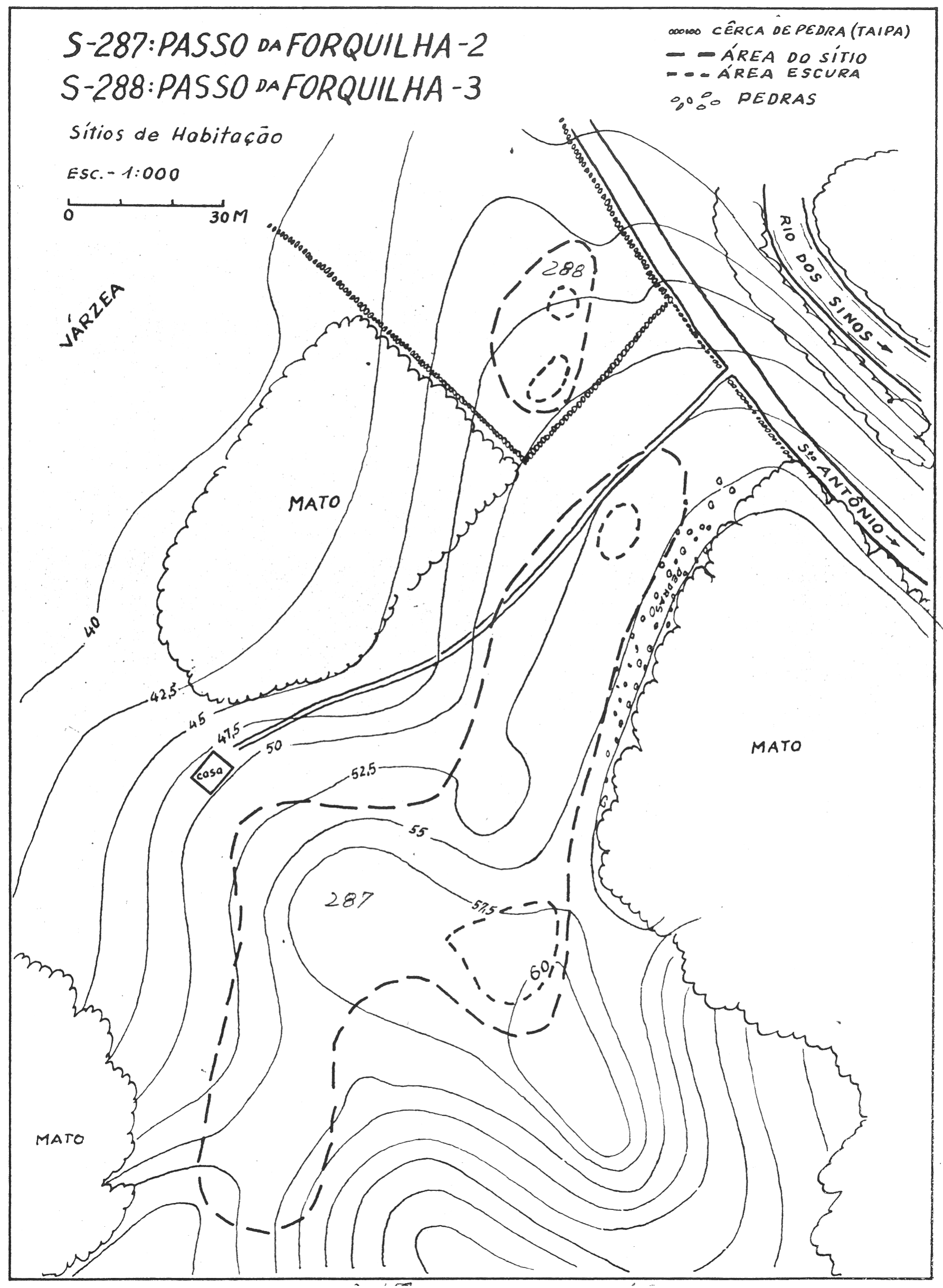


17. RS-S-284: Carvalho

Original de Eurico T. Miller (28/12/1965)

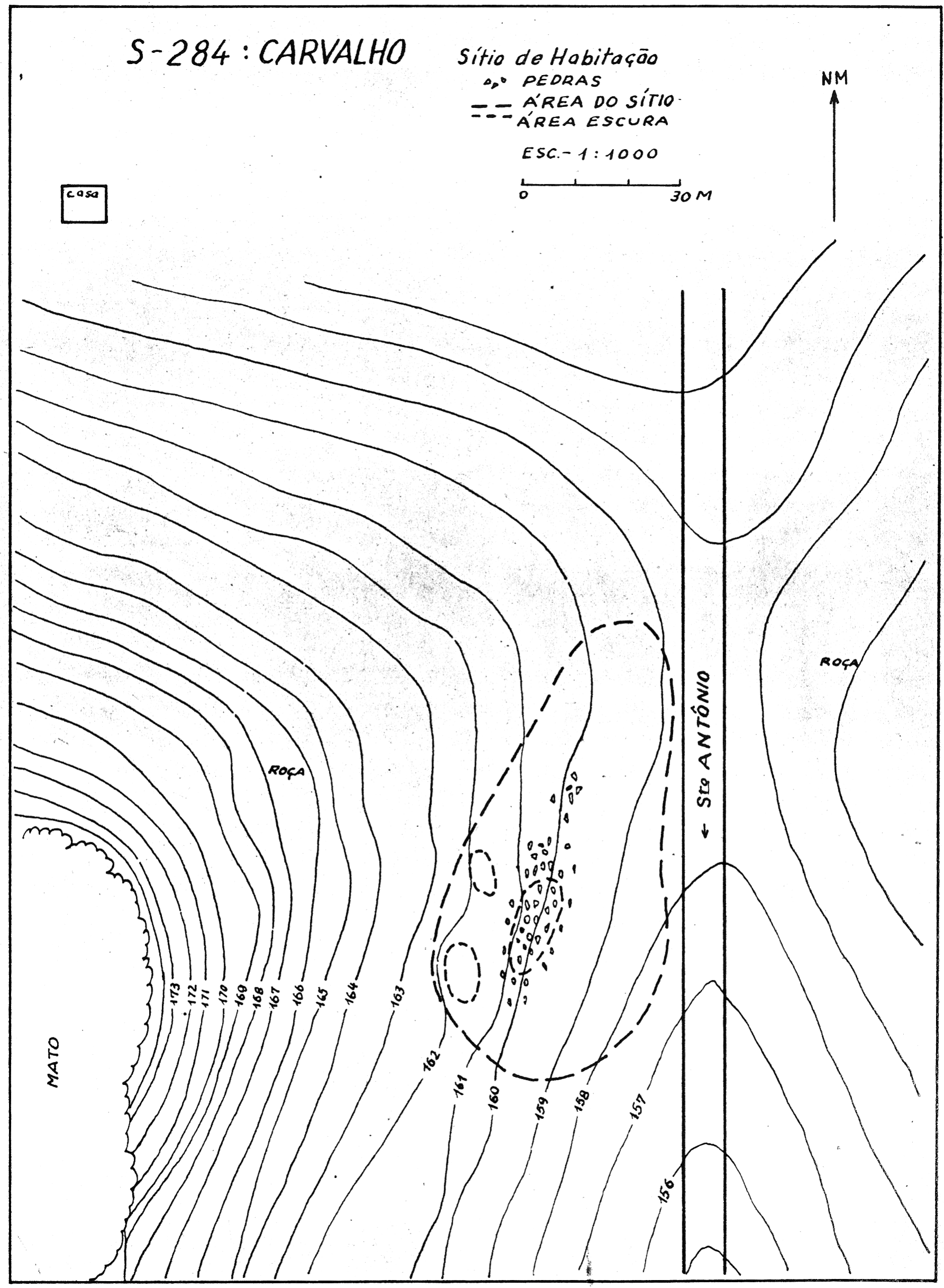


Anexo 5

Perfis das escavações

Legenda:

BA - Bloco de arenito

BAD - Bloco de arenito decomposto

SAF - Sedimento arenoso fino

SAG - Sedimento arenoso grosso

SAM - Sedimento arenoso marrom

SCC - Sedimento cinza com carvões

+ Carvão

${ }^{+}+{ }^{+}+$
$+{ }_{+}^{+}+{ }_{+}^{+}$
${ }_{+}+{ }_{+}^{+}$

Bola de cinza (scc)

Datação

Toca de inseto

I Raiz

6 Buraco de raiz

$\overbrace{=}^{2 y}$ Toca de tatu

aloco de arenito

Lente de cinzas

Lente de madeira e palha

म

Lente de folhas

Cupinzeiro 
1. RS-S-360: Marimbondo

Escala 1:20

PERFIL LESTE

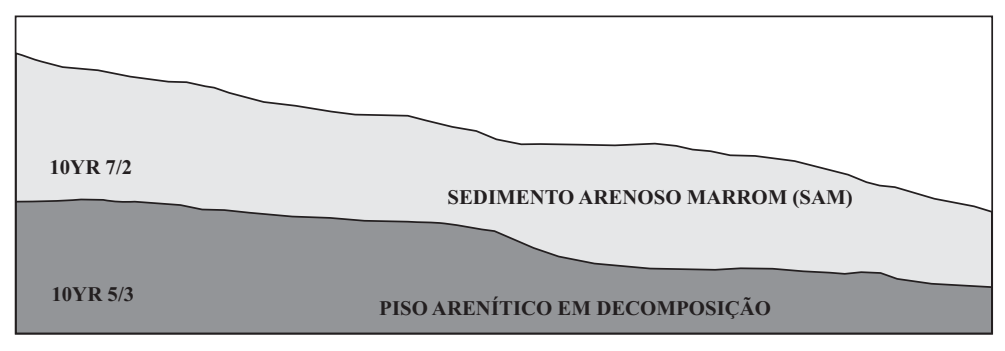

D48

D47

2. RS-S-360: Marimbondo

Escala 1:20

PERFIL SUL

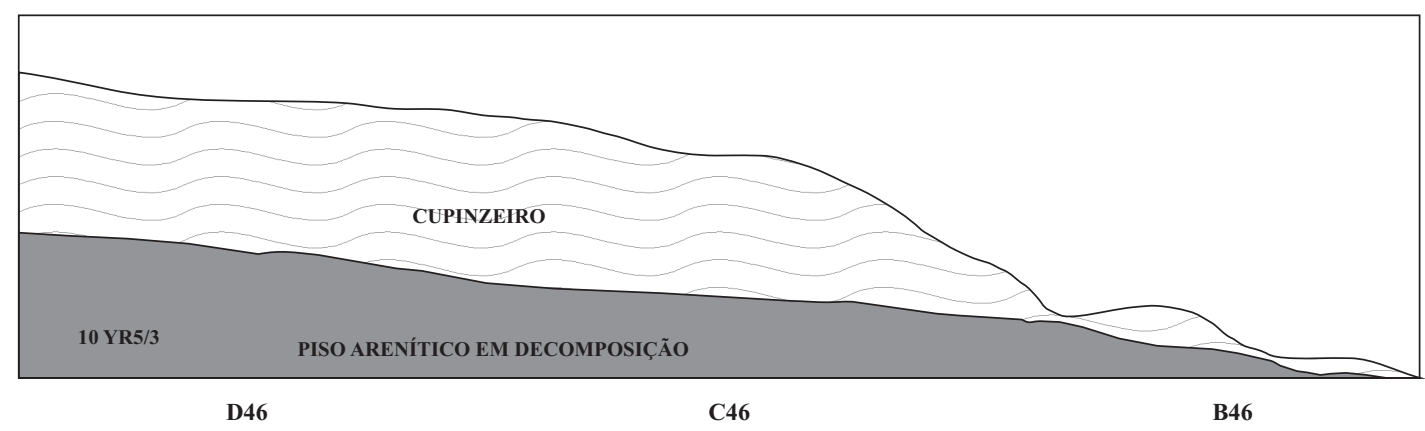


3. RS-S-327: Sangão Escala 1:20

D14 - PERFIL OESTE
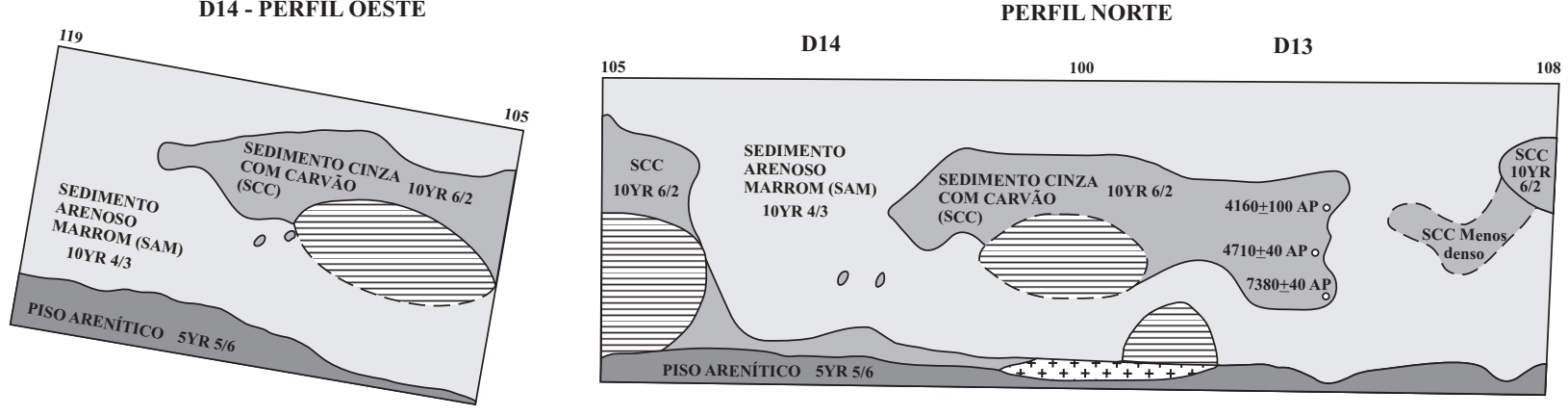

\section{RS-S-327: Sangão}

Escala 1:20

PERFIL SUL

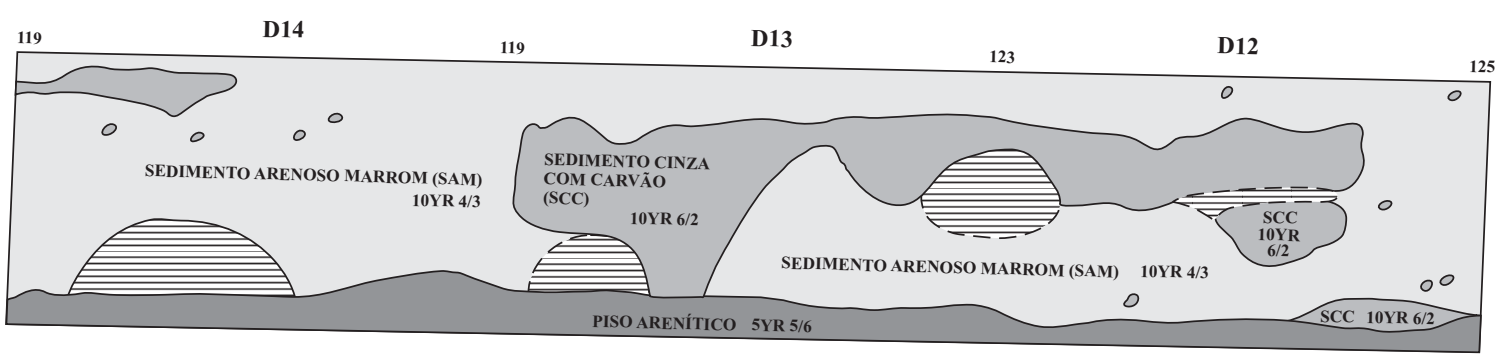

\section{RS-S-327: Sangão}

Escala 1:20

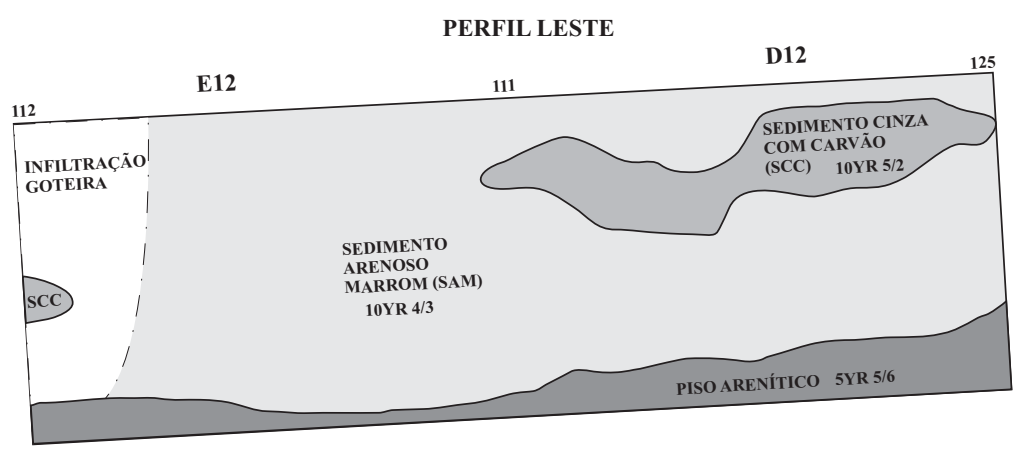

7. RS-S-327: Sangão

Escala 1:20

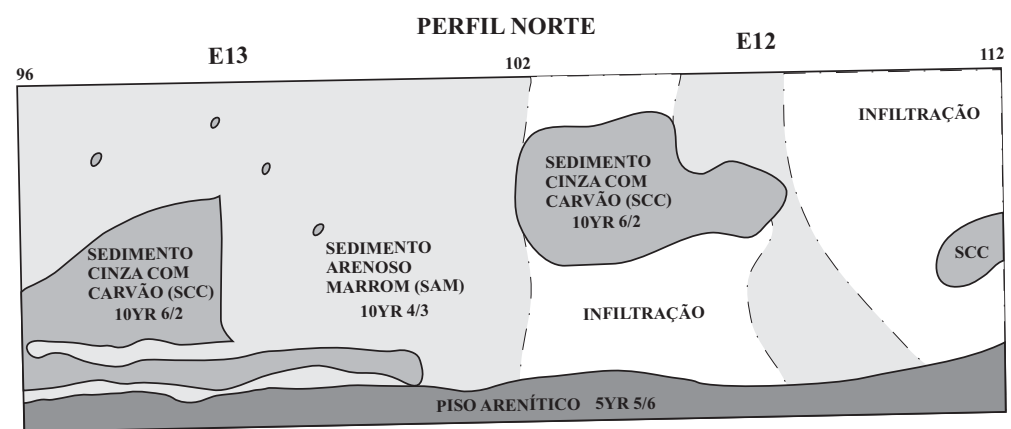




\section{RS-S-327: Sangão}

Escala 1:20

PERFIL OESTE

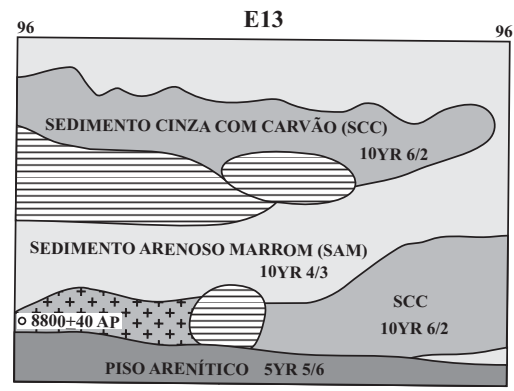

9. RS-S-327: Sangão

Escala 1:20

PERFIL LESTE

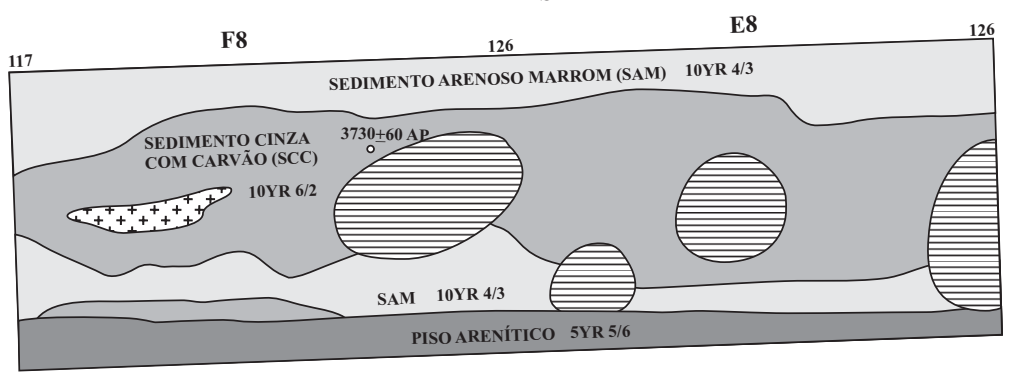

10. RS-S-327: Sangão

Escala 1:20

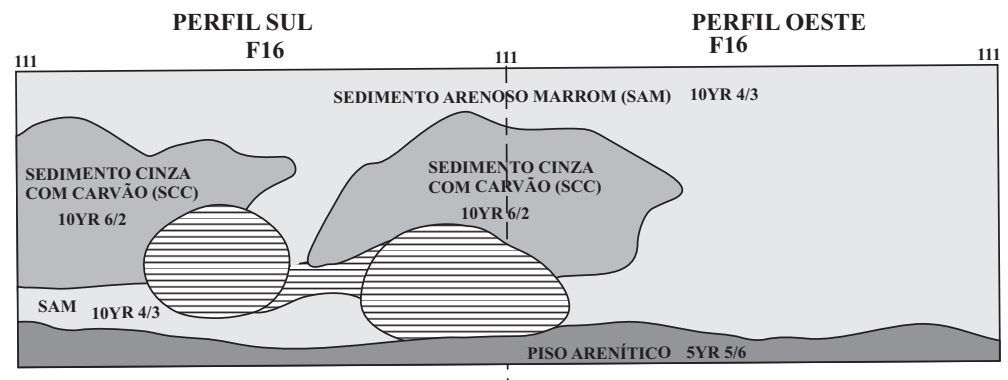

11. RS-S-327: Sangão

Escala 1:20

PERFIL NORTE

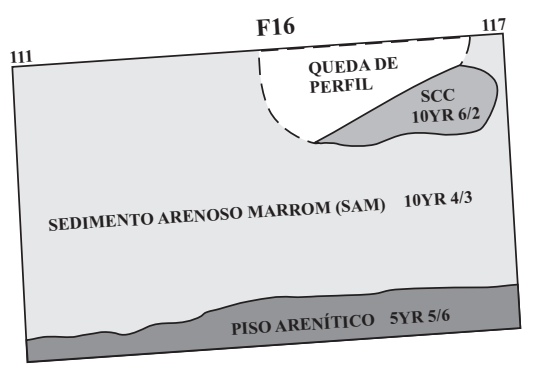


12. RS-S-337: Monjolo

Escala 1:20

PERFIL LESTE

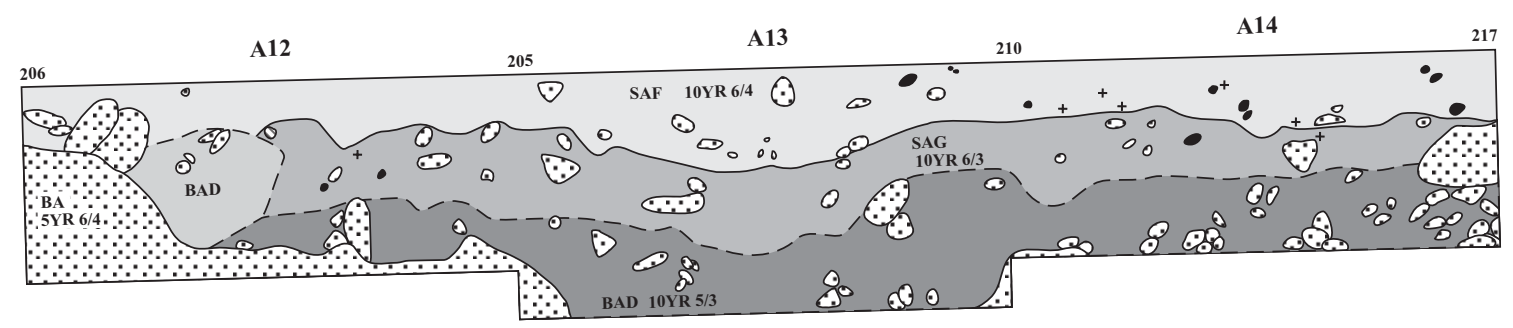

13. RS-S-337: Monjolo

Escala 1:20

PERFIL SUL

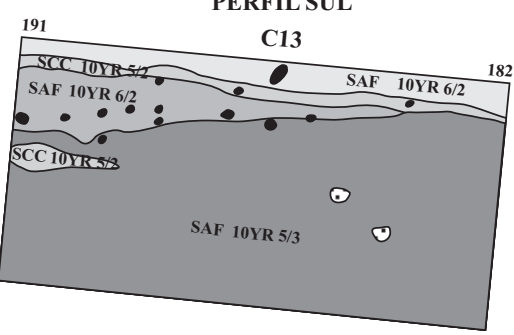

14. RS-S-337: Monjolo

Escala 1:20

PERFIL SUL

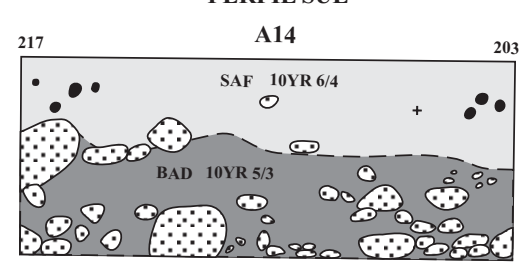

15. RS-S-337: Monjolo

Escala 1:20

PERFIL OESTE

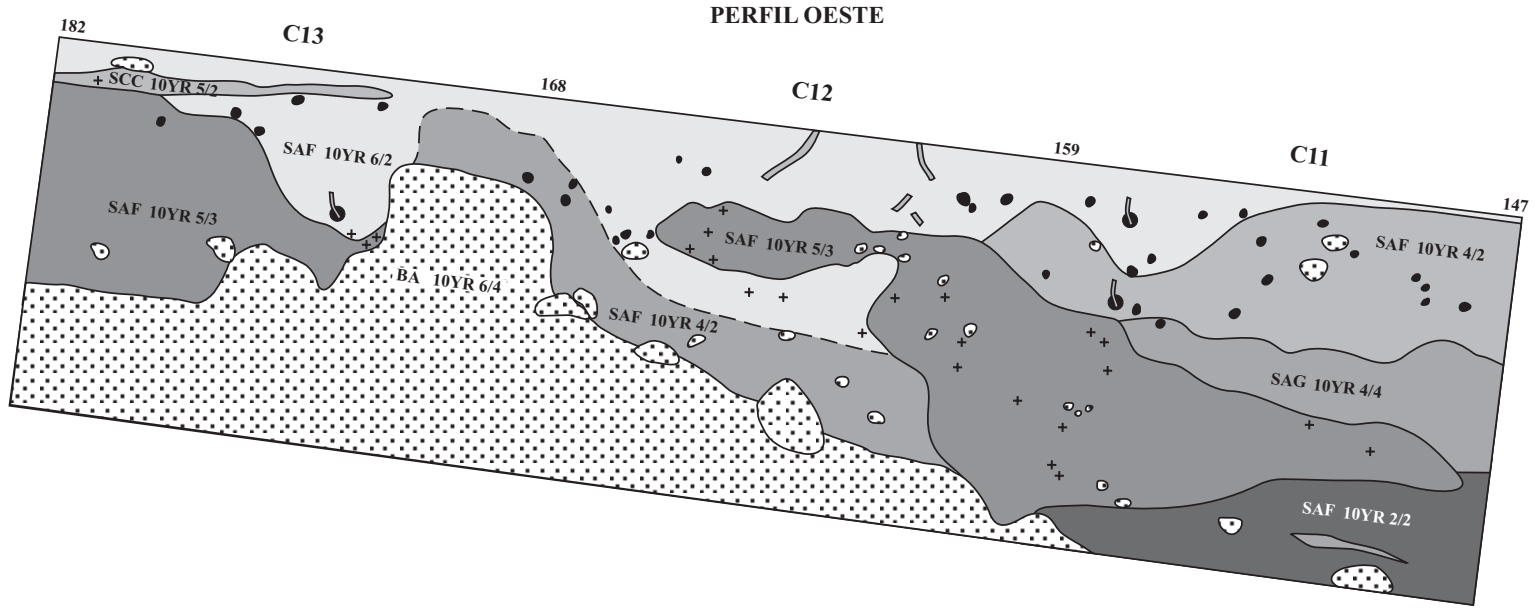

16. RS-S-337: Monjolo

Escala 1:20

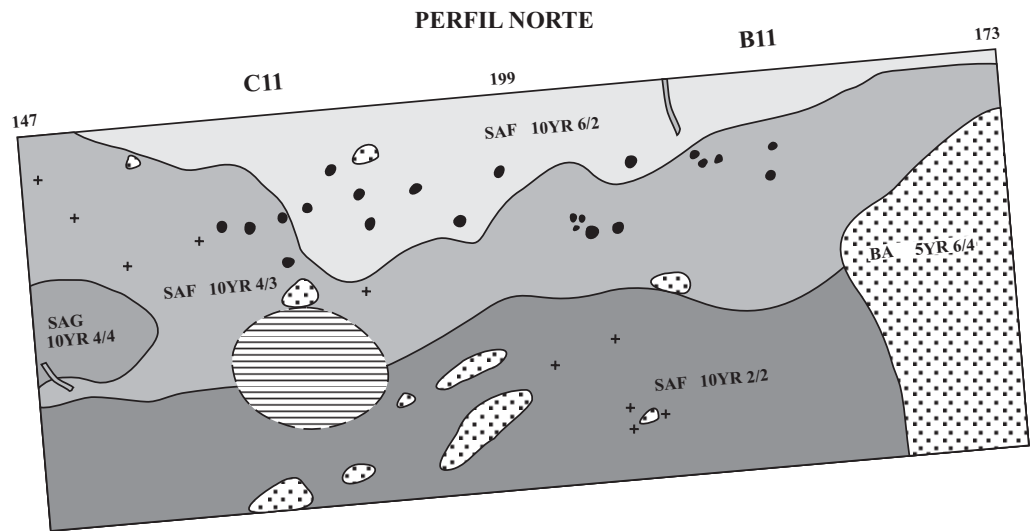



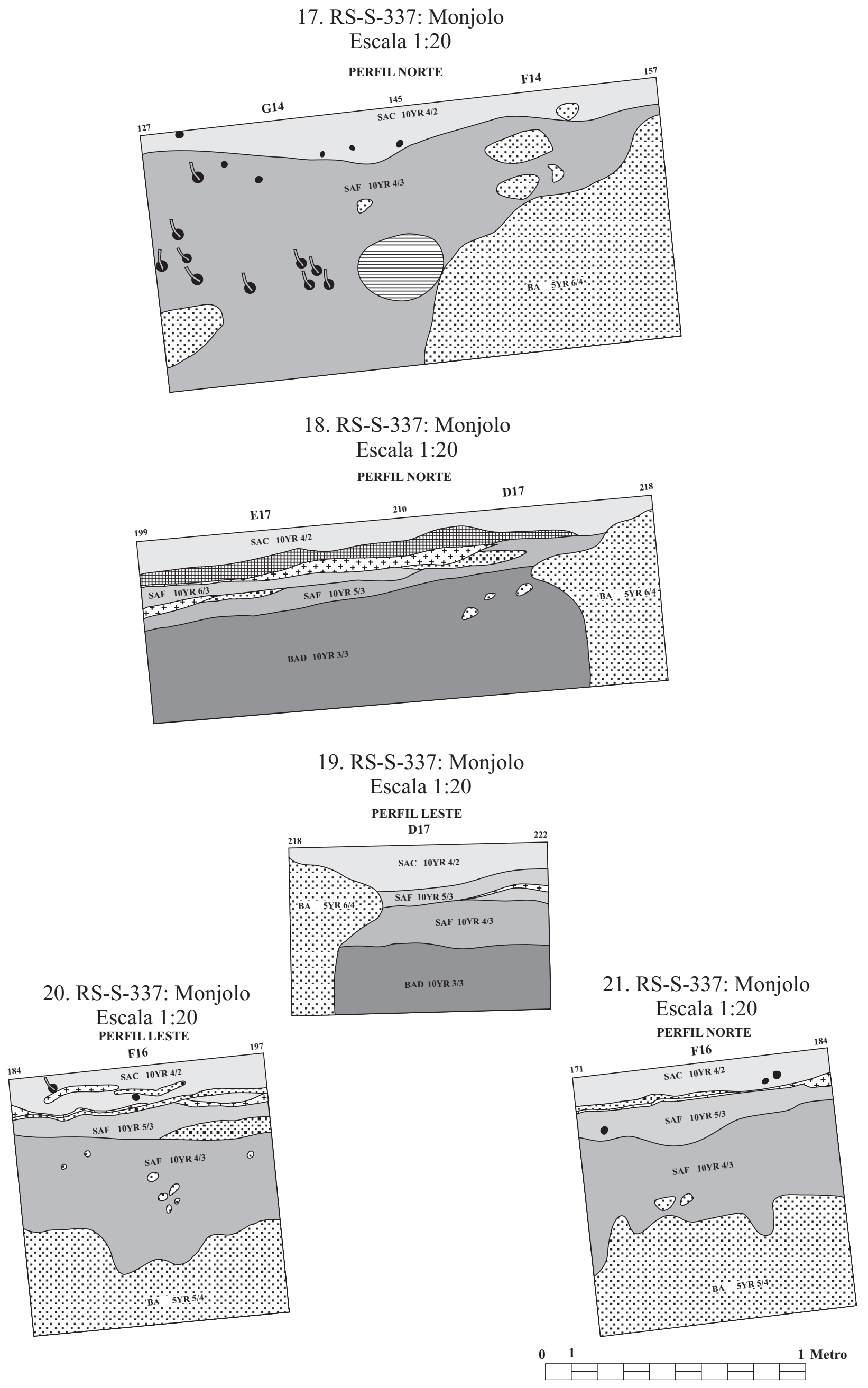
22. RS-S-337: Monjolo

Escala 1:20

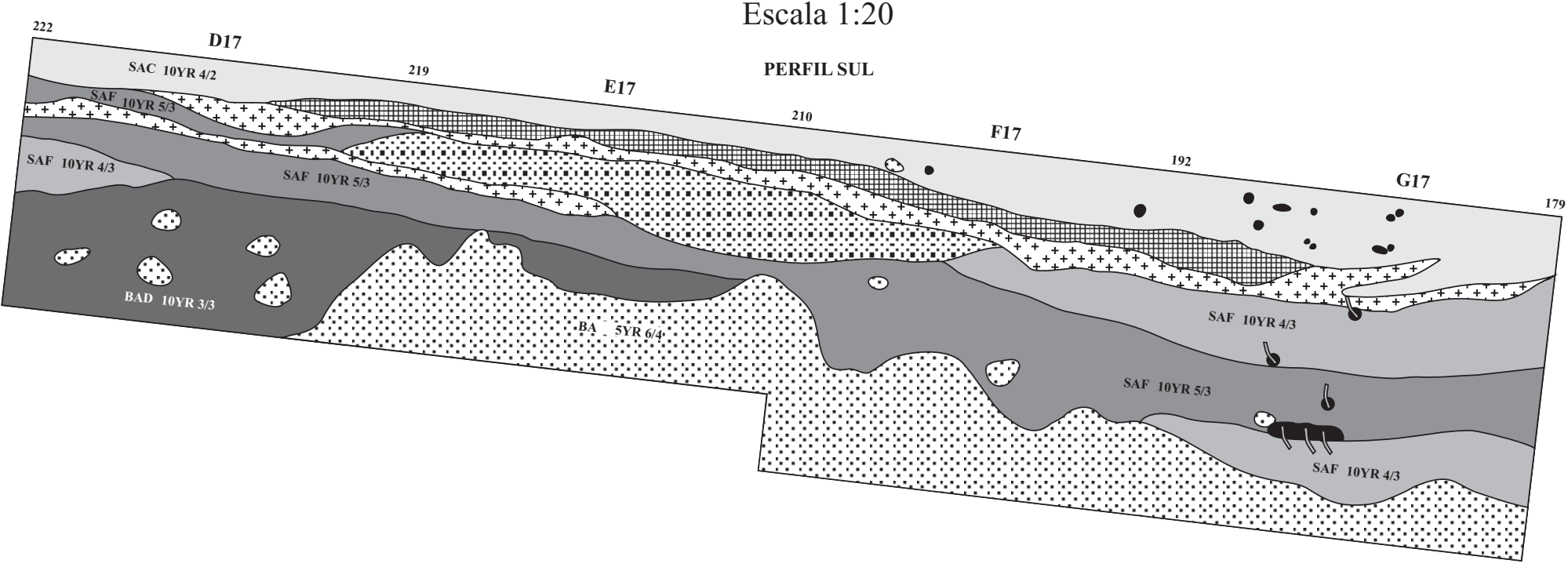

23. RS-S-337: Monjolo

Escala 1:20

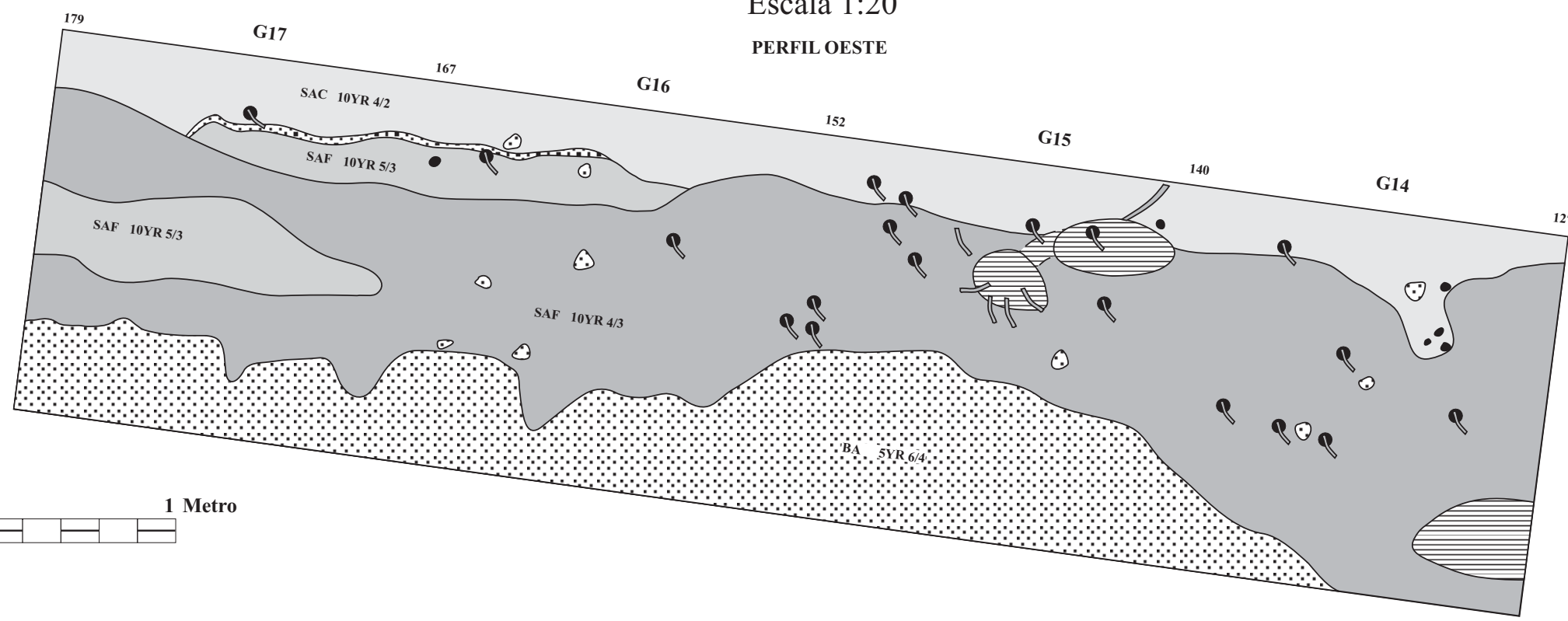


Anexo 6

Planos de plotagens das escavações

Legenda:

Bloco de arenito

+ Carvão

- Concha

$\odot 3$ Artefato conchífero

$\odot 4$ Coquinho

๑5 Folhas

- Ósseo

๑2 Dente

๑3 Artefato ósseo

$\odot 4$ Ósseo humano

$\odot 5$ Dente humano

- Lítico

๑1 Lasca unipolar

$\odot 2$ Lasca bipolar

$\odot 3$ Núcleo unipolar

$\odot 4$ Núcleo bipolar

$\odot 5$ Fragmento de lascamento

- 6 Fragmento seixo ou bloco basalto

- 7 Fragmento placa basalto

$\odot 8$ Fragmento placa basalto com lascamento

-9 Fragmento placa ou seixo

-10 Fragmento térmico

๑11 Pré-forma

$\odot 12$ Ponta de projétil

- 13 Micro-raspador

$\odot 14$ Fragmento de artefato bifacial

$\odot 15$ Lasca unipolar de peça polida

$\odot 16$ Hematita

$\odot 17$ Polidor arenito

$\odot 18$ Biface

$\odot 19$ Calcedônia polida

๑20 Placa basalto polida

- Cerâmica tradição neo-brasileira (fase Monjolo)

$\bigcirc$ Fragmento de metal

Coleta de fogueira

Coleta completa de fogueira

Datação

Buraco

$\bigcirc$ Piso arenítico

$\checkmark$ Vestígios PRONAPA

Cupinzeiro 
1. RS-S-360: Marimbondo

Escala 1:40

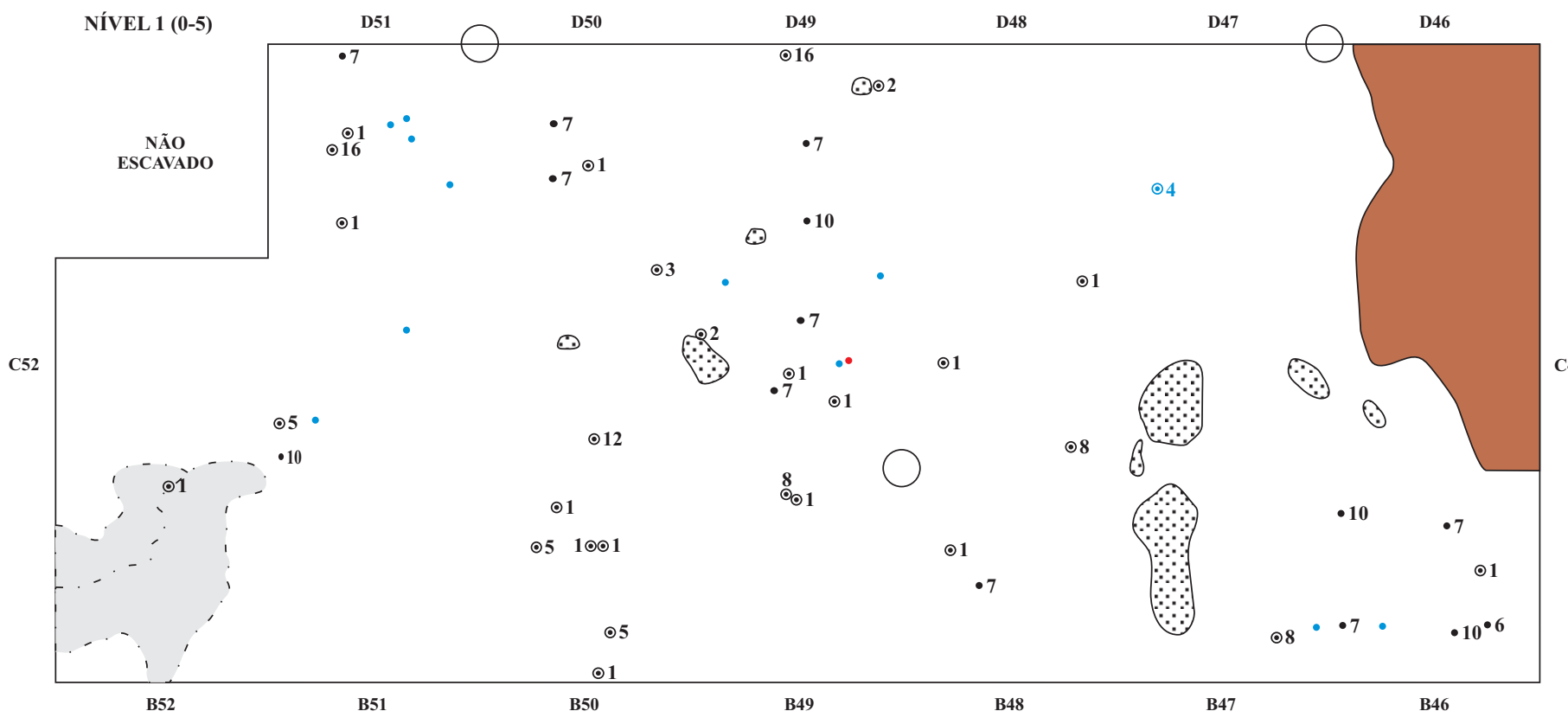

2. RS-S-360: Marimbondo

Escala 1:40

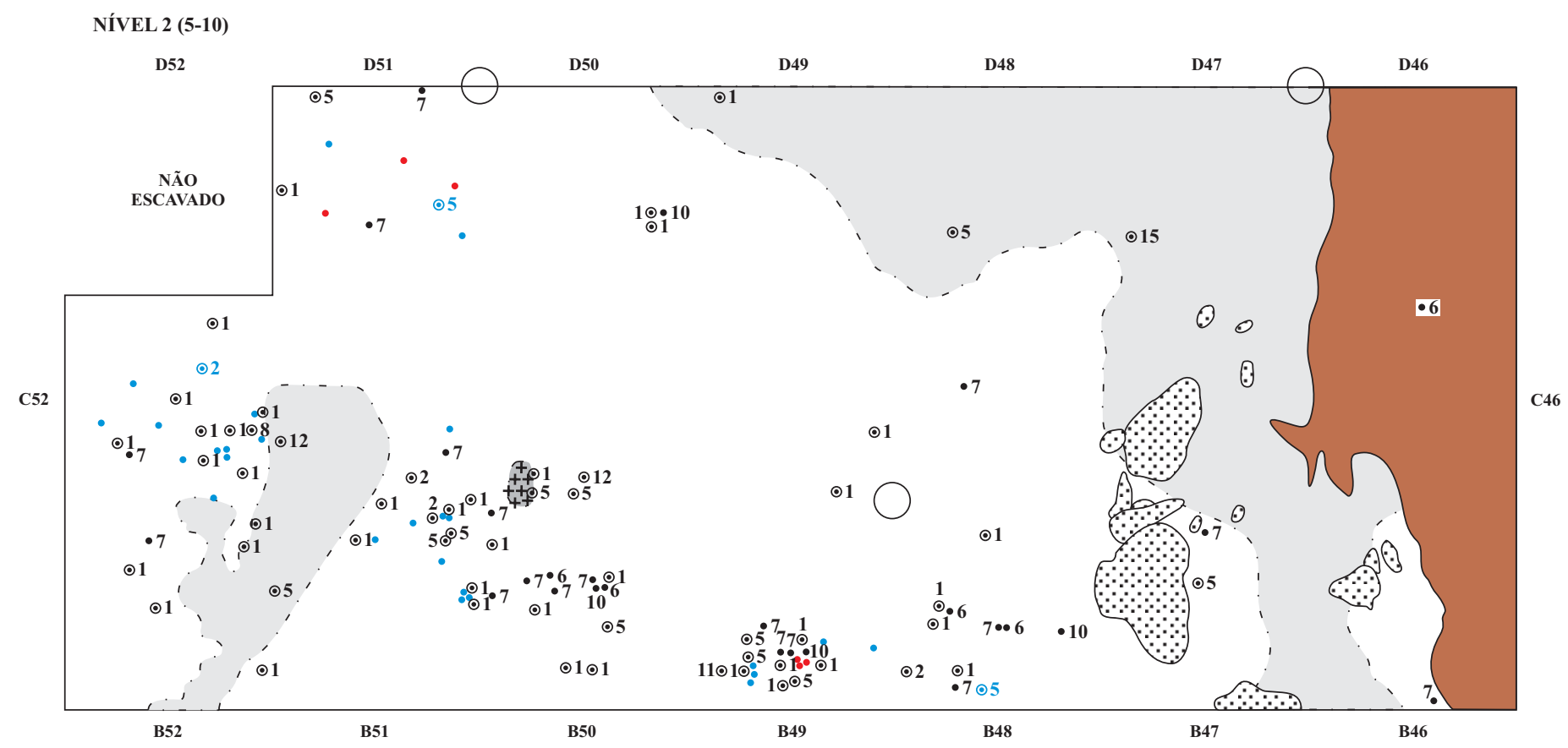


3. RS-S-360: Marimbondo

Escala 1:40

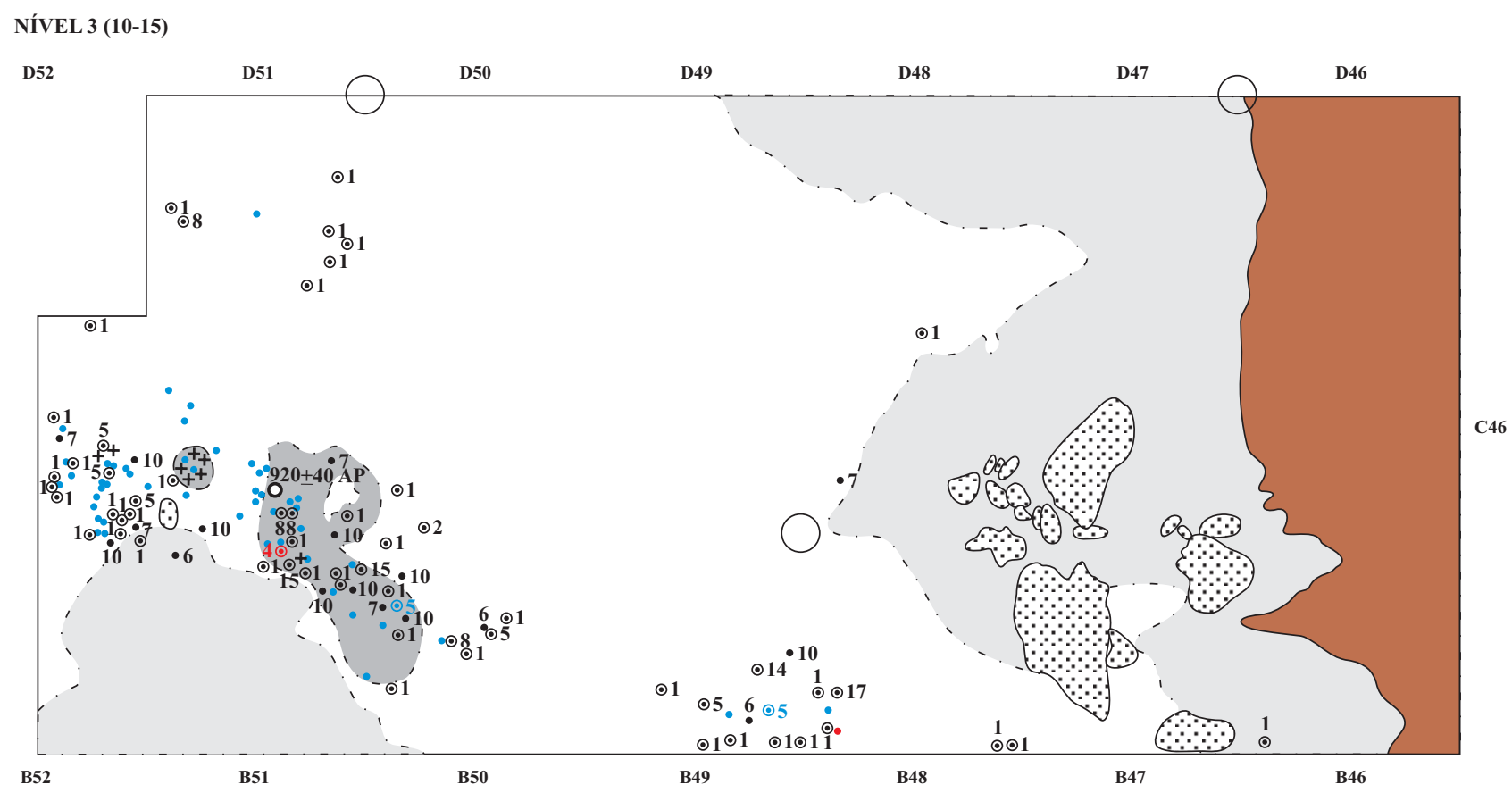

4. RS-S-360: Marimbondo

Escala 1:40

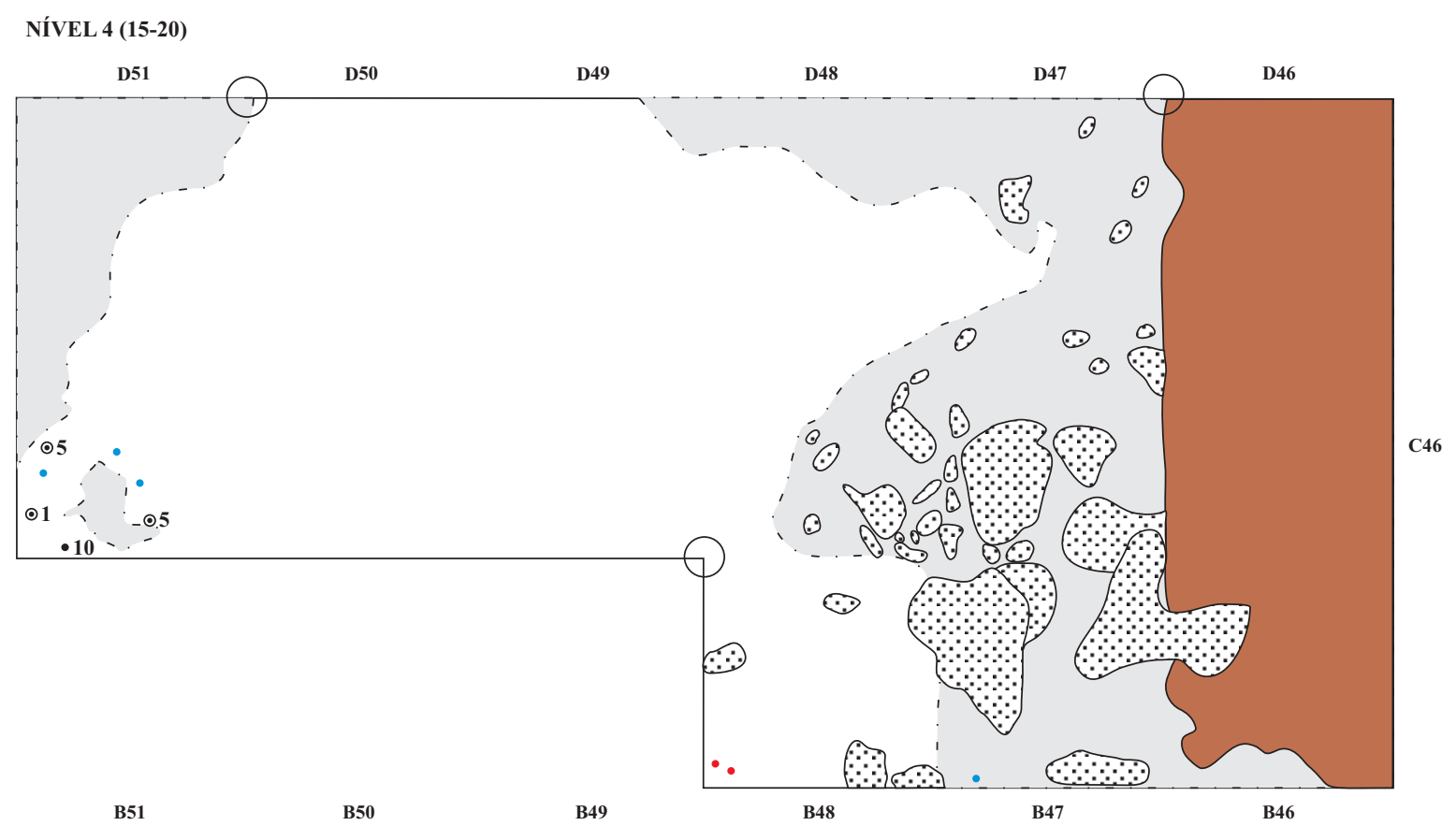


5. RS-S-360: Marimbondo

Escala 1:40

NÍVEL 5 (20-25)

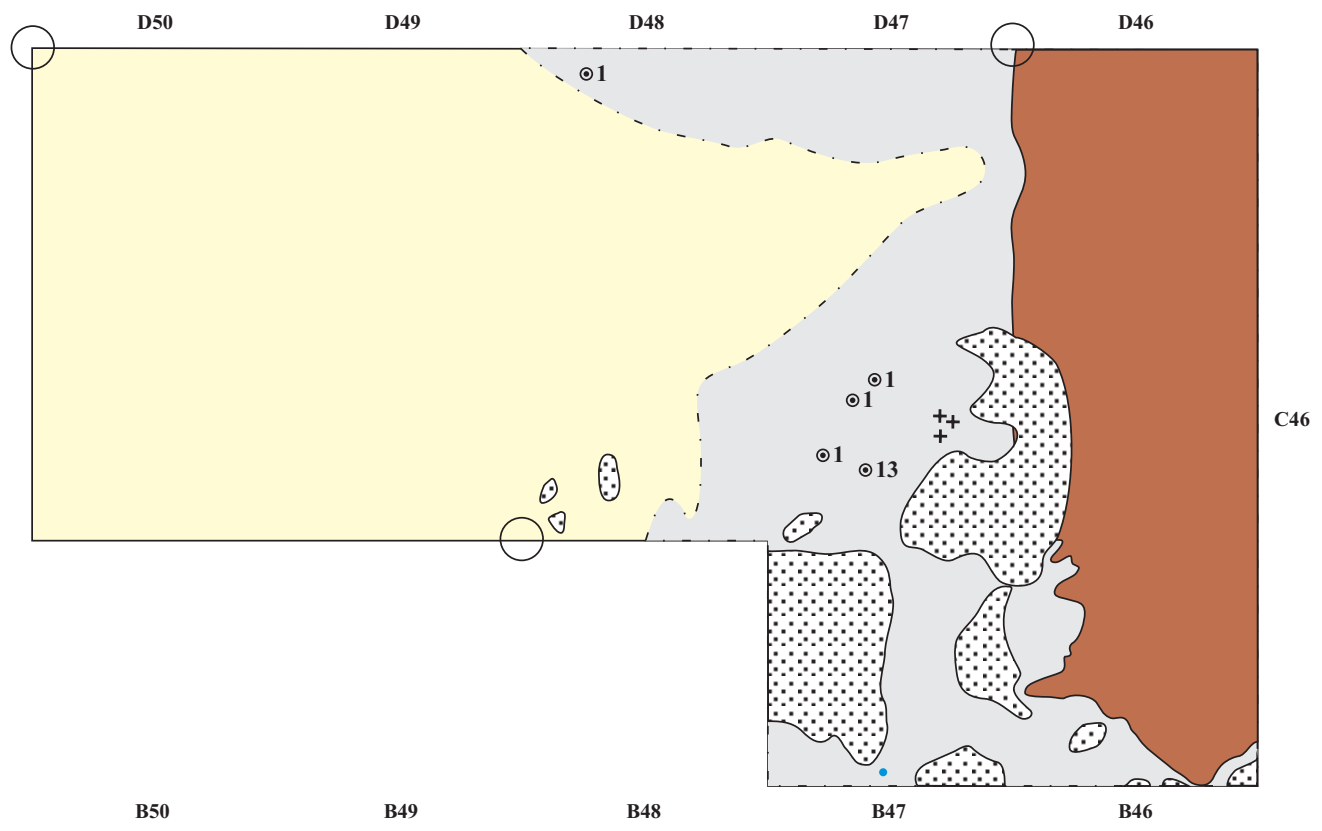

6. RS-S-360: Marimbondo Escala 1:40

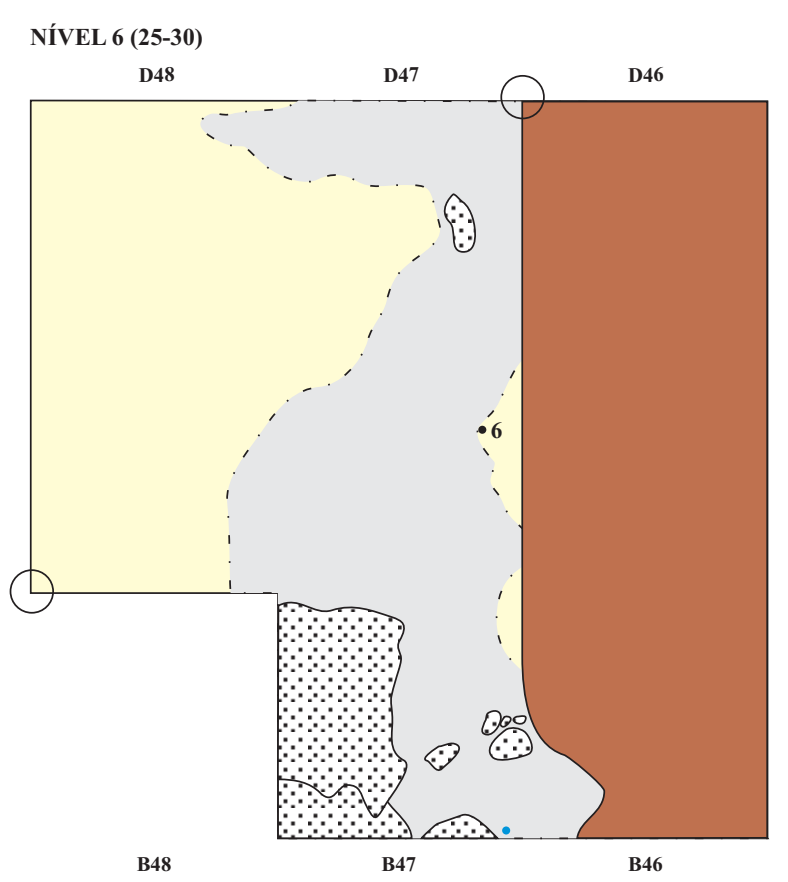

7. RS-S-360: Marimbondo Escala 1:40

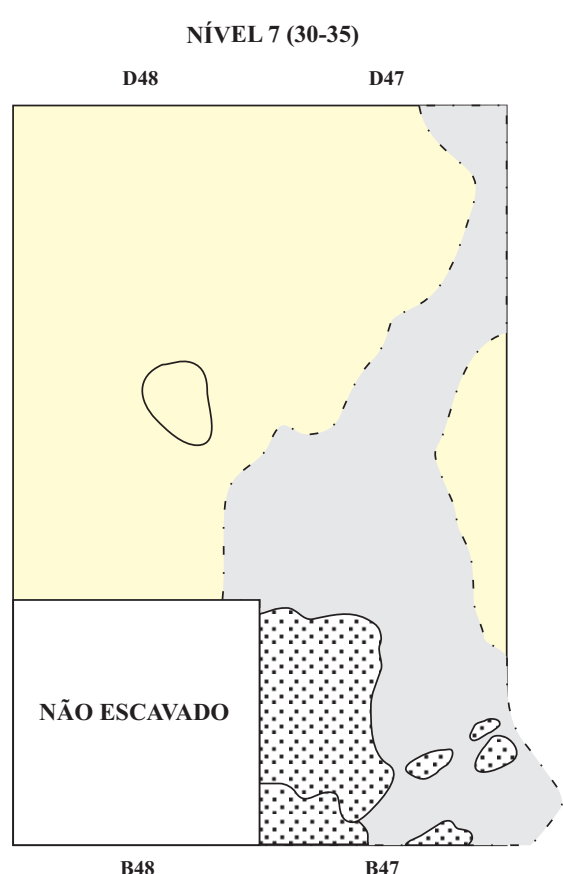

8. RS-S-360: Marimbondo Escala 1:40 NÍVEL 8 (35-40)

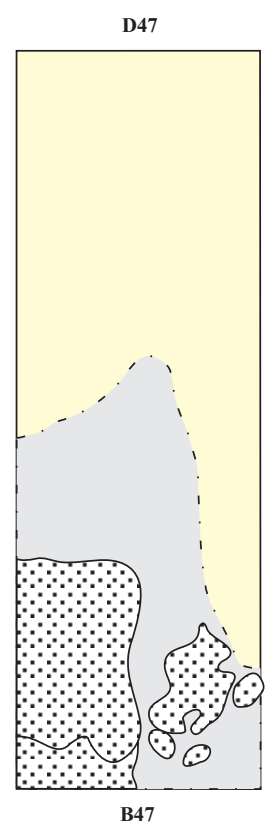


9. RS-S-327: Sangão

Escala 1:20

NÍVEL 1

E13

E12

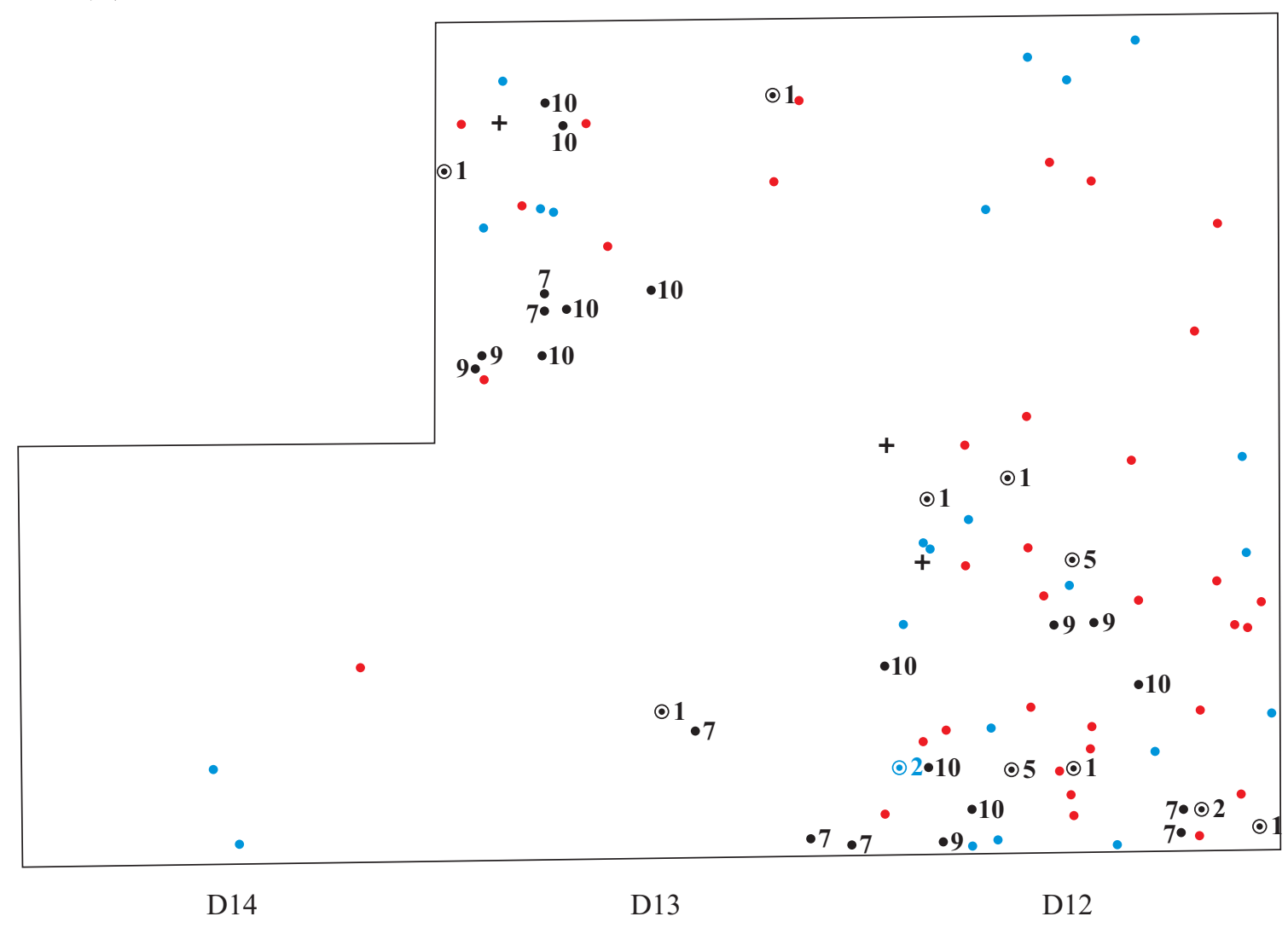

10. RS-S-327: Sangão

Escala 1:20

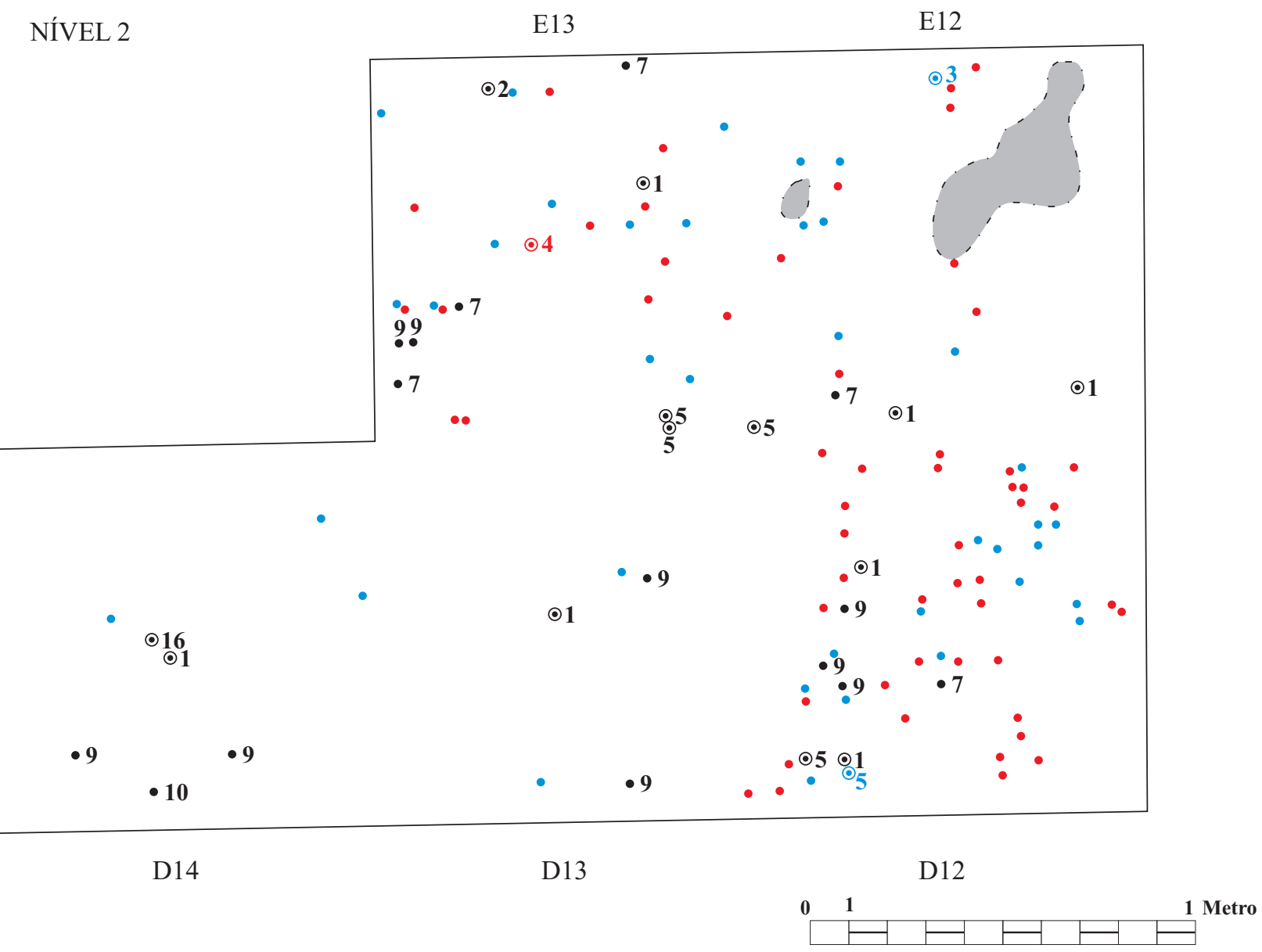


11. RS-S-327: Sangão

Escala 1:20

NÍVEL 3

E13

E12

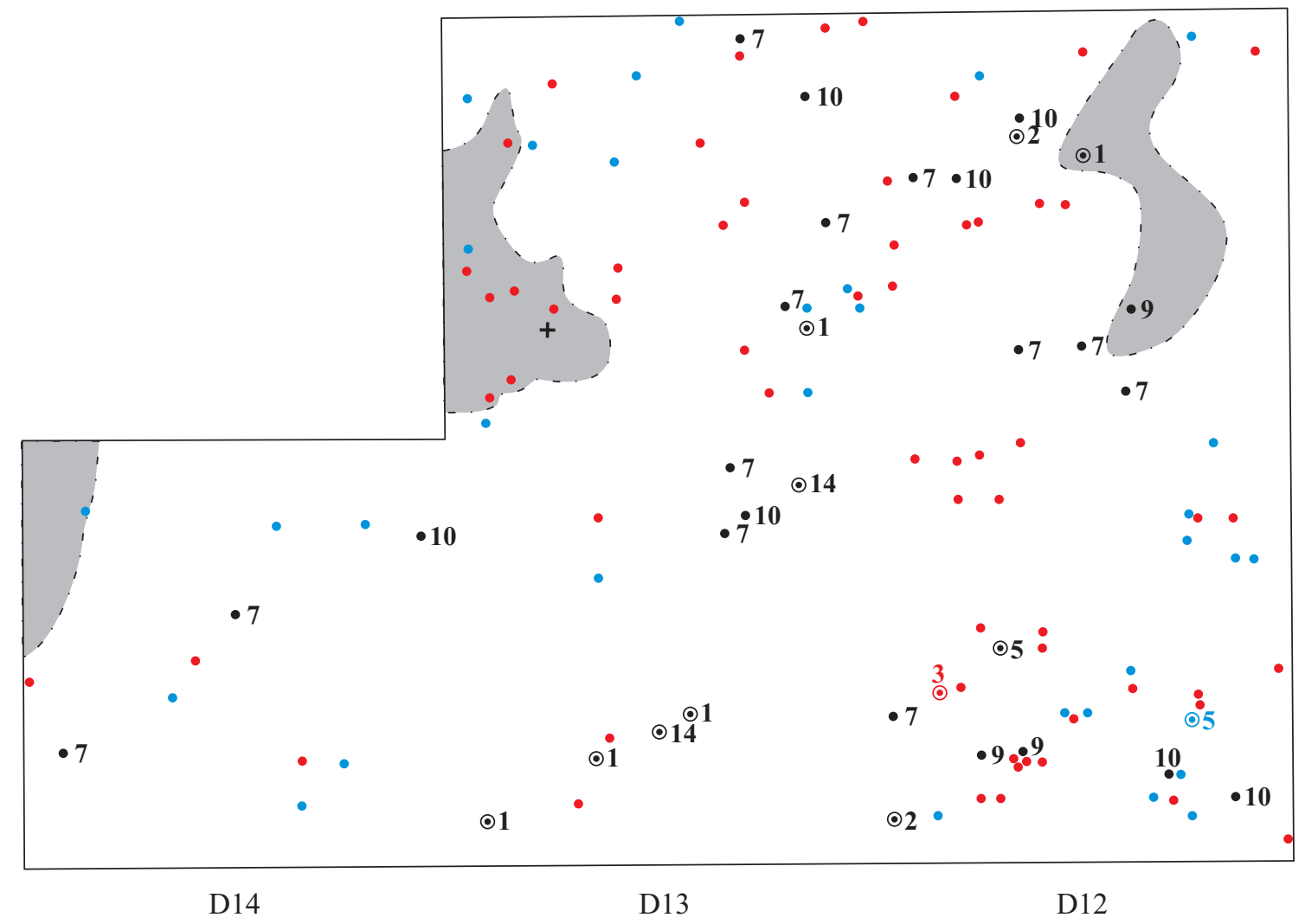

12. RS-S-327: Sangão

Escala 1:20

NÍVEL 4

E13

E12

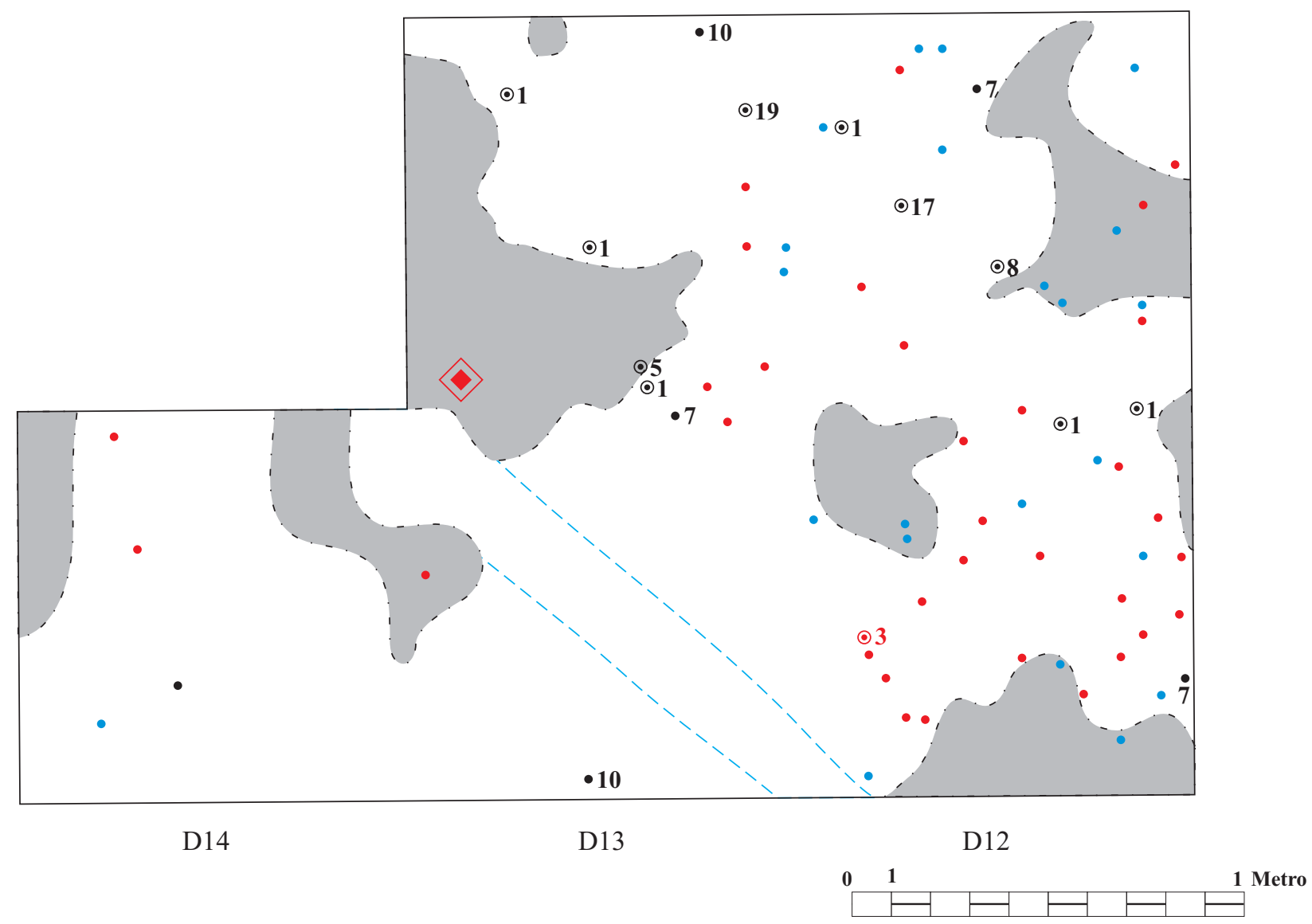


13. RS-S-327: Sangão

Escala 1:20

NÍVEL 5

E13

E12

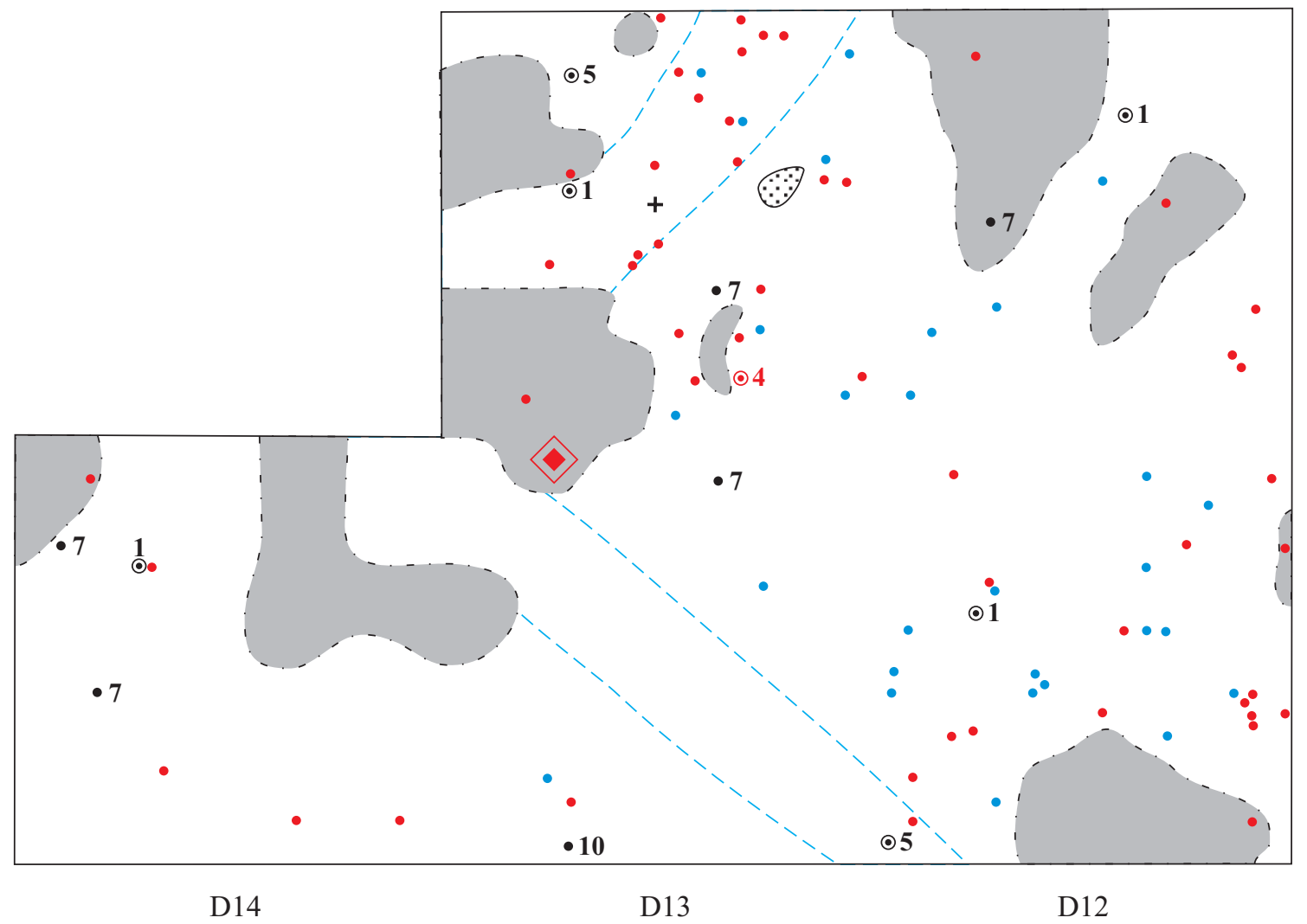

14. RS-S-327: Sangão

Escala 1:20

NÍVEL 6

E13

E12

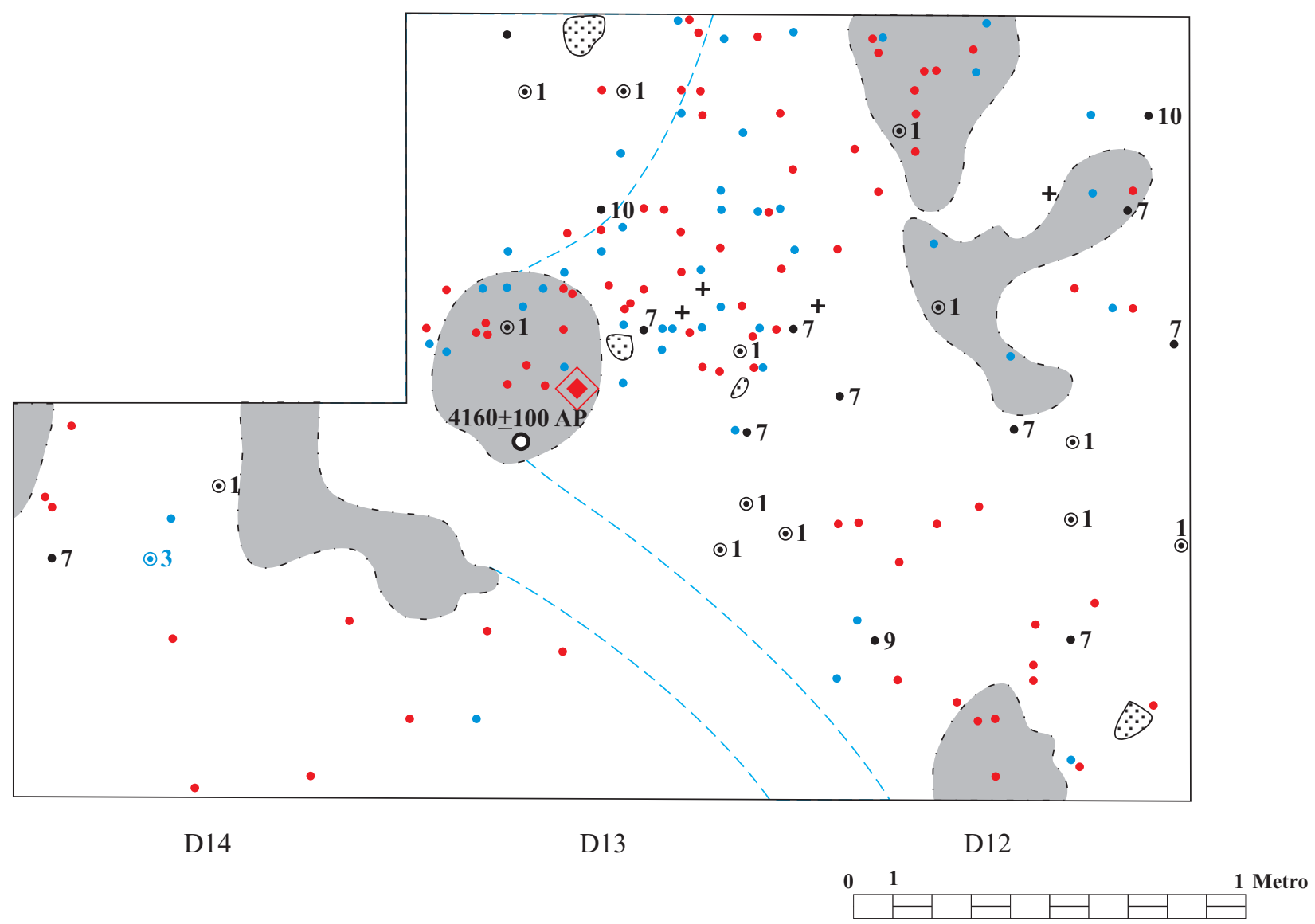


15. RS-S-327: Sangão

Escala 1:20

NÍVEL 7

E13

E12

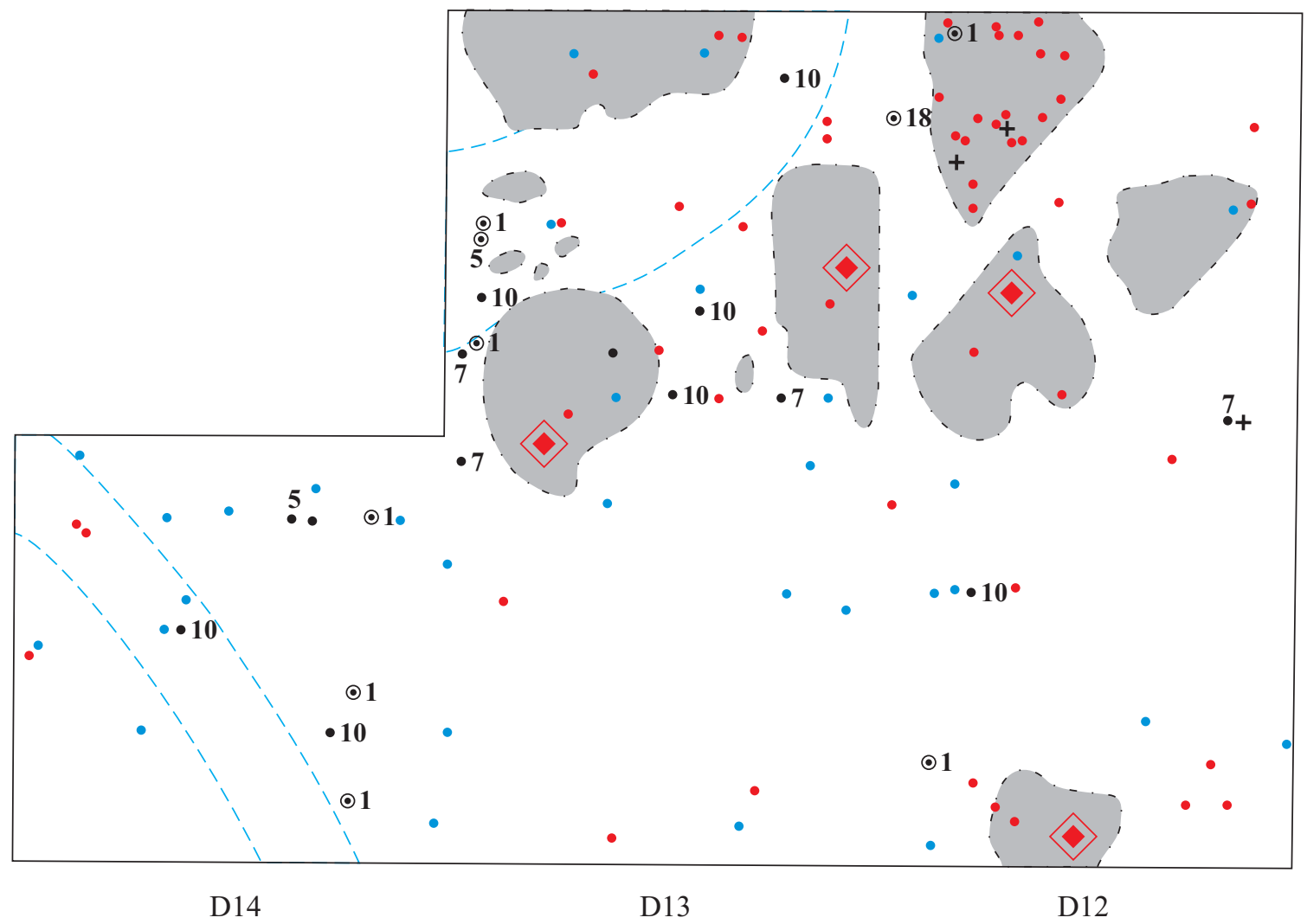

16. RS-S-327: Sangão

Escala 1:20

NÍVEL 8

E13

E12

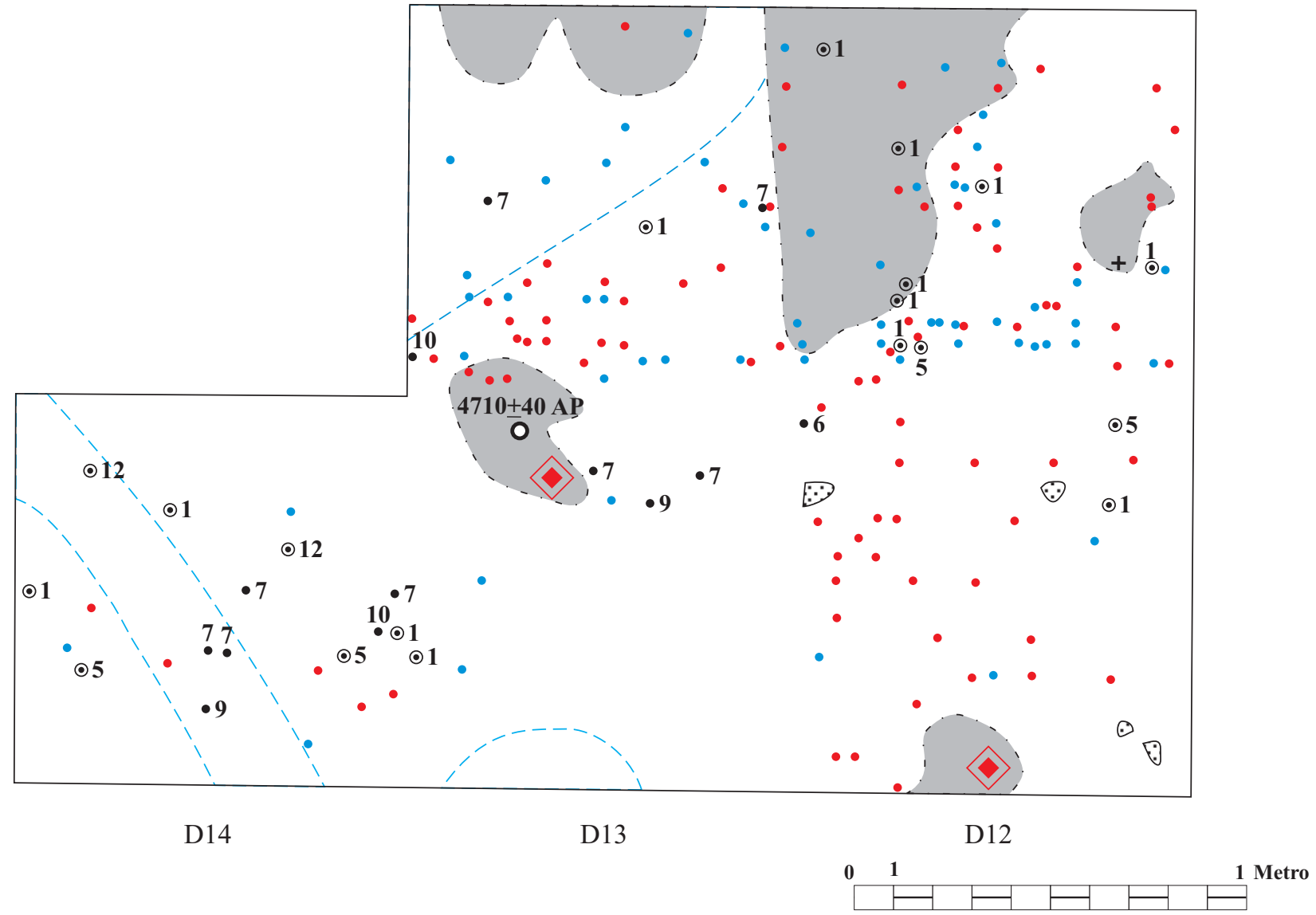


17. RS-S-327: Sangão

Escala 1:20

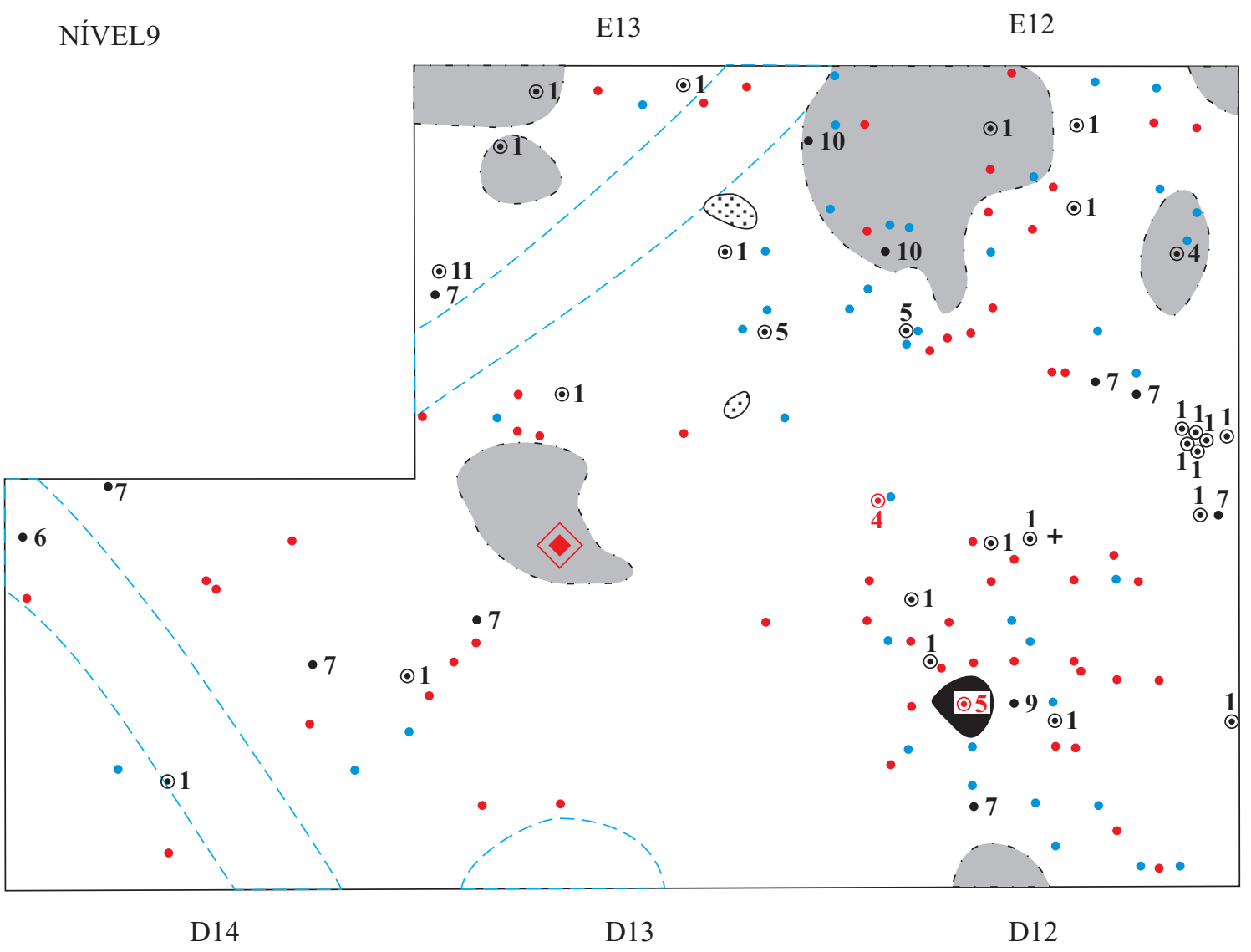

18. RS-S-327: Sangão

Escala 1:20

NÍVEL 10

E13

E12

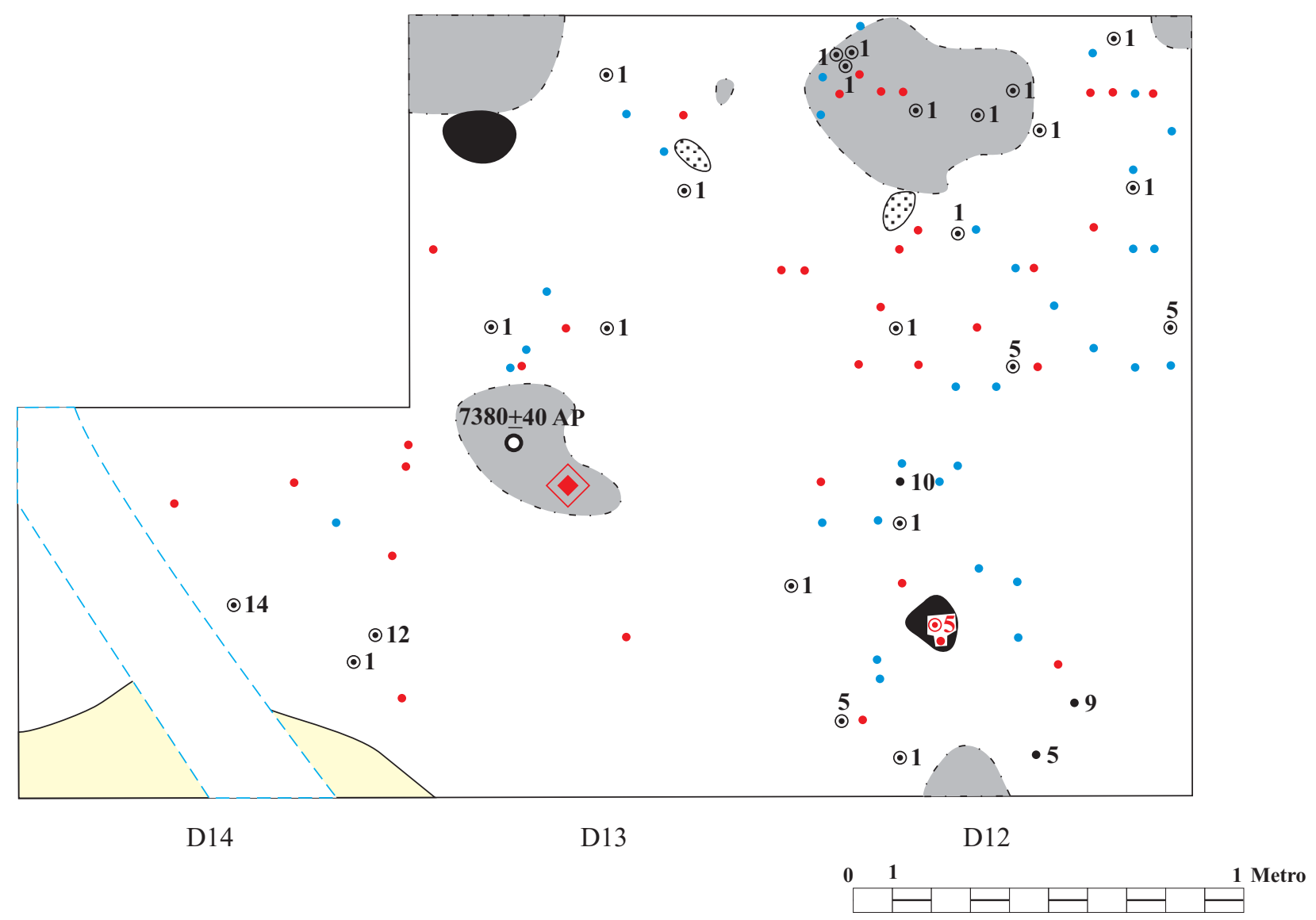


19. RS-S-327: Sangão

Escala 1:20

NÍVEL 11

E13

E12

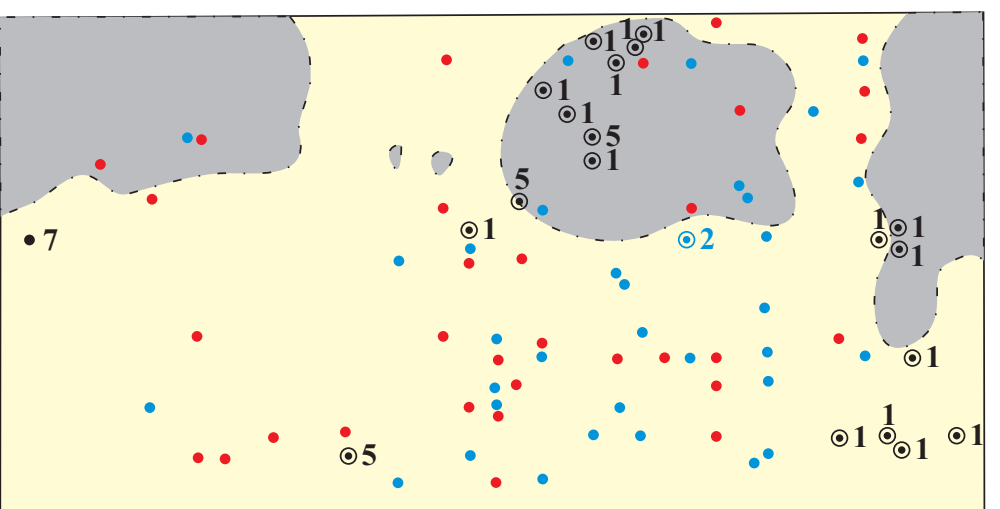

$\odot 1$

$\odot 1$

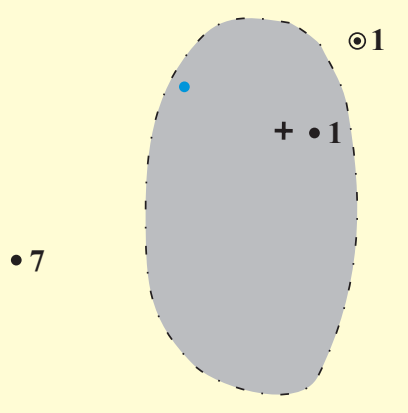

D14

D13

D12

20. RS-S-327: Sangão

Escala 1:20

NÍVEL 12

E13

E12

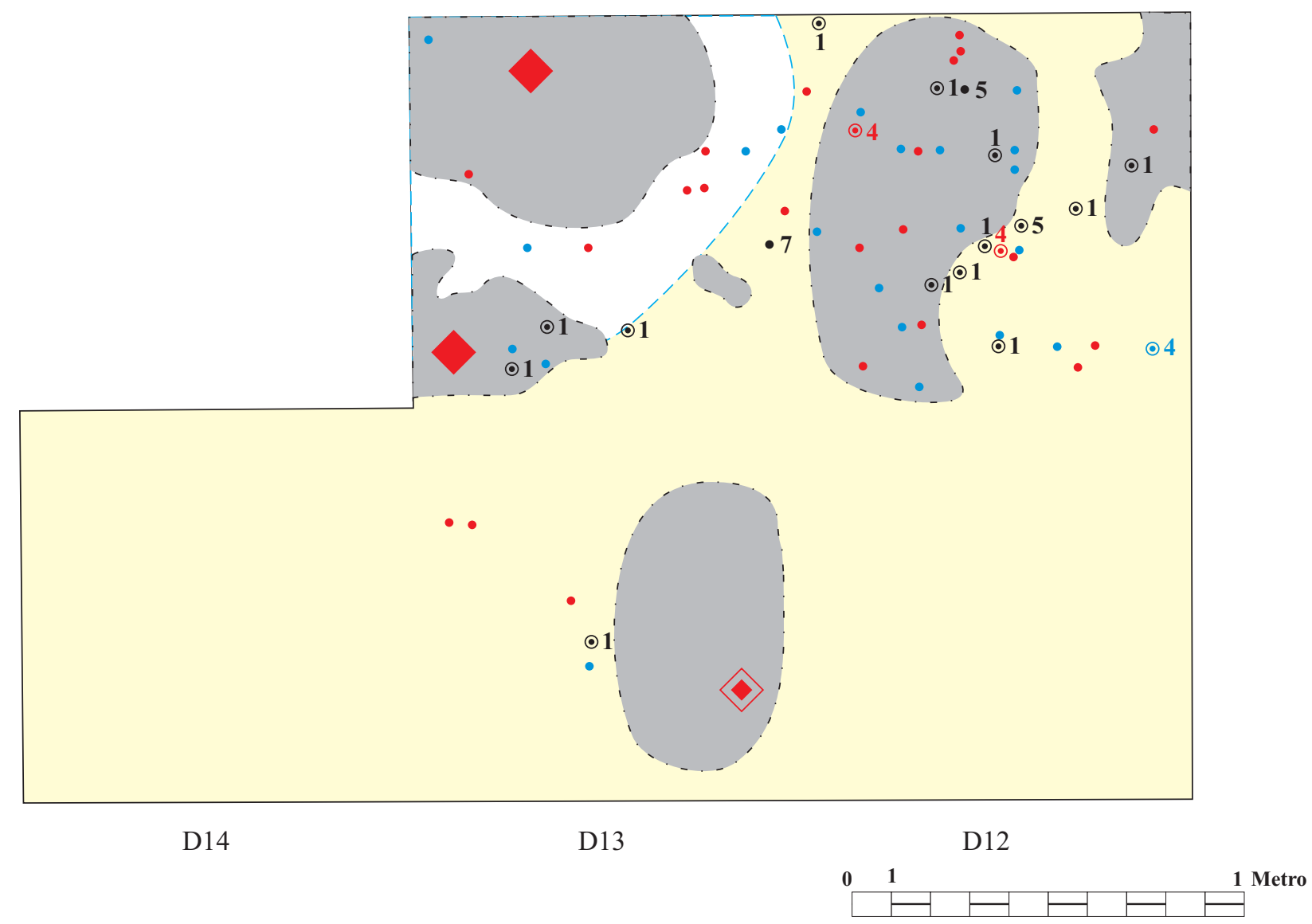


21. RS-S-327: Sangão

Escala 1:20

NÍVEL 13

E13

E12

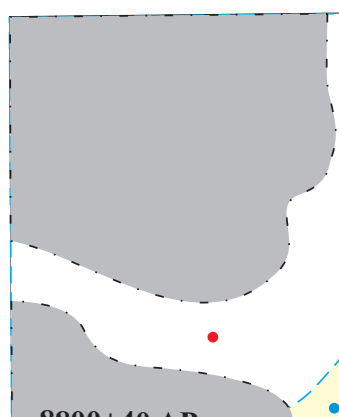

$8800+40$ AP

$\overline{0}$

111.

$\begin{array}{r}21 \\ +\quad 01 \\ \hline\end{array}$

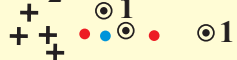

- $\bullet$

$\odot 1$

D14

D13

D12 
22. RS-S-327: Sangão

Escala 1:20

NÍVEL 1

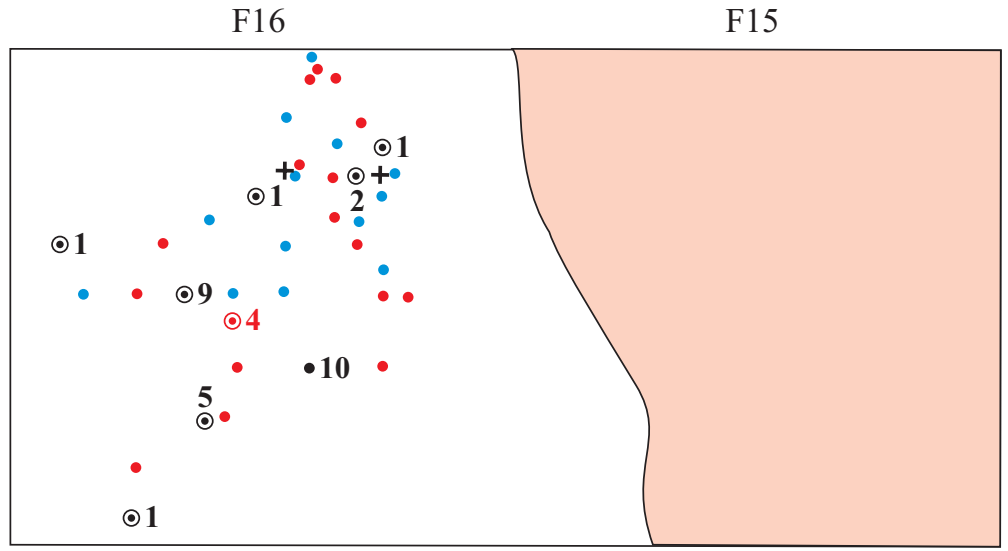

23. RS-S-327: Sangão

Escala 1:20

NÍVEL 2

F16

F15

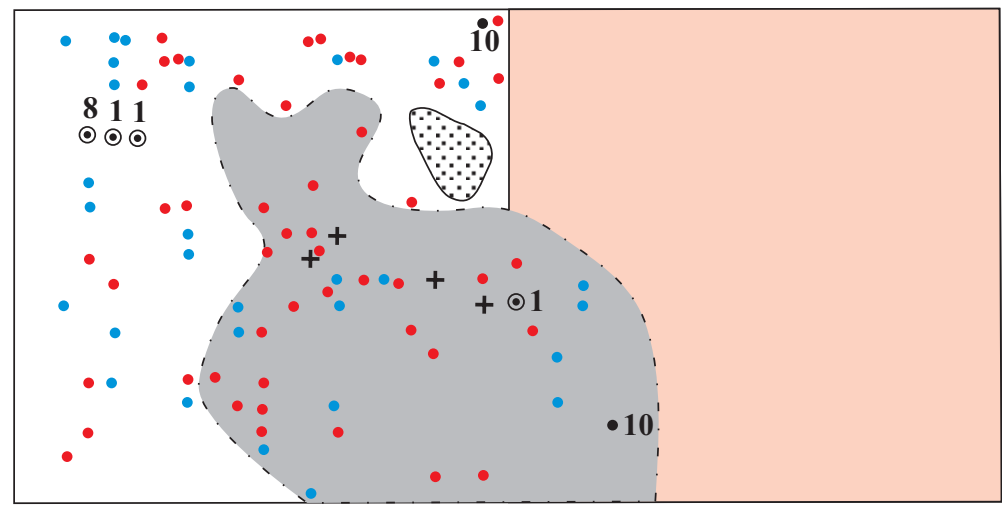

24. RS-S-327: Sangão

Escala 1:20

NÍVEL 3

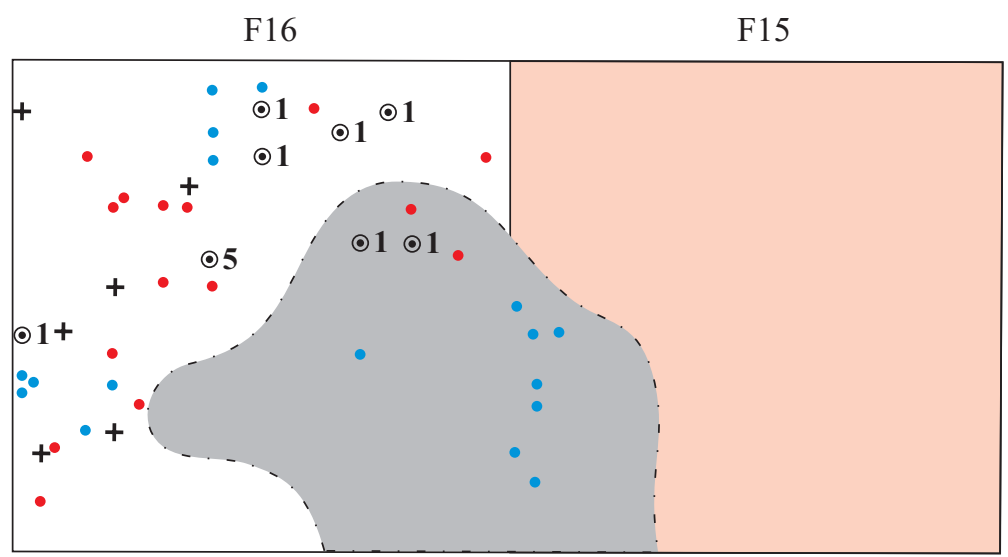




\section{RS-S-327: Sangão}

Escala 1:20

NÍVEL 4

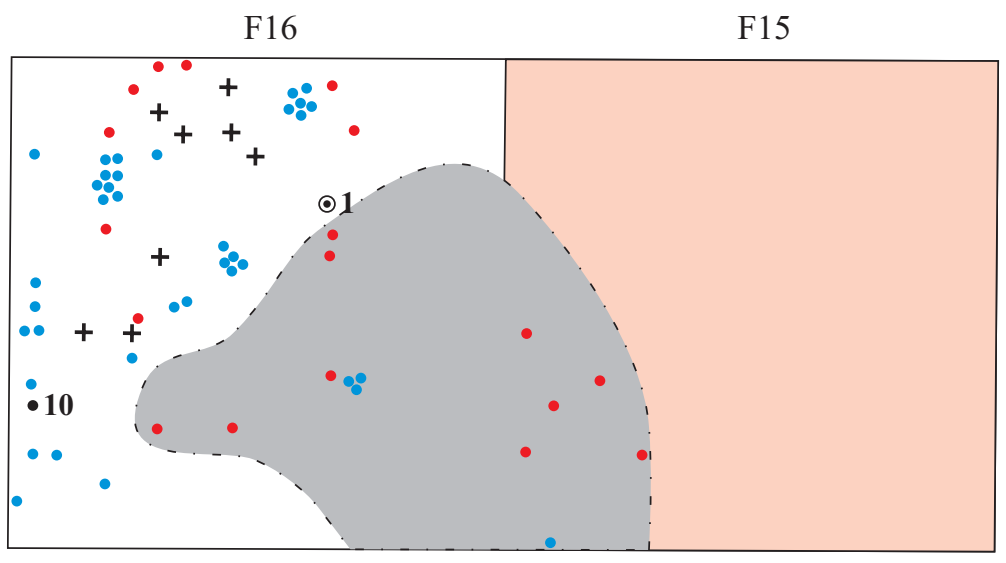

26. RS-S-327: Sangão

Escala 1:20

NÍVEL 5

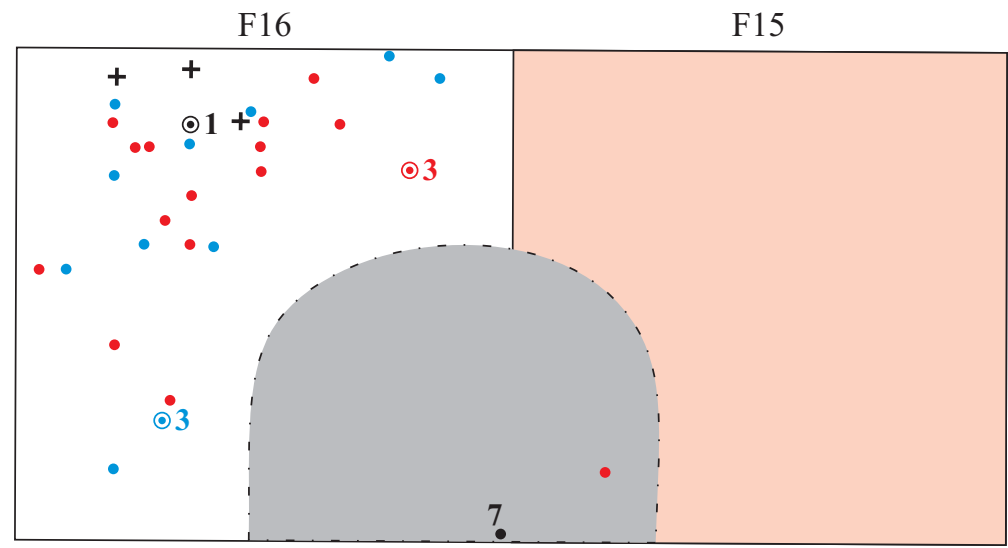

27. RS-S-327: Sangão

Escala 1:20

NÍVEL 6

F16

F15

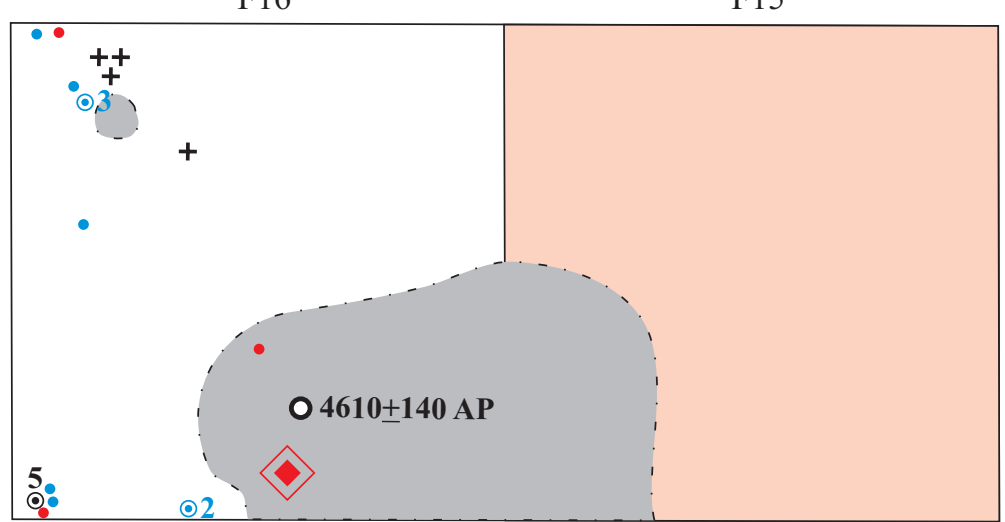


28. RS-S-327: Sangão

Escala 1:20

NÍVEL 7

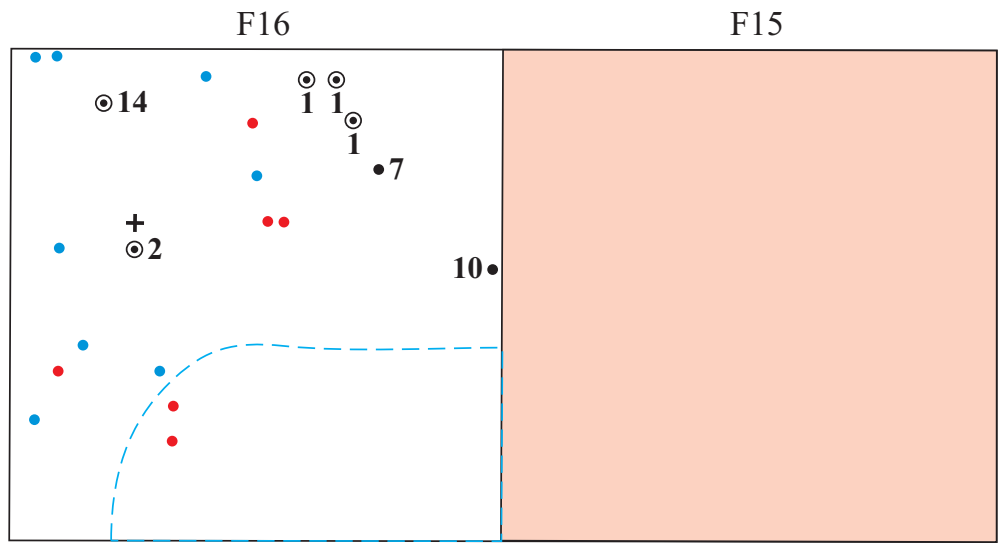

29. RS-S-327: Sangão

Escala 1:20

NÍVEL 8

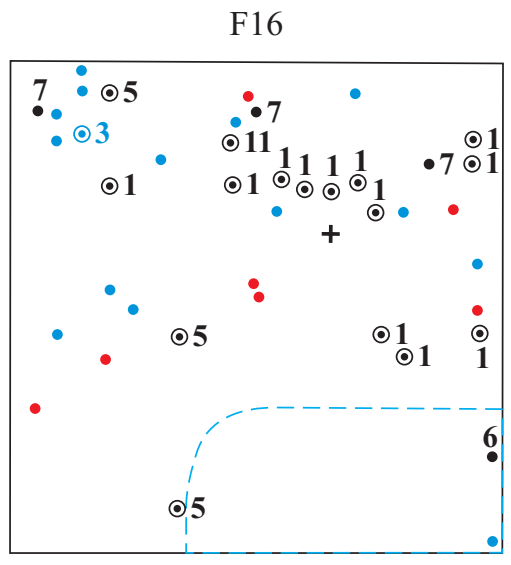

30. RS-S-327: Sangão

Escala 1:20

NÍVEL 9

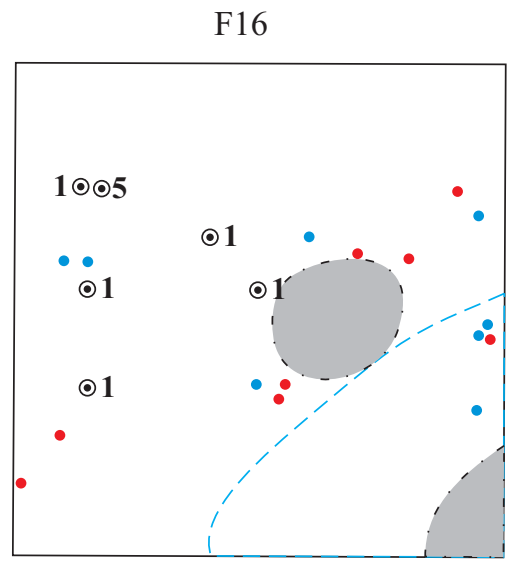

31. RS-S-327: Sangão

Escala 1:20
NÍVEL 10

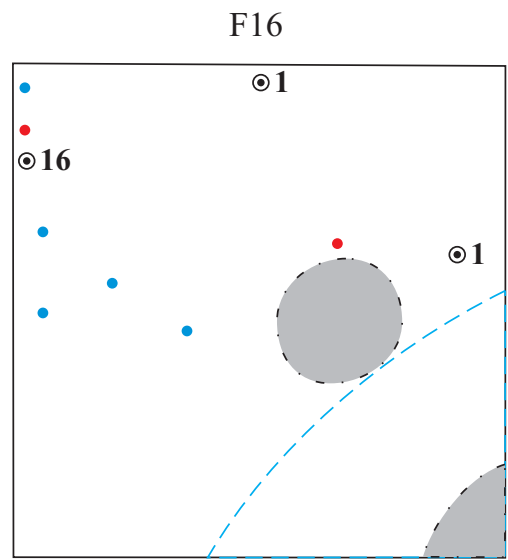

32. RS-S-327: Sangão

Escala 1:20

NÍVEL 11

F16
33. RS-S-327: Sangão

Escala 1:20

NÍVEL 12

F16

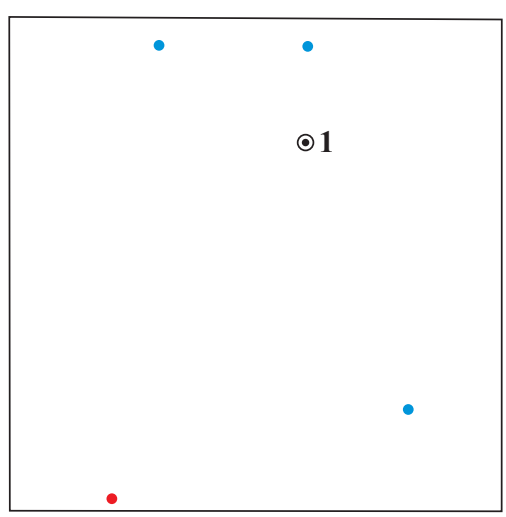


35. RS-S-327: Sangão

Escala 1:20

NÍVEL 2

I9

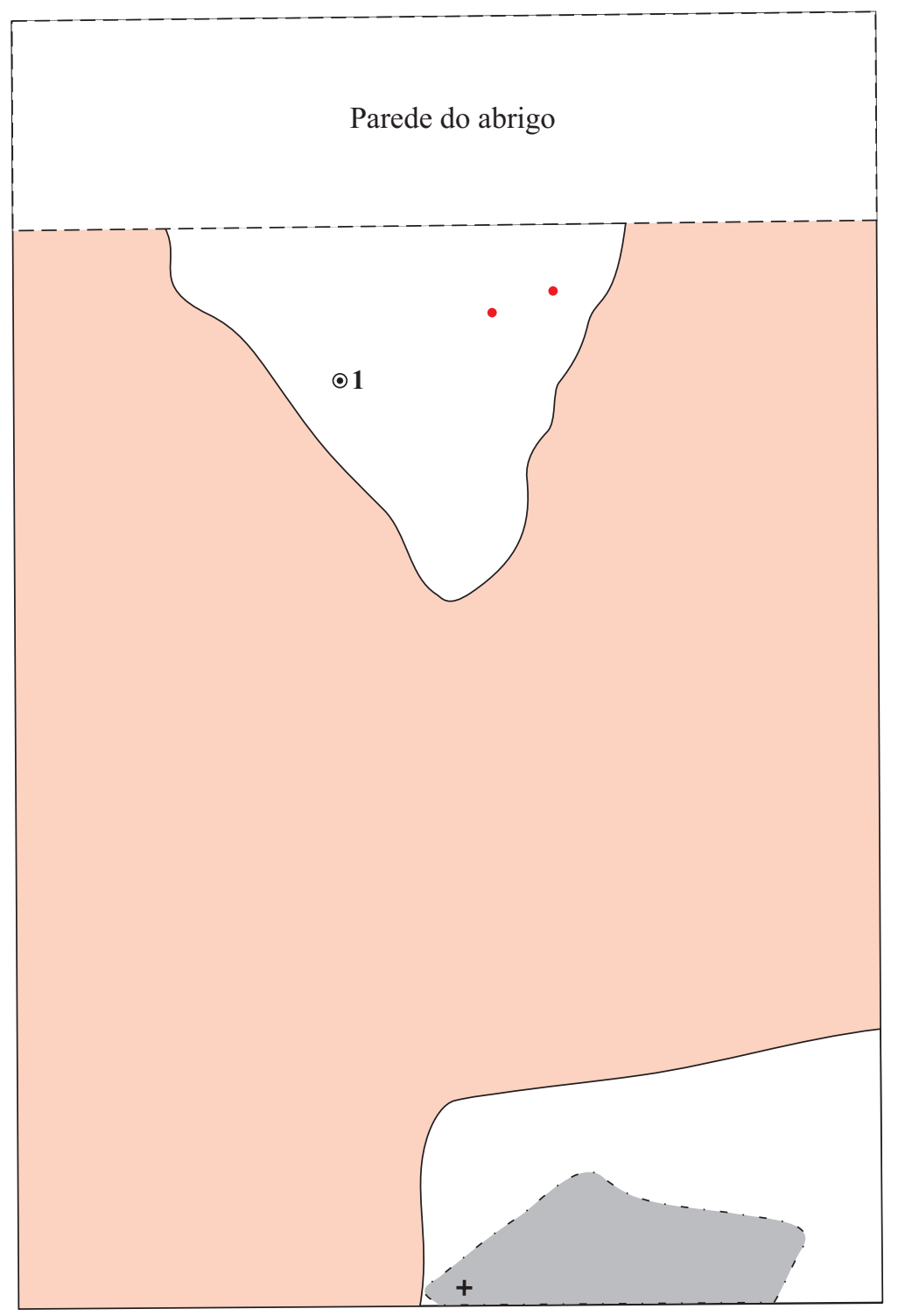

34. RS-S-327: Sangão

Escala 1:20

NÍVEL 1

I8

H8

I9

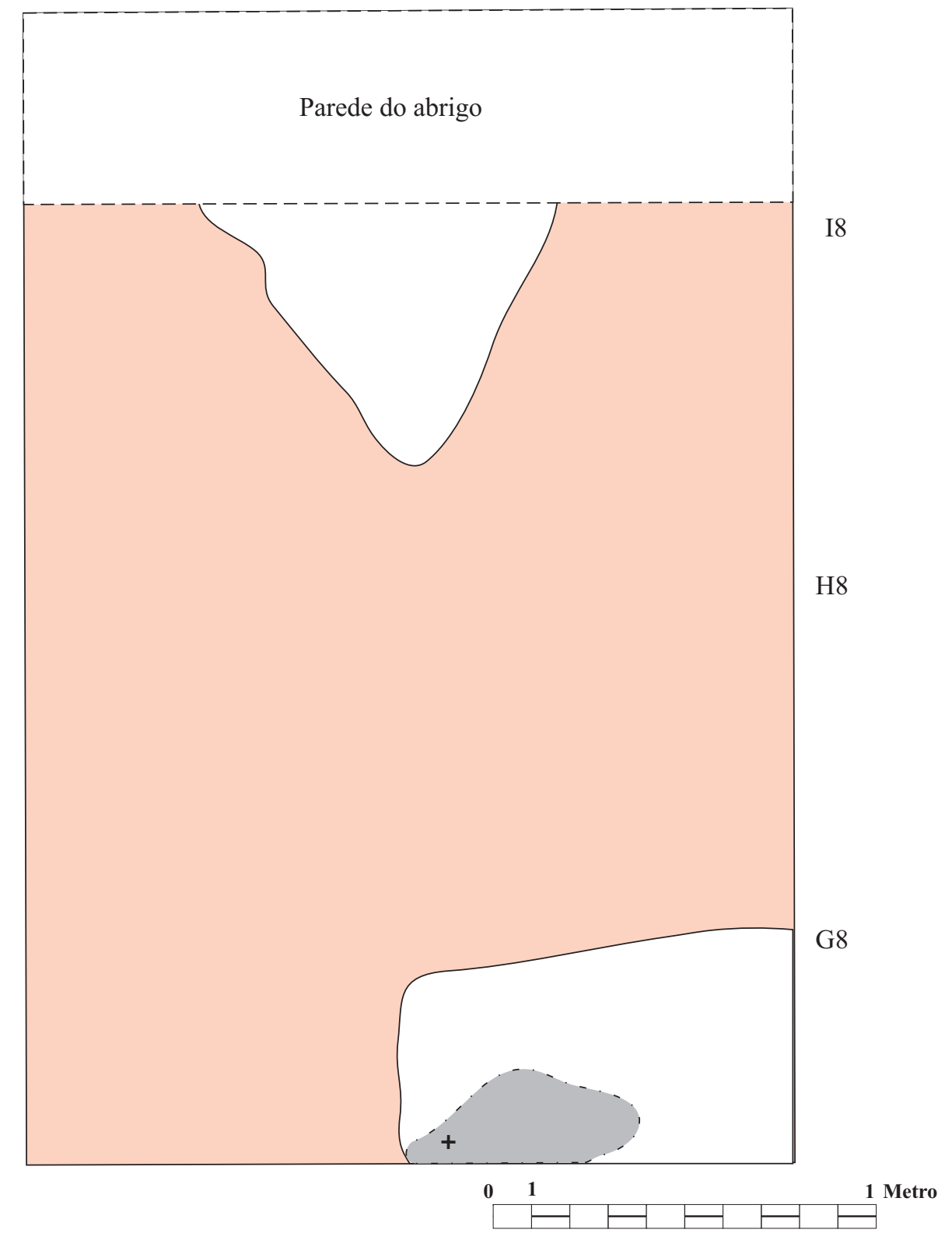


36. RS-S-327: Sangão

Escala 1:20

NÍVEL 3

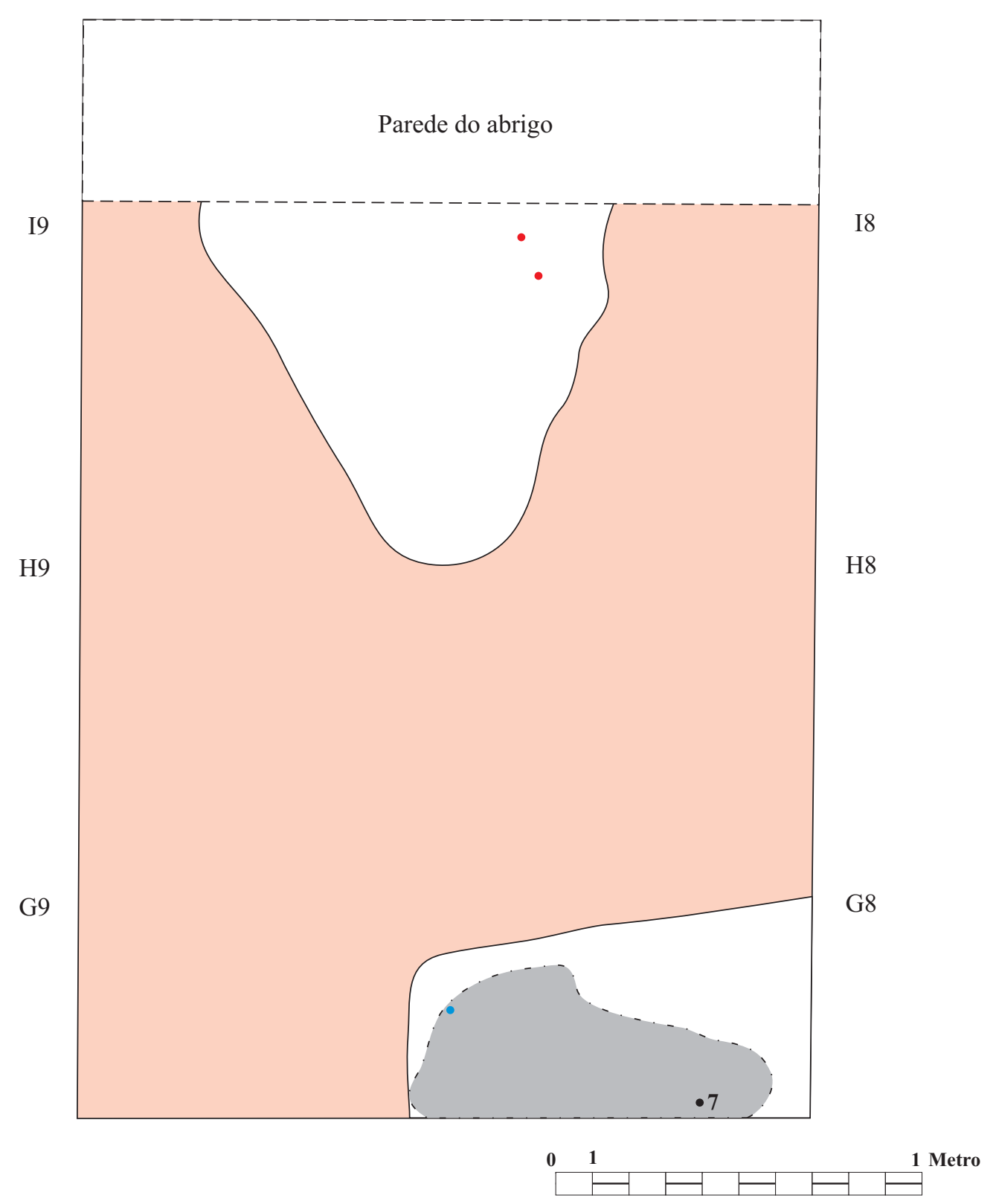


37. RS-S-327: Sangão

Escala 1:20

NÍVEL 4

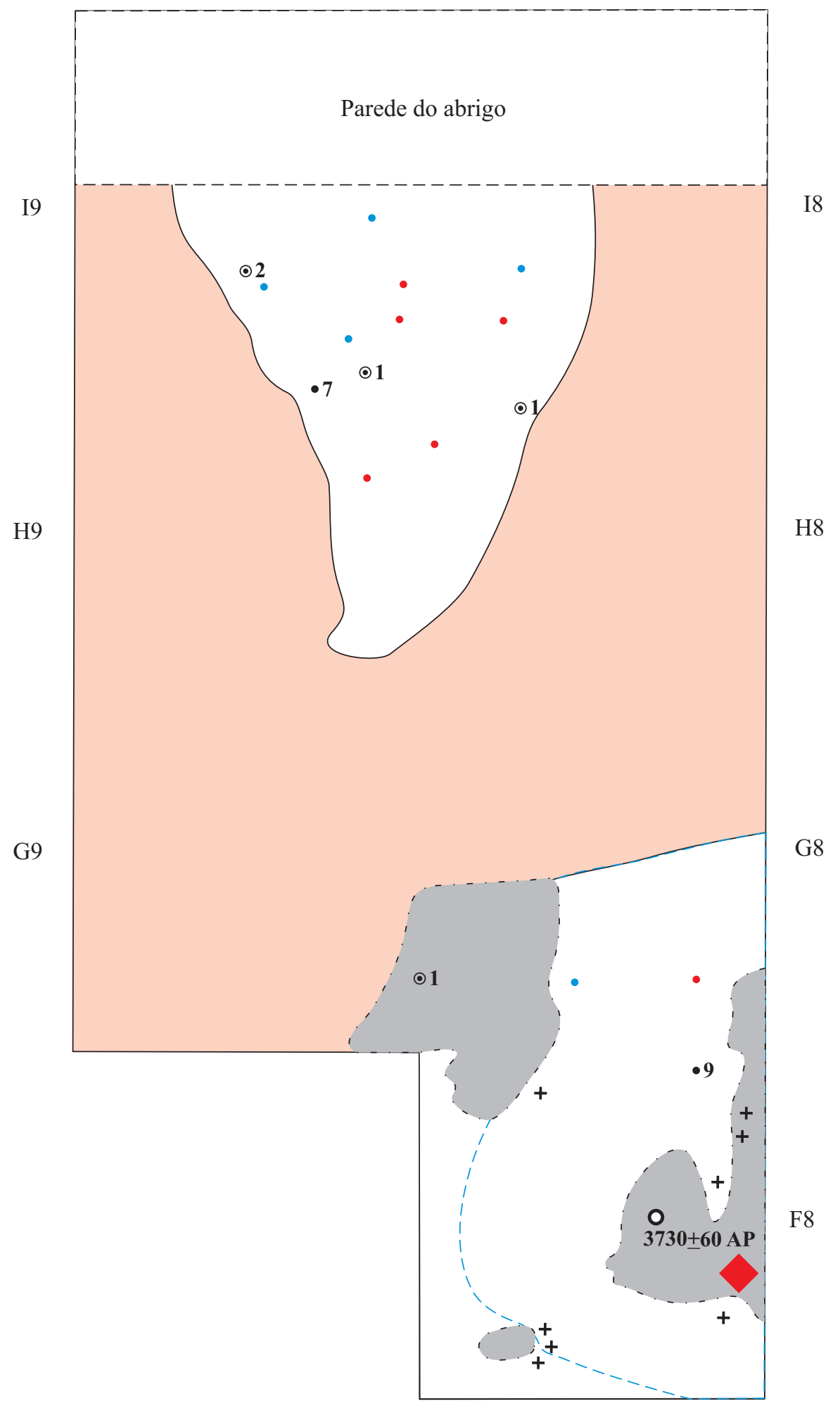


38. RS-S-327: Sangão

Escala 1:20

NÍVEL 5

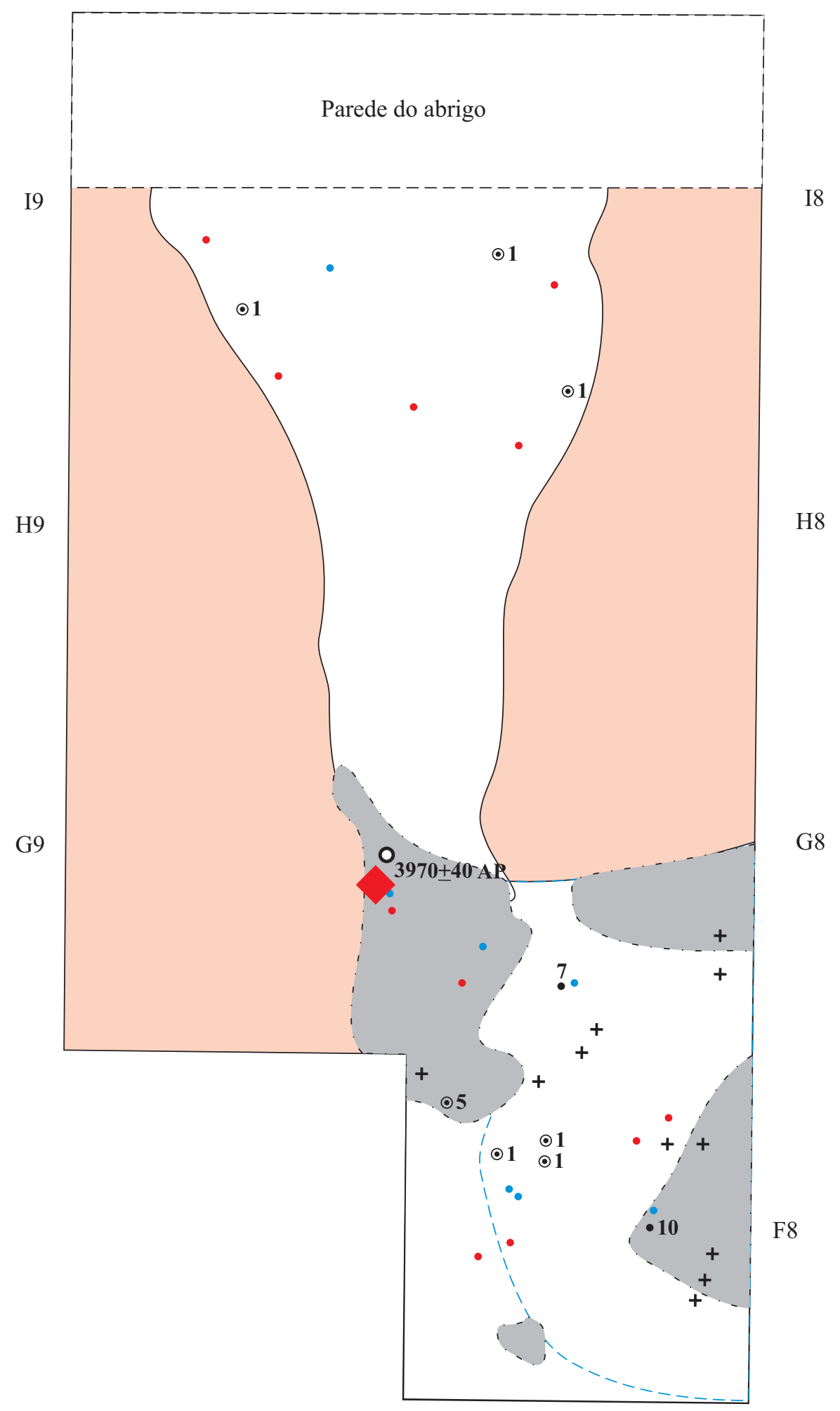


39. RS-S-327: Sangão

Escala 1:20

NÍVEL 6

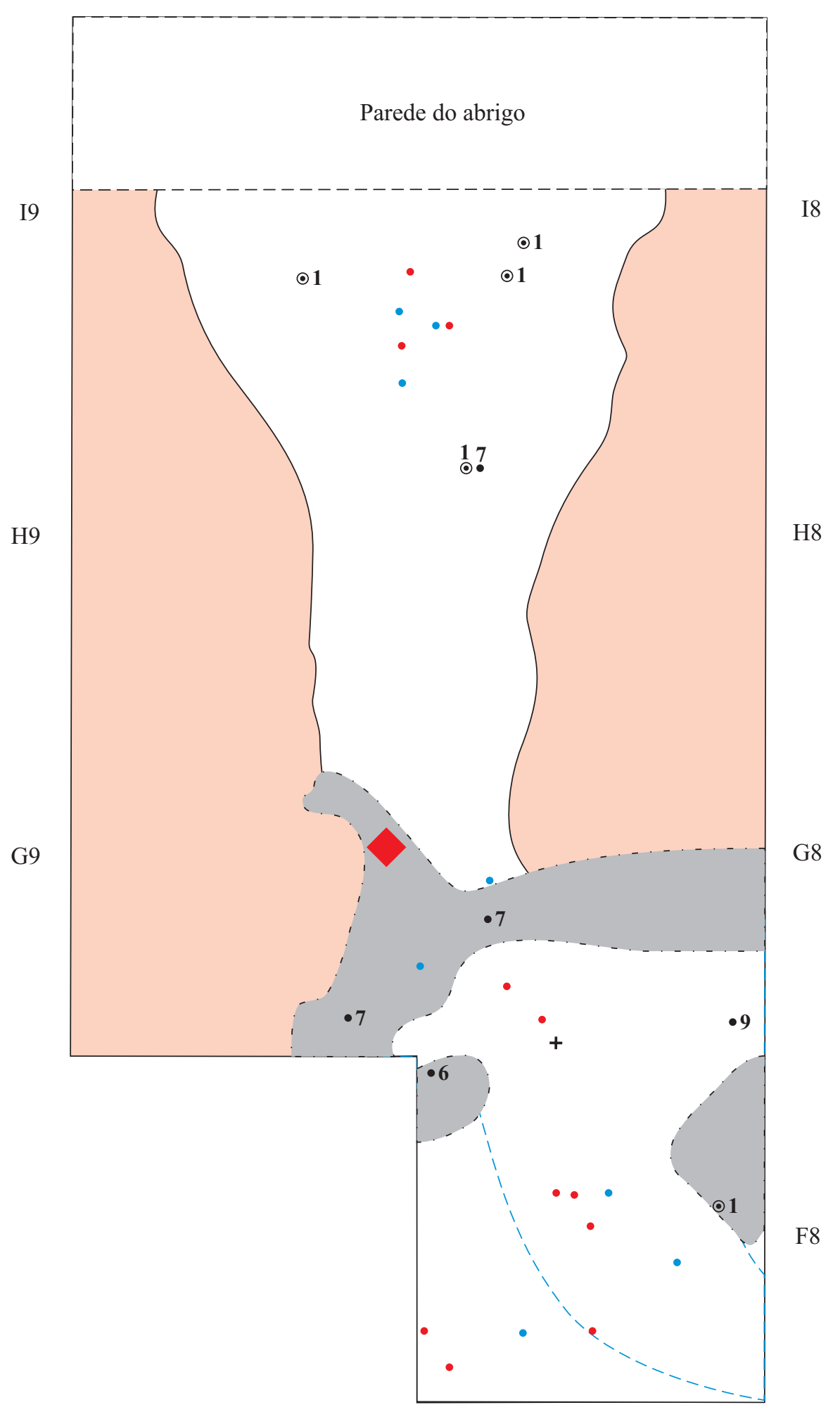


40. RS-S-327: Sangão

Escala 1:20

NÍVEL 7

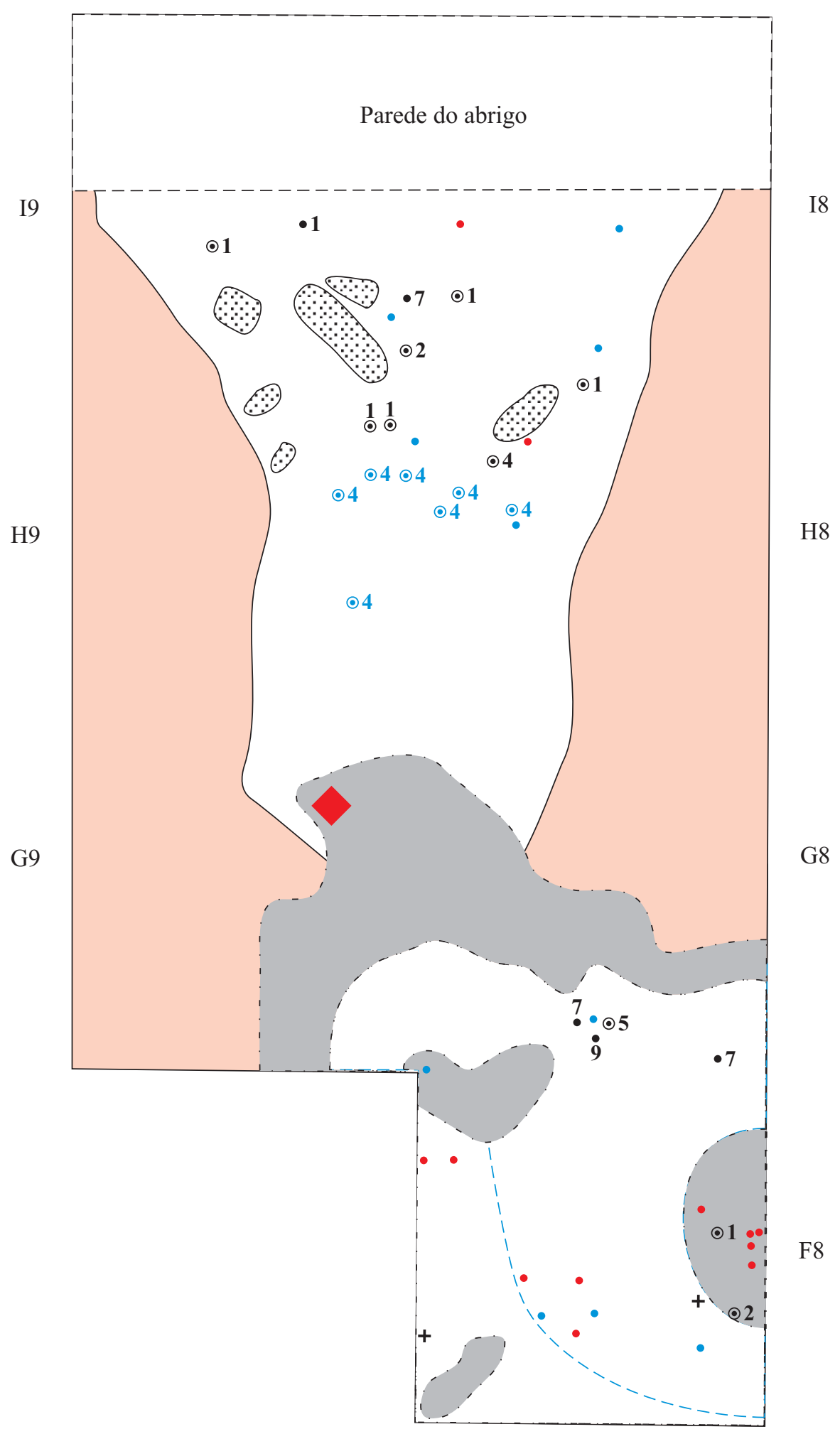


41. RS-S-327: Sangão

Escala 1:20

NÍVEL 8

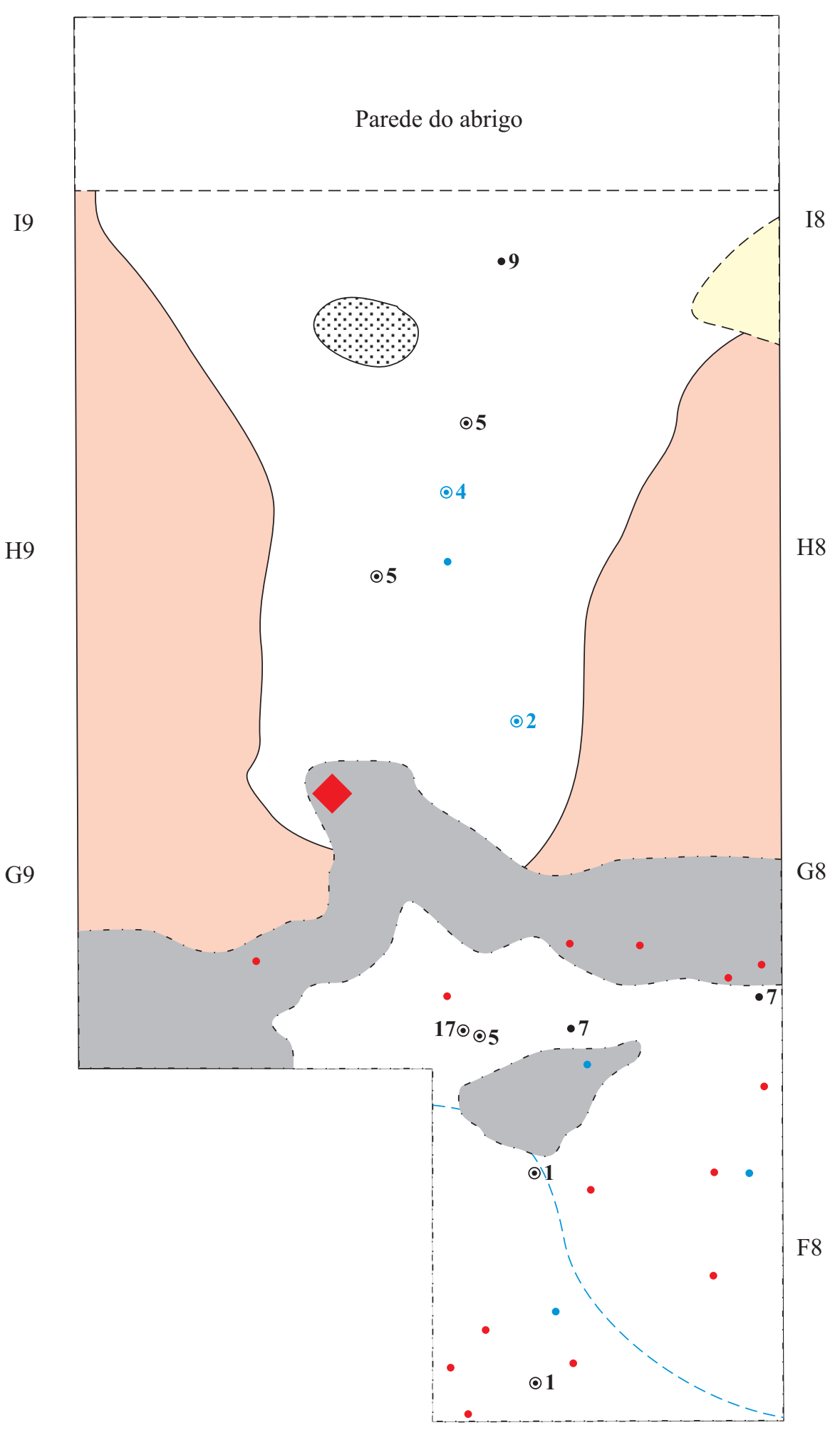


42. RS-S-327: Sangão

Escala 1:20

NÍVEL 9

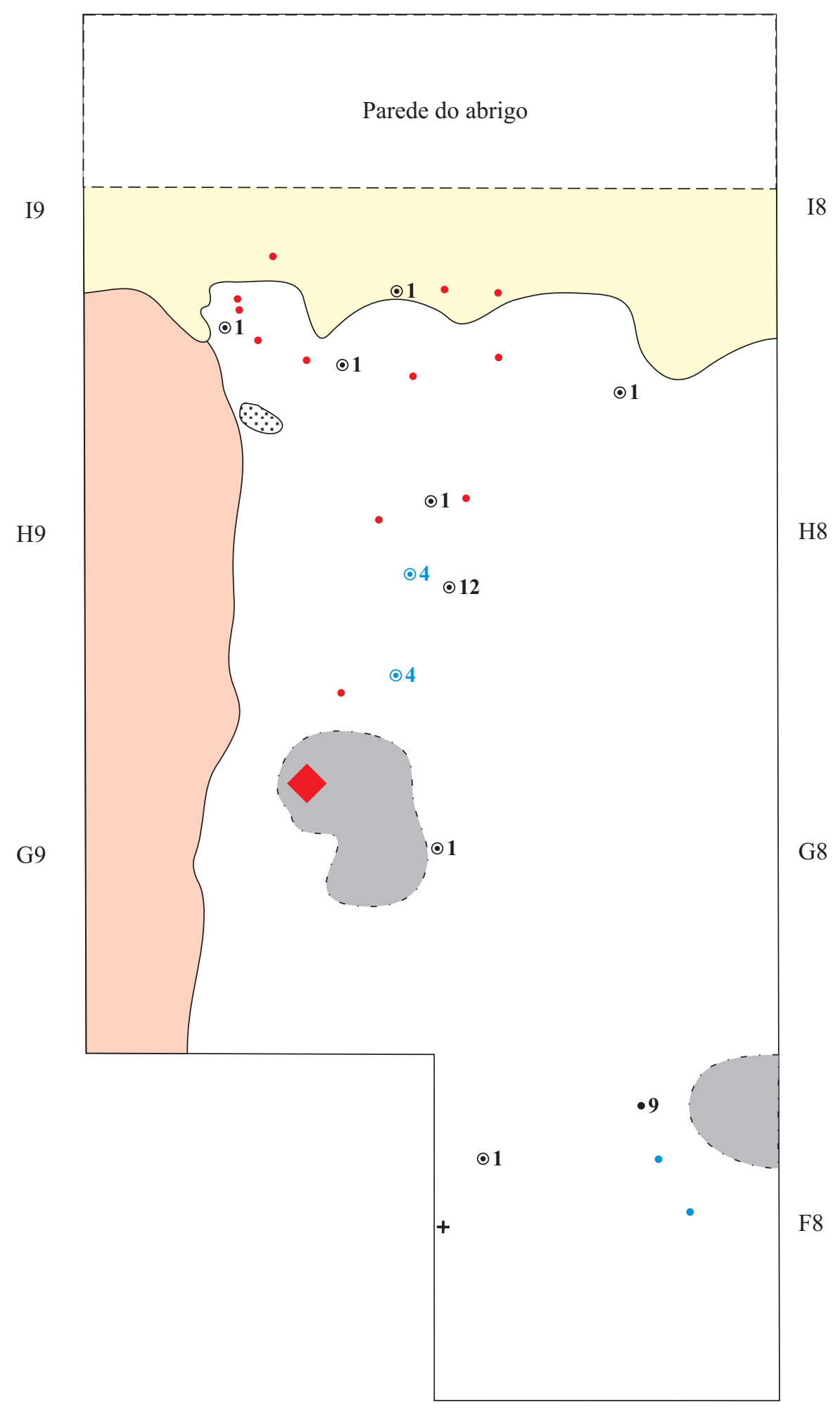


43. RS-S-327: Sangão

Escala 1:20

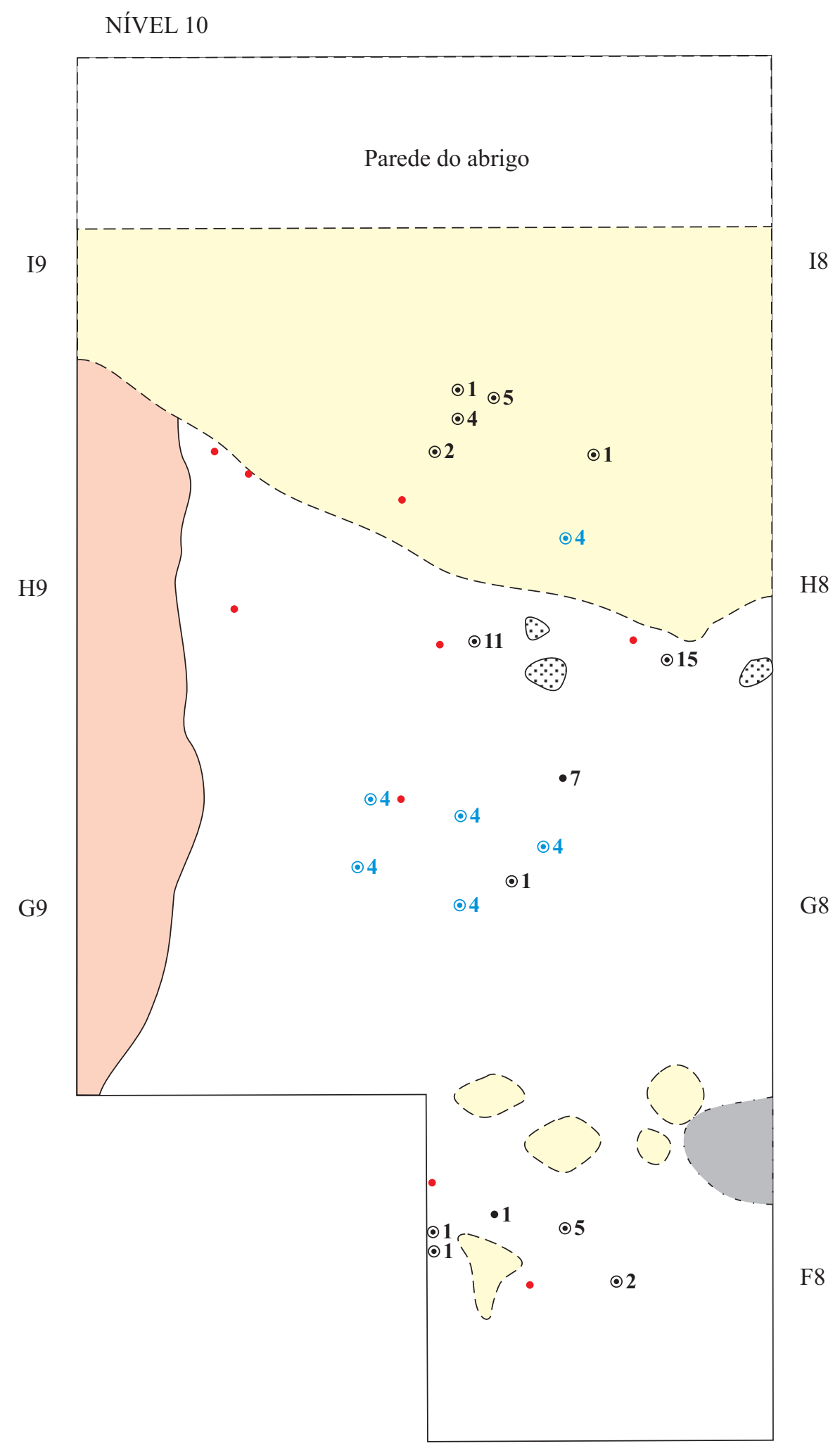


44. RS-S-327: Sangão

Escala 1:20

NÍVEL 11

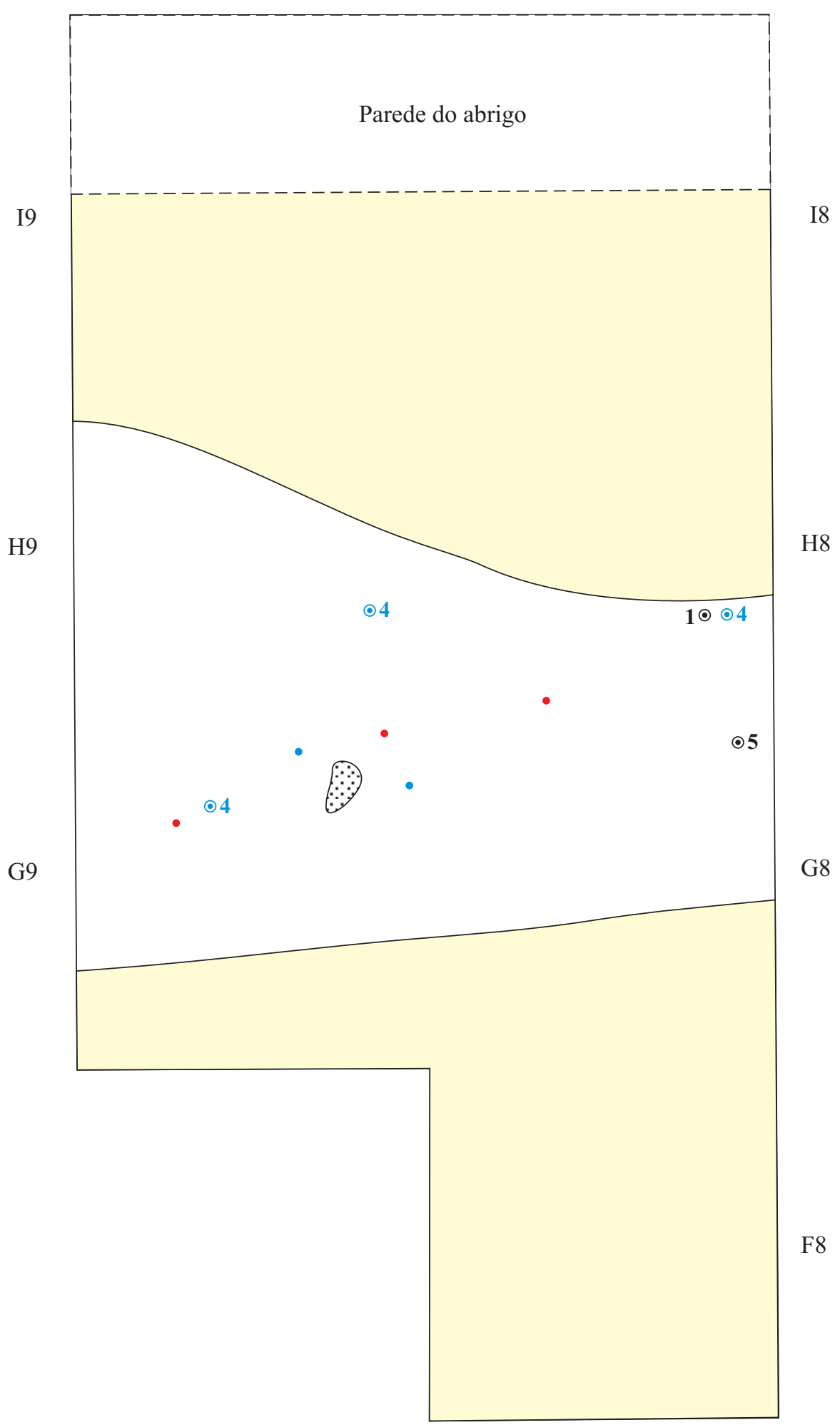




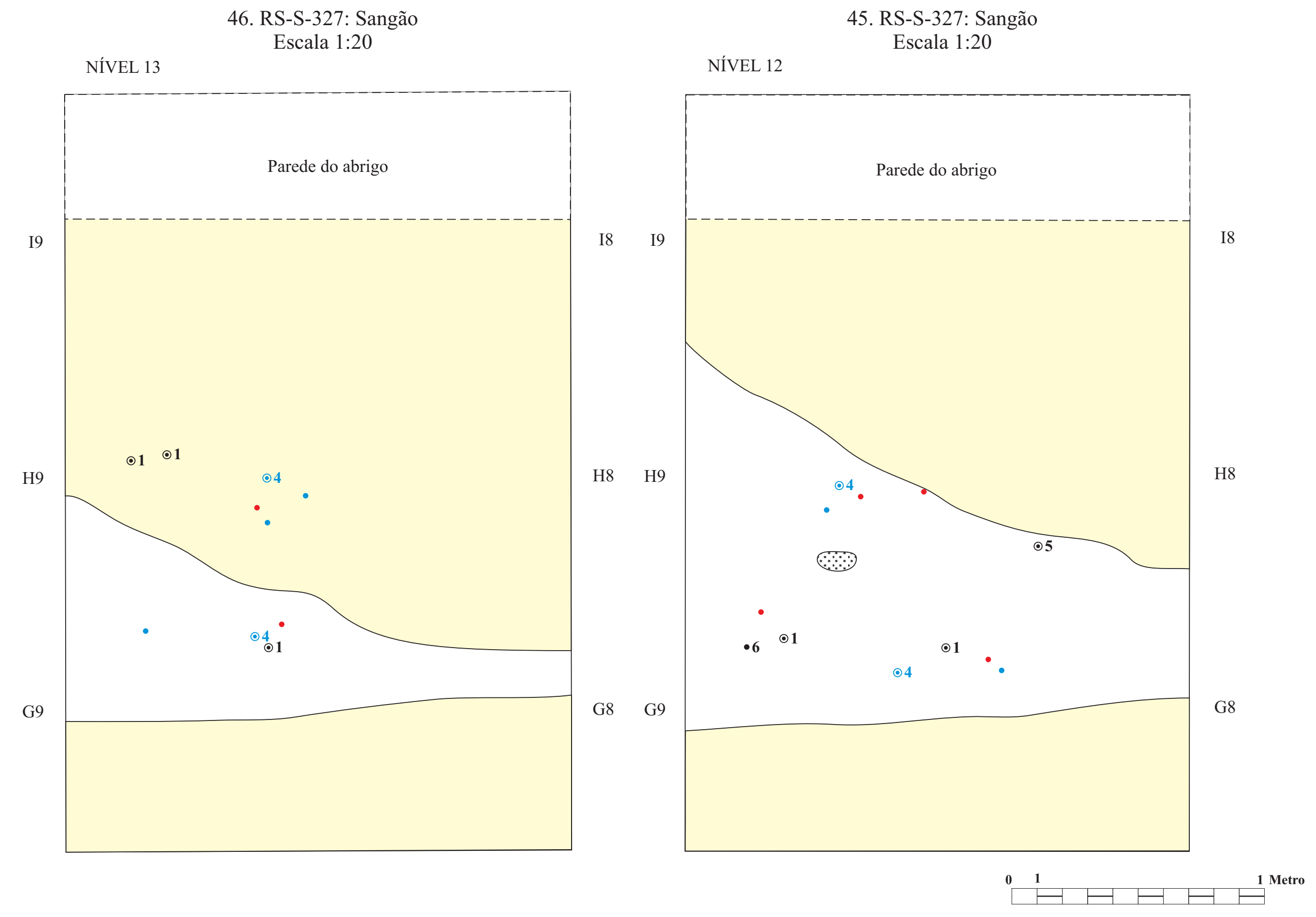


47. RS-S-327: Sangão

Escala 1:20

NÍVEL 14

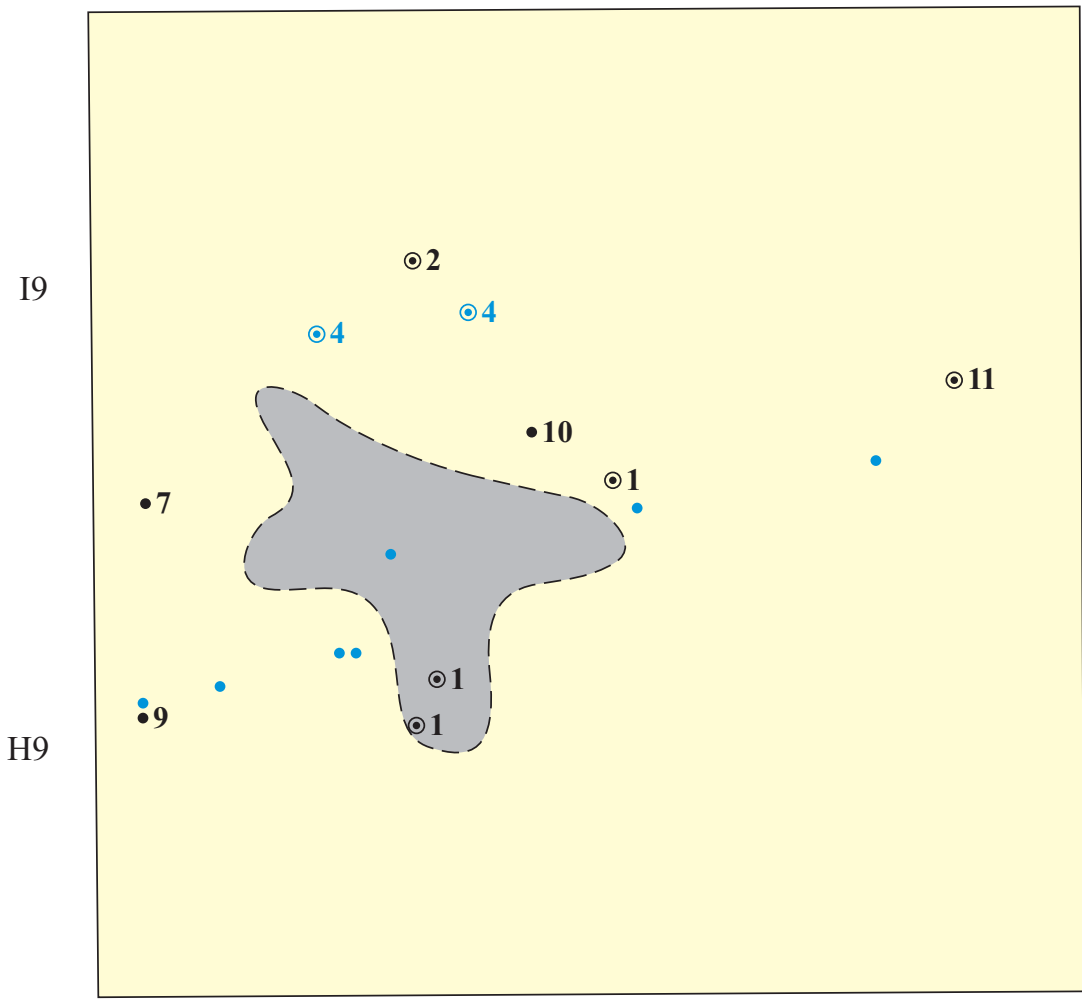

48. RS-S-327: Sangão

Escala 1:20

NÍVEL 15

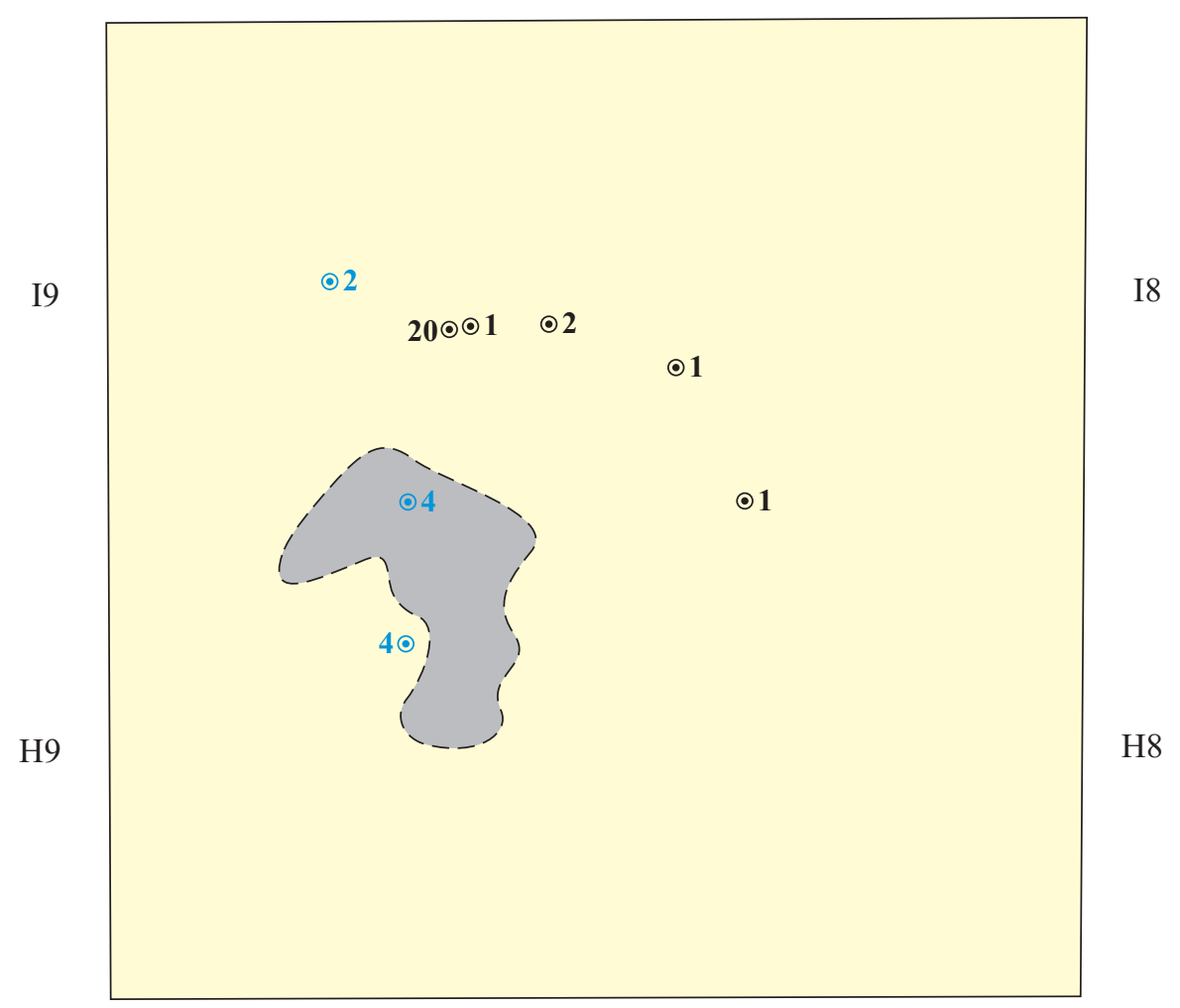


49. RS-S-337: Monjolo Escala 1:20

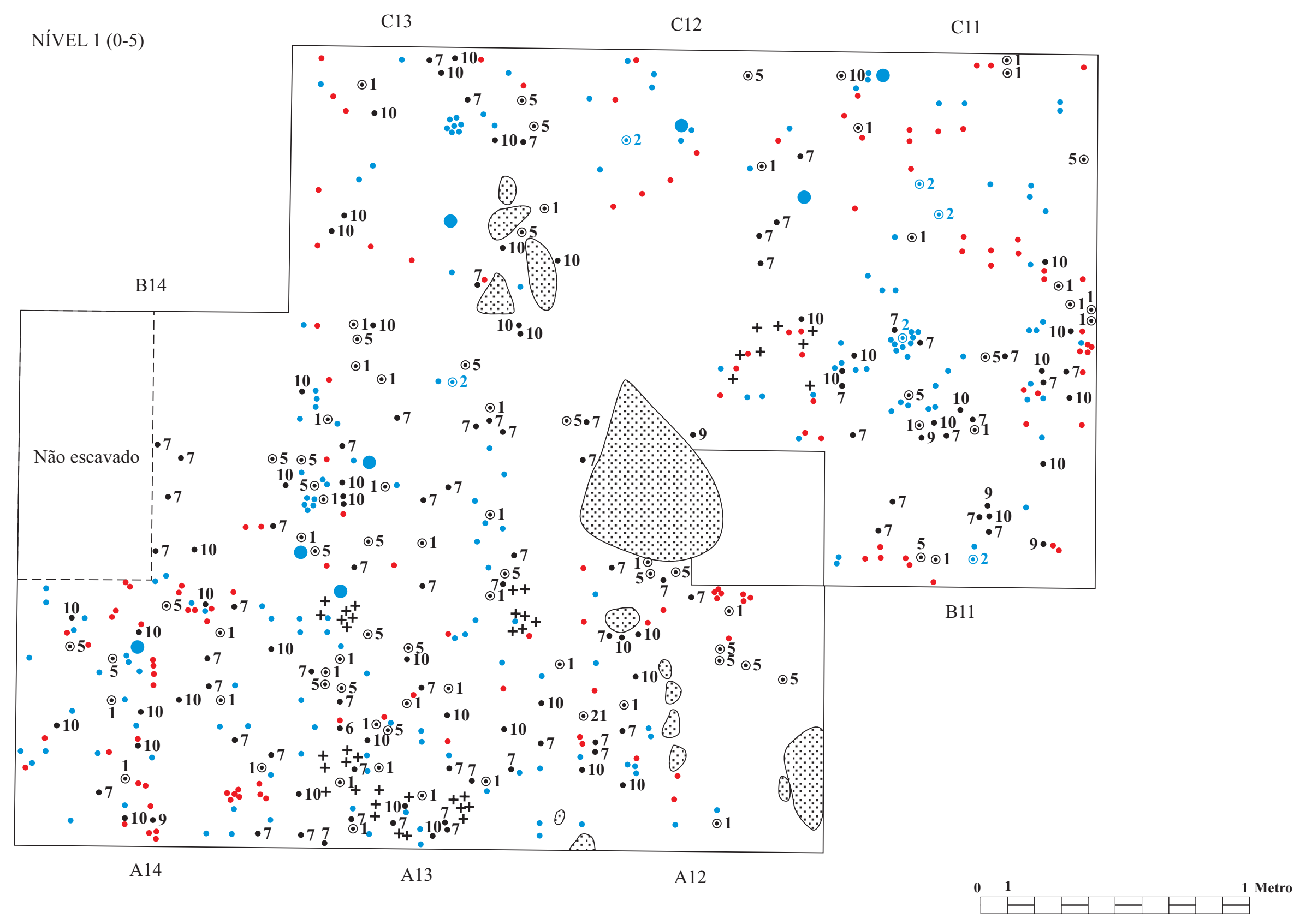


50. RS-S-337: Monjolo Escala 1:20

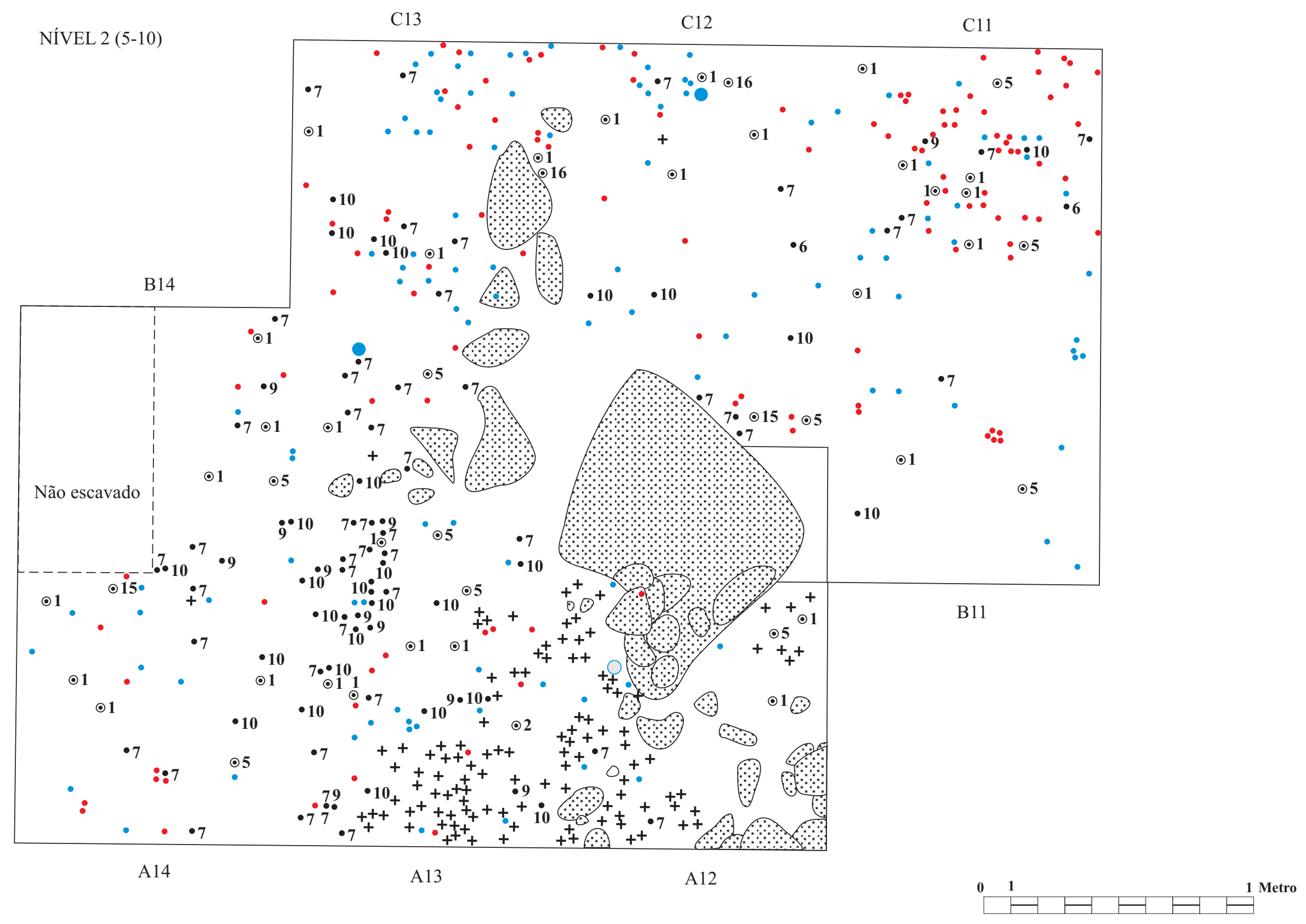


51. RS-S-337: Monjolo Escala 1:20

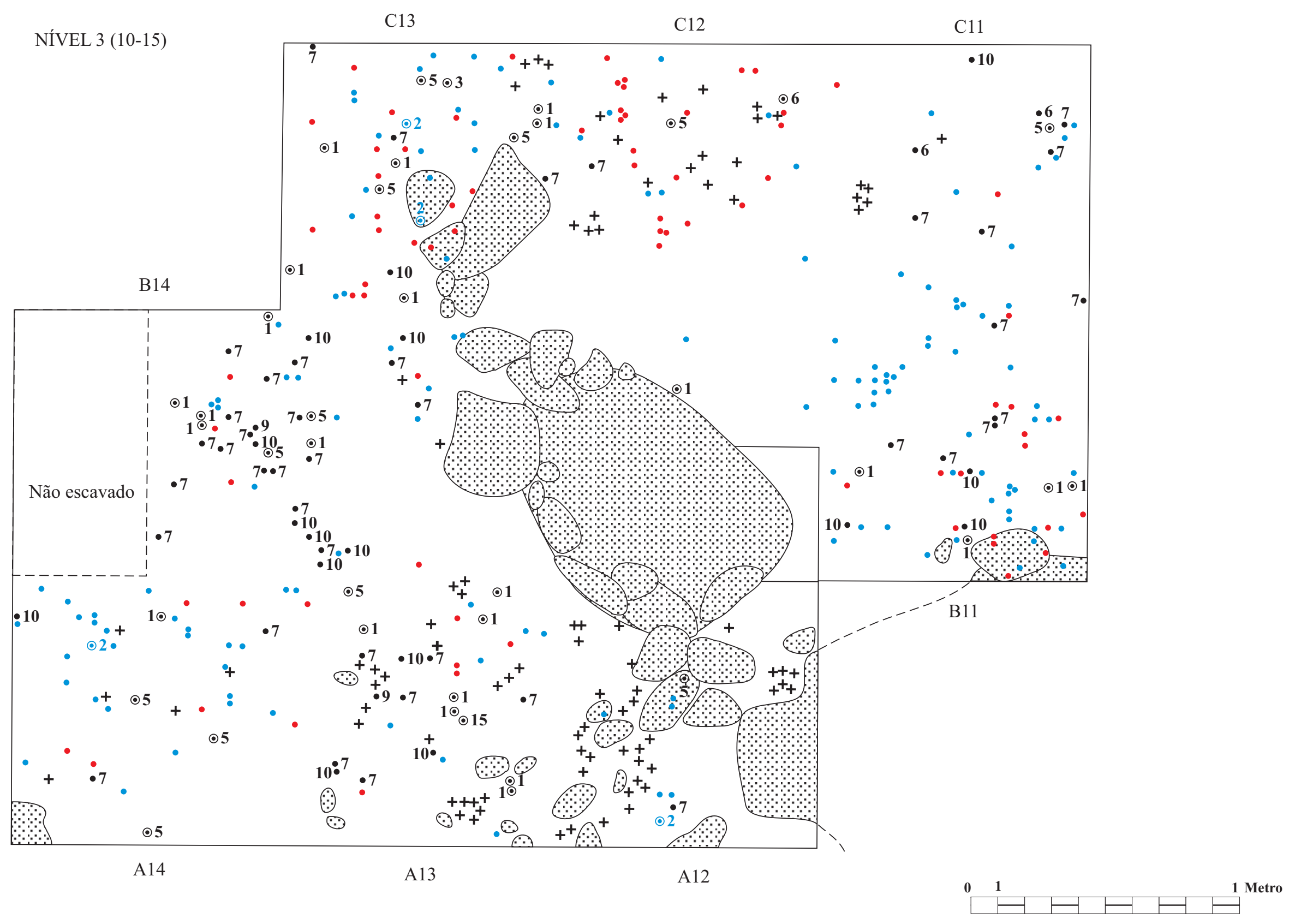


52. RS-S-337: Monjolo Escala 1:20

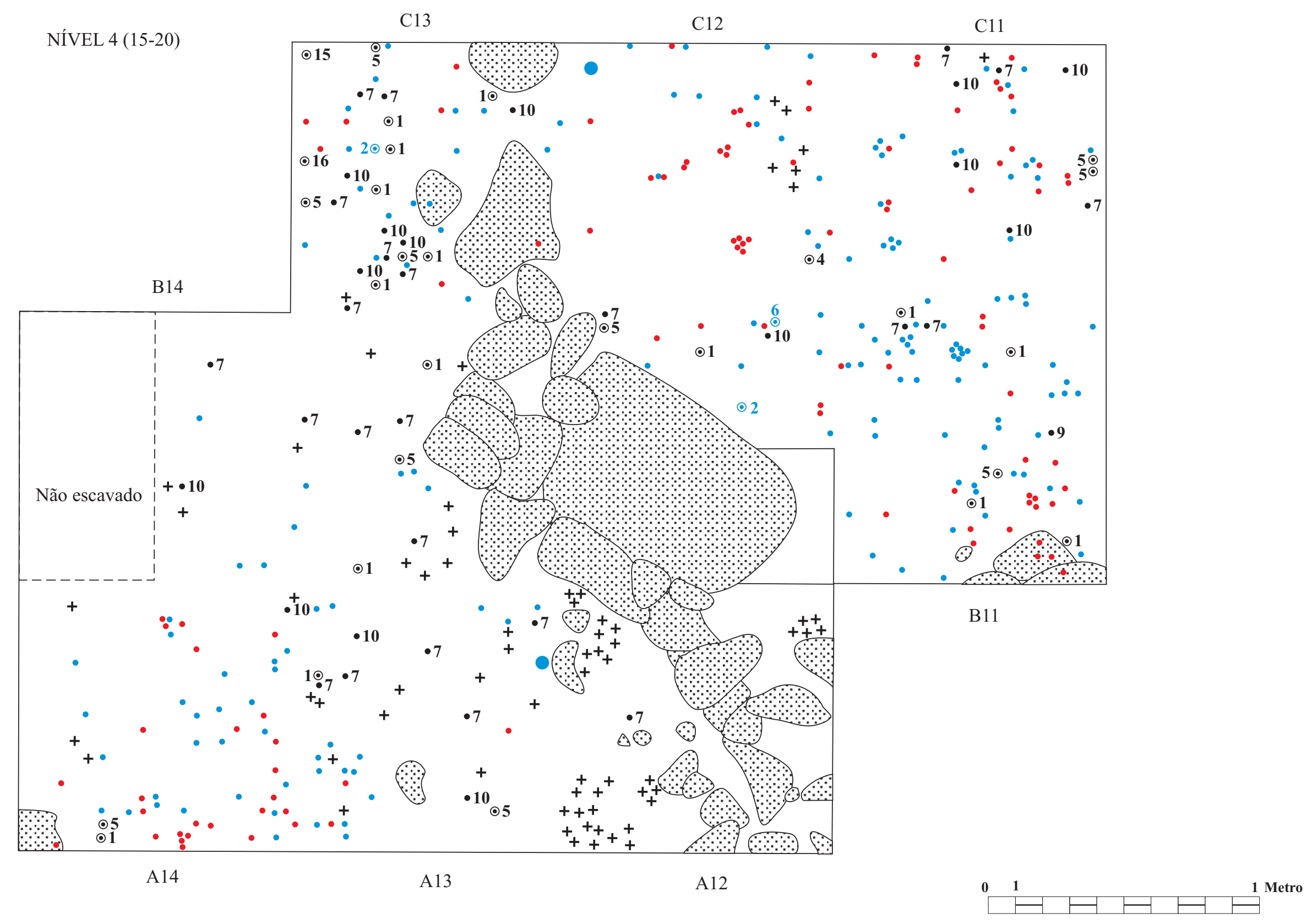


53. RS-S-337: Monjolo Escala 1:20

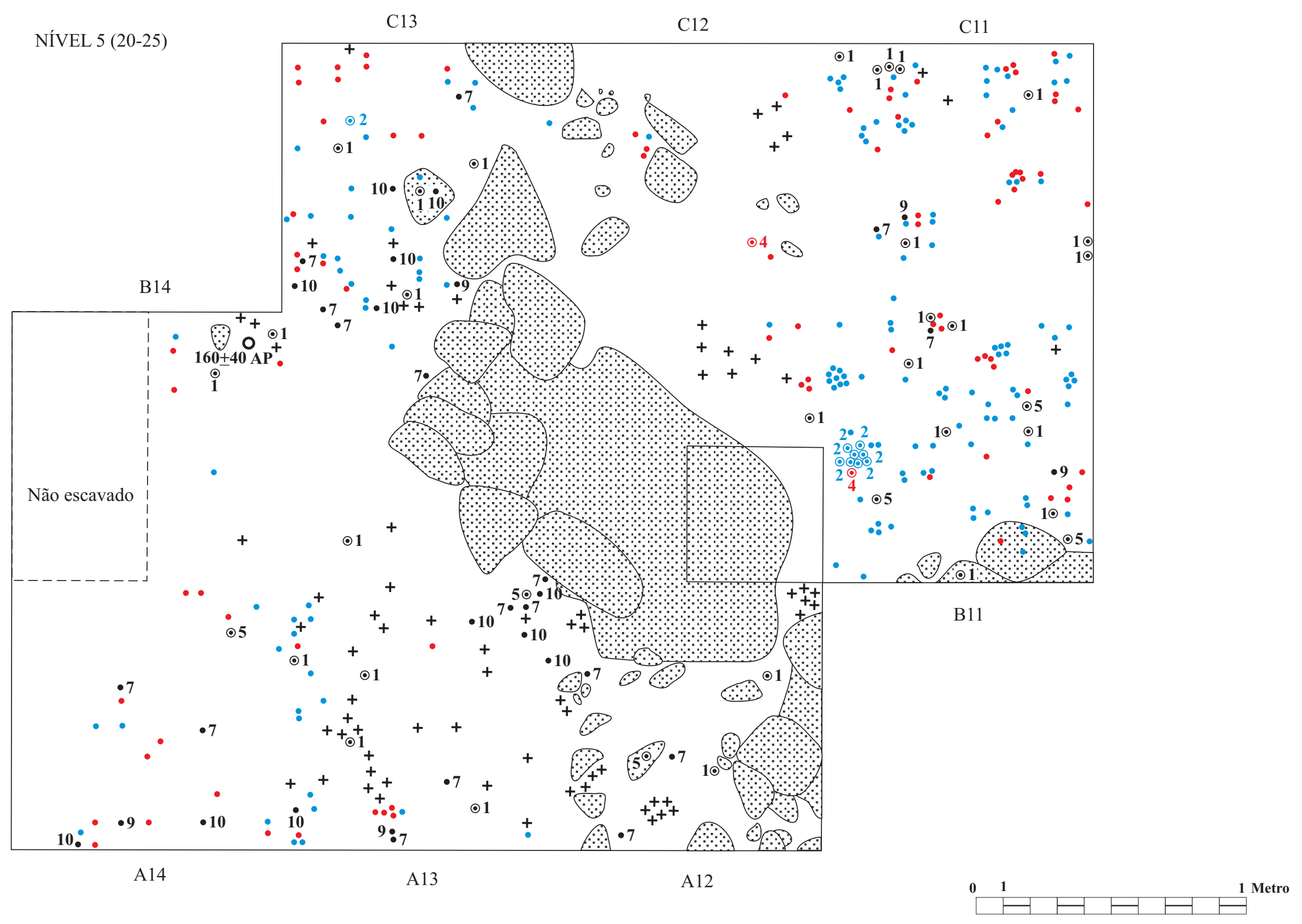


54. RS-S-337: Monjolo Escala 1:20

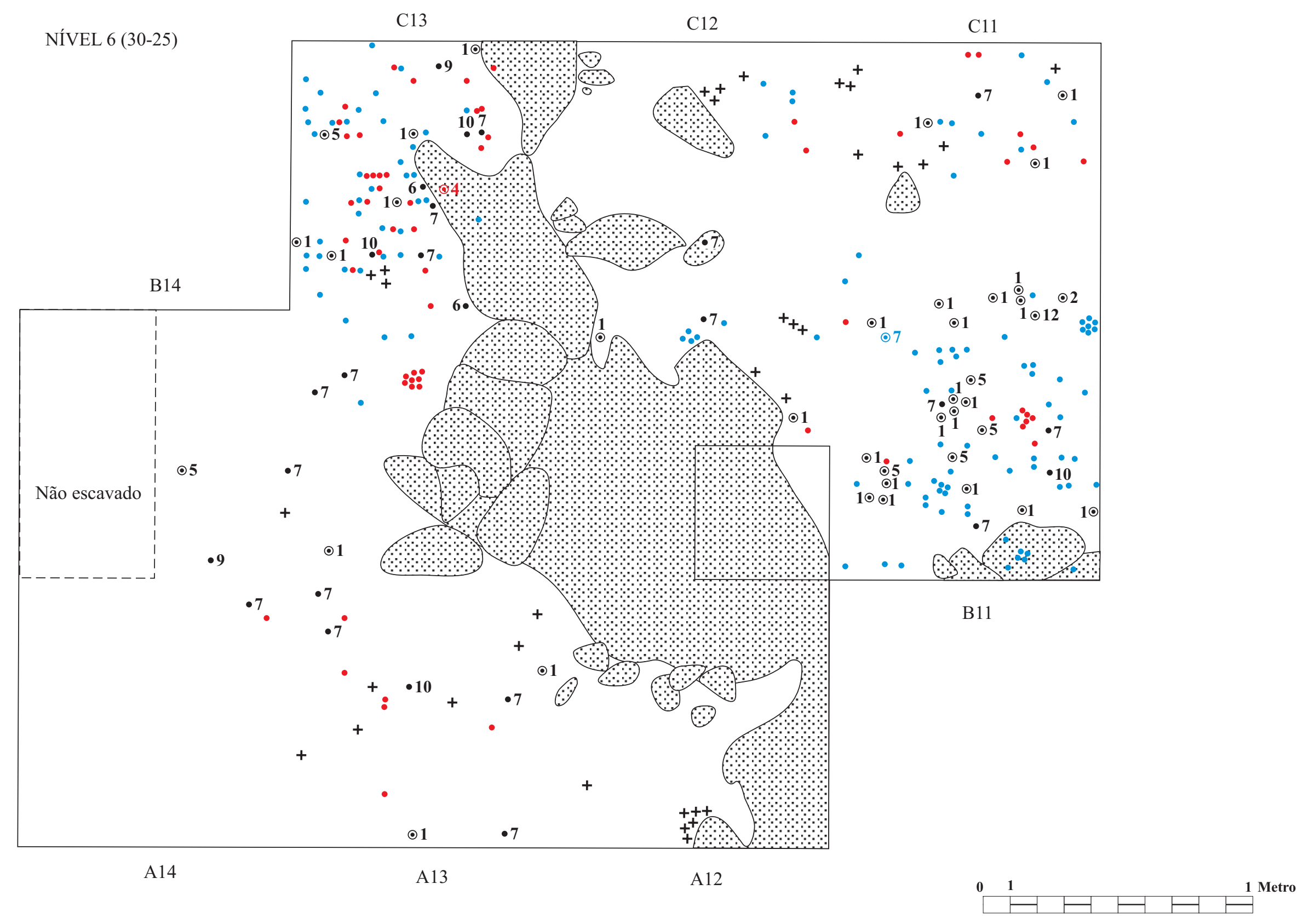


55. RS-S-337: Monjolo Escala 1:20

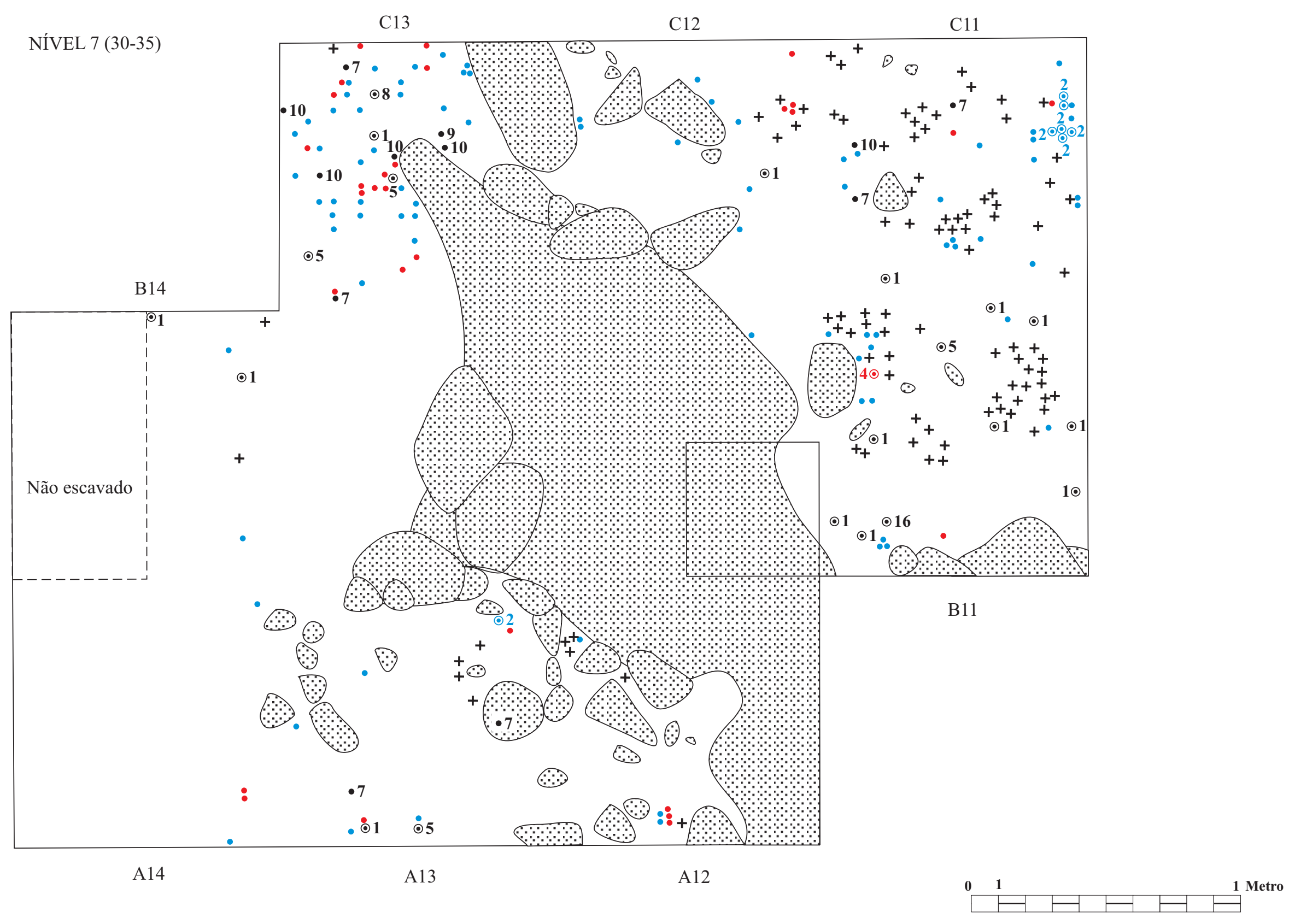


56. RS-S-337: Monjolo Escala 1:20

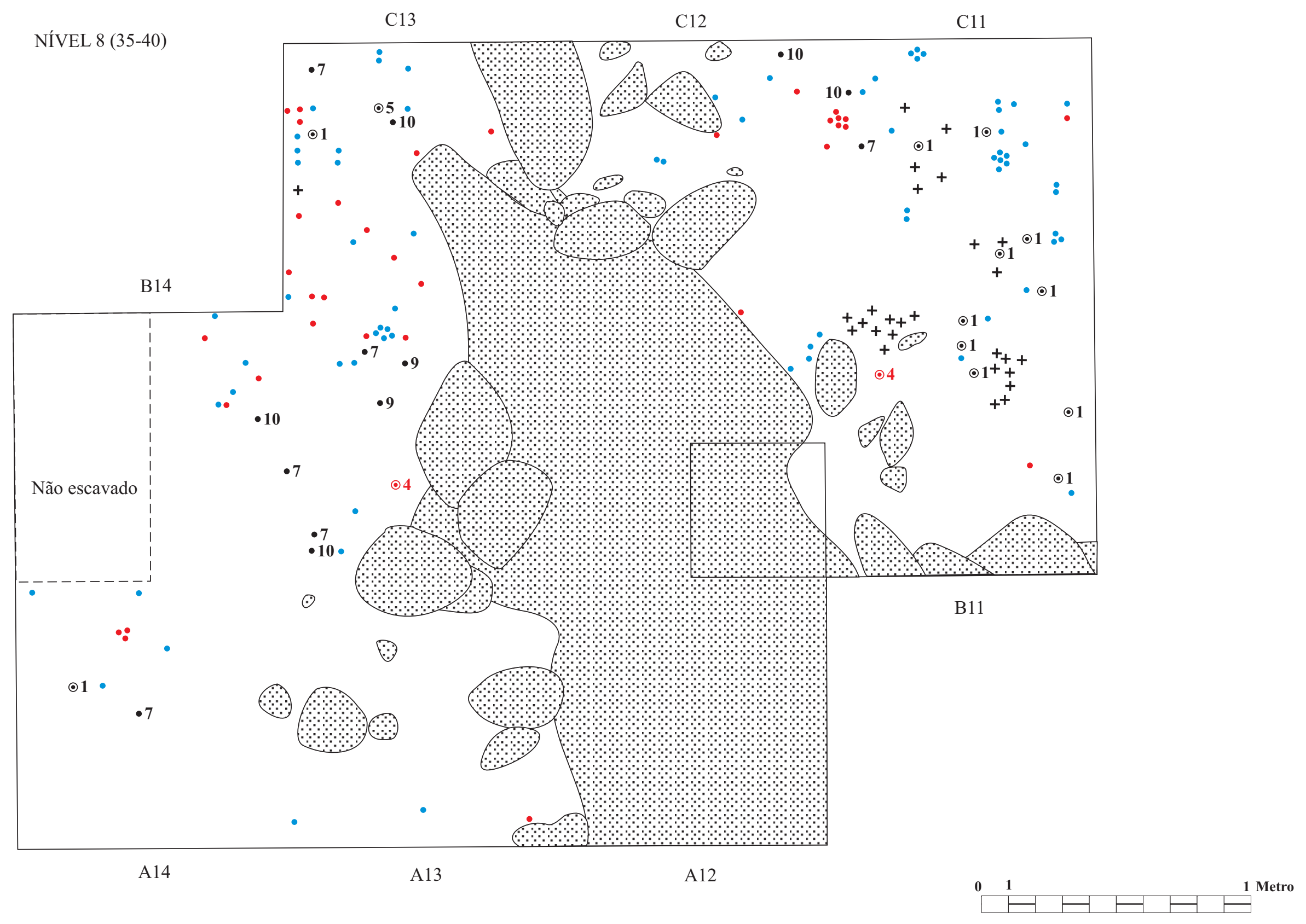


57. RS-S-337: Monjolo Escala 1:20

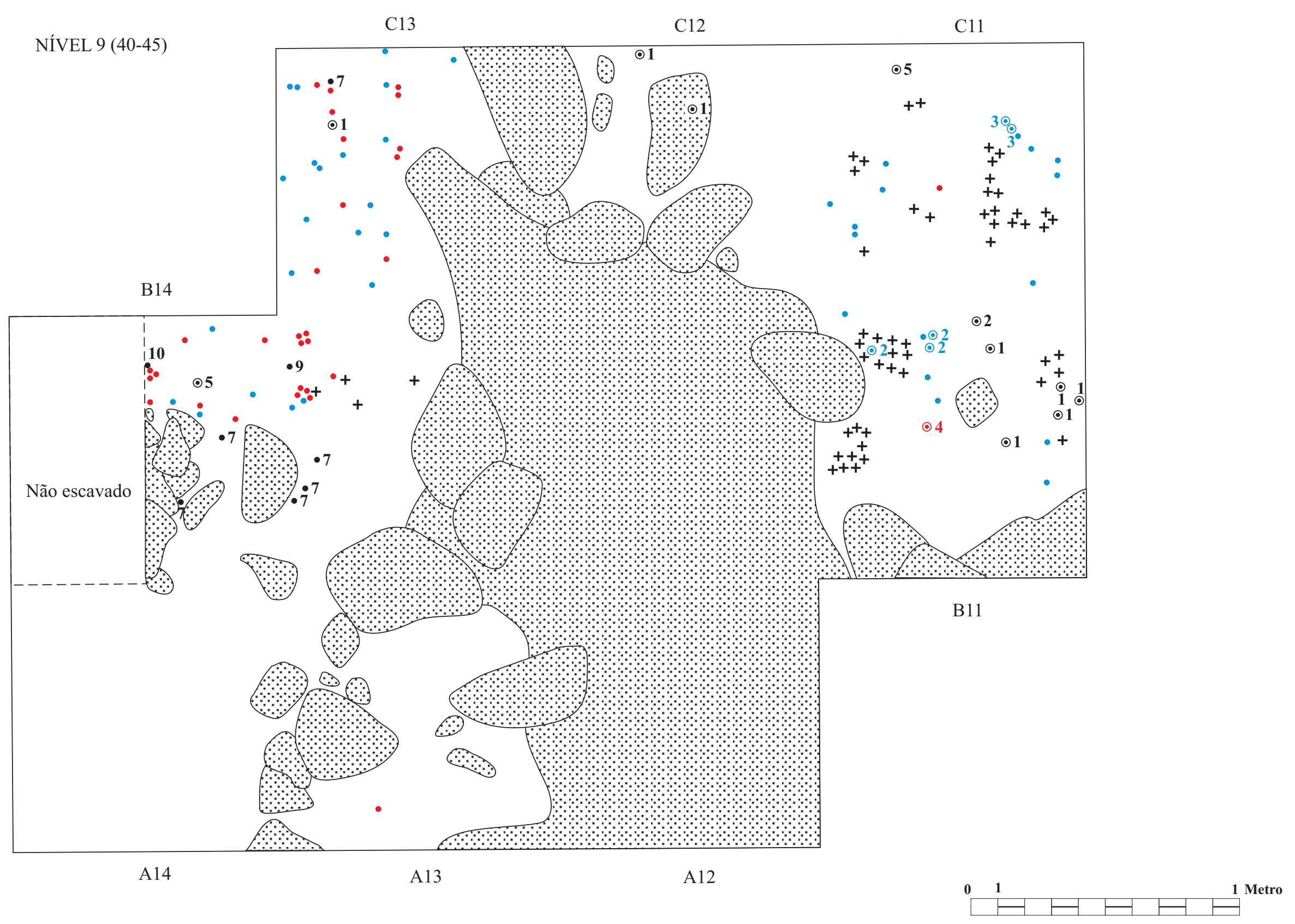


58. RS-S-337: Monjolo Escala 1:20

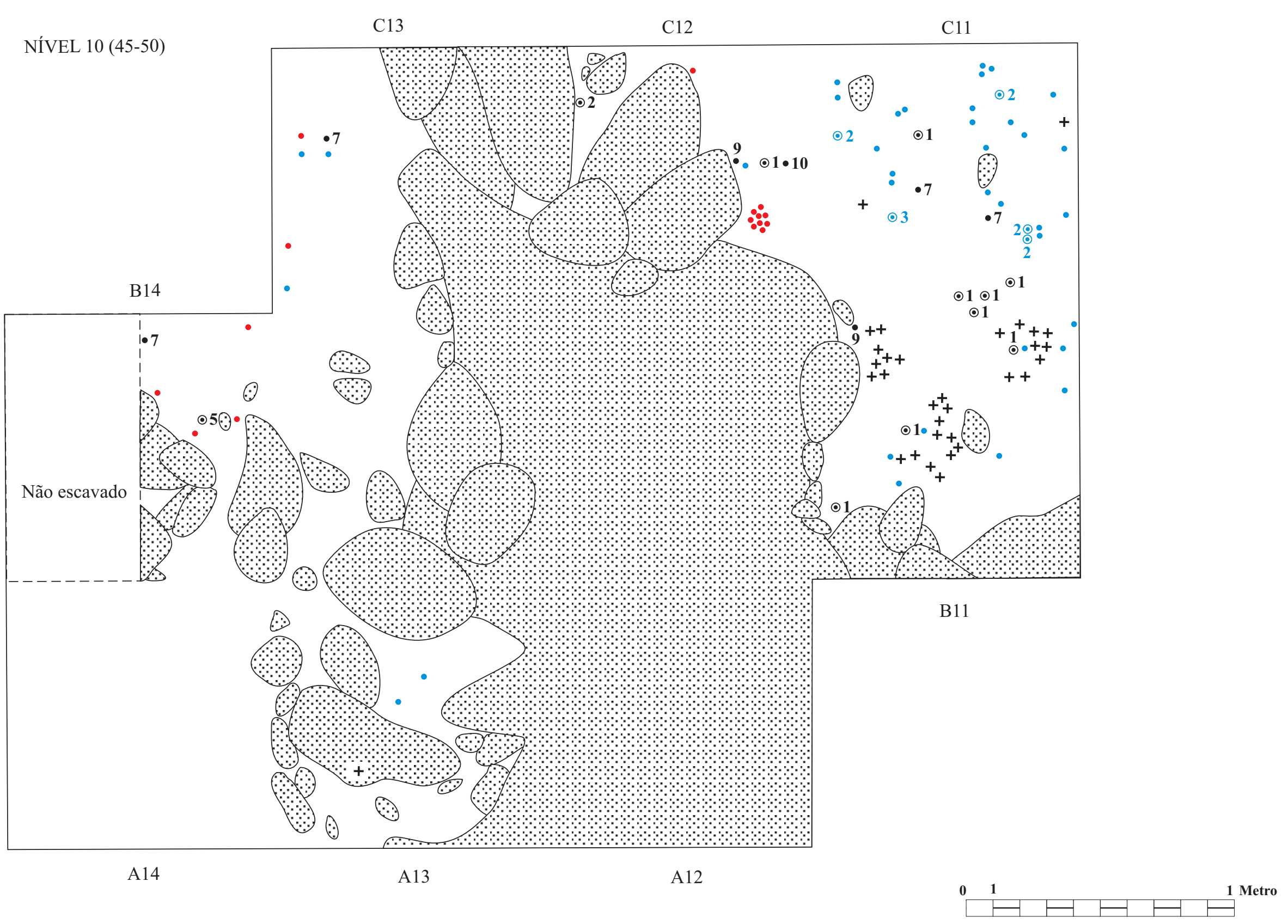


NIVEL 11 (50-55)

59. RS-S-337: Monjolo

Escala 1:20

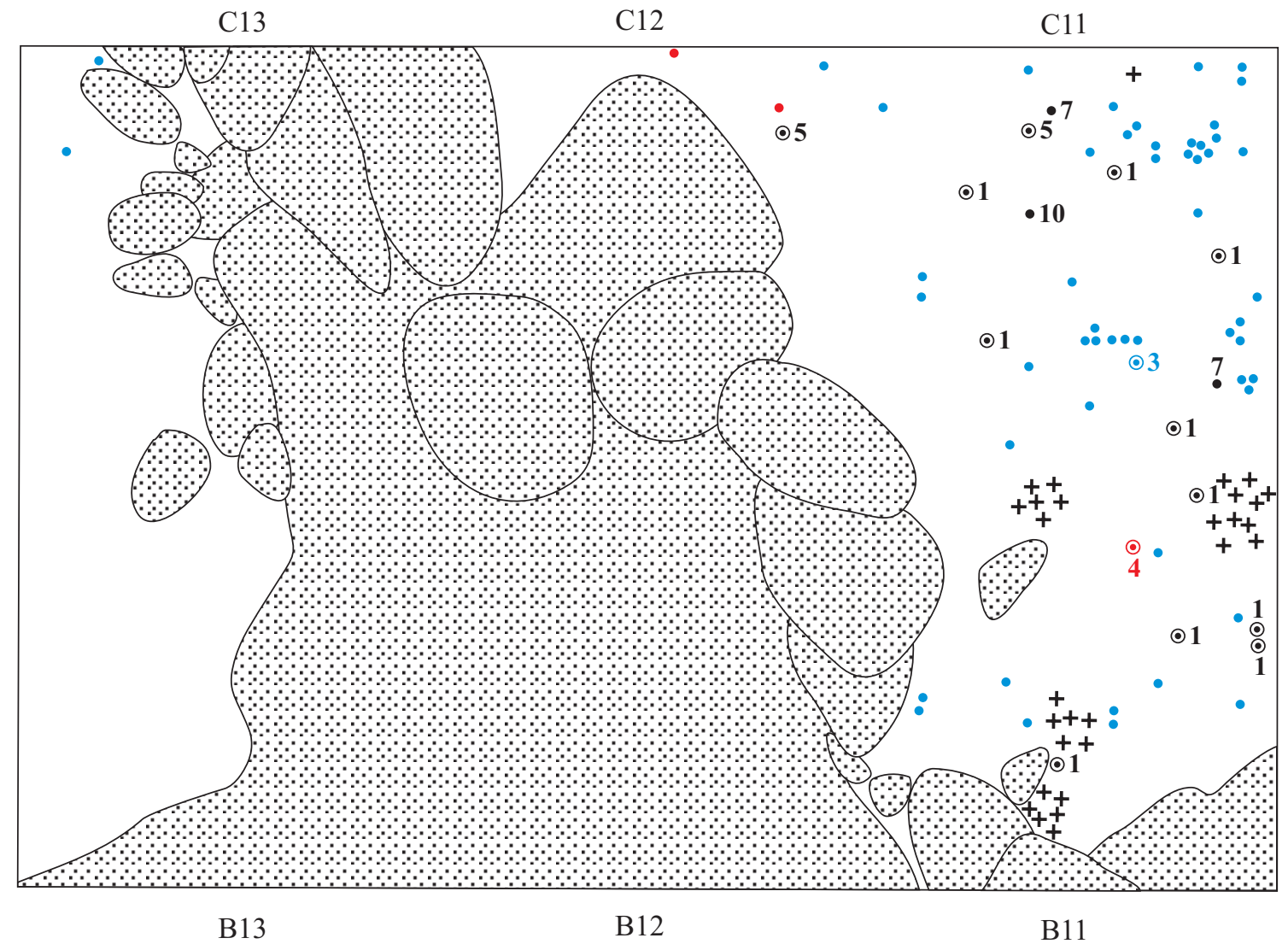

60. RS-S-337: Monjolo

NÍVEL 12 (55-60)

Escala 1:20

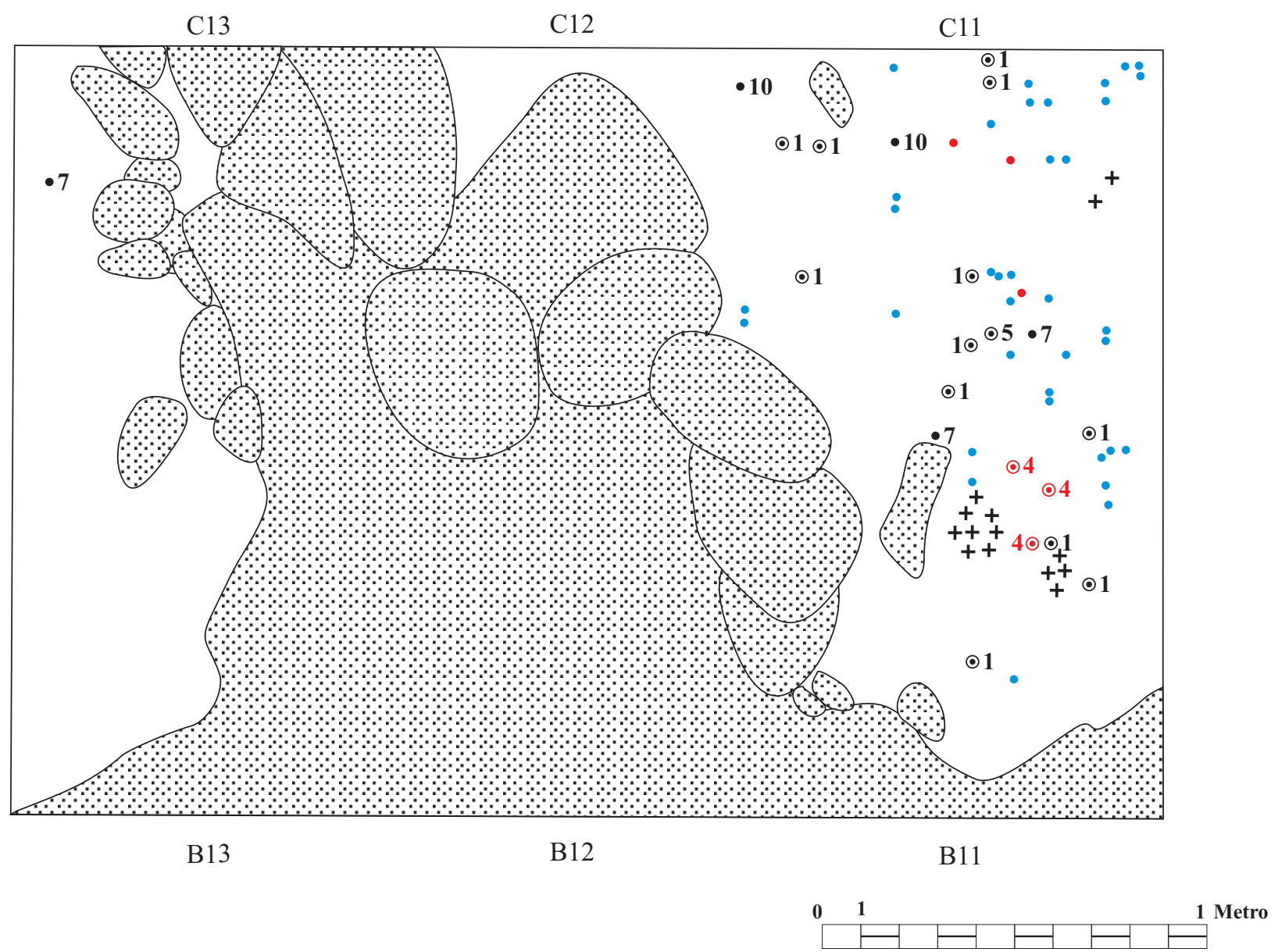



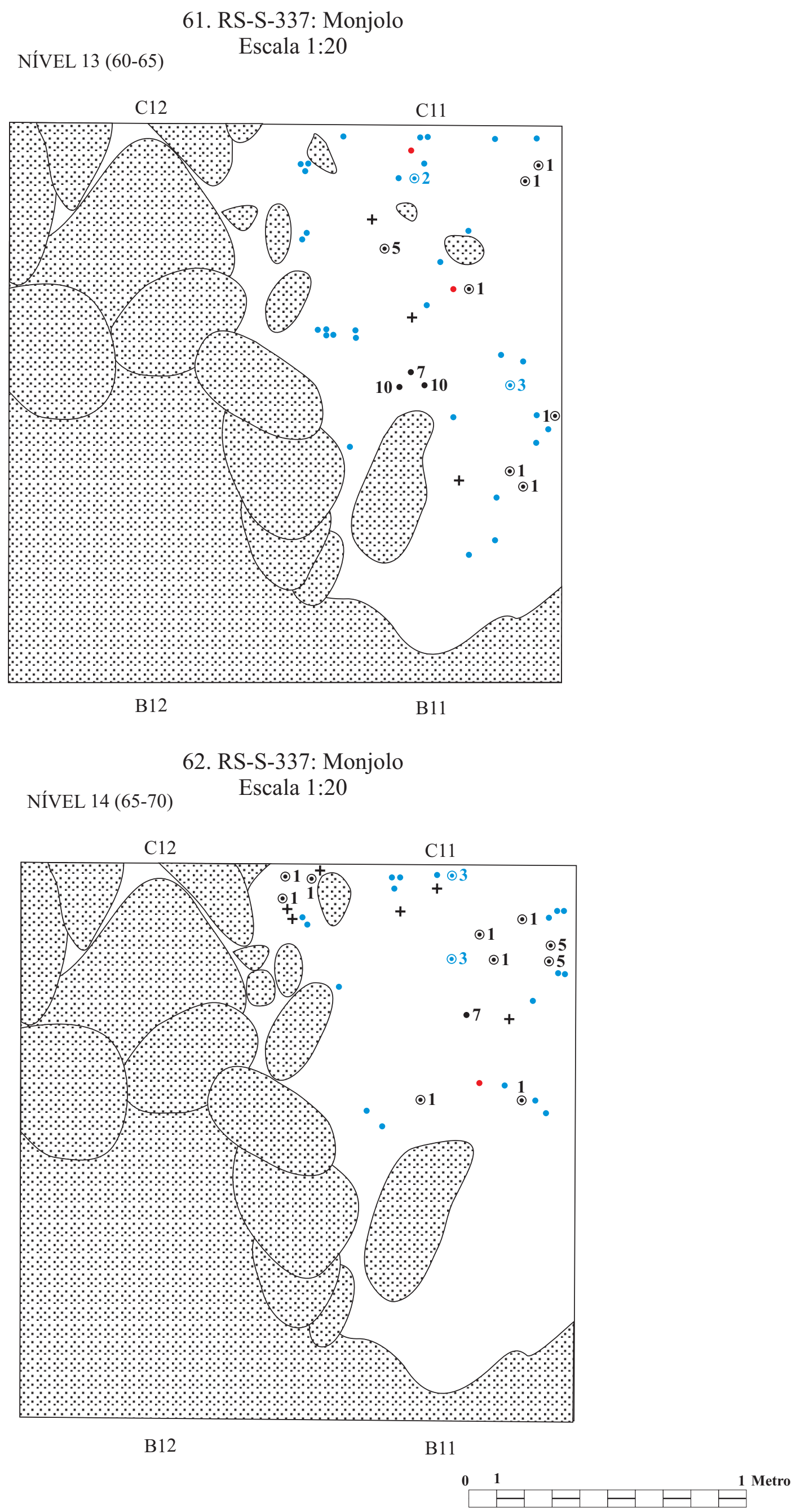

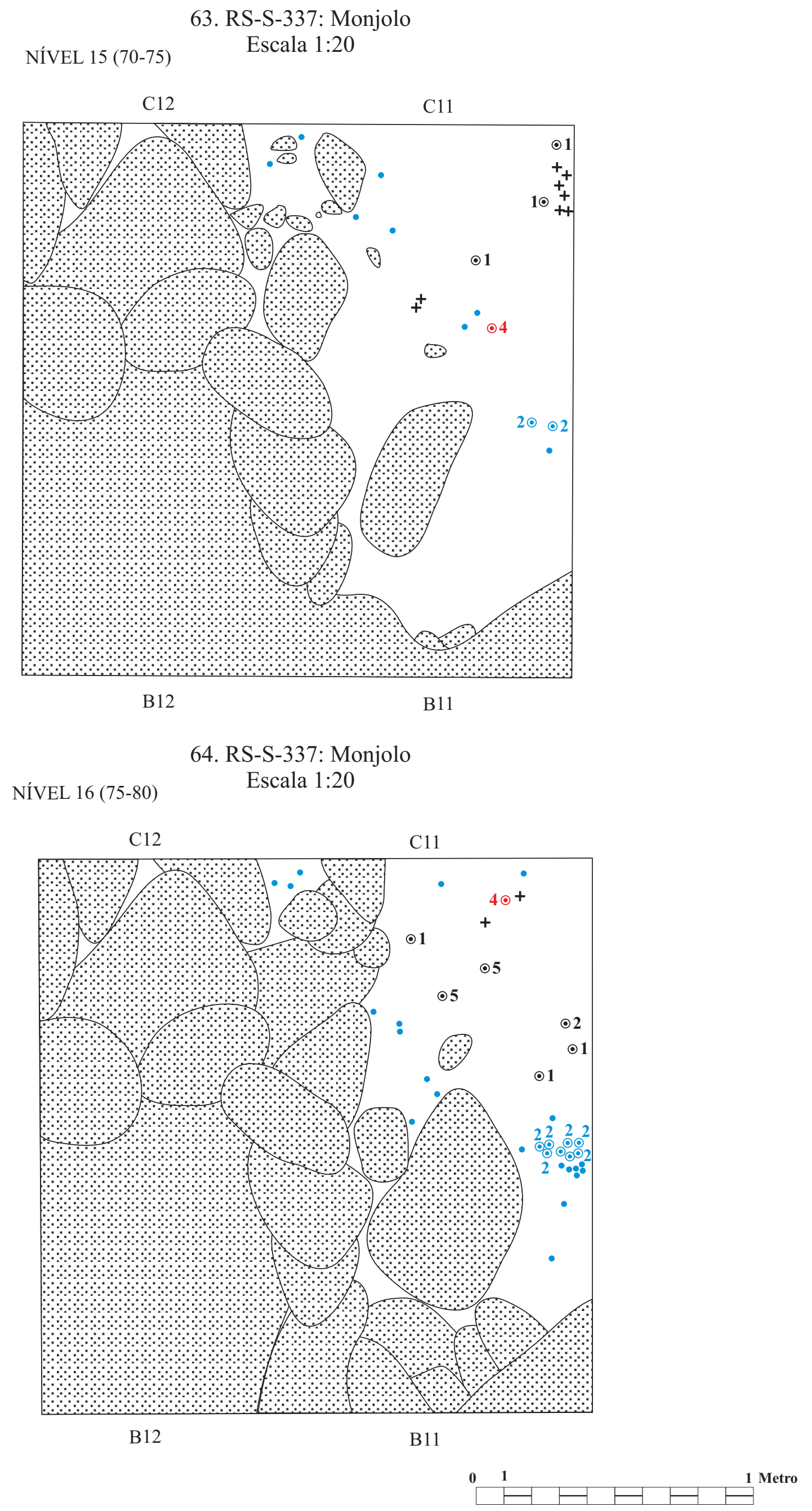
65. RS-S-337: Monjolo

Escala 1:20

NÍVEL 17 (80-85)

C11

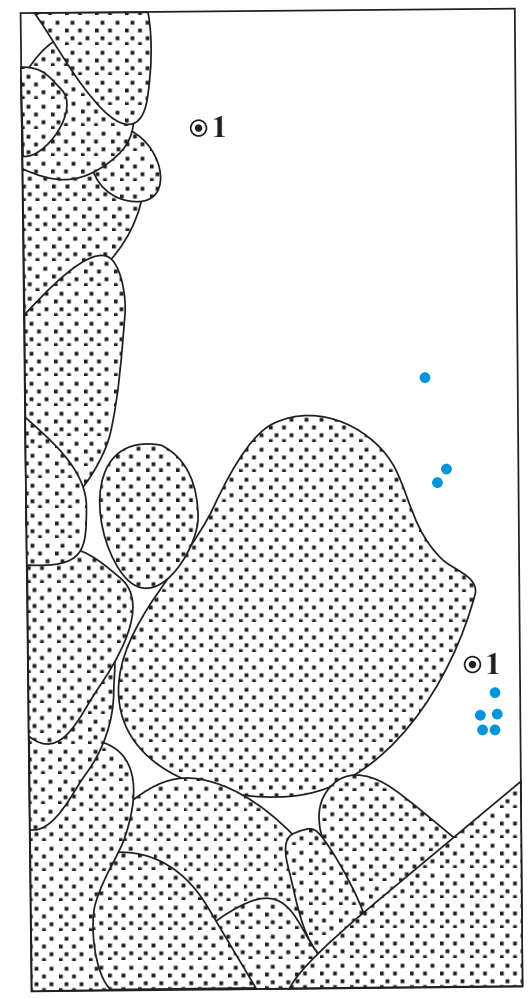

B11

67. RS-S-337: Monjolo

Escala 1:20

NÍVEL 19 (90-95)

C11

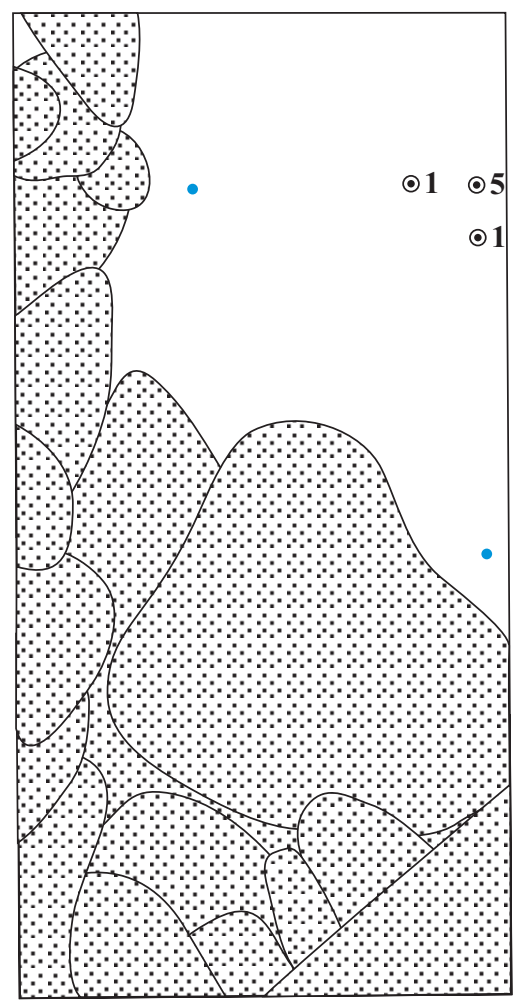

B11
66. RS-S-337: Monjolo

Escala 1:20

NÍVEL 18 (85-90)

C11

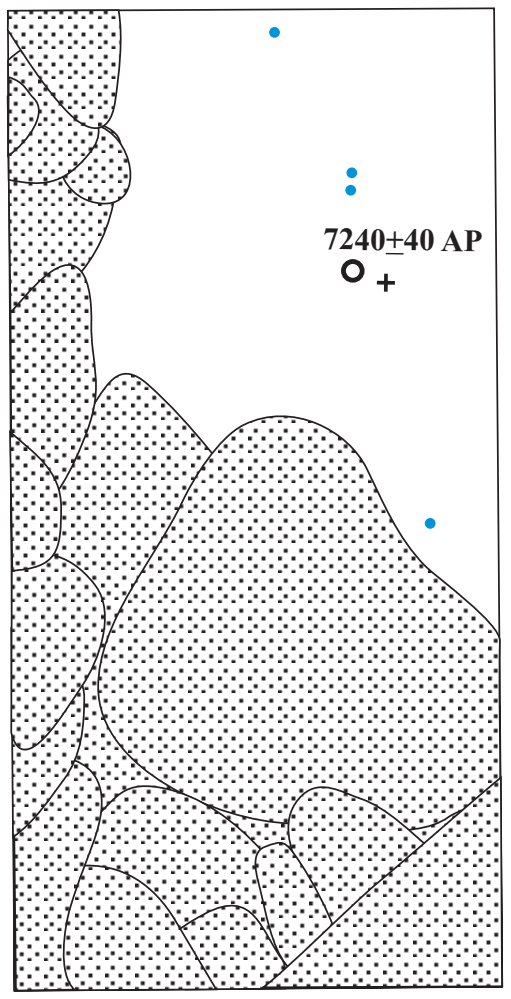

B11

68. RS-S-337: Monjolo Escala 1:20

NÍVEL 20 (95-100)

$\mathrm{C} 11$

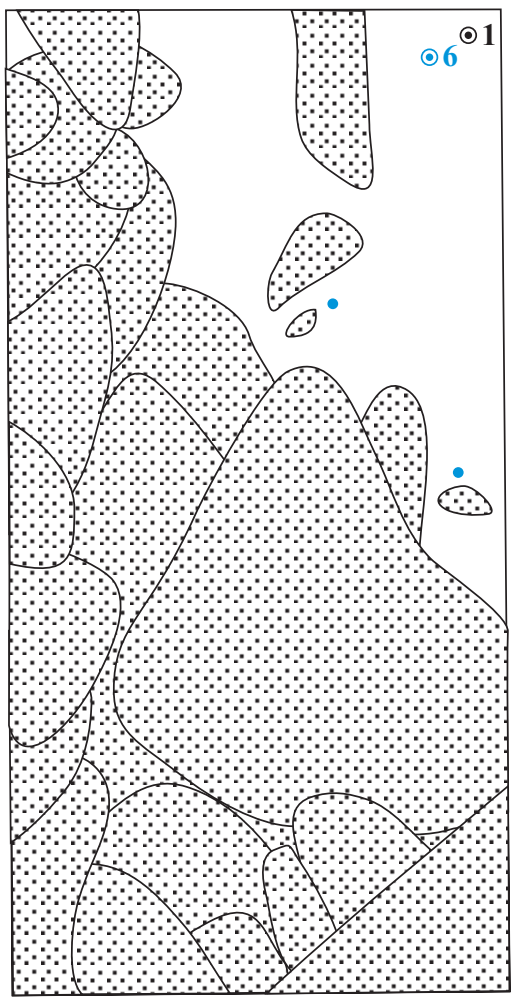

B11 
69. RS-S-337: Monjolo

NÍVEL 15 (70-75)

Escala 1:20

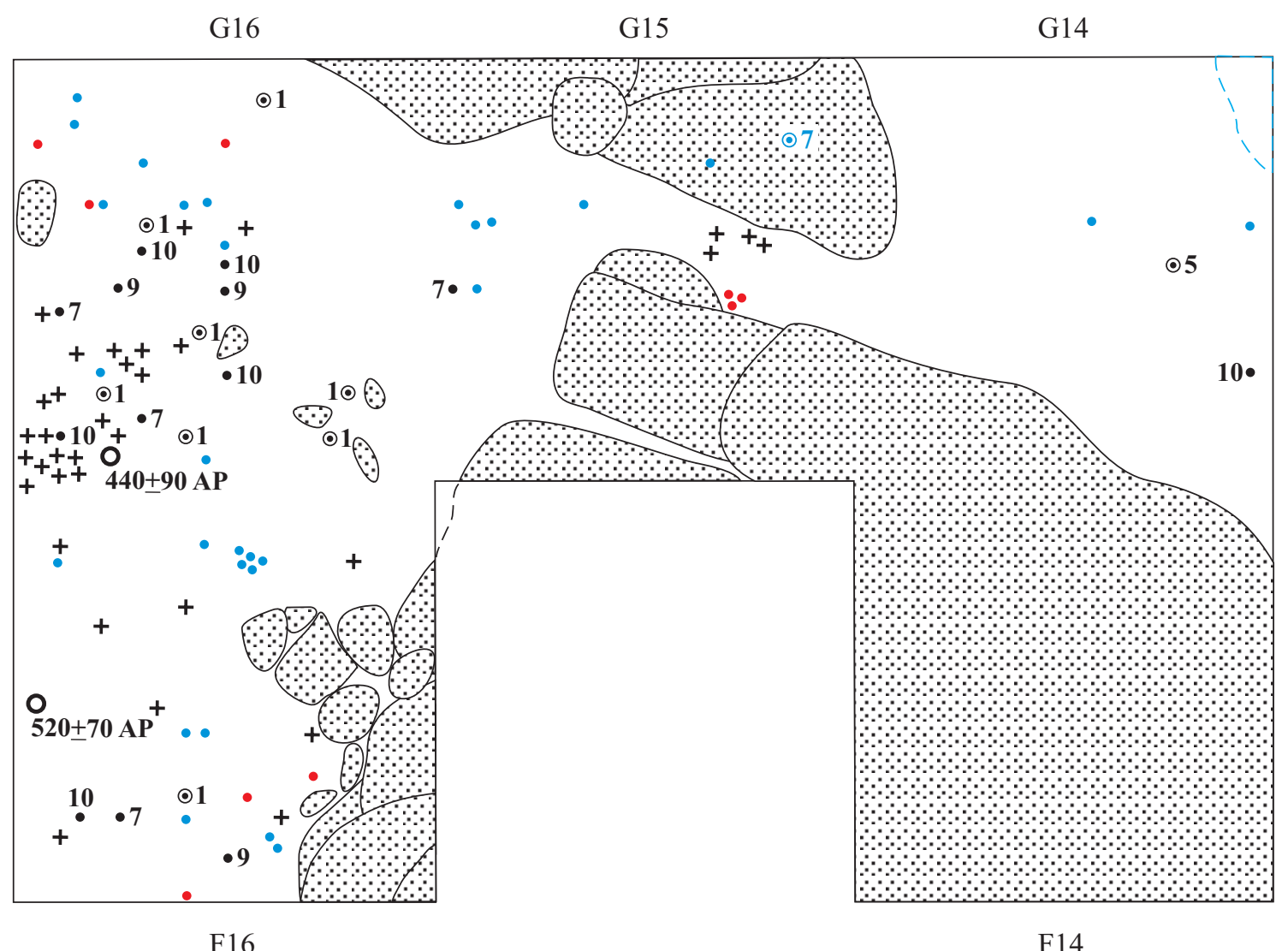

70. RS-S-337: Monjolo

NÍVEL 16 (75-80)

Escala 1:20

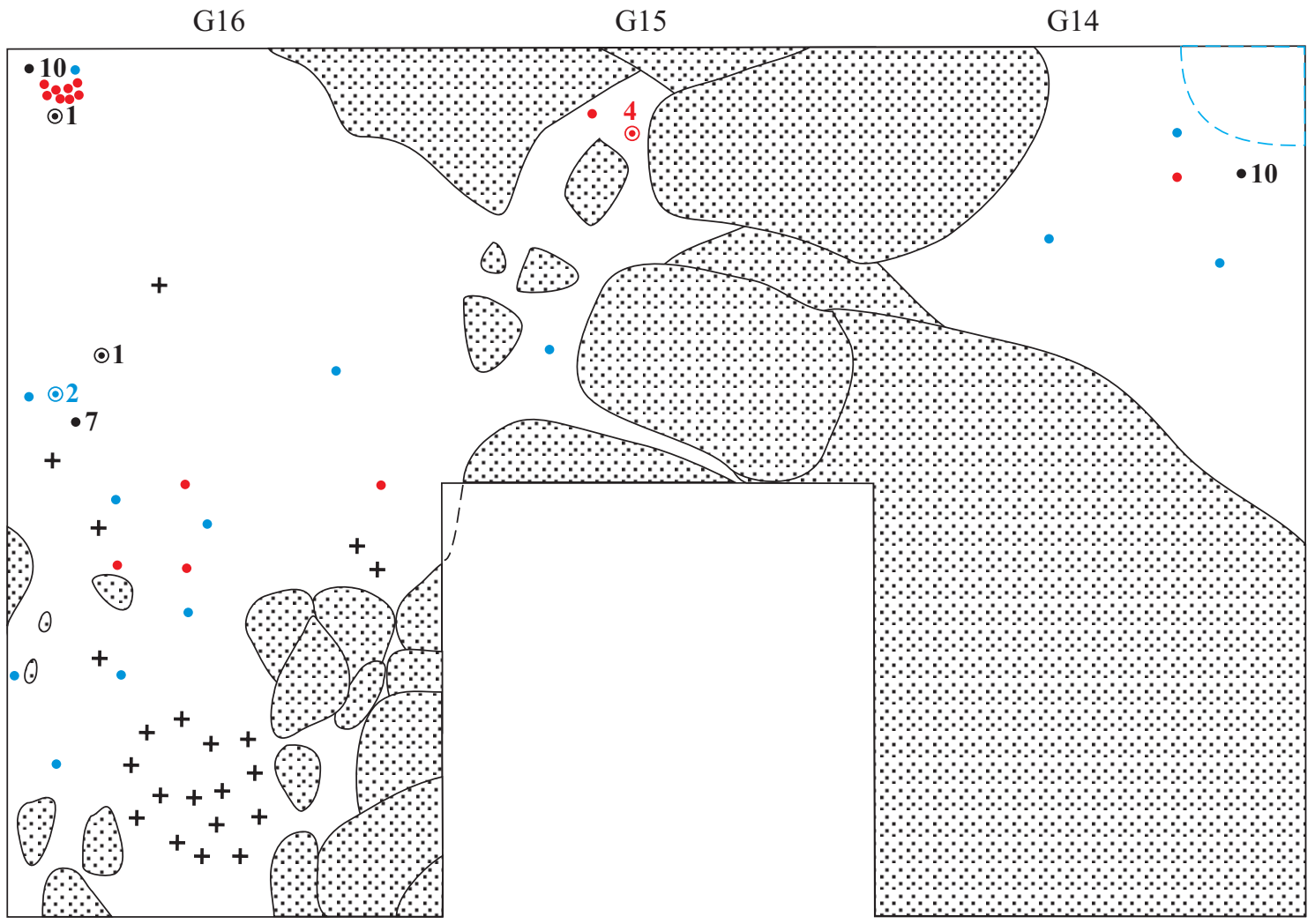

F16 
71. RS-S-337: Monjolo

Escala 1:20

NÍVEL 17 (80-85)

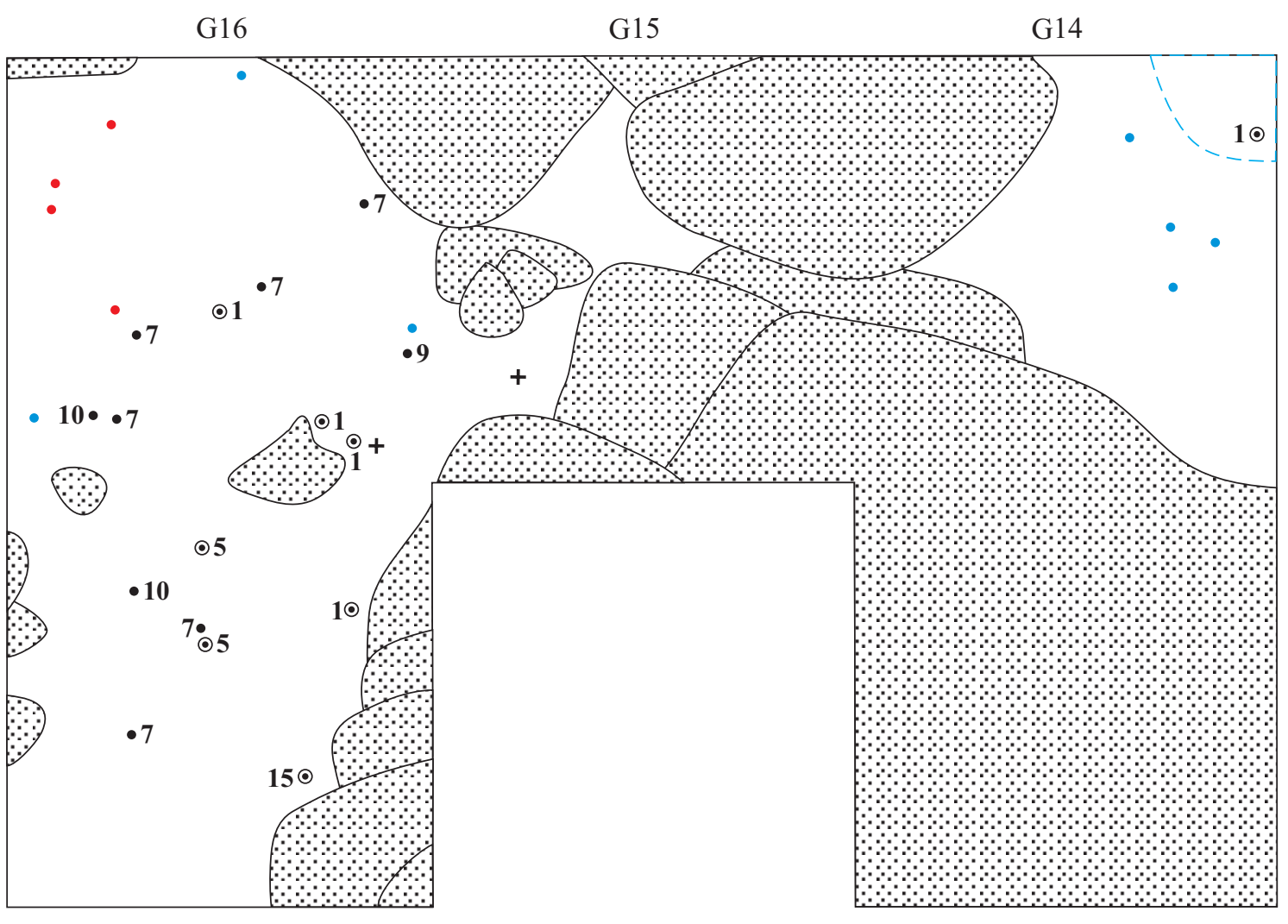

F16

F14

72. RS-S-337: Monjolo

NÍVEL 18 (85-90)

Escala 1:20

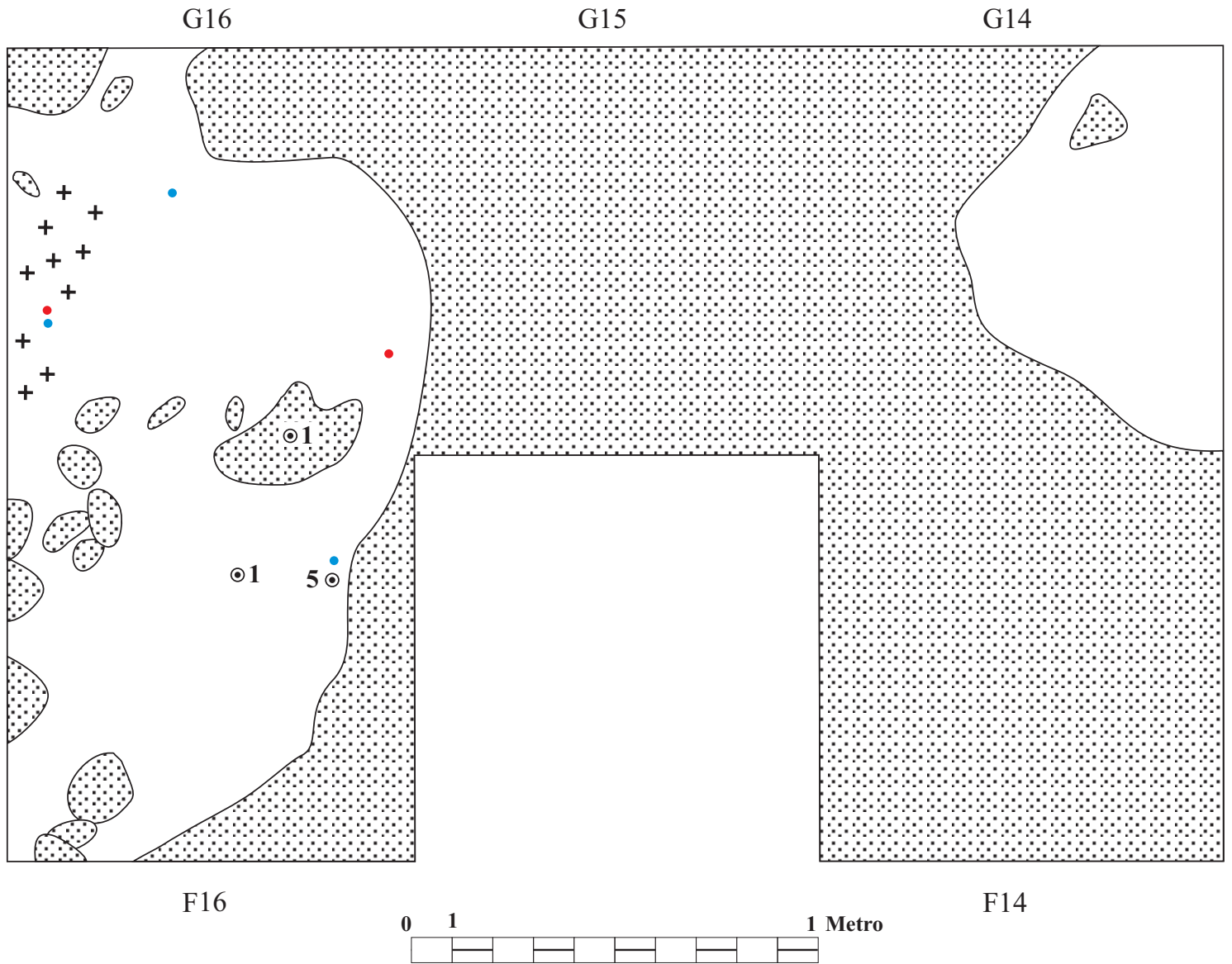


73. RS-S-337: Monjolo

Escala 1:20

NÍVEL 19 (90-95)

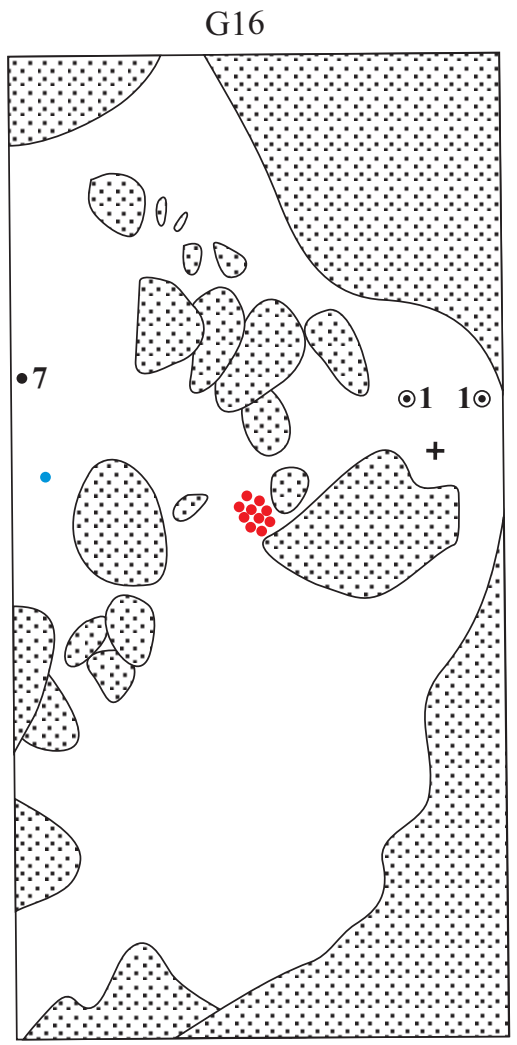

F16

76. RS-S-337: Monjolo

Escala 1:20

NÍVEL 22 (105-110)

G16

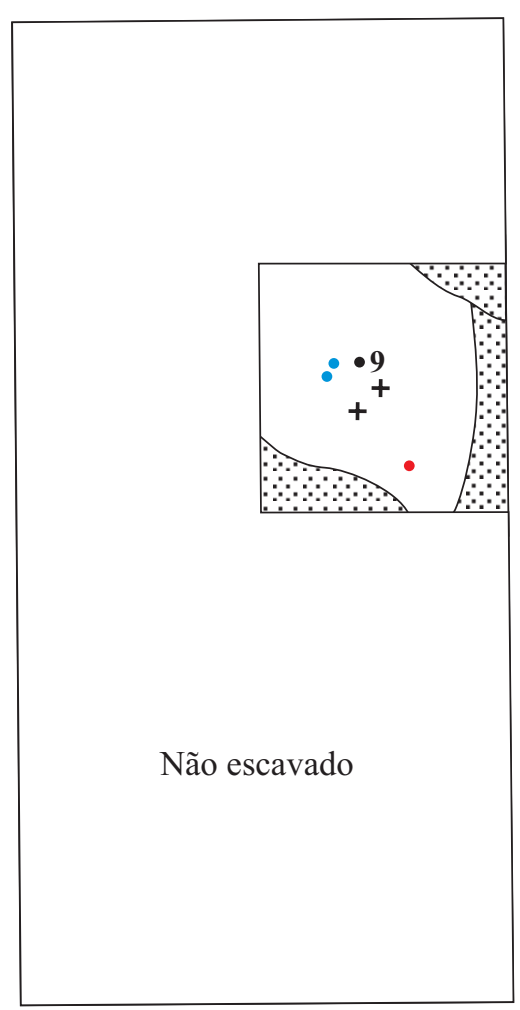

F16
74. RS-S-337: Monjolo

Escala 1:20

NÍVEL 20 (95-100)

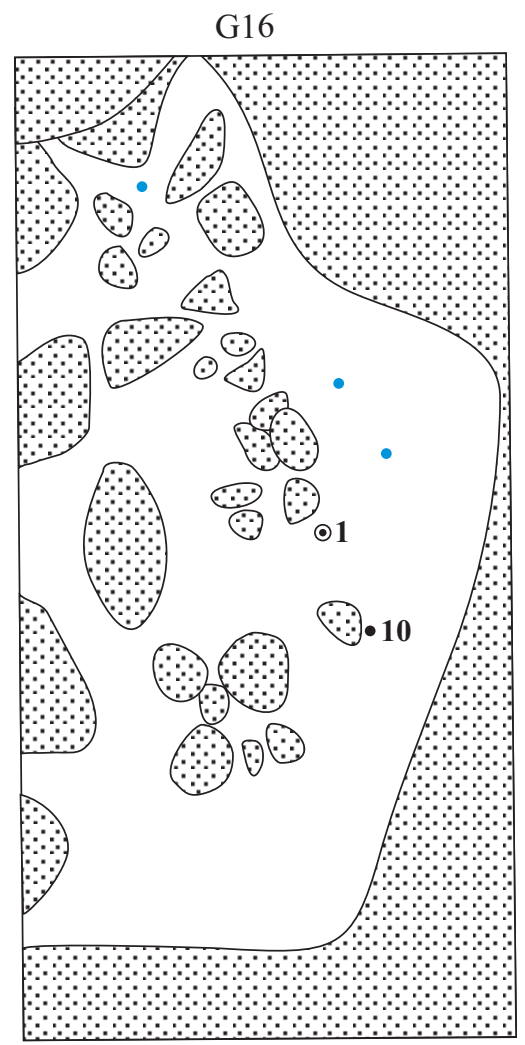

F16

77. RS-S-337: Monjolo

Escala 1:20

NÍVEL 23 (110-115)

G16

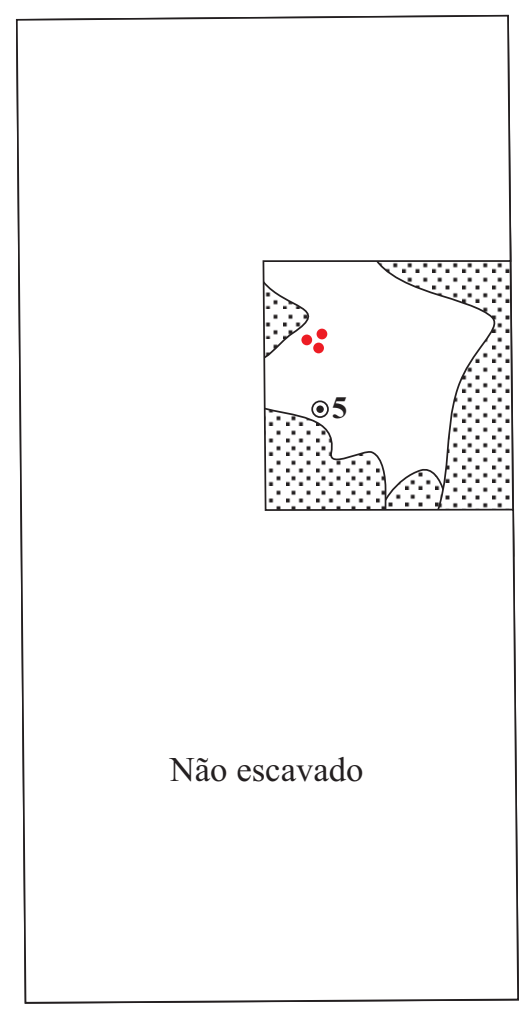

F16
75. RS-S-337: Monjolo

Escala 1:20

NÍVEL 21 (100-105)

G16

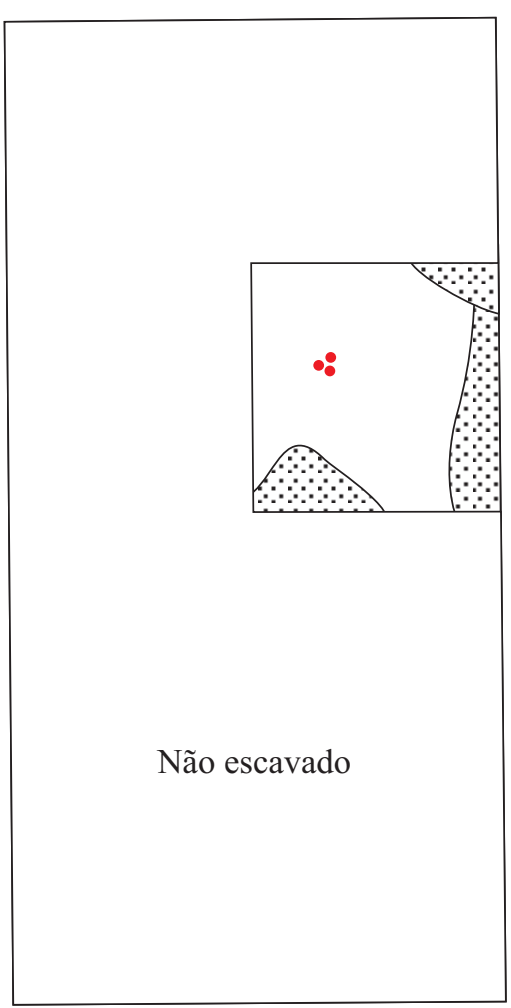

F16

78. RS-S-337: Monjolo

Escala 1:20

NÍVEL 24 (115-120)

G16

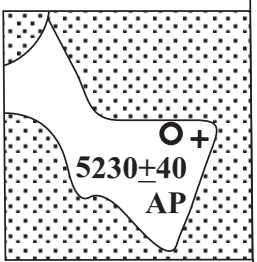

Não escavado

F16 
Anexo 7

Mapas de densidade de material arqueológico

Escala 1:200 
1. RS-S-360: Marimbondo

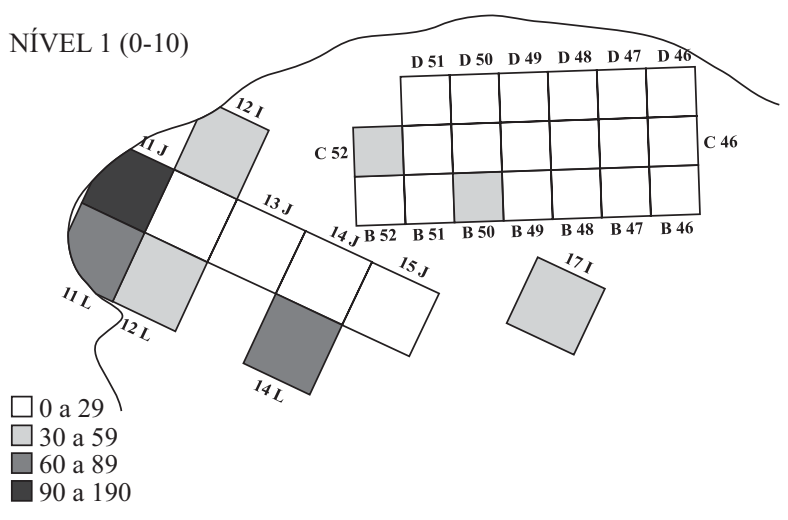

3. RS-S-360: Marimbondo

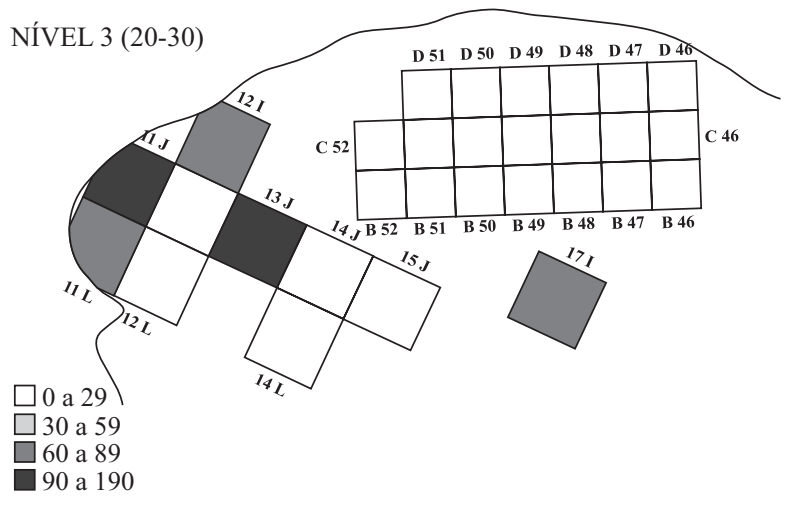

2. RS-S-360: Marimbondo

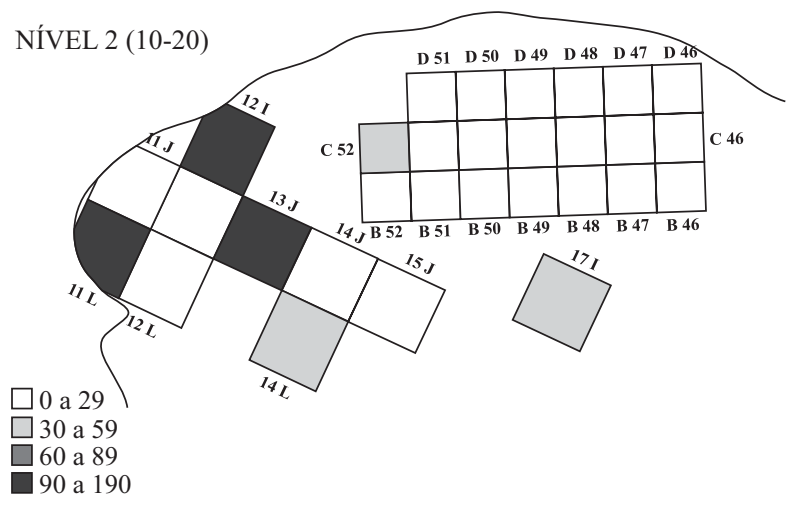

4. RS-S-360: Marimbondo

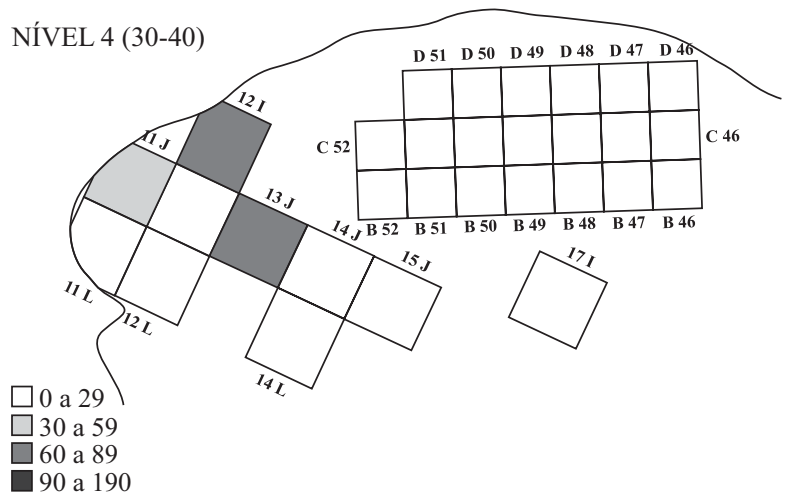




\section{RS-S-227: Sangão}

NÍVEL 1 (0-10)
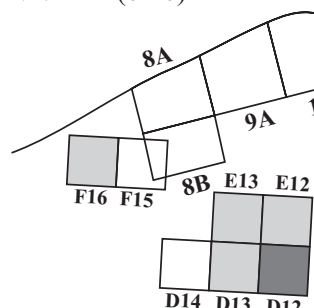

$\square 0$ a 49

$\square 50$ a 99

100 a 149

150 a 200

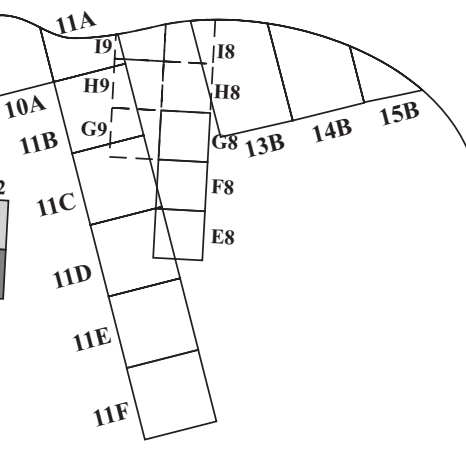

\section{RS-S-227: Sangão}

NÍVEL 3 (20-30)

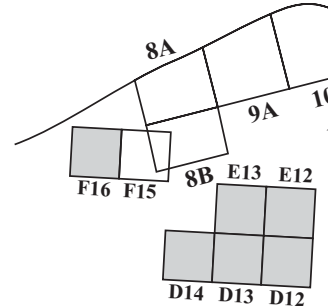

$\square 0$ a 49
$\square 50$ a 99
$\square 100$ a 149

150 a 200

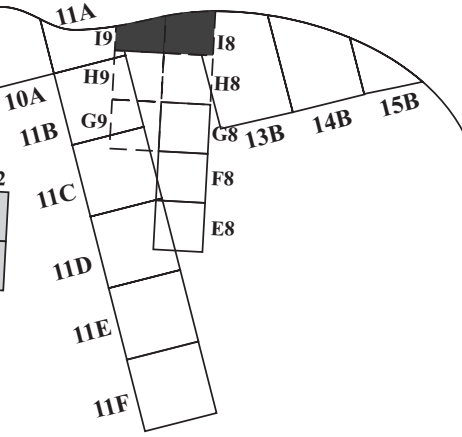

\section{RS-S-227: Sangão}

NÍVEL 5 (40-50)

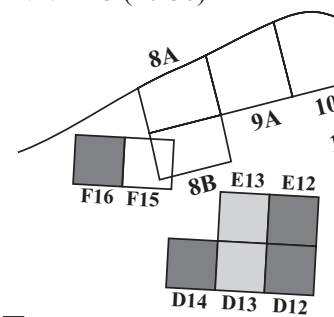

$\square 0$ a 49

\begin{tabular}{l}
150 a 200 \\
\hline
\end{tabular}

\section{RS-S-227: Sangão}

NÍVEL 7 (60-70)

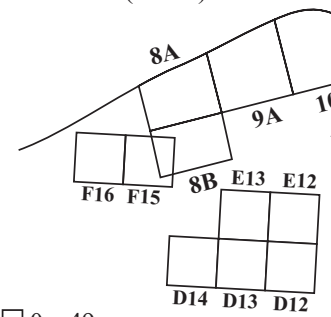

$\square 0$ a 49
$\square 50$ а 99

100 a 149

150 a 200

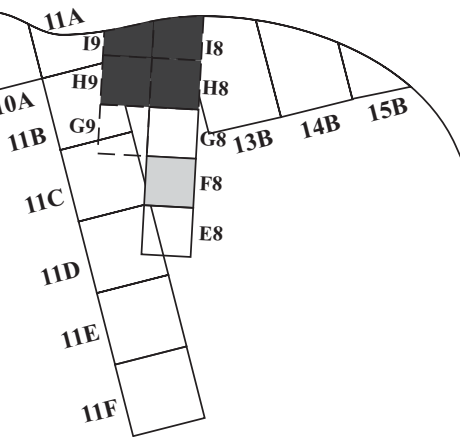

10. RS-S-227: Sangão

NÍVEL 6 (50-60)

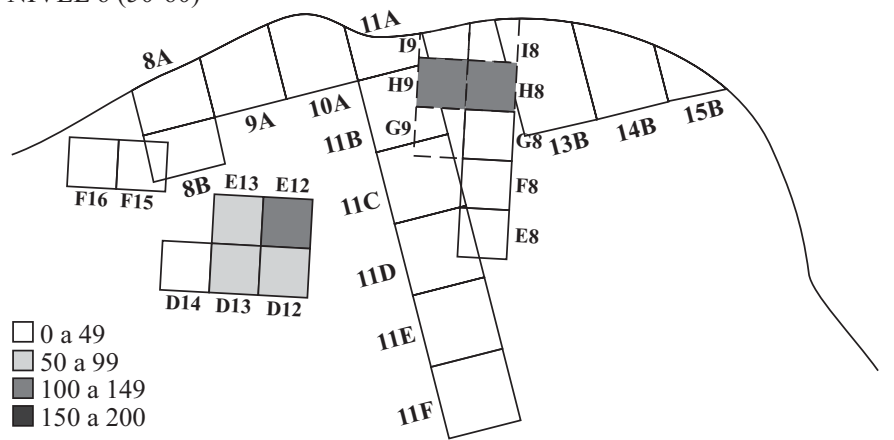

12. RS-S-227: Sangão

NÍVEL 8 (70-80)

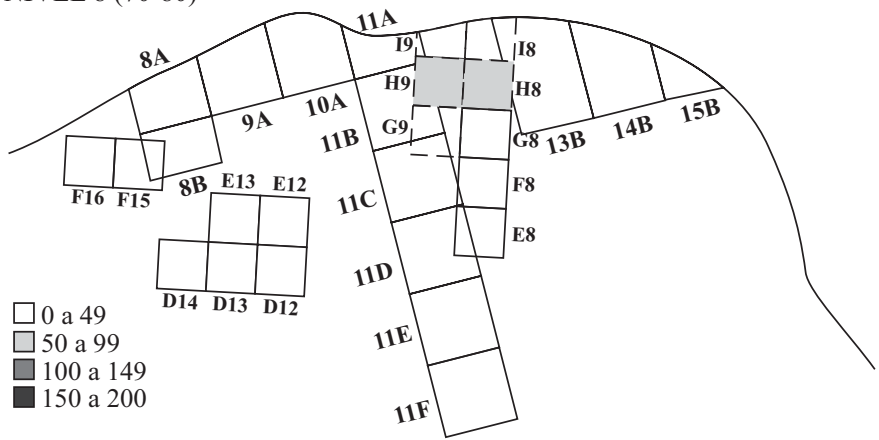

